Seriualde

Necefamae Aclumbatéte
TIAPATPAMATR Ka. TIAPa PeoOpd

ariocana ineerec.

政

medieval worlds Nopottonce

acomparative \& interdisciplinary studies

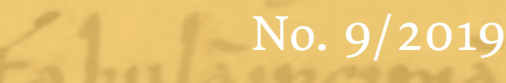

cerapxomai fabulaincipia

MHTINA

ANACTPO WE
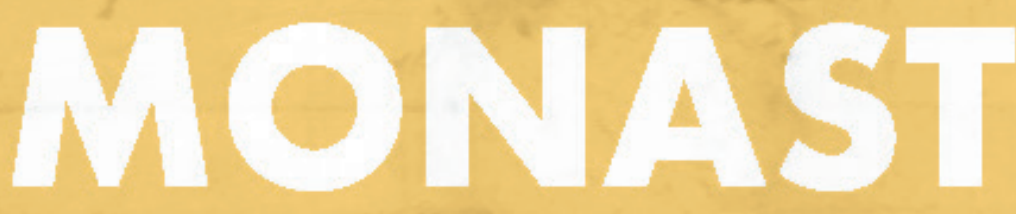

$+$

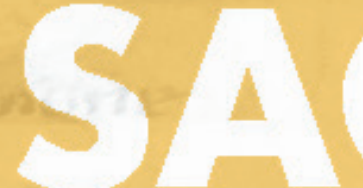

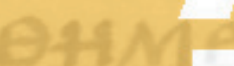

mporbi 4
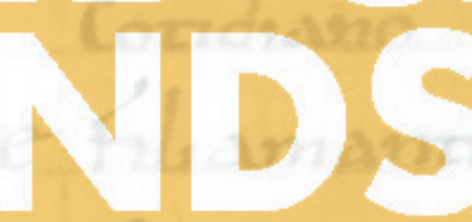

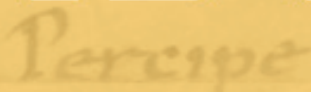

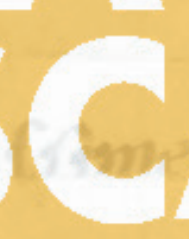

TaARze 12
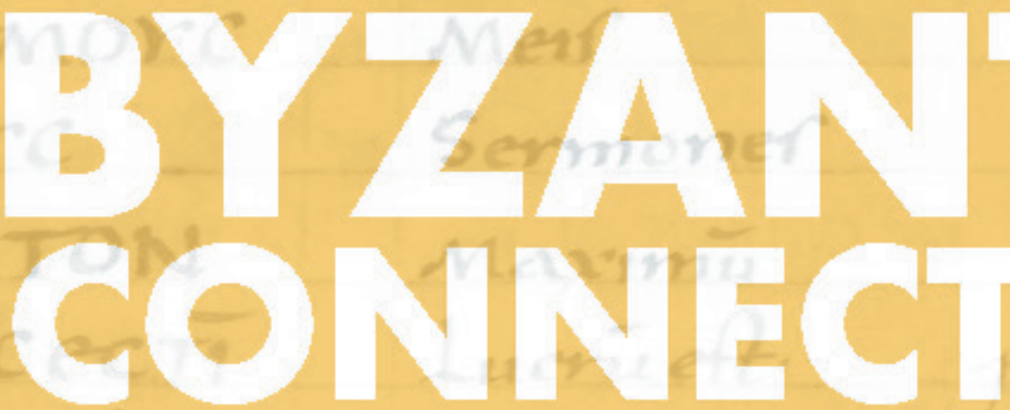

Pantã

Gpape

Mudire

Manecuengo

Anzeromá

imeramagemie

भITATPOC

rores in

epiceror

OHANTON1

ITIC RONe

LN CDANTTCC

Inceolam

Inlucarcenze
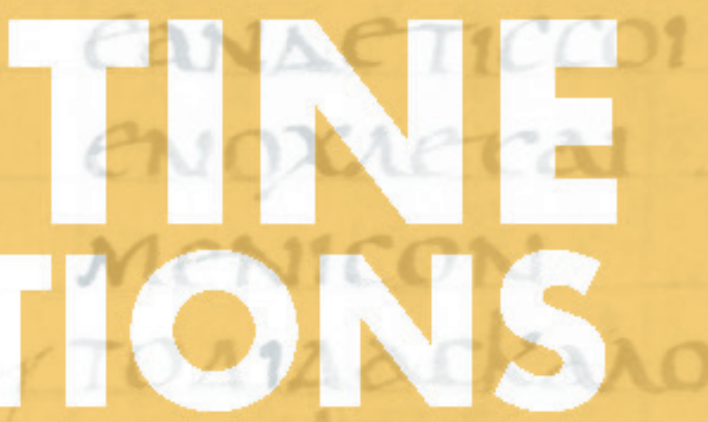

atNaTNoce

hepicon

mpocentiat

Tenakmazó

Me Kena

medieval worlds

OPANOr

Cielo

comparative \& interdisciplinary studies 


\section{medieval worlds \\ comparative \& interdisciplinary studies}

Volume 2019.9

Monasteries and Sacred Landscapes $\&$ Byzantine Connections

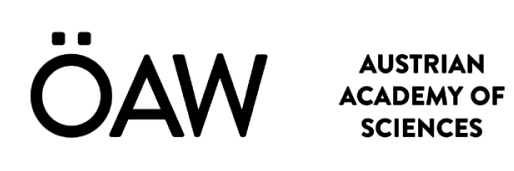




\section{medieval worlds comparative \& interdisciplinary studies}

All rights reserved

ISSN 2412-3196 Online Edition

Media Owner: Institute for Medieval Research

Copyright $\odot 2019$ by Austrian Academy of Sciences, Vienna

Cover design, layout: Anneke Gerloff

Cover image: Carolingian Greek Grammar

(c) British Library Board, Harley MS 5642, f. 29 r (modified).

Austrian Academy of Sciences Press

Dr. Ignaz Seipel Platz 2, 1010 Vienna, Austria

Tel. +43-1-515 81/DW 3402-3406

Fax +43-1-515 81/DW 3400

hw.oeaw.ac.at, verlag.oeaw.ac.at 


\section{Editors}

Walter Pohl, Austrian Academy of Sciences/University of Vienna

Andre Gingrich, Austrian Academy of Sciences/University of Vienna

\section{Editorial Board}

Maximilian Diesenberger, Austrian Academy of Sciences

Christian Gastgeber, Austrian Academy of Sciences

Johann Heiss, Austrian Academy of Sciences

Nina Mirnig, Austrian Academy of Sciences

Claudia Rapp, Austrian Academy of Sciences/University of Vienna

Helmut Reimitz, Princeton University

Irene van Renswoude, Huygens Institute for the History of the Netherlands/

Royal Netherlands Academy of Arts and Sciences

Pavlína Rychterová, Austrian Academy of Sciences

Celine Wawruschka, Danube University Krems

Veronika Wieser, Austrian Academy of Sciences

\section{International Advisory Board}

Glenn Bowman , University of Kent

Sabrina Corbellini, University of Groningen

Mayke de Jong, Utrecht University

Nicola di Cosmo, Institute for Advanced Study, Princeton

Stefan Esders, Free University of Berlin

Patrick Geary, Institute for Advanced Study, Princeton

John Haldon, Princeton University

William C. Jordan, Princeton University

Osamu Kano, Nagoya University

Hugh Kennedy, SOAS, University of London

Gábor Klaniczay, Central European University

Elisabeth Lambourn, De Montfort University Leicester

Eduardo Manzano, Centro de Ciencias Humanas y Sociales (CSIC)

Lars Boje Mortensen, University of Southern Denmark

Marina Rustow, John Hopkins University

Dittmar Schorkowitz, Max Planck Institute for Social Anthropology

Teresa Shawcross, Princeton University

Naomi Standen, University of Birmingham

John Tolan, University of Nantes

Przemysław Urbańczyk, Polish Academy of Sciences

Dan Varisco, University of Bonn

Luo Xin, Peking University

Journal Management

Ingrid Hartl

\section{Homepage}

www.medievalworlds.net 


\section{Table of Contents}

Editor's Preface

2

Walter Pohl and Ingrid Hartl

MONASTERIES AND SACRED LANDSCAPES

An Old Ritual Capital, a New Ritual Landscape:

4

Understanding the Transformation of Angkor Thom, Cambodia

through the Construction and Placement of Theravāda "Buddhist Terraces«

Andrew Harris

The Monasteries of Athos and Chalkidiki (8th-11th Centuries): A Pioneering Front? 63

Michel Kaplan

Pro qualitate loci et instantia laboris:

Monasteries and their Human and Natural Environments in Late Antique Gaul

Matheus Coutinho Figuinha

The Limitations of Asceticism

112

Albrecht Diem

\section{ByZANTINE ConNECTIONS}

Greeks and »Greek« Writers in the Early Medieval Italian Papyri

Edward M. Schoolman

Resenting Byzantine Iconoclasm. Its Early Reception in Italy

through an Inscription from Corteolona

Francesca Dell'Acqua and Clemens Gantner

Mercantile and Religious Mobility between Byzantines, Latins and Muslims, 1200-1500: On the Theory and Practice of Social Networks

Johannes Preiser-Kapeller and Ekaterini Mitsiou

"A Universal Narrative of Humanity". Travelling to the >Other

from Constantinople: Priscus of Panion (5th c. CE)

and William of Rubruk (13th c. CE)

Pia Carolla 


\section{Editor's Preface}

\section{Walter Pohl and Ingrid Hartl}

This year's summer issue presents articles clustered around two topics: Monasticism and Sacred Landscapes and Byzantine Connections.

Under the heading Monasticism and Sacred Landscapes we have assembled articles discussing the interaction of monastic institutions with their environment. How did they shape the landscape, both in an economic/ecological sense, and in ritual and symbolic ways? This topic is explored in case studies from Southeast Asia, Byzantium and Western Europe: Cambodia, Greece and Gaul. Monasteries are among the medieval institutions that seem most easily comparable, at least between Christian and Buddhist spheres, as Jesuit missionaries already noted. But we have to be careful that the classification of non-Christian institutions as >monasteries` does not transport any unreflected assumptions into our analysis. The present papers put apparent cross-cultural similarities of monastic communities to the test. They are supplemented by a fairly theoretical essay about the significance of rasceticism in Christian monasteries but also in modern scholarly discourse, which may encourage further reflection about the topic.

An Old Ritual Capital, a New Ritual Landscape uses architectural evidence to trace changes not only in religious practice but also in the interaction between religious and non-religious spaces in the urban environment of Angkor Thom from the thirteenth to the seventeenth centuries CE. The Monasteries of Athos and Chalkidiki (8th-11th centuries) examines the influence the foundation of monasteries had on the development of an entire region, and focuses thereby on regional conflicts between local agricultural and religious communities in which competition for the control of land seems to have been a driving motive. Pro qualitate loci et instantia laboris undertakes a close reading of the founding myths of late antique monasteries in Gaul, exploring - in combination with archaeological evidence - the interaction between the monks and their human and natural environment in the fourth and fifth centuries CE.

The Limitations of Asceticism is based on a critical reading of scholarly language used in the study of religious communities. Three different angles are employed: the roots and history of the terms asceticism, Askese, ascétisme are outlined, the origins of the term askesis traced in Greek monastic discourse and the transformations of religious rascetic practices in a number of Latin hagiographic and normative texts described. The article offers an innovative and challenging approach to traditional ideas about monastic practices. Submissions critically engaging with its argument, or applying it to other macro-regions, would be welcome.

The cluster Byzantine Connections addresses the cultural, commercial and diplomatic exchanges of Byzantium with its eastern and western neighbours. Two articles focus on the reception of Byzantine culture in Italian sources: Greeks and "Greek" Writers in the Early Medieval Italian Papyri examines Greek script used in the sixth- and seventh-century papyri documents of Ravenna, whereas Resenting Byzantine Iconoclasm investigates an eighth-century inscription in Lombard Italy providing new aspects of the reception of Byzantine iconoclasm. 
Mercantile and Religious Mobility between Byzantines, Latins and Muslims, 1200-1500 uses historical network analysis and social theory to describe commercial dynamics between individuals, families and groups in the late medieval Eastern Mediterranean, and religious conversions along Islamic-Christian borders. "A Universal Narrative of Humanity « addresses issues of otherness in the travel reports of Priscus of Panion (fifth century CE) and William of Rubruk (thirteenth century CE) - one who travelled from Byzantium to Attila the Hun, and the other via Byzantium to the Mongol Empire.

These two thematic clusters will be continued with further papers, hopefully in the next issue, 10, which will be uploaded on 1 December 2019. The main thematic cluster in this issue will be Uses of the past in times of transition: Forgetting, using and discrediting the past, which confronts aspects of the >Transformation of the Carolingian World « with comparable situations in Byzantium or parts of Asia in about the same period, the ninth to the eleventh centuries. 


\title{
An Old Ritual Capital, a New Ritual Landscape: Understanding the Transformation of Angkor Thom, Cambodia through the Construction and Placement of Theravāda "Buddhist Terraces«
}

\author{
Andrew Harris*
}

This paper serves as the first focused study since 1918 exploring the sub-structural remains of Theravāda Buddhist monasteries, known to scholarship as "Buddhist terraces", at the Cambodian Khmer capital of Angkor Thom. Thought to have been constructed between the late 13th-16th centuries, prayer halls (vihara or prah vihar) and other Theravāda buildings are seen by traditional scholarship to be the products of an officially undocumented but visible religious transition from the Khmer Brahmano-Buddhist royal cult, manifested through the construction of universal temple-mountains and esoteric religious practices, to a more socially-inclusive monastic tradition which abandoned epigraphy, the deification of kings, and large-scale religious building. Data acquired from two seasons of site investigations within Angkor Thom has revealed an expansive collection of over seventy "Buddhist terraces" demarcated by sīmā boundary stones, suggesting not only a notable Theravāda building campaign within this cosmologically designed Mahāyāna Buddhist urban space but also the conversion and incorporation of Brahmano-Buddhist monuments as landmarks of the new religion. The interaction of Buddhist monastic architecture with non-religious urban infrastructure, too, most notably the road-grid of Angkor Thom previously mapped through LiDAR and GIS, has revealed intriguing patterns of construction that appear to match a configuration with the southerly temple of Angkor Wat, heavily restored as a royally patronized Theravāda sanctuary in the mid-16th century. Understanding the significance of this shift is necessary to understanding the re-appropriation of the vast urban ritual landscape of Angkor, and in turn serves as a valid study for further understanding the significance and retransformation of ritual space transcending specifically-delineated historical epochs.

Keywords: Angkor, Cambodia, Buddhism, Theravada, monasteries, ritual, 16th century, archaeology, survey, mapping

\footnotetext{
* Correspondence details: Andrew Harris, PhD Candidate, Department of Anthropology, University of Toronto, 19
} Russell Street, Toronto, Ontario, Canada, M5S 2S2; Email: andrewsr.harris@mail.utoronto.ca. 


\section{Introduction}

Past and present scholarship has typically framed the history of the Khmer Empire (c. 802$1431 \mathrm{CE}$ ) within three distinct phases defined primarily by the religious alignment of kings and the resulting material remains constructed surrounding their capital center at Angkor. Working within this academic context while excluding traditions of animistic worship, ${ }^{1}$ these three "phases" are traditionally identified as Brahmanic (Śaivism or Vaiṣnavism), Mahāyāna Buddhist, and Theravāda Buddhist. ${ }^{2}$ The first two "phases " have been delimited and interpreted through the analysis of temple inscriptions enclosed within monumental temple-complexes scattered across Cambodia, Thailand, and Laos; ${ }^{3}$ Brahmanic practice is typically seen as the Khmer historical norm, while Mahāyāna Buddhism is primary associated with the great king Jayavarman VII (r. 1181-1220) and his immediate successors' expansive campaign of monumental religious construction. Despite the lack of other extant historical records such as palm-written texts and chronicles due to Cambodia's tropical climate, epigraphers have been able to successfully piece together many of the prominent historical events defining the empire's first five centuries of existence. Thus, an elite-focused history of the Brahmanic and Mahāyāna Buddhist "phases « forms the majority of our understanding of what aspects of Khmer Imperial history are deemed significant.

In contrast, the third religious "phase" of Cambodian history at Angkor is poorly documented and sparsely researched. Theravāda Buddhism, thought to have been worshipped in Cambodia as early as the 9 th century, ${ }^{4}$ is believed to have risen to prominence in the late 13 th century ${ }^{5}$ and is most notably marked by the cessation of temple-building in favor of the construction of less durable, more localized prayer halls. The $1296 \mathrm{CE}$ account of Angkor by the Yuan Dynasty emissary Zhou Daguan, entitled Customs of Cambodia, has proved invaluable for understanding Theravāda's early ascendancy alongside reconstructing Khmer livelihoods and interactions with religion. Alongside his descriptions of monasteries and bhikkus ${ }^{6}$ within Angkor Thom, Zhou proclaimed that "every family practices Buddhism ${ }^{7}$ and attests to the growing dominance of Theravāda practice alongside previous traditions such as Brahmanism. ${ }^{8}$ His descriptions also correlate with the scant historical evidence recovered from a few short inscriptions from the first decade of the 14th century translated by Cœdès (K.300; K.470; K.754) ${ }^{9}$, and later votive epigraphy dated to the "post-Angkorian period« (15th-19th

See Groslier, Angkor and Cambodia, 164; Ang, La communauté rurale Khmère, 135-154; Ang, Place of animism, 35-41.

2 Also known as Hinaya, or derogatorily as the "Lesser Vehicle« compared to the Mahāyāna »Greater Vehicle«.

3 See Inscriptions de Cambodge, ed. Cœdès, Vols. 1-8; Lustig et al., Words across space and time, 12-20.

4 Murphy (The Buddhist Boundary Markers, 113) notes that simā at Phnom Kulen stylistically dated to the 8th-9th centuries (199) are more artistically characteristic of Dvaravati examples found on the Khorat plateau instead of the »leaves « (Ang, Place of animism, 36) found surrounding modern Cambodian monasteries.

5 NARA, Western Prasat Top, 192-193.

6 Monks.

7 Harris, Zhou Daguan, 55.

8 Harris, Zhou Daguan, 52.

9 K.489, a votive Buddhist inscription found at Terrasse Bouddhique No. 1 (Prah Ngok/ATVoo1) north of the Bayon temple, is undated but should be noted. The main epigraphic evidence for a Theravāda conversion is the switch from Sanskrit to Pali as the primary votive language. The final Sanskrit inscription appears at Angkor Wat in 1327 CE (K.470). See Cœdès, Etudes Cambodgiennes, 145-46. 
centuries) ${ }^{10}$ found primarily within the converted Vaiṣnavaite temple of Angkor Wat. ${ }^{11}$ However, the relative lack of epigraphy in comparison to the previous two "phases «, ${ }^{12}$ as well as the lack of new temples built under the auspices of imperial power, departs from trends in traditional Khmer scholarship and its reliance on these sources. This explains in part the neglect of this important period, and as a result Theravāda institutions and practices have often been relegated to historical footnotes ${ }^{13}$ or considered narrowly within the conventional »decline and fall« narrative of the Khmer Empire ${ }^{14}$ rather than studied for their own historical and archaeological merits.

Following recent trends in Khmer and Angkorian scholarship aiming to explore and publicize the abundant archaeological evidence from this time period in both Angkor and greater Cambodia, ${ }^{15}$ this study will explore relationships believed to exist between the numerous Theravāda Buddhist architectural remains constructed at Angkor Thom between the late 13th and early 17th centuries. This objective has been undertaken through the analysis of "Buddhist terraces", the stone substructural remains of prayer halls delimited by sima boundary stones. Over seventy »Buddhist terraces« have thus far been identified within and in the immediate vicinity of Angkor Thom, and as ritual architecture these are thought to have indefinitely replaced Śaivaite and Mahāyāna Buddhist temple-mountains as the primary focal spaces of religious worship in Cambodia. Typically erected in recycled stone quarried from older temples, ${ }^{16}$ these substructures provided the mechanism through which the ancient Khmer capital was ritually validated and politically renewed by Theravāda-practicing populations of the late- and post-Angkorian Periods, and acted to convert Brahmanic and Mahāyāna Buddhist spaces in a similar manner to the construction of earlier Śaivaite temple-mountains. »Buddhist terraces« also aided in the repurposing and continued use of secular infrastructure at Angkor Thom, namely their placement and construction vis-à-vis the original road-grid of Angkor Thom thought to have first been constructed under Jayavarman VII. ${ }^{17}$ Unique patterns of monastic construction along these roads are also hypothesized to correlate with the restoration and conversion of several earlier temples. Most notably Angkor Wat, which became the spiritual hub of Theravāda practice during the reign of King Ang Chan (r. 1516-1566) and his immediate successors. ${ }^{18}$ This article thus synthesizes past studies and presents recently collected material evidence from Angkor Thom to demonstrate the distinctiveness of this religious transition and the manifestation of Theravāda Buddhism which has survived in the archaeological record to this day.

The first mention of the "post-Angkorian« period comes from Giteau, Iconographie du Cambodge.

1 See Appendix.

12 See study by Lustig et al., Words across space and time, 12-20.

13 Although not always, for example in Thompson, Ancestral Cult in Transition, 273-295; Thompson, Memoires du Cambodge, 1-551; Thompson, Buddhist Cosmopolis, 88-119.

14 See Briggs, Ancient Khmer Empire, 54; Cœdès, Indianized States.

15 See fn. $13,33,69$.

16 Marchal, Monuments Secondaires, 26.

17 Gaucher, L'Archéologie Urbaine, 43. His hypotheses likely come from the establishment of the city, and do not come from any published AMS radiocarbon or other dates.

18 Groslier, Angkor and Cambodia, 18; Pou, Inscriptions modernes d'Angkor, 99-126. Thirty-eight translations of post-Angkorian inscriptions were published by Pou between 1970-1976. Almost all of these inscriptions were found within Angkor Wat. 


\section{A transformation based on place}

"Foundational « acts of place-making in the Khmer Empire, defined by Swenson as "the complex process by which built environments were constructed, maintained, perceived, lived, and imagined $",{ }^{19}$ traditionally consisted of an inscription etched onto a stele or temple doorjamb. Alongside votive evocations and religious texts, these detailed various royal lineages or events which occurred during the lives of the respective Khmer kings who commissioned them. ${ }^{20}$ The approximately $1300^{21}$ inscriptions thus far identified have, as noted, customarily served as the main source of historical interpretation for the lion's share of medieval Southeast Asian scholarship, and illustrate the role of religious architecture as validations of the kingship of rulers and "cosmic renewal « of the land over which they ruled. ${ }^{22}$ Stark notes that the planning, construction, and worship of architectural and spatial places of worship on an imperial scale during the Khmer Śaivaite/Vaishnavaite and Mahāyāna Buddhist "periods" were all factors of this renewal, ${ }^{23}$ creating social power radiating outwards from a place of perceived ritual significance. ${ }^{24}$ It is thought as well that Khmer rites of cosmic renewal were localized, ${ }^{25}$ drawing more from the performance of traditional rites than any specific Brahmano-Buddhist textual tradition to secure power over local elites. ${ }^{26}$

The material result of these repeated ritual performances between the 9th and 13th centuries $^{27}$ at Angkor is upwards of twenty temple-landscapes, each thought to have formed the focal points of several meticulously-planned urban/ritual landscapes in the same immediate region. ${ }^{28}$ Constructed as monuments central to the propagation of an elite-patronized religion, Śaivaite temple-mountains and later Mahāyāna Buddhist temple-plains ${ }^{29}$ formed the literal focal point of both the mortal and divine universes; heaven (the five peaks of Mount Meru), earth (the mortal realm), and water (the Universal Ocean) were represented in different constructed mediums. ${ }^{30}$ Similar examples of this degree of urban planning in connection with ritual elements exist within Mesoamerican temple-cities structured surrounding sacred pyramid-temple and astrological centers ${ }^{31}$ and Dynastic Chinese notions of feng shui ${ }^{32}$ found in the construction of cityscapes and palace-complexes to embody the perfect harmonization of the built environment with the universe.

Swenson, Timing is everything, 210.

Pottier, Yasovarman's Buddhist Āśrama, 201.

Goodall and Wareham, Gifts of power, 174.

Mabbett, Devarāja, 204; Wales, The Universe Around Them, 111; Marston and Guthrie, History, 44;

Stark, Southeast Asian urbanism, 75.

Brown, Dvaravati Wheels of the Law, 3-10; Marston and Guthrie, History, 91-93.

Ang, Place of animism, 35-36.

See Geertz, Negara, 1-312; Ang, Place of animism.

Ak Yum (7th century) is thought to be the oldest temple mountain in the Angkor region.

Wales, The Universe Around Them, 121.

Mabbett, Devarāja, 203.

Dagens, Cosmogonie et architecture, 1-3.

See Coe, Social Typology, 65-85 for an older but innovative comparison.

See Meyer, »Feng-Shui« of the Chinese city, 138-155. 
In these cases, any activity beyond the original intended purpose of a religious monument, urban area, or landscape remain unclear unless explicitly noted. Thus, the recycling of spiritual places and continuous place-making as an alternative yet equally validating form of "cosmic renewal« is poorly researched archaeologically. This comes despite the visible conversion of numerous Khmer religious complexes, the evidence of which rests in the somewhat problematic seriation of Buddhist images and statues featuring identical mudra and carving-styles; these have typically been ascribed to the Theravāda tradition in Cambodia through cross-cultural art-historical comparisons with contemporary polities in northern and central Thailand such as Ayutthaya and Sukhothai. ${ }^{33}$ As a result, it proves difficult for scholars to determine how the perception of material remains reflecting a specific religious affiliation may have changed either quickly or over time; ${ }^{34}$ quoting Van Dyke, "archaeological landscapes are palimpsests - earlier sites and places are avoided, appropriated, reinterpreted, and reconfigured over time" and their products "... followed through life histories that extend from production through multiple reuse and discard $«{ }^{35}$ With that in mind, questions emerge: why were some sites converted and others abandoned? Was this a religious or secular decision, and solely based on patterns of urban settlement? How did an augmented temple or shrine embody a new understanding of universe and polity? How did local or imperial factions influence these monumental conversions? And, more importantly in the case of Angkor Thom, how did a collective understanding of a monument's prior ritual significance factor into any new role it was given by its congregated population?

The repurposing of Khmer Brahmanic and Mahāyāna Buddhist urban infrastructure for Theravāda use in the late Angkorian (c. 14th-15th centuries) and post-Angkorian periods raise all these questions. Arguably nowhere else in Southeast Asia did a single geopolitical entity undertake such a drastic shift of the overall cosmic worldview while incorporating such a vast infrastructure of surviving religious monuments from prior affiliations. ${ }^{36}$ In addition, the overall structural repurposing of Angkor Thom for Theravāda Buddhist worship, rather than the traditional foundation of a new politico-religious urban center within Angkor, represents a fundamental change in previously established traditions of Khmer urban planning. Angkor Thom was itself constructed in an act of cosmic renewal by Jayavarman VII, and while the capital absorbed numerous Śaivaite temples into its urban layout, Angkor Thom itself was a new creation.

Inclusion of the adoption of Theravāda Buddhism into a narrative of state decline, ${ }^{37}$ especially considering that Angkor was indeed abandoned by its Khmer rulers for a series of successive capitals outside of Phnom Penh in the mid-15th century after a century of domination by the Thais of Ayutthaya, often lessens any nuanced or even positive observation of 107.

34 See Shiner, Sacred space, profane space; Assmann, Religion and Cultural Memory.

35 Van Dyke, Imagine pasts imagined, 239.

36 Thompson, Buddhist Cosmopolis, 203-205.

37 Garnier, Ayutthaya, 42. 
the infrastructural, architectural, or spatial innovations attributed to this period of Theravāda practice at Angkor. It is therefore necessary to rethink these material conversions beyond the reductive narrative of "an absence of new temples«. Instead, Theravāda activity at Angkor is best respected as its own era of continuous construction and restoration within the same ritual landscape, transcending specific religious affiliation but embodying local traditions associated with the same. Angkor was "Angkor" as much as Yaçodharapura, Hariharilaya, or Indrapattha at various points in time. These politico-religious centers were interpreted through epigraphy, but "Angkor « itself was a timeless place of significance and social memory ${ }^{38}$ for populations within Cambodia and Southeast Asia overall. ${ }^{39}$ Thus, many of the material remains found within Theravāda-Period Angkor embody a localized "Angkorian" tradition of construction that does not necessarily correlate with the literal translation of any inscription or Sanskrit/Pali text. This suggests a uniqueness to the ritual agency of structures and landscapes within Angkor, indeed communicated through construction, that is not easily comparable to other regional contexts or Buddhist traditions of monastic establishment. The distinctiveness found in the transformation of Angkor Thom will be illustrated below.

\section{Reading the Angkor Thom "Grid"}

Angkor Thom was both the longest-serving and terminal politico-religious center built in the Angkor region. Founded as Indrapatt tha $a^{40}$, Angkor Thom was commissioned by Jayavarman VII during the late 12th century and was noted by Zhou Daguan as continuing to serve as the principal political center of the Khmer Empire as of 1296 CE. Fifteenth century Thai chronicles also suggest Indrapattha (Phra Nakhon) as the walled »city« sacked at various points by Ayutthayan armies during the mid-late 14th century, which was then definitively defeated at some point surrounding the year $1431 .^{41}$

Much like other Khmer politico-religious centers, this $3 \times 3 \mathrm{~km}$ urban area embodied the Indic universe with physical manifestations of the divine and mortal realms. In that same vein, Angkor Thom physically represented the Churning of the Ocean of Milk, an episode of kingship validation from Brahmano-Buddhist mythology. The moat surrounding the capital represented the World Ocean, while each causeway into the city was constructed with a row of carved devas and asura demons. Each row of figures held an enormous naga, the churning mechanism. At the center of the city stood the Bayon Temple ${ }^{42}$, an architectural pantheon of Brahmano-Buddhist deities that was constructed to embody both Mount Meru, home of Lord Indra, and Mount Mandara, the churning post. ${ }^{43}$ The date of the consecration of the Bayon is unknown, as a dedication inscription has never been recovered, but the 216 face-towers which rise from all three enclosures of the temple give stylistic evidence for the foundation of the temple to have occurred during the reign of Jayavarman VII (r. 1181-1220 CE). ${ }^{44}$

\footnotetext{
38 Swenson, Interpreting the political landscape, 472.

39 Aasen, Architecture of Siam, 61.

40 Jacques, Khmer Empire, 296.

41 Vickery, 2k/125 fragment, 55-56; Vickery, Cambodia and its neighbors, 3; Polkinghorne et al., Evidence, 116-117. A discussion on the Luang Prasoet (LP) Ayutthayan chronicles and recent unpublished inscriptions can be found in Polkinghorne et al., Evidence, fn. 93, 96.

42 See Appendix for image and floorplan of the Bayon.

43 Williams, Churning of the Ocean of Milk, 151; See also Mus, Sourire d'Angkor, 363-381.

44 Clark, The Bayon, 178.
} 
The construction of the capital also transformed the emplacement and interrelationship of ritual and vernacular structures. However, since almost all non-religious or non-imperial buildings were built of perishable wooden architecture, the reorganization of space is poorly understood. ${ }^{45}$ Mapped both by Gaucher ${ }^{46}$ and through more recent LiDAR investigations, ${ }^{47}$ what remains is a grid-plan of roads. This urban road network was assumedly laid down during the reign of Jayavarman VII ${ }^{48}$ and the canal/moat system flowing northwest to southeast from the Siem Reap River through the capital are also thought to have been installed during this time. ${ }^{49}$

The grid-plan of Angkor Thom is dominated by five arterial roads. Crossing under each gopura $^{50}$, these formed the main thoroughfares entering and exiting the capital. Four of these roads were perfectly cardinally aligned, radiating outward from the Bayon, and divided Angkor Thom into four subcardinal quadrants; these have often defined a monument's location within the capital..$^{51}$ The fifth, the Victory Gate Road, terminated at the Jayavarman VII-era Terrace of the Elephants fronting the 1oth-century Royal Palace. As earlier scholars correctly hypothesized,,$^{52}$ LiDAR and GIS analysis has proved that this road likely predated Jayavarman VII, as the eastern terminus of the Victory Gate Road appears to have been the shore of the late-9th-century East Baray marked by a large cruciform building similar in structure to a contemporary mandapa found fronting numerous temples such as Angkor Wat. ${ }^{53}$

As a result of the heavily favored eastern alignment of Śaivaite and Mahāyāna Buddhist structural layouts, ${ }^{54}$ almost every ritual feature within Angkor Thom faces east. The grid system appears to also embody this preference, with nearly twice the number of east-west (latitudinal) running roads than those laid on a north-south (longitudinal) alignment. This created rectangular city blocks inside a near-perfectly square city, varying in size, ${ }^{55}$ and as a result many smaller religious monuments are flanked on both sides by latitudinal roads without a single longitudinal road in proximity.

Previous ground surveys ${ }^{56}$ have shown that the smaller non-arterial roads which cut through the majority of these city blocks measure a maximum of $3 \mathrm{~km}$ long and $18 \mathrm{~m}$ wide, and are visible as long, slightly depressed ditches across the otherwise flat landscape. ${ }^{57}$ Thus, structures built in direct association with these roads appear to be raised, and in several cases, laterite staircases were sometimes constructed to reconcile the gentle slope between the road

Thompson, Buddhist Cosmopolis, 200.

46 Gaucher, Une utopie réalisée, 64.

47 Evans et al., LiDAR, 1-6.

48 Gaucher, L’Archéologie Urbaine, 41-42.

49 See Groslier, La cité hydraulique angkorienne, 161-202; Fletcher et al., Water management network, 658-670.

50 Gate.

51 Gaucher, L’Archéologie Urbaine, 43.

52 Cœdès, Indianized States, 174-176; See Dumarçay and Royère, Cambodian Architecture.

53 See Hendrickson, Historic routes to Angkor, 480-496; EFEO, JF 07, 158-166.

54 Gaucher, The city of Angkor, 48-49.

55 City blocks range in size from approximately $145 \times 80 \mathrm{~m}$ to $285 \times 365 \mathrm{~m}$ (measured using ArcGIS).

56 Gaucher, Archaeology and town planning, 2.

57 Gaucher, Une utopie réalisée, 67-68. 
and the monuments in question. A visible example of this placement survives at Western Prasat Top Temple (Fig. 1.O), where burnt sindora wood excavated to the southwest of the temple's "Buddhist terrace« returned AMS radiocarbon dates between 1270 and $1360 \mathrm{CE}$; NARA has interpreted this range as the upper limit range of the initial Theravāda Buddhist renovation of the temple. ${ }^{58}$



Fig. 1.o: Remains of laterite staircase to and from Western Prasat Top Temple and Buddhist terrace facing a cleared "local "road.

This grid system both incorporated older monuments and spatially prescribed the erection of newer constructions. For example, the Baphuon temple, an early-11th-century Śaivaite temple-mountain located just north of the Bayon, formed the terminus of a non-arterial (secondary or local) latitudinal road running through the Northwest Quadrant of the capital; as a result, this particular road is not equidistant between the East Gopura and Victory Gate Roads, located $62 \mathrm{~m}$ closer to the latter. In contrast, the small 1295 CE-founded Śaivaite Mangalartha temple, the final temple with a dedication inscription, was built in direct association with the same latitudinal road some $50 \mathrm{~m}$ to the south. Thus the main difference between these two temples within the Angkor Thom grid system, aside from their size and varied time periods of construction, was the way in which each monument "interacted « with the urban landscape: the grid system was built to integrate the Baphuon, while the Mangalartha appears to have been constructed in relation to the surrounding roads. Spatial analysis, in this case, can be used as a form of relative dating to determine monuments constructed before and after the implementation of the Angkor Thom road-grid. 


\section{"Buddhist Terraces«: Architectural Layout and Ritual Diacritics}

It is indeed possible that this grid-plan of local and arterial roads remained in use up until Angkor Thom's definitive abandonment. The most notable evidence for this comes not from excavations along the grid, ${ }^{59}$ but through the analysis of the stone and laterite substructures of over seventy substantial Theravāda monastic buildings (Figs. 2.1-2.4). A handful of these constructions were first mapped and cleared by Lunet de Lajonquière (1911), ${ }^{60}$ and more than sixty others were identified by Marchal (1918), ${ }^{61}$ Parmentier (1930), ${ }^{62}$ Trouvé (1935), ${ }^{63}$ Pottier (1999) ${ }^{64}$ and Gaucher (2004) ${ }^{65}$ during the 2oth century. Marchal, the only scholar thus far to have focused a publication on these remains, grouped them under the all-encompassing structural category of terrasses bouddhiques - "Buddhist Terraces « ${ }^{66}$ Since this 1918 publication, Buddhist terraces have been incorporated as evidence of larger arguments exploring Theravāda activity at Angkor, but have thus far not been extensively researched nor has the term itself been properly deconstructed. ${ }^{67}$ This inattention appears due to a lack of epigraphic evidence, and Buddhist terraces were commonly relegated to the status of "secondary monuments ${ }^{68}$. Furthermore, the only Buddhist terraces that have been studied in any detail are those identified within Angkor Thom; a small number exist in the vicinity of other temples at Angkor but are not analyzed in any publication beyond their relative cartographic positions. ${ }^{69}$

59 These were undertaken from 1992-2004. See Gaucher, Une utopie réalisée, 67-69.

60 Lajonquière, Carte du Groupe d'Angkor.

61 Marchal, Monuments Secondaires, 37.

62 Parmentier, Carte du Groupe et du Parc d'Angkor.

63 Trouvé, Angkor: Le Groupe.

64 Pottier, Carte Archéologique.

65 Gaucher, Schema Directeur.

66 Marchal, Monuments Secondaires, 1-40.

67 See Giteau, Bornage Rituel, 44; De Bernon, About Khmer monasteries, 203; Thompson, Buddhist Cosmopolis, 12; Harris, Cambodian Buddhism, 36-67.

68 Marchal, Monuments Secondaires, 1-2.

69 World Monuments Fund, Preah Khan Conservation Project, 30-31; Polkinghorne et al., Evidence, 118. 

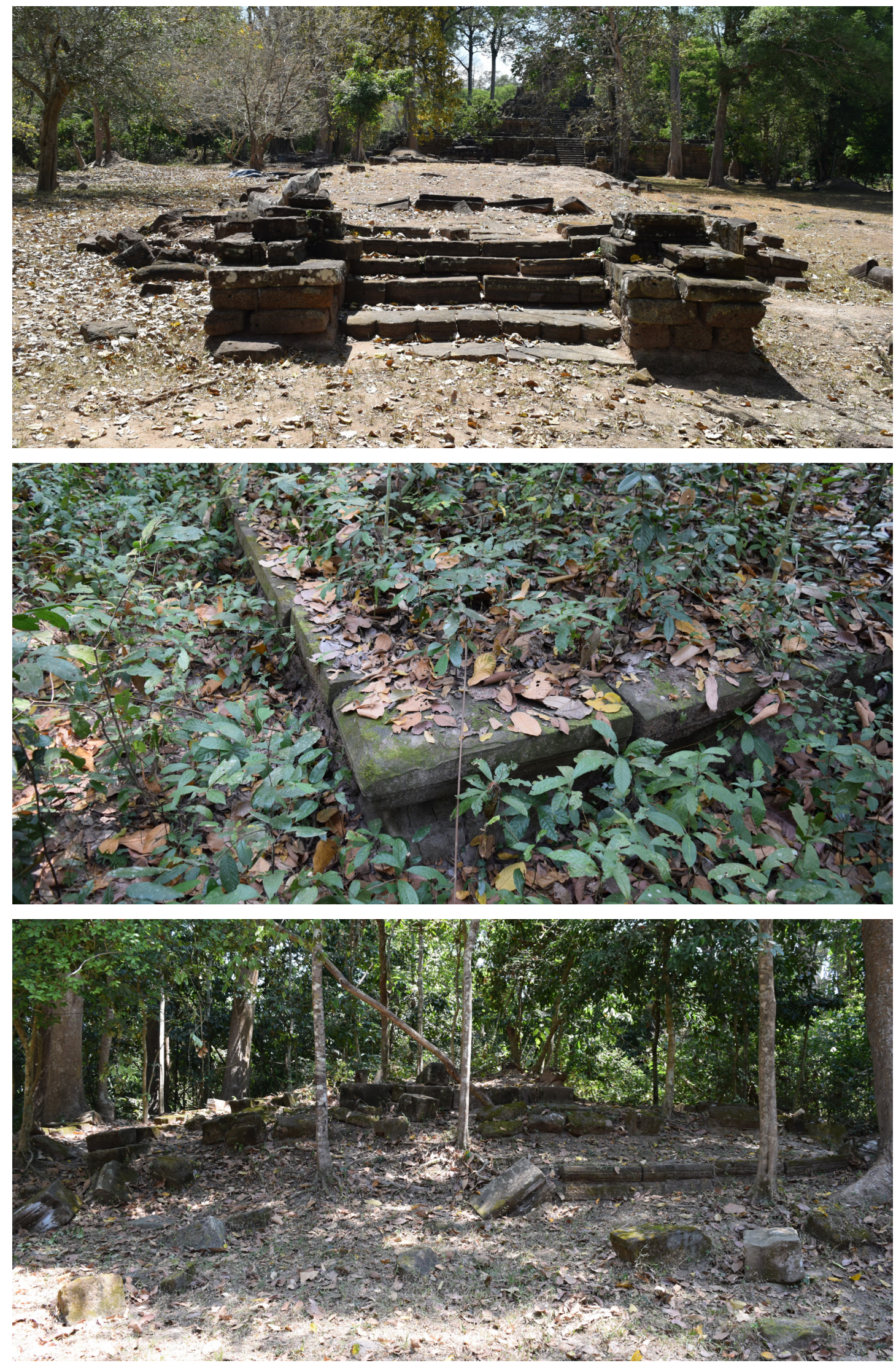

Fig 2.1 (3): Terrace adjacent to Preah Pithu Temple X (Ta Tuot) (ATVo16), Terrace J (ATVO43), and Terrace Q (ATV037), Angkor Thom: three Buddhist terraces in varied states of clearance/preservation. 


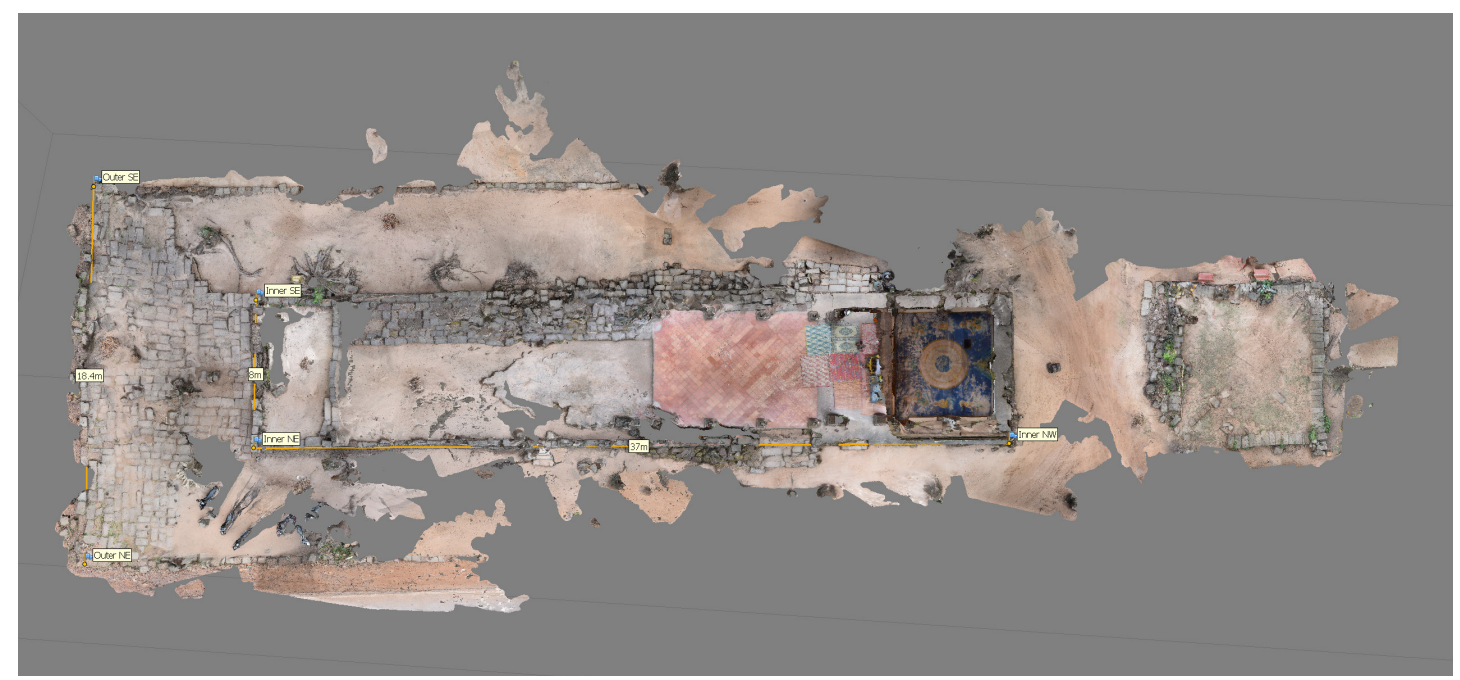

Fig 2.2.: Scaled photogrammetric floorplan with measurements of Terrasse Bouddhique III/Prah Eintep (ATVoo3), Angkor Thom. Note: the seated Buddha is covered by the roof of a modern pagoda.

Temples affiliated with both Theravāda and Mahāyāna practice, for example the Rajendravarman-era (944-968 CE) sanctuary of Bat Chum (K.266) ${ }^{70}$ were constructed at Angkor alongside Śaivaite temples as early as the 10th century. Furthermore, a Buddhist áśrama was built under Yasovarman I (r. 889-910 CE) in proximity to his state temple at Pre Rup. ${ }^{71}$ As stated, Zhou Daguan provides the first account of an active sangha ${ }^{72}$ at Angkor in 1296 $\mathrm{CE},{ }^{73}$ noting "for their temples ... there is just one icon, an exact likeness of the Sakyamuni Buddha ... it is clothed in red, sculpted from clay, and painted in many colors «, ${ }^{74}$ a likely reference to the large sandstone statues which form the ritual focal points of many Buddhist terraces identified in this study. Zhou also mentions a royal procession he witnessed, during which »the King " visited "a little golden pagoda in front of which stood a golden statue of the Buddha ${ }^{75}$ While Zhou Daguan describes saffron-robed monks during this time period, he gives no real indication as to where they practiced beyond »temples«. Vihära or prayer halls, are also mentioned within a handful of inscriptions from the 14th century, most notably the Pali-engraved K. $754^{76}$ dated to $1309 \mathrm{CE}^{77}$ which describes the dedication of one such building by Indravarman III (r. 1295-1308) prior to his abdication of the throne to pursue the life of a

70 See Sharrock, Garuda, Vajrapani, and Change, 130.

71 See Pottier, Yasovarman's Buddhist Āśrama, 199-208; Estève and Soutif, Les Yasodhāśrama, 331-355.

72 Monastic order.

73 Zhou is often inaccurate in his identifications of religion beyond the knowledge he carries from a Chinese context. For example, he frequently notes the presence of Taoist worshippers (Haris, Zhou Daguan, 52-55), a tradition not endemic to Cambodia during the Angkorian period. Harris, Zhou Daguan, 52. Also see Harris, Cambodian Buddhism, 67.

75 Harris, Cambodian Buddhism, 38.

76 Found at Wat Kok Kphos Temple, Siem Reap Province.

77 Thompson, Memoires de Cambodge, 46. 
bhikku. ${ }^{78}$ This inscription is one of very few; as Lusting et al.'s extensive tabulations have illustrated, inscriptions from the 14th century onwards are incredibly rare and thus pass down to scholars a jarringly incomplete historical record. ${ }^{79}$

Alongside large-scale renovations to pre-existing temples such as Angkor Wat, Western Prasat Top, the Bayon, the Baphuon ${ }^{80}$, and Phnom Bakheng, Buddhist terraces and stupas of varying sizes are thought to be the only durable buildings constructed at Angkor during both the late- and post-Angkorian periods. As noted, these originally supported a wooden superstructure and were covered by a tall roof applied with thatch or tile. ${ }^{81}$ Despite being markedly smaller than earlier Brahmano-Buddhist constructions, the surface area of a "Buddhist terrace« was larger in area than the central sanctuary of any temple or shrine. This larger hall was necessary to accommodate a larger congregation, which physically marked the shift to more inclusive religious practice at Angkor. ${ }^{82}$

The basic floorplan of a Buddhist terrace consists of an earthen mound, not dissimilar to the foundations of a temple, leveled and shaped by varying numbers of tiered retaining walls erected in sandstone or laterite. Floors were earthen, wooden, or tiled flagstones, and were often adorned with guardian statues (sen) or naga balustrades. The central sanctuary comprised of a large stone pedestal or collection of sandstone altars located on the easternmost edge of the highest tier, and either a large sandstone standing or seated Buddha would have been placed atop this pedestal; these sculptures today rarely exist in situ unless they were reconstructed (Fig. 3.O). Some Buddhist terraces are also associated with large octagonal or square stupas, either in proximity to or directly to the west of the central sanctuary following the same linear trajectory; others are surrounded by smaller stupas, the number of which suggests continuous significance and patronage of the monastery over time (Figs. 4.1-4.2). In some cases, a stone or laterite processional path would connect the terrace from a local or arterial road. All but three Buddhist terraces thus far identified are east-facing.

78 Epigraphers believe this event to have begun the disassociation of kings with Gods (Wales, The Universe Around Them, 123); a Śaivaite monarch is thought to have ruled until he died or was deposed by a rival.

79 Lustig et al., Words across space and time, 12-20.

80 A recent study by Leroy et al. (First Direct Dating) has dated the $85 \mathrm{~m}$ Parinirvana image on the western side of the Baphuon within a range of 1408-1451 CE through AMS radiocarbon, taken from charcoal fragments embedded in iron crampons used to support the relief.

81 Zhou Daguan notes that tile was reserved for elite or religious structures (Harris, Zhou Daguan, 49-50); roof-tiles have thus far been identified surrounding forty-one Buddhist terraces.

82 Harris, Cambodian Buddhism, 36. 


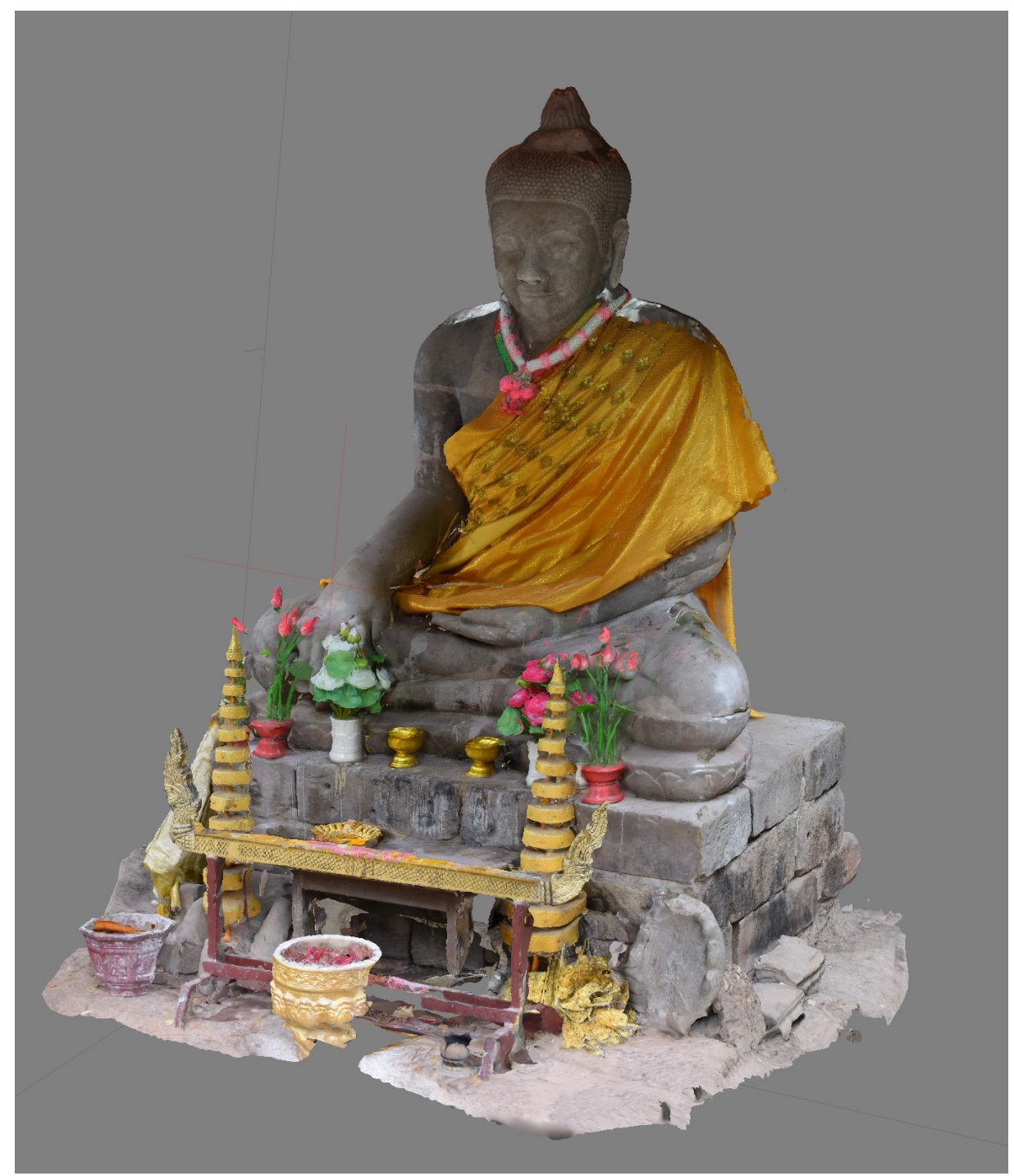

Fig. 3.o: Photogrammetric model of a Seated Buddha in situ, Preah Palilay Buddhist Terrace (ATTSOO1). 
Beyond these basic parameters, the architectural variation of Buddhist terraces found at Angkor Thom is noteworthy. Structures built on more vertical earthen mounds (1.9-4.2m in height) appear to have originally been Śaivaite or Mahāyāna Buddhist shrines renovated for Theravāda use, evident from the absence of pedestals in favor of square depressions resembling the interior of a prasat ${ }^{83}$ (Fig. 5.O) or visible renovations made to the original masonry of the structure visible as an architectural »break (Fig. 6.o). Those with flatter, tiered rectangular structures, meanwhile, bear a striking resemblance to the late-14th-16th-century monastic structures found in abundance at the successive Thai capitals of Sukhothai and Ayutthaya (Fig. 7.0); in Thailand, these were primarily constructed in baked brick and finished with plaster. ${ }^{84}$

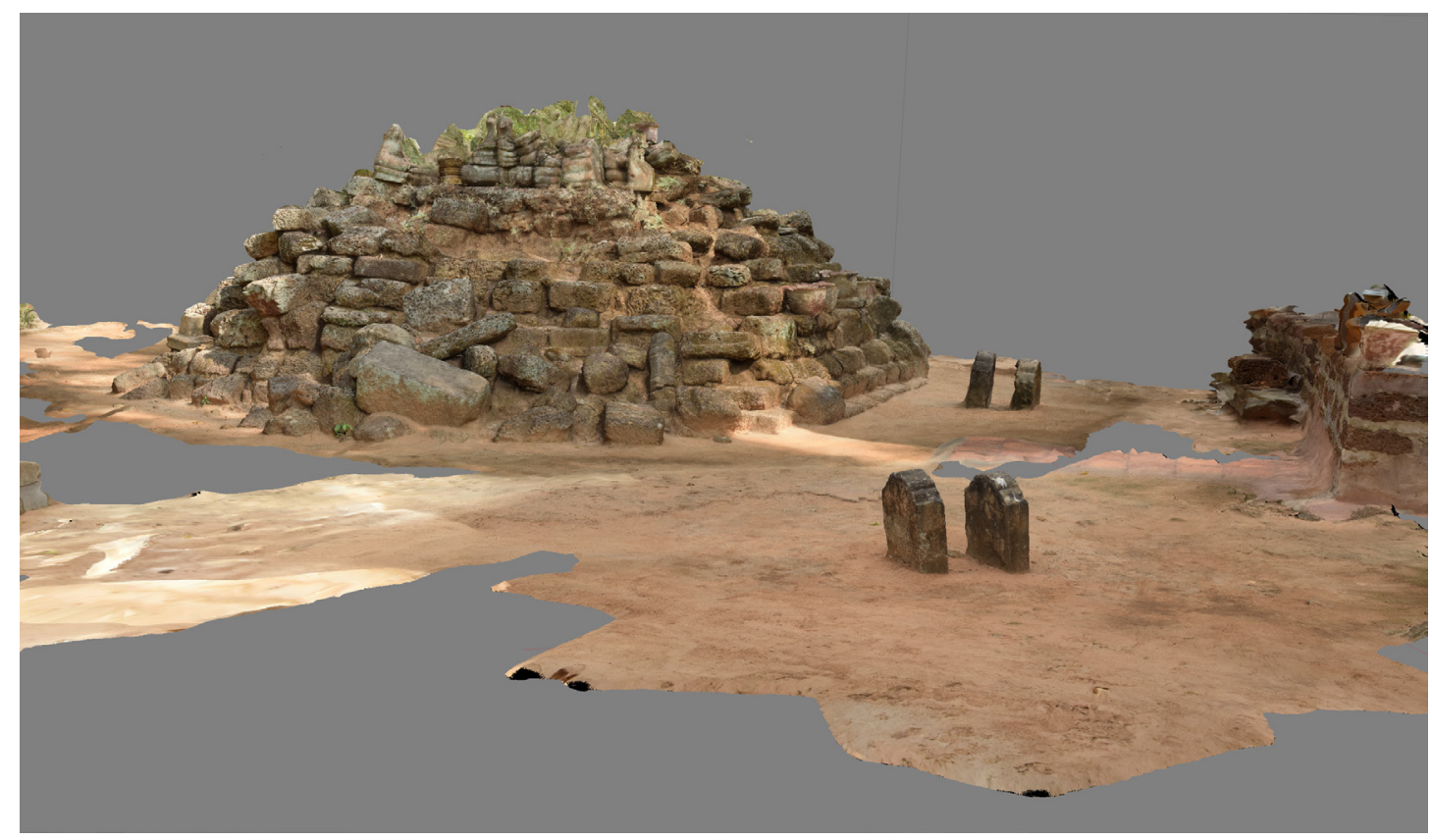

Fig. 4.1: Photogrammetric model of square-based laterite Buddhist Shrine, Terrasse Bouddhique II/Prah Kok Thlok (ATVOO2)

83 Temple tower.

84 Doehring, Buddhist Temple Building in Siam, C-3; Marchal, Monuments Secondaires, 15; Garnier, Ayutthaya, 42; See Appendix for a longer discussion on architectural comparisons between Angkor and Ayutthaya. 


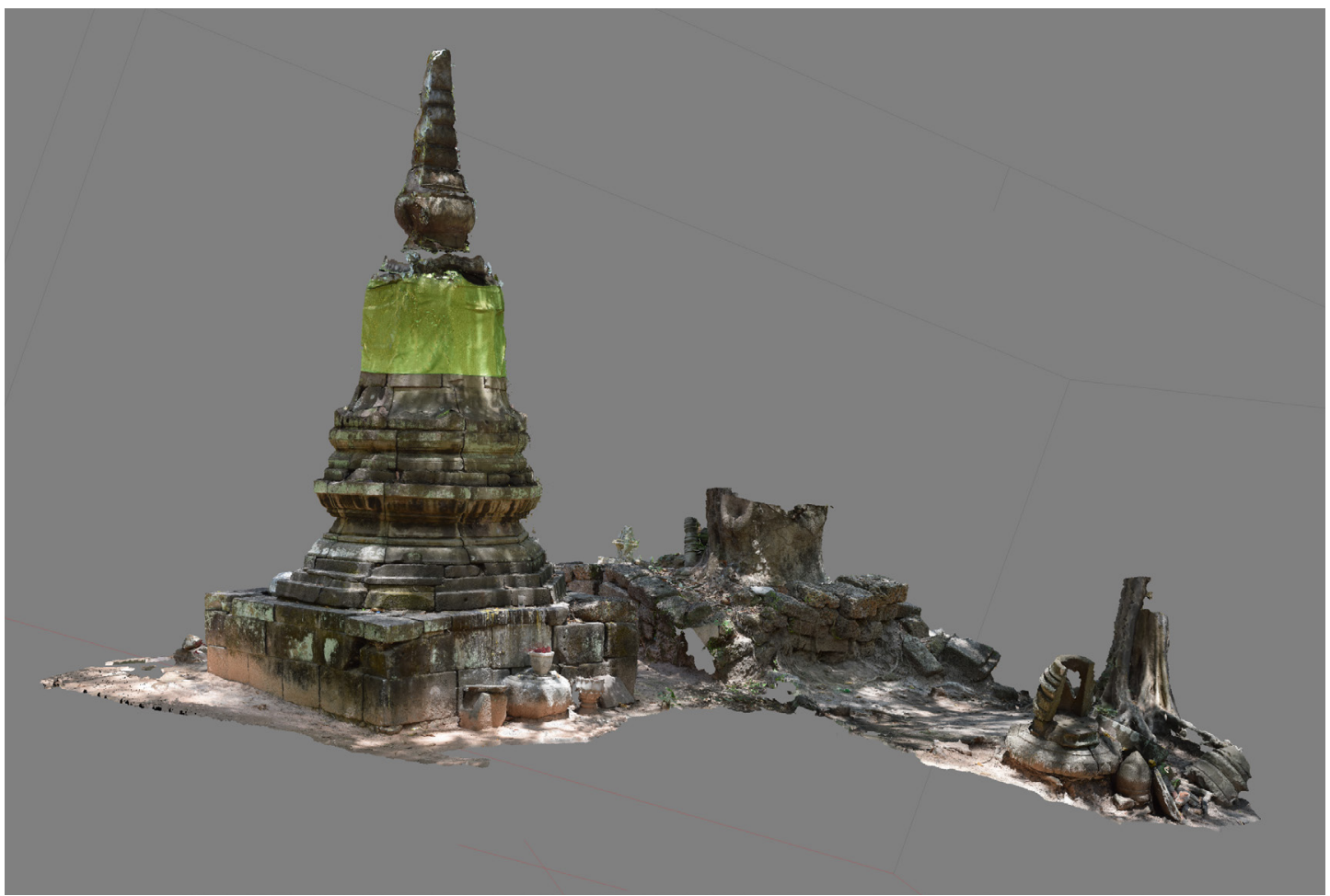

Fig. 4.2: Photogrammetric model of a stupa, Terrace S (ATV057). Reconstructed under Parmentier in 1929.

Thai influence on Angkorian Theravādin architecture and statuary ${ }^{85}$ is to be expected during this period, considering the encroachment of Ayutthayan control towards Angkor which occurred prior to its "abandonment $«{ }^{86}$ The practice of Theravāda Buddhism in Cambodia is also thought to have been heavily influenced by Thai traditions, despite gathered evidence to suggest that religious connections were forged between Cambodia and Theravāda polities in Sri Lanka. ${ }^{87}$ As a result, indirect or direct Sukothai or Ayutthayan influence on Angkor, possibly even because of direct occupation, ${ }^{88}$ is thought to have occurred in the later years of the Khmer Empire.

85 See Giteau, Iconographie du Cambodge, 142.

86 Briggs, Ancient Khmer Empire, 244; Vickery, Cambodia and its neighbors, 1-71; Garnier, Ayutthaya, 42; Rooney, Ancient Sukhothai, 217.

87 Goonatilake, Sri Lanka-Cambodia relations, 196-201. The son of Jayavarman VII, Tamalinda, journeyed to Sri Lanka with a party of Burmese monks to receive blessing and ordination at the Mahavihara (possibly in Anuradhapura) in $1180 \mathrm{CE}$.

88 See Polkinghorne et al., One Buddha can hide another, 575-624; Polkinghorne et al., Evidence, 99-113. 


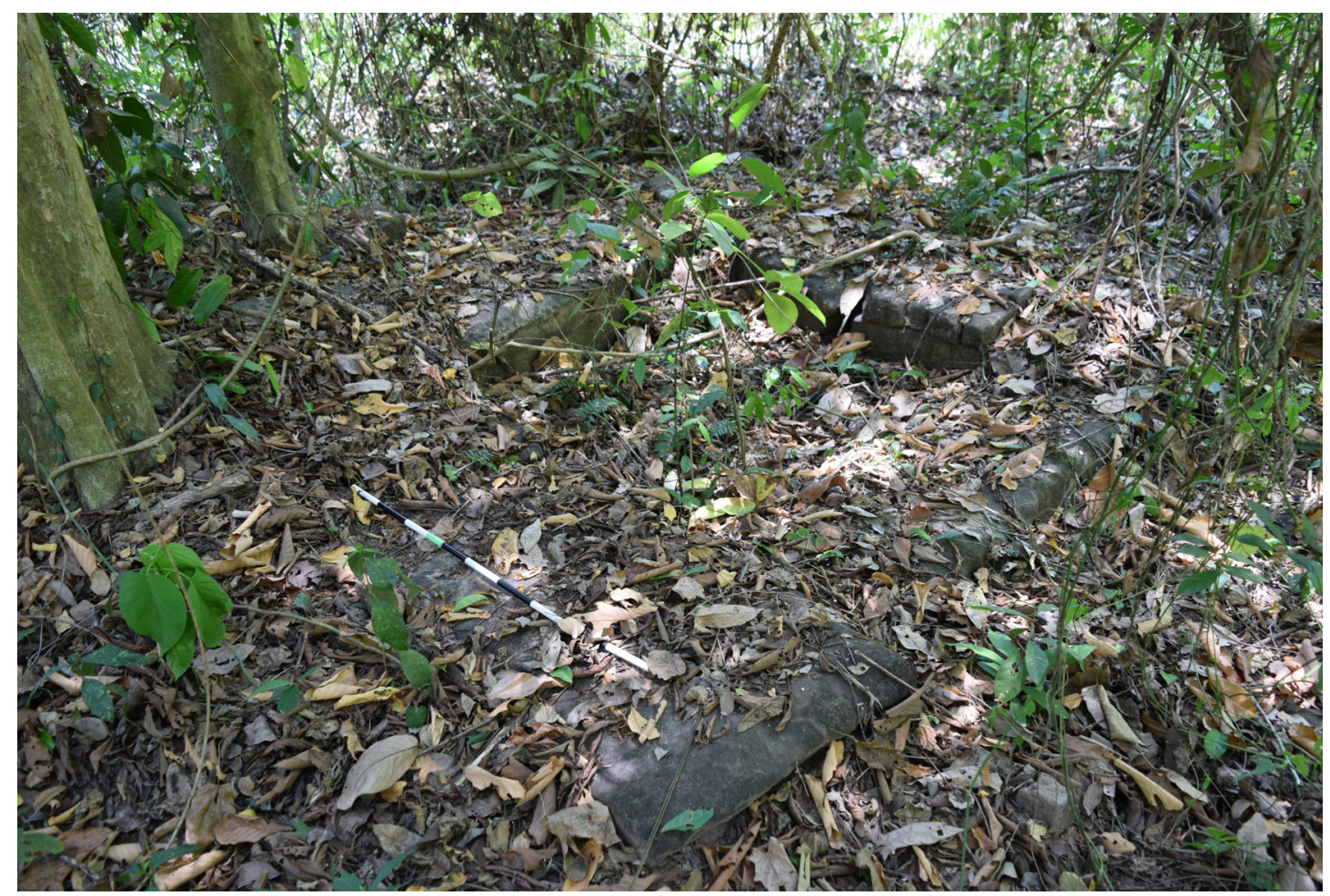

Fig. 5.o: Base of a prasat depression marking the central sanctuary of a possible converted temple (ATVo33), SW Quadrant, Angkor Thom. Scale $=1 \mathrm{~m}$. 

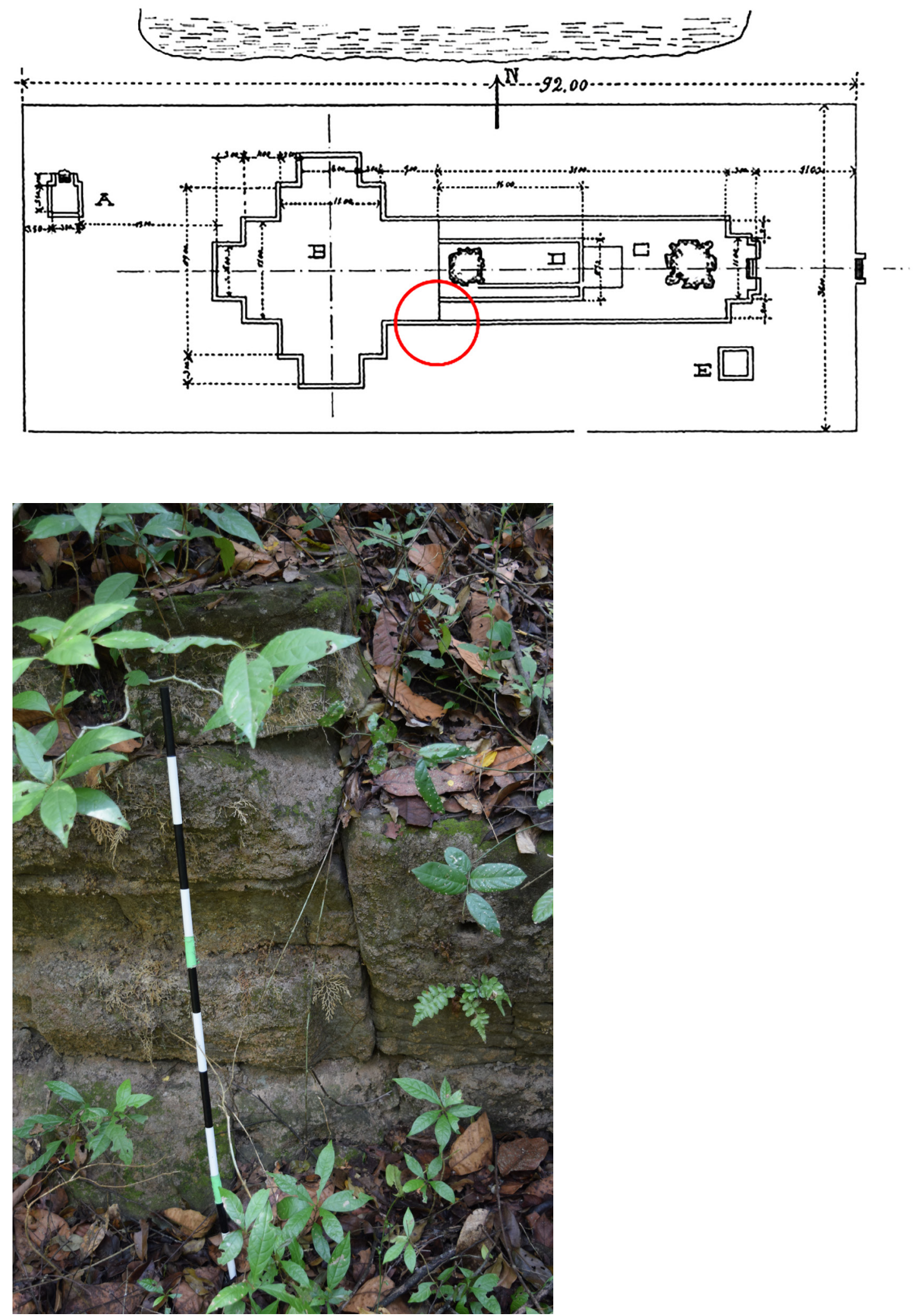

Fig. 6.0 (2): Architectural "break" between vihära and original building, Terrasse Bouddhique No. 4 (ATVOog). Shown referenced on original drawing of Buddhist terrace by Henri Marchal (Monuments Secondaires, $\mathrm{Pl} . \mathrm{X}$ ) 
The most ritually significant aspect of Buddhist terraces is the presence of $\operatorname{sim} \bar{a}$, a series of blessed buried stone orbs or votive deposits ${ }^{89}$ demarcating the cardinal and subcardinal points of the majority of Theravāda monastic structures at Angkor Thom. Above ground, the placement of sima are denoted by carved $8 \times 2$ tombstone-shaped boundary markers ( $\operatorname{sim} \bar{a}$ stones) $;{ }^{90}$ these remain in situ or are overturned in close proximity to their original positions (Fig. 8.1-8.2). According to the Mahāvagga in the Vinaya Pitaka of the Theravāda canon, ${ }^{91}$ sima delineate a place where novice monks can be ordained into the sangha. While this Pali text declares that any number of blessed objects can be used to demarcate ordination space, ${ }^{92}$ the tradition of erecting boundary stones is thought to have originated in Mon monasteries of the Dvaravati Culture of northern Thailand during the 8th century. ${ }^{93}$ The use of simā is believed to have then been adopted in Sukhothai as early as the 12th century, ${ }^{94}$ and was later imported to Cambodia, ${ }^{95}$ though the specifics of this cultural transmission are unclear. That said, while sima $\bar{a}$ vary little from monastery to monastery at the Thai capitals, thirteen distinct artistic styles and shapes of simā have thus far been identified within Angkor Thom alone, suggesting a degree of individualization of craftsmanship from monastery to monastery.

89 Marchal, Monuments Secondaires, 9.

90 Giteau, Bornage Rituel, 108.

91 Murphy, The Buddhist Boundary Markers, 88.

92 De Bernon, About Khmer monasteries, 208-211; Murphy, The Buddhist Boundary Markers, 88.

93 Murphy, The Buddhist Boundary Markers, 77.

94 Murphy, The Buddhist Boundary Markers, 201.

95 Jessup, Temples of Cambodia, 236. 

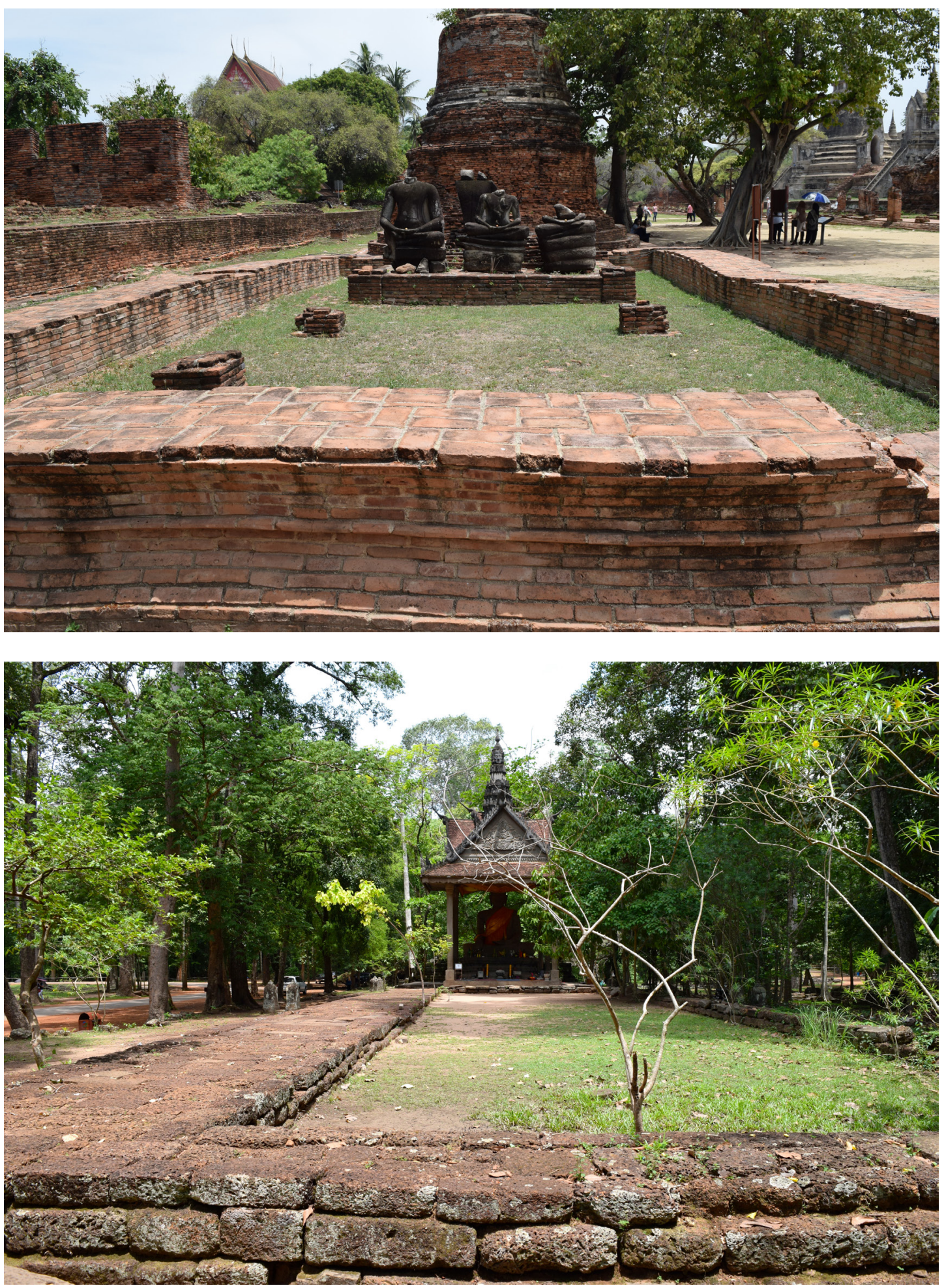

Fig. 7.o (2): Side-by-side architectural comparison of image house from Wat Phra Si Sanphet (1), Ayutthaya, and Prah Ngok Buddhist Terrace (ATVoo1) (2), Angkor Thom. 
Oddly, no simā stones are mentioned within 14th-century inscriptions attributed to early Theravāda patronage in Cambodia, nor are they mentioned in Zhou's account, suggesting that the placement of boundary stones was introduced to Angkor no earlier than the mid-late 14th century, which potentially gives credit to the more dominant city-state of Ayutthaya for the introduction of sima to Cambodia. ${ }^{96}$ NARA, too, dates the placement of the sima at Western Prasat Top to the 16th century, although it is unclear how they come to this conclusion beyond their studies of block placement through anastylosis. ${ }^{97}$ In some instances, especially in more inaccessible areas of Angkor Thom, simā surround areas containing only fragmented statuary and altars (Fig. 9.0)..$^{98}$
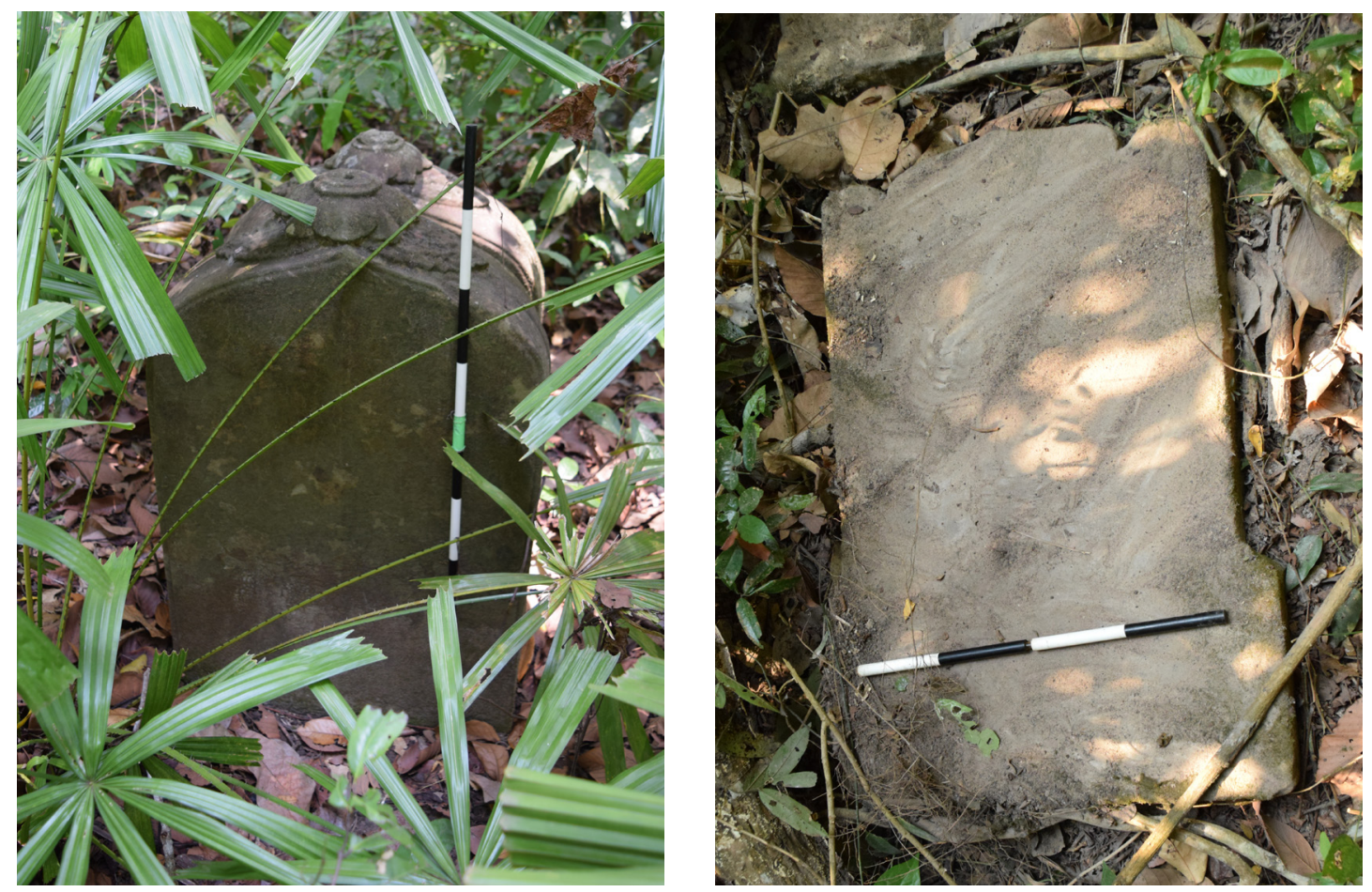

Fig. 8.1: Pair of simà boundary stones in situ, Terrasse Bouddhique No. 3 (ATVoo7). Scale $=1 \mathrm{~m}$. Fig. 8.2: Simä boundary stone uprooted with visible base, Monument 26 (ATVo52). Scale $=0.2 \mathrm{~m}$.

96 See Cœdès, Indianized States, 236; Vickery, 2k/125 fragment, 54-56

97 See NARA, Western Prasat Top, 119.

98 Giteau, Bornage Rituel. 


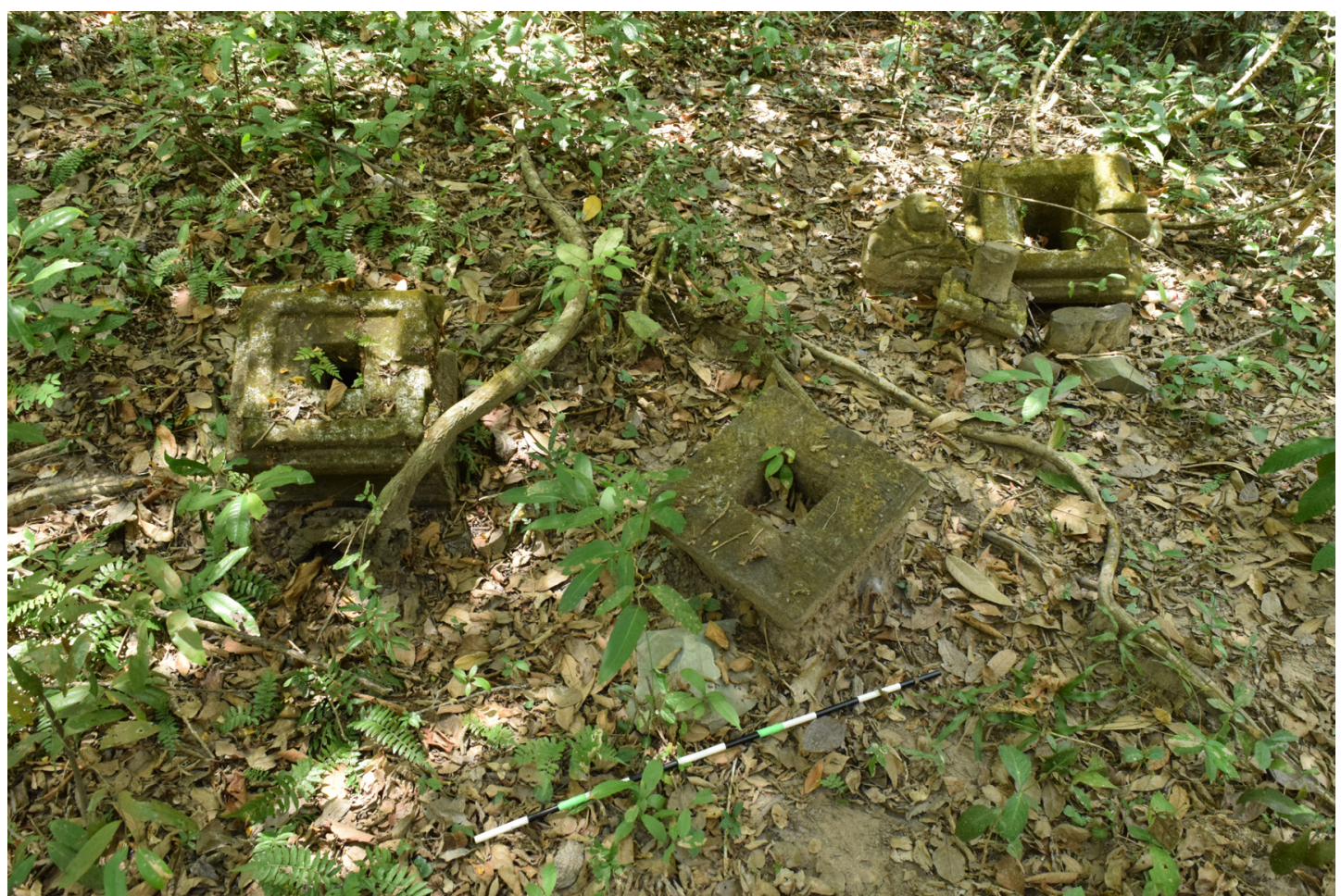

Fig. 9.o: Altar scree demarcated by simā, Terrace R (ATVO49). Scale $=1 \mathrm{~m}$.

Thompson classifies Buddhist terraces and other monastic structures, which she categorizes solely as a post-Angkorian architectural feature, as a ritual hybrid of the traditionally separate vihära (prayer hall) and uposathāgära (ordination hall) ${ }^{99}$. Thompson cites K.82, an inscribed stele from the 12th-century Mahāyāna Buddhist temple of Wat Nokor, Kampong Cham Province, written in both Pali and Khmer, which clearly states that sima were placed surrounding a vihāra during its conversion to a Theravādin sanctuary in $1566 \mathrm{CE} .{ }^{100}$ Thompson also argues that the term uposathägära is not found in any epigraphic sources from the Angkorian or post-Angkorian periods. ${ }^{101}$ The placement of simā surrounding this structure therefore permitted both ordination and prayer to take place in a single building, which no doubt established simā-delineated Buddhist terraces as the most significant structures constructed within Theravāda Angkor for daily ritual. ${ }^{102}$ In fact, Buddhist terraces might be best classified as a specific type of Theravāda architecture resembling Ayutthayan prayer halls, while the term prah vihar might better reference Theravāda spaces in a Khmer context surrounded by boundary stones irrespective of structural form. ${ }^{103}$

99 Also known as ubosot (Thai) or bot (later Cambodian).

100 Thompson, Memoires du Cambodge, 402-403.

101 Thompson, Memoires du Cambodge, 46.

102 Converted temples such as Angkor Wat were no doubt held in higher regard, and may have been significant enough to bypass the need for simā to conduct rituals. No Theravāda boundary markers have been unearthed directly surrounding Angkor Wat, the Bayon, the Baphuon, or any other converted temple except for Western Prasat Top.

103 The Khmer term prah vihar refers to both Hindu/Mahayana and Theravāda sanctuaries and is today used to reference many unidentified or unnamed ancient sacred places in modern Cambodia. The term wihan is used in the Thai context, as a translation of the more pan-regional term vihära. 
Worship directed towards a single monastic structure with multifunctional ritual agencies, atypical to Theravāda worship elsewhere in Southeast Asia, could indeed be directly inspired by the "focal point " position of religious areas within prior Khmer religious practices of Śaivism and Mahāyāna Buddhism. Almost always confined to a single structure, Buddhist terraces appear as no more than an evolution of the traditional prasat space to suit the tenets of a new religious tradition. While clusters of monastic structures do exist, ${ }^{104}$ there are very few areas which embody the layout of a Sinhalese or Thai complex with a single sima $\bar{a}$ demarcated structure for ordination. Thus, Buddhist terraces reflect the reality that culture is arguably the heaviest influence on religion regardless of instruction given by any traditional text or sangha lineage.

\section{Infrastructural Interaction: Old Roads, New Monasteries}

Two seasons of extensive site investigation were undertaken at Angkor Thom from FebruaryMay 2017 and February-April 2018. Data was initially collected through the layering of 2oth-century French hand-drawn maps, GIS data, satellite imagery, and aerial LiDAR data acquired from Phase I (2010-2011) of the Greater Angkor Project. ${ }^{105}$ Points of interest were plotted using ArcGIS and uploaded onto a Garmin Montana 6800, and structures/areas which were identified as Buddhist terraces/prah vihar through ground-truthing were catalogued, measured, and photographed (Map 1).

Fifty-nine Buddhist Terraces were catalogued within the walls of the Khmer capital during the time this study was undertaken. ${ }^{106}$ As discussed above, this designation denotes simā stones in situ, rather than those salvaged from other monastic structures and placed in the central sanctuary as votive deposits. ${ }^{107}$ Alongside these, classified under the label ATV (Angkor Thom Vihār/Vihära), twelve Buddhist terrace-type structures without simā stones were also noted under the heading ATTS (Angkor Thom Terrace Structure) ${ }^{108}$. This created a sample size of seventy-one monastic buildings within a $9 \mathrm{~km}^{2}$ area from which to extrapolate data. ${ }^{109}$

104 See Appendix Section 2 for a discussion on multi-structured monasteries and structural and spatial connections to Ayutthaya.

105 Evans et al., LiDAR, 2.

106 Many of these structures were identified on maps of Angkor Thom by Trouvé (Angkor: Le Groupe) and by Gaucher (Schema Directeur) but were never specifically marked as Buddhist terraces. Gaucher's map notes many nowcatalogued Buddhist terraces as "vestiges maçonnée identifié«, "zone de vestige identifiée«, and "zone de vestige étendue non-identifiée/zone de vestige ponctuelle non-identifiée«; no attempts at further classification were undertaken. However, in publication, Gaucher briefly glosses over his drawing of a sanctuaire Bouddhique (Terrace H(ATV012)) (Une utopie réalisée, 72-73), but does little more than present this as an element of his fieldwork.

107 Giteau, Bornage Rituel, 7-8

108 ATTS classifications do not suggest these structures never were surrounded by simä; rather, they are no longer in situ. It is assumed that the sima were either removed from their cardinal and subcardinal places of consecration at an unknown point or the construction of ATTS-classified structures predates the tradition of sima used to demarcate Theravāda places of worship in Cambodia. More excavation work and absolute dating must be undertaken at sites without simā to determine a possible structural chronology based on boundary stone placement.

109 The original classification of monuments was undertaken through a series of mapping projects (see fn. 60-65) between 1900-1957, but the numerical system appears individualized by the cartographer (See Table 1). 


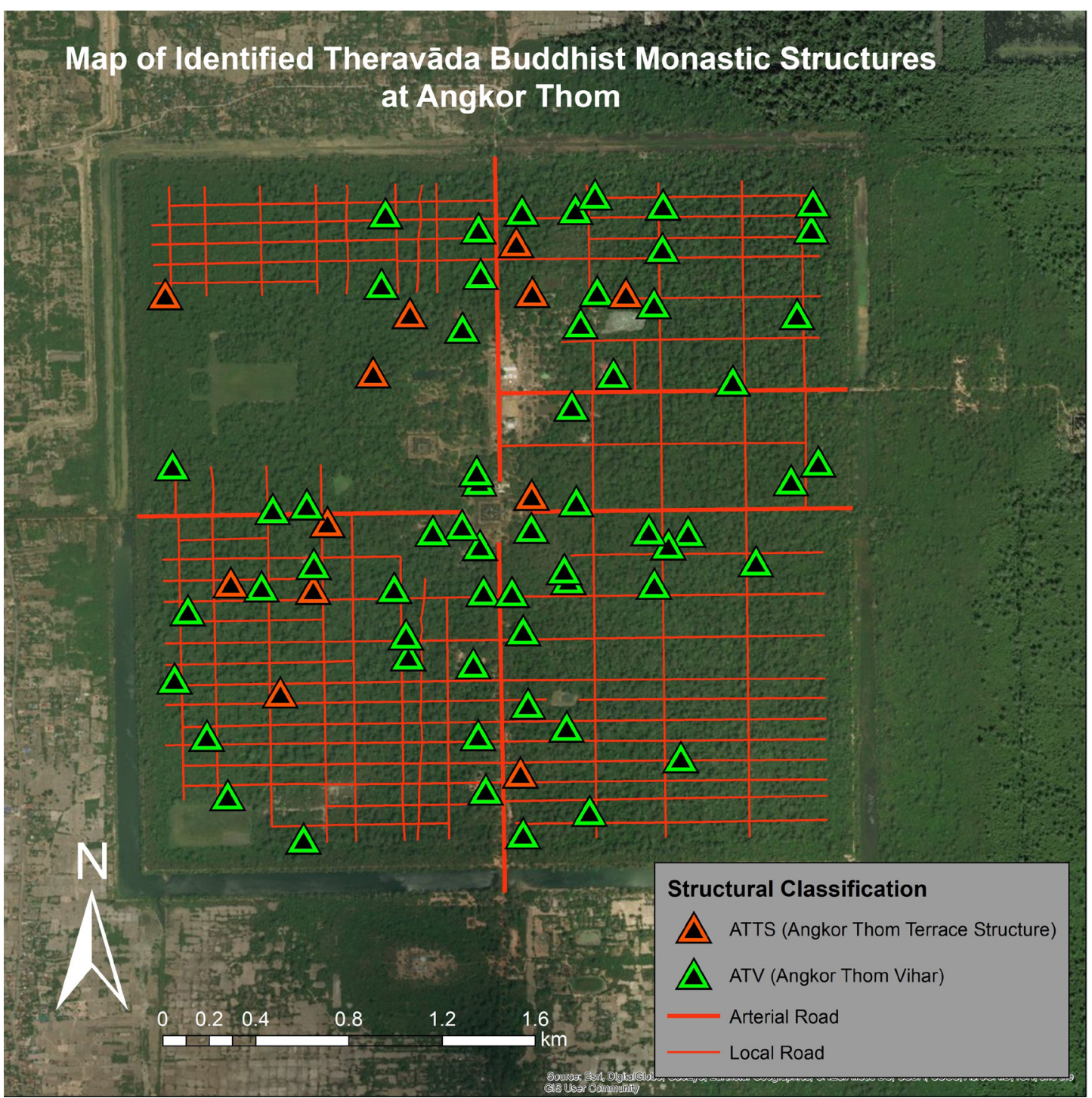

Map 1: Location of Theravāda Buddhist monastic structures catalogued within Angkor Thom in relation to the ancient road-grid. Grid-plan mapping attributed to Gaucher (Schema Directeur) and Evans et al. (LiDAR, 2). 
In conjunction with the analysis of LiDAR, the spatial and structural data observed and documented during this study aided in proving that the Jayavarman VII-era road grid had a direct impact on the placement and construction of Buddhist terraces at Angkor Thom. Thus, the urban infrastructure of Angkor Thom likely remained intact following the "abandonment " of the Khmer elite class in the mid-15th century. All fifty-nine sima-demarcated Buddhist terraces and twelve non-delineated structures identified at Angkor Thom are constructed within 10om of any road, though non-arterial roads were favored for construction by monastic communities; thirty-two vihära were built more than 100m away from the city's five main arteries. This distribution suggests that monasteries were more likely built to serve small local congregations, a practice that departed notably from the more centralized yet exclusive elite worship embodied by earlier Khmer Śaivaite traditions ${ }^{110}$.

Roads no doubt had a significant influence on the placement and construction of monastic structures, given that roads also influenced the construction of secular buildings and domestic dwellings. Buddhist terraces associated with a road running in any direction, even adjacent to the western side closest to the central sanctuary, were almost always found to feature raised landscaping in the form of a tract $^{111}$ or "ramp « leading directly from the road to the monastery. Bridges are also hypothesized to have been used to connect Buddhist terraces to arterial roads over the dykes which lined them; these may have continued to supply water into the capital after the 15 th century, ${ }^{112}$ which, in rare cases, are marked with the remains of guardian statues which stood at the terminus of the bridge; these have, over time, tumbled into the extant canal dykes. Modern examples of these bridges can be found south of Angkor in the modern town of Siem Reap, for example at the converted 1oth-century temple of Preah Einkosei, where a (formerly) wooden bridge flanked by guardian statues leads across the Siem Reap River to the monastery.

\section{The North-South Gopura Road Zig-Zag}

Arterial roads are believed to have continuously formed the major thoroughfares within the capital during the post-Angkorian period despite their terminuses being less clear than earlier epochs. Evidence for this comes from the seemingly largest concentration of Theravāda monastic structures identified anywhere at Angkor Thom built along the South Gopura Road. The nine substructures located here, combined with the four monasteries built following the North Gopura Road, the complex of Tep Pranam, and six identified Buddhist terrace structures surrounding the Bayon, together form a continuous uninterrupted line of twenty purpose-built monastic structures spanning $3 \mathrm{~km}$ from North to South Gopura. No structure

110 Harris, Cambodian Buddhism, 36; Woodward, Practice and belief, 250. The argument of »inclusivity« vs. »exclusivity « defined by religious transition is primarily predicated on the expansion of central sanctuary spaces in relation to prasat, the rapid production of these spaces in non-centralized areas, and the abdication of Indravarman III rather than his death on the throne as noted in K.754 as a stark contrast to the apotheosis of previous kings. It should be noted that this argument is less predicated on physical evidence and instead on deductive assumptions based on the above in lieu of actual inscriptions, but the sudden change in ritual architecture is no doubt noteworthy and also appears to embody a more inclusive tradition. More work is thus necessary to properly assess social hierarchies vis-à-vis religious practice during the late- and post-Angkorian periods.

111 Marchal, Monuments Secondaires, 24.

112 Fletcher et al., Development of the Water Management System, 65. 
is located further than $110 \mathrm{~m}$ from either arterial road, and no terrace is constructed further than $300 \mathrm{~m}$ from the next. Furthermore, there is evidence that these monasteries were staggered, allowing for only one monastic structure to be constructed between each pair of latitudinal running local roads intersecting each arterial road (See Map 2). No supporting buildings except for brick-inlaid occupation mounds and stupas were found alongside any structure south of the Bayon nor north of Tep Pranam, creating a series of single-structure "focal point " monasteries. These structures may have been more spatially affiliated with others in the layout than any since-disappeared wooden supporting structures, and may have also reflected patterns of dense settlement along arterial routes during this period of Angkor Thom's history. This fascinating spatial phenomenon was designated the NorthSouth Gopura Road Zig-Zag.

It is important to note that only thirteen of these structures can be readily associated with any "zig-zag" based on layout alone, and even then without excavation or accurate radiocarbon dates this hypothesis is heavily reliant on spatial association. Tep Pranam for example, undated but originally housing a 9th-century stele imported from a Buddhist áśrama dedicated by Yasovarman I (r. 889-910 CE) ${ }^{113}$ formed the focal point of its own walled monastic complex, and, similar to others such as Western Prasat Top Temple, featured a »break" between the original Brahmano-Buddhist building and the rectangular viharra renovation. Tep Pranam is therefore really only associated with this zig-zag by extension, being located along the North Gopura Road, and does not warrant further discussion. The large simādemarcated viharra surrounding the Bayon, too, are most likely associated with this temple and only spatially with a more complex longitudinal alignment of structures; that said, the Bayon undoubtedly played a role in the establishment of the southern portion of this route as a ritually-significant monument.

What is odd about these remaining structures is their relative ordinariness compared to other Buddhist terraces/prah vihar and monastic "focal point " structures within the capital. In terms of base tier structural area, of which the average of all ATV and ATTS structures at Angkor Thom was measured to be $583.91 \mathrm{~m}^{2}$, the cumulative average of these thirteen monuments along the zig-zag was almost $90 \mathrm{~m}^{2}$ less at $495.64 \mathrm{~m}^{2}$ (Table 1 ). ${ }^{114}$ Two converted temples feature in this layout on the Southern Zig-Zag, and three Ayutthayan-style tiered structures and one funerary structure were identified, but the majority of these structures are currently too dilapidated ${ }^{115}$ to determine the original layout or to complete a definitive structural typology. Only one features the remains of a monumental Buddha in proximity to its pedestal. This structural variation is of course significant, and suggests both the tenacity of populations to build religious structures along well-traveled urban roads and a gradual structural morphology which, with further research, may someday successfully be chronologized.

113 Pottier, Yasovarman’s Buddhist Āśrama, 200.

114 Measurements recorded in the table were taken of the base tier of each structure. In cases where no masonry could easily be identified, measurements were taken between the four cardinal sīmā.

115 Or have been restored as modern monasteries - see Table 1. 


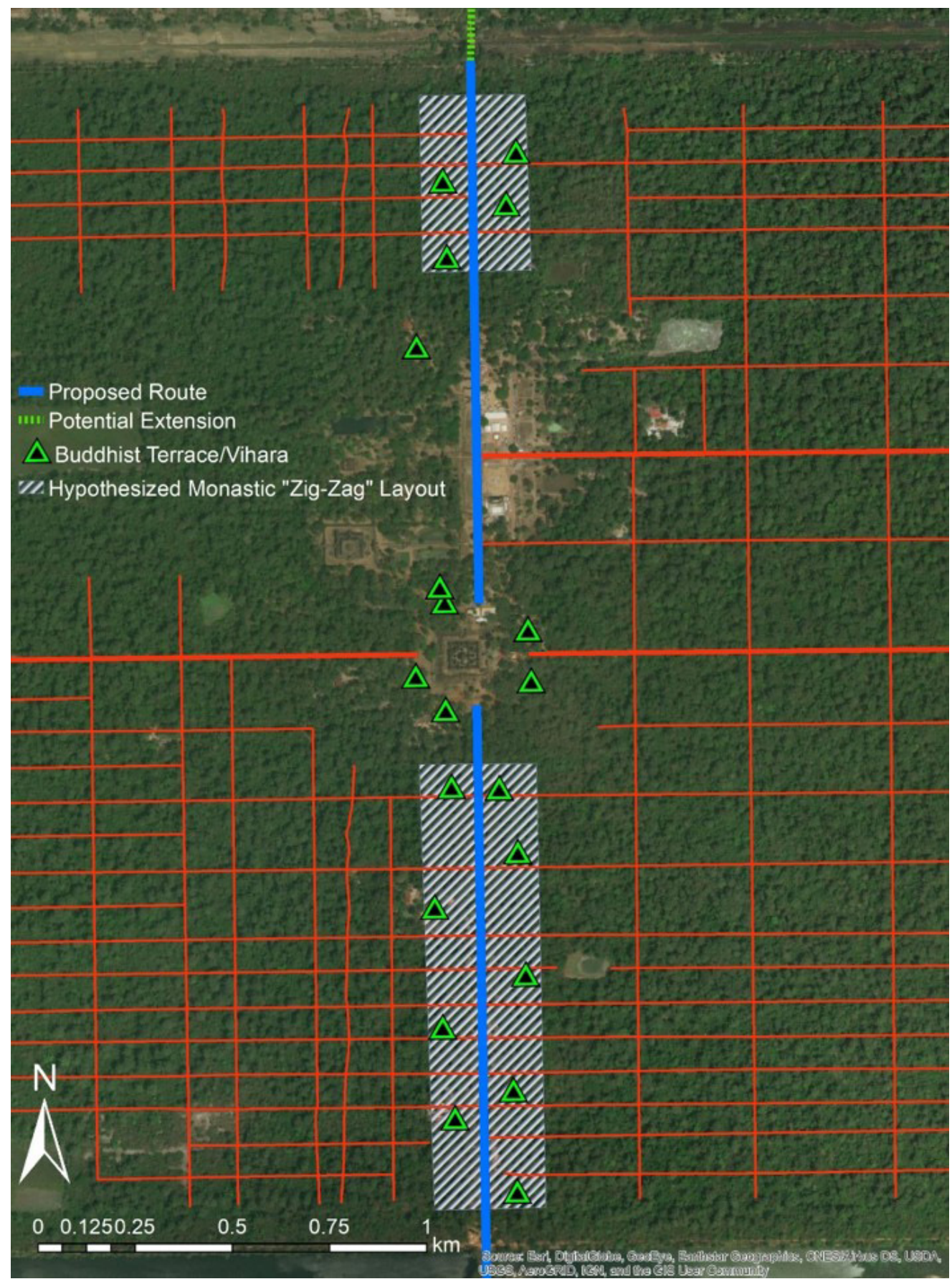

Map 2: Map of the North-South Gopura Road Zig-Zag spatial pattern (center), mapped in 2017. 


\begin{tabular}{|c|c|c|c|c|}
\hline $\begin{array}{l}\text { ORIGINAL } \\
\text { MAPPED NAME }\end{array}$ & $\begin{array}{l}\text { CLASSIFICATION } \\
\text { \# FOR THIS } \\
\text { STUDY }\end{array}$ & NOTES & $\begin{array}{l}\text { NORTH OR } \\
\text { SOUTH ZIG-ZAG? }\end{array}$ & $\operatorname{AREA}\left(\mathrm{m}^{2}\right)$ \\
\hline Terrasse IV & ATV004 & Modern restoration. & South & 1120 \\
\hline Terrace D & ATV013 & Ayutthaya-type layout. & North & 225 \\
\hline Terrace B $(2$ of 2$) *$ & ATV014 & $\begin{array}{l}\text { Faces west, Ayutthaya-type } \\
\text { layout. }\end{array}$ & North & 352 \\
\hline Terrace E & ATV015 & $\begin{array}{l}\text { Ayutthaya-type layout - poor } \\
\text { condition. }\end{array}$ & North & 140 \\
\hline Terrace $\mathrm{M}$ & ATV032 & $\begin{array}{l}\text { Modern restoration - } \\
\text { measurements based on } \\
\text { Monuments Secondaires } \\
\text { (31). }\end{array}$ & South & 98 \\
\hline Monument 68 & ATV033 & Converted Temple & South & 420 \\
\hline Terrace U & ATV035 & Converted Temple & South & 350 \\
\hline Terrace V & ATV036 & $\begin{array}{l}\text { Funerary structure } \\
\text { surrounded by sim } \bar{a} \text {. }\end{array}$ & South & 748.24 \\
\hline Terrace Q & ATV037 & Ayutthaya-type layout. & South & 712.5 \\
\hline N/A & ATV038 & $\begin{array}{l}\text { East edge has been destroyed } \\
\text { - dimensions are of extant } \\
\text { remains. }\end{array}$ & South & 505.6 \\
\hline Terrace B ( 1 of 2$)$ & ATTS003 & $\begin{array}{l}\text { Only structure with extant } \\
\text { pedestal Buddha remains. }\end{array}$ & North & 210 \\
\hline Monument Inedit & ATTS009 & Structure unclear, no sìmā & South & 1240 \\
\hline $\mathrm{N} / \mathrm{A}$ & ATV058 & $\begin{array}{l}\text { Structure unclear, } \\
\text { dimensions approximate, } \\
\text { length based on simm } \bar{a} \\
\text { position. }\end{array}$ & South & 322 \\
\hline & & & AVERAGE $\left(m^{2}\right)$ & 495.64 \\
\hline
\end{tabular}

* Marchal (Monuments Secondaires, 24-25) grouped these structures together in a single site description.

Table 1: Measurements and structural notes for monasteries mapped as part of the North-South Gopura Road zig-zag spatial alignment.

A traditional ritual importance surrounding the South Gopura is suggested in Zhou Daguan's writings, as he notes: "The seventh month is the time for "rice burning", when new rice that is ready for harvesting is ceremoniously received outside the south gate, and burned as an offering to all the Buddhas ". ${ }^{116}$ This indicates that such Buddhist affiliations surrounding at least the South Gopura may have originated as early as Jayavarman VII's Mahāyāna reforms. Thus, the ritual construction seen here, at least if undertaken during the late Angkorian period, could be intentional and in some manner patronized by local sangha groups; it is unclear how involved kings were in the patronage of religious structures, despite evidence for these events noted in K.754. In fact, the procession of independent monasteries finds an interesting parallel to the use of naga balustrades, supporting shrines, cruciform terraces, or guardian statues fronting the central sanctuary of earlier temple-mountains like Angkor Wat or Phnom Bakheng.

116 Harris, Zhou Daguan, 63. "All the Buddhas« may be indicative of the continued presence of Mahāyāna Buddhism at Angkor. 
Using the span of an entire arterial thoroughfare from the North to the South Gopura to construct a uniformly spaced layout of religious buildings, the zig-zag configuration points to the continuous cosmological significance of the larger regional spatial configuration of Angkor Thom beyond site-level simä demarcation. Much like Jayavarman VII's original capital, the most prominent and significant structure most likely remained the Bayon, with two equidistant Buddhist terraces constructed $275 \mathrm{~m}$ south demarcating what is likely the southern ritual or spatial boundary of the former state temple. It could even be argued that this layout is undoubtedly truer to the original purpose behind the 12th-century construction of Angkor Thom and that of earlier Khmer temple-complexes: that of ritual significance, regardless of the way it was manifested.

\section{Interpreting the Larger Theravāda Landscape of Greater Angkor}

An additional eight Buddhist terraces have thus far been identified outside of Angkor Thom during this study. ${ }^{117}$ Each of these is located within a $2.4 \mathrm{~km}$ range of one of Indrapattha's five gopura, and five of these are located directly or indirectly proximate to an extension of the South Gopura Road connecting Angkor Thom to Angkor Wat. Unlikely coincidental, a number of Buddhist terraces, both purpose-built vihära and converted temples, are laid out along this road in a similar zig-zag pattern to what is found on the South Gopura Road. These include Baksei Chamkrong, the Yasovarman I-era state-temple of Phnom Bakheng, the Jayavarman VII-era hospital of Ta Prohm Kel, and a small shrine known as Prasat Rorng Ramong. All four of these temples appear to have been restored in a similar manner to Angkor Wat. For instance, the central sanctuary of Phnom Bakheng was converted into a colossal sculpture of a seated Buddha, ${ }^{118}$ Baksei Chamkrong features a parinirvana image inside its central shrine, ${ }^{119}$ the eastern doorway of Ta Prohm Kel features roundels carved in a postAngkorian style in a similar manner to Angkor Wat, and a ruined brick shrine with Theravāda statue debris is found immediately north of Prasat Rorng Ramong.

117 The map by Trouvé notes an eighth Buddhist terrace southwest of Preah Khan on the shore of the Jayatataka Baray, but this has proved inaccessible at the time of writing.

118 Late 9th-early 10th century original construction. The seated Buddha was dismantled in 1916 by French conservators. The outline of a block parinirvana on the western edge can still be seen. There is also a small bronze buddhapäda below the eastern side of the temple thought to mark the spot where a monastery previously existed.

119 10th-century original construction. This image is identical in style and size to one found in the bakan of Angkor Wat. 
Two additional Buddhist terraces are found along this route, with an area of dilapidated Buddhist terraces and hilltop pedestal-structures found approximately 50om south of Angkor Wat; these small prah vihar may have been directly or indirectly affiliated with the northerly temple (Map 3). Within the Angkor Wat complex as well, two Buddhist terraces were identified north and south of the interior causeway. ${ }^{120}$

Beyond the North Gopura segment of the zig-zag, meanwhile, a Buddhist terrace identified in the second enclosure of the Jayavarman VII-era temple complex of Preah Khan in 1997 suggests a trend of continued northward expansion of Theravāda occupation ${ }^{121}$. This hypothesis is supported by the transformation of the central sanctuary of Preah Khan to incorporate a stupa of similar architectural style to those found surrounding the Bayon. Identical sima stones delineating the Preah Khan Buddhist Terrace known today as Wat Preah Khan and the more southern of the two at Angkor Wat suggest a similar date of consecration as well (Fig. 10.0). Future excavation work at the latter Buddhist terrace ${ }^{122}$ will no doubt help in solidifying this theory.

120 Polkinghorne et al., Evidence, 118. Polkinghorne cites Cœdès' earlier translation of the Nong fragment (translated by Cœdès, Essai de Classification, 15-28) which describes the erection of two vihara following the conquest of Angkor by Chao Sam Phraya in 1431-1432 CE at the request of abbots living at Angkor Wat called Jetavana and Vet Noi.

121 Important to note, however, is that other temples not located on this trajectory were also repurposed. For example, Ta Prohm features a Buddhist terrace structure with Buddhist statue remains in the Fourth Enclosure to the southeast of the road leading to the East Gate of the Third Enclosure

122 Excavations are noted to have occurred at »Wat Preah Khan« in World Monuments Fund, Preah Khan Conservation Project, 30-31, immediately following the identification of the structure in 1995-1997 but have never been published. 


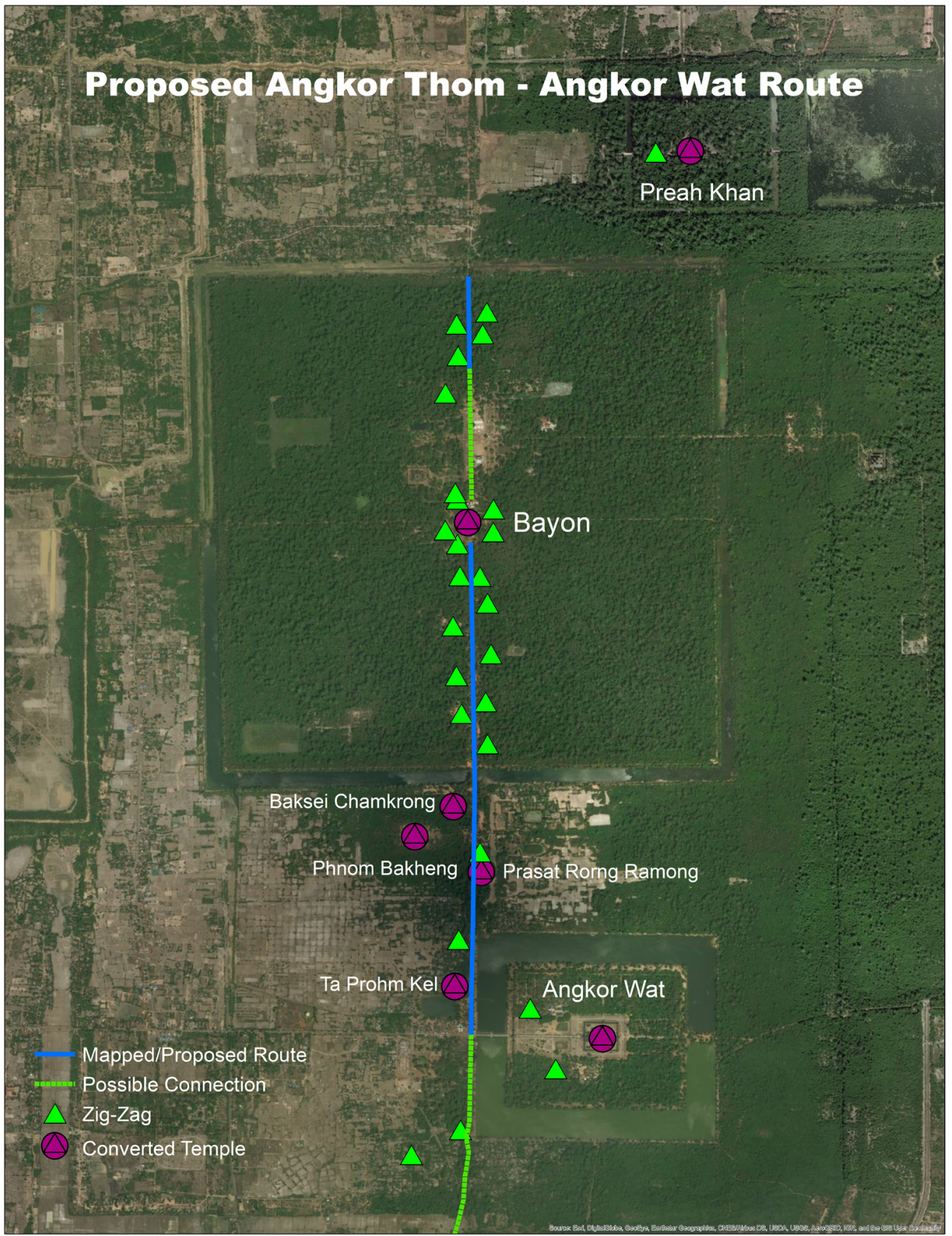

Map 3: Proposed route of converted monuments and Buddhist terraces between Angkor Wat and Angkor Thom, with possible extensions/incorporations north and south of Preah Khan Temple and monasteries mapped south of Angkor Wat. 


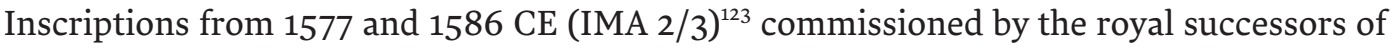
Ang $\mathrm{Chan}^{124}$ in the bakan ${ }^{125}$ of Angkor Wat detail its restoration and the installation of Buddhist images in the temple's formerly Vaiṣnavaite prasat. This makes clear that Angkor Wat was established as the regional focal point of Theravāda ritual practice and post-Angkorian imperial worship, ${ }^{126}$ considering that inscriptions have been found almost nowhere else in Angkor dating to this period. The temple's significance also continued into the 17th century; inscriptions from Angkor Wat dating to 1630 and 1684 rededicating Preah Poan (Angkor Wat's Hall of 1000 Buddhas) with votive deposits of statuary are evidence of this. ${ }^{127}$ Elite factions thus no doubt continuously viewed Angkor as Cambodia's spiritual heartland in a manner similar to earlier Śaivaite kings ${ }^{128}$ regardless of any political situation Cambodia faced.
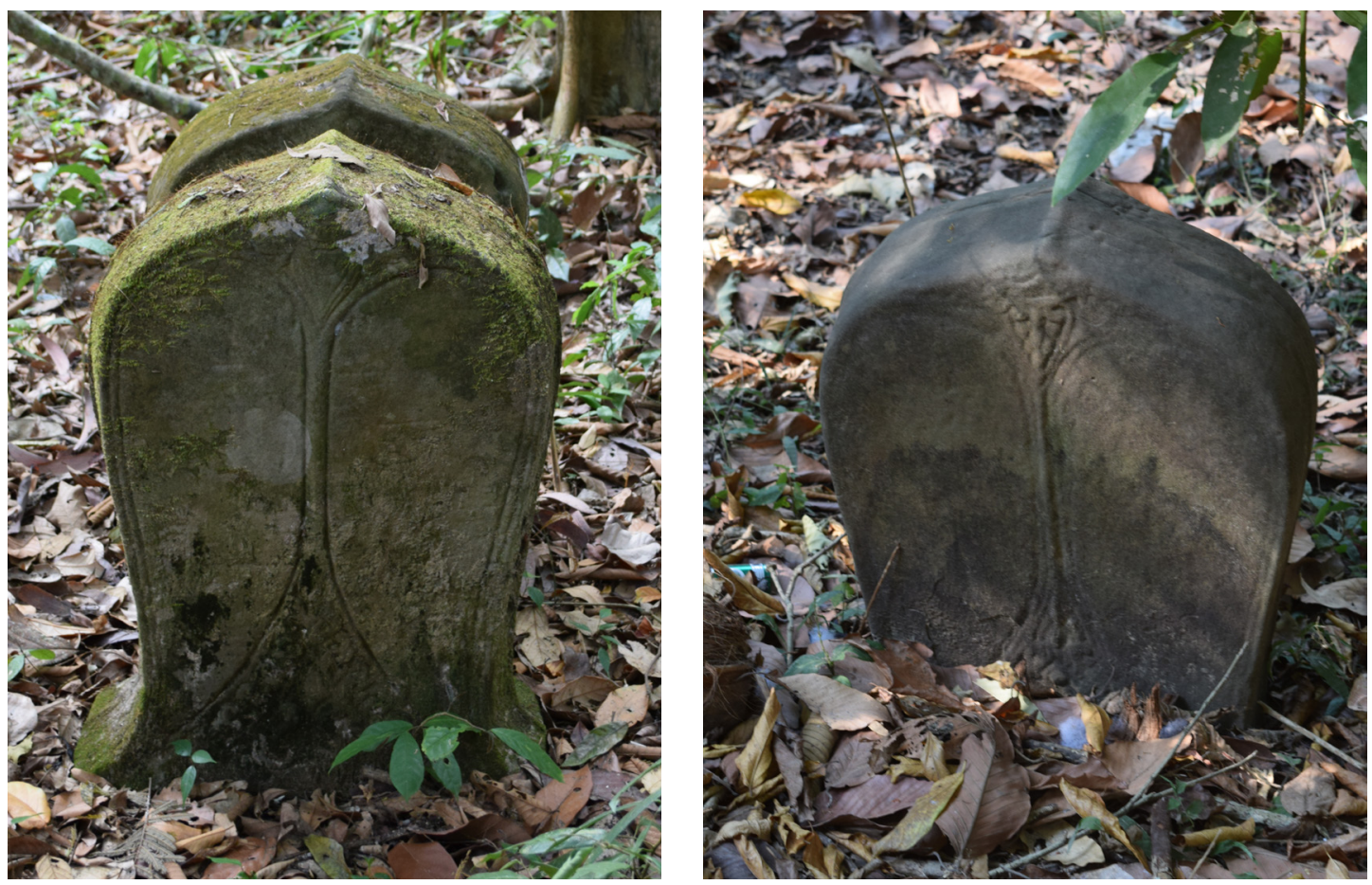

Fig. 10.0 (2): Identical simà surrounding Buddhist terraces at Preah Khan (left) and Angkor Wat (right).

123 Pou, Inscriptions modernes d'Angkor, 99-126.

124 The former was completed by the Queen Mother and the latter by a court dignitary (Thompson, Buddhist Cosmopolis, 204-207).

125 Central Sanctuary, specifically used to reference the uppermost tier of Angkor Wat.

126 Thompson, Memoires de Cambodge, 410-420.

127 Giteau, Bornage Rituel, 116

128 Wales, The Universe Around Them, 123. 
However, while this oft-cited evidence has typically been given to support the argument that Angkor was never definitively abandoned, these inscriptions have rarely been utilized in order to answer questions concerning the relationship between Angkor Wat and other repurposed areas such as Angkor Thom. For example, why do exponentially more Theravāda monastic structures exist inside Angkor Thom than at Angkor Wat? Why, compared to the rest of Angkor, do Theravāda ritual places cluster along the road between both sites, and almost exclusively between both sites? Were these temples, and by extension the Buddhist terraces along this route, converted simply out of convenience and an abundance of space or was it a result of a higher ritual purpose? And, most importantly, what relationship did populations at these two sites (and those surrounding other converted temples or vihära on this road) have with one another to spur this volume of monastic construction?

The continued preservation of much of the Angkor Thom road-grid, the volume of constructed Buddhist terraces, and the sheer number of converted Brahmano-Buddhist monuments are evidence that a religiously-active population within the ancient capital continuously augmented the ritual landscape in which they lived to suit the needs of contemporary worshippers, regardless of the mid-15th-century exodus of their former rulers. Because it is not clear what relationship rulers and elites had with the lay residents or sangha/bhikkus at Angkor Thom between the 15th and 16th centuries, no answer as to why some temples were converted and others were not can currently be given. It is thus entirely possible that the entire layout within Angkor could simply be chalked up to convenience, with ritual architecture opportunely erected and restored along an arterial thoroughfare continuously used as a transportation route between the spiritually-significant Kulen Hills to the north and the Tonle Sap Lake to the south. That said, the semi-ritualization of roadways indeed has precedence in Angkorian history; the construction of roads leading solely to and from Angkor during the 10th to 11 th centuries ${ }^{129}$ or the construction of rest-houses and fire-shrines along roads between major temple-complexes during the reign of Jayavarman VII are evidence of this. ${ }^{130}$ The infrastructure found forming this zig-zag is no doubt multifaceted, especially at Angkor Thom where the vestiges of three separate ritual traditions form the interpretable archaeological remains, but if viewed as agents continuously enabling patterns of human activity across the same landscape they can be seen to act as a cohesive whole achieving a combined result, regardless of the unknown original purpose. ${ }^{131}$

It lastly deserves mention that a single undedicated relief located in the southeast pavilion of the Bayon's third enclosure provides additional evidence of the connection between these two complexes (Fig. 11.o). The relief, shallowly carved with crude flat chisel-marks suggestive of late/post-Angkorian artistry ${ }^{132}$ atop what appears as an earlier incomplete Jayavarman VII-era depiction of a religious procession, may in fact depict three of the five central towers forming the bakan of Angkor Wat. This image could, of course, be simply dismissed as

129 Hendrickson, Historic routes to Angkor, 482. An ancient Khmer highway lined with Jayavarman VII-era resthouses and fire-shrines was mapped between Angkor and Phimai (modern Thailand).

130 See Hendrickson, People around the Houses of Fire, 63-79.

131 See Smith, Political Landscape; Martin, Agents in interaction, 286.

132 Roveda, Carved Reliefs, 56; Polkinghorne et al., One Buddha can hide another, 596. In the hallway immediately south are etched figures in a similar artistic style to those found in "Victory « bas-reliefs located in the NE Quadrant of the Third Enclosure at Angkor Wat. These are denoted by K.296 and K.297 as being carved in 1546 and 1564 CE. 


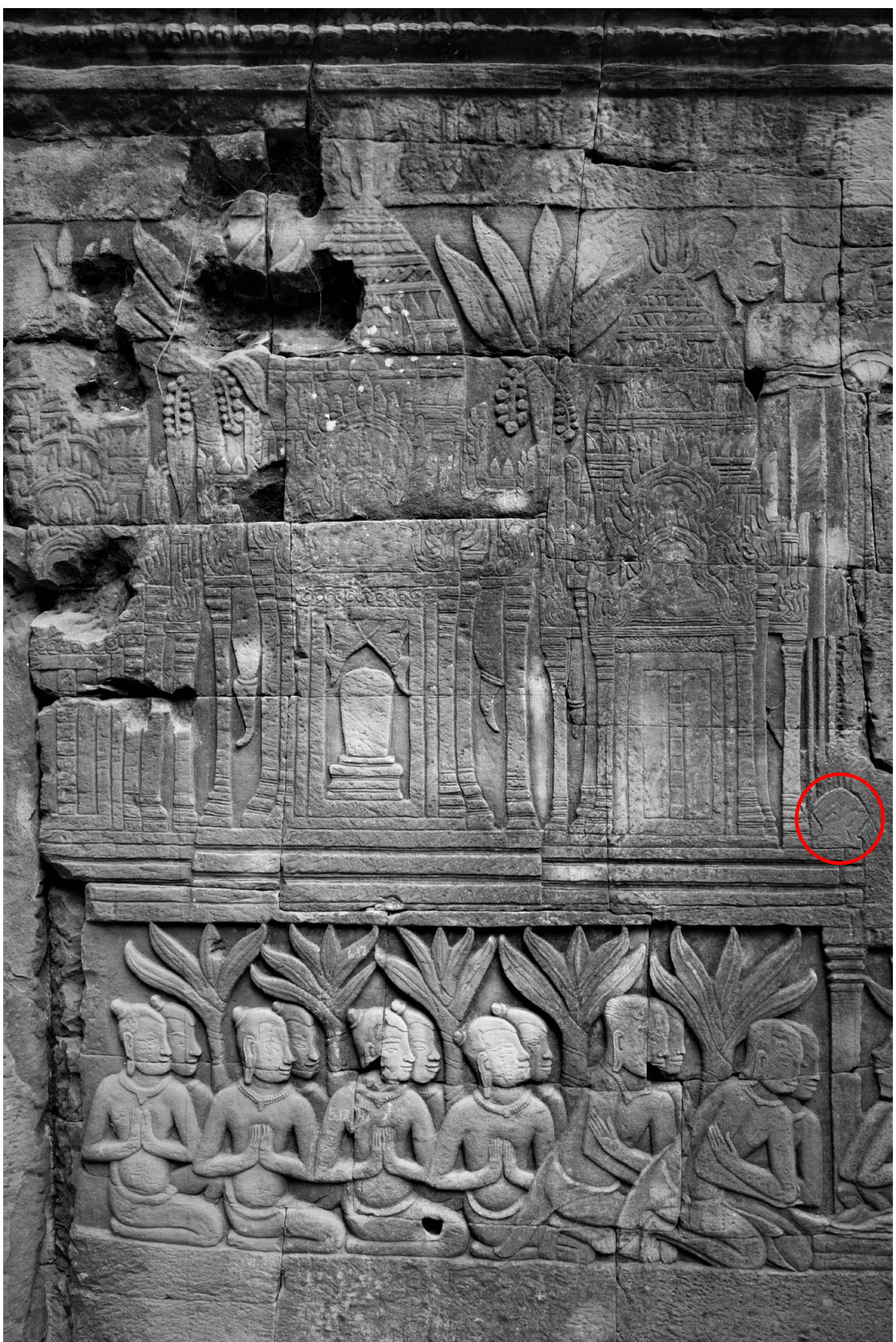

Fig. 11.o: Bas-relief hypothesized to depict Angkor Wat (simà center-right), Bayon Temple. 
incomplete, or incorrectly identified as Angkor Wat due to the carved Shiva lingam visible in the central tower, but a carving potentially depicting a sima $\bar{a}$ stone at the right edge of the temple platform appears to reveal the relief's association with the larger program of Theravàda Buddhist place-making at Angkor suggested here. Whether this relief possibly commemorated the re-consecration of Angkor Wat by the immediate successors of Ang Chan or any previous Khmer ruler remains unclear, but the carved sima likely proves that the Theravāda populations functioning at the Bayon, as evidenced by the Buddhist terraces and stupas surrounding the temple, viewed Angkor Wat as significant. ${ }^{133}$

\section{Conclusion: A Framework for "When " as well as "What"}

A 1609 CE account by Spanish historian Bartolomé de Argensola describes the overgrown state of a walled city, which is likely Angkor Thom, less than half a century after the restorative activities of Ang Chan at Angkor Wat were first mentioned by various European chroniclers $^{134}$ :

"One finds the interior within inaccessible forests, a city of six thousand houses, called Angon. The monuments and roads are made of marble ... There is a strong wall ... The bridges are supported by stone giants ... There are epitaphs, inscriptions ... And in all this city ... there were no people, no animals, nothing living ... Today the city is uninhabited. ${ }^{135}$

To believe this is to suggest that any relationship between Angkor Wat and Angkor Thom lasted little longer than the end of the 16th century. De Argensola's chronicles, too, appear to chronologically coincide with the sack of the contemporary Cambodian capital of Longvek in 1594 CE by Thai forces from Ayutthaya. After this time, Angkor became part of a neglected border region, shifting from Thai to Cambodian hegemony multiple times during the ensuing centuries. ${ }^{136}$ Epigraphic evidence suggests that Angkor Wat remained the sole ritually patronized complex in the Angkor region then afterwards, but numerous small laterite pedestals and altar screes identified within Angkor Thom not easily identified as Buddhist terraces feature post-Angkorian-style Theravāda statuary. ${ }^{137}$ It is thus possible that small religious groups remained active within the former capital, dismantling Buddhist terraces and earlier monuments to create small vernacular vihära alongside various animistic rituals. ${ }^{138}$

At present, problems of absolute chronology remain in the absence of more than a few epigraphic or radiocarbon dates, which, in turn, limits any thorough interpretation of how monastic construction and activity may have progressed at Angkor Thom in relation to what has been observed across the urban landscape. The role of ritual architecture within the Theravāda transformation of Angkor was indeed complex, multifaceted, and more likely than

133 While numerous temple-reliefs are carved on the walls of the Bayon, no publications have argued that any of these appear to depict real, active sites of worship.

134 Groslier, Angkor and Cambodia, 52-71.

135 Higham, Civilization of Angkor, 140.

136 Wales, The Universe Around Them, 121.

137 Giteau, Histoire d'Angkor, 16-18.

138 Ang, Place of animism, 37-38.

medieval worlds • No. 9 • 2019 • 4-62 
not gradual across four centuries based on the variation of both structure and sima and further research will no doubt shed light on the "when« of this visible religious transition from Brahmano-Buddhism. The discussion presented here exploring the spatial variation within Angkor Thom created by the construction of Buddhist terraces/prah vihar in relation to earlier features of the urban landscape serves as an intriguing case study and framework from which to expand our understanding of both the imperfect and idiosyncratic nature of religion-based urban planning in Southeast Asia. Angkor and its Theravāda remains, as has been argued through this paper, undoubtedly embody that idiosyncrasy.

\section{Acknowledgements}

I thank the APSARA Authority of Angkor, Cambodia for the permission to conduct research at Angkor Thom as well as all future permissions, and would like to graciously thank their researchers and administrators including HE DG Sum Map, Dr. Tin Tina, Dr. Ea Darith, and Chhay Rachna.

I also thank Dr. Damian Evans of the École Française d'Extrême Orient (EFEO) for access to LiDAR and other geospatial data; Dr. Dominique Soutif of the EFEO for his above-andbeyond support through every step of the research process; and Drs. Edward Swenson and Heather Miller (University of Toronto), Dr. Alison Carter (University of Oregon), Dr. Ashley Thompson (SOAS), Dr. Mitch Hendrickson (University of Illinois, Chicago), and Dr. Christophe Pottier (EFEO) for their guidance and mentorship.

This research was made possible through funding from the Robert H. N. Ho Family Foundation Dissertation Fellowship in Buddhist Studies.

\footnotetext{
About the author

Andrew Harris is a PhD Candidate studying Archaeology in the Department of Anthropology at the University of Toronto, with previous education at the School of Oriental and African Studies in London, UK (MA Distinction, History of Art and Archaeology) and Queen's University, Kingston (BA Hons., History). His Doctoral Research consists of an in-depth analysis of monastic construction at Angkor Thom, Cambodia, between the 14th and 17th centuries through survey, GIS analysis, and excavation within a theoretical framework of social memory, place-making, and spatial context, with an estimated defense date of mid-2020.
} 


\section{References}

Aasen, Clarence, Architecture of Siam: A Cultural History Interpretation (Kuala Lumpur, 1998).

Ang Choulean, The place of animism within popular Buddhism in Cambodia: The Example of the Monastery, Asian Folkore Studies 47/1 (1988) 35-41.

Ang Choulean, La communauté rurale Khmère du point de vue Sacré, Journale Asiatique 277/1-2 (1990) 135-154.

Assmann, Jan, Religion and Cultural Memory, translated from German by Rodney Livingstone (Stanford, 2006).

de Bernon, Olivier, About Khmer monasteries: organization and symbolism, in: Pierre Prichard and Francois Lagirarde (eds.), The Buddhist Monastery: A Cross-Cultural Survey (Paris, 2003) 209-218

Briggs, Lawrence Palmer, The Ancient Khmer Empire, Transactions of the American Philosophical Society, New series 41/1 (1951) 1-295.

Brown, Robert, The Dvaravati Wheels of the Law and the Indianization of Southeast Asia (Leiden, 1996).

Clark, Joyce, The Bayon: an archaeological and architectural study, in: Joyce Clark (ed.), Bayon: New Perspectives (Bangkok, 2007) 138-229.

Coe, Michael D., Social typology and the tropical forest civilizations, Comparative Studies in Society and History 4/1 (Nov. 1961) 65-85.

Cœdès, Georges, Essai de Classification des documents historiques conservés à la bibliotheque de l'École Française d'Extreme-Orient, BEFEO 18/9 (1918) 15-28.

Cœdès, Georges, Études Cambodgiennes, BEFEO 28/1 (1928) 81-146.

Cœdès, Georges, The Indianized States of Southeast Asia (Honolulu, 1968).

Dagens, Bruno, Cosmogonie et architecture: l'appropriation de l'Inde par le Cambodge ançien (2005). Retrieved on 20 February 2019: www.clio.fr/bibliotheque/cosmogonie_ et_architecture_l_appropriation_de_l_inde_par_le_cambodge_ancien.asp

De Vos, Ashley, The Buddhist monastic architectural tradition of Sri Lanka. In: Prichard, Pierre and Francois Lagirarde (eds.), The Buddhist Monastery: A Cross-Cultural Survey. (Paris, 2003) 38-58.

Doehring, Karl, Buddhist Temple Building in Siam (Bangkok, 1916).

Dumarçay, Jacques, Les Effets Perspectifs de L’Architecture de l'Asie Méridionale, Memoires Archéologiques (BEFEO: 1993), pp. 1-40.

Dumarçay, Jacques and Pascal Royère, Cambodian Architecture: Eighth to Thirteenth Centuries, Handbook of Oriental Studies 3: Southeast Asia 12 (Leiden, 2001).

EFEO (Henri Parmentier), Journal des Fouilles 7 (Siem Reap, Juillet 1928 - Janvier 1930).

Estève, Julia and Dominique Soutif, Les Yasodharāśrama, marqueurs d'empire et bornes sacrées: conformité et spécificité des stèles digraphiques khmères de la région de Vat Phu, BEFEO 97/98 (2010) 331-355.

Evans, Damian, Roland J. Fletcher, Christophe Pottier, Jean-Baptiste Chevance, Dominique Soutif, Boun Suy Tan, Sokrithy Im, Darith Ea, Tina Tin, Samnang Kim, Christopher Cromarty, Stéphane De Greef, Kasper Hanus, Pierre Bâty, Robert Kuszinger, Ichita Shimoda and Glenn Boornazian, Uncovering Archaeological Landscapes at Angkor Using LiDAR, PNAS 110/31 (2013) 12595-12600. 
Fletcher, Roland J., Dan Penny, Damian Evans, Christophe Pottier, Mike Barbetti, Matti Kummu, Terry Lustig and APSARA Department of Monuments and Archaeology Team, The water management network of Angkor, Cambodia, Antiquity 82 (2008) 658-670.

Fletcher, Roland, Christophe Pottier, Damian Evans and Matti Kummu, The development of the water management system of Angkor: a provisional model, IPPA Bulletin 28 (2008) 57-66.

Garnier, Derick, Ayutthaya: Venice of the East (Bangkok, 2004).

Gaucher, Jacques, Archaeology and town planning: an Indian model in Southeast Asia, Urban Morphology 6/1 (2002) 46-49.

Gaucher, Jacques, The City of Angkor: what is it? Museum International, Vol. 54, No. 1\&2 (2002b) 28-36.

Gaucher, Jacques, Schema Directeur Archéologique D'Angkor Thom: Evaluation, Risques, Recommandations. FSP "Site d'Angkor: Patrimoine et Développement" Mission archéologique française à Angkor Thom (Paris, 2004).

Gaucher, Jacques, Angkor Thom, une utopie réalisée? Structuration de l'espace et modèle indien d'urbanism dans le Cambodge Ancien, Arts Asiatiques 59 (2004) 58-86.

Gaucher, Jacques, L'Archéologie Urbaine à Angkor Thom, in: EFEO (ed.), Un Siècle D'Histoire: L'École Française D'Extrême Orient et le Cambodge (Paris, 2011) 39-44.

Geertz, Clifford, Negara: The Theatre State in Nineteenth-Century Bali (1980).

Giteau, Madeleine, Le Bornage Rituel des Temples Bouddhiques Au Cambodge, BEFEO 68 (Paris, 1969).

Giteau, Madeleine, Histoire D'Angkor (Paris, 1974).

Giteau, Madeleine, Iconographie du Cambodge post-Angkorien, Publications de l'EFEO 100 (Paris, 1975) 1-381.

Goonatilake, Hema, Sri Lanka-Cambodia relations with special reference to the period 14th20th centuries, Journal of the Royal Asiatic Society of Sri Lanka, New Series 48 (2003) 191-211.

Goodall, Dominic and Andrew Wareham, The political significance of gifts of power in the Khmer and Mercian Kingdoms 793-927, Medieval Worlds 6 (2017) 156-195.

Groslier, Bernard P., Angkor and Cambodia in the Sixteenth Century according to Portuguese and Spanish Sources (Paris, 1958).

Groslier, Bernard P., La cité hydraulique angkorienne: exploitation ou surexploitation du sol?, BEFEO 66/1 (1979) 161-202.

Harris, Ian, Cambodian Buddhism: History and Practice (Honolulu, 2004).

Harris, Peter, Zhou Daguan: A Record of Cambodia - The Land and its People. (Chiang Mai, 2007).

Hendrickson, Mitch, Historic routes to Angkor: development of the Khmer Road System (9th-13th centuries AD) in mainland Southeast Asia, Antiquity 84 (2010) 480-496.

Hendrickson, Mitch, People around the Houses with Fire: archaeological investigation of settlement around Jayavarman VII's "resthouse« temples, Journal of Khmer Studies. UDAYA, 9 (2008) 63-79.

Higham, Charles, The Civilization of Angkor (London, 2001).

Inscriptions du Cambodge, Georges Cœdès (ed.), EFEO (Textes et documents sur l'Indochine) 1-8 (Paris, 1937, 1942, 1951, 1952, 1953, 1954, 1964, 1966).

Jacques, Claude, The Khmer Empire: Cities and Sanctuaries from the 5th to the 13th Century (Bangkok, 1997).

Jessup, Henry Ibbitson, Temples of Cambodia: The Heart of Angkor (Bangkok, 2011). 
Lajonquière, Lunet De, Inventaire Descriptif des Monuments du Cambodge, 1: 50.000 (Paris, 1911).

Leroy, Stéphanie, Mitch Hendrickson, Emmanuelle Delqué-Kolic, Enrique Vega and Philippe Dillmann, First direct dating for the construction and modification of the Baphuon temple mountain in Angkor, Cambodia, PLOS One (2015), DOI: 10.1371/journal.pone.0141052.

Lustig, Eileen, Damian Evans, and Ngaire Richards, Words across space and time: an analysis of lexical items in Khmer inscriptions, sixth-fourteenth centuries CE, Journal of Southeast Asian Studies 38/1 (2007) 1-26.

Mabbett, Ian W., Devarāja, Journal of Southeast Asian History 10/2 (1969) 202-223.

Marchal Henri, Monuments secondaires et tèrrasses bouddhiques d'Ankor Thom, BEFEO 18 (1918) $1-40$.

Marchal, Henri, Notes sur le forme du stupa au Cambodge, BEFEO 44/2 (1951) 581-590.

Martin, Andrew, Agents in inter-action: Bruno Latour and agency, Journal of Archaeological Method and Theory 12/4 (2005) 283-311.

Marston, John, and Elizabeth Guthrie, History, Buddhism, and New Religious Movements in Cambodia (Honolulu, 2004).

Meyer, Jeffrey F., "Feng-Shui« of the Chinese city, History of Religions 18/2 (1978) 138-155.

Murphy, Stephen, The Buddhist Boundary Markers Of Northeast Thailand And Central Laos, 7th-12th Centuries CE: Towards An Understanding Of The Archaeological, Religious And Artistic Landscapes Of The Khorat Plateau. Unpublished PhD Thesis (University of London, 2010).

Mus, Paul, Le sourire d'Angkor: art, foi et politique bouddhiques sous Jayavarman VII, Artibus Asiae 24/3-4 (1961) 363-381.

NARA, Western Prasat Top Site Survey Report on Joint Research for the Protection of the Historical Site, NARA National Research Institute for Cultural Properties (ed.) (Siem Reap, 2012).

Parmentier, Henri, Carte du Groupe et du Parc d'Angkor: map recto, 1: 40.000 (Paris, 1930).

Pichard, Pierre, The Thai monastery. In: Prichard, Pierre and Francois Lagirarde (eds.), The Buddhist Monastery: A Cross-Cultural Survey. (Paris, 2003) 93-117.

Polkinghorne, Martin, Christophe Pottier, and Christian Fischer, One Buddha can hide another, Journal Asiatique, 301/2 (2013) 575-624.

Polkinghorne, Martin, Christophe Pottier and Christian Fischer, Evidence for the 15th century Ayutthayan occupation of Angkor, in: Siam Society (ed.), The Renaissance Princess Lectures: In Honour of Her Royal Highness Princess Maha Chakri Sirindhorn on Her Fifth Cycle Anniversary (2018) 99-113.

Pottier, Christophe, Carte Archèologique de la Règion d'Angkor Zone Sud. Unpublished PhD Thesis (Université de Paris III , 1999).

Pottier, Christophe, Yasovarman's Buddhist Āśrama in Angkor, BEFEO 1032 (2004) 199-208.

Pou, Saveros (née Lewitz), Textes en kmer moyen. Inscriptions modernes d'Angkor 2 et 3, BEFEO 57 (1970) 99-126.

Rooney, Dawn, Ancient Sukhothai: Thailand's Cultural Heritage. (Bangkok: 2008).

Roveda, Vittorio, Sacred Angkor: The Carved Reliefs of Angkor Wat (Bangkok, 2002).

Sharrock, Peter D., Garuda, Vajrapani, and change in Jayavarman VII's Angkor, Journal of Southeast Asian Studies 40/1 (2009) 111-151.

Shiner, Larry E, Sacred space, profane space, lived space, Journal of the American Academy of Religion 40/4 (1972) 425-436. 
Smith, Adam, The Political Landscape: Constellations of Authority in Early Complex Polities (Berkeley, 2003).

Stark, Miriam, Southeast Asian urbanism: from early city to classical state, in: Norman Yoffee (ed.), The Cambridge World History, Vol. 3: Early Cities in Comparative Perspective, 4000 BCE - 1200 CE (2015) 74-93.

Swenson, Edward, Timing is everything: religion and the regulation of temporalities in Precolumbian Peru, in: Arthur Joyce and Sarah Barber (eds.), Religion and Politics in the Ancient Americas (New York, 2017) 210-233.

Swenson, Edward, Interpreting the political landscape of early state religions, in: Michael Lambek and Janice Boddy (eds.) A Companion to the Anthropology of Religion, (London, 2013) 471-488.

Thompson, Ashley, The ancestral cult in transition: reflections on spatial organization of Cambodia's early Theravāda complex, in: Marijke J. Klokke and Thomas de Bruijn (eds.), Southeast Asian Archaeology: Proceedings of the 6th International Conference of the EurASEAA, (Hull, 1998) 273-295.

Thompson, Ashley, Memoires du Cambodge. Unpublished PhD thesis (Université de Paris VIII, 1999).

Thompson, Ashley, Pilgrims to Angkor: a Buddhist rcosmopolis in southeast Asia? Bulletin of Students of the Department of Archaeology, Royal University of Fine Arts, Phnom Penh 3 (2004) 88-119.

Trouvé, Georges and Henri Marchal, Angkor: Le Groupe: D'Apres Le Plan Dressée Par Georges-Trouvé en 1934 et Complêté Par Henri-Marchal En 1935, 1: 20.000 (Paris, 1957).

Van Dyke, Ruth M., Imagine pasts imagined: memory and ideology in archaeology, in: Bernbeck Reinhart and Randall H. McGuire (eds.), Ideologies in Archaeology (Tucson, 2011) 233-253.

Vickery, Michael, The 2k/125 fragment: a lost chronicle of Ayutthaya, The Siam Society 65/1 (1977) 1-81.

Vickery, Michael, Cambodia and its neighbors in the 15th century, ARI Working Paper Series 27 (2004) 1-71.

Wales, H.G. Quartrich, The Universe Around Them: Cosmology and Cosmic Renewal in Indianized South-East Asia (London, 1977).

Williams, Joanna, The Churning of the Ocean of Milk - Myth, Image, and Ecology. India International Centre Quarterly 19/1-2 (1992) 145-155.

Woodward, Hiram W. Jr., Practice and belief in ancient Cambodia: Claude Jacques Angkor and the Devaraja question, Journal of Southeast Asian Studies 32/2 (Jun., 2001) 249-261.

Woodward, Hiram W. Jr., Some Buddha images and the cultural developments of the late Angkorian Period, Artibus Asiae, 42/2 (1980), 155-174.

World Monuments Fund, Preah Khan Conservation Project: Report IX, Field Campaign VI (New York, 1999). 


\section{List of figures}

Fig. 1.0: Remains of laterite staircase to and from Western Prasat Top Temple and Buddhist terrace facing a cleared »local « road.

Fig 2.1 (3): Terrace adjacent to Preah Pithu Temple X (Ta Tuot) (ATVo16), Terrace J (ATVo43), and Terrace Q (ATV037), Angkor Thom: Three Buddhist terraces in varied states of clearance/preservation.

Fig 2.2.: Scaled photogrammetric floorplan with measurements of Terrasse Bouddhique III/ Prah Eintep (ATVo03), Angkor Thom. Note: the seated Buddha is covered by the roof of a modern pagoda.

Fig. 3.0: Photogrammetric model of a Seated Buddha in situ, Preah Palilay Buddhist terrace (ATTSO01).

Fig. 4.1: Photogrammetric model of square-based laterite Buddhist Shrine, Terrasse Bouddhique II/Prah Kok Thlok (ATVoo2)

Fig. 4.2: Photogrammetric model of a stupa, Terrace S (ATV057). Reconstructed under Parmentier in 1929.

Fig. 5.0: Base of a prasat depression marking the Central Sanctuary of a converted temple (ATVo33), SW Quadrant, Angkor Thom. Scale $=1 \mathrm{~m}$.

Fig. 6.0 (2): Architectural "break" between vihära and original building, Terrasse Bouddhique No. 4 (ATVoo9). Shown referenced on original drawing of Buddhist terrace by Henri Marchal (Monuments Secondaires, Pl. X)

Fig. 7.0 (2): Side-by-side architectural comparison of image house from Wat Phra Si Sanphet (1), Ayutthaya, and Prah Ngok Buddhist Terrace (ATVoo1) (2), Angkor Thom.

Fig. 8.1: Pair of sima boundary stones in situ, Terrasse Bouddhique No. 3 (ATV007). Scale = $1 \mathrm{~m}$.

Fig 8.2: Sīmā boundary stone uprooted with visible base, Monument 26 (ATV052). Scale = $0.2 \mathrm{~m}$.

Fig. 9.0: Altar scree demarcated by simā, Terrace R (ATV049). Scale $=1 \mathrm{~m}$.

Fig. 10.0 (2): Identical simā surrounding Buddhist terraces at Preah Khan (left) and Angkor Wat (right).

Fig. 11.0: Bas-relief hypothesized to depict Angkor Wat (simā center-right), Bayon Temple.

\section{Maps}

Map 1: Location of Theravāda Buddhist monastic structures catalogued within Angkor Thom in relation to the ancient road-grid. Grid-plan mapping attributed to Gaucher (Schema Directeur) and Evans et al. (LiDAR, 2).

Map 2: Map of the North-South Gopura Road Zig-Zag spatial pattern (center), mapped in 2017.

Map 3: Proposed route of converted monuments and Buddhist terraces between Angkor Wat and Angkor Thom, with possible extensions/incorporations north and south of Preah Khan Temple and monasteries mapped south of Angkor Wat.

\section{Tables}

Table 1: Measurements and structural notes for monasteries mapped as part of the NorthSouth Gopura Road zig-zag spatial alignment. 


\section{List of appendix figures}

Appendix Fig. 1.0: Angkor Wat Temple

Appendix Fig. 2.0: Angkor Wat Temple and Site-Plan (Dumarçay, Les Effets Perspectifs, 32)

Appendix Fig. 3.0: Bayon Temple, Angkor Thom

Appendix Fig. 4.0: Bayon Temple Floorplan, Angkor Thom, with Bayon simā bas-relief location circled (Dumarçay and Royère, Cambodian Architecture, Fig. 80)

Appendix Fig. 5.0: Hand-Drawn Map. Titled: Pl I: Plan d'Ankor Thom. Created by Henri Marchal in 1918 (Marchal, Monuments Secondaires)

Appendix Fig. 6.0: Map of Ayutthaya (Pichard, The Thai monastery, 100)

Appendix Fig. 7.0: Ubosot of Wat Phra Phai Luang (12th-13th century), Sukhothai

Appendix Fig. 8.1: Floorplan of Wat Ratchaburana, Ayutthaya (Pichard, The Thai monastery, 101)

Appendix Fig. 8.2: Wihan of Wat Ratchaburana facing eastward, Ayutthaya

Appendix Fig. 8.3: Prang of Wat Ratchaburana, Ayutthaya

Appendix Fig. 9.0: Floorplan of Wat Phra Si Sanphet, Ayutthaya (Pichard, The Thai monastery, 101) Appendix Fig. 10.0: Wat Maha Saman, Southwest Area, Ayutthaya

Appendix Fig. 11.1: Buddha "niche« from prang-shaped chedi, Wat Mahathat, Ayutthaya

Appendix Fig. 11.2: Remains of a possible prang-shaped central sanctuary within an unexcavated prah vihar (AWBToo1), Angkor Wat

Appendix Fig. 12.0: Simmā from Wat Wora Chet Tha Ram (c. 1593-1605 CE), Ayutthaya, and Wat Preah Khan (Date Unknown), Angkor

Appendix Fig. 13.1: Remains of "Prah Ngok« (ATV051), Angkor Thom

Appendix Fig. 13.2: Image house (Pațimāghara/Pilimagē), Lankarama Complex (Established 1st century CE), Anuradhapura.

Appendix Fig. 14.0: Temple of the Tooth Relic (c. 1272-1284 CE), Yapahuwa, Sri Lanka 


\section{Appendix}

\section{SECTION 1}

Images, Floorplans and Maps

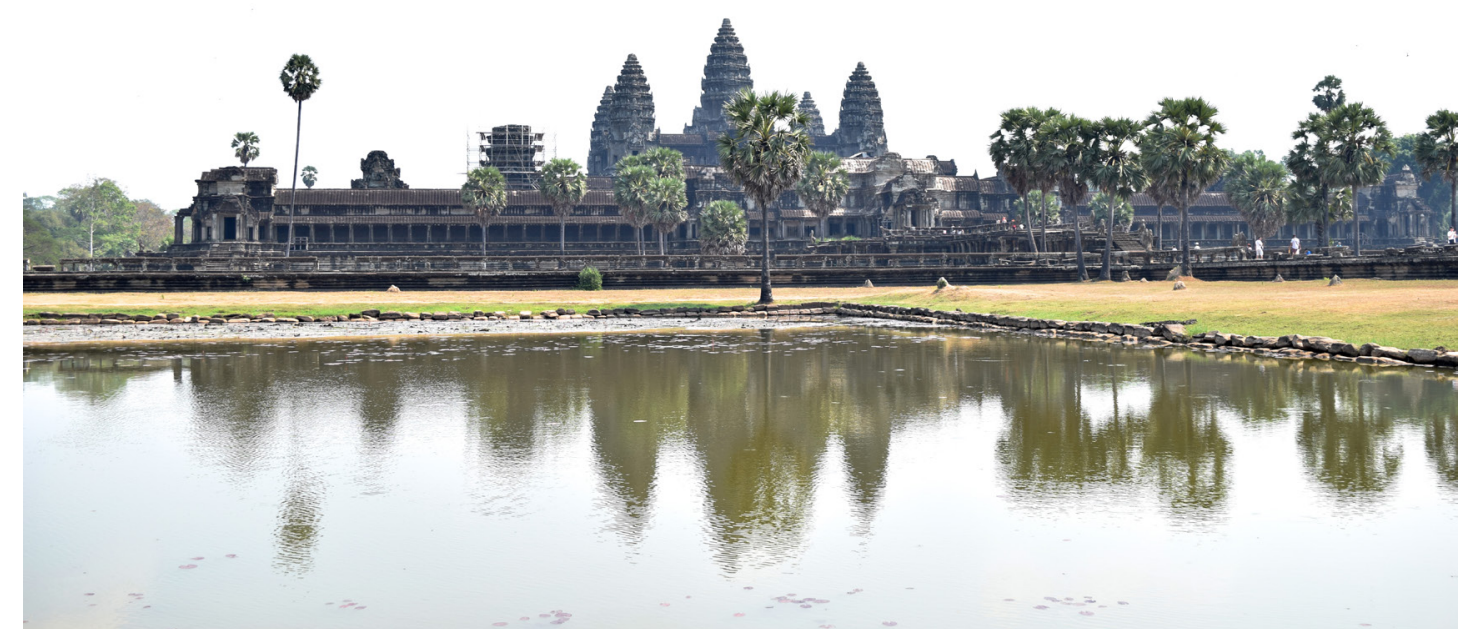

Appendix Fig. 1.o: Angkor Wat Temple 

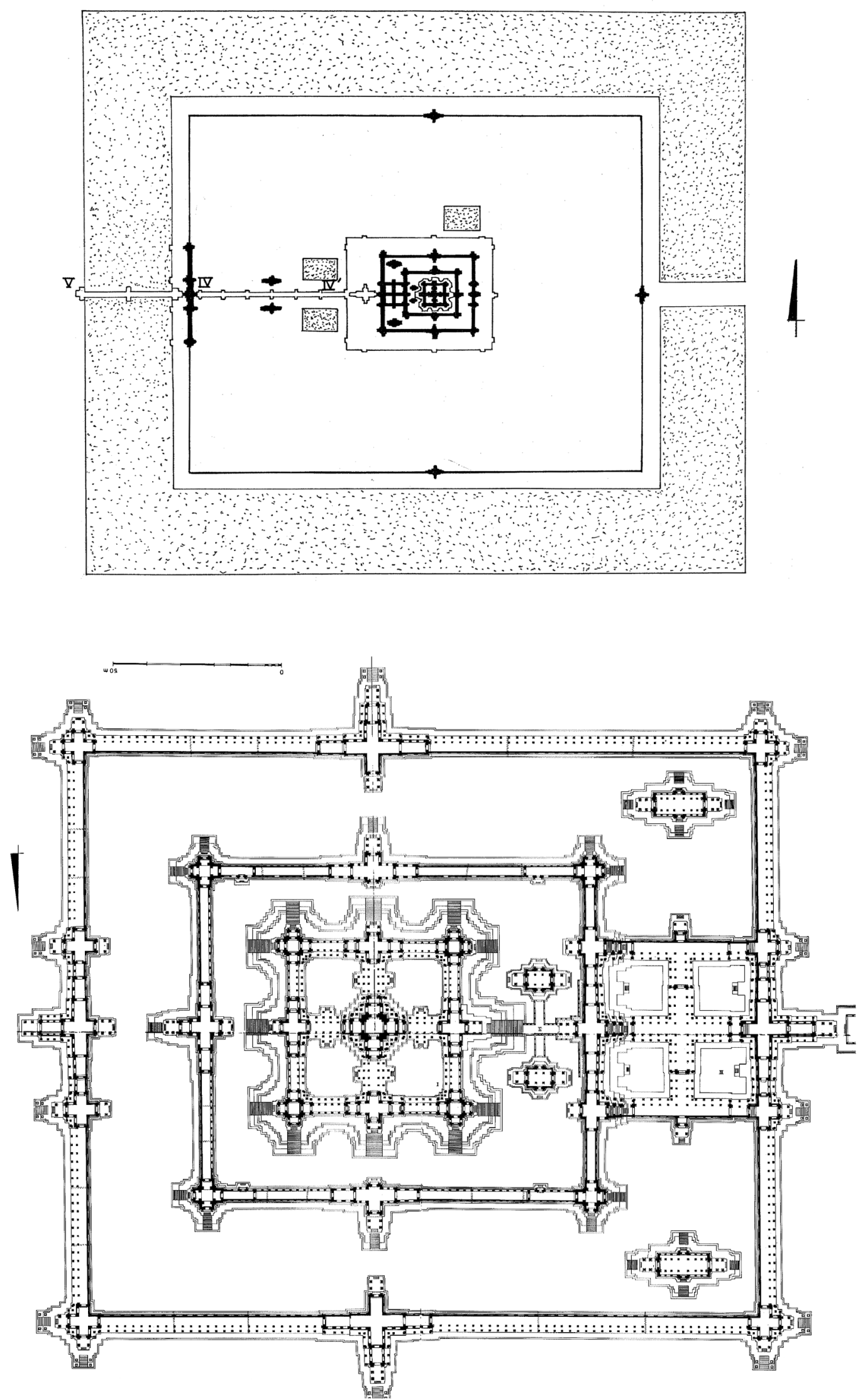

Appendix Fig. 2.o: Angkor Wat Temple and Site-Plan (Dumarçay, Les Effets Perspectifs, 32) 


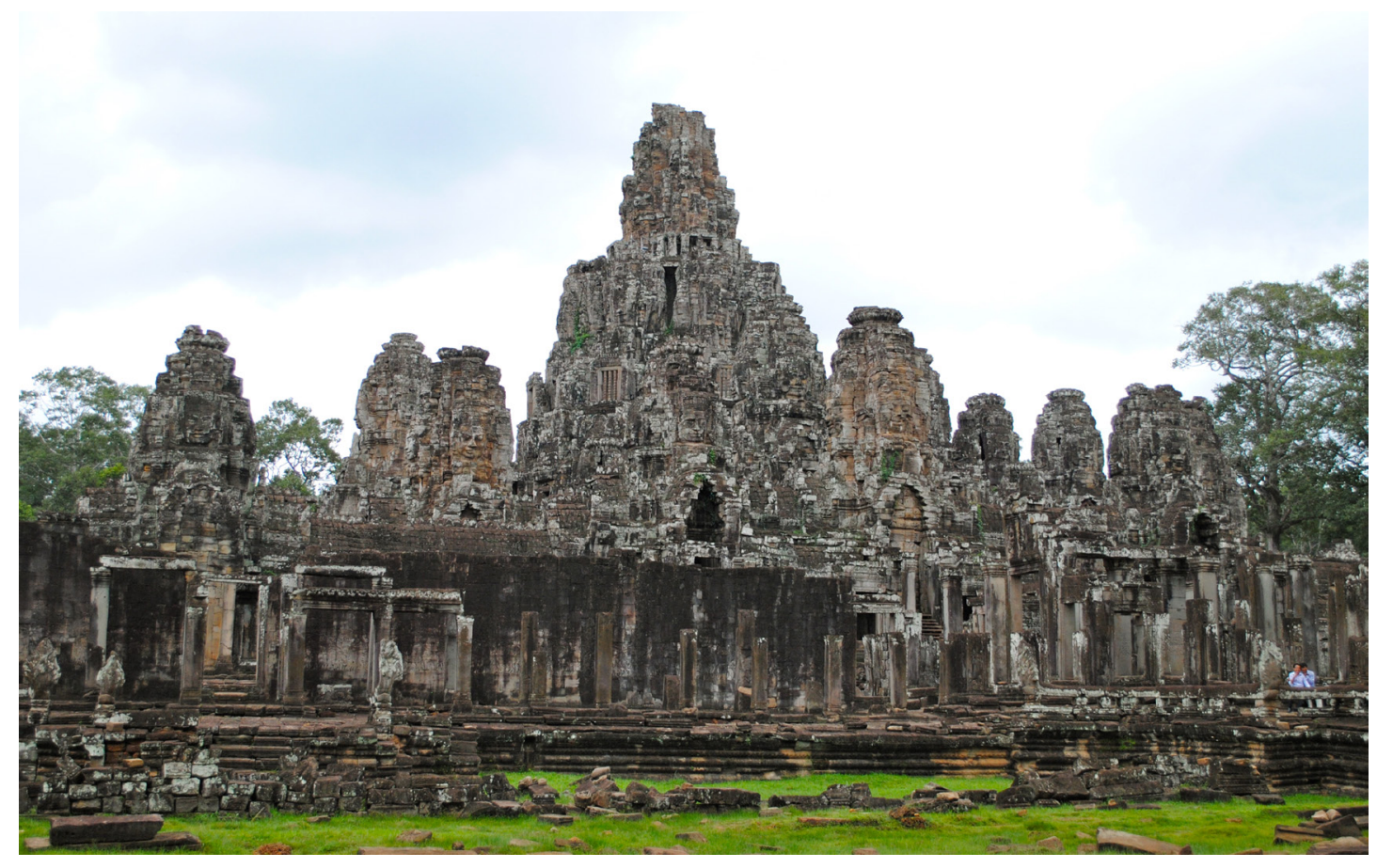

Appendix Fig. 3.o: Bayon Temple, Angkor Thom
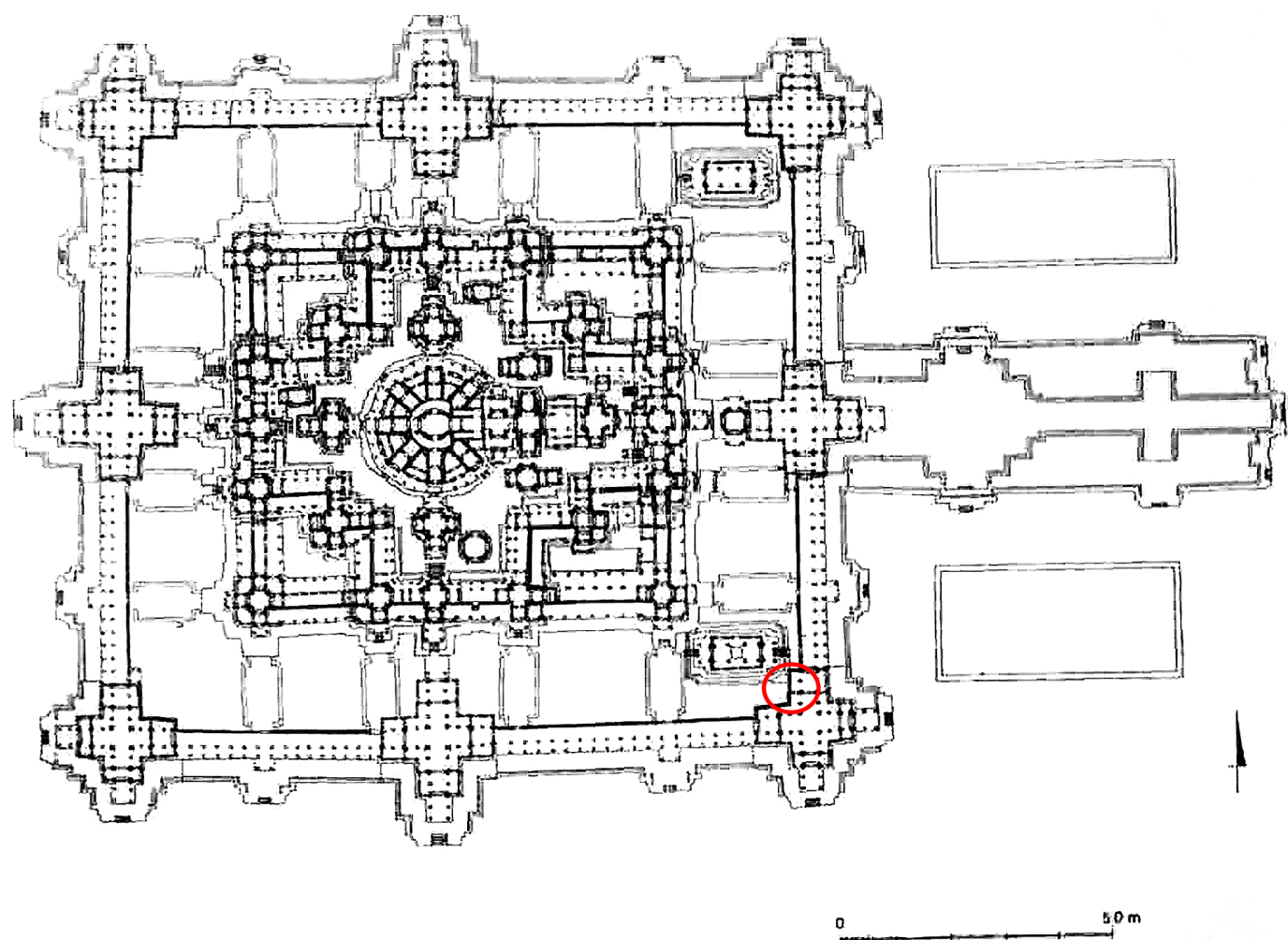

Appendix Fig. 4.o: Bayon Temple Floorplan, Angkor Thom, with Bayon simā bas-relief location circled (Dumarçay and Royère, Cambodian Architecture, Fig. 80) 


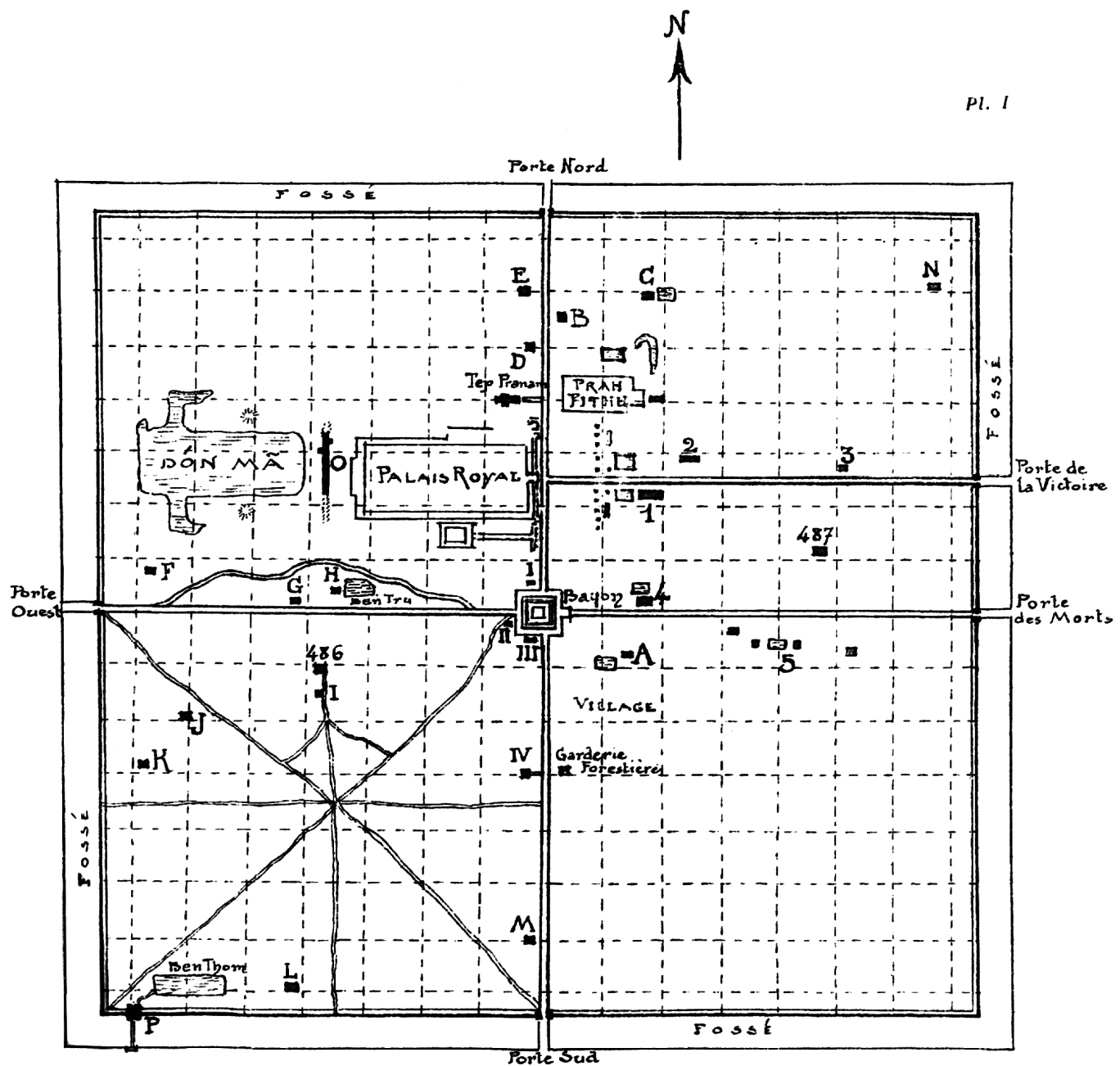

Appendix Fig. 5.o: Hand-Drawn Map. Titled: Pl I: Plan d'Ankor Thom. Created by Henri Marchal in 1918 (Marchal, Monuments Secondaires) 


\section{SECTION 2}

\section{Ayutthayan/Sukhothai Cultural Context and Architectural Comparison:}

Expanded from Text

The majority of cross-cultural observations made in this study of Buddhist terrace/prah vihar structures come from the analysis of similar monuments found at the two successive Thai capitals of Sukhothai (c. 1180-16th century CE) and Ayutthaya (1350-1767 CE) (Fig. 6.0). These capitals served as centers of cultural, political, and religious influence in Southeast Asia, and are thought to have visually and spatially influenced the religious architectures of nearby polities such as the Lanna Empire (1292-1775), Lao Lan Xang (1353-1707) and the Kingdom of Cambodia (1434-present). Both, in extension, were influenced by Khmer monuments as both are believed to have been occupied between the 11th and 13th centuries by governors and/or princes who answered to Angkor. With a lack of epigraphic or written sources, evidence of this influence in Cambodia is mainly structural but is easily visible at Angkor alongside later successive seats of power such as Srei Santhor (c. 1434), Longvek, (1511-1594), and Oudong (1618-1863)

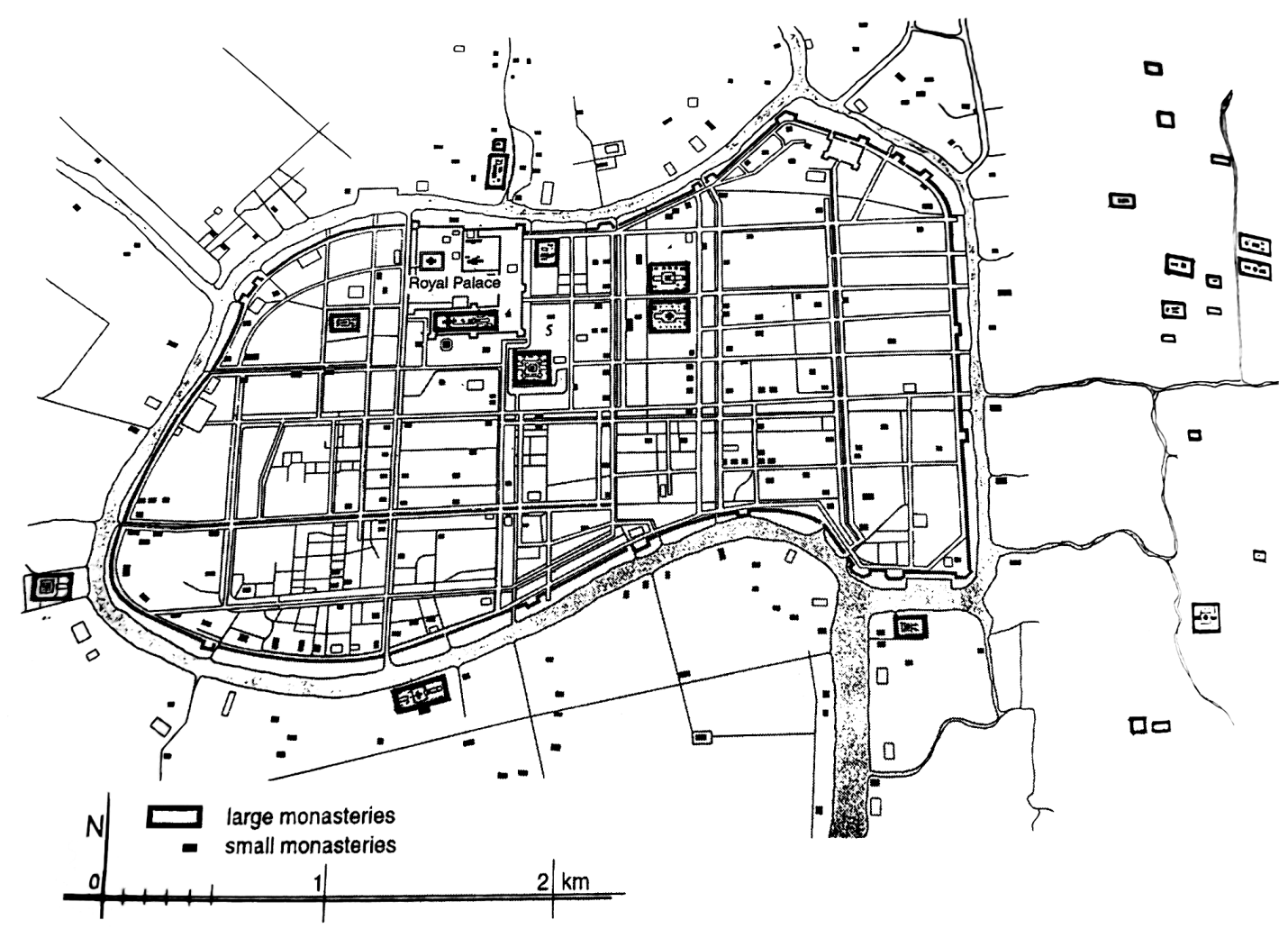

Appendix Fig. 6.0: Map of Ayutthaya (Pichard, The Thai monastery, 100) 
The geopolitical influence of these two polities over Cambodia is recorded in several Siamese Ayutthayan chronicles such as the $2 \mathrm{k} / 125$ fragment translated by Vickery and the Luang Prasoet translated by H. R. H. Prince Damrong, as well as the Burmese Glass Palace Chronicle of $1796 \mathrm{CE}$. As early as 1180 CE Sukhothai rebelled against the Khmer rule of Jayavarman VII, an event undocumented in Khmer inscriptions from the time period. Zhou Daguan notes a war between Sukhothai and the Khmer Empire at some point prior to his arrival at Angkor, and writes that "as a result of repeated wars with the Siamese the land has been completely laid to waste ${ }^{140}$ It is clear at this point from the splintering of Khmer provinces in modern Thailand into smaller states, with foundation myths dating to the late 12th to early 14 th centuries, that Angkorian influence over the region was dwindling; the Kingdom of Lopburi (c. early 13th-14th centuries) sent independent missions to China in $1299 \mathrm{CE} .^{141}$

The Kingdom of Sukhothai is often presented as the "Golden Age" of the Thai civilization, but this history is heavily influenced by the efforts of Chakri Dynasty (1792 CE-present) Thai kings such as Mongkut II (r. 1851-1868 CE) to create a national historical narrative; ${ }^{142}$ this occurred in order to legitimize the independence of the Kingdom of Siam to British and French invaders who had already absorbed Burma and Indochina (Laos, Vietnam, and Cambodia), respectively, into their colonial empires. Modern Thailand was thus, according to tradition, established after a legendary uprising against the Khmer Empire in $1180 \mathrm{CE}$, and Thai art, culture, and politics are reported to have reached their peak at Sukhothai during the next two centuries.

By 1350 CE, the Kingdom of Ayutthaya (Siam) was founded following a rebellion of princes from Lopburi, and for four centuries was one of the most dominant polities in Southeast Asia; the Kingdom of Sukhothai was absorbed in the process. Successive Siamese attacks on Angkor between 1350 and $1431 \mathrm{CE}^{143}$ were one of the primary causes of the collapse of the Khmer Empire and the abandonment of Angkor by the elites and royalty; Angkor remained populated until at least the 17th century, but the frontier with Siam proved too dangerous and too far inland to reap valuable income and taxation from maritime trade through the Mekong Delta. ${ }^{144}$ Angkor thus changed hands between Ayutthaya and Longvek multiple times until 1594 CE when Longvek was sacked by forces dispatched by King Naresuan the Great (r. 1590-1605 CE). Following this, Cambodia was governed by a series of puppetrulers from Siam and neighboring Vietnam at Oudong. Angkor, meanwhile, remained under Siamese dominion until 1907 CE when it was brought with Siem Reap, Banteay Meanchey, and Battambang provinces under the dominion of the French Empire.

\footnotetext{
140 Harris, Zhou Daguan, 79.

141 Cœdès, The Indianized States, 160.

142 Aasen, Architecture of Siam, 44.

143 Dates for these attacks are suggested by various inscription/chronicle fragments to be 1350 CE, 1380, 1394, and/ or $1418 \mathrm{CE}$, with the most accurate date coming from $1431 \mathrm{CE}$ (Vickery, Cambodia and its neighbors, 3-4).

144 Giteau, Histoire d'Angkor, 111.
} 
The monastic tradition which promoted Theravāda Buddhism in post-Angkorian (c. 1431$1863 \mathrm{CE}$ ) Cambodia is most likely derived from that which was practiced within monastic communities in Sukhothai or Ayutthaya. The current form practiced in Cambodia was heavily augmented by French officials following rebellions by the sangha against colonial rule in the late 19th century, ${ }^{145}$ but the architecture built to facilitate this tradition no doubt descends from structures built at Angkor Thom. Comparisons of structures at Angkor with monastic complexes at Ayutthaya are admittedly more easily and accurately made than comparisons with those at Sukhothai, which are convoluted by undocumented building phases and renovations during the 15 th-16th centuries. ${ }^{146}$ This brief appendix section will thus focus on structural and spatial layouts of monastic buildings built within the latter of the two capitals.

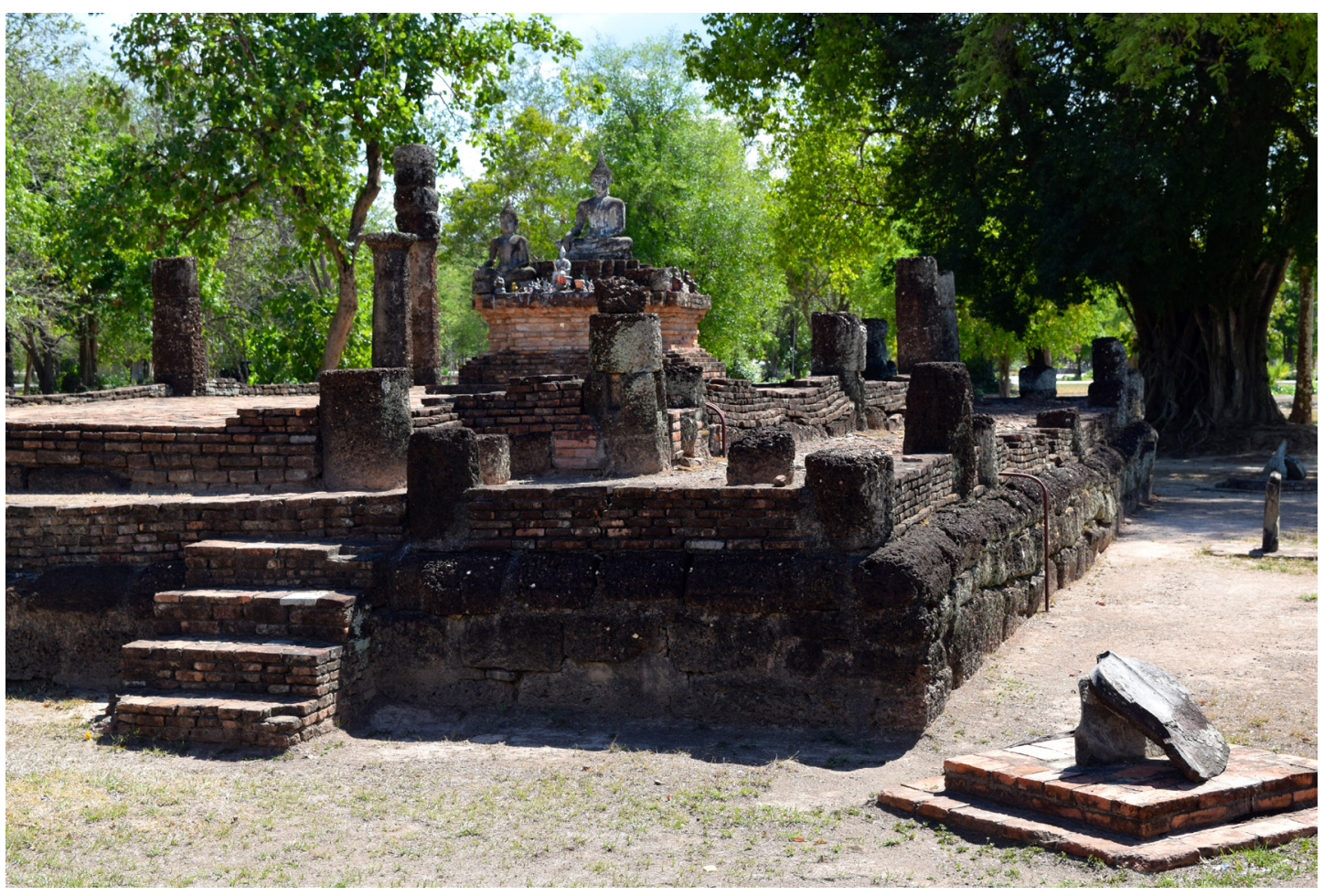

Appendix Fig. 7.o: Ubosot of Wat Phra Phai Luang (12th-13th century), Sukhothai ${ }^{147}$

145 Marston and Guthrie, History, 51.

146 Pichard, The Thai monastery, 94

147 The Khmer-style prang which centers Wat Phra Phai Luang is thought to predate the Kingdom of Sukhothai, and may have been erected as early as the reign of Suryavarman II (1102-1150). The ubosot features a laterite foundation with brick renovations, which points to its construction using materials from the original Khmer temple or its foundation during an earlier period than the renovation of the complex. 
The first imperially-constructed Ayutthayan monastic complexes are no doubt influenced by the layout of Khmer prasat, with a large prang anchoring the monastery flanked by rectangular brick wihan (prah vihar/vihära) facing east and simä-demarcated ubosot to the west; the wihan and ubosot were often connected to a narrow cloister which circumambulated the prang in a similar manner to corridors constructed at temple-complexes commissioned by Jayavarman VII. Image houses, supplementary prayer halls, and funerary stupas are placed surrounding the main complex over time; these were, like Sukhothai, often renovated or augmented over time and these renovations are either documented in chronicles or inscriptions. The earliest monasteries at Ayutthaya such as Wat Ratchaburana (Figs. 8.1-8.3) and Wat Mahathat (Ayutthaya) feature this layout, and were also discovered to house reliquary deposits within the crypts of their prang. ${ }^{148}$

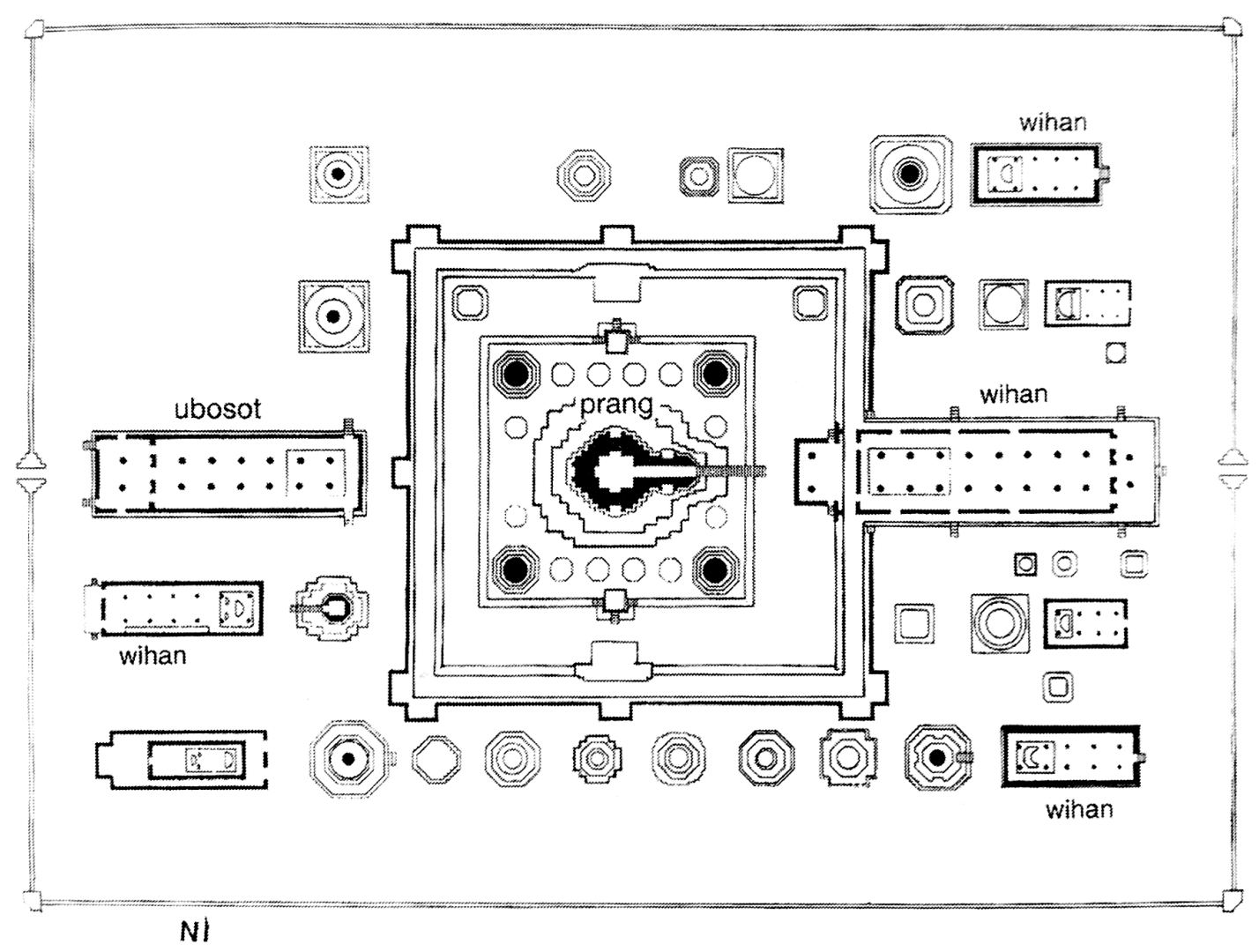

Appendix Fig. 8.1: Floorplan of Wat Ratchaburana, Ayutthaya (Pichard, The Thai monastery, 101)

148 Woodward, Some Buddha images, 160. 


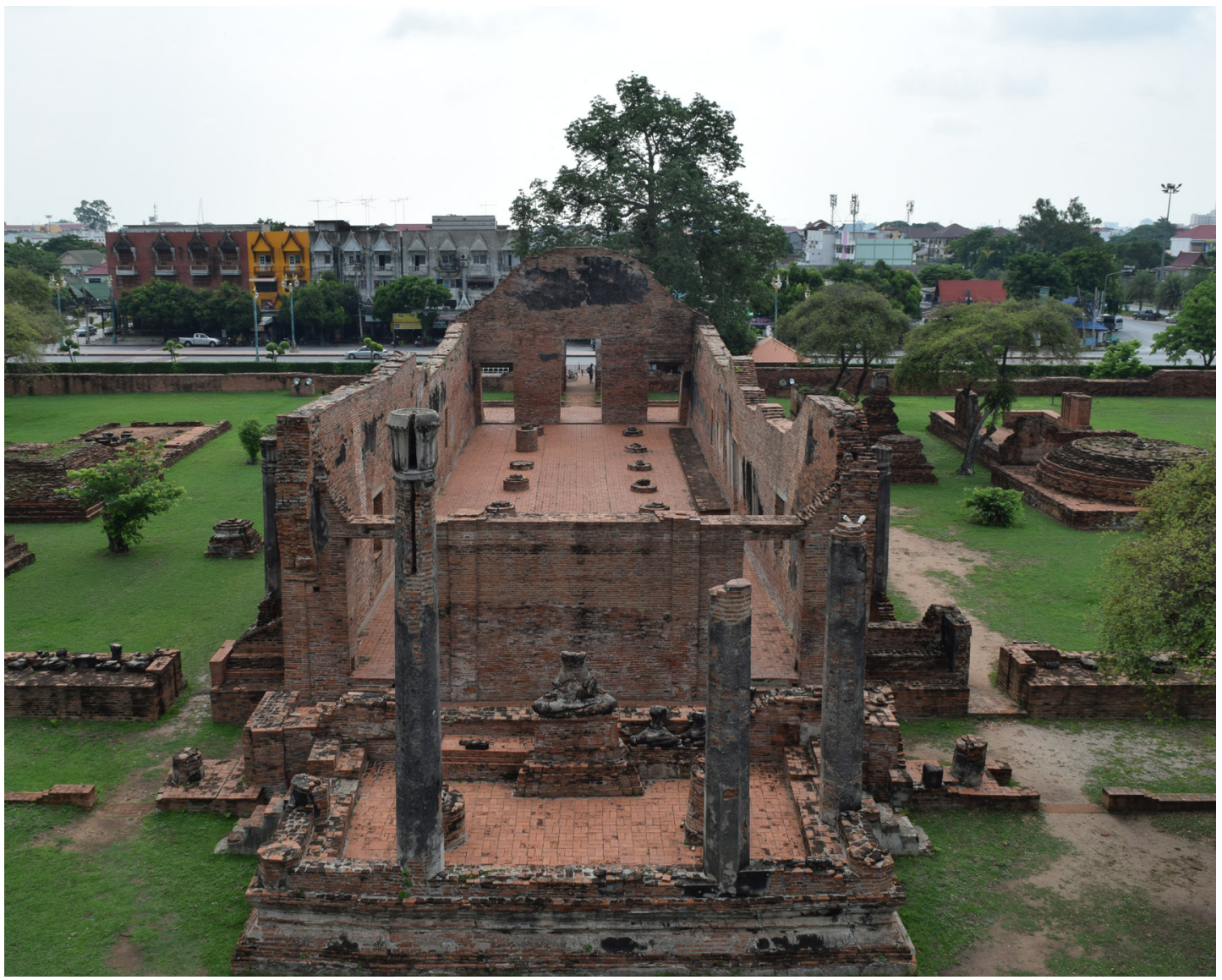

Appendix Fig. 8.2: Wīhan of Wat Ratchaburana facing eastward, Ayutthaya

Monasteries dedicated or thought to have been constructed during the mid-15th-early 16th centuries at Ayutthaya, such as the late 15th-century royal complex of Wat Phra Si Sanphet (Fig. 9.0), relegate the ubosot to the size of smaller image houses while the winan remains prominent in its original east-facing direction. Stupas (chedi) also change during this period, and feature a bell-shape with a conical ribbed spire instead of the earlier prasat-influenced architecture. This may be indirectly influenced by earlier Sri Lanka dagoba (large mound stupa) architecture, but more likely from Burma or Lanna ${ }^{149}$ to the northwest.

149 Chedi thought to have been erected during this period feature a variety of different styles; for example, Wat Thammikarat (north of the city) among others features a ribbed conical mound similar to chedi found in Lanna (modern Chiang Mai region), while Wat Yannasen nearby features a triangular prismic spire. 


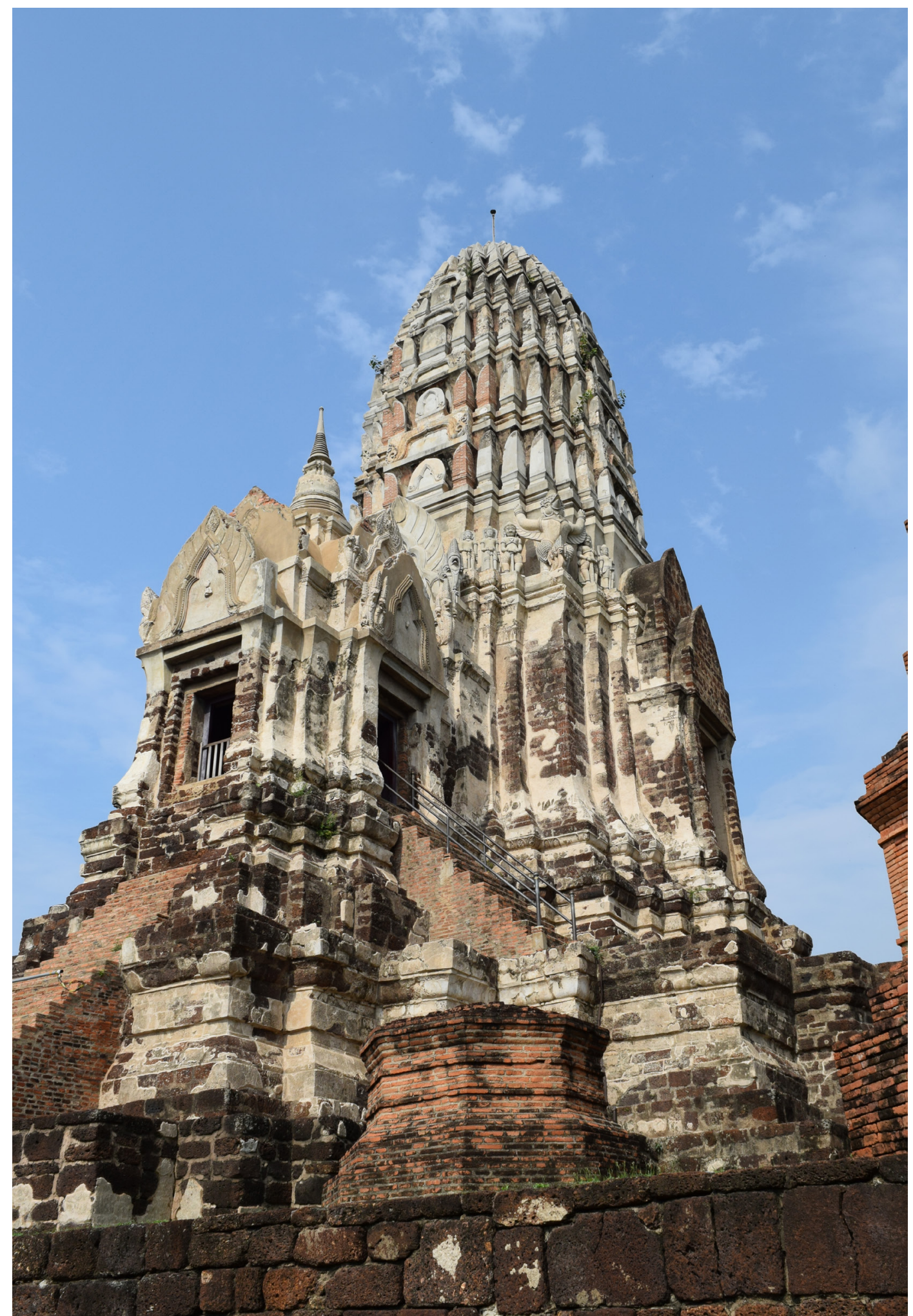

Appendix Fig. 8.3: Prang of Wat Ratchaburana, Ayutthaya 
To make a brief comparison to extant architecture at Sukhothai, the majority of the temples such as Wat Mahathat (Sukhothai) feature the ubosot as a secondary structure to a more typical wihan-prang layout. The layout of localized, less prominent monasteries at Sukhothai are similar to those of Ayutthaya, although the chedi is often replaced by a large brick-andplaster standing Buddha image which may be indicative of an earlier tradition.

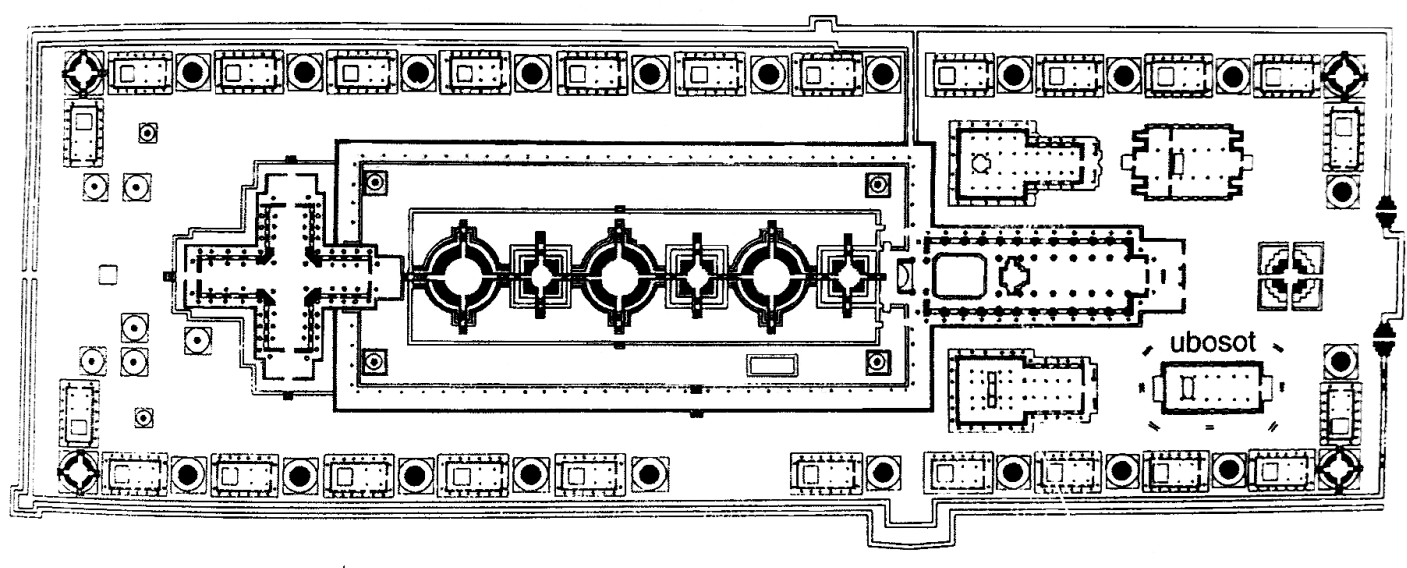

N)

Appendix Fig. 9.o: Floorplan of Wat Phra Si Sanphet, Ayutthaya (Pichard, The Thai monastery, 101)

The later period of Ayutthaya, from the 17th to the mid-18th century prior to its destruction in 1757 CE by the Burmese, is poorly-represented by inscriptions, but is thought to feature eastward-facing sim $\bar{a}$-demarcated structures directly attached with, or linear to, chedi in similar styles to those constructed in earlier centuries. The one exception is the enormous Wat Chaiwatthanaram commissioned in 1630 CE under King Prasat Thong (r. 1629-1656) as a brick replica of Angkor Wat's central bakan with a soaring Khmer-style prang. In all cases, the wihan has been entirely replaced by the ubosot and all structures are eastward-facing. 


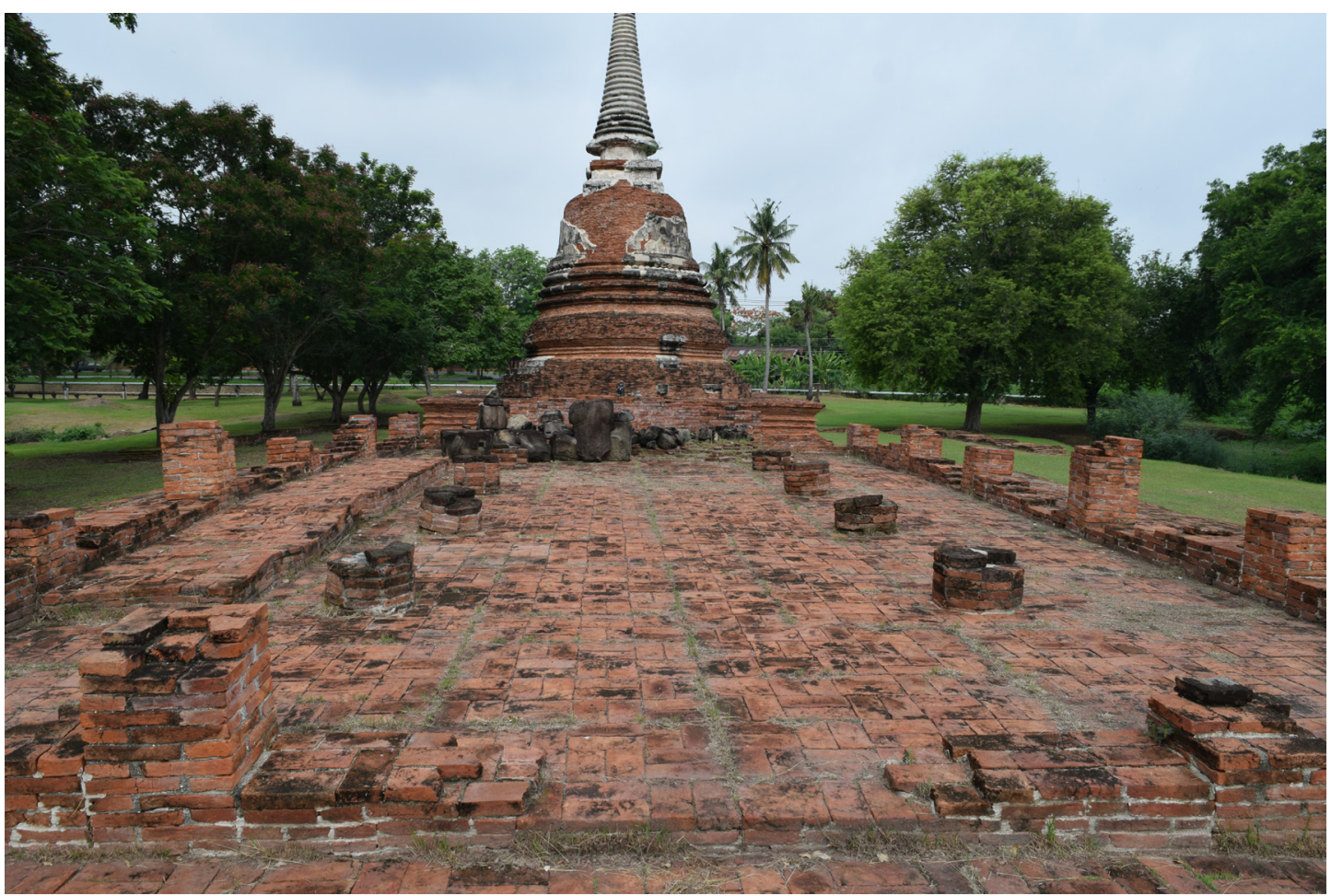

Appendix Fig. 10.0: Wat Maha Saman, Southwest Area, Ayutthaya

Outside the central areas of Ayutthaya, for example in the southwest of the capital and on the northern riverbank of the Khlong Muang tributary (See Fig. 6.o), a scattering of small local monasteries ${ }^{150}$ feature various types of differently-styled chedi, but no foundation inscriptions have been found for these; ${ }^{151}$ it is thus possible that the wihan-prang-ubosot layout from the earlier periods was reserved for imperially commissioned architecture. Confined monastic complexes indeed feature an ubosot, but single-hall monasteries with a wihanchedi layout do not; instead, there may be an ubosot in the vicinity of a large cluster of wihan or image houses. If the monastery is incredibly remote, the ubosot-chedi layout seems to dominate structural planning; this may indicate a later manufacture.

With these factors in mind, there are no monasteries or monastic complexes that feature the wihan-prang-ubosot layout thus far identified at Angkor. As no absolute dates are currently published for the placement of sima at Angkor, there is also no sense of when the boundary stone tradition within the capital began. Sima are believed to be a product of direct influence from Ayutthaya, originating from large boundary stones surrounding earlier Mon Dvaravati (6th-11th centuries) ubosot and wihan which have been debated to have in turn descended from megalithic stones demarcating ancient burials. ${ }^{152}$ It is thus not clear when

150 Many of these structures can be found today in Somdet Prah Si Nakharin Park in Ayutthaya.

151 In a similar manner to Angkor, those not associated or in proximity to an imperially commissioned monastic complex or a main arterial thoroughfare.

152 See Murphy, The Buddhist Boundary Markers, 365-372 for a thorough debate on this theory. 
this tradition arrived at Angkor, although Zhou Daguan does not mention simā within his description of the earliest Theravāda Buddhist monasteries in 1296 CE. It is argued within the body of the paper that the demarcation of a prah vihar with simā is a tradition of centrality descended from the construction of temples, and until the mid-late eras of monastic construction at Ayutthaya no ubosot were believed to have been built as solitary structures and thus the focal points of worship. Sima-demarcated structures thus formed a single area of a "cluster« of buildings forming a monastery, each with a different function, which because of the prasat tradition or a simple lack of resources rarely exists at Angkor.

That said, the overall rectangular structure, the raised southern tract, the central sanctuary pedestal, the mudra of of each Buddha statue, the relative dimensions of each building, the gradual shift to Sinhalese bell-shaped stupas, baked bricks used in the renovations of various prah vihar over time, and, as noted, the tradition of the placement of $\operatorname{sim} \bar{a}^{153}$ are directly influenced by architecture in both successive Thai capitals. Styles of simā, too, can be traced back to temples at Ayutthaya. ${ }^{154}$ Even the remains of Khmer-inspired Thai prang in brick are thought to have been constructed, for example at one of the hypothesized yet unexcavated 15th-century prah vihar at Angkor Wat ${ }^{155}$ (Figs. 11.1-11.2). This is best illustrated in the body of the paper in Fig 7.0 which features a direct comparison between the Buddhist terrace/prah vihar Prah Ngok (ATVo01) at Angkor Thom and an image house at Wat Phra Si Sanphet (late 15th-mid 16th centuries) at Ayutthaya.

$153 \operatorname{Sim} \bar{a}$ in a Thai context are first dedicated with the placement of a simā kil, a blessed stone orb that cements its place as an ordination hall. At Angkor, votive deposits beneath simā have been identified and have included bronze figures, burnt offerings such as bones or charcoal, and/or glazed local or Chinese ceramics.

154 The identical simā at Wat Preah Khan and Angkor Wat are in turn identical to a set found at Wat Wora Chet Tha Ram in northwestern Ayutthaya dated to 1593 CE by a foundation inscription (See Fig 12.0).

155 See fn. 125 in main text. 


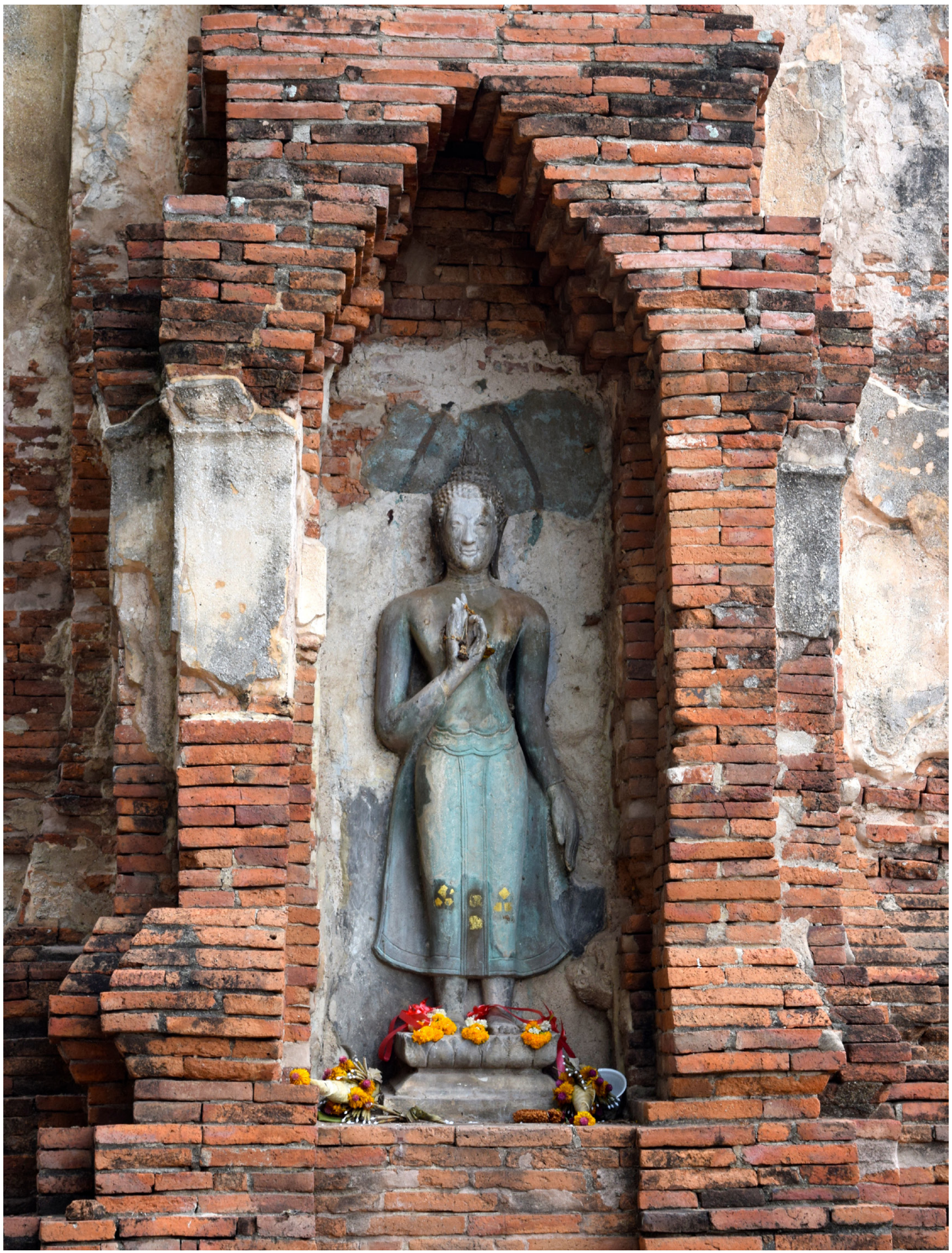

Appendix Fig. 11.1: Buddha "niche" from prang-shaped chedi, Wat Mahathat, Ayutthaya 


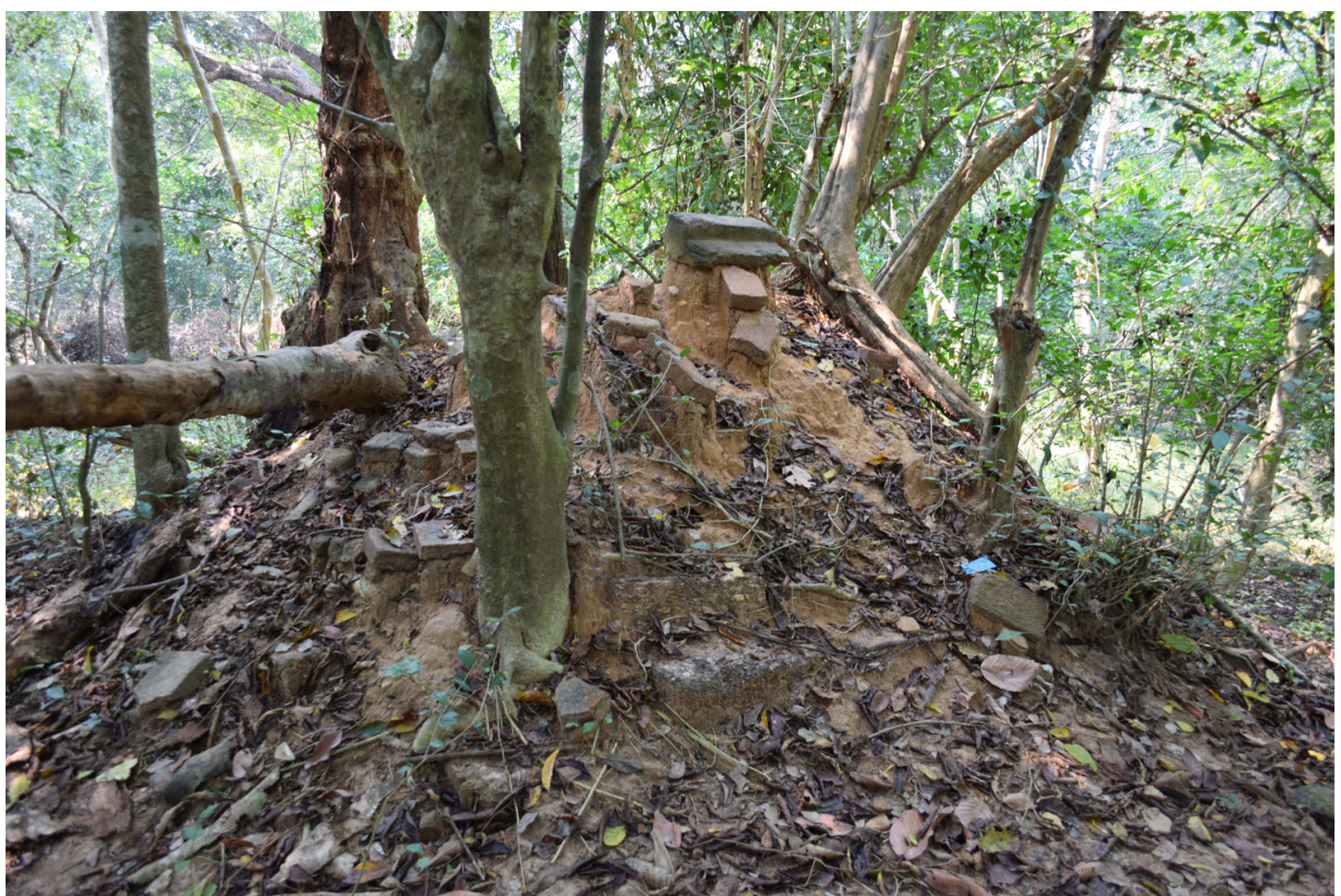

Appendix Fig. 11.2: Remains of a possible prang-shaped central sanctuary within an unexcavated prah vihar (AWBToo1), Angkor Wat
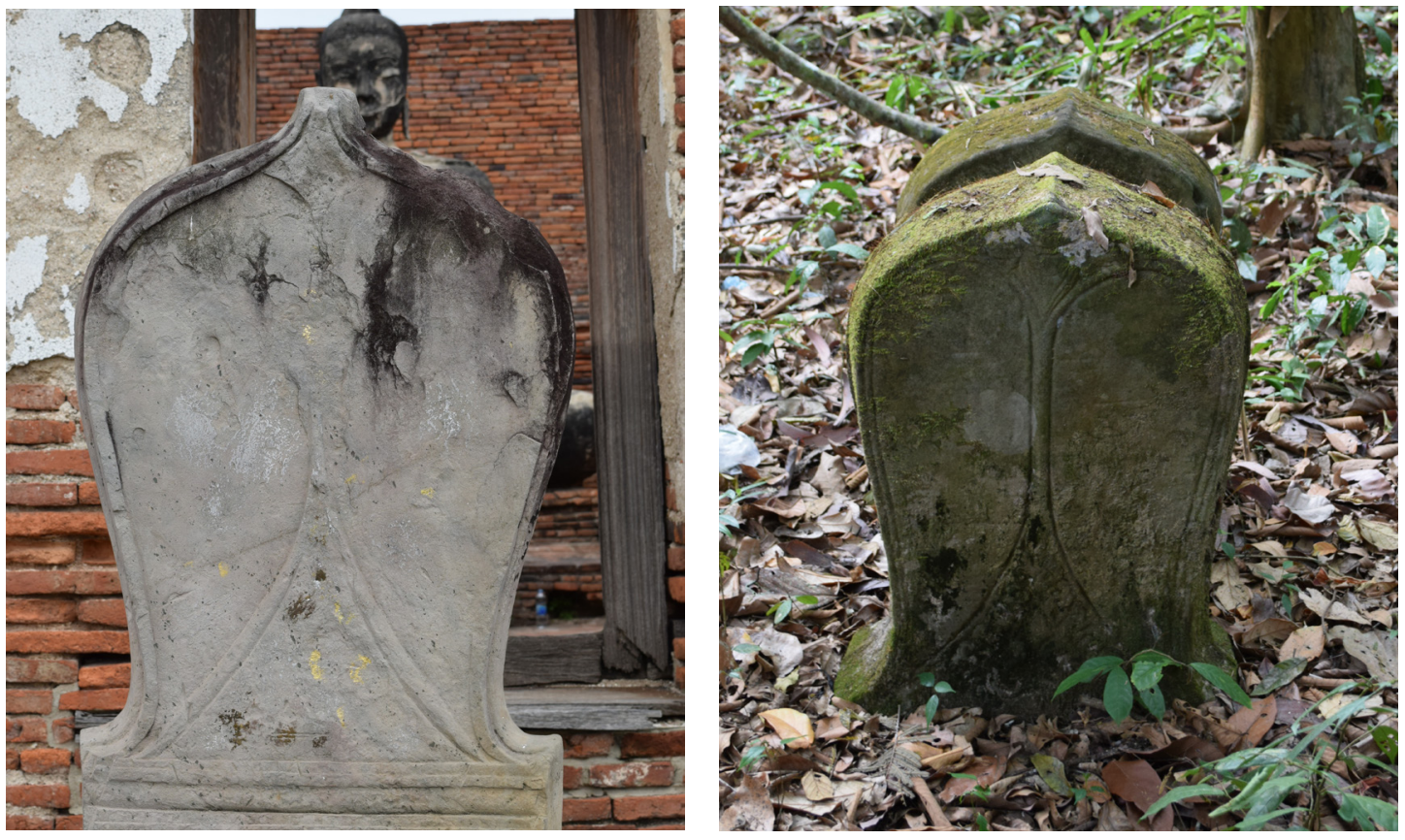

Appendix Fig. 12.o: Sīmā from Wat Wora Chet Tha Ram (c. 1593-1605 CE), Ayutthaya, and Wat Preah Khan (Date Unknown), Angkor 
It is also possible to explore connections with the Buddhist traditions of Sri Lanka, which are thought to have originally influenced earlier Mon Dvaravati Theravāda traditions in Thailand as early as the 6th century CE. ${ }^{156}$ Connections between Angkor and Sinhalese monks and monarchs have been determined to have been established at various points in time, but there are very few architectural connections that can be made directly between Khmer and Sinhalese structures based on site comparisons alone. Photographs of early 20th-century French clearance work surrounding the Bayon reveal that one structure, called ATV051, ${ }^{157}$ was found to feature "guardstones" depicting Buddhas flanking its eastern causeway, a Sinhalese tradition possibly dating as early as the Buddhist history of the holy city of Anuradhapura in the 4th century CE, ${ }^{158}$ alongside sima (Figs. 13.1-13.2). Noteworthy too is the presence of a Sinhalese-style stupa with a conical ribbed spire within the central sanctuary of Preah Khan Temple, though it is unclear whether this formed the original focal point of the temple or whether this was a later augmentation. Comparisons with Sinhalese architectural traditions also come from analysis of the Temple of the Tooth Relic found at the briefly serving capital of Yapahuwa (1272-1284 CE), where the temple takes on the form of a Khmer prasat ${ }^{159}$ up a mountainside (Fig. 14.O).

156 Thompson, Memoires du Cambodge, 56. Known as murugala in Pali; guardstones at the base of steps in monastic residential quarters at Anuradhapura (c. 4th-12th centuries CE) are left blank and resemble simä, while those fronting more prominent buildings such as dagoba (enormous rounded brick stupas - not Yoda's home planet in Star Wars) feature carved lokapala (guardian), dwarf, or nägarāja (serpent-king) figures.

157 This structure was originally called Prah Ngok, the title now given to the large prah vihar (ATVoo1) to the south, and has been partially destroyed in its contemporary use as a refuse for broken colonettes placed there during the anastylosis of the nearby Baphuon Temple undertaken intermittently between 1960-2011.

158 De Vos, Tradition of Sri Lanka, 53.

159 Goonatilake, Sri Lankan-Cambodian relations, 193. 


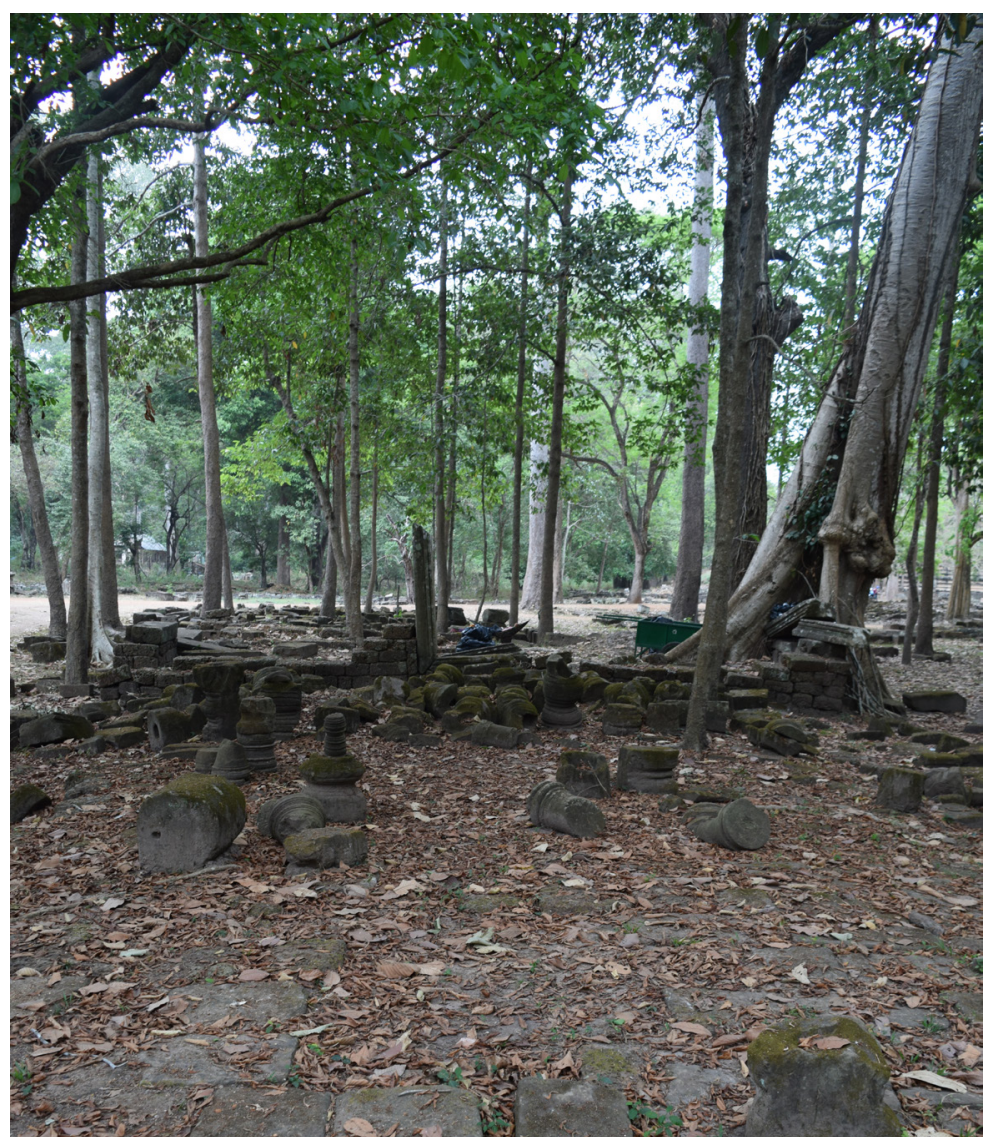

Appendix Fig. 13.1: Remains of "Prah Ngok" (ATV051), Angkor Thom

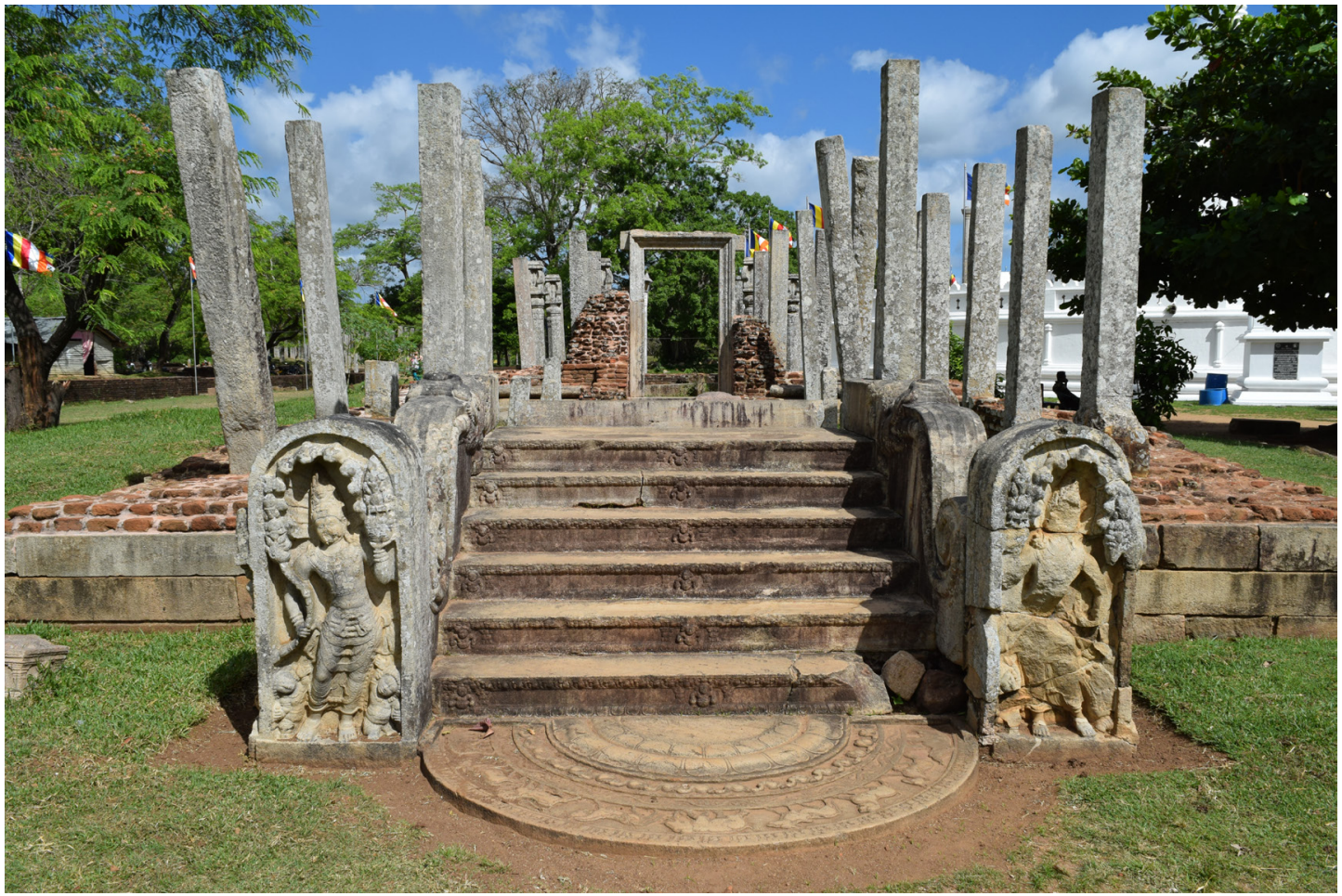

Appendix Fig. 13.2: Image house (Pațimāghara/Pilimagē), Lankarama Complex (Established 1st century CE), Anuradhapura. 
However, compared to the visible similarities between Ayutthayan and Sukhothai monastic architecture, the direct or indirect influence of the Sinhalese Theravāda architectural tradition on Angkor appears speculative at best. It could be argued that the scholarly enthusiasm to make these comparisons stems from the identification of a fragment of the Burmese Glass Palace chronicle noting that the son of Jayavarman VII, Tamalinda, traveled to the Mahavihāra monastery at Anuradhapura in 1180 CE to learn the dharma. ${ }^{160}$ More likely, however, past Sri Lankan-Cambodian Theravāda Buddhist exchanges are often emphasized over those with Ayutthaya and Sukhothai in order to avoid retreading historically sensitive ground without an abundant historical record available.

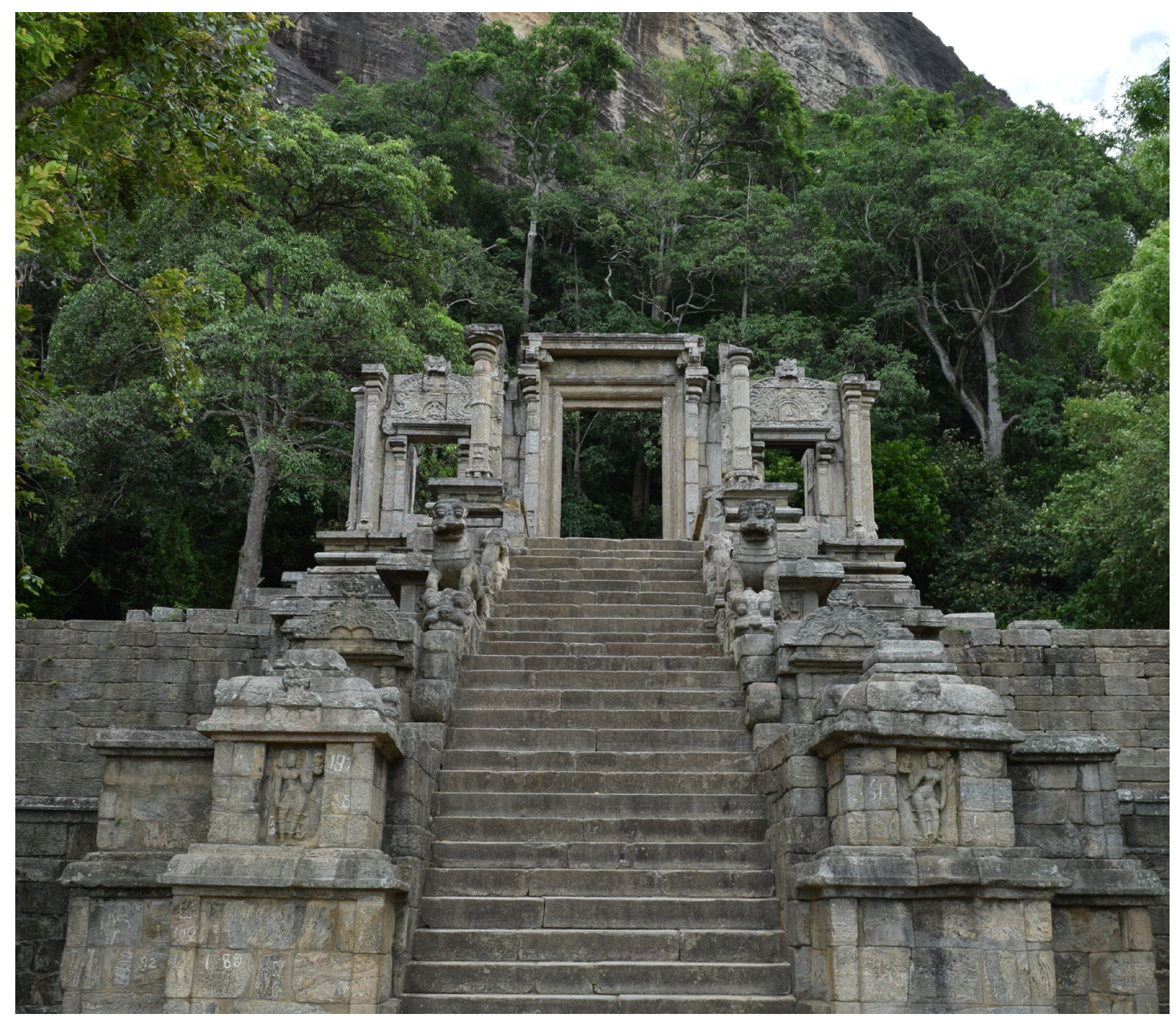

Appendix Fig. 14.o: Temple of the Tooth Relic (c. 1272 - 1284 CE), Yapahuwa, Sri Lanka

160 Harris, Cambodian Buddhism, 23. Harris notes that he stayed there for 10 years but died in Burma instead of returning to Cambodia, so the introduction of Theravàda Buddhism was later if one is to believe the end of the account in the Glass Palace Chronicle. 


\title{
The Monasteries of Athos and Chalkidiki (8th-11th Centuries): A Pioneering Front? ${ }^{1}$
}

\author{
Michel Kaplan*
}

Following the re-establishment of the Cult of Images in 843, the Bithynian Olympus (present-day Uludağ, Turkey) became the site of so many monastic settlements that it was all but impossible for the ascetics there to find true solitude. Therefore, they set their sights on Mount Athos in Chalkidiki, and began to settle there from the ninth century onwards. It was a turbulent time for the region, and as a result of complex political developments the land was abandoned and reverted to the state (klasma lands), with the tax revenues benefitting central authorities rather than local communities. The economic growth of the ninth century thus explains the conflicts over the lands around Mount Athos between the peasant population, the monasteries founded in the Chalkidiki region, and the monks on Athos itself. These conflicts were exacerbated by the foundation of the large institutions of Xeropotamou, Lavra and Iviron - the latter two of which also enjoyed the status of simperial monasteries". The extant documentation allows us to better understand both the attempts by the monastery to appropriate the lands and the resistance to these attempts by the village communities, who were particularly concerned with retaining grazing lands for their animals. Interestingly, the officials and judges in charge of the region seemed to have favoured the village communities in these conflicts.

Keywords: Monasticism, Chalkidiki, Athos, village communities, Byzantine taxation.

The Slavic invasions left the region south of Thessaloniki, and in particular Chalkidiki, in a state of semi-desertion. Gradually, farmers and monasteries in the region handed over this area, which is relatively favourable to agriculture, not without conflict. The establishment of monasticism on the Athonite peninsula was to become an important factor in the development of this region, especially after the middle of the 10th century and the foundation of large communities on the holy mountain, such as Xèropotamou, Lavra and Iviron. On both sides, as the conflicts that have occurred show, a real concern for territorial conquest has emerged.

After the official end of the Iconoclast Controversy in 843, the Bithynian Olympus (present-day Uludağ, Turkey), which was thought to have been the centre of resistance to the iconoclast movement, was all but overrun by a multitude of new monastic and eremitic foundations. This prompted the ascetics, who lived there in the hope of finding isolation

* Correspondence details: Michel Kaplan, Université Paris 1 (Panthéon-Sorbonne); kaplan@univ-paris1.fr. This article was translated from the French by Rutger Kramer with the assistance of Ella Kirsh.

1 I am referring to a concept familiar to geographers, but also often used to describe territorial conquests (such as those in the American West), without taking into account the fact that my article deals with relatively modest territorial gains. 
from society, to go looking for a new place of retreat. For reasons that will be explained below, they found what they were looking for in Chalkidiki in present-day Greece, and more specifically on the most mountainous and inhospitable of the three peninsulas that jut forth into the Aegean Sea: Mount Athos.

According to legend, the first of these hermits on Athos was called Peter, but there is no proof he ever really existed. ${ }^{2}$ That means that the first credible source on this process is the Life of Euthymius the Younger. ${ }^{3}$ The protagonist of this hagiography, born in 823/824, fled from his former life as a married soldier-peasant and settled on the Bithynian Olympus in 841. Once there, he heard rumours of Mount Athos, a new El Dorado for those seeking to escape secular life. And so it was that around the year 860, Euthymius, together with one disciple, left for Mount Athos, which he reached after a long journey that involved a number of ascetic adventures, such as a brief period as a stylite in Thessaloniki or the foundation of several monasteries on Chalkidiki. He retired alone to the island of Hiéra, in the shadow of the peninsula of Athos, where he died in 898. There does not seem to have been a coenobitic settlement yet in the period described. Rather, several more or less isolated eremitic colonies dotted the landscape, each harbouring a small group of anchorites. Euthymius, who had been ordained a deacon, had undoubtedly received a mission from the archbishop of Thessaloniki to hold services for the hermit who already lived on the mountain, and maybe even to organise them. ${ }^{4}$

The region had suffered greatly under the Avar and especially Slavic invasions of the 6th and 7th centuries, followed by Bulgarian raids in the 9th and 10th centuries. The settlement of Slavic peoples in Chalkidiki may be seen in the many toponyms and names of villages even today, as well as in the volume of Slavic names in the peasant lists maintained by the Athonite monks. ${ }^{5}$ The available source material does not allow us, however, to establish with certainty the moment when the Byzantine administration took control of the regions to the southeast of Thessaloniki, between that city and the river Strymon. The first mention of a strategos in Thessaloniki dates to 836, but an 824 letter by Michael II to Louis the Pious shows that there were already themes established for defensive purposes (but also to facilitate the reconquest of the area). ${ }^{6}$ Perhaps we even have to go back to the age of Nikephoros I (802-811) to find the

2 An older vita (BHG 1505) attributed to a certain bishop Nicholas, has been edited in Lake, Early Days, 18-39, and later also by Binon, La vie, 41-53. This dossier has been reassessed by Papachryssanthou, La vie ancienne, 19-61. For the version by the fourteenth-century theologian Grégory Palamas (BHG 1506), see Rigo, La Vita di Pietro, 177-190.

3 Vie d'Euthyme le Jeune (BHG 655), ed. Petit, 168-205. This vita was written by a disciple of the saint, whom he tonsured himself around the year 875; it was therefore composed shortly after the death of the saint. The oldest extant manuscript dates to the eleventh century. Euthymius: PMBZ 1851.

4 Papachryssanthou, La vie de saint Euthyme le Jeune, 225-45. The same author gives us a handy summary of the Life in Actes du Prôtaton, ed. Papachryssanthou, 18 and 22-29.

5 F. Brunet, Sur l'hellénisation, 235-265; Lefort, Toponymie et anthroponymie, 169-170. More generally, see Lemerle, Invasions et migrations.

6 Concilia, 2.2, ed. Werminghoff, 477, l. lo-11. We only have the Latin translation of this text, dated to 10th April, second indiction, which gives "Thraciae, Macedoniae, Thessaloniae et circumiacentibus Sclaviniis" as the regions whose leaders and armies were supposed to recognise the authority of the Empire. The theme of Thracia was given a strategos from 679-680 onwards (Oikonomidès, Listes, 349), whereas the theme of Macedonia already had one between 789 and 802 (ibid.); it seems logical that the theme of Thessaloniki would have existed in 824 as well, surrounded by Sclaveni, that is the Slavic population, which remained more or less independent. 
origins of this phenomenon, ${ }^{7}$ but by and large it seems clear that Byzantine institutions were established in the region in the first half of the 9th century - and wherever Byzantine institutions appear, taxation would follow. And yet, a fiscal system had already been in place during the reign of Nikephoros I. ${ }^{8}$ We catch a glimpse of his policies through the entry for 809/810 in the famous Chronographia by Theophanes. The historian was not a fan of Nikephoros, who had usurped the throne of his idol, Irene; in fact, he goes so far as to call him a tyrant. To

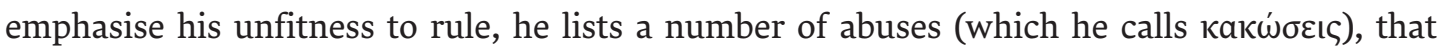
he compares to the Ten Plagues of Egypt that God had visited upon the pharaoh in order to prompt him to let the Hebrew people go. ${ }^{9}$ The third of these goes as follows: "His third abuse was to order a general census, and to increase the taxes by an additional levy of two kératia ${ }^{10}$ for administrative expenses."

It is here that we stumble across a seemingly intractable difficulty posed by the sources at our disposal. We know about Byzantine modes of tax collection, and even have teaching manuals for administrators, which show us the inner workings of the state apparatus in later periods. ${ }^{11}$ Newly cultivated lands were reviewed, entered into a land register, ${ }^{12}$ and taxed at the instigation of a censor (ávaypaфzúc), whereas the level of these taxes in pro-

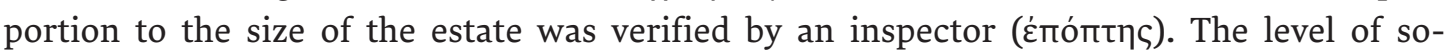
phistication leads us to believe that the system was already fully functional under the Isaurian dynasty (717-802), ${ }^{13}$ something which seems to be confirmed by Theophanos' mention of a general census under Nikephoros. It seems logical that the empire exerted or reasserted a significant level of control over Chalkidiki in the first half of the ninth century. But, even if the lands had been registered on paper, the situation on the ground was still far from stable. This explains the increasing quantity of klasma lands in the region.

To gain an idea of what exactly this means, and how these lands came to be, the fiscal treaty extant in the Codex Marcianus gr. 173 fols. $276 \mathrm{v}-281$ is enlightening:

7 At the same time as that of Macedonia: Oikonomidès, Listes, 352.

8 On the Byzantine fiscal administration, see the seminal work by Oikonomidès, Fiscalité.

9 Theophanes, Chronographia, 486-487.

10 The dikératon was undoubtedly invented by Leo III (see next footnote); Nikephoros may have transformed it into a regular contribution. When he took power by overthrowing Irene on 31 October 802, Nikephoros was General Logothete (genikos logothetēs), that is to say in charge of the finances and the taxes of the Empire.

11 Oikonomidès, Fiscalité. See also Géométries du fisc byzantin, ed. Lefort et al. The texts in question are difficult to date; the oldest passages might even go back to the early tenth century, given the mention of an interest rate levied by the state of 7 nomismata per pound, which was the going rate under Leo VI (886-912). Even if the text transmitted to us dates from after the reforms of Alexis I Komnenos (1081-1118) - cf. Morrisson, La logarikè, 419-464 - these treatises allow us to know how things functioned from the eighth century onwards, as one of the surtaxes mentioned was instigated by Leo III (717-741) in order to repair the city walls of Constantinople (Theophanes, Chronographia, 412). Two fiscal treatises are still extant in the Codex Marcianus: Dölger, Beiträge; completed by Karayannopoulos, Fragmente, 318-334. English translation in Brand, Byzantine Treatises.

12 On the Byzantine land registry, see Oikonomidès, Fiscalité, 31-34.

13 See the above note. Some people even argue that it goes back to the century before: Gorecki, Heraclian land tax reform, 127-146. This question will be revisited in 2019-2020 during a seminar by Constantin Zuckermann at the École Pratique des Hautes Études. 


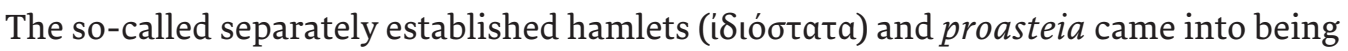
this way. When parts of the countryside ( $\chi \omega \dot{\rho} \rho$ ) were devastated by some foreign incursion or by some other act of divine wrath, and the surviving inhabitants were likely to move on account of being compelled [to pay taxes] even for what had been devastat-

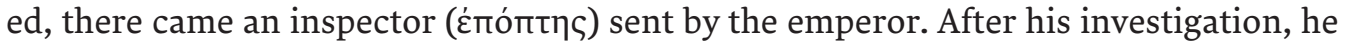

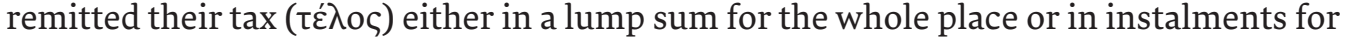
the devastated parcels ( $\sigma$ tíxol). Then if these owners returned within thirty years, the sympatheia [remission] was restored [to full taxability]; but if they did not return and the thirty-year period passed, another inspector is again sent and removes that former sympatheia to the register of desolated land ( $\kappa \lambda \dot{\sigma} \sigma \mu a)$. So when these things happened, either the inspector who created the klasma or another one after him separates into a special part the land pertaining to those parcels which have been made klasiria and

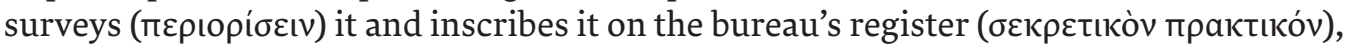
and he will make separate and enrol the survey of the remaining devastated taxable area of the village land and thereafter this division which has been made klasma might

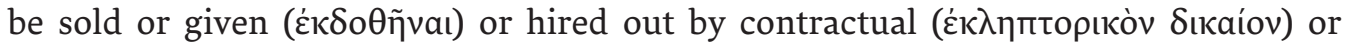

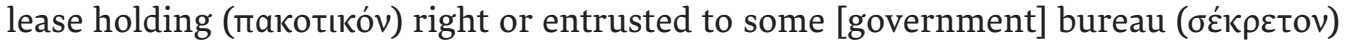
and thus be inhabited and improved. ${ }^{14}$

The oldest document conserved on Mount Athos is a copy of the sigillion ${ }^{15}$ (a charter signed and sealed by the emperor) drawn up in June 883 by Basilios I (867-886) in favour of the monks living on Mount Athos, but also favouring the monastery founded by John Kolobos close to Ierissos, at the edge of the peninsula. ${ }^{16}$ The emperor granted protection to the monks of Athos and the Kolobou monastery against any form of harassment they might suffer from both administrators (strategoi, the emperor's men, or basically anybody who felt responsible for the region) and inhabitants of the Ierissos region, from villagers to fishermen. It becomes clear immediately that the main imperial agents affected would be those in charge of the fisc. Given that there is no question of fiscal exemption - and indeed there would not be for a long time - this implied that the lands of Athos and the Kolobou monastery were fiscally unproductive, meaning they had become klasma lands after having been deserted for at least thirty years. A while later, in a charter for the Protatos monastery recording a judgement by Leo $\mathrm{VI}^{17}$ from February 908, we learn that the monks of Kolobou had obtained from the emperor certain unwarranted benefits which he now sought to revoke. The Athonite monks would no longer need to be worried: the villages in the region would retain their properties, and Kolobou's reach would be limited to Ierissos and the town of Kaména. The judgement finished with an important clause for our current purposes: "all the neighbours will benefit from the liber-

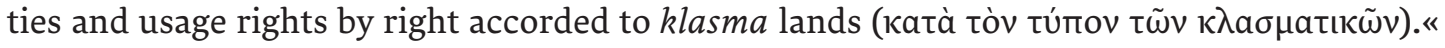




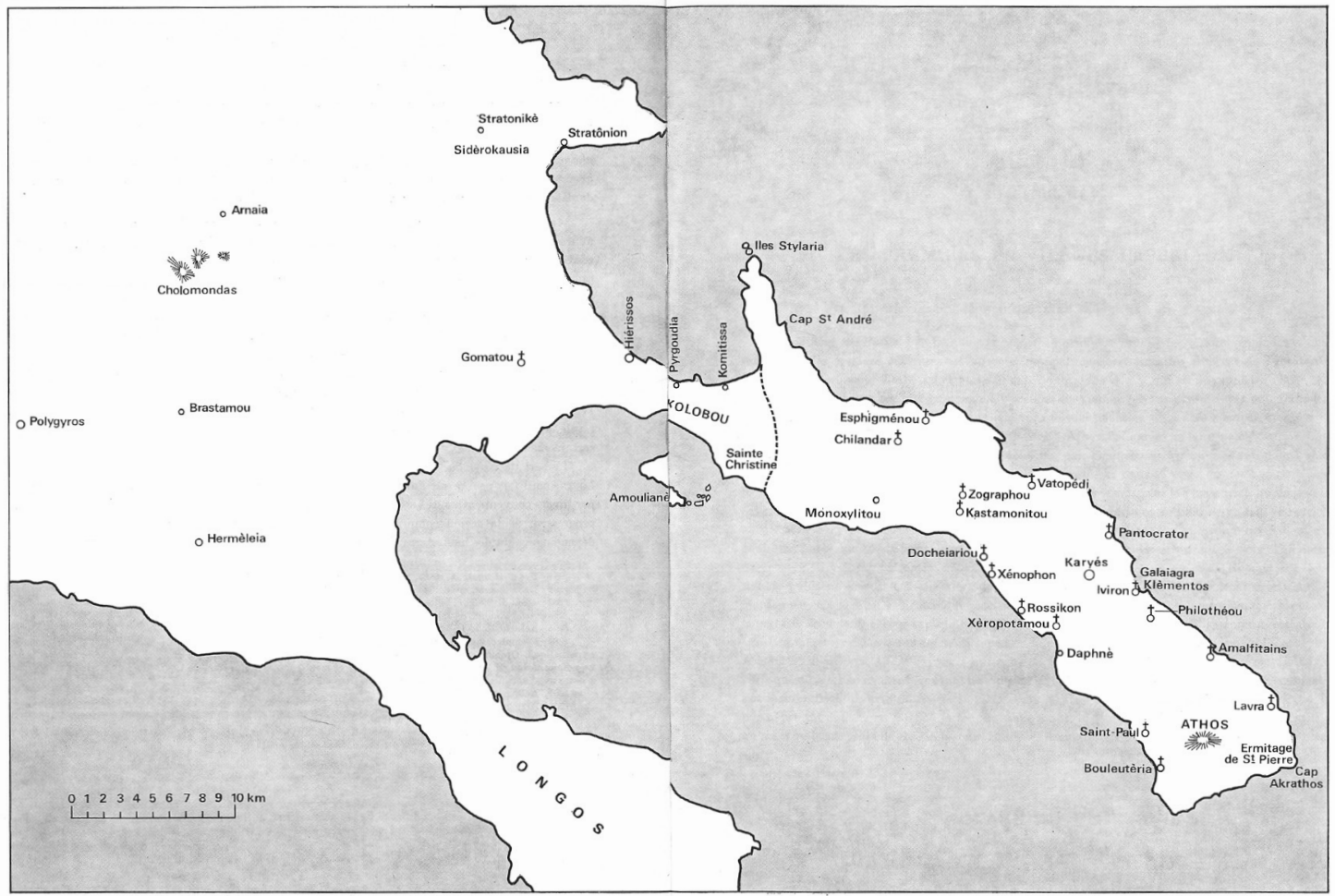

Fig. 1: Map of Chalkidiki, in: Actes du Prôtaton, no. 1, ed. Papachryssanthou, 42-43.

We learn a bit more about this statute through charters that have been conserved in the archives of Lavra and Xeropotamou, a monastery that had been founded before even Lavra, albeit at an uncertain date. These charters date from before the year 963, i.e. before the foundation of Lavra by Athanasius the Athonite ${ }^{18}$ and Nicephoros Phocas. The latter of these two would go on to become emperor shortly afterwards (r. 963-969), and the monastery, which was the property of its founder, ipso facto obtained imperial status. Nonetheless, Lavra retained ownership titles for the lands that had been donated to them, most notably those of the monastery of Saint Andrew in Peristerai, founded in 870/1 by Euthymius the Younger. He had obtained a cloister consecrated to the apostle Andrew, located about 30 kilometres southeast of Thessaloniki, which had been ruined and transformed into a sheep pen. In 884, he installed his male heirs there; his female followers would found a small nunnery nearby. Euthymius, who had been its first hegumen, relinquished that position to his grandson Methodius $^{19}$ in 884, so he could retire, first as a stylite in Thessaloniki, later on Mount Athos - although not without visiting his monastery on the way there. At an unknown point in time, the monastery in Peristerai became imperial: between 944 and 959, a chrysobull by Constantine Porphyrogenitos confirmed the independence of the community as an imperial monastery, thus clarifying its relation to the metropolitan of Thessaloniki. ${ }^{20}$ In 963 , Nicephoros Phocas donated the imperial monastery of Peristerai to Lavra, which had just been founded.

18 PMBZ 20670.

19 PMBZ 25073.

20 Mentioned in the chrysobull of Constantine X Doukas in favour of Lavra, no. 33, June 1060, Actes de Lavra I, ed. Lemerle et al., 202-203, 1. 25-40. 
Among the ownership deeds that entered the archives of Lavra at that point, we find a charter confirming the acquisition of klasma lands in the course of a general sale in 941.

»+++ I, Thomas, imperial protospatharios, asekretis, inspector and anagrapheus of Thessaloniki, acting on a divine ruling by our great and peaceful emperors, sent by God, Romanos, Constantine, Stephen and Constantine ${ }^{21}$, who commanded me to sell the lands on the peninsula of Pallenee, also called Kassandra, to those among the inhabitants of the theme of Thessaloniki who would want it; because, based on the authority of the chrysobull about these lands sent by our holy emperors, it concerns klasma lands, I have sold to you, Euthymius ${ }^{22}$, monk and hegumen of the monastery known under the name of Saint Andrew the First-Called Apostle, that is of [the community of] Peristerai, the very pious imperial monastery which you represent, an area of 800 modioi situated in the place called Leukon, together with Posidiou and Korakeon, as well as another measuring 1000 modioi situated in the place called Ptelaia, together with Stephanike, the field situated in Apebreos, and the field of Moutaleos together with the adjoining uncultivated lands. In total, I have sold you, if the two are tallied up, 1200 modioi of cultivated lands, and 600 more modioi of wild lands, which makes a total area of 1800 modioi. ${ }^{23}$ For this reason I have received from the aforementioned Euthymios, monk and hegumen, 36 nomismata of gold, which I must turn over to the fisc. You will also contribute to the outstanding taxes for these lands, which are as high as 12 nomismata, proportional to what you retain. Nobody among those who have acquired lands on the peninsula of Pallene will be able to contest your right to water, to logging and gathering brushwood, or your grazing rights, any more than you can forbid those who so desire from making use of the uncultivated lands that you have acquired. Because it has been decreed and disposed that everybody shall be master only over the [part of their] fields which have [has] been sown, but that the grand total of the grazing lands on the peninsula will be, as has been said, owned by and accessible to all, not just those who have bought these lands, but also those who have not sold it but who, faced with raids and barbarian invasions, have come to take refuge there. Thus, for your security, I have written this, I have signed it with my own hand, and I have authenticated it by affixing my seal. Written in the month of August, Fourteenth Indiction, Year 6449. +

$+\mathrm{I}$, Thomas ${ }^{24}$, imperial protospatharios, asekretis, and inspector of Thessaloniki, have completed [this charter] with my autograph and my seal in the above-mentioned month and indiction. ${ }^{25}+$ « 
Of course, we should not forget that, at the same time, the same administrator also sold 100 modioi $^{26}$ under the same conditions to a peasant called Nicolas, ${ }^{27}$ son of Agathon. ${ }^{28}$ This allows us to establish two important points about the status of klasma lands: they allowed for grazing on the uncultivated parts, and refugees had the right to settle there under pressure of »barbarian invasions", which, in 941, probably meant the Bulgarian raids in the area. Moreover, if these two documents from Lavra indeed concern the same area - that is, the peninsula of Pallene or Kassandra, at the southernmost tip of Chalkidiki - similar situations occurred elsewhere in the region as well. This may be seen, for instance, in the first charter for Xeropotamou, dated to April 956, in which John, the chartoularios of the general logothesion, ${ }^{29}$ under orders from the emperors Constantine VII and Romanos II, re-evaluated the klasma status of the lands in Ierissos which had been sold to the peasants by the inspector Thomas, ${ }^{30}$ as well as their allocation to the monastery of Saint Nikephoros in Xeropotamou. ${ }^{31}$ As it happened, Thomas had sold these too cheaply, and consequently at a tax rate that was lower than allowed. Eleven peasants had each acquired 50 modioi, and two had even bought 200, all close to Ierissos, a small town and episcopal see situated close to the Athonite peninsula. John declared: "In my estimation, they [should] have been sold at a value of $38 \mathrm{nom}$ ismata, of which 19 have been put aside as they have already been paid; as for the remaining 19, I went to collect them and turn them over to the general logothésion «.

The monks of Xeropotamou were treated thusly: "[they] also displayed an imperial horismos by our holy purple-born emperors, enjoining me to give them 1000 modioi of the lands mentioned straight away, so they could possess it; because the monastery did not have an inch of land to take care of its needs, in order that they pray for their imperial majesties. After the monks had paid up the 19 nomismata, ${ }^{32}$ the monastery of Xeropotamou was made proprietor, by imperial prostagma, of the above-mentioned land, sold by the aforementioned protospatharios Thomas. Nevertheless, the monastery must retain and possess these lands for the good of the mountain and pray for the might of the emperors, in accordance with the orders given in the above-mentioned imperial horismos. This was written on venerable purple, and I have imposed upon the monastery for security [the sum of] 9 miliaresia and 11 foleis. « $^{33}$ It did not seem to matter whether or not Xeropotamou had other possessions outside of Mount Athos: the monastery immediately seized the opportunity offered by the cadastral revision 15 years after 941, to obtain lands in a coveted area, the "suburbs « of Ierissos. And with that, the competition with the peasantry, both rich and poor, ${ }^{34}$ for control of the lands of Chalkidiki began in earnest.

26 About 10 hectares.

27 PMBZ 25954.

28 PMBZ 20177.

29 The institution led by the General Logothete, in charge of maintaining the registry and levying taxes.

30 This is the same Thomas mentioned earlier in the context of sales for the benefit of Peristerai and Nicholas, son of Agathon.

31 Actes de Xèropotamou 1, ed. Bompaire, 39-40. This charter could well indicate that Xeropotamou is the oldest monastery on Mount Athos.

32 Those deposited in 941 by the peasants.

33 Dölger, Beiträge, c. 21, 120 : »The buyer ... is not required to pay the tax that was the subject of the temporary relief

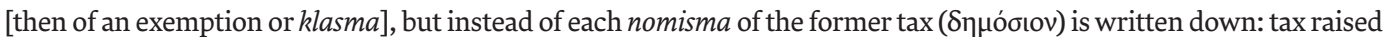
under a libellos ( $\left.\lambda_{\iota} \beta \varepsilon \lambda \lambda_{\iota \kappa o ́ v}\right)$, one-twelfth of a nomisma. « On this specifically, see Oikonomidès, Das Verfalland.

34 Kaplan, Les élites rurales byzantines, 299-312. 
Before that could happen, however, another, even more impactful process would need to be completed. This was the delineation of the Athonite territories - which has persisted until the present day, even if it has not always been easy. The year was 942, and a conflict was brewing between, on the one hand, the peasants and the monasteries in Chalkidiki close to the Athos peninsula, and on the other hand those who simply called themselves the monks of Athos, working in the name of the community of Athonites - even if one of the signatories ${ }^{35}$ of the eventual treaty ${ }^{36}$ used the title "John, monk and hegumen of Athos". As it happened, the monasteries and the peasants from the region around Ierissos acquired the klasma lands up to Mount Zygos, but the monks of Athos claimed to hold the same territories. ${ }^{37}$

It is clear that the Athonite monks did participate in the sale of the klasma lands. The two

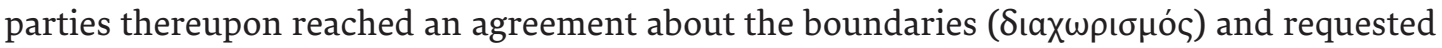
that the inspector, Thomas, would come to trace them physically. What follows is a report by said Thomas, ${ }^{38}$ who explains how the Athonite monks claimed possession of the whole of Mount Athos, because this was inscribed under their name in the ancient klasma register

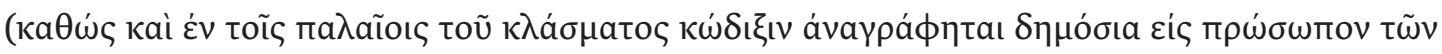
$\mu$ ovax $\tilde{\omega} v$ tov " $\left.A \theta \mathrm{o}^{39}\right)$. Once the boundary had been fixed, however, the lands situated between Athos and the monastery of Kolobou were sold to the local people, who received the

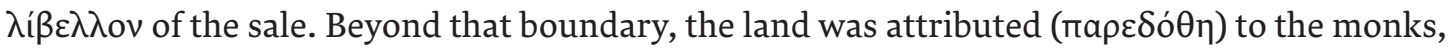

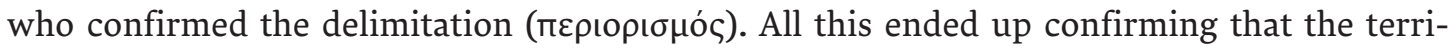
tories held by the Athonites were klasma lands, which follows from such statutes on klasma lands as we have seen in Lavra no. 2. On top of all that, the peasants retained the right to bring their flocks to Athos for protection in case of a foreign invasion, provided they notified the monks and refrained from building sheep pens or beehives. The animals were already a nuisance to the monks, who had only received a small plot of infertile land.

What follows is a charter served and sealed by the strategos of Thessaloniki, in which the boundaries between the territory of the monks of Athos and the inhabitants of Ierissos are traced and fixed. ${ }^{40}$ However, it is but a brief document, revisiting the charter of the inspector Thomas without bringing anything new to the table. Still, the monks complained to the emperor about the dealings of the administrator, whom they thought was on the side of the peasants; and as we will see, this was more often the case. The emperor, for his part, essentially stonewalled them and sent a prostagma to the strategos of Thessaloniki in order to

What is meant here are signa at the top of the document, i.e. those of the parties to the contract, not to be confused with the signatures of the guarantors, which were much longer and which feature the archbishop of Thessaloniki at the top of the list.

Prôtaton no. 4, May 942, Actes du Prôtaton, ed. Papachryssanthou, 191-192.

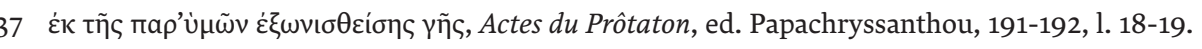

38 Prôtaton no. 5 (entre mai 942 et août 943), Actes du Prôtaton, ed. Papachryssanthou, 195-197.

39 Actes du Prôtaton, ed. Papachryssanthou, 195-197, 1. 20-22.

40 Prôtaton no. 6, Actes du Prôtaton, ed. Papachryssanthou, 201-202. 
wrap things up. Added to this was a letter of advice by the magistros Kosmas, ${ }^{41}$ which probably dealt with the klasma lands, given that he actually went there. He journeyed at the head of an imposing delegation (albeit without Thomas, so as to avoid provoking the locals), in order to set the boundaries (1. 6) "in accordance with the charter of Thomas Morokoumoulos «. ${ }^{42}$ Likewise, at the end, "having thus fixed the boundaries and established the border lines according to the delimitation set by the inspector, we have enacted this decision in writing, and presented the [resulting] document to all parties involved.« ${ }^{43}$ In short, the monks' reclamation failed a second time. The message was clear this time: the same boundaries exist even today.

At this point, the monks of Mount Athos were still living in small colonies of hermits, even if, from an outside perspective, they were already organised in a way that allowed them to be a single party in the legal procedures and to negotiate with the emperor directly. Near the end of the tenth century, the situation had changed fundamentally, most notably following the foundation of Lavra in 963 and that of Iviron in 979/980 by Iberian monks (from the ancient kingdom of Iberia, also known as Kartli in present-day Georgia) from the monastery of Athanasius - both monasteries with imperial status from the get-go. ${ }^{44}$ Each of these communities was soon given a host of smaller monasteries, notably those situated in Chalkidiki. With regards to Lavra, ${ }^{45}$ Athanasius obtained the imperial monastery of Saint Andrew of Peristerai in 964, a monastery that was rich to the point of decadence. In 989, he received the patriarchal monastery of Gomatos, also in Chalkidiki, which he immediately transformed into a metochion. ${ }^{46}$

41 This was an important person: PMBZ 24110. Kosmas was the nephew of the patriarch Photios, who was one of the most important advisors to Romanos I Lekapenos, and who is generally seen as having taken a leading role in the composition of the novella of Romanos of 934, aimed at land acquisition by the aristocracy. Cf. Lemerle, The Agrarian History.

42 Prôtaton no. 6, Actes du Prôtaton, ed. Papachryssanthou, 201-202, 1. 6.

43 Prôtaton no. 6, Actes du Prôtaton, ed. Papachryssanthou, 201-202, 1. 39-41.

44 By seceding, the Iberian monks of Lavra continued to benefit from their imperial status.

45 Actes de Lavra I, ed. Lemerle et al., 58-61.

46 A metochion is a dependency of a monastery; the monastery staffs it with monks so as to ensure it is administered to its advantage. 


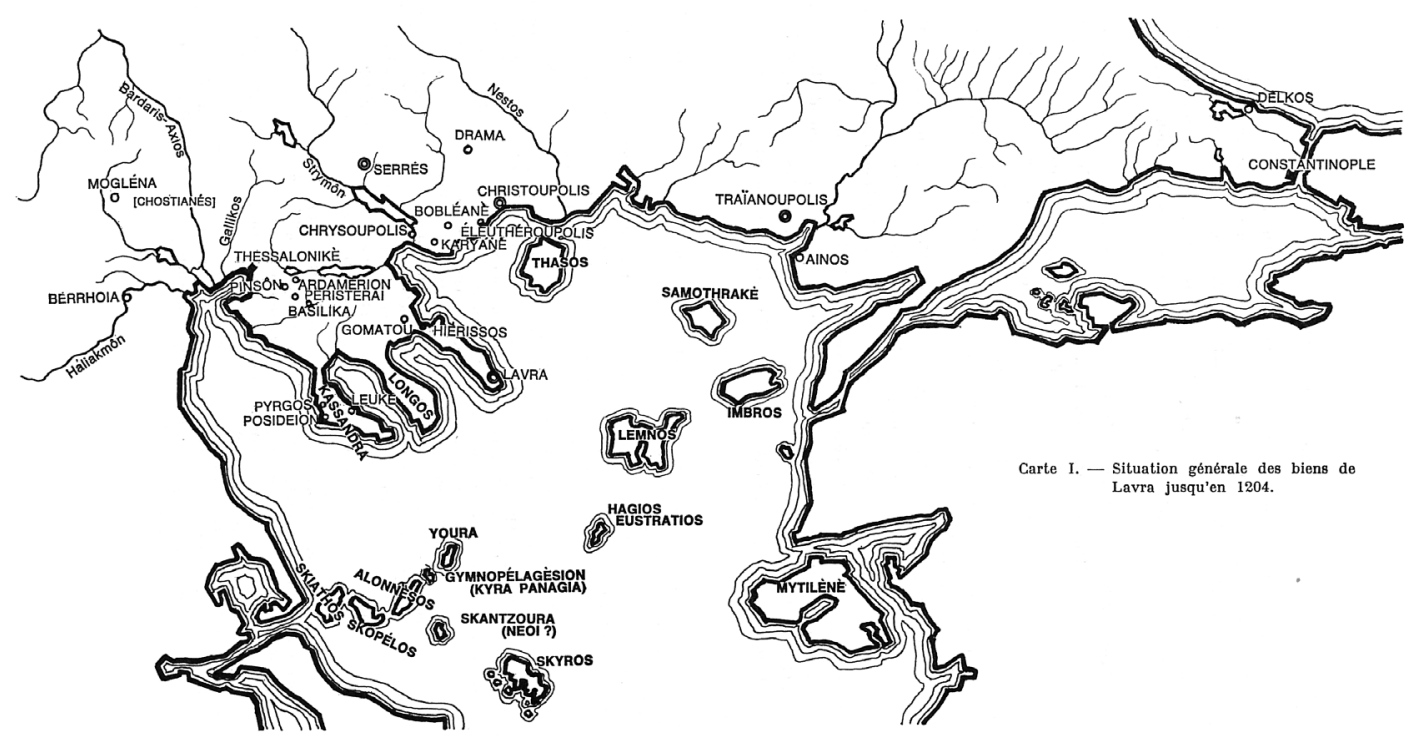

Fig. 2: The possessions of the Lavra monastery until 1204, in: Actes de Lavra I, ed. Lemerle et al., 57.

As for Iviron, its main acquisition was the Kolobou monastery, founded around 866 by John Kolobos in the region of Siderokausia. Before 883, John also founded the monastery of Prodrome in Ierissos, to which he also attached the community in Siderokausia; meanwhile, he obtained imperial status and a swathe of important klasma lands for the monastery of Prodrome - at the time still called Kolobou as well. In 975, this community was given the monastery of Polygyros, located in the centre of Chalkidiki and founded in the earlier tenth century by the protospatharius Demetrios Pteleotes, ${ }^{47}$ who had provided it with about 50,000 modioi of land. Afterwards, Iviron also obtained the monastery of Leontia, which was located in Thessaloniki but had possessions on Chalkidiki as well, and which, in turn, was in possession of the monastery of Abbakoum, which had become its metochion. Moreover, Iviron had obtained the monastery of Kolobou immediately upon its foundation. ${ }^{48}$ With this also came its possessions and dependencies, as well as the conflicts surrounding these. The most spectacular among these was a competition between the monastery and the inhabitants of the town of Siderokausia, where the Kolobou monastery had been founded. It was a conflict that clearly demonstrated the role of Iviron in the "conquest " of the territory, as shown in this explication by the judge Nicolas ${ }^{49}$, who arbitrated the conflict in December $995^{:{ }^{50}}$

47 PMBZ 21481.

48 Lefort, Une grande fortune foncière, 727-742, esp. 728-730 ; Id., Rural economy, 286-287. Kaplan, Les moines et leurs biens fonciers, 216-218.

49 PMBZ 26039.

50 Actes d'Iviron I, no. 9, ed. Lefort et al., 160-163. All the persons mentioned are introduced in the document itself (see below). Siderokausia was situated in the present-day village of Stagira: see the note by Lefort et al., Paysages de Macédoine, 241-242. 
Those who follow a monastic lifestyle, far from sorrow, need any small bit of material assistance that will help them avoid the complete decay of their bodies, so that, through this assistance, their soul may accomplish something useful. In fact, a soul separated from its body can do neither good nor evil; but what does happen is that, under pressure of bodily necessities, even monks would harm their neighbours and can become insufferable.

After the monks of the imperial monastery of Kolobou had thus pestered their neighbours and fellow taxpayers, the inhabitants of the village of Siderokausia, these villagers called together a tribunal in order to give them the appropriate aid. This was an ancient and confusing affair; [the judge has deemed it useful to explain] its origins in order to make it easier to understand the judgement for those who would learn of it in the future. Several religious establishments are dependent on the aforementioned village of Siderokausia; they are situated within its limits (пврьорı $\sigma \mu$ ó $)$ ), in accordance with the ancient delimitations established by the former spatharokandidatos and inspector Nicolas, under the reign of kyr Leo and Alexander. This document, which has been produced by the very venerable monks Euthymius the priest, son of the kyr John of Iviron, ${ }^{51}$ and George, ${ }^{52}$ the nephew of this John, ${ }^{53}$ gives the following itinerary: it begins in the place known as the »Three Churches", and, crossing numerous heights, tops, hills, descents and other landmarks that are mentioned, it reaches the sea at the port of Papas - and from there, it returns to the aforementioned "Three Churches«. Within the perimeter of this périorismos, mention is made of several isolated farms that belong to the monastery of Kolobou, as well as a place called Arsinikeia, which is not otherwise named, a small and clearly delineated place bordered on three sides by the aforementioned hills and by the river that runs alongside it, and on the other side by the water mills of the monastery of Saint John (Kolobos) and the wall of trees delineating them. [The terrain] close to the sea, which goes all the way there by way of an isthmus, is called not only Arsinikeia, but has been given a name by the isolated farms (áypísıa) of the village ( $\kappa \dot{\omega} \mu \eta)$ of the Siderokausites, which are built there. These flat, wooded lands came into the possession of the Siderkokausites and belong to them with the exception of a part, the metochion of Belikradou, which is close to Upper Arsinikeia (Ano Arsinikeia), as indicated by the decisions of the judges from the capital and the memories of the judges in the province. While Lower Arsinikeia (Katô Arsinikeia), as mentioned, was once completely covered in woodland and trees, with canals dug to bring waters from the heights to operate the mills and make fertile the gardens and orchards, as well as the grazing lands for the beasts, the monks thought it would be a good idea to allow a multitude of animals loose there, which ruined the seeds that the Siderokausites living there had planted.

These inhabitants, refusing to bear such damages, agreed to go to the tribunal, and, once there, started shouting all at once like a bunch of louts; one, that the grain that had just been sown had been trampled to such a degree that it could not grow anymore; another, that the grain that had just grown, had been eaten by the cattle; yet

53 These are the leaders of the monastery of Iviron in 995. The fact that Kolobou was still called a "monastery « here indicates that it had not yet been demoted to the status of metochion. 
another, that the harvest had been done by the teeth of the animals before harvest time. The monks, furious, responded: "we alone should be in possession of the entirety of Arsinikeia, just as it has been recorded in this delimitation in the name of our monastery. " The mob responded: "The record only mentions the metochion of Belikradou: by which right would they retain the sole rights to Arsinikeia under the pretext that they have established a great number of paroikoi? « The monks objected: »By the judgement of the tribunals of the capital and of the province, not only do we hold the property rights over Arsinikeia, but you have had the right to use a part of those lands since time immemorial, and you retain it without being hindered." Having said that, they showed the judgement of the protospatharius and former high chartoularios, Constantine Karamalos, ${ }^{54}$ as well as another by Nikephoros, ${ }^{55}$ who was anthypatos, patrician and strategos of Thessaloniki at the time, and who would subsequently be elevated to the dignity of magistraton, and who died in the themata of Italy. The mob, thrown into complete disarray, cried out: "You have the right to the metochion in Upper Arsinikeia, but not to Lower Arsinikeia, because different names distinguish them ... there where you have built mills, made gardens and planted orchards, in the process aggrieving the community (tò koเvóv). You know very well that it was established thusly, given that the judge at the time had visited and examined each of these placed by himself."

Confronted by the hullaballoo caused by these incomprehensible cries, the judge came up with an appropriate solution, well thought-out and profitable to both parties: he divided the region. He determined that the monks of the monastery of Kolobou would become the proprietors of the territory of Upper Arsinikeia, the metochion of Belikradou and all the other assets featured in the brebion of the imperial sakellion, ${ }^{56}$ just as had been recognised in their favour in their documentation - and he had crosses engraved showing the division of the territories. In the main part of the metochion, from the large and elevated plane tree on the edge of the creek, the boundary descends from the house belonging to the village ( $\chi \omega$ wíov) of Kloutzésta, and, from there, towards a forked tree, and from there, towards another tree close to which lies a rock in the shape of a root; after the stream that is there, there looms another plane tree at the foot of the hill. And just like that, the separation to the advantage of the Siderokausites had been made, to the agreement of both parties. As far as the division between the metochion and the mills was concerned, this started from a tree planted on the Mnemoria hill, where the people also put up a venerable cross; from there, towards another tree that grew close to the paved square, and then towards the other plane tree situated in the middle of the small islet separating the two streams; from there, the boundary runs to the large rock on the side of the hill.

\footnotetext{
54 PMBZ 23918.

55 PMBZ 25608.

56 The lands of Kolobou, being an imperial monastery, were also imperial lands, managed by the imperial sakelle; the brébion is the administration of the imperial goods.
} 
Now that the places had thus been delineated and separated from those that fell within Arsinikeia, the monks took care to record the decision and guarantee full and entire ownership ... over the slopes on both sides of the mountain; but they did not have any decision and could not impose themselves on any other place, no matter what it was called, in Arsinikeia. Because the judge had the campsites reduced to ashes and chased away the paroikoi, after which he stipulated that they (i.e. the monks) could only drive their flocks there for three months per year, namely from the first of July until the end of September, and nothing more. They did not have the right to gather or take away even the smallest morsel of seasonal fruit, nuts, plums or whatever else, from the trees that grew there. If anyone among them were to be caught in the act, they would be punished and receive a heavy yet equitable fine of 1 miliaresion per .... Only the ownership of water mills, gardens and orchards that had belonged to the monastery were not signed over to the monastery of Kobolou; this community was given possession of six water mills which belonged to them in each.... but the monks would not have the right to either construct new mills or to enlarge their gardens and orchards, which must always remain in the same state and surrounded by fences. If, through their own negligence, their fences were to break down and some four-footed animal came in and caused some kind of damage, its owner would not be held responsible. Given that

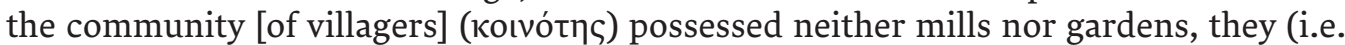
the villagers acting together as a community) received the right to divert the waters from the canal for the mills in shifts of 24 hours to wherever they wished in order to irrigate the gardens they would make there. The right was granted to the territory of the monastery of Kolobou to keep only the part of the communal fishery, for the foreseeable future, in the river called Arsinikeia, and to receive the three quarters that are allocated to them. Concerning the mountain that dominates the zone allocated to the metochion - a part of the area that specifically belongs to the monastery of Kolobou - should the harvest of acorns or chestnuts or the fruits of the mountain not be sufficient, the monastery would not prevent the inhabitants of Siderokausia from going to the woods. The pigs owned by the monastery, which were also fed regardless of their

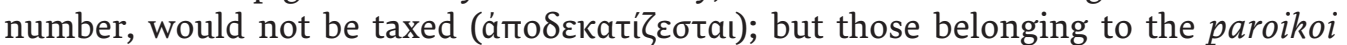
and the local people would be subject to the levy of the balanistron as well as other pastoral taxes (غ́vขófıov); the villagers would share this levy equally with the monastery. For the annual tax, the monks will pay 1 nomisma and the community of Siderokausia 2 nomismata because they possess twice the amount of arable and grazing lands. In order to keep the memory of these judgements intact, the current record (engraphon hypomnèma) has been established by Nicolas, the protospatharius and judge of Strymon and Thessaloniki. It has been given to the monastery of Kobolou along with a copy to confirm it (íov) to the village ( $\chi \omega \rho$ íov) of the Sidèrokausites. Signed by the hand who has given the judgement, and furnished with his usual seal.« 


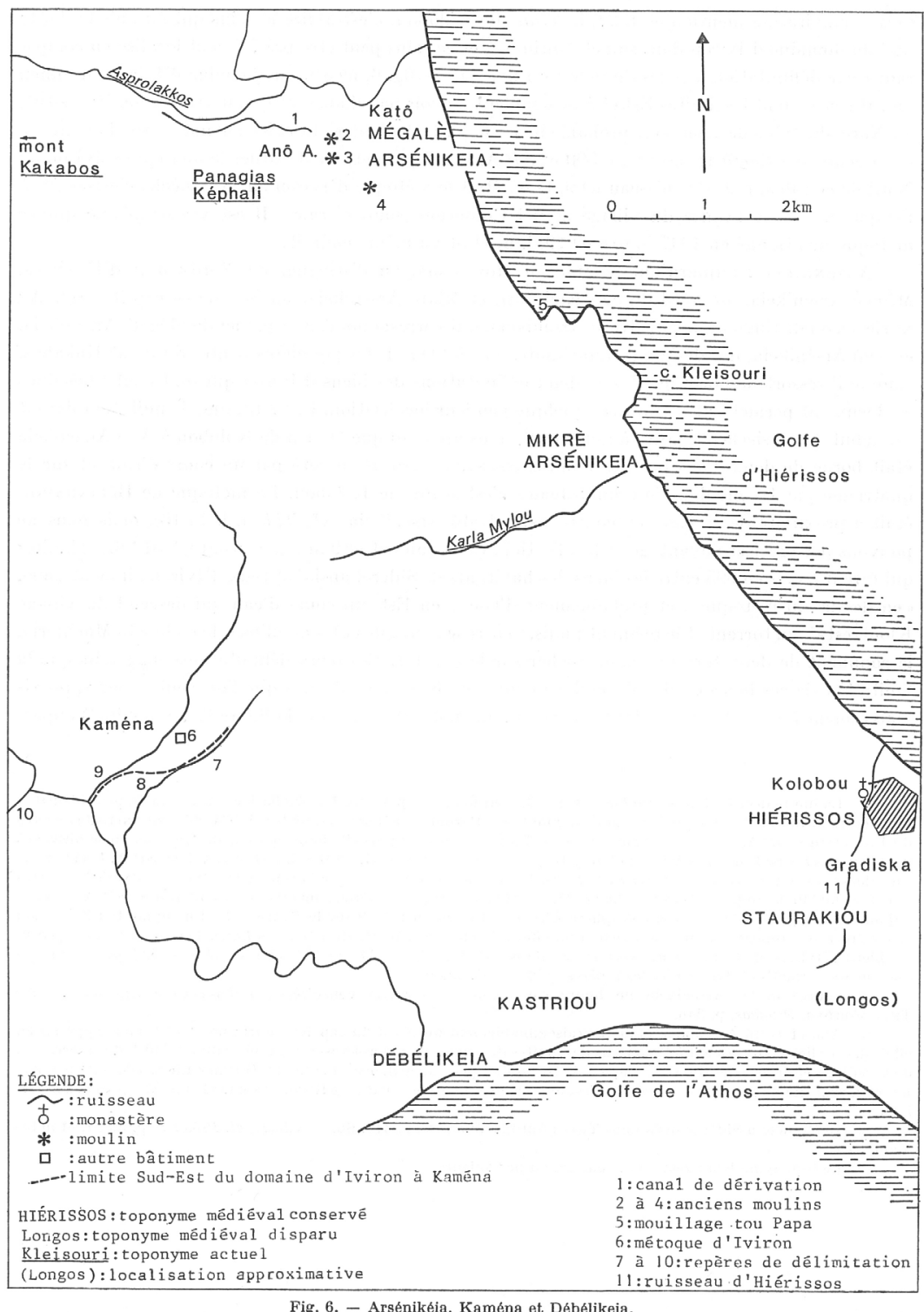

Fig. 3: The possessions of the Iviron monastery, in: Actes d'Iviron I, ed. Lefort et al., 81.

This document is important for several reasons, chief among which is the pride of place it gives to village communities. It becomes clear immediately that the entire village - or at least the heads of the families - was present at the tribunal. Also, the text is emblematic of the struggle to enhance the value of newly cultivated lands during a time of tremendous economic and demographic growth. ${ }^{57}$ The village that started it all was situated at the relatively high altitude of 500m, at least ten kilometres from the coast of the Strymonian Gulf. 
The entire affected area evidently stretched all the way to the sea, with a coastal plain that used to be quite inhospitable, while the village dominated over it from a relatively steep hill. This was where John Kolobos had originally founded his monastery, before it was moved to Ierissos. He must have retained lands there, however. The metochion of Belikradou could well be the original site of the monastery, and, as happened quite often, the lands would have been exploited by < paroikoi $>$ who would pay rent. The coastal plain was from the outset in the state evoked at the end of the second paragraph of the translation above: water was led to the mills through a network of canals, cutting through gardens, orchards and grazing lands. Nevertheless, the villagers had already started the "conquest" of the territory, which had always been thought of as a wasteland, and thus especially well-suited for keeping animals. Several families from the town established themselves there, leading to the foundation of the "isolated farms (áypísıa ${ }^{58}$ of the village $(\kappa \dot{\omega} \mu \eta)$ of the Siderokausites «. These farmers, who were first and foremost landholders, had even sown grain there, which inadvertently led to their protestations when the < paroikoi > of the monastery let their animals out there to feed during crop season. The judge, for his part, would only allow grazing after the harvest, "for three months per year, namely from the first of July until the end of September, and nothing more«.

On the other hand, the monks had also gone on the offensive. Outside their metochion of Belikradou, they had built encampments for the < paroikoi > in an attempt to occupy the lands that had been considered wasteland until recently. The judge would not budge on this point, however: he "had the campsites reduced to ashes, and chased away the < paroiko $i$ «. This might well have been the most sensible option given the pressure exercised by the mob of villages at the tribunal: the judge essentially decided in favour of the peasants. ${ }^{59}$ Nevertheless, Kolobou belonged to an otherwise powerful institution, the original monastery of Iviron. It is clear that the latter also tried to obtain part of the territory of Chalkidiki, despite the fact that it already possessed vast tracts of land there through the donations granted to the monasteries of Polygyros and Leontia. ${ }^{60}$

Naturally, we could give more examples by perusing the dossiers about Mount Athos in ever greater detail. One of the best examples stems from the archives of Iviron, and tells of a conflict about $70 \mathrm{~km}$ north of Ierissos, around the episcopal see of Ézoba close to Strymon. The people living in that town, which was mostly inhabited by farmers, contested the pretensions of the monastery of the Georgians (or Iberians, that is, Iviron) with the help of their bishop whose possessions were entangled with those of the townspeople. ${ }^{61}$ If we add to this

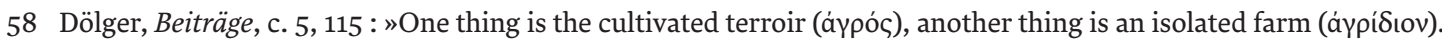
Indeed, cultivated land refers to any area ( $\chi \tilde{\omega} \rho \circ \varsigma)$ exploited, while an isolated farm is a part of the territory of a large village that constitutes a wedge and also holds a part of the exploited area.«. The text describes the various reasons leading to the rise of the isolated farms in the taxable land of the village ( $\chi \omega \rho$ íov).

59 We should not forget that this administrator, in agreeing with the peasants, also agrees with the empire. The last novella aimed specifically at the protection of the poor/powerless, credited to Basil II, was issued on 1 January 996: Svoronos, Les Novelles, 190-217.

60 See my commentary on this dossier: Kaplan, Les hommes et la terre, esp. 113-114 and Id., L'activité pastorale, 418419. Lefort, Rural economy, 283-284.

61 Kaplan, Villes et Campagnes, 21-22. 
the considerable efforts put into the foundation of Lavra by Athanasius, who even went so far as to drill into the mountains to irrigate the monastic gardens ${ }^{62}$ and who, above all, thought it would be useful to have a deep-water harbour ${ }^{63}$ where passenger ships could make land, we get an idea why I have chosen the title for this article.

From the 9th century onwards, based on the models of Peristerai and Kolobou, the monasteries in the region of Thessaloniki invested huge efforts in their lands, which would more often than not start out as klasma lands and thus be partially uncultivated still. In the course of the tenth century, the great foundations on the peninsula of Athos, such as Xèropotamou, Lavra and Iviron, absorbed parts of the older monasteries and in the process imposed themselves on the development of the land. The example of the competition between Iviron, with its old rights to Kolobou, and the village community of Siderokausia is enlightening in that regard.

Thus, the monasteries of Chalkidiki played a major role in the expansion of southern Macedonia in the 10th and 11th centuries, benefiting for themselves from the efforts also made by the medium and small peasantry.

\section{Acknowledgements}

This article is dedicated to the team currently busy editing the archives of Athos, and more specifically to Jacques Lefort, who left us too soon and who led this team for over twenty years with an exceptional maestria, not to mention his eternal good humour.

62 Kaplan, Aumônes, artisanat, domaines fonciers, 367. See Vie A d'Athanase l'Athonite, c. 234, ed. Noret, 112-113, 1. 11-25 and Vie B d'Athanase l'Athonite, c. 66, ed. Noret, 201, l. 1-11.

63 Kaplan, Aumônes, artisanat, domaines fonciers, 367, and Id., Monks and trade, 56-57. 


\section{References}

\section{Abbreviations}

PMBZ = Ralph-Johannes Lilie, Claudia Ludwig, Beate Zielke and Thomas Pratsch, Prosopographie der mittelbyzantinischen Zeit. Accessed on 24 May 2019: www.degruyter.com/view/ $\mathrm{db} / \mathrm{pmbz}$.

Actes d'Iviron I, Des origines au milieu du XIe siècle, ed. Jacques Lefort, Nicolas Oikonomidès and Denise Papachryssanthou, Archives de l'Athos XIV (Paris, 1985).

Actes de Lavra I, Des origines à 1204, ed. Paul Lemerle, André Guillou, Nicolas Svoronos and Denise Papachryssanthou, Archives de l'Athos V (Paris, 1970).

Actes du Prôtaton, ed. Denise Papachryssanthou, Archives de l'Athos 7 (Paris, 1975).

Actes de Xèropotamou, ed. Jacques Bompaire, Archives de l'Athos 3 (Paris, 1965).

Binon, Stéphane, La vie de s. Pierre l'Athonite, Studi Bizantini e Neoellenici (SBN) 5 (1939) 41-53.

Brand, Charles M., Two Byzantine Treatises on Taxation, Traditio 25 (1969) 35-60.

Brunet, François, Sur l'hellénisation des toponymes slaves en Macédoine byzantine, Travaux et Mémoires 9 (1985) 235-265.

Concilia Aevi Karolini, ed. Albert Werminghoff, Monumenta Germaniae Historica, Leges 3, Concilia 2.2 (Hannover, 1908).

Dölger, Franz, Beiträge zur Geschichte der byzantinischen Finanzverwaltung besonders des 10. und 11. Jahrhunderts, (second edition), (Darmstadt, 1960).

Géométries du fisc byzantin, ed. Jacques Lefort, René Bondoux, Jean-Claude Cheynet, JeanPierre Grélois, Vassiliki Kravari and Jean-Marie Martin, Réalités byzantines 4 (Paris, 1991).

Gorecki, Danuta, The Heraclian land tax reform: Objectives and consequences, Byzantine Studies/Études Byzantines 4 (1977) 127-146.

Harvey, Alan, Economic Expansion in the Byzantine Empire, 90o-1200 (New York, 1989).

Kaplan, Michel, Les hommes et la terre à Byzance du VIe au XIe siècle: propriété et exploitation du sol, Byzantina Sorbonensia 10 (Paris, 1992).

Kaplan, Michel, Byzance. Villes et campagnes, Les médiévistes français 7 (Paris, 2006).

Kaplan, Michel, Villes et campagnes à Byzance du vie au xiie siècle: aspects économiques et sociaux, Città e campagna nei secoli altomedievali, Settimane di studio della Fondazione Centro Italiano di Studi sull'alto Medioevo 56 (Spolète, 2009) 495-536.

Kaplan, Michel, L'activité pastorale dans le village byzantin du viie au xiie siècle, in: Elias Anagnostakis, Taxiarchis Kolias and Eftychia Papadopoulou (eds.), Animals and Environment in Byzantium (7th-12th c.), National Hellenic Research Foundation, Institute for Byzantine Research, International Symposium 21 (Athens, 2011) 407-420.

Kaplan, Michel, Les moines et leurs biens fonciers à Byzance du viiie au xe siècle: acquisition, conservation et mise en valeur, Revue Bénédictine 103 (1993) 209-223 (see also Id., Byzance. Villes et campagnes, 216-225 and Id., Pouvoirs, Église et sainteté à Byzance. Études sur la société byzantine, Les Classiques de la Sorbonne 3 [Paris, 2011] 479-495).

Kaplan, Michel, Les élites rurales byzantines: historiographie et sources, Les élites rurales méditerranéennes au Moyen Âge (Ve-XVe siècle), Mélanges de l'École française de Rome: Moyen Âge (MEFRM) 124/2 (2012) 299-312. 
Kaplan, Michel, Monks and trade in Byzantium from the tenth to the twelfth Century, in: Paul Magdalino, Nevra Necipoğlu and Ivana Jevtić (eds.), Trade in Byzantium, Papers from the third international Sevgi Gönül Byzantine Studies Symposium, (Istanbul, 2016) 55-64.

Kaplan, Michel, Aumônes, artisanat, domaines fonciers: les monastères byzantins et la logique économique (ve-xe siècle), in: Olivier Delouis and Maria Mossakowska-Gaubert (eds.), La vie quotidienne des moines en Orient et en Occident (ive-xe siècle), 2, Questions transversales, Bibliothèque d'Étude 170 (Cairo, 2019) 359-371.

Karayannopoulos, Johannes, Fragmente aus dem Vadecum eines byzantinischen Finanzbeamten, in: Peter Wirth (ed.), Polychronion, Festschrift F. Dölger zum 75. Geburtstag (Heidelberg, 1966) 318-334.

Lake, Kirsopp, The Early Days of Monasticism on Mount Athos (Oxford, 1909).

Laiou, Angeliki and Morrisson Cécile, The Byzantine Economy (Cambridge, 2007).

Lefort, Jacques, Une grande fortune foncière aux Xe-XIIIe siècles: les biens du monastère d'Iviron, in: Structures féodales et féodalisme dans l'Occident méditerranéen (Xe-XIIIe siècles). Bilan et perspectives de recherches. Actes du Colloque de Rome (10-13 octobre 1978), Collection de l'École française de Rome 44 (Rome, 1980) 727-742.

Lefort, Jacques, Bellier, Paul, Bondoux, René-Claude, Cheynet, Jean-Claude, Geyer Bernard, Grélois, Jean-Pierre, Kravari, Vassiliki, Paysages de Macédoine, Monographies 3 (Paris, 1986).

Lefort, Jacques, The rural economy, seventh-tenth centuries, in: Angeliki Laiou (ed.), The Economic History of Byzantium from the Seventh Century through the Fifteenth Century (Washington DC, 2002); trans. in French: Id., Société rurale et histoire du paysage à Byzance, Bilans de recherche 1 (Paris, 2006) 395-478.

Lefort, Jacques, Toponymie et anthroponymie: le contact entre Grecs et Slaves en Macédoine, in: Jean-Michel Poisson (ed.), Castrum 4, Frontière et peuplement dans le monde méditerranéen au Moyen Âge (Rome, 1992) 161-171; also in: Id., Société rurale et histoire du paysage à Byzance, Bilans de recherche 1 (Paris, 2006) 265-278.

Lemerle, Paul, The Agrarian History of Byzantium from the Origins to the Twelfth Century. The Sources and Problems (Galway, 1979); revised articles: Esquisse pour une histoire agraire de Byzance, les sources et les problèmes, Revue Historique (RH) 219 (1958) 33-74 et 254-284 et 220, and $R H 220$ (1958) 43-94.

Lemerle, Paul, Invasions et migrations dans les Balkans depuis la fin de l'époque romaine jusqu'au viiie siècle, Revue Historique (RH) 211 (1954) 265-308; also in: Id., Essais sur le monde byzantin, Collected Studies series 115 (London, 1980) I.

Morrisson, Cécile, La logarikè: réforme monétaire et réforme fiscale sous Alexis Ier Comnène, Travaux et Mémoires 7 (1979) 419-464; also in: Ead., Monnaie et finances à Byzance: analyses, techniques, Variorum collected studies series (Aldershot, 1994) VI.

Oikonomidès, Nicolas, Les listes de préséance byzantines des IXe et Xe siècles. Introd., texte, traduction, et commentaire, Monde byzantin (Paris, 1972).

Oikonomidès, Nicolas, Das Verfalland im 10.-11. Jahrhundert: Verkauf und Besteurung, Fontes Minores 7 (1986) 161-168; English translation: Id., Byzantium from the Ninth Century to the Fourth Crusade, Collected Studies Series 309 (Aldershot, 1992) V.

Oikonomidès, Nicolas, Fiscalité et exemption fiscale à Byzance (IXe-XIe s.), Institut de recherches byzantines, Monographie 2 (Athens, 1996).

Papachryssanthou, Denise, La vie ancienne de saint Pierre l'Athonite, Analecta Bollandiana (AB) 92 (1974) 19-61. 
Papachryssanthou, Denise, La vie de saint Euthyme le Jeune et la métropole de Thessalonique à la fin du IXe et au début du Xe siècle, Revue des études byzantines (REB) 32 (1974) 225245.

Rigo, Antonio, La Vita di Pietro l'Athonita (BHG 1506) scritta da Gregorio Palama, Rivista di Studi Bizantini e Neoellenici (RSBN) n.s. 32 (1995) 177-190.

Svoronos, Nicolas, Les novelles des empereurs macédoniens concernant la terre et les stratiotes, (posthumous edition, Paris Gounaridis), (Athens, 1994).

Théophane, Chronographia, ed. Carl de Boor (Leipzig, 1883).

Vie A d'Athanase l'Athonite (par Athanase de Panagiou, BHG 187), Vie d'Athanase l'Athonite (Vie A par Athanase de Panagiou, BHG 187), ed. Jacques Noret, Vitæ duæ antiquæ sancti Athanasii athonitæ, Corpus Christianorum, Series Græca 9 (Leuven, 1982) 3-124.

Vie B d'Athanase l'Athonite (BHG 188), ed. Jacques Noret, Vitæ duæ antiquæ sancti Athanasii athonitæ, Corpus Christianorum, Series Græca 9 (Leuven, 1982) 127-213.

Vie d'Euthyme le Jeune (BHG 655), ed. Louis Petit, Revue de l'Orient Chrétien 8 (1903), 168205 (= Bibliothèque hagiographique orientale, t. 5 [Paris 1904] 14-51).

\section{List of Figures}

Fig. 1: Map of Chalkidiki, in: Actes du Prôtaton, no. 1, ed. Papachryssanthou,42-43.

Fig. 2: The possessions of the Lavra monastery until 1204, in: Actes de Lavra I, ed. Lemerle et al., 57.

Fig. 3: The possessions of the Iviron monastery, in: Actes d'Iviron I, ed. Lefort et al., 81. 


\section{Pro qualitate loci et instantia laboris: Monasteries and their Human and Natural Environments in Late Antique Gaul}

\section{Matheus Coutinho Figuinha*}

Focusing on the cases of Martin of Tours' Marmoutier, the monastery of Lérins, and the Jura monasteries, this article explores the conceptions and interactions of Gallic monks with the human and natural environments in relation to their subsistence. Fourth- and fifth-century authors described these monasteries in similar terms, relying on both Christian and classical literary models. Accordingly, the local human and natural environments were depicted as characteristic of a remote desert. Archeologists, however, have shown that these monasteries were not isolated. One of the reasons for that, I argue, is that they depended on the contributions of visitors and on urban and commercial centers for their own existence. I also argue that, due to different conceptions of the monastic life and practice, monks' interactions with the human and natural environments varied greatly from one monastery to the other. At Marmoutier, Martin's disciples relied on the woodland nearby and on the Loire to get part of what they consumed. But because they did not practice manual labor, they may have acquired most of the necessary food from local farmers. At Lérins, where all the monks were required to work, it is possible that they practiced agriculture. But because of the restricted extension of the cultivated terrain and the Mediterranean climate, they did not produce all the food they consumed. As for the Jura monasteries, the monks deforested and cultivated large areas. They also reared cattle, poultry, and sheep, and constructed a mill and tilting hammers to grind grain. But their effort to sustain themselves only through the work of their hands was not enough, for they also relied on the Burgundian kings and pilgrims for their subsistence. The Jura monasteries in particular show us that the practice of agriculture is not per se evidence of economic autonomy.

Keywords: Gaul; human and natural environments; monasticism; Marmoutier; Lérins; Jura Fathers.

* Correspondence details: Matheus Coutinho Figuinha, Universidade Estadual de Campinas (UNICAMP), Departamento de História, Rua Cora Coralina, 100, Cidade Universitária Zeferino Vaz, 13083-896, Campinas/SP, Brazil. Email: figuinha@yahoo.com. 


\section{Introduction}

My purpose in this article is to investigate how late antique monks conceived and interacted with the human and natural environments in relation to their subsistence. I understand subsistence here as the obtainment of everything each monastery considered necessary for the monastic life, from food and clothes (that is, all that monks needed according to late antique authors, who intended to underline their austere discipline and material restrictions) to parchment. This article focuses on three case studies from Gaul, where there are both strong literary and archaeological sources: (1) Marmoutier, the monastery Bishop Martin founded close to the city of Tours around 372; (2) the monastery Honoratus founded on the island of Lérins, in the bay of Cannes, between 400 and $410 ; ;^{1}$ (3) the monasteries of Condat and Laucone, founded by Romanus and his brother Lupicinus in the Jura forests after 435 .

All these monasteries and the very distinct human and natural environments around them were similarly described as deserts, according to the model of saints' Lives and to classical literary traditions. However, different conceptions of the monastic life and practice from one monastery to the other led to different interactions with the human and natural environments. Even though monks invariably depended on the contributions of visitors and on the proximity to urban and commercial centers to acquire what they needed, their dependence varied according to what exactly they had to acquire and to what they could get in the nearby woodland (a constant presence) or produce locally.

\section{Martin of Tours' Marmoutier}

Martin was ordained as bishop of Tours in 371, but, according to his hagiographer Sulpicius Severus, he did not abandon his commitment to the monastic life: "There was the same humility in his heart, and the same vileness in his garments [...] in such a way as not to lay aside the resolution and virtues of a monk «. ${ }^{2}$ Martin initially established himself at a cell adjacent to the church of Tours, but sometime later, he founded a monastery two miles away from the city to avoid the disturbance of visitors. Sulpicius describes the monastery, the landscape around it, and the monks' discipline:

This spot was so secret and retired that he enjoyed in it the solitude of a hermit. For, on one side, it was surrounded by a precipitous rock of a lofty mountain, while the river Loire had shut in the rest of the plain by a bay extending back for a little distance; and the place could be approached only by one, and that, a very narrow passage. Here, then, he possessed a cell constructed of wood. Many also of the brethren had, in the same manner, fashioned retreats for themselves, but most of them had formed these out of the rock of the overhanging mountain, hollowed into caves. There were altogether eighty disciples, who were being disciplined after the example of the saintly master. No one there had anything which was called his own; all things were possessed in common. It was not allowed either to buy or to sell anything, as is the custom among most monks. No art was practiced there, except that of transcribers, and even

2 Sulpicius Severus, Vita sancti Martini, 10.2, ed. Fontaine, vol. 1, 272 and 274: "Eadem in corde eius humilitas, eadem in vestitu eius vilitas erat; atque ita, plenus auctoritatis et gratiae, inplebat episcopi dignitatem, ut non tamen propositum monachi virtutemque desereret«. Trans. Roberts, Life of St. Martin, 9, slightly adapted. 
this was assigned to the brethren of younger years, while the elders spent their time in prayer. Rarely did any one of them go beyond the cell, unless when they assembled at the place of prayer. They all took their food together, after the hour of fasting was past. No one used wine, except when illness compelled them to do so. Most of them were clothed in garments of camels' hair. Any dress approaching to softness was there deemed criminal, and this must be thought the more remarkable, because many among them were such as are deemed of noble rank. ${ }^{3}$

As Jacques Fontaine has pointed out, Sulpicius' description of the community Martin established and its surrounding landscape recalls not only the harshness of the monastic deserts represented by older saints' Lives and pilgrims' oral accounts, but also the symbolic language of the landscape depictions of the Aeneid. In joining these two literary models, Sulpicius intended both "to confer the inner dignity of a new scity of God to the setting of Marmoutier" and "to touch all learned readers", who certainly recognized and treasured his Virgilian borrowings. ${ }^{4}$ More recently, archeologists have been able to appreciate how far Sulpicius' stylized description distorted the human environment surrounding Marmoutier. Far from being a "secret and retired " place, the monastery could be easily accessed from the city. Nothing less than three wooden bridges connected the latter to the other bank of the Loire and one, constructed in the third century, still likely functioned when Martin founded the monastery. Sulpicius' "very narrow passage«, moreover, was actually a long, ancient road that passed through Marmoutier and that remained in use until the fourteenth century. ${ }^{5}$

As for Sulpicius' description of the monastery, in particular, Fontaine has already observed that the cliff still seen on the site was depicted as a "lofty mountain «, due to the symbolism of the mountain in the Bible and the Life of Anthony. ${ }^{6}$ However, archeologists have recently unearthed fragments and remains that indicate that the site was continuously occupied from the first century CE up to Martin's arrival. ${ }^{7}$ For the time being, it is impossible

3 Sulpicius Severus, Vita sancti Martini, 10.4-8, ed. Fontaine, vol. 1, 274: "Qui locus tam secretus et remotus erat, ut eremi solitudinem non desideraret. Ex uno enim latere praecisa montis excelsi rupe ambiebatur, reliquam planitiem Liger fluvius reducto paululum sinu clauserat; una tantum eademque arta admodum via adiri poterat. Ipse ex lignis contextam cellulam habebat, multique ex fratribus in eundem modum; plerique saxo superiecti montis cavato receptacula sibi fecerant. Discipuli fere octoginta erant, qui ad exemplum beati magistri instituebantur. Nemo ibi quicquam proprium habebat, omnia in medium conferebantur. Non emere aut vendere, ut plerisque monachis moris est, quicquam licebat; ars ibi, exceptis scriptoribus, nulla habebatur, cui tamen operi minor aetas deputabatur: maiores orationi vacabant. Rarus cuiquam extra cellulam suam egressus, nisi cum ad locum orationis conveniebant. Cibum una omnes post horam ieiunii accipiebant. Vinum nemo noverat, nisi quem infirmitas coegisset. Plerique camelorum saetis vestiebantur: mollior ibi habitus pro crimine erat. Quod eo magis sit mirum necesse est, quod multi inter eos nobiles habebantur, qui longe aliter educati ad hanc se humilitatem et patientiam coegerant [...] «. Trans. Roberts, Life of St. Martin, 9.

4 Fontaine, Sulpice Sévère. Vie de Saint Martin, vol. 2, 667-672. Cf. also de Vogüé, Histoire littéraire, vol. 4, 44, for other reminiscences.

5 Lorans, Aux origines du monastère, 179-184; id., Marmoutier, 60. I am very grateful to Professor Lorans for kindly sharing with me many of her publications.

6 Fontaine, Sulpice Sévère. Vie de Saint Martin, vol. 2, 669.

7 For all the archaeological discoveries, cf. Lorans, Aux origines du monastère, 196-200; Lorans and Creissen (ed.), Site 2013; id., Site 2014; id., Site 2015; id., Site 2016; Lorans, Marmoutier, 58-60; Lorans and Simon, Autour de Marmoutier, 88-91. 
to know exactly how such an occupation was. It may well have been, as Élisabeth Lorans has suggested, "a road station ${ }^{8}{ }^{8}$ In any case, there can be little doubt that Martin deliberately chose the site for the foundation of his monastery and that he, therefore, did not intend to be isolated. Quite the opposite. He wanted to maintain constant contact with the city - after all, he was the bishop - and with travelers passing by. ${ }^{9}$ He may also have taken advantage of the road network to which the monastery was connected to move in his campaigns of Christianization of the Touraine.

The ease of contact with the city and the countryside around it was crucial to the monastery's existence. In the Life of Saint Martin, Sulpicius narrates a telling episode:

On one occasion the devil, holding in his hand the bloody horn of an ox, rushed into Martin's cell with great noise, and holding out to him his bloody right hand, while at the same time he exulted in the crime he had committed, said: ,Where, O Martin is thy power? I have just slain one of your peopler. Then Martin assembled the brethren, and related to them what the devil had disclosed, while he ordered them carefully to search the several cells in order to discover who had been visited with this calamity. They report that no one of the monks was missing, but that one peasant, hired by them, had gone to the forest to bring home wood in his wagon. Upon hearing this, Martin instructs some of them to go and meet him. On their doing so, the man was found almost dead at no great distance from the monastery. ${ }^{10}$

According to Fontaine, the peasant was "a day laborer, foreign to the monastery «, for the expression mercede conducere, which in the passage characterizes how the peasant was hired, indicated since the time of Cicero the »temporary employment of modest people«. Because the monks did not practice manual labor, as Sulpicius attests in the tenth chapter of the Life, Fontaine concludes that they hired peasants to do some labors related to their »immediate material necessities «. ${ }^{11}$ However, the words "one of your people « attributed to the devil contradict Sulpicius' own use of mercede conducere and Fontaine's suggestion. They seem to reinforce Richard Goodrich's perception that the monastery possessed "servants or slaves" so that the monks did not need to practice manual labor. ${ }^{12}$

Lorans, Marmoutier, 59-60; Lorans and Creissen (ed.), Site 2017, 101; id., Site 2015-2017, 13; Lorans and Simon, Autour de Marmoutier, 91.

9 Lorans, Marmoutier, 60; Lorans and Simon, Autour de Marmoutier, 91.

10 Sulpicius Severus, Vita sancti Martini, 21.2-4, ed. Fontaine, 298 and 300: "Quodam autem tempore, cornu bovis cruentum in manu tenens, cum ingenti fremitu cellulam eius inrupit, cruentamque ostendens dexteram et admisso recens scelere congaudens: ubi est, inquit, Martine, virtus tua? unum de tuis modo interfeci. Tunc ille convocatis fratribus refert quid diabolus indicasset; sollicitos esse praecipit per cellulas singulorum quisnam hoc casu adfectus fuisset. Neminem quidem deesse de monachis, sed unum rusticum, mercede conductum ut vehiculo ligna deferret, isse ad silvam nuntiant. Iubet igitur aliquos ire ei obviam; ita haud longe a monasterio iam paene exanimis invenitur «. Trans. Roberts, Life of St. Martin, 14.

11 Fontaine, Sulpice Sévère. Vie de Saint Martin, vol. 3, 958-959.

12 Goodrich, Contextualizing Cassian, 193. 
It is not impossible that Sulpicius used the expression mercede conducere for literary embellishment, disregarding the precise relationship between the killed peasant and Marmoutier. Yet he had no reasons to use the expression knowing that the peasant belonged to the monastery. ${ }^{13}$ The same logic, however, holds for the words "one of your people « attributed to the devil: they may also be a literary stylization, intended to add drama to the account. Even though they may not be completely imprecise, it is anachronistic to assume, as Fontaine rightly reminds us, that the monks prayed cloistered in the monastery and that the works outside it were then ascribed to laymen. ${ }^{14} \mathrm{~A}$ middle ground would be to consider that Martin's disciples maintained recurrent contact with local peasants. In fact, we do not have any evidence that the former practiced agriculture or that Marmoutier owned land, so they probably had to acquire most of the food they consumed from local peasants. Given the importance of wood for cooking and heating, the latter may also have been hired much more frequently than Sulpicius indicates.

The forest quite certainly furnished Martin's disciples (and many other inhabitants of Tours) not only with wood, but also with food and other materials. ${ }^{15}$ A passage from Sulpicius' Dialogues indicates that the monks depended even on the Loire for food: "Being accustomed to eat fish at the time of Easter, he [Martin] enquired a little before the hour for refreshment, whether it was in readiness. Then Cato, the deacon, to whom the outward management of the monastery belonged, and who was himself a skillful fisher, tells him that no capture had fallen to his lot the whole day [...] «. ${ }^{16}$ Sulpicius continues the narrative saying that Cato, thanks to the miraculous intervention of Martin, was able to fish a "pike" (immanem isocem) that day. Martin and his disciples may well have eaten fish on days other than Easter. Considering Martin's question to Cato, Jacques Fontaine and Nicole Dupré have even envisaged the hypothesis that Marmoutier, similarly to Cassiodorus' Vivarium, had fishponds. ${ }^{17}$

If the monks did not buy the wine offered to the ill (Vita 10.7) from the peasants close to them, they bought it from merchants. The copyist job done by the younger monks also required papyrus, parchment, and other materials that needed to be acquired, not to mention the "garments of camels' hair" they wore (Vita 10.8). Martin and his disciples, therefore, had to maintain intense contact with the city not only because of the clerical duties some of them had, but also to get some of the products they consumed. Actually, since a road passed through the monastery, it was possible for them to acquire what they needed directly from merchants passing by. Their (or their fifth- and sixth-century successors') contact with city markets and merchants is corroborated by recent archaeological discoveries. Some fragments of ceramics and amphorae dated from the fourth to the sixth centuries and produced not only in Gaul, but also in North Africa and the East, have been brought to light.

On Sulpicius' reliability, cf. Fontaine, Sulpice Sévère. Vie de Saint Martin; Stancliffe, St. Martin and His Hagiographer. Fontaine, Sulpice Sévère. Vie de Saint Martin, vol. 3, 958-959.

15 Rothé, Carte archéologique, 139, has summarized the importance of forests for local inhabitants: "Sur le plan économique, la forêt constituait une ressource importante d'où tirait du bois (de chauffe, de construction ou pour la confection de meubles et/ou objets), de la résine, de la poix, des fruits sauvages, mais également du gibier qui trouvait son alimentation dans les forêts de feuillus (altitude inférieure à $800 \mathrm{~m}$ )《.

16 Sulpicius Severus, Dialogi, 3.10.1-2, ed. Fontaine and Dupré, 328: „Piscem Paschae diebus edere consuetus, paulo ante horam refectionis interrogat an haberetur in promptu. Tum Cato diaconus, ad quem monasterii administratio pertinebat, doctus ipse piscari, negat per totum diem sibi ullam cessisse capturam [...]«. Trans. Roberts, Dialogues, 50.

17 Fontaine and Dupré, Sulpice Sévère. Gallus, 324, n. 7. 
Other fragments have even suggested that, in the fifth and sixth centuries, monks were involved in craftwork (metallurgy and tabletterie work), which could have been a source of income for them and could have then intensified their contacts with markets and merchants. ${ }^{18}$

It is likely, however, that this artisanal production was not carried out at the time of Martin, for Sulpicius said - and that sounds indeed like a Martinian precept - that monks could not engage in craftwork (ars) and lucrative activities; instead, they (except the younger ones) should stay in their cells praying. ${ }^{19}$ Because of such instructions, scholars tend to suppose that the monetary resources of Marmoutier came from the properties possessed by the "many nobles « mentioned by Sulpicius in the tenth chapter of the Life.$^{20}$ However, only two disciples of Martin (Clarus and Gallus) seem to have come from local aristocratic families. Furthermore, a passage from Sulpicius' Dialogues contradicts the impression that the monastery depended on the properties of wealthy monks:

He [Lycontius] also offered a hundred pounds of silver, which the blessed man neither rejected nor accepted; but before the amount of money touched the threshold of the monastery, he had, without hesitation, destined it for the redemption of captives. And when it was suggested to him by the brethren, that some portion of it should be reserved for the expenses of the monastery, since it was difficult for all of them to obtain necessary food, while many of them were sorely in need of clothing, he replied, 'Let the church both feed and clothe us, as long as we do not appear to have provided, in any way, for our own wants.$^{21}$

Martin's disciples would not have faced destitution if they could count on the resources of many nobles' properties.

Relying on this passage, some scholars have alternatively argued that Martin's reply to the monks indicates that it was the church of Tours that sustained Marmoutier. ${ }^{22}$ There is no reason to question such an assumption, but we must not overlook the allusions to contributions

18 For all the archaeological discoveries and their possible implications for our understanding of the monks' practices, cf. Lorans and Creissen (ed.), Site 2015; id., Site 2016; Lorans, Marmoutier, 63-64; Lorans and Creissen (ed.), Site 2017; id., Site 2015-2017; Lorans and Simon, Autour de Marmoutier, 91.

19 Bord, Aux origines du monachisme, 19. Some scholars have considered these instructions an influence of Messalianism, known by Martin through Hilary of Poitiers, his spiritual master, who remained exiled in Phrygia between 356 and 360. Cf. Sulpicius Severus, Chronica 2.42.1, ed. de Senneville-Grave, 322; Gribomont, Influence du monachisme oriental, 137; Stancliffe, St. Martin and His Hagiographer, 260-261; Fontaine and Dupré, Sulpice Sévère. Gallus, 70. This view, however, is disputed. De Vogüé, Histoire littéraire, vol. 4, 47-48, argues that Martin was influenced instead by Eusebius of Vercelli, and Caner, Wandering, Begging Monks, 125, n. 191, suggests that "more likely Martin found his precedents in the Gospels and Acts«. In any case, Martin should not be seen as being in opposition to eastern monasticism. The ideal that monks should practice manual labor in order to overcome acedia and to sustain themselves or their communities became predominant in Egypt only at the end of the fourth century; and yet Messalianism and other monastic lifestyles that favored continuous prayer and begging remained diffuse in the East (even in Egypt) until much later. On this issue, cf. Caner, Wandering, Begging Monks.

20 Since the appearance of Fontaine, Sulpice Sévère. Vie de Saint Martin. I have already examined the supposed presence of "many nobles« at Marmoutier and the sources of income of the monastery in Figuinha, Monasticismo; id., Subsistence.

21 Sulpicius Severus, Dialogi, 3.14.5-6, ed. Fontaine and Dupré, 346: „Centum etiam argenti libras obtulit, quas vir beatus nec respuit nec recepit; sed priusquam pondus illud monasterii limen adtingeret, redimendis id captivis continuo deputavit. Et cum ei suggereretur a fratribus ut aliquid ex eo in sumptum monasterii reservaret - omnibus in angusto esse victum, multis deesse vestitum: `Nos, inquit, ecclesia et pascat et vestiat, dum nihil nostris usibus quaesisse videamur«. Trans. Roberts, Dialogues, 52.

22 Cf. most recently de Vogüé, Histoire littéraire, vol. 4, 47-48 and 146-147. 
from devotees. Lycontius' generous donation would have been brought to the monastery if Martin had not destined it for another purpose. Finally, the monks who were consecrated as clerics provided alternative revenue as they received wages from the Church. ${ }^{23}$ We can only understand how the monk-priest Brice could buy horses and slaves for himself if he received a salary, for he did not possess anything before being a cleric. ${ }^{24}$

\section{The monastery of Lérins}

At the end of 427 or the beginning of 428 , Honoratus, founder of the monastery of Lérins, in the bay of Cannes, was consecrated as bishop of Arles. ${ }^{25} \mathrm{He}$ departed for the city accompanied by Hilary, a younger relative who had also established himself at Lérins. Due to his "love of the desert «, however, Hilary rejoined the monastery some months later. ${ }^{26}$ Yet he was not sure of his decision. Honoratus sent letters asking him to return to Arles, ${ }^{27}$ but he, in his turn, requested the opinion of others. It is in response to one of his letters that Eucherius, a fellow monk of Lero, the largest of the Lérins islands in the bay of Cannes, composed the Praise of the Desert. Trying to persuade Hilary to stay at Lérins, Eucherius argued that deserted and isolated places, as Lérins supposedly was, were privileged because of their proximity to God. ${ }^{28}$

As Eucherius claims in chapters 39-41, one of the privileges of the desert was the abundance and fertility it offered. Its inhabitants, according to him, could earn "numerous products and a hundred fruits ". ${ }^{29}$ Leaning on the parable of the sower (Matthew 13.4-7; Mark 4.3-7; Luke 8.5-7), he asserts that the seeds thrown there hardly fall on the path, where they would be eaten by birds, or on rocky soils, where they would be dried by the sun, or among thorns, where they would be prevented from growing. And he adds:

The colonus will reap there an abundant-yield harvest and in these rocks it is produced that fruit through which even bones grow fat. It is also found in there sthe living bread that came down from the sky< (John 6.51), and overflowing springs and living waters, which can satisfy not only those who need to quench their thirst, but also those who need to be saved, burst forth from those cliffs. Here is the meadow and delight of the interior man, here is the uncultivated desert, but there is the pleasure of wonderful loveliness, at the same time desert of the body and paradise of the soul. ${ }^{30}$

23 De Vogüé, Histoire littéraire, vol. 4, 147.

24 Sulpicius Severus, Dialogi, 3.15.2, ed. Fontaine and Dupré, 350. We cannot know, however, if the charges are really true, for Sulpicius is clearly trying to defame Brice.

25 On the date, cf. Chadwick, Euladius of Arles.

26 Eucherius, De laude eremi 1.1-5 and 44.1, ed. Pricoco, 134, 136, and 184; Hilary, Sermo de vita sancti Honorati 36.2, ed. Valentin, 168.

27 Hilary, Sermo de vita sancti Honorati 36.2, ed. Valentin, 168.

28 Eucherius, De laude eremi 3.2, ed. Pricoco, 138; Leyser, »This Sainted Isle«, 196. On the development of the idea of the monastic desert in the West, cf. Markus, End, 157-211.

29 Eucherius, De laude eremi 39.2, ed. Pricoco, 176: "Illic multiplex germen et centenos accola fructus recondit«.

30 Eucherius, De laude eremi 39.3-5, ed. Pricoco, 176 and 178: »Uberi illic messem proventu colonus metet, producitur in his saxis seges illa per quam etiam ossa pinguescunt. Invenitur etiam illic spanis vivus qui de caelo descendit، (Io 6.51), erumpunt in illis rupibus fontes irrigui et aquae vivae, quae non satiandis solum, verum etiam possint sufficere salvandis. Hic interioris hominis pratum et voluptas, hic incultum desertum, illic mira amoenitate iocundum est, eademque corporis est eremus, animae paradisus«. Unless indicated otherwise, the translations are those of the author. 
Eucherius continues his description of the fertility of the desert stating that no other land could produce as much food: in there, "that wheat which satiates the hungry with its nutrients grows exceedingly«. Vineyards were more abundant: in there, "that wine which fully scheers men's heart` (Psalm 103.15) is produced exceedingly«. Pastures were unparalleled: in there, "those sheep about which it is said: >Pasture my sheep (John 21.17) pasture in the most salutary manner ". Flowers were more colorful: in there, "that true swild flower and lily of the valley< (Song of Songs 2.1) shines exceedingly". And there were also copious quantities of precious metals and gold: in there, »the many splendors of gems shine with vibrant light«. For Eucherius, therefore, the desert offered much more wealth than any other land. ${ }^{31}$

Some scholars have read Eucherius' words on the fertility of the desert as a description of the natural resources of Lérins, which had supposedly been transformed by the Lerinians since Honoratus' arrival..$^{32}$ It has even been suggested that the "natural riches of the island" described by Eucherius were precisely one of the factors that prompted the monastery to become an autonomous villa in less than three decades. ${ }^{33}$

It is important to note, however, that Eucherius' description of the fertility of the desert does not refer to Lérins. He starts to deal with the island only in chapter 42, when he writes: "I truly own reverence to all desert places which are illuminated by the retirement of pious men, but I embrace my Lérins with special honor «. ${ }^{34}$ This sentence indeed indicates a clear change of subject: from desert places in general he moves to Lérins in particular, with which he will deal (chapters 42-43) until the conclusion of the work (chapter 44). ${ }^{35}$

Eucherius' words in chapters 39-41, moreover, are not to be read literally. They are allegorical, for the fertility of the desert is purely spiritual. ${ }^{36}$ As Manté Lenkaityté has pointed out, the key to understanding these chapters (39-41) of the Praise of the Desert is another work composed by Eucherius himself, the Formulae of Spiritual Knowledge, in which he presents an allegorical meaning to terms of the Bible. The harvests are said to be "the abundance or the multitude of the faithful " (Messis ubertas vel copia fidelium); the bread suggests "Christ or the word of the Lord " (Panis Christus vel sermo domini); the meadows recall »the enjoyment of a progressing soul" (Herbae iucunditas quaedam proficientis animae); the wheat recalls "the saints or the elected of God" (Triticum sancti vel electi dei); the vineyard symbolizes

31 Eucherius, De laude eremi 40.1-5, ed. Pricoco, 178: "In hac maxime nascitur frumentum illud, quod esurientes adipe suo satiat. [...]. In hac maxime profertur vinum illud, quod bene slaetificat cor hominis` (Ps 103.15). [...]. In hac saluberrime pascunt oves illae, de quibus dicitur: >Pasce oves meas` (Io 21.17). [...]. In hac maxime verus ille sflos campi et lilium convallium ‘ (Ct 2.1) refulget. [...]. In hac varii lapidum micant vibrante luce fulgores".

32 Kasper, Theologie und Askese, 80; Rousseau, Cassian: Monastery and world, 72; Heijmans and Pietri, "Lobby« lérinien, 54.

33 Nouailhat, Saints et patrons, 223-225.

34 Eucherius, De laude eremi 42.1, ed. Pricoco, 180: "Equidem cunctis eremi locis quae piorum illuminantur secessu reverentiam debeo, praecipuo tamen Lirinum meam honore complector [...]

35 De Vogüé, Histoire littéraire, vol. 7, 94-95.

36 Pricoco, Isola dei santi, 163-164; de Vogüé, Histoire littéraire, vol. 7, 93-95; Lenkaityté, Eucher; Pricoco, Eucherio. Elogio dell'eremo, 64 and 307-312. On p. 313, however, Pricoco supposes that "Senza dubbio, descrivendo gli aspetti dell'eremo monastico ed esaltando le virtù dei suoi asceti, lo scrittore ha avuto nella mente e negli occhi il modello lerinese« (cf. also p. 46). 
"the church or the people of Israel «(Vinea ecclesia vel populus Israhel); the pasture represents "the spiritual refection " (Pascua refectio spiritalis); the flowers evoke »Christ or the ornament of justice" (Flores Christus vel specimen iustitiae); and the gems "occasionally are Christ or the saints" (Lapides interdum Christus aut sancti) or even "the apostles, the saints or the own works of virtue " (Lapides pretiosi apostoli vel sancti sive ipsa opera virtutum) ${ }^{37}$ Lenkaityte then concludes: "The gracious image of the desert is not a simple locus amoenus, a literary topos. In the author's thought, this nice image encompasses a more profound meaning, anchored in Scripture: the Christian community within the church, nourished by God's word and on the way to the Lord «. ${ }^{38}$

Eucherius did not intend to show, consequently, that the desert offered material wealth to its current inhabitants, the monks. In that location, they could obtain only spiritual wealth. Chapter 41 leaves no doubt as to the spiritual meaning, and spiritual meaning only, of the fertility of the desert: "Therefore, you rightfully presented yourself, venerated land, as inhabitable or desirable to the saints who have been placed in you or removed not far from you, because, in exchange of all goods, you are fertile of him in whom everything is possessed «. ${ }^{39}$ There is a clear opposition here between the material poverty of the desert and its spiritual wealth and such an opposition is consequential: the desert can only be fertile of God because it does not have any material goods.$^{40}$ That is why Eucherius says that the "desert of the body « is the "paradise of the soul«. His only purpose in chapters 39-41, therefore, was to deal with the spiritual advantages that the desert supposedly offered to monks.

As Eucherius starts to deal with Lérins in chapter 42, he presents the nature of the island: "Gushing with waters, green with vegetation, shining with flowers, pleasant to the sight and the smell, it shows to those who possess it the paradise which they will possess «. ${ }^{41}$ In this passage, Eucherius clearly borrows from the literary tradition of the locus amoenus, ${ }^{42}$ but he also associates with Lérins, through a repetition of elements, the spiritual fertility of the desert he enumerates in chapters 39-41. However, we cannot confuse the allegorical fertility of the abstract desert and of Lérins with the actual nature of the island. Eucherius certainly felt affection for Lérins and alluded to elements that Hilary could see on it, but he did not intend to offer a realistic description of its nature. ${ }^{43}$ His purpose was to simply pinpoint those

37 Lenkaityté, Eucher, 97-98.

38 Lenkaityté, Eucher, 98.

39 Eucherius, De laude eremi 41.1, ed. Pricoco, 178: »Recte ergo tu, veneranda tellus, sanctis aut in te positis aut non procul a te remotis aut habitabilis dudum aut desiderabilis exstitisti, quia pro universis bonis illius es fertilis, in quo habentur universa«.

40 De Vogüé, Histoire littéraire, vol. 7, 97.

41 Eucherius, De laude eremi 42.2, ed. Pricoco, 180: „Aquis scatens, herbis virens, floribus renitens, visibus odoribusque iocunda, paradisum possidentibus se exhibet quem possidebunt [...]«.

42 Rapp, Desert, city, and countryside, 109.

43 Pricoco, Isola dei santi, 164. 
elements that had a spiritual meaning for him, a meaning he had just indicated in chapters 39-40, in order to demonstrate to Hilary that the "desert" of Lérins was the best place for a monastic life. Therefore, Eucherius did not contemplate, as some scholars have thought, the transformations of the island performed by the monks. ${ }^{44}$ Actually, Lérins' nature appears paradisiac in the passage precisely because it is still inviolate.

In a kind of "reply to Eucherius«, preached in 431 as a sermon to the community of Arles to commemorate one year of Honoratus' death, Lérins is depicted in a very different fashion..$^{45}$ Before Honoratus landed on the island, it was a wild and hostile place, »uninhabited because of the excess of squalor and unapproachable because of the fear of poisonous animals«. ${ }^{46}$ According to Hilary, Lérins was a »terrible desert « (terribilem illam vastitatem), an "arid place" (in illis ariditatibus), dominated by »the obscurity of a previously unknown exile" (ignoti prius exilii obscuritas). It was only with Honoratus' arrival that it was transformed in a way that it became illuminated by "the works of angels «. ${ }^{47}$ He made the "horror of the desert « disappear and the "crowd of serpents « that lived on the island go away. ${ }^{48}$ Even the abundant spring there was the result of a Honoratus' miracle. ${ }^{49}$

Hilary's account is not more reliable than Eucherius', for his Lérins is also romanticized following other common tropes. He emphasized the contrast of the desolated Lérins before Honoratus to the angelic Lérins after him in order to praise his charisma and holiness. ${ }^{50}$ Concerning the foundation of the monastery and its maintenance, Hilary is quite vague. He only states that Honoratus built a church and habitations for the monks, and that the community grew quickly, receiving postulants from many places. ${ }^{51}$ He also says that Honoratus saved from the donations of the faithful only what was necessary for their daily food and clothes. All the rest he donated to the poor and for the release of prisoners..$^{22}$ But here, again, Hilary intended to celebrate Honoratus. He would have been so detached from the material world that he had not only disposed of all his possessions, following Matthew 19.21, but also distributed to the poor the huge amount of money donated by pilgrims, following Biblical and monastic precepts to do charity. ${ }^{53}$

44 Nouailhat, Saints et patrons, 223-225; Pricoco, Eucherio. Elogio dell'eremo, 314, though he recognizes "una sicura valenza allegorica« to the passage (cf. also p. 46).

45 Leyser, »This Sainted Isle«, 197-200. This whole paragraph depends on Leyser's reading of Hilary's Sermo.

46 Hilary, Sermo de vita sancti Honorati 15.2, ed. Valentin, 108: "Vacantem itaque insulam ob nimietatem squaloris et inaccessam venenatorum animalium metu [...] .

47 Hilary, Sermo de vita sancti Honorati 16.1, ed. Valentin, 110.

48 Hilary, Sermo de vita sancti Honorati 15.4, ed. Valentin, 110.

49 Hilary, Sermo de vita sancti Honorati 17.1, ed. Valentin, 112 and 114.

50 On Hilary's purposes in the Sermo, cf. Leyser, »This Sainted Isle«; Natal, »A Suitable Successor«.

51 Hilary, Sermo de vita sancti Honorati 17.1, ed. Valentin, 112; 20.4 and 19.1, ed. Valentin, 128 and 124.

52 Hilary, Sermo de vita sancti Honorati 20.4, ed. Valentin, 128.

53 Hilary, Sermo de vita sancti Honorati 20.3-4, ed. Valentin, 126 and 128. 
In their works, Eucherius and Hilary were not interested in the growth of the monastery. ${ }^{54}$ But we know from John Cassian that it became a "great monastery of brothers " shortly before Honoratus left for Arles. ${ }^{55}$ At that time, it may have gathered one hundred monks or more.$^{56}$ The change in the work regime from the Rule of the Four Fathers, written between 414 and $419,{ }^{57}$ to the Second Rule of the Fathers, composed when Honoratus was ordained as bishop,,$^{58}$ also indicates that the monastery grew. The Rule of the Four Fathers, whose composition was very much influenced by Egyptian monasticism, ${ }^{59}$ determined that monks should dedicate themselves to reading from the first hour to the third and to manual labor from the third hour to the ninth. ${ }^{60}$ The Second Rule of the Fathers also prescribed reading until the third hour and manual labor from the third to the ninth, but it stipulated that reading should be put aside if there was something to do for the community. ${ }^{61}$

The growth of the monastery and the requirement of manual labor can be seen as indications that Lerinians practiced agriculture on the island..$^{62}$ In a homily, however, Faustus asserted that Maximus, Honoratus' successor as abbot, had once hidden in the »dense wood" of Lérins for three whole days, during which he was sought by an "invading multitude of faithful« from Fréjus who wanted him to be consecrated as bishop of the city. ${ }^{63}$ For Maximus to be able to do that, most of the island still had to be covered by a wood. A study of the charcoal found in a fire pit directly associated with the remains of an architectonic structure from the second half of the fifth century excavated under the Saint-Sauveur chapel seems to corroborate this impression, for it shows precisely the burning of tree species that existed on Lérins. ${ }^{64}$ In fact, a "dense wood « allows us to better understand the presence on a small and plain island of »those old saints", in Eucherius' words, "who in separated cells brought to our Gauls the Egyptian Fathers «. ${ }^{65}$ If we assume that Lerinians practiced agriculture, we need also to assume, therefore, that they deforested and cultivated only a small part of the island. It was much more important for their survival to have a wood close by (because of wood, and perhaps food and other products) than to cultivate the whole island.

54 Leyser, »This Sainted Isle«, 189, 192, and 205.

55 John Cassian, Conlationes 11-17, preface, ed. Pichery, 98. Cf. Pricoco, Isola dei santi, 40-41.

56 Nouailhat, Saints et patrons, 236-237; Figuinha, Economy.

57 Figuinha, Data.

58 De Vogüé, Règles, 209-266.

59 De Vogüé, Règles, 55-205.

60 Regula quattuor patrum 3.10-11, ed. de Vogüé, 194.

61 Secunda regula patrum 23-25, ed. de Vogüé, 278.

62 The monastery of Lérins is presented as a productive villa by Nouailhat, Saints et patrons, 234-238; Brown, Through the Eye, 420; Alciati, Sistema agricolo familiare, 134-135.

63 Eusebius Gallicanus, Homilia 35.8, ed. Glorie, 407.

64 Gillot and Codou, Témoin.

65 Eucherius, De laude eremi 42.3, ed. Pricoco, 182: »[...] sanctos senes illos, qui divisis cellulis Aegyptios patres Galliis nostris intulerunt«. See also Secunda regula patrum 30, ed. de Vogüé, 280. Archaeological excavations conducted by Yann Codou under the chapel of Saint-Sauveur brought to light remains of a church and a building that may have been occupied by a hermit or a group of them. Cf. Codou, Île Saint-Honorat; id., Aux origines du monachisme en Gaule; id., Aux origines du monachisme. 
Concerning the amount of food Lerinians could have produced, we need to consider not only the extent of the cultivated land, but also the effect of the Mediterranean climate. Peregrine Horden and Nicholas Purcell have shown that none of the microregions that formed the basin of the Mediterranean - and Lérins may be considered one of them - was independent from the others. Because the climatic and geographical conditions of a microregion were in constant change, what could be cultivated in one year could not be cultivated in the next. The inhabitants of each microregion, consequently, had to maintain an intense interaction between them. They needed to import what they had not been able to produce and export what they had in excess. ${ }^{66}$

But Lerinians did not need only food and clothes for their subsistence, as Hilary stated. We know from their writings that the monastery had a great library, ${ }^{67}$ and because the Rule of the Four Fathers instituted three hours of reading, ${ }^{68}$ those who did not know how to read - perhaps some of the "wild beasts " of barbaric origin transformed into "gentle doves « by Honoratus in Hilary's Sermon, or some of the poor mentioned by the Rule of the Four Fathers - had to learn. ${ }^{69}$ Eucherius' sons, Salonius and Veranus, who arrived still very young, were educated on the island. ${ }^{70}$ It all means that Lerinians had to acquire wax, papyrus, parchment, and other materials.

To do that, they depended on the land and maritime routes that connected the island to the nearby continent and commercial centers of the Mediterranean. ${ }^{71}$ These links underscore that Lérins was not an isolated desert as Eucherius and Hilary portrayed it. Even though it had not been inhabited before Honoratus, it had been visited regularly: archaeological research has identified a range of objects and fragments that date from the first to the second half of the fourth century. ${ }^{72}$ Pliny says that Lérins had once had "a town called Berconum «, ${ }^{73}$ but that town was most likely situated at Lero, which he also mentions, located less than half a mile north of Lérins. For Lero, indeed, seems to have been continuously occupied from the third century BCE to the fifth century CE. Strabo says that Lero had a colonial settlement and a sanctuary dedicated to Lero, ${ }^{74}$ and archeologists have discovered not only fragments and remains that corroborate the existence of Strabo's sanctuary, possibly erected in the sixth century BCE, and perhaps of Pliny's town, possibly built in the third century BCE, but also

66 Horden and Purcell, The Corrupting Sea.

67 The classic text is Courcelle, Nouveaux aspects. Cf. more recently Kasper, Theologie und Askese, 14-18; Dulaey, Bibliothèque; Gioanni, Culture profane. These authors have identified more than one hundred classical and ecclesiastical works quoted by the Lerinians, works that they quite likely had at their disposal on the island.

68 Regula quattuor patrum 3.10, ed. de Vogüé, 194; de Vogüé, Règles, 131-135.

69 Hilary, Sermo de vita sancti Honorati 17.4, ed. Valentin, 114; Regula quattuor patrum 2.18-28, ed. de Vogüé, 188 and 190.

70 Pricoco, Isola dei santi, 47; Pietri and Heijmans, Prosopographie chrétienne, vol. 2, 1685 and 1926.

71 Nouailhat, Saints et patrons, 143-144, has already called attention to this point.

72 Statues of pagan gods, funerary, military, and votive inscriptions, as well as sarcophagi. The origin of these objects and fragments, however, is not completely certain. On all of them, cf. Codou, Les îles de Lérins, 279-282.

73 Pliny, Naturalis historia 3.5.79, ed. LCL 352, 58: "[...] Lero et Lerina adversum Antipolim, in qua Berconi oppidi memoria«. Trans. Rackham, 59.

74 Strabo, Geographikon 4.1.10, ed. LCL 50, 191. 
remains of other buildings and complexes. There were on the island a sanctuary dedicated to Pan, honorific walls dated from the time of Augustus, a sophisticatedly decorated complex from the beginning of the first century $\mathrm{CE}$, a thermal complex, and perhaps a villa, of which the thermal complex may have been part. There are also attestations of a building that was adapted at the end of the fourth century CE to become a furnace for ceramics and that was used until the mid-fifth century, and of an artisanal complex (zone artisanale). Moreover, archeologists have found ceramics from Italy, Gaul, and Africa, amphorae from Chios, Italy, Gaul, Baetica, and Africa, and many other objects associated with some of these structures. ${ }^{75}$

All these archaeological objects and remains show that there were sailing routes that connected both islands to Cannes (a North-South route) and to Italy, Marseille, Arles, Narbonne, and Spain (an East-West route). Indeed, the Itinerary of Antoninus mentions Lero and Lérins as a stop between Antibes and Fréjus. ${ }^{76}$ The workers and other inhabitants of Lero consumed food, clothes, tools, and other products that could be brought from the nearby continent or from an important commercial center like Marseille (a little more than one hundred miles from Cannes). At the same time, the objects produced at Lero needed to reach commercial centers or other destinations, and transport could be directly by the sea or, reaching the nearby continent, by land.

Hilary alludes to the insertion of Lérins into these land and maritime routes when he says that Honoratus once came back home just to take him to the island. ${ }^{77}$ Honoratus may have gone to Cannes or even Fréjus by boat and then reached his patria through land routes. Many pilgrims also came to Lérins just to see Honoratus. Hilary rhetorically asked his community in Arles: "Who did not gladly interrupt a prosperous navigation or favorable winds, despising his own advantage, in favor of the desire to meet so great a man? Or who did not evaluate a powerful thrust favorable to navigation as the most violent storm if he could not land on the island? « $^{78}$ Prisoners redeemed by Honoratus also came "from diverse regions " to Lérins ${ }^{79}$ and the poor stopped by to receive his generous donations. According to Hilary, Honoratus once donated the only gold coin remaining (out of other donations) to a "passing poor man ${ }^{80}{ }^{80}$ People came to Lérins, moreover, to deliver mail, to which Honoratus answered with "gravity, charm, and sweetness «. ${ }^{81}$

Hilary certainly exaggerated the amount of pilgrims, poor people, and mail coming to Lérins, again, to praise Honoratus. However, the monastery established intense contact with the Christian community of many cities of Gaul. It was under the jurisdiction of the church of Fréjus and, thanks to the literary and theological skills of some of its monks, it became an intellectual and spiritual center. The contact of the monastery with other cities is indicated

75 For all the archaeological findings, cf. Codou, Les îles de Lérins, 269-279. According to him, some remains even attest »une occupation de la fin du Néolithique, du Bronze moyen et de tout l'âge du Fer« (p. 271). One wonders how Eucherius' and his wife's settlement on Lero may have been. Could they be the owners of some of the structures that existed on the island?

76 Itinerarium provinciarum Antonini Augusti 504-5-505.1, ed. Parthey and Pinder, 246-247.

77 Hilary, Sermo de vita sancti Honorati 23.2, ed. Valentin, 132 and 134.

78 Hilary, Sermo de vita sancti Honorati 20.1, ed. Valentin, 126: »Quis non quamlibet prosperam navigationem, quamlibet secundos ventos mox pro tanti viri desiderio commodi sui contemptor abrupit aut, si insulam tenere non licut, violentum secundae navigationis obsequium acerbissimam tempestatem computavit?«.

80 Hilary, Sermo de vita sancti Honorati 21.1, ed. Valentin, 128.

81 Hilary, Sermo de vita sancti Honorati 22.1, ed. Valentin, 130: "[...] quam gravia, quam blanda, quam dulcia!«. 
mostly by the fact that many of its members were ordained bishops: Honoratus and Hilary in Arles, Maximus and Faustus in Riez, Lupus in Troyes, Eucherius in Lyon, Salonius in Geneva, Venantius in Vence, and Antiolus in an unknown city. ${ }^{82}$ Devotees from these and other Christian communities, therefore, may have come regularly to Lérins to meet the monks, traveling via the land and maritime routes that connected the island to big cities and commercial centers. It was on these same routes that Lerinians depended to get what they consumed.

The money to spend on what they needed came from different sources. ${ }^{83}$ Scholars suppose that money and all the stuff they consumed on the island came either from the practice of manual labor or from the land properties that wealthy postulants offered to the monastery ${ }^{84}$ The Rule of the Four Fathers and the Second Rule of the Fathers, indeed, established manual labor for all the monks. However, there is no evidence that they were able to procure all they consumed only through their work or that the sale of what they produced was enough to buy all they lacked. Not even Egyptian monks, who were so highly praised by Cassian and other writers of the time for their discipline to manual labor, were able to do so ${ }^{85}$ As for properties, monks were formally allowed to offer part of their wealth to the community since the composition of the Rule of the Four Fathers. ${ }^{86}$ But none of the Lerinians' Lives that came down to us attest donations to the monastery. ${ }^{87}$ We may, then, suppose that the majority of the donations were actually movable property ${ }^{88}$

Despite Hilary's overestimation of donations to Honoratus, it is quite possible that they partially contributed to the maintenance of the monastery. But most of the monks' resources came from the church of Fréjus. In the Arrangements of the third council of Arles, gathered between 449 and 461, the bishops requested Theodorus of Fréjus, »as befits a former abbot and bishop, to perpetually send the pious and necessary contribution to him [Faustus, abbot of Lérins at the time], and to fully send the corresponding relief, which he deigned to promise in words, to those things that necessity demands « ${ }^{89}$ Most probably, the church of Fréjus contributed to the Lerinians' subsistence since the beginning. Not only was the monastery under its jurisdiction, but also, Honoratus decided to establish himself at Lérins to be close to Leontius, Theodorus' predecessor..$^{90}$

82 On all of them, cf. Pietri and Heijmans, Prosopographie chrétienne.

83 I have examined this question with more detail in Figuinha, Economy.

84 From manual labor: Quacquarelli, Lavoro e ascesi, 63; Labrousse, Origines, 68. From land properties: Pricoco, Isola dei santi, 119-120; Nouailhat, Saints et patrons, 238-244; Brown, Through the Eye, 413-417 (who suggests that the monastery was also sustained by the donations of wealthy laymen, to whom Lerinians were connected either by blood or by intellectual culture); Pricoco, Eucherio. Elogio dell'eremo, 45.

85 Wipszycka, Aspects économiques.

86 Regula quattuor patrum 2.34, ed. de Vogüé, 190.

87 On Hilary: Eucherius, De laude eremi 3.1, ed. Pricoco, 138; Honoratus of Marseille, Vita sancti Hilarii 6, ed. Jacob, 102. On Honoratus: Hilary, Sermo de vita sancti Honorati 11.4, ed. Valentin, 98 and 100. On Maximus: Eusebius Gallicanus, Homilia 35.2, ed. Glorie, 402. On Lupus: Vita sancti Lupi episcopi 3, ed. Krusch, 296.

88 Regula quattuor patrum 2.35, ed. de Vogüé, 190 and 192, allowed monks to bring some of their slaves to the monastery, but as long as the former considered the latter their brothers. This topic is treated right after that of the donations.

89 Institutio sanctorum episcoporum in causa insulae Lerinensis 17-20, ed. Munier, 133: "Quin potius collationem, utpote antiquus abba et episcopus, ei ut piam ac necessariam perpetuo exhiberet et solacia secutura, quae verbis dignabatur promittere, rebus ipsis in quo usus exigeret plenissime exhiberet«. Trans. Figuinha, Economy.

90 Hilary, Sermo de vita sancti Honorati 15.2, ed. Valentin, 108. 


\section{The Jura monasteries}

Between 512 and 514, an anonymous author composed the Life of the Jura Fathers at the request of John and Armentarius, members of a monastery next to the shrine of Saint-Maurice, in Agaune. ${ }^{91}$ The text presents a history of the monasteries of Condat and Laucone, in the Jura forests, through the biography of their founders, Romanus and his brother Lupicinus, and of their disciple and successor as abbot Eugendus. The author of the Life was himself a monk of Condat and disciple of Eugendus, and his account is detailed and, most of the time, reliable. ${ }^{22}$ That is why the text has been recently considered as "one of the most consistent sources that we have on western monasticism before Saint Benedict $"{ }^{93}$ For scholars dealing with post-Benedictine monasticism, it can appear as an odd text, for it does not present a rich and powerful abbey (Condat became so only after the Life was written). Rather, it shows that, in the fifth century, the maintenance of a monastery was not a given and that monks consequently had to struggle, in a process of trial and error, for their subsistence.

In the Life of the Jura Fathers, Romanus enters the Jura forests around 435 as a new Anthony. ${ }^{94}$ The place he chose to settle, "a small plain « enclosed by three mountains (the Avignon, the Bayard, and the Chabot) at the confluence of two rivers (the Bienne and the Tacon), was "suitable and appropriate to his monastic intention «. ${ }^{95}$ It was a "desert", an »inaccessible solitude" that "was many miles distant from any habitation because of the scarcity of dwelling places $" \cdot{ }^{96}$ At the foot of the Bayard, Romanus sheltered under "a dense fir tree whose branches, spread out in a circle, were covered with an abundance of leaves", just beside »a flowing spring [which] poured forth an icy cold stream of water $" .{ }^{97}$ He was so isolated there that he »enjoyed the sight of nothing except wild beasts and, rarely, hunters ${ }^{98}{ }^{98}$ The anonymous author even conjectures about the reasons that supposedly made the site so remote:

91 Vita patrum iurensium 1-2, ed. Martine, 238. For the date, cf. Masai, "Vita patrum iurensium «, 56-57.

92 Scholars have attributed the authorship of the Vita patrum iurensium to Viventiolus, who was ordained as bishop of Lyon in 515. Cf. Moyse, Origines du monachisme, 44; Wood, Prelude to Columbanus, 27-28, n. 118; de Vogüé, Histoire littéraire, vol. 8, 123-126. On the reliability of the Vita patrum iurensium, cf. Martine, Vie.

93 De Vogüé, Histoire littéraire, vol. 8, 41.

94 Vita patrum iurensium 12, ed. Martine, 252: Romanus is an »imitator Antonii«. On the reminiscences of the Life of Anthony in the beginning of the Vita patrum iurensium, cf. the commentaries of Martine, Vie; and of Vivian et al., Life; as well as de Vogüé, Histoire littéraire, vol. 8, 46-52.

95 Vita patrum iurensium 6, ed. Martine, 244: »[...] professioni congruas aptasque [...] in planitiem aliquantulum [...]«. Trans. Vivian et al., Life, 102-103.

96 Vita patrum iurensium 5, ed. Martine, 244 (secretis heremi); 9, ed. Martine, 248 (solitudinem ipsam inviam); 12, ed. Martine, 252 (secreto heremi); 13, ed. Martine, 254 (heremo); 8, ed. Martine, 246: »[...] non parvis spatiis ob raritatem consistentium distabat ab incolis [...] . Trans. Vivian et al., Life, 104.

97 Vita patrum iurensium 7, ed. Martine, 246: »[...] repperit ab orientali parte sub radice saxosi montis, porrectis in orbitam ramis, densissimam abietem, quae patulis diffusa comis [...]. Extra cuius arboris orbem fons inriguus gelidissima fluenta praestabat [...]«. Trans. Vivian et al., Life, 103. Cf. Rothé, Carte archéologique, 631-632.

98 Vita patrum iurensium 12, ed. Martine, 252: "[...] nullo nisi ferarum ac raro venantium frueretur adspectu [...]«. Trans. Vivian et al., Life, 106. 
the abundant cultivation in the distant plain had given no reason to cross a succession of forests in order to come live in the vicinity. Moreover, if someone decided, with audacious daring, to cut across this roadless wilderness toward the territory of the Equestres, in addition to the dense forest and the heaps of fallen trees, he found high and lofty mountain ridges and steep valleys dividing the regions. There stags and broad-horned deer live. Even if the traveler were strong and lightly equipped, he would scarcely be able to cross it in a day, even the longest day of the year. Given the distance and the difficulties of its natural inaccessibility, no one could blaze a trail through this mountain range, to right or to left, from the regions of the Rhine and the raging of the north wind all the way to the farthest wooded regions. ${ }^{99}$

Despite the accuracy with which the Life of the Jura Fathers describes the local geography, ${ }^{100}$ Romanus' establishment appears as highly romanticized. The mountain, the tree and the spring, for example, are clear references to Jerome's Life of Paul, as the author himself emphasized. ${ }^{101}$ Considering the cold weather of the region, as the Life of the Jura Fathers repeatedly remarks, it would have been challenging, if not impossible, for Romanus to shelter under a tree. And indeed, Romanus appears to be living in a hut (tugurium) when his brother Lupicinus comes to find him. ${ }^{102}$ The chapters about Romanus' establishment in the Jura (4-12), therefore, are fundamentally a literary construction. The author goes out of his way to adjust the Jura forests and Romanus to the model of the desert and the founding Fathers of Egyptian monasticism. ${ }^{103}$

But in his explanation on why the Jura forests were supposedly so isolated, the anonymous author abandons the model of Anthony and Paul. Such abandonment does not make the explanation more reliable than the description of Romanus' lifestyle, for the site in which he settled was quite probably at the intersection of two roads (see below). It did not even occur to the author to question the isolation of the site. In fact, he tried to imagine how it would have looked at the time of Romanus for it to be so isolated. But in that imaginative recreation, monastic literature was not at play. The author reverted instead to particularities of the human and natural environments of the Jura (the cultivation of plain and fertile areas in other places, the dense forest, the roughness of the area around Condat, and the distance to other cities).

99 Vita patrum iurensium 8-9, ed. Martine, 246 and 248: "[...] quia abundans procul in campestri cultura minime per successionem silvae illic permiserat quempiam vicinari. Ceterum, si quis solitudinem ipsam inviam contra Aequestris territorii loca ausu temerario secare deliberet, praeter concretionem silvestrem sive congeries arborum caducarum, inter iuga quoque praecelsa cervorum platocerumve praerupta convallia, vix validus expeditusque poterit sub longa solstitii die transcendere. Nam dextra, certe sinistra, serrae ipsius tractum, a limite scilicet Rheni sive flatibus aquilonis usque pagi Nemausatis extimum, nullus omnino ob longitudinem vel difficultatem inaccessibilis naturae poterit penetrare«. Trans. Vivian et al., Life, 104.

100 Martine, Vie, 264, n. 1.

101 For the references, cf. Martine, Vie, 247, n. 2; de Vogüé, Histoire littéraire, vol. 8, 48.

102 Vita patrum iurensium 12, ed. Martine, 252; de Vogüé, Histoire littéraire, vol. 8, 48.

103 Vivian et al., Life, 88; de Vogüé, Histoire littéraire, vol. 8, 51-52.

medieval worlds $•$ No. $9 \cdot 2019 \cdot 82-111$ 
According to the Life of the Jura Fathers, Romanus also imitated Anthony in the practice of manual labor. ${ }^{104}$ Romanus' "small plain « was "an open area that could be cultivated «, and he »brought seeds and a hoe with him $"{ }^{105}$ In this way, »between the times required for frequent prayer and reading ", he cultivated a small plot »to support a modest way of life there by means of the monastic institution of manual labor $« .{ }^{106}$ And similarly to Paul the Hermit, he ate the fruits supplied by »a few wild bushes « ${ }^{107}$

The growing number of disciples, however, led Romanus and his brother Lupicinus, who had joined him, to change residence from their hut to the top of "a small hill« nearby, where the cathedral of Saint-Claude now lies. They hewed the trees and "constructed small dwellings for themselves and prepared others for those who would come in the future ${ }^{108}$ But the number of monks and pilgrims grew so much that the crops became insufficient to feed all: "Suspended as the place was in hills and declivities, between overhanging cliffs and rocky ground, and disturbed by the frequent flooding of the rugged landscape, the cultivation of crops there waned and decreased, not only because of the limited and difficult terrain, but also the mediocre harvests and uncertain yields «. ${ }^{109}$

Because Condat was founded at the top of a hill, the monks transferred Romanus' original crops in the "small plain « to the "gentle slope " of the hill itself. But with the constant growth of mouths to feed, it proved a failure, for the crops on the sloping terrains not only required more labor, but were also quite unproductive and more prone to flooding. The author of the Life of the Jura Fathers gives even more details why the crops failed:

The harsh winter not only covers the place with snow but buries it; so too in the spring and summer and fall either the summer heat, warmed by the nearby rocks, burns everything, or the irresistible rains carry away in torrents not only the tilled and cultivated land, but often the uncultivated and stony earth, too - along with grass, trees, and shrubs. When the rocks are laid bare, the very clods of earth that still remain are carried off from the monks and given over to the waters. ${ }^{110}$

104 I have already dealt with some of the questions that follow in Figuinha, Vida dos Padres do Jura.

105 Vita patrum iurensium 6, ed. Martine, 244: »[...] culturae patulum locum [...]«. Trans. Vivian et al., Life, 103; 10, ed. Martine, 248: »[...] adlatis seminibus vel sarculo [...] «. Trans. Vivian et al., Life, 104.

106 Vita patrum iurensium 10, ed. Martine, 248: "Igitur, adlatis seminibus vel sarculo, coepit illic vir beatissimus inter orandi legendique frequentiam necessitatem victus exigui institutione monachali labore manuum sutentare [...] . Trans. Vivian et al., Life, 104.

107 Vita patrum iurensium 8, ed. Martine, 246: „Erant praeterea paucae silvestres arbusculae, quae [...] pomula ministrabant«. Trans. Vivian et al., Life, 103. Cf. de Vogüé, Histoire littéraire, vol. 8, 48, for the reminiscence of the Life of Paul.

108 Vita patrum iurensium 13, ed. Martine, 254: »[...] in quodam molli colliculo [...] et sibi construxere habitacula et praeparavere venturis«. Trans. Vivian et al., Life, 107.

109 Vita patrum iurensium 22, ed. Martine, 262: "Siquidem cultura loci ipsius pendula collibus vel adclinis inter eminentes scopulos vel acervos, crebro salebrarum labefactata conluvio, non solum in spatiis parva ac difficilis, sed etiam in ipsis frugibus, reditu nutante, torpuerat«. Trans. Vivian et al., Life, 112.

110 Vita patrum iurensium 23, ed. Martine, 262 and 264: "Nam ut hiemali asperitate loca ipsa non solum sunt nivibus obruta, sed sepulta, ita verno aestivoque vel autumnali tempore aut aestas alterno vicinoque saxorum vapore conflagrat, aut intolerabiles imbres non solum eventilatam culturis asportant in torrentibus terram, sed ipsam etiam incultam ac rigidam saepe cum herbis et arboribus ac frutectis, cum gleba quoque ipsa, nudatis quibus insiderat saxis, aufertur monachis, aquis infertur«. Trans. Vivian et al., Life, 112. 
The monks then "cut down and removed the fir trees in the neighboring forests, which were by no means lacking in level and fertile areas", and founded the monastery of Laucone there, close to the current city of Saint-Lupicin. According to the anonymous author, the monks "leveled the fields with the sickle, and the plains with the plow, so that these places, now fit for cultivation, would alleviate the needs of the monks of Condadisco «. ${ }^{111}$ If we believe the author, the foundation of Laucone, certainly intended to allow the expansion of the crops to the new place, brought an abundance of food. He even recounts how the devil, resorting to "the abundance and fruitfulness of the harvest «, »incited the brothers to rise up, not only against the Rule, but almost against the abbot himself « ${ }^{112}$ In the whole Life, indeed, we find indications that Laucone grew to a complex farm. The author mentions its granary and storeroom, which were managed by a steward, its garden, in which vegetables were cultivated, and its fields, which were situated at some distance from the residential building and in which grains and turnips were cultivated. ${ }^{113}$ The rearing of cattle, poultry, and sheep is also referenced. ${ }^{114}$

Not surprisingly, the Jura monasteries have been described as being sections of Romanus' and Lupicinus' family villa, which, due to the villa crisis of the fifth century, was restructured into "smaller productive units ${ }^{115}$ One of the signs of such a restructuring would be the monks' dedication to agriculture and, similar to the Marchiennes and Hamage abbeys (both founded in the seventh century), the employment of slaves or salaried workers. ${ }^{116}$ However, we must be careful not to project on Condat, Laucone, or on any other monastery of the time the social and economic organization of medieval monasteries, for there is no indication concerning the use of slaves or salaried workers in the Life of the Jura Fathers. Actually, it is always the monks who work: Lupicinus, at least sometimes, went ad culturam; ${ }^{117}$ once, all the monks went ad agriculturam to work; ${ }^{118}$ the deacon Sabinianus "was in charge of the mills and tilting hammers on the nearby river below the monastery of Condadisco, which

111 Vita patrum iurensium 24, ed. Martine, 264: "[...] in vicinis exinde silvis quae et planitie et fecunditate minime fallebantur, exsectis excisisque abietibus, aut falce in prata aut vomere in aequora conplanarunt, ut loca oportuna culturis Condatescensium inopiam sublevarent«. Trans. Vivian et al., Life, 112.

112 Vita patrum iurensium 35, ed. Martine, 278: »[...] non solum contra regulam, sed in ipsum paene patrem fecit insurgere fratres. Primitus namque materia huiusce modi exstitit ubertas fecunditasque fructuum [...]«. Trans. Vivian et al., Life, 119.

113 Vita patrum iurensium 68 and 69, ed. Martine, 314 and 316 (spicarium); 75, ed. Martine, 320 (cellariolum); 68, 70, 75, and 172, ed. Martine, 314, 316, 320, and 424 (oeconomus); 73 and 75, ed. Martine, 320 (hortellus); 76, ed. Martine, 322 (hortulus); 64, ed. Martine, 310 (etiamsi [Lupicinus] prolixius egressus est ad culturam); 102, ed. Martine, 346 (fomites and rapae).

114 Vita patrum iurensium 66, ed. Martine, 312: "Nam cum nullus in Condatescensi praesertim coenobio hodie usque in Christi nomine de animali quicquam, exceptis lactibus, aut de alitibus, praeter ovis, infirmans dumtaxat, audeat degustare [...]«; 74, ed. Martine, 320: »[...] expansis in terra vervecum pellibus [...]«; 173, ed. Martine, 424: »[...] lanasque netas etiam suendi consuendique [...]«. Cf. Rothé, Carte archéologique, 167. For an overview of agrarian production and its social organization in Late Antiquity, cf. Wickham, Framing, 259-302 and 383-588.

115 Alciati, Sistema agricolo familiare, who refers to Condat.

116 Alciati, Sistema agricolo familiare, 135-139. Alciati also considers indications of the restructuring of Romanus' and Lupicinus' villa the fact that Romanus settled in the Jura forests close to his villa (Vita patrum iurensium 5, ed. Martine, 244) and the practice of artisanal labor. In my opinion, however, the proximity of Romanus' settlement to his villa and the dedication to artisanal labor do not per se indicate that Condat was the result of the fragmentation of his property. We would need more evidence concerning specifically the Jura monasteries to state that.

117 Vita patrum iurensium 64, ed. Martine, 310.

118 Vita patrum iurensium 73, ed. Martine, 318.

medieval worlds • No. 9 • 2019 • 82-111 
served the brothers", and he had a "little hut « there; ${ }^{.19}$ when Sabinianus decided to undertake a larger task, he called for the help of monks; ${ }^{120}$ the monk Dativus, who »by divine help [...] was also adorned with great qualities and gifts for every kind of work «, took his utensils with him when he left the monastery; ${ }^{121}$ and monks had hoes or axes in their personal cells before such cells caught fire and were replaced by a common dormitory. ${ }^{122}$ In fact, the eighth canon of the Council of Épaone, gathered in 517, indicates that, at the time, some monks of the Burgundian kingdom still refused to use slaves in their fields. ${ }^{123}$

The Jura monks also constructed mills and tilting hammers (pisae) on the Tacon to maximize their labor. ${ }^{124}$ As we have just seen, a single monk, Sabinianus, was in charge of the operation of this machinery and therefore had his cell there. Unfortunately, the author does not tell us when this machinery was originally built. But since he praises Sabinianus in the Life of Romanus and states that Sabinianus was a disciple of Stephen, »the first person to hold this ministry «, ${ }^{125}$ we can assume that it occurred soon after the monks transferred the crops to the sloping terrain around Condat. When they expanded the crops to Laucone, they had to bring the grain from there to Condat, grind it, and take some back to Laucone. We should also note that this machinery was perfected through the years. The anonymous author recounts the works coordinated by Sabinianus to "raise the channel of the river by which water was brought to the mill ${ }^{126}$ His intention was certainly to increase the speed of the grinding process.

But we cannot accept all too quickly the author's portrait and suppose that Condat and Laucone became economically autonomous. For, despite the practice of agriculture and animal breeding and the use of technology, the monks actually could not produce all the food they and their guests consumed. In his Life of the Fathers, Gregory of Tours recounts an episode that is absent in the Life of the Jura Fathers. The account is highly hagiographic, but it most probably derives from a historical episode. Between 463 and 469, Lupicinus came to Geneva to ask the Burgundian king Chilperic for a contribution to the Jura monasteries. ${ }^{127}$

119 Vita patrum iurensium 52, ed. Martine, 296: »[...] in vicino flumine sub ipso Condatescensi coenobio molinas pisasque fraternis usibus gubernabat [...]«. Trans. Vivian et al., Life, 127, slightly adapted; 53, ed. Martine, 298.

120 Vita patrum iurensium 57, ed. Martine, 300 and 302

121 Vita patrum iurensium 87, ed. Martine, 332: »[...] gratiarum dotibus in omni artificio divinitus adornatus«. Trans. Vivian et al., Life, 142; 88, ed. Martine, 332.

122 Vita patrum iurensium 163 and 170, ed. Martine, 414 and 422. That is why I am of the opinion that the two fratres who planned to leave the monastery taking a hoe and an axe with them (Vita patrum iurensium 79, ed. Martine, 324 and 326) were monks, not »operai salariati« or "schiavi«, as Alciati supposes.

123 The possession of slaves seems inconsistent with the words attributed by Gregory of Tours to Lupicinus in his meeting with the Burgundian king Chilperic (see below).

124 Vita patrum iurensium 52, ed. Martine, 296.

125 Vita patrum iurensium 52, ed. Martine, 296: "[...] ministerii huius principem Stephanum [...]«. Trans. Vivian et al., Life, 127.

126 Vita patrum iurensium 57, ed. Martine, 300: »[...] alveum torrentis ipsius quo molinaris advehebatur aqua [...]«. Trans. Vivian et al., Life, 129.

127 It is usually assumed that this episode occurred at the same time Lupicinus came to Chilperic's court to plead "[...] pro adflictione pauperum, quos persona quaedam, honore dignitatis aulicae tumens, vi pervasionis inlicitae servitutis iugo subdiderat [...] (Vita patrum iurensium 92, ed. Martine, 336, see below). However, Vita patrum iurensium 63, ed. Martine, 310, attests that Lupicinus came to the court more than once to act as an intercessor: "Calciamento namque tum tantummodo usus est, cum pro aliquibus forsitan ad comitatum intercessurus egressus est «. In any case, Lupicinus' request for a contribution to the Jura monasteries quite probably dates from the same timespan as his pleading in favour of the enslaved poor, i.e. 463-469. On this timespan, cf. Favrod, Histoire politique, 102, n. 120. 
As Lupicinus told him: "II am the father of the Lord's sheep. The Lord nourishes them with spiritual food, under the yoke of discipline, but they now lack bodily food. This is why we implore Your Potency that you might give us something for our food and clothing « ". ${ }^{128}$ Chilperic offered Lupicinus "fields and vineyards «, but he refused. Lupicinus requested instead: ")We will not accept fields and vines; but, if it pleases Your Potency, give us some of the fruits that they produce. It does not suit monks to live by worldly riches [...] « ${ }^{129}$ Chilperic then donated him "an order to receive each year 300 modii of wheat and the same measure of wine, and 100 gold solidi for clothing for the brothers". According to Gregory, "Even now they receive all this, it is said, from the estates of the fisc «. ${ }^{130}$

The Life of the Jura Fathers recounts that »the enormous community of monks and the multitude of lay people who had come to the monastery « was menaced only once by an »imminent scarcity and the danger of famine«. The steward told Lupicinus that there was "nothing more than a fifteen-day supply of food for the three months that remained until the new harvest promised relief . ${ }^{131}$ Lupicinus prayed into the granary and miraculously multiplied the grain, thus saving the monks and pilgrims from starvation. This episode, however, may well be related to Gregory's account, for the author of the Life of the Jura Fathers may have transformed Lupicinus' success at the court of Chilperic into a miraculous multiplication of grain.

The Life of the Jura Fathers and the account De Lupicino atque Romano abbatibus in the Life of the Fathers have analogies that have prompted scholars to consider that they derive from a short and more ancient Life of Romanus and Lupicinus. ${ }^{132}$ Gregory may have learned about Lupicinus' request of a contribution to Chilperic through this Life, but the author of the Life of the Jura Fathers may also have learned about it through oral reports and accounting records as a member of Condat. If in the end he excluded the episode from his narrative, it is because it did not fit his purposes. The composition of the Life was prompted by John and Armentarius, two members of the monastery attached to the shrine of Saint-Maurice in Agaune, soon after they read »the institutes regarding the rules and regulations " the same author, at the request of the abbot Marinus of Lérins, had sent to their monastery. ${ }^{133}$ The Life of the Jura Fathers was thus intended as a complement to such

128 Gregory, Liber vitae patrum 5, ed. Krusch, 217: "'Pater sum`, inquid, >dominicarum ovium, quas cum Dominus spiritalibus cibis iugi administratione reficiat, corporalia eis interdum alimenta deficiunt. Ideo petimus potentiae vestrae, ut ad victus vestitusque necessaria aliquid tribuatis«". Trans. James, Life of the Fathers, 9.

129 Gregory, Liber vitae patrum 5, ed. Krusch, 217: »Rex vero haec audiens, ait: >Accipite agros vineasque [...] . Qui respondit: >Agros et vineas non accipiemus, sed, si placet potestati vestrae, aliquid de fructibus deligate. Quia non decet, monachos facultatibus mundanis extolli [...] «. Trans. James, Life of the Fathers, 9-10.

130 Gregory, Liber vitae patrum 5, ed. Krusch, 217: »At rex [...] dedit eis praeceptionem, ut annis singulis trecentos modios tritici eiusdemque mensurae numero vinum accipiant et centum aureos ad conparandum fratrum indumenta. Quod usque nunc a fisci ditionibus capere referuntur«. Trans. James, Life of the Fathers, 10.

131 Vita patrum iurensium 68, ed. Martine, 314: »[...] cum enormis congregatio atque expetentum saecularium multitudo, iam iamque inminente penuria, famis periculo conturbaret oeconomum, ac praeter dierum quindecim victum trimenstre tempus, donec seges nova succurreret, penitus nihil haberet [...]«. Trans. Vivian et al., Life, 135.

132 Martine, Vie, 72-73, n. 2.

133 Vita patrum iurensium 1-2, ed. Martine, 238; 179, ed. Martine, 432: "[...] instituta quae de informatione monasterii vestri [...] «. Trans. Vivian et al., Life, 184. As Masai, »Vita patrum iurensium«, has pointed out, »le coenobium auquel la Vie des Pères du Jura fut destinée n'était pas l'abbaye de Sigismond. Celle-ci n'existait pas encore à l'époque où la >Vita` fut écrite!« (p. 56). The author also notes that »les correspondants du moine de Condat ne sont pas, comme on l'a cru à tort, des religieux expérimentés, mais des novices au contraire, en quête d’instructions et de modèles de vie pour s'organiser en coenobium « (pp. 57-58). 
»institutes", to show John and Armentarius, through the deeds of the three abbots, how monasticism should be practiced. Hence the title, Life and Rule of the Holy Fathers Romanus, Lupicinus, and Eugendus, Abbots of the Jura Monasteries, attributed to the text. ${ }^{134}$ In such a Life and Rule, the anonymous author praised the model of Basil, Lérins, Pachomius, and Cassian, ${ }^{135}$ and therefore situated the Jura monasteries in a desert and, most importantly, presented them as economically autonomous, as if the monks could support themselves only through their work. If the author had included Lupicinus' request to Chilperic in his narrative, he would have compromised the image of the Jura Fathers he was aiming to project.

Despite the omission of Lupicinus' appeal to Chilperic, the author of the Life of the Jura Fathers may have subtly alluded to the fact that the Jura monks could not produce all the food they consumed in his meticulous explanation why the crops failed in Condat. From chapter 22 to chapter 23 , tenses change from the past perfect to the present. The reason for that, I argue, is that in chapter 23 the author is resorting to his own experience. He probably supposed that, other than the inclination of the terrains in Condat, Romanus and Lupicinus had faced the same difficulties his contemporaries still faced more than seventy years later. If this is indeed the case, it corroborates the fact that the monks were unable in the long term to harvest abundant crops in the areas they deforested. ${ }^{136}$

What is even more important to note is that the author of the Life of the Jura Fathers is so meticulous in chapters $22-23$ because he is explaining to his most immediate readers, John and Armentarius, why the crops failed at the time of Romanus and in his own time. In this way, he is implicitly justifying to John and Armentarius, who certainly knew the Jura monasteries very well, why the latter had to be maintained by the Burgundian kings. These chapters, indeed, summarize a tension that is perceptible in the whole text between the ideal monastic life, as it is advertised in more ancient hagiographic and monastic texts, and the real monastic life, constrained by the local natural environment. In the Life of Romanus, the Jura forests change from the perfect place for a monastic life at the beginning to a hindering to the monastic life after the foundation of Condat. The Jura monks had been very much influenced by Cassian, who argued that monks should sustain themselves only through the practice of manual labor. ${ }^{137}$ But in the Jura forests, even though they worked hard, the monks could not live only on what they produced. They could not be like the monks Cassian had presented. And the fault for that was to be attributed to the local natural environment, which was not favorable to agriculture. That is why the author says at the end of the Life of Eugendus that, despite reading "daily" the "institutions" of Basil, Lérins, Pachomius, and Cassian, the Jura monks "strive to follow those of Condadisco « ${ }^{138}$ The institutions of Condat, he continues, had been formulated pro qualitate loci et instantia laboris, "according to the features of the place and the requirements of labor «. The Jura monks soon realized, therefore, that, despite all their effort, they could not live like the monks they knew through their books.

134 Vita vel regula sanctorum patrum Romani Lupicini et Eugendi monasteriorum iurensium abbatum, ed. Martine, 236. On this aspect of the text, cf. Wood, Prelude to Columbanus, 4; Diem, Who is allowed, 57.

135 Vita patrum iurensium 174, ed. Martine, 426.

136 Rothé, Carte archéologique, 651: the soil of Saint-Lupicin has been qualified as "'peu fertile««.

137 On Cassian's thoughts on manual labor, cf. Goodrich, Contextualizing Cassian, 198-200.

138 Vita patrum iurensium 174, ed. Martine, 426 and 428. Trans. Vivian et al., Life, 182.

medieval worlds • No. 9 • 2019 • 82-111 
The author omits not only the Burgundian kings' contribution to the Jura monasteries, but also pilgrims' donations to the monks. In the Life of Lupicinus, he attests that monks "frequently accomplished gifts of healing and other wonders " and went away "without receiving any kind of monetary gift in return «. ${ }^{139}$ But he is clearly being rhetorical, for he is contrasting his own time with the mythical one of the founding Fathers. Lupicinus and Eugendus were closely connected with powerful people who may well have made donations to them: Domnulus, a poet and quaestor sacri palatii during the reign of Majorian (457-461), was a frequent guest of the Jura monasteries; Agrippinus, after his tenure as comes and magister militum in Gaul (451-456), was freed from the charge of high treason through the miraculous intercession of Lupicinus; and Syagria, member of a powerful family of Lyon, was cured of a "grave disease « through a letter of Eugendus. ${ }^{140} \mathrm{In}$ fact, the author noted »that the greatest and most powerful people of the time frequently asked to be protected and blessed by his [Eugendus'] letters « ${ }^{141}$ It is certainly not by chance that he presents Syagria as a »formerly mother of a family, and now through her almsgiving mother of churches and monasteries «. ${ }^{142}$ He probably intended to praise her for her contributions to the Jura monasteries without saying directly that she had made any contributions.

A last point concerning the account of Romanus' establishment in the Jura forests is that Condat was not isolated. ${ }^{143}$ It was quite likely at the intersection of an East-West road that connected Geneva to Izernore (Romanus', Lupicinus', and Eugendus' hometown) ${ }^{144}$ through the Bienne valley and a North-South road. ${ }^{145}$ The author himself mentions the road to Geneva. ${ }^{146}$ It is also possible that two roads, one that connected Geneva to Lons-le-Saunier through Condat and the other that connected Fort-du-Plasne to Izernore, passed close to Laucone. ${ }^{147}$ Condat and Laucone, moreover, were close to inhabited sites, as archaeological discoveries a few miles away from Saint-Claude suggest. ${ }^{148}$ The author's allusion to "local inhabitants" (indigenis) and the hunters Romanus saw at the beginning of his retreat in the Jura (if it is not purely a romantic idealization) are also indications of it. ${ }^{149}$ Condat's own

139 Vita patrum iurensium 114, ed. Martine, 358: "[...] saepe per Domini servos [...] sanitatum et mirabilium dona perfecta sunt $[. .$.$] absque venalitate gratiae festinabant [...] «. Trans. Vivian et al., Life, 154$.

140 Domnulus: Sidonius Apollinaris, Epistula 4.25.5, ed. Loyen, 170; Agrippinus: Vita patrum iurensium 96-110, ed. Martine, 342-354; Syagria: Vita patrum iurensium 145-146, ed. Martine, 394 and 396. On them, cf. Pietri and Heijmans, Prosopographie chrétienne.

141 Vita patrum iurensium 139, ed. Martine, 388: »[...] summae saeculi potestates sospitari se crebro ac benedici eius litteris exorarent [...]«. Trans. Vivian et al., Life, 166.

142 Vita patrum iurensium 145, ed. Martine, 394: "Materfamilias quondam Syagria, nunc quoque ecclesiarum monasteriorumque per eleemosynam mater [...]«. Trans. Vivian et al., Life, 169.

143 As has been well known since specially Mordefroid, Quel désert.

144 Vita patrum iurensium 120, ed. Martine, 366.

145 On these and the other roads in the Jura, cf. Rothé, Carte archéologique, 82-88 and 168. Scholars have been aware of this aspect of Condat since Wood, Prelude to Columbanus, 5 .

146 Vita patrum iurensium 153, ed. Martine, 402: »[...] semitam qua Genuam usque transcenditur [...]«.

147 Rothé, Carte archéologique, 651.

148 Mordefroid, Quel désert, 7-9; Bully, Archéologie.

149 Vita patrum iurensium 145 and 12, ed. Martine, 394 and 252.

medieval worlds • No. 9 • 2019 • 82-111 
site had already been inhabited. In a campaign conducted in the cathedral of SaintClaude, archeologists brought to light objects and remains of a prehistoric occupation and of a second-century building. ${ }^{150}$ It may well be, as some scholars have considered, that Romanus chose the site in order to Christianize the local territory. ${ }^{151}$

The connection of Condat and Laucone with Christian and commercial centers appears many times in the Life of the Jura Fathers. Romanus and Lupicinus were frequently on the road. Romanus even had a trip companion and miracles are attributed to Romanus while he was in Poncin and Geneva. ${ }^{152}$ Lupicinus sometimes went "to the [Burgundian] court in order to intercede on behalf of this or that person ${ }^{153}$ Probably in 467 , he came to Chilperic "moved by the plight of some poor persons whom a certain man, puffed up by the prestige of being at court, had through unlawful coercion violently subjected to the yoke of servitude ${ }^{154}$ At the time of Lupicinus, monks were "sent out of the monastery by the abbot for some reason or other " and two monks came to Rome and stayed out for around two years. ${ }^{155}$ During Eugendus' abbacy, monks continued to travel to the north of Condat despite fearing "the terrible incursions of the Alemanni in their very neighborhood «. ${ }^{156}$

The author contrasts Romanus and Lupicinus, who "often left the monastery, going here and there on acts of mercy «, to Eugendus, who, "after he entered the monastery, never took a step outside «. ${ }^{157}$ As I have already mentioned, however, Eugendus was constantly reached by mail from "the greatest and most powerful people of the time « requesting "to be protected and blessed by his letters". These people either sent letters or came personally to the Jura to get "the special favor or intercessions of the friend of Christ $"{ }_{.}^{158}$ In the Life, indeed, Condat and Laucone seem always crowded by clerical and secular visitors. Since the beginning, as the anonymous author asserts, Romanus' and Lupicinus' "renown [...] persuaded throngs of believers " to join them in the monastic life. "Some came there" - he continues - "to see the miracles of this institution and to take home with them exemplary and harmonious gifts",

150 Mordefroid, Quel désert, 6-7.

151 Vivian et al., Life, 88; Bully and Mordefroid, De Saint Désiré, 178.

152 Vita patrum iurensium 44, ed. Martine, 286 (trip companion); 43, ed. Martine, 286 (Poncin); 44-50, ed. Martine, 286-294 (Geneva).

153 Vita patrum iurensium 63, ed. Martine, 310: »[...] pro aliquibus forsitan ad comitatum intercessurus egressus est «. Trans. Vivian et al., Life, 134.

154 Vita patrum iurensium 92, ed. Martine, 336: „Quadam namque vice, dum pro adflictione pauperum, quos persona quaedam, honore dignitatis aulicae tumens, vi pervasionis inlicitae servitutis iugo subdiderat [...]«. Trans. Vivian et al., Life, 144. For the date, cf. Favrod, Histoire politique, 102: »entre 463 et 469, très probablement vers $467 \lll$.

155 Vita patrum iurensium 113, ed. Martine, 358: »[...] frater ab abbate foras ob causam aliquam destinatus [...] «. Trans. Vivian et al., Life, 153-154; 155, ed. Martine, 404 (trip to Rome).

156 Vita patrum iurensium 157, ed. Martine, 406: »[...] diros metuunt ac vicinos Alamannorum incursus [...]«. Trans. Vivian et al., Life, 173. As Martine, Vie, 407, n. 3, has pointed out, these incursions likely occurred at the beginning of Eugendus' abbacy (from 472-475 to 512-515), before the Burgundians expelled the Alemanni out of Sequania in the second half of the 470 s or in the early 480 s. On the dates of Eugendus' abbacy, cf. Pietri and Heijmans, Prosopographie chrétienne, vol. 1, 679-683.

157 Vita patrum iurensium 126, ed. Martine, 374: "Illis dumtaxat huc illucque necessitate misericordiae e monasterio saepe progressis, iste vero [...] nusquam exinde post ingressum extulit pedem«. Trans. Vivian et al., Life, $160-161$.

158 Vita patrum iurensium 139, ed. Martine, 388: »[...] Christi amici gratiam sive suffragia [...] «. Trans. Vivian et al., Life, 166. Cf. above n. 141. On the Jura Fathers' intercessory activities, cf. Diem, Who is allowed, 61-62. 
while »Others brought people tormented by demons and by other spirits of the Devil, along with the insane and paralyzed, so that through the prayer of the saints and their own faith these might be healed «. ${ }^{159}$ At the time of Eugendus, the ill "seemed almost more numerous than the companies of monks «. ${ }^{160}$

The Jura monks depended on the same roads through which pilgrims reached Condat and Laucone to obtain what they needed, such as honey, olive oil, salt, and wine. ${ }^{161}$ In the Life of Eugendus, the author states that the monks used to get salt in Salins, around forty miles north of Condat. ${ }^{162}$ However, they had other, more distant, options if they needed. On one occasion, some monks went "as far away as the shores of the Mediterranean« in order to avoid "the terrible incursions of the Alemanni ${ }^{163}{ }^{163}$ The products the Burgundian kings annually donated to the Jura monks also reached the monasteries through the roads that connected them with the whole kingdom.

\section{Conclusion}

Although set in very different places, the three cases investigated here display remarkable consistencies regarding the way their members conceived and interacted with the human and natural environments:

1. Relying on both Christian and classical Roman literary traditions, monastic authors presented their or their heroes' monasteries and the local human and natural environments as a "desert", an isolated place. Authors intended to associate themselves or their heroes with the Fathers of Egyptian monasticism and therefore did not hesitate to distort the human and natural environments to achieve their purpose. In truth, there are some particularities. The elements Eucherius used to characterize the fertility of the monastic desert, in general, and of Lérins, in particular, had a Biblical meaning for him, while the anonymous author of the Life of the Jura Fathers resorted to characteristics of the Jura geography and topography to explain the supposed isolation of Romanus' original settlement.

2. Despite the authors' insistence on the monastic desert, the monasteries they describe were not isolated. On the contrary. They were close to inhabited centers and could be easily reached via land and maritime routes.

159 Vita patrum iurensium 14-15, ed. Martine, 254 and 256: »[...] fama [...] credentium turbas persuaderet [...]. Nonnulli institutionis huius visuri miracula atque exempli dona convenientia domi reportaturi conveniunt. Alii etiam vexatos daemoniis ceterisque diaboli larvis oratione sanctorum cum propria fide curandos, et mente inpotes et corpore nexos, adducunt«. Trans. Vivian et al., Life, 107-108. Cf. Wood, Prelude to Columbanus, 5.

160 Vita patrum iurensium 147, ed. Martine, 396: »[...] paene catervis videretur numerosior monachorum«. Trans. Vivian et al., Life, 169.

161 Vita patrum iurensium 116, ed. Martine, 360 (mel); 38, 66, 75, and 170 (to light lamps), ed. Martine, 282, 312, 320, and 422 (oleum); 38 and 157, ed. Martine, 282 and 408 (sal); 66 and 75, ed. Martine, 312 and 320 (vinum). We should not forget that wine was also used at the celebration of the Eucharist.

162 Vita patrum iurensium 157, ed. Martine, 408; Martine, Vie, 409, n. 2.

163 Vita patrum iurensium 157, ed. Martine, 406 and 408: "[...] diros metuunt ac vicinos Alamannorum incursus [...] e limite Tyrreni maris [...] coctile decernunt petere sal«. Trans. Vivian et al., Life, 173. For the date of this instance, cf. n. 156 above. 
3. These monasteries, indeed, could not be isolated, for they depended on the human and natural environments for their subsistence. Their members had to buy the products they could not produce or get in nearby forests, such as food, papyrus, and parchment. It is perhaps important to stress that, even when monks practiced agriculture on large scale, as in the Jura, we cannot assume, as a simple consequence, that they were able to produce all the food they consumed. Part of the money necessary for their subsistence was donated by the devotees and ill people who constantly came to meet them.

Despite these similarities, the monks and monasteries considered in this analysis show that they interfered in very particular ways in the human and natural environments. At Marmoutier, Martin's disciples were not meant to practice manual labor or do any lucrative activities, so that they could dedicate themselves to continuous prayer. There is also no indication that they practiced agriculture or that the monastery owned land properties. Because of that, they quite likely bought most of the food they consumed from local peasants, who were also hired to bring wood from the nearby forest. In the Jura, on the contrary, the monks practiced manual labor with the intention of supporting themselves: they deforested and cultivated large areas, reared cattle, poultry, and sheep, and constructed a mill and tilting hammers to grind grains. In all that, they were trying to follow the precepts of John Cassian.

But because of the difficulties of cultivating the land in the Jura forests, they failed to sustain themselves only through the labor of their hands. They also depended on the contributions of the Burgundian kings and on the donations of pilgrims. At Lérins, though monks were also influenced by Egyptian monasticism and required to work with their hands, it is not certain if they dedicated themselves to agriculture. If they did, the extension of the deforested and cultivated terrain was limited to a small part of the island.

The way monks conceived and practiced monasticism in late antique Gaul was very different from one to the other. ${ }^{164}$ It comes then as no surprise that different monastic practices and conceptions of how monks were to support themselves led to different interactions with the human and natural environments. Unfortunately, we cannot measure their impact on the local economy and the circulation of products, on the circulation of people, and on deforestation and the consumption of natural resources. But, considering the differences in their interactions with their human and natural environments, we can assume quite confidently that their impact on it was particular to each one of them.

\section{Acknowledgements}

This work was supported by Coordenação de Aperfeiçoamento de Pessoal de Nível Superior (CAPES).

164 Cf. especially the works of Diem, Monastisches Experiment; id., Inventing the Holy Rule; id., Who is allowed; id., Gregory's chess board; id., Columbanian monastic rules. 


\section{References}

Abbreviations

CCSL = Corpus Christianorum Series Latina

LCL $=$ Loeb classical library

MGH SRM = Monumenta Germaniae Historica, Scriptores Rerum Merovingicarum

TTH $=$ Translated texts for historians

SC = Sources Chrétiennes

Alciati, Roberto, Un sistema agricolo familiare ovvero ciò che è chiamato il monachesimo del Giura, in: Valerio Neri and Beatrice Girotti (eds.), La famiglia tardoantica: Società, diritto, religione, Quaderni di Erga-Logoi 5 (Milan, 2016) 129-144.

Bord, Lucien-Jean, Aux origines du monachisme en Gaule: Les communautés martiniennes du IVe siècle", Annales de Bretagne et des Pays de l'Ouest 119 (2012) 13-24.

Brown, Peter, Through the Eye of a Needle: Wealth, the Fall of Rome, and the Making of Christianity in the West, 350-550 AD (Princeton, 2012).

Bully, Sébastien, Archéologie des monastères du premier millénaire dans le Centre-Est de la France: Conditions d'implantation et de diffusion, topographie historique et organisation, Bulletin du Centre d'Études Médiévales d'Auxerre 13 (2009) 257-290.

Bully, Sébastien and Jean-Luc Mordefroid, De Saint Désiré à Saint Claude (v. 400-v. 700): Les premières communautés chrétiennes du Jura - Notes, documents et perspectives de recherche, in: Marie-Pierre Rothé, Carte archéologique de la Gaule, vol. 39: Le Jura (Paris, 2001) 176-183.

Caner, Daniel, Wandering, Begging Monks: Spiritual Authority and the Promotion of Monasticism in Late Antiquity, The Transformation of the Classical Heritage 33 (Berkeley, 2002).

Chadwick, Owen, Euladius of Arles, Journal of Theological Studies 46 (1945) 200-205.

Codou, Yann, Aux origines du monachisme en Gaule (Ve-XIe s.): Les fouilles de l'église du Saint-Saveur, Lérins, île Saint-Honorat, Alpes-Maritimes, Hortus Artium Medievalium 19 (2013) 63-71.

Codou, Yann, Aux origines du monachisme: Le dossier de Saint-Honorat de Lérins, in: Michèle Gaillard (ed.), L'empreinte chrétienne en Gaule du IVe au IXe siècle (Turnhout, 2014) 291-310.

Codou, Yann, Îles de Lérins. Île Saint-Honorat, les chapelles du Saint-Sauveur et de la Trinité, in: Monuments de Nice et des Alpes-Maritimes, Congrès archéologique de France (Paris, 2012) 77-84.

Codou, Yann, Les îles de Lérins, in: Laurence Lautier and Marie-Pierre Rothé, Carte archéologique de la Gaule, vol. 06: Les Alpes-Maritimes (Paris, 2010) 269-283.

Courcelle, Pierre, Nouveaux aspects de la culture lérinienne, Revue des études latines 46 (1968) 379-409.

Diem, Albrecht, Columbanian monastic rules: Dissent and experiment, in: Roy Flechner and Sven Meeder (eds.), The Irish in Early Medieval Europe: Identity, Culture and Religion (London, 2016) 68-85.

Diem, Albrecht, Das monastische Experiment: Die Rolle der Keuschheit bei der Entstehung des westlichen Klosterwesens, Vita Regularis 24 (Münster, 2005). 
Diem, Albrecht, Gregory's chess board: Monastic conflict and competition in Early Medieval Gaul, in: Philippe Depreux, François Bougard and Régine Le Jan (eds.), Compétition et sacré au haut Moyen Âge: Entre médiation et exclusion, Haut Moyen Âge 21 (Turnhout, 2015) 165-191.

Diem, Albrecht, Inventing the Holy Rule: Some observations on the history of monastic normative observance in the Early Medieval West, in: Hendrik Dey and Elizabeth Fentress (eds.), Western Monasticism ante litteram: The Spaces of Monastic Observance in Late Antiquity and the Early Middle Ages, Disciplina Monastica 8 (Turnhout, 2011) 53-84.

Diem, Albrecht, Who is allowed to pray for the king? Saint-Maurice d'Agaune and the creation of a Burgundian identity, in: Walter Pohl and Gerda Heydemann (eds.), Post-Roman Transitions: Christian and Barbarian Identities in the Early Medieval West, Cultural Encounters in Late Antiquity and the Middle Ages, Identities in the Latin West 14 (Turnhout, 2013) 47-88.

Dulaey, Martine, La bibliothèque du monastère de Lérins dans les premières décennies du Ve siècle, Augustinianum 46 (2006) 187-230.

Eucherius, De laude eremi, ed. Salvatore Pricoco, Eucherio. Elogio dell'eremo, Biblioteca Patristica (Bologna, 2014).

Eusebius Gallicanus, Collectio homiliarum, ed. François Glorie, CCSL 101 (Turnhout, 1970).

Favrod, Justin, Histoire politique du royaume burgonde (443-534), Bibliothèque Historique Vaudoise 113 (Lausanne, 1997).

Figuinha, Matheus Coutinho, A data da Regra dos quatro Padres e o início do monastério de Lérins, Romanitas - Revista de Estudos Grecolatinos 5 (2015) 168-185.

Figuinha, Matheus Coutinho, A Vida dos Padres do Jura e a subsistência dos monges de Condat, História (São Paulo) 34 (2015) 243-262.

Figuinha, Matheus Coutinho, O monasticismo de Martinho de Tours e as aristocracias na Gália do século IV, Revista Brasileira de História 36 (2016) 13-33.

Figuinha, Matheus Coutinho, The economy of the monastery of Lérins (c. 400-c. 460), in: Giovanni Alberto Cecconi, Rita Lizzi Testa and Arnaldo Marcone (eds.), The Past as Present. Essays of Roman History in Honor of Guido Clemente, Studi e testi tardoantichi. Profane and Christian Culture in Late Antiquity 17 (Turnhout, forthcoming).

Figuinha, Matheus Coutinho, The subsistence of Martin of Tours' Marmoutier, in: Bernard Sawicki (ed.), Monasticism and Economy: Rediscovering an Approach to Work and Poverty (Rome, forthcoming).

Fontaine, Jacques, Sulpice Sévère. Vie de Saint Martin, SC 133-135, 3 vols (Paris, 1967-1969).

Fontaine, Jacques and Nicole Dupré, Sulpice Sévère. Gallus: Dialogues sur les "vertus" de Saint Martin, SC 510 (Paris, 2006).

Gillot, Isabelle and Yann Codou, Un témoin de l'environnement de l'île Saint-Honorat de Lérins (Alpes-Maritimes): Le combustible utilisé dans la chapelle Saint-Sauveur durant l'Antiquité tardive et le haut Moyen Âge, Bulletin Archéologique de Provence 38 (2017) 95104.

Gioanni, Stéphane, La culture profane et la littérature monastique en Occident: L'exemple des ascètes provençaux (Ve-VIe siècles), in: Éric Rebillard and Claire Sotinel (eds.), Les frontières du profane dans l'Antiquité tardive, Collection de l'École française de Rome 428 (Rome, 2009) 177-195.

Goodrich, Richard J., Contextualizing Cassian: Aristocrats, Asceticism, and Reformation in Fifth-Century Gaul (Oxford, 2007). 
Gribomont, Jean, L'influence du monachisme oriental sur Sulpice Sévère, in: Élie Griffe (ed.) Saint Martin et son temps. Mémorial du XVIe centenaire des débuts du monachisme en Gaule, 361-1961, Studia Anselmiana 46 (Rome, 1961) 135-149.

Gregory, Liber vitae patrum, ed. Bruno Krusch, MGH, SRM 2 (Hanover, 1885) 211-294; English trans. Edward James, Gregory of Tours: Life of the Fathers, TTH 1 (second edition), (Liverpool, 1991).

Heijmans, Marc and Luce Pietri, Le »lobby « lérinien: Le rayonnement du monastère insulaire du Ve siècle au début du VIIe siècle, in: Yann Codou and Michel Lauwers (eds.), Lérins, une île sainte de l'Antiquité au Moyen Âge, Collection d'Études Médiévales de Nice 9 (Turnhout, 2009) 35-61.

Hilary, Sermo de vita sancti Honorati, ed. Marie-Denise Valentin, Hilaire d'Arles. Vie de Saint Honorat, SC 235 (Paris, 1977).

Honoratus of Marseille, Vita sancti Hilarii episcopi Arelatensis, ed. Paul-André Jacob, Honorat de Marseille. La Vie d'Hilaire d'Arles, SC 404 (Paris, 1995).

Horden, Peregrine and Nicholas Purcell, The Corrupting Sea: A Study of Mediterranean History (Oxford, 2000).

Institutio sanctorum episcoporum in causa insulae Lerinensis, ed. Charles Munier, Concilia Galliae, a. 314-a. 506, CCSL 148 (Turnhout, 1963) 133-134.

Itinerarium provinciarum Antonini Augusti, ed. Gustav Parthey and Moritz Pinder, Itinerarium Antonini Augusti et Hierosolymitanum (Berlin, 1848) 1-234.

John Cassian, Conlationes, ed. Eugène Pichery, Jean Cassien. Conférences VIII-XVII, SC 54 (Paris, 1958).

Kasper, Clemens M., Theologie und Askese: Die Spiritualität des Inselmönchtums von Lérins im 5. Jahrhundert, Beiträge zur Geschichte des alten Mönchtums und des Benediktinertums 40 (Münster, 1991).

Labrousse, Mireille, Les origines du monastère (Ve-VIIe siècle), in: Mireille Labrousse (ed.), Histoire de l'abbaye de Lérins, Cahiers Cisterciens: Des Lieux et des Temps 9 (Bégrolles-enMauges, 2005) 21-124.

Lenkaityté, Manté, Eucher interprète de la Bible dans l'»Éloge du désert«, in: Yann Codou and Michel Lauwers (eds.), Lérins, une île sainte de l'Antiquité au Moyen Âge, Collection d’Études Médiévales de Nice 9 (Turnhout, 2009) 83-104.

Leyser, Conrad, »This Sainted Isle«: Panegyric, Nostalgia, and the Invention of Lerinian Monasticism, in: William E. Klingshirn and Mark Vessey (eds.), The Limits of Ancient Christianity: Essays on Late Antique Thought and Culture in Honor of R. A. Markus (Ann Arbor, 1999) 188-206.

Lorans, Élisabeth, Aux origines du monastère de Marmoutier: Le témoignage de l'archéologie, Annales de Bretagne et des Pays de l'Ouest 119 (2012) 177-203.

Lorans, Élisabeth, Marmoutier (Tours), a late Roman and early medieval monastery in the Loire Valley (4th-11th centuries), Anglo-Saxon Studies in Archaeology and History 20 (2017) 55-66.

Lorans, Élisabeth and Thomas Creissen (eds.), Le site de l'abbaye de Marmoutier (Tours, Indreet-Loire), Rapport 2013, 2 vols. (2013). Retrieved on 4 October 2015: citeres.univ-tours.fr/ spip.php?article1305.

Lorans, Élisabeth and Thomas Creissen (eds.), Le site de l'abbaye de Marmoutier (Tours, Indreet-Loire), Rapport 2014, 2 vols. (2015). Retrieved on 19 May 2016: citeres.univ-tours.fr/ spip.php?article1305. 
Lorans, Élisabeth and Thomas Creissen (eds.), Le site de l'abbaye de Marmoutier (Tours, Indreet-Loire), Rapport 2015, 2 vols. (2015). Retrieved on 19 May 2016: citeres.univ-tours.fr/ spip.php?article1305.

Lorans, Élisabeth and Thomas Creissen (eds.), Le site de l'abbaye de Marmoutier (Tours, Indre-et-Loire), Rapport 2016, 2 vols. (2016). Retrieved on 07 December 2018: citeres.univtours.fr/spip.php?article1305.

Lorans, Élisabeth and Thomas Creissen (eds.), Le site de l'abbaye de Marmoutier (Tours, Indreet-Loire), Rapport 2017, 2 vols. (2017). Retrieved on 07 December 2018: citeres.univ-tours. fr/spip.php?article1305.

Lorans, Élisabeth and Thomas Creissen (eds.), Le site de l'abbaye de Marmoutier (Tours, Indreet-Loire), Rapport 2015-2017 (2017). Retrieved on 07 December 2018: citeres.univ-tours. fr/spip.php?article1305.

Lorans, Élisabeth and Gaël Simon, Autour de Marmoutier: Les premiers siècles du monachisme en Touraine, in: Sébastien Bully (ed.), Construire l'Europe: Colomban et son héritage, Actes du Colloque de Luxeuil (16-20 septembre 2015) (Rennes, 2018) 87-106.

Markus, Robert A., The End of Ancient Christianity (Cambridge, 1990).

Martine, François, Vie des Pères du Jura, SC 142 (Paris, 2004).

Masai, François, La »Vita patrum iurensium« et les débuts du monachisme à Saint-Maurice d'Agaune, in: Johanne Autenrieth and Franz Brunhölzl (eds.), Festschrift Bernhard Bischoff zu seinem 65. Geburtstag dargebracht von Freunden, Kollegen und Schülern (Stuttgart, 1971) 43-69.

Mordefroid, Jean-Luc, Quel désert pour les Pères du Jura? Résultats du sondage archéologique effectué dans la cathédrale en avril 1990, in: Pierre Lacroix, Andrée Renon, Marie-Claude Mary and Éliane Vergnolle (eds.), Pensée, image et communication en Europe médiévale: $A$ propos des stalles de Saint-Claude, Colloque international, Saint-Claude, Lons-le-Saunier, 2426 septembre 1990 (Besançon, 1993) 3-10.

Moyse, Gérard, Les origines du monachisme dans le diocèse de Besançon (Ve-Xe siècles), Bibliothèque de l'École des Chartes 131 (1973) 21-104.

Natal, David, "A Suitable Successor«: Building Legitimacy in Hilary's Sermon on the Life of Honoratus, Reti medievali 16 (2015) 147-168.

Nouailhat, René, Saints et patrons: Les premiers moines de Lérins, Centre de Recherches d'Histoire Ancienne 84, Annales Littéraires de l’Université de Besançon 382 (Paris, 1988).

Pietri, Luce and Marc Heijmans (eds.), Prosopographie chrétienne du Bas-Empire: La Gaule chrétienne (314-614), 2 vols (Paris, 2013).

Pliny, Naturalis historia, vol. 2, trans. Harris Rackham, Pliny. Natural History, LCL 352 (Cambridge, MA, 1989).

Pricoco, Salvatore, Eucherio. Elogio dell'eremo, Biblioteca Patristica (Bologna, 2014).

Pricoco, Salvatore, L'isola dei santi: Il cenobio di Lerino e le origini del monachesimo gallico, Filologia e Critica 23 (Rome, 1978).

Quacquarelli, Antonio, Lavoro e ascesi nel monachesimo prebenedettino del IV e V secolo, Quaderni di »Vetera Christianorum« 18 (Bari, 1982).

Rapp, Claudia, Desert, city, and countryside in the early Christian imagination, Church History and Religious Culture 86 (2006) 93-112.

Regula quattuor patrum, ed. Adalbert de Vogüé, Les Règles des saints Pères, vol. 1: Trois Règles de Lérins au Ve siècle, SC 297 (Paris, 1982) 180-205.

Rothé, Marie-Pierre, Carte archéologique de la Gaule, vol. 39: Le Jura (Paris, 2001). 
Rousseau, Philip, Cassian: Monastery and world, in: Miles Fairburn and W. H. Oliver (eds.), The Certainty of Doubt: Tributes to Peter Munz (Wellington, 1996) 68-89.

Secunda regula patrum, ed. Adalbert de Vogüé, Les Règles des saints Pères, vol. 1: Trois Règles de Lérins au Ve siècle, SC 297 (Paris, 1982) 274-283.

Sidonius Apollinaris, Epistulae, ed. André Loyen, Sidoine Apollinaire, vol. 2: Correspondance, Livres I-V, Collection des Universités de France (Paris, 2003).

Stancliffe, Clare, St. Martin and His Hagiographer: History and Miracle in Sulpicius Severus (Oxford, 1983).

Strabo, Geographikon, vol. 2, trans. Horace Leonard Jones, The Geography of Strabo, LCL 50 (Cambridge, MA, 1988).

Sulpicius Severus, Chronica, ed. Ghislaine de Senneville-Grave, Sulpice Sévère. Chroniques, SC 441 (Paris, 1999).

Sulpicius Severus, Dialogi, ed. Jacques Fontaine and Nicole Dupré, Sulpice Sévère. Gallus: Dialogues sur les "vertus" de Saint Martin, SC 510 (Paris, 2006); English trans. Alexander Roberts, The Dialogues of Sulpitius Severus, A Select Library of Nicene and Post-Nicene Fathers of the Christian Church, second series 11 (New York, 1894) 24-54.

Sulpicius Severus, Vita sancti Martini, ed. Jacques Fontaine, Sulpice Sévère. Vie de Saint Martin, SC 133, 1 (Paris, 1967) 247-317; English trans. Alexander Roberts, Sulpitius Severus on the Life of St. Martin, A Select Library of Nicene and Post-Nicene Fathers of the Christian Church, second series 11 (New York, 1894) 3-17.

Vita patrum iurensium, ed. François Martine, Vie des Pères du Jura, SC 142 (Paris, 2004); English trans. Tim Vivian, Kim Vivian, and Jeffrey Burton Russell, The Life of the Jura Fathers (Kalamazoo, 1999).

Vita sancti Lupi episcopi, ed. Bruno Krusch, MGH, SRM 7 (Hanover, 1920) 295-302.

Vivian, Tim, Kim Vivian and Jeffrey Burton Russell, The Lives of the Jura Fathers (Kalamazoo, 1999).

De Vogüé, Adalbert, Histoire littéraire du mouvement monastique dans l'Antiquité, vol. 4: Sulpice Sévère et Paulin de Nole (393-409), Jérôme, homéliste et traducteur des »Pachomiana" (Paris, 1997).

De Vogüé, Adalbert, Histoire littéraire du mouvement monastique dans l'Antiquité, vol. 7: L'essor de la littérature lérinienne et les écrits contemporains (410-500) (Paris, 2003).

De Vogüé, Adalbert, Histoire littéraire du mouvement monastique dans l'Antiquité, vol. 8: De la Vie des Pères du Jura aux ouvres de Césaire d'Arles (500-542) (Paris, 2003).

De Vogüé, Adalbert, Les Règles des saints Pères, vol. 1: Trois Règles de Lérins au Ve siècle, SC 297 (Paris, 1982).

Wickham, Chris, Framing the Early Middle Ages: Europe and the Mediterranean, 400-80o (Oxford, 2006).

Wipszycka, Ewa, Les aspects économiques de la vie de la communauté des Kellia, in: Philippe Bridel (ed.), Le site monastique des Kellia: Sources historiques et explorations archéologiques (Geneva, 1986) 117-144. Reprinted in: Ewa Wipszycka, Études sur le christianisme dans l'Égypte de l'Antiquité tardive, Studia Ephemeridis Augustinianum 52 (Rome, 1996) 337362.

Wood, Ian, A prelude to Columbanus: The monastic achievement in the Burgundian territories, in: Henry B. Clarke and Mary Brennan (eds.), Columbanus and Merovingian Monasticism, BAR International Series 113 (Oxford, 1981) 3-32. 


\title{
The Limitations of Asceticism
}

\author{
Albrecht Diem*
}

This article discusses the limitations and advantages of using rasceticism « as a universal category and as a hermeneutic tool in the study of late antique religious life and comparative studies of religious communities. It first explores the roots and the history of the terms rasceticism<, >Askese and rascétismer arguing that they originate from early modern scholarly traditions rather than being based on the language of late antique and early medieval Christian texts. A second part traces the origins of the term askèsis in Greek monastic discourse, using the Vita Antonii, the Historia Lausiaca, Theodoret's Historia religiosa and the Greek and Latin versions of the Vita Pachomii as case studies. I argue that Athanasius of Alexandria's decision to use askésis as a key term of his monastic program was motivated by limiting the range of appropriate religious practices rather than praising what we might call radical asceticism. Askésis took on a life of its own and attained various meanings in Greek monastic texts but never found an equivalent in Latin monastic language. The third part describes the diversification of rascetic practices and ideals in a number of Latin hagiographic and normative texts. I question to what extent it makes sense to consider religious practices emerging in the West (following a rule, unconditional obedience, humility, enclosure, sexual abstinence, liturgical discipline, etc.) as forms of Western rasceticism « and argue that using rasceticism« uncritically carries the danger of obfuscating nuances, diversity and transformations of religious practices in the Latin (but also in the Greek) world of Late Antiquity and the early Middle Ages.

Key words: asceticism, hagiography, monastic rules, humanist scholarship, Athanasius, Theorodet of Cyrrus, Antony (the desert father), Palladius, late antique and early medieval monasticism

This contribution is the result of a slight unease about the use of the term rasceticism<, even though it seems to be entirely unavoidable when studying the late antique and early medieval religious worlds and for any comparative study of religious practices across periods, regions, and cultures. Not talking about rasceticism‘, not calling those who choose to place their own body in the center of their religious practices rascetics`, and not calling these practices rascetic ‘ would be, for a scholar of a religion, like playing Taboo on an advanced level; it would lead to tedious circumlocutions and paraphrases and shut down cross-disciplinary and cross-cultural scopes. ${ }^{1}$

* Correspondence details: Albrecht Diem, Dept. of History, 145 Eggers Hall, Syracuse University, Syracuse, NY 13244, USA.

1 This contribution expands upon a short essay on rasceticism< to be published in the Routledge Medieval Encyclopedia Online. Research for this article was conducted as a contribution to the Austrian Science Fund (FWF): F42-G18 Visions of Community. I would like to thank Julian Hendrix and the anonymous peer reviewers for their very helpful comments and suggestions and Harrison Allen for his assistance in finalizing the footnotes. Currently the best critical reflection on asceticism in early Christian studies and the history of scholarship on asceticism is Rebecca Krawiec's essay Asceticism. Krawiec takes a slightly different approach by taking the assumption of an rabstract concept $<$ of asceticism as a point of departure, seeing it as an ranalytical took, assuming that there was a shared rascetic discourse and discussing various possible definitions. 
My unease with rasceticism eradicate the term from our shared scholarly language, but I hope that I can turn this unease into something productive that opens avenues for new inquiries. One side of it, which applies not just to rasceticism of religions, is fueled by the fact that most of them have a purely Christian pedigree that shapes their meanings and implications. Applying them outside of the context of Christianity inevitably forces us to look at other religions and their cultural frameworks through a Christian lens. Calling, for example, Buddhist monasteries >monasteries` and Buddhist monks 'monks carries the danger of misunderstanding their religious practices, their motivations and their role in society at large.

If we, to use a different example, apply shared Western notions of religion, faith and piety to Christian Late Antiquity and the Middle Ages, we enter a dangerous terrain of anachronisms; if we apply them to the Classical world, we might already be completely lost in translation. ${ }^{2}$ How much more is this the case if we uncritically use religion, faith and piety outside the Western and the Judeo-Christian-Islamic context? Conversely, there are very few cases in which terms and concepts that originated in non-Christian cultures became part of the language of religious studies, such as taboo and fetish. Using them as hermeneutic tools to understand Christianity still sounds like a provocation - as much as it makes sense. ${ }^{3} \mathrm{My}$ unease with rasceticism ‘ goes further: we talk about rasceticism ‘ as a universal concept as if we use it with a shared understanding across disciplines and as if we speak the language of our sources. So there is another opportunity for getting lost in translation, to confuse source evidence with scholarly analysis and to be at cross purposes whenever talking to someone of a neighboring discipline.

I will elaborate on this unease in three reflections. The first one examines the supposedly Christian pedigree of rasceticism early modern, modern and contemporary scholarly traditions rather than being rooted in late antique and early medieval sources or simply derived from the classical Greek term

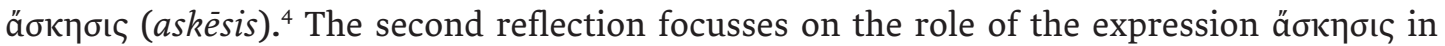
Greek Christian texts and the difficulties in translating the term into Latin. Athanasius of

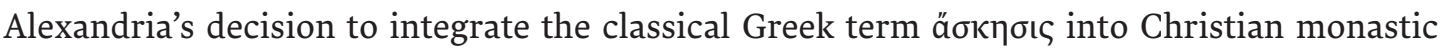
discourse was, as I would argue, part of his strategy for domesticating and utilizing Egyptian religious movements. Once established, the term took on a life if its own and developed a broad range of meanings in Greek sources but never received a Latin equivalent in Western monastic texts. The third reflection is an attempt to describe the diversity of monastic practices and their underlying theological rationales in early medieval Latin sources. It raises the question to what extent rasceticism ‘ forms a useful hermeneutic tool for understanding the emergence of Eastern and Western monasticism(s). All three reflections point to questions that primarily pertain to Christian religious life in the late antique and early medieval period but that might be productively transferred and adapted to studying religious communities outside the Christian sphere.

2 A classical study addressing this problem is Veyne, Did the Greeks believe in their myths?.

3 On taboo, see Steiner, Taboo, truth and religion; on the fetish: Kohl, Die Macht der Dinge; Pietz, Problem of the fetish. I-IIIa; Antenhofer (ed.), Fetisch als heuristische Kategorie.

4 For overviews on the history of rasceticism` see Wimbush and Valantasis, Introduction; Graiver, Asceticism of the Mind. 
$I$.

A word search on the string ascetic* in the Patrologia Latina database provides 251 hits in 122 documents - a fairly widespread term, so it seems. If we click on sexclude apparatus and >medieval authors only<, 21 hits in 11 documents remain, and all of them point to erroneously labeled introductions to primary sources. A word search in the digital Monumenta Germaniae Historica leads to similar results: no traces in the sources themselves, occasional use in introductions and footnotes. There is no monachus asceticus, no uita ascetica, and there are no opera ascetica mentioned in medieval texts. The initial number of hits in the Patrologia Latina database shows, however, that asceticus became a widely used descriptive term in early modern scholarship and one of the key terms of the master narrative about the origins of Christian monastic life that present scholarship tries to complicate. ${ }^{5}$ The expression asceticus, thus, does not generalize and abstract a late antique or early medieval rascetic practice (which would in itself be problematic) but it superimposes an artificial label on a world that might have perceived itself as indefinitely diverse and not at all guided by a universal principle of what scholars from the early modern period onwards called >uita ascetica<.

The roots of rasceticism`, the French rascétisme ‘ and the German >Askese ‘ are to be found in the works of seventeenth-century Latin-writing scholars and their attempts to order and edit the wealth of source material of the late antique and medieval world and to read them as historical and theological sources. ${ }^{6}$ Scholars like Heribert Rosweyde (d. 1629), NicolasHugues Ménard (d. 1664), Jean Bolland (d. 1665) and Jean Mabillon (d. 1707) not only gave us access to the wealth of late antique and medieval Latin Christian texts but they still have an impact on how we read and understand them.

Initially, the adjective asceticus did not refer to groups and individuals, forms of life, practices, or places, but it emerged in the process of translating, editing, and categorizing sources: the opera ascetica of patristic authors, sermones asceticae or epistolae asceticae. As an instrument for creating order and defining genres, it inevitably became a lens through which we read and understand texts - just like the new titles and chapter divisions that humanist scholars quite often imposed on many late antique and medieval texts when editing them for the first time. It is virtually impossible to get rid of them in subsequent editions.

One of the oldest witnesses (possibly the oldest one) of the term asceticus is a Latin

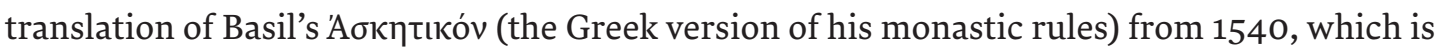
titled Diui Basilij Magni Archiepiscopi Caesariensis moralia; Ascetica magna; Ascetica parua. ${ }^{7}$

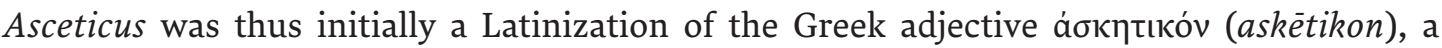
word that does not appear in Classical Greek sources. It is thus only indirectly related to the

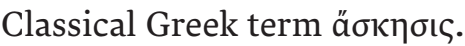

5 See Rapp and Diem, Monastic laboratory, and various other contributions to the forthcoming Cambridge History of Western Monasticism edited by Beach and Cochelin.

6 A first introduction to these pioneering endeavors, especially the work of the Bollandists and the Maurists, is provided by Knowles, Great Historical Enterprises.

7 Diui Basilij Magni Archiepiscopi Caesariensis moralia; Ascetica magna; Ascetica parua, ed. Gryphius. Accessed on 26 April 2019: digibug.ugr.es/handle/10481/11770. 
Asceticus became subsequently not only a genre description of late antique Greek and Latin texts pertaining to rigorous Christian life, but also of those texts that claim to continue these traditions into the medieval period. ${ }^{8}$ It became an instrument to intimate that the ideals of the desert fathers were by no means abandoned throughout the Middle Ages. ${ }^{9}$ A case in point would be the twelve volumes of Bernard Pez's Bibliotheca ascetica antiquo-nova, hoc est: collectio veterum quorundam et recentiorum opusculorum asceticorum, quae hucusque in variis mss, codicibus et bibliothecis delituerunt, which was published between 1723 and $1740 .{ }^{10}$ None of the texts in Pez's collection are late antique or early medieval; they are products of various reform movements reaching into his own time. As such, they form part of an argument of unbroken continuity made in response to the challenges of the Reformation on the one hand and the Counterreformation on the other. ${ }^{11}$

Later on, various loan words derived from asceticus were adopted in vernacular languages - particularly in French. The first volume of Diderot's Encyclopédie (1751) has a lemma on ascétique, which traces the term back to Basil's work but also refers to a group of sascetes [sic] and to a vie ascétique showing that not only the adjective but also the noun had been established in French at that time. ${ }^{12}$ The first edition of the Encyclopedia Britannica (1771) contains a short lemma on >Ascetics.$^{13}$ Johann Heinrich Zedler's Grosses vollständiges Universal-Lexicon aller Wissenschafften und Künste (1731-1754), however, does not yet contain the lemmas Asket or Askese. ${ }^{14}$ Neither does the first Volume of Grimm's Wörterbuch from 1854.

Jacques-Paul Migne's monumental project to make the Greek and Latin patristic heritage along with its scholarly introductions available to a broad clerical readership in the affordable volumes of the Patrologia Latina (1844-1855) and the Patrologia Graeca (18561858) played a key role in turning the study of the desert fathers and the first monks into

8 An early example would be Pierre Poussines, Thesaurus asceticus (Paris, 1634), which contains, among others, works of John Chrysostom, Macarius the Great, Theodor Studite and the Apophtegmata Patrum in Greek and in Latin translation.

9 See, for example, Negrone, De cura minimorum.

10 Pez, Bibliotheca ascetica antiquo-nova.

11 On Pez, see Wallnig, Gasthaus der Gelehrsamkeit; Wallnig, et al. (eds.), Europäische Geschichtskulturen.

12 Diderot, Encyclopédie, vol. 1, 750b: "Ascétique, adj. qui concerne les Ascetes. On a donné ce titre à plusieurs livres de piété qui renferment des exercices spirituels, tels que les ascétiques ou traité de dévotion de S. Basile, évêque de Césarée en Cappadoce. Dans les bibliotheques on range sous le titre d'ascétiques tous les écrits de Théologie mystique : on dit aussi la vie ascétique, pour exprimer les exercices d'oraison \& de mortification que doit pratiquer un religieux. Voyez MYSTIQUE. La vie ascétique des anciens fideles consistoit, selon M. Fleury, à pratiquer volontairement tous les exercices de la pénitence. Les Ascetes s'enfermoient d'ordinaire dans des maisons, où ils vivoient en grande retraite, gardant la continence, \& ajoûtant à la frugalité chrétienne des abstinences \& des jeûnes extraordinaires. Ils pratiquoient la xérophagie ou nourriture seche, \& les jeûnes renforcés de deux ou trois jours de suite, ou plus longs encore. Ils s'exerçoient à porter le cilice, à marcher nuds piés, à dormir sur la terre, à veiller une grande partie de la nuit, lire assiduement l'Ecriture-sainte, \& prier le plus continuellement qu'il étoit possible. Telle étoit la vie ascétique : de grands évêques \& de fameux docteurs, entre autres Origene, l'avoient menée. On nommoit

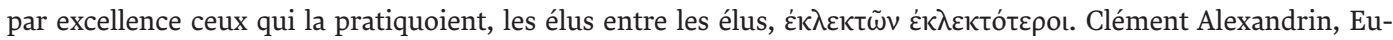
sebe, hist. lib. VI. c. iij. Fleury, moeurs des Chrétiens, II. part. $n^{\circ}$. 26. Bingham, orig. eccles. lib. VII. c. j. S. 6. (G)." Accessed 4 June 2019: enccre.academie-sciences.fr/encyclopedie/article/v1-3164-o/.

13 Encyclopedia Britannica, vol. 1, 419: "ASCETICS, in church-history, such Christians in the primitive church as inured themselves to great degrees of abstinence and fasting, in order to subdue their passions «.

14 Accessed on 4 June 2019: www.zedler-lexikon.de. 
the study of ascétisme. ${ }^{15}$ A Dictionnaire d'Ascétisme was published in 1865 by the monks Jean Claude Gainet and J. Clovis Poussin in Migne's publishing house. ${ }^{16}$ Firmly embedded in Catholic scholarly traditions, as markers of religious practices, of a period, of a theology, and a genre, in nineteenth-century French scholarship ascétisme held an unequivocally positive connotation and it is firmly a part of Catholic church history. Aside from the lemma on gnosis, the Dictionnaire d'Ascétisme does not contain any entry that pertains to religious practice outside a Catholic Christian tradition. The Revue d'ascétique et de mystique, which was founded in 1920 and lasted until 1971, published exclusively on matters pertaining to Christianity. It serves as a witness of this unbroken tradition, ${ }^{17}$ as does the massive lemma on >Ascèse/Asétismer in the Dictionnaire de Spiritualité from 1937 which praises ascétisme as an essential aspect of Christian tradition and theology with 'pagan roots, rather than an object of comparative religious studies that would address non-Western and non-classical religious traditions. ${ }^{18}$

English rasceticism and the German `Askese probably the Protestant historian Otto Zöckler (d. 1906) who established Askese as an object of historical research in his Kritische Geschichte der Askese (first published in 1863, revised under the title Askese und Mönchtum in 1897). ${ }^{19}$ Unlike the French scholarly tradition, Zöckler put an emphasis on the roots of Askese in classical philosophical and in Jewish tradition, addressed rasceticism < outside the boundaries of orthodoxy and in non-Christian religions, and approached it with a scholarly and critical distance, with a stronger emphasis on its negative aspects (renunciation, negation, and punishment of the body etc.), and as a phenomenon of religious history rather than as an essential part of a Christian tradition and identity. Anglo-Saxon scholarship approached rasceticism which made it possible to apply the concept outside of Christian or even Western contexts and to turn it into a corner stone of comparative religious studies. ${ }^{20}$

One of the earliest philosophical works that addresses rasceticism، outside a purely religious context is the third treatise of Friedrich Nietzsche's Zur Genealogie der Moral (1887) on -Was bedeuten asketische Idealer (What is the meaning of ascetic ideals), which discusses the limitations of the artistic, philosophical, priestly and rationalist pursuit of rascetic ideals. ${ }^{21}$ Max Weber's Protestantische Ethik und der Geist des Kapitalismus (German 1920; English 1930; French 1964) ${ }^{22}$ led to a surge of publications on Askese and rasceticism academic disciplines but also in non-scholarly venues. It became a category of research in fields outside history, theology and religious studies and, at least partly, dissociated from its

17 The journal was published as Revue d'ascétique et de mystique until 1971. From 1972-1977 the journal was published as Revue d'histoire de la Spiritualité.

18 De Guibert et al., >Ascése/aséticismer.

19 Zöckler, Kritische Geschichte der Askese; Zöckler, Askese und Mönchtum.

20 See, for example, Campbell, The Mystics, Ascetics, and Saints of India; Hardman, Ideals of Asceticism.

21 Nietzsche, Zur Genealogie der Moral, 355-430.

22 Weber, Gesammelte Aufsätze zur Religionssoziologie; The Protestant ethic and the spirit of capitalism, transl. by Parsons; Weber, L'Éthique protestante. 
purely religious context. Anna Freud, for example, identified an rascetic phase in adolescent development. ${ }^{23}$ Michel Foucault and Geoffrey Harpham identified rasceticism technique of the self and as a constituting element of Western societies and their perceptions of the body. ${ }^{24}$ Vincent L. Wimbush and Richard Valantasis established rasceticism category of cultural studies ranging from comparative religious studies to postmodernism in a massive edited volume published in $1995 .{ }^{25}$ Their approach of asceticism $<$ as a universal cultural phenomenon required definitions of rasceticism « as broad as that of Geoffrey Harpham, as "any act of self-denial undertaken as a strategy of empowerment or gratification ${ }^{26}$ or Richard Valantasis: "performances within a dominant social environment intended to inaugurate a new subjectivity, different social relations and an alternative symbolic universe «. ${ }^{27}$ Virtually every written language contains today a loanword that is based on rasceticism<, Askese or ascétisme. ${ }^{28}$

Meanwhile, scholars of late antique and early medieval religious life published various standard works that carry the words rasceticism^ or rascetics` in their titles, such as those of Susan Ashbrook-Harvey, ${ }^{29}$ David Brakke, ${ }^{30}$ Patricia Cox Miller, ${ }^{31}$ James Goehring, ${ }^{32}$ Richard Goodrich, ${ }^{33}$ Hannah Hunt, ${ }^{34}$ Conrad Leyser, ${ }^{35}$ Philip Rousseau, ${ }^{36}$ and most recently Inbar Graiver. ${ }^{37}$ Most of these works use rasceticism as a broad marker of late antique or early medieval religious - especially monastic - practice, but do not discuss the term and its etymology or question whether rasceticism « indeed works as a universal concept. >Asceticism< is, thus, used as a place holder and a convenient description of the diversity of late antique religious practices - keeping together what seems to belong together. But it might be worthwhile to deliberately avoid working with this supposedly universal concept (with its crooked genealogy) that created a unity ever since humanist scholars labeled the sources on which our knowledge is based as opera ascetica. What happens, for example, if we return to the term that allegedly forms the root of this universal concept of rasceticism

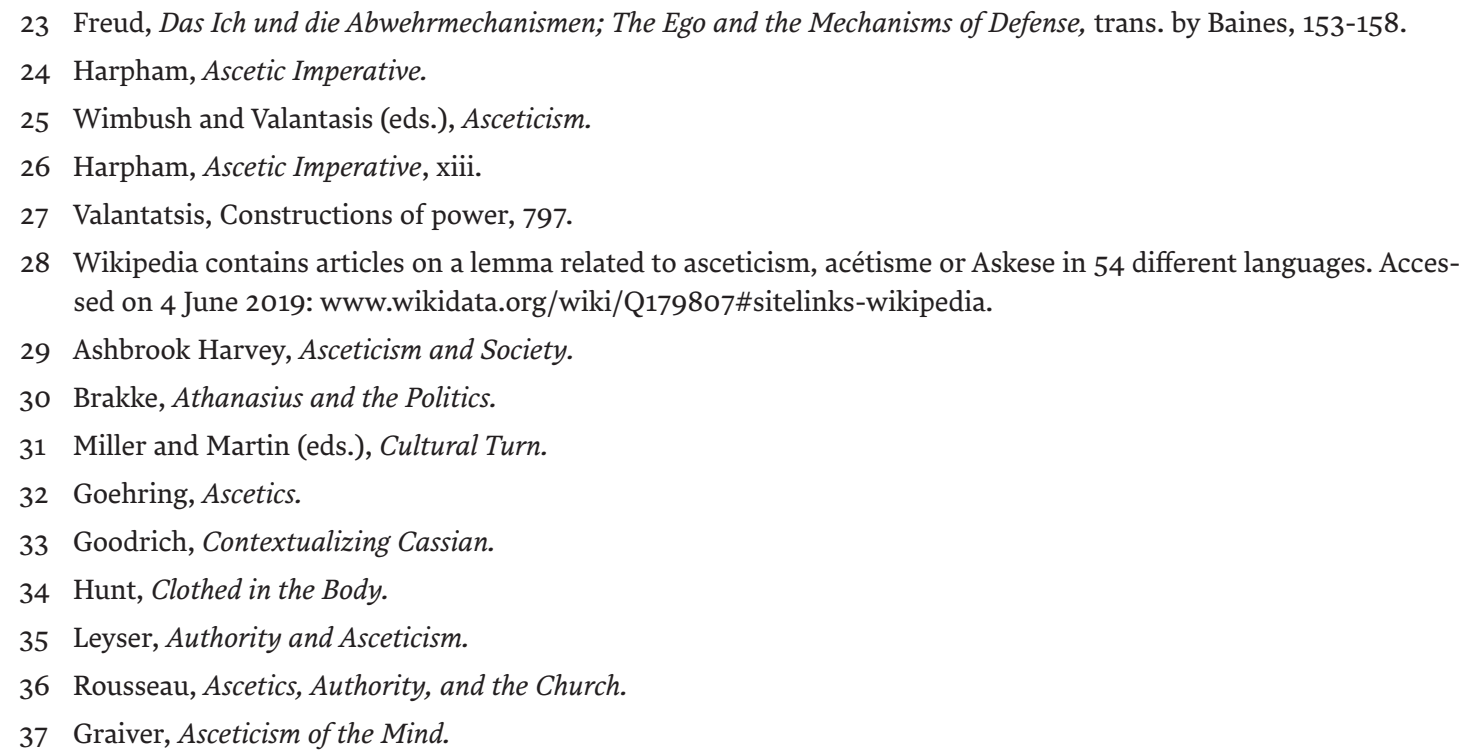


II.

The etymological roots of rasceticism` are to be found in the term ä $\sigma \kappa \eta \sigma \iota \varsigma$, which refers in classical Greek texts to >exercise`, 'practice` or straining،, primarily military exercise, but also physical exercise and, later, the exercise of virtues. ${ }^{38}$ All three meanings may have motivat-

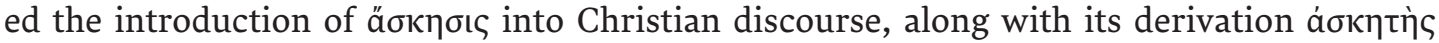

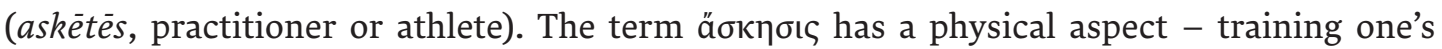
body in and by austerity and overcoming bodily needs. It might also have retained its military implications by being tied to the understanding of monks and nuns fighting as soldiers of Christ. ${ }^{39}$ Its understanding as moral training, however, was probably the main motivation for integrating it into Christian and, later on, monastic language. We have to keep in mind,

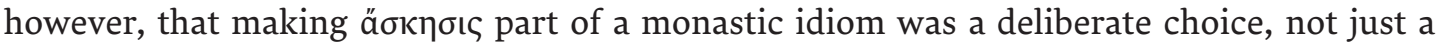
natural adaptation of an existing semantic repertoire and not a matter of course. The same

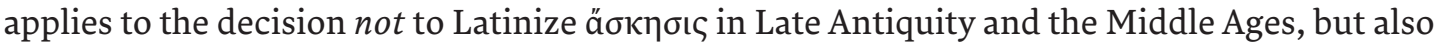
the invention of the expression asceticus in early modern scholarship. It is also important to keep in mind that ä $\sigma \kappa \eta \sigma ı \varsigma$ was certainly not the only Greek term representing what we today consider rasceticr. Claudia Rapp, for example, is currently working on a genealogy of

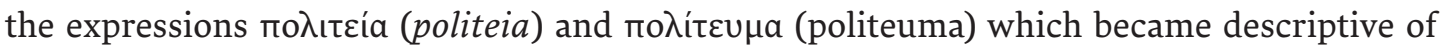
solitary rascetic $<$ life. ${ }^{40}$

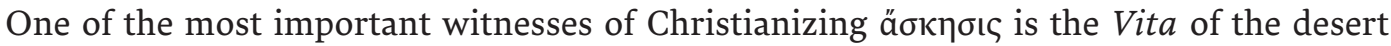
monk Antony ascribed to Athanasius of Alexandria, a text that had a deep impact on monastic literature in the Greek world and, through its Latin translation by Evagrius of Antioch, in the Western world as well. ${ }^{41}$ It became one of the main documents describing, shaping and propagating the life of the desert fathers. Previous Christian authors, particularly Clement of Alexandria, use ä $\sigma \kappa \eta \sigma \varsigma \varsigma$ as well, but do not apply it to monastic life. Clement still uses the term in reference to physical and military exercise, albeit metaphorically in reference

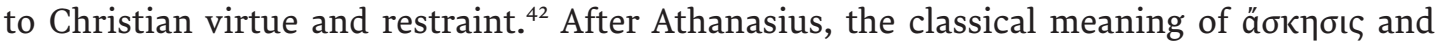

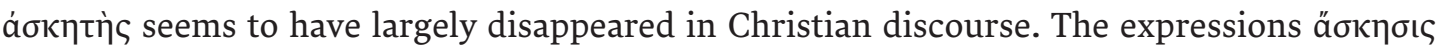

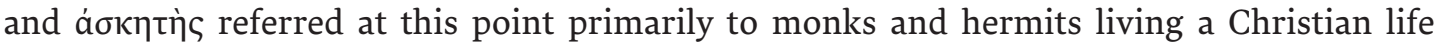
according to higher, self-imposed standards. In this process, new derivations of ä $\sigma \kappa \eta \sigma \iota \varsigma$

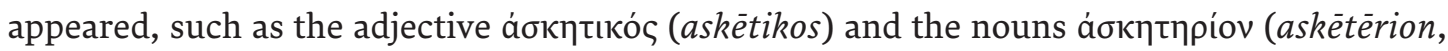

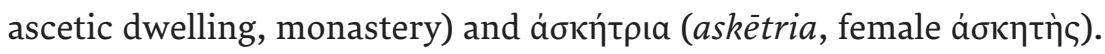

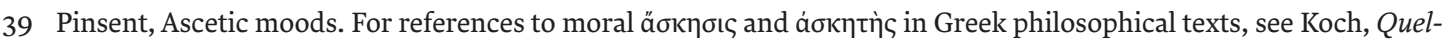
len zur Geschichte der Askese.

40 Rapp, Monastic jargon.

41 Athanasius of Alexandria, Vita Antonii (Greek text), ed. Bartelink, henceforth quoted as SC 400. On the question of authorship: Rubenson, Apologetics of asceticism. I assume that Athanasius was indeed the author of the Vita Antonii, though my argument would not become invalid if the text, or parts of it, were written by someone else. The two Latin versions have been recently edited by Gandt and Bertrand. On the reception of the Vita Antonii, see Bremmer, Athanasius' Life of Antony.

42 Clement of Alexandria, Paedagogus I.7.57.1/3, SC 70, 212; II.4.42.3, SC108, 32; II.9.80.2, SC 108, 160; II.10.94.3, SC 108, 182; II.10.97.3, SC 108, 186; II.11.117.2, SC 108, 222; III.6.35.3, SC 158, 78; III.8.43.4, SC 158 , 94. 


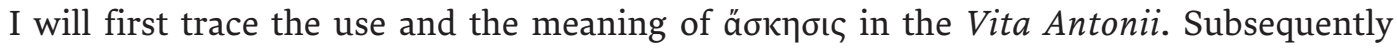
I will look at å $\sigma \kappa \eta \sigma \iota \varsigma$ and its derivates in two collections of lives of monks and rascetics`, Palladius' Historia Lausiaca and Theodoret of Cyrrhus' Historia monachorum (both written in the first half of the fifth century). Finally I will briefly compare a Greek and a Latin version of the Vita of the desert father Pachomius, the alleged father of coenobitical monasticism.

Palladius' Historia Lausiaca and the Vita Pachomii were, like the Vita Antonii, translated into Latin and had a deep impact on the imagination of the world of the desert fathers in the Western Christian tradition. ${ }^{43}$ There is no Latin translation of Theodoret's Historia religio$s a$, possibly because of Theodoret's allegedly Nestorian sympathies, but maybe also because Western readers had a difficult time relating to the rascetic practices praised in this work.

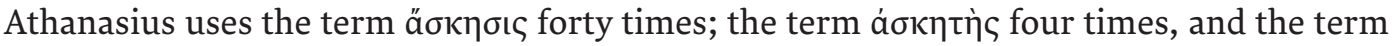

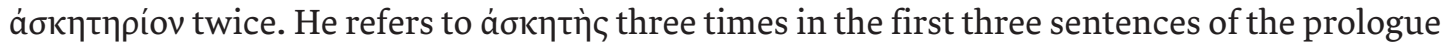
of the Vita Antonii which reveals what the author wants to achieve by introducing this term:

We have entered into a noble contest with the monks of Egypt by choosing, through

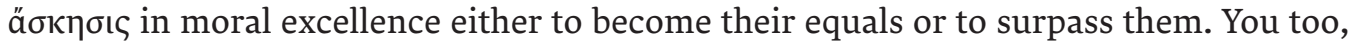

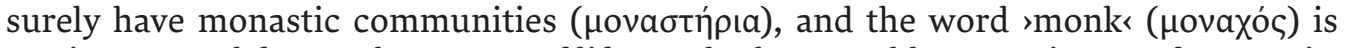
not just a word for you but a way of life. Justly then would one praise you for your intentions and justly would God grant your prayers. Since you have asked me about the life of the blessed Antony, clearly wishing to learn how he started his ä $\sigma \kappa \eta \sigma \iota c$ and who he was before that and how he concluded his life and whether what is said about him is true, in order to emulate his zeal I have taken up your questions with great enthusiasm. I must tell you that the mere mention of Antony is an extraordinary benefit to me. I do know that, after you hear what I have to say and come to admire the man, you will also want to emulate his intention. To be sure, for monks the life of Antony is a fine model

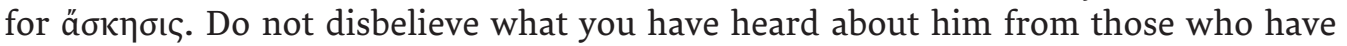
sung his praises but realize that what you have heard about him from them represents only a small part of what there is to tell. They have hardly told you anything at all. ${ }^{44}$

43 Palladius, Historia Lausiaca, ed. Butler; Theodoret, Historia religiosa, ed. Canivet and Leroy-Molinghen, henceforth quoted as SC 234/SC 257.

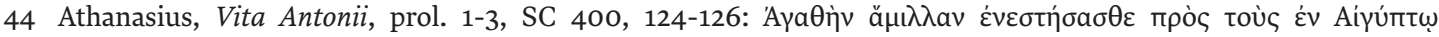

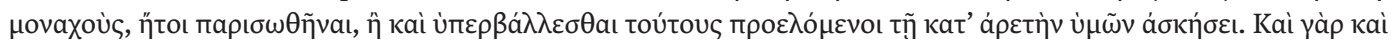

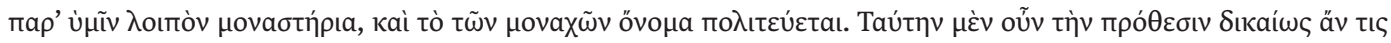

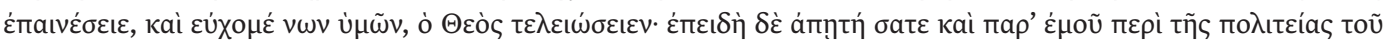

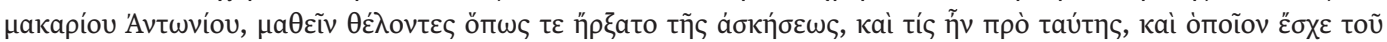

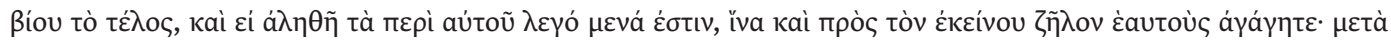

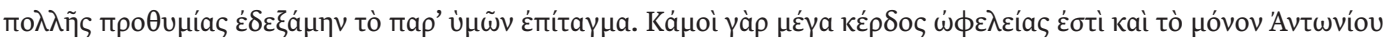

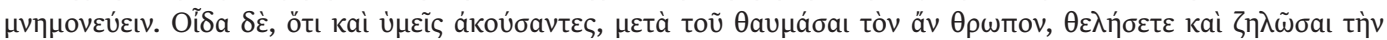

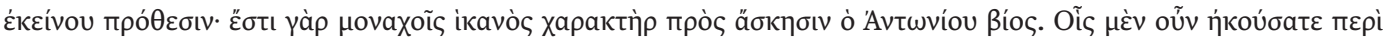

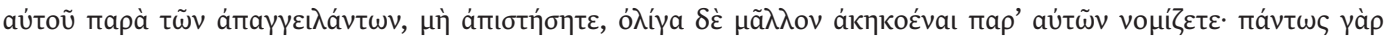

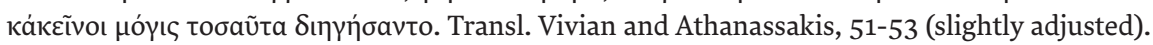


The Vita Antonii has, thus, a double purpose: to put a discursive monopoly on the recently deceased desert monk Antony and to use Antony's deeds and teachings (as they are narrated

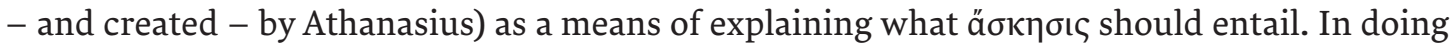

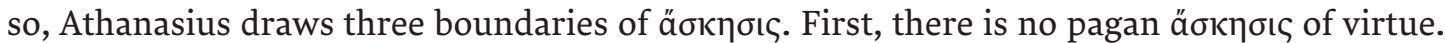
Even if pagan philosophers were to perform similar deeds of renunciation as Antony, it would not be ä $\sigma \kappa \eta \sigma ı .^{45}$ The only true philosophers are Antony and other practitioners of Christian å $\sigma \kappa \eta \sigma ı c$. Secondly, the same applies to heretics (Meletians and Arians) who could possibly

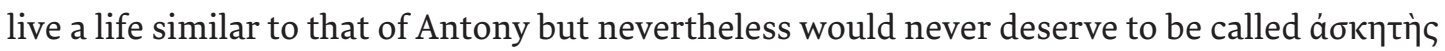
and should by absolutely no means be considered misguided fellow rascetics ${ }^{46}{ }^{4}$ Thirdly - and that is most important for us - Athanasius defines a relatively narrow repertoire of acts that

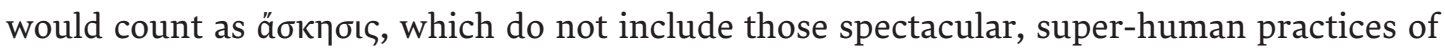
bodily mortificatio that might draw the admiration of ordinary believers and make them seen as something like Christian fakirs and hunger artists. Antony is not even a saint. Athanasius never calls him ă Antony is a later textual construction based on sspin offs ' of the Vita Antonii. ${ }^{47}$ Athanasius makes the point that ä $\sigma \kappa \eta \sigma ı \varsigma$ may be acted out in a bodily and social way but that its purpose is neither the punishment nor the mortification of the body, nor the complete withdrawal

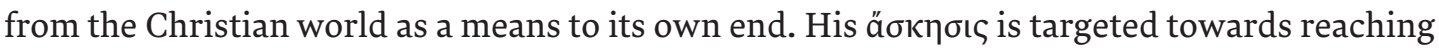

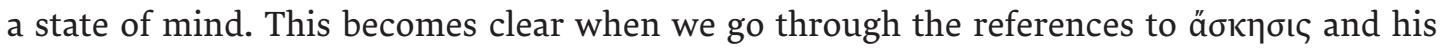

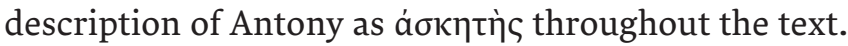

The Vita Antonii can be roughly divided into three parts. Antony's transformation into a desert monk and hermit which includes a dramatic description of his battles with demons and his twenty year-long self-incarceration, ${ }^{48}$ his teachings on demons and monastic life, ${ }^{49}$ and, finally, his life as a desert monk moving back and forth between solitude in the rinner mountain and acting as a public persona who engages in debates with pagans, fights heretics, performs miracles and teaches his community of followers. ${ }^{50}$ The notion of Antony as the sfirst hermit and of Antony's fierce battles against demons, imprinted in our mind, for example, through the Isenheim Altarpiece, is, thus, a product of a selective reading of the work. Such a reading ignores the fact that almost half of the text consists of his teachings and that he lived large parts of his life in a community and played a public role as wonder worker, mediator, healer and exorcist..$^{51}$ Gregory of Nazianzus' characterization of the Vita

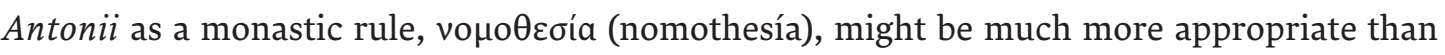
understanding the text as the heroic biography of the rfirst hermit..$^{52}$

On pagan philosophers: Athanasius, Vita Antonii, c. 72-80, SC 400, 320-340.

Athanasius, Vita Antonii, c. 68-69, SC 400, 314-316; c. 82, SC 400, 344-350; c. 89, SC 400, 362-364. See also Brakke, Athanasius and Asceticism, 201-265.

See Diem, Antony.

Athanasius, Vita Antonii, c. 1-15, SC 400, 124-176.

Athanasius, Vita Antonii, c. 16-43, SC 400, 176-252; c, 55-56, SC 400, 280-288; c. 74-76, SC 400, 324-330.

Athanasius, Vita Antonii, c. 44-94 (interrupted by his teachings), SC 400, 252-376.

See Brown, Rise and function.

Gregory of Nazianzus, Oratio 21, c. 5, PG 35, col. 1085D-1088A. 


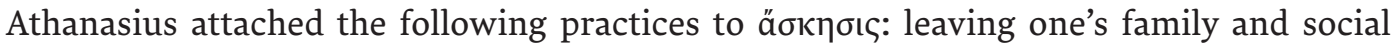
environment behind and banning the memory of one's kin from one's mind, ${ }^{53}$ submitting oneself to vigils, fasting, eating once a day, sleeping uncomfortably and not oiling one's body. The purpose of these practices is avoiding temptation..$^{54}$ At another place Athanasius adds wearing hair cloth and animal skin and not washing oneself to the list of practices of ä $\sigma \kappa \eta \sigma \iota \varsigma .{ }^{55} \mathrm{He}$ and other monks turn the desert into a city of ä $\sigma \kappa \eta \sigma \iota \varsigma .{ }^{56}$ Antony gathers followers who want to imitate his ä $\sigma \kappa \eta \sigma \iota,^{57}$ which is to be understood as daily practice and as perseverance..$^{58}$ The purpose of ä $\sigma \kappa \eta \sigma \iota c$ is gaining the spirit of discernment, ${ }^{59}$ and it is a

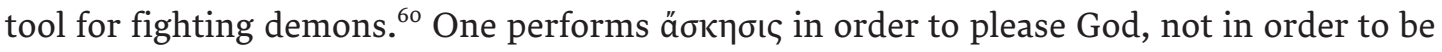

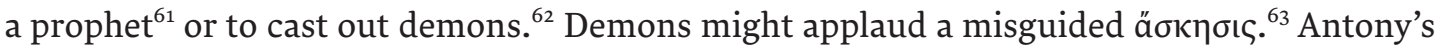

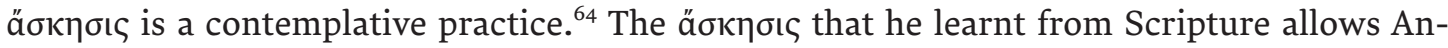
tony to be a teacher instead of a martyr. Antony practices his ä $\sigma \kappa \eta \sigma \iota c$ in solitude; ${ }^{65}$ he prays

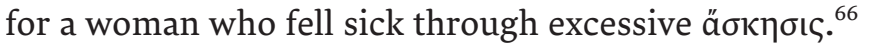

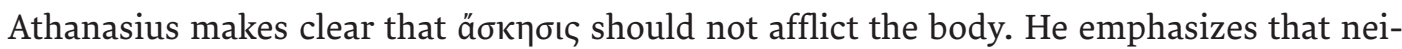

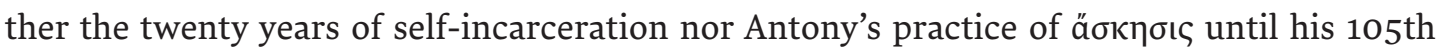
year of life really affected his body. Antony leaves the cave as young as he had entered it and even shortly before death he retained perfect eyesight and bodily strength. ${ }^{67}$

If we think of other texts praising the life of Egyptian and Syrian desert fathers, the ă $\sigma \kappa \eta \sigma ı s$ propagated by Athanasius in the Vita Antonii is remarkably tame and may even be considered boring. There is no self-destructive mortification or self-inflicted punishment. It is possible that Athanasius responded to all the wild tales going around about Antony by describing him as someone who practices a moderate form of austerity and solitude that is socially compatible and can indeed be emulated by those following his teachings. ${ }^{68}$

53 Athanasius, Vita Antonii, c. 3.1, SC 400, 136; c. 3.5, SC 400, 136-138; c. 5.2, SC 400, 142.

54 Athanasius, Vita Antonii, c. 7.3/8/11, SC 400, 150-154

55 Athanasius, Vita Antonii, c. 47.1-2, SC 400, 262; c. 93.1, SC 400, 372-374.

56 Athanasius, Vita Antonii, c. 8.2, SC 400, 156.

57 Athanasius, Vita Antonii, c. 14.2, SC 400, 172; c. 15.3, SC 400, 176.

58 Athanasius, Vita Antonii, c. 18.2, SC 400, 184; c. 91.2, SC 400, 368.

59 Athanasius, Vita Antonii, c. 22.3, SC 400, 196; c. 66.8, SC 400, 310.

60 Athanasius, Vita Antonii, c. 25.4, SC 400, 206; c. 27.4, SC 400, 210; c. 30.1, SC 400, 218; c. 40.6, SC $400,244$.

61 Athanasius, Vita Antonii, c. 34.1, SC 400, 228.

62 Athanasius, Vita Antonii, c. 38.2, SC 400, 238.

63 Athanasius, Vita Antonii, c. 35.1, SC 400, 230.

64 Athanasius, Vita Antonii, c. 45.1, SC 400, 256; c. 84.2, SC 400, 352.

65 Athanasius, Vita Antonii, c. 51.1, SC 400, 272; c. 82.2, SC 400, 344.

66 Athanasius, Vita Antonii, c. 61.2, SC 400, 294.

67 Athanasius, Vita Antonii, c. 14, SC 400, 172-174; c. 93, SC 400, 372-376.

68 This reading slightly deviates from Jan Bremmer's interpretation of the Vita Antonii as a text having the purpose of spatially and socially marginalizing Antony. The purpose, keeping Antony under control, remains the same in Bremmer's and my reading. See Bremmer, Athanasius' Life of Antony. 


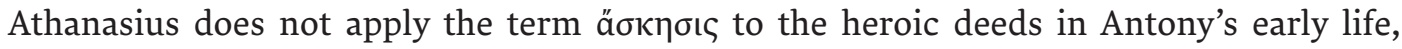
which may have shaped the imagination of the desert father and been received most in literary and artistic renditions of the saint. His self-incarceration in the tombs and barracks is clearly marked as a transitory state that Antony gives up in order to become a teacher of

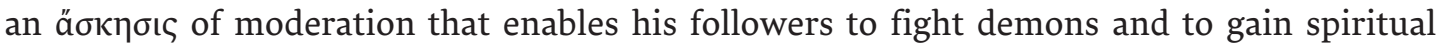
understanding.

Soon after its composition, the Vita Antonii was translated into Latin twice and it is important to keep in mind that stranslation is not only a linguistic endeavor - finding Latin equivalents of a fairly new monastic idiom - but also a translation from one cultural context to another. The first attempt to translate the Vita Antonii is preserved only in one manuscript. ${ }^{69}$ As a literal rendition of its content it may not have sufficed to be a cultural translation, which may have been the reason why it was replaced by a new, freer rendition by Evagrius of Antioch, which is preserved in more than 400 manuscripts in the West. $^{70}$

These Latin translations of the Vita Antonii convey the same message of praising a life of moderate solitude, fasting, prayer, poverty and renunciation of luxury, but the specific context in which the original version was written, the competition with philosophers, the battles with Arians and Meletians and the aim of domesticating a potentially subversive rascetic movement, may not have mattered as much to a Latin readership. For the readers of the Latin Vita Antonii, the desert inhabited by Antony and his followers was a far-away and exotic country.

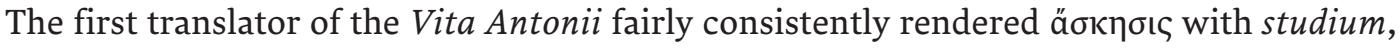
sometimes studium religionis or studium uirtutis, a much weaker term not carrying the con-

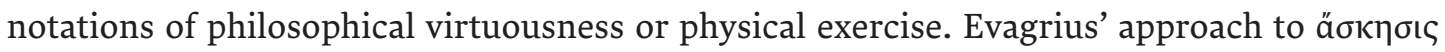

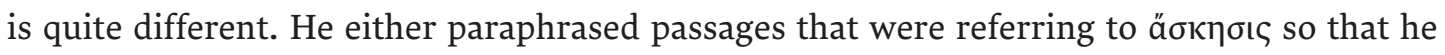

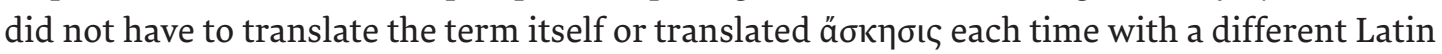
expression. Evagrius' deconstruction - or maybe rather destruction - of Athanasius' key term may be a sign of disagreement with Athanasius' attempt to depict Antony as the Christian counter model to those who practiced a philosophical training of virtues.

If this was the case, it turned out to be a constructive deconstruction that created a semantic debris field open for those who wanted to shape a new Latin idiom of monastic life. We find instantia uirtutis; sanctum propositum; asperum et arduum institutum; sollicitudo; studium; arreptum institutum; subiugere corpus suum; labor; propositum; uigor; rigor instituti; consuetudo nostra; merces instituti boni; conuersatio; studium beatae uitae; merita; studium religiosum and principia meritorum..$^{71}$ Many of these expressions became key terms in Latin monastic language; most of them re-surface, for example, in the Regula Benedicti.

69 Vita Antonii, uersio uetustissima, ed. Bertrand and Gandt, textus, 105-177.

70 Vita Antonii, uersio Euagrii, ed. Bertrand and Gandt, textus, 1-103.

71 Vita Antonii, uersio Euagrii, prologue 1, ed. Bertrand and Gandt, textus, 3: sanctum propositum and instantia uirtutis; c. 3.1, ibid., 7: asperum et arduum institutum; c. 3.5, ibid., 7: sollicitudo; c. 4.1, ibid., 8: studium; c. 5.2, ibid., 9: arreptum institutum; c. 7.3, ibid., 12: subiugere corpus suum; c. 7.8, ibid., 12: labor; c. 14.2, ibid., 20: propositum; c. 16.3, ibid., 22: uigor; c. 19.1, ibid., 25: rigor instituti; c. 27.4, ibid., 34: consuetudo nostra; c. 34.1, ibid., 40: merces instituti boni; c. 35.1, ibid., 40: studium; c. 38.2, ibid., 43: conuersatio; c. 40.6, ibid.,: propositum; c. 45.1, ibid., 50: studium beatae uitae; c. 82.2, ibid., 89: rigor; c. 84.2, ibid., 92: merita; c. 88.1, ibid., 96: merita; c. 91.2, ibid., 101: studium religiosum; c. 93.1, ibid., 101: principia meritorum. 


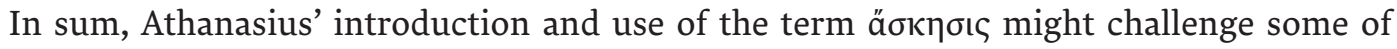

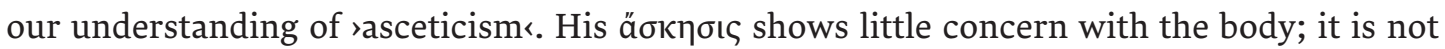
directed against the body and it is by no means excessive or disruptive. Athanasius succeeded

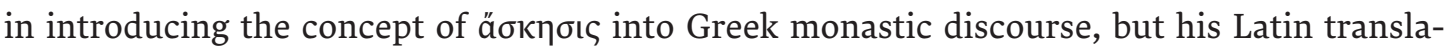
tors showed little interest in appropriating the term and using it for shaping a unified Latin language of monastic life.

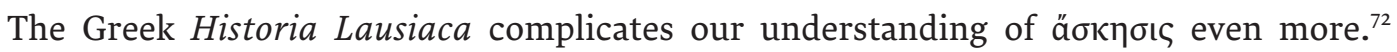

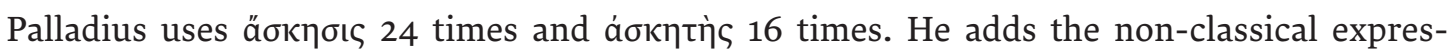

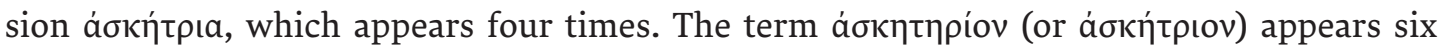

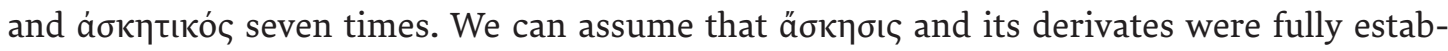
lished in monastic language at that point and Palladius shows no inclination to explain what

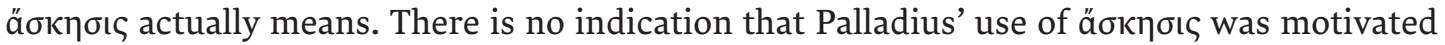
by responding to philosophical traditions of rascetic life. There is, however, a remarkable tension: Palladius describes in his Historia Lausiaca a wide array of Christian religious practices ranging from mutilating oneself in order to avoid priesthood or sexual temptations, enduring dropsy while healing others, sitting in the desert completely naked in order to be eaten by insects, fasting for forty days and extreme sleep deprivation to living a chaste marriage, acts of charity, taking care of a cripple, acting as a midwife, providing monasteries with medicine, supporting the poor, and disinheriting one's children to support the church. Palladius makes the point that there are innumerable more or less radical options for monks, nuns, and lay people to live a God-pleasing life and that one is not preferable to another. It

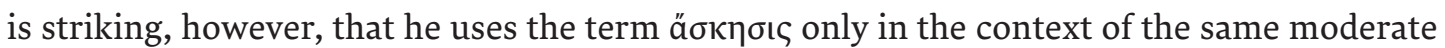
rascetic practices that are praised in the Vita Antonii and that he calls only those individuals

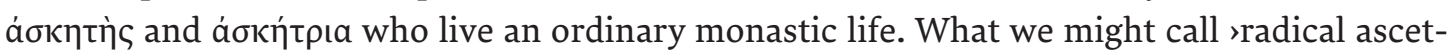

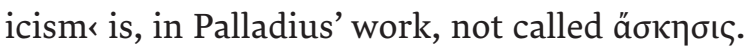

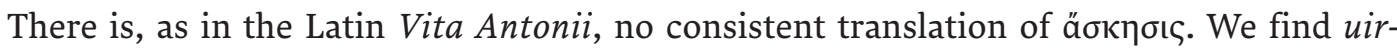
tutes abstinentiae $;{ }^{73}$ uita $;{ }^{74}$ meritum $;{ }^{75}$ obseruatio $;{ }^{76}$ uirtus $;{ }^{77}$ propositum uitae monachorum $;{ }^{78}$

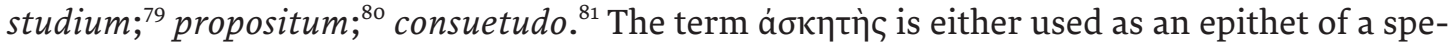

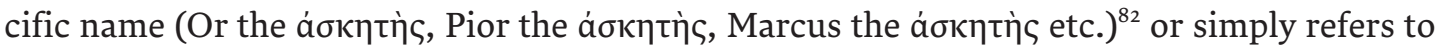
monks in general. It is almost exclusively translated with monachus. The female version also refers to members of a monastic community and is translated with uirgo Dei, ancilla Dei, or

Edition of the Greek text by Butler, Lausiac History of Palladius.

Palladius, Historia Lausiaca, Gr. XII.1, ed. Butler, 35/Lat. 12.1, ed. Wellhausen 519.

Palladius, Historia Lausiaca, Gr. XVI.3, ed. Butler, 38/Lat. 14.3, ed. Wellhausen, 523; Gr. XXVIII.1, ed. Butler, 84/ Lat. 28.3, ed. Wellhausen, 586.

Palladius, Historia Lausiaca, Gr. XVII.5, ed. Butler, 44/Lat. 17.8, ed. Wellhausen, 532.

Palladius, Historia Lausiaca, Gr. XVIII.2, ed. Butler, 48/Lat. 18.3, ed. Wellhausen, 537.

Palladius, Historia Lausiaca, Gr. XVIII.3, ed. Butler, 48/Lat 18.4, ed. Wellhausen, 537; Gr. XLVII.2, ed. Butler, 136/ LatXLVII.2, ed. Wellhausen, 647.

Palladius, Historia Lausiaca, Gr. XIX.10, ed. Butler, 61/Lat. 19.15, ed. Wellhausen, 556.

Palladius, Historia Lausiaca, Gr. XLVII.9, ed. Butler, 138/Lat. 48.2, ed. Wellhausen, 656.

Palladius, Historia Lausiaca, Gr. LXI.6, ed. Butler, 157/Lat. 61.8, ed. Wellhausen, 677.

Palladius, Historia Lausiaca, Gr. LXVIII.1, ed. Butler, 163/Lat. 68.1, ed. Wellhausen, 685.

Palladius, Historia Lausiaca, Gr. IX, ed. Butler, 29; X, ibid., 32; XVIII.25, ibid., 56. 


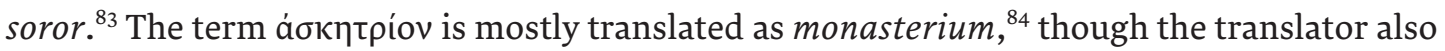
uses asceterium - to my knowledge the one and only instance of Latinizing a derivative of ă $\sigma \kappa \eta \sigma \iota \varsigma .{ }^{85}$ The Latin version of the Codex Iustinianus uses asceterium as well, which shows

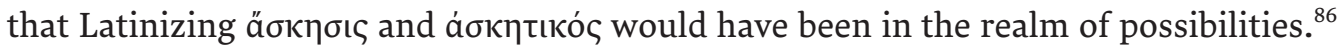

Another example of an early and influential narrative rendition of monastic life is Theodoret of Cyrrhus' Historia religiosa, which describes the life of radical desert monks in Syria who performed various forms of extreme bodily rasceticism`, ranging from living a life of a stylite; having oneself being eaten up by maggots and bitten by snakes and insects; ${ }^{87}$ living without shelter, ${ }^{88}$ immured or enclosed in caves, holes and pits; ${ }^{89}$ enduring snow, rain, and burning heat; ${ }^{\circ 0}$ fasting and enduring thirst for days or weeks; ${ }^{91}$ eating only uncooked food; ${ }^{92}$ wearing heavy iron chains; ${ }^{93}$ standing for days or remaining in uncomfortable positions; ${ }^{94}$ sleeping on the ground; ${ }^{95}$ keeping complete silence; $;{ }^{96}$ wearing masks of skin with just an opening to breathe; ${ }^{97}$ keeping one's bowels under control in spite of diarrhea, ${ }^{98}$ etc. Unlike the Historia Lausiaca, the Historia religiosa describes hardly any forms of moderate rascet-

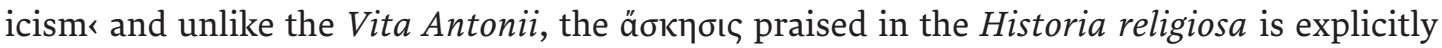
meant to wear out and harm the body ${ }^{99}$ and to overcome its nature. ${ }^{100}$ The practices praised

83 Palladius, Historia Lausiaca, Gr. XXXVII.12, ed. Butler, 113/Lat. 37.16, ed. Wellhausen, 617: uirgo Dei; Gr. LXIX.1, ed. Butler, 164/Lat. 69.1, ed. Wellhausen, 687: ancilla Dei; Gr. LXX.4, ed. Butler, 166/Lat. 70.9, ed. Wellhausen, 690: soror.

84 Palladius, Historia Lausiaca, c. XXIX.1, ed. Butler, 84; XXXVII.12, ibid., 113; LXIX.1, ibid., 164.

85 Palladius, Historia Lausiaca, c. XVIII.12. ed. Butler, 52/Lat. 18.16, ed. Wellhausen, 542.

86 Codex Iustinianus, Corpus iuris civilis, vol. 2, ed. Krueger, for example I.53(54).3-4, ibid., 37.

87 Theodoret, Historia religiosa XXII.5, SC 257, 130; XXVI.10, SC 257, 178.

88 Theodoret, Historia religiosa XVIII.1, SC 257, 34; XXI.3, SC 257, 72.

89 Theodoret, Historia religiosa II.2, SC 234, 196; III.2, SC 234, 248; IV.3, SC 234, 294; VII.1, SC 234, 366; VIII.1, SC 234, 372-374; IX.3, SC 234, 410-412 ; XIII.2, SC 234, 476; XV.1, SC 257, 18; XVII.1, SC 257, 34; XVIII.2, SC 257, 54; XIX.1, SC 257, 58; XX.1, SC 257, 64; XXII.5, SC 257, 130; XXV.2, SC 257, 154-156; XXVI.4, SC 257, 164-166; XXVI.6-7, SC 257, 170-174; XXVII.1, SC 257, 216-218; XXIX.2-3, SC 257, 232-234.

90 Theodoret, Historia religiosa XXI.6, SC 257, 78; XXI.13, SC 257, 90; XXIV.9, SC 257, 152; XXVII.1, SC 257, 216-218.

91 Theodoret, Historia religiosa II.2, SC 234, 194; III.3, SC 234, 250; XII.3, SC 234, 462-464; XVIII.4, SC 257, 56; XXI.23-24, SC 257, 106-108; XXVI.9, SC 257, 176-178.

92 Theodoret, Historia religiosa XI.1, SC 234, 454; XIII.3, SC 234, 478-480; XV.1, SC 257, 18; XVII.6, SC 257, 42-44; XVIII.1, SC 257, 52-54; XXI.11, SC 257, 84-88.

93 Theodoret, Historia religiosa IV.6, SC 234, 302; XV.2, SC 257, 18-20; XXI.8, SC 257, 80; XXIII.1, SC 257,134; XXVI.10, SC 257, 178-180; XXIX.4, SC 257, 234-236.

94 Theodoret, Historia religiosa III.2, SC 234, 248; III.5, SC 234, 254; IV.7, SC 234, 256-258; XVII.1, SC 257, 34; XXIV.1, SC 257, 138; XXIV.4, SC 257, 142-144; XXIV.6, SC 257, 146; XXVI.2, SC 257, 160-162; XXVI.22-23, SC 257, 204-208; XXVII.1, SC 257, 216-218; XXVIII.3, SC 257, 226-228; XXIX.4, SC 257, 234-236.

95 Theodoret, Historia religiosa XII.1, SC 234, 260; XVII.6, SC 257, 42-44.

96 Theodoret, Historia religiosa IV.3, SC 234, 294; XIX.1, SC 257, 58; XXII.2, SC 257, 126.

97 Theodoret, Historia religiosa XXVII.2, SC 257, 218-220.

98 Theodoret, Historia religiosa XXI.5, SC 257, 76-78; XXII.4, SC 257, 128-130.

99 See, e.g. Theodoret, Historia religiosa, Prologue.5, SC 234, 132; VIII.9, SC 234, 392-394; XVII.7, SC 257, 44; XVIII.1, SC 257, 52-54; XVIII.4, SC 257, 56; XIX.3, SC 257, 60-62; XXI.3, SC 257, 72-74; XXIV.1, SC 257, 138; XXVI.2, SC 257, 160-162; XXVI.5, SC 257, 166-168; XXVII.2, SC 257, 218-220; XXVIII.3, SC 257, 226-228; XXX.2, SC 257, 242. 100 Theodoret, Historia religiosa XXI.3, SC 257, 72-74. 
in the Historia religiosa create fame and admiration in a manner analogous to the fame of actors and athletes, ${ }^{101}$ and allow the monks to perform miracles, but there is no indication that

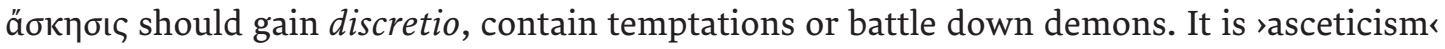
for the sake of the body, not for the sake of moral improvement: a sport and philosophy and a way of pursuing the love of God.

The monks and nuns described in the Historia religiosa are superstars, who were to be admired from a safe distance. Theodoret limits their subversive potential not by downplaying their achievements but by acting as their impresario, to use a term coined by Peter Brown. ${ }^{102}$

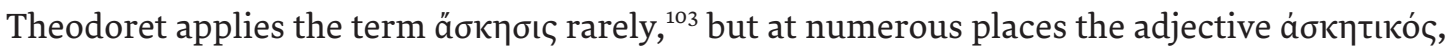
most often in reference to space: the rascetic dwelling; rascetic cave‘; rcell; rascetic wresthing school $; ;{ }^{104}$ sometimes in reference to an rascetic life $<;{ }^{105}$ rascetic community $<;{ }^{106}$ rascetic cloak $;{ }^{107}$ rascetic virtues $<{ }^{108}$ His objective is to show his readers where to find them by defining specific spaces as rasceticr. It is the framework that is rascetic rather than the protago-

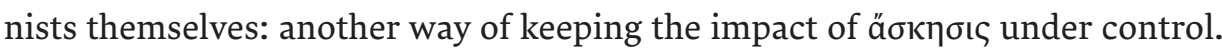

Even though Theodore's saints may have been the polar opposite of Athanasius' Antony, ${ }^{109}$ both authors share one objective. They framed their ideal of radical religious life in opposition to non-Christian, especially philosophical, feats of endurance. Instead of Christianizing

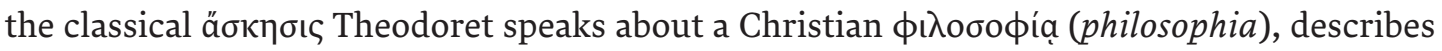

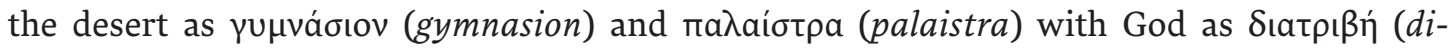
atribe, umpire). Moreover, he deploys the language of Platonic pederasty to describe the

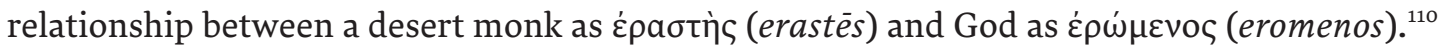
Theodoret's rasceticism ‘ could thus be most aptly described as an often bizarre and slightly

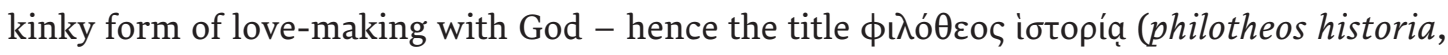
God-loving history).

101 Theodoret, Historia religiosa, prologue.1-3, SC 234, 124-130.

102 Brown, Cult of the Saints, 38. Brown refers to bishops organizing and monopolizing the cult of martyrs, but the term is certainly as applicable to bishops organizing and controlling the veneration of living or recently deceased saints. On Theodoret's role as simpresario<, see, for example, Historia religiosa IX.11, SC 234, 426; IX.15, SC 234, 434; XX.4, SC 257, 66-68; XXI.5-11, SC 257, 76-88; XXIX.1, SC 257, 232.

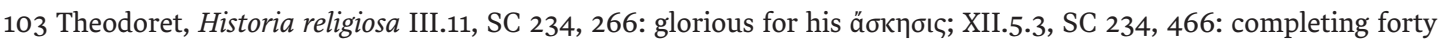

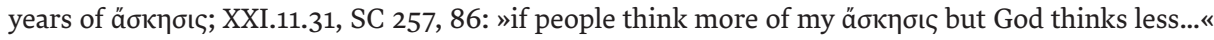

104 Theodoret, Historia religiosa II.1, SC 234, 194; II.9, SC 234, 216; II.21, SC 234, 240; III.4, SC 234, 252; III.12, SC 234, 268; IV.13, SC 234, 324; XIII.11, SC 234, 494; XXII.1, SC 257, 124; XXVI.4, SC 257, 164.

105 Theodoret, Historia religiosa II.9, SC 234, 216; IV.12, SC 234, 320; VI.8, SC 234, 356; XII.5, SC 234, 468; XIII.1, SC 234, 474; XXV.1, SC 257, 18.

106 Theodoret, Historia religiosa V.7, SC 234, 338; XIII.3, SC 234, 478.

107 Theodoret, Historia religiosa V.8, SC 234, 340.

108 Theodoret, Historia religiosa XVII.2, SC 257, 34.

109 On the differences between Syrian and Egyptian monastic life, see Brown, Treasure in Heaven, 51-118; idem, Rise and function.

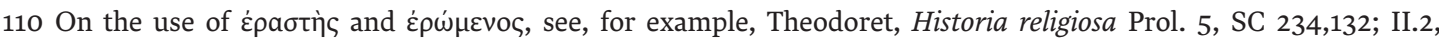
SC 234, 198; II.6, SC 234, 210; II.10, SC 234, 216; II.17, SC 234, 232; III.4, SC 234, 252; IV.3, SC 234, 294; IV.4, SC 234, 296; IV.5, SC 234, 298; VI.8, SC 234, 356; XI.3, SC 234, 458; XVII.10, SC 257, 46; XXIV.8, SC 257, 150; XXIX.6, SC 257, 236; XXXI.4, SC 257, 264; XXXI.8, SC 257, 276; XXXI.15, SC 257, 296; XXXI.17-18, SC 257, 300/304; XXXI.21, SC 257, 312. 
A last, slightly later, example is the Vita of Pachomius, which exists in various Coptic and Greek versions and also in a Latin translation of Dionysius Exiguus (d. 544). ${ }^{111}$ Dionysius' translation is based on a text very close to the Greek so-called Vita tertia which allows another comparison to be made leading to a strikingly similar observation. The author of this

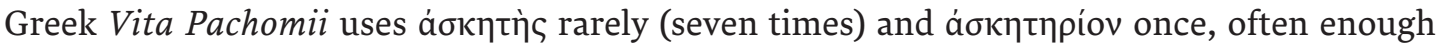
to argue that it was part of his monastic language but rarely enough not to consider it a key

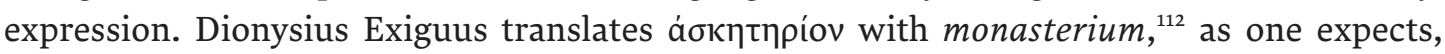

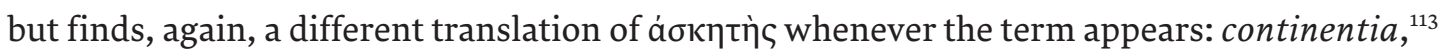
perfecta conuerstatio, ${ }^{114}$ regula districtior,${ }^{115}$ sollicitudo ${ }^{116}$ instituta monachorum. ${ }^{117}$

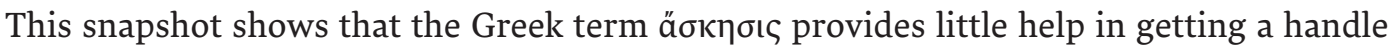
on late antique rasceticismr. Athanasius, Palladius, Theodoret and the author of the Greek Vita Pachomii made different, maybe consciously opposing, claims on the meaning and the

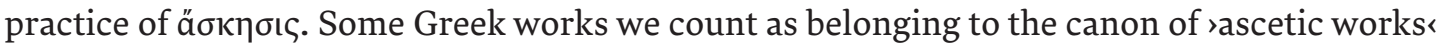

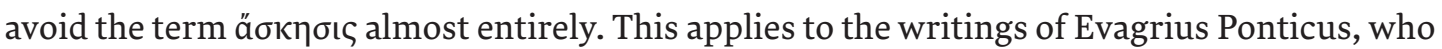
was a major source of inspiration for John Cassian (the major Western theorist of rascetic

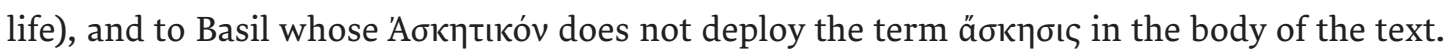
All of this shows that any attempt to become more precise by replacing rasceticism « with raskésis - as it is done quite often - is not at all helpful. Distilling a true, all-encompassing

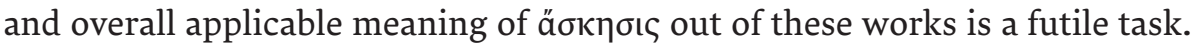

\section{III.}

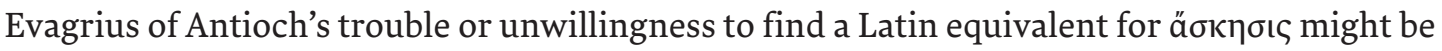
a good starting point for complicating the rascetic nature of Western monasticism as well. Of all variants of rascetic life described in the Vita Antonii, the Historia Lausiaca, and the Historia religiosa, the moderate set of practices proposed by Athanasius took the strongest roots in the Latin West. Western monks and nuns did not emulate the body-tormenting athletes and God-lovers of Theodoret's desert, nor did they embrace the whole spectrum of religious practices we find in the Historia Lausiaca. They probably regarded many of these practices as admirable from a distance in time and space, practiced in exotic countries but not to be tried at home, where equally worthy but more sustainable options became available. ${ }^{118}$ Gregory of Tours tells the melancholic tale of Vulfilaic, a Gallic stylite who endured snow and rain on his

111 For an overview of the hagiographic tradition on Pachomius and an attempt to determine a chronology and interdependences, see Veilleux, Pachomian Koinonia 1, 1-21 and Rousseau, Pachomius, 37-48.

112 Vita Pachomii tertia, c. 31/Vita Pachomii Latina, c. 31, ed. Cranenburgh, 158-159.

113 Vita Pachomii tertia, c. 13/Vita Pachomii Latina, c. 13, ed. Cranenburgh, 108-109.

114 Vita Pachomii tertia, c. 19/Vita Pachomii Latina, c. 18, ed. Cranenburgh, 124-125.

115 Vita Pachomii tertia, c. 21/Vita Pachomii Latina, c. 22, ed. Cranenburgh, 130-131.

116 Vita Pachomii tertia, c. 21/Vita Pachomii Latina, c. 22, ed. Cranenburgh, 130-131.

117 Vita Pachomii tertia, c. 23/Vita Pachomii Latina, c. 24, ed. Cranenburgh, 138-139.

118 See, for example, Sulpicius Severus, Dialogi I, c. 24-25, ed. Fontaine and Dupré, 198-204, contrasting the achievements of the desert fathers with those of home-grown religious life. 
column and relentlessly converted worshipers of Diana to Christianity. Vulfilaic had clearly missed the point in his attempt to become a desert monk in Northern Gaul. His bishop lured him from his column, which was then immediately destroyed. The only option left to Vulfilaic was becoming just an ordinary monk. ${ }^{119}$

John Cassian argues against radical and spectacular rasceticism< in the first two books of his Collationes in which Abba Moses explained to him and his friend Germanus that desert monks do not deserve admiration and emulation for their endurance of hunger and physical pain, which more often than not appeared to be misguided and harmful. No forms of restraint, fasting, prayer, solitude, are ever a means to their own end but tools to achieve puritas cordis (purity of the heart) and to strive for control over one's cogitationes (thoughts). ${ }^{120}$ Instead of bodily mortification, Cassian recommends submitting oneself to spiritual guidance and introspection that may help to cope with the loss of discretio that came along with original sin. ${ }^{121}$ Michel Foucault sees in Abba Moses' advice the beginning of Christian confession and a turning point in the history of subjectivity. ${ }^{122}$

Athanasius recounts in the Vita Antonii how Antony recommended his monks to write down their sinful thoughts on wax tablets in order to expose themselves to shame by re-reading them $a s$ if someone else were reading them. ${ }^{123}$ Evagrius' Latin rendition makes an important change. Monks should write down their thoughts not as if someone else were reading them but in order that they be read by others. ${ }^{124}$ Can we add the imperative of the confession of one's innermost thoughts and feelings and the willingness to expose oneself to external scrutiny and shame to a specifically Western rascetic repertoire? As I will show, the same question - is this still rasceticism<? - can be asked with regard to various other practices emerging in Western texts - and the problem is that each answer modifies the nature of the supposedly universal concept of rasceticismr.

Fasting, vigils, prayer, solitude, austerity and perseverance, the barebones rasceticism praised in the Vita Antonii, remain in the center of Latin rascetic discourse, but it undergoes three crucial transformations. The first one has been indicated by Robert Markus as the rascetic invasion<. Fifth- and sixth-century bishops who underwent a monastic training before returning to the world as ecclesiastical leaders transformed monastic ideals into the basis of pastoral care and instruction. ${ }^{125}$ Caesarius of Arles' sermons, which urged ordinary Christians to restrain their sexuality, to avoid drunkenness and to partake in the liturgical hours, belong to the prime documents of an imperative of lay rasceticism ${ }^{126}$ But there are two other important rascetic transformations،. Monks and nuns placed their rascetic achievements, which supposedly brought them closer to God, in the service of the non-rascetic « world in

119 Gregory of Tours, Decem Libri Historiarum VIII.15, ed. Krusch and Levison, 382-383.

120 Cassian, Collationes I, ed. Pichery, 78-108.

121 Cassian, Collationes II, ed. Pichery, 111-134.

122 Foucault, On the Government of the Living, 261-313.

123 Athanasius, Vita Antonii, c. 55.6-13, SC 400, 282-286.

124 Vita Antonii, uersio Euagrii, c. 55, ed. Bertrand and Gandt, textus, 62-63. See also ibid., textus, 276-278 for a synoptic presentation of all three versions.

125 Markus, End of Ancient Christianity, 199-211.

126 Bailey, Lisa Kaaren, »These Are Not Men«, 23-43.

medieval worlds • No. 9 • 2019 • 112-138 
order to act as intercessors. 'Ascetic purity became, in this way, a tool for spiritual power and this spiritual power could be used to perform intercessory prayer on behalf of those who were unable to live an rascetic life. ${ }^{127}$ The sholy poor replaced the real poor as recipients of charity. ${ }^{128}$ The ultimately unachievable state of chastity as still described in the works of John Cassian, was transformed into the notion of an organized and demonstrable sexual abstinence as a necessary condition for effective intercession. ${ }^{129}$ Does it make sense to depict this >organized chastity a as sexual rasceticism ^ or is virginity and continence a worthy replacement of rasceticism «? Can rasceticism « be used to achieve something like >purity

A third rascetic transformation<, which is closely related to the integration of monastic life into broader social structures, consists of regulating and de-individualizing the barebones rasceticism < of the Vita Antonii. This can be observed most prominently in the Regula Benedicti. Fasting turns into regulated eating, the observance of periods of Lent, vegetarianism, and the strict prohibition against eating outside the designated meal times. ${ }^{130}$ Prayer and vigils turn into strict liturgical ordines, liturgical hours spread over day and night, and into provisions of liturgical discipline that ensure the high squality of the prayer performed by monks and nuns. ${ }^{131}$ Poverty becomes the renunciation of private property within the safe structures of wealth held in common by the community. The rugged clothing of the desert monks give place to uniform habits and keeping a small wardrobe. ${ }^{132}$ Renunciation of the world transforms into a legalized and ritualized procedure of monastic conversion and the irreversibility of monastic vows. ${ }^{133}$ This rascetic transformation allowed monks to integrate Antony and other desert fathers into their collective past while not having to live a desert father life themselves. The Regula Benedicti presents itself as a >Rule for Beginners mends the reading and emulation of the uitae patrum. For those who have tested themselves in coenobitic life, it offers the additional option of moving into the desert like Antony. ${ }^{134}$

Benedict - and to a certain extent other authors of monastic rules - not only rregulates rasceticism × and transforms fasting, prayer, poverty, and austerity from an individual pursuit of self-perfection into a collective endeavor, but he also places three other practices at the heart of monastic existence: unconditional oboedientia, the attitude of humilitas, and the renunciation of one's propria uoluntas (individual will). ${ }^{135}$ Should the unconditional subordination towards a superior, the institution or a rule, the renunciation of one's will, and the delegation of responsibility for one's salvation be considered the end of rasceticism as an expansion of the rascetic repertoire? Should we consider the rise of medieval monasticism the demise of rasceticism??

127 An example for using rascetic practices to gain the power of intercession (in this case not towards God but towards the emperor) can be found in Sulpicius Severus, Dialogi II, c. 5.5-10, ed. Fontaine and Dupré, 240-242.

128 See Brown, Treasure in Heaven.

129 Diem, Das monastische Experiment.

130 Regula Benedicti, c. 41, ed. de Vogüé and Neufville, 580-584; c. 49, ibid., 604-606.

131 Regula Benedicti, c. 19-20, de Vogüé and Neufville, 534-538.

132 Regula Benedicti, c. 55, de Vogüé and Neufville, 618-622.

133 Regula Benedicti, c. 58-61, de Vogüé and Neufville, 626-640.

134 Regula Benedicti, c. 1.5, de Vogüé and Neufville, 438.

135 Esp. Regula Benedicti, c. 5, de Vogüé and Neufville, 464-468 and c. 7, ibid., 472-490. On obedience see Bhaldraithe, Obedience: The doctrine of the Irish monastic rules. 
Latin hagiography is profoundly influenced by the Vita Antonii. ${ }^{136}$ Many saints' lives share Athanasius' technique of identifying radical, body-centered rascetic practices as a matter of the past rather than the present and turning them into attributes of sanctity rather than guidelines to be practiced. Many Latin saints' lives depict forms of radical religious life as markers of a transitional phase that is followed by a re-integration into society and the adoption of a much more moderate regime that can be emulated without having the power of a saint, a process that, as many hagiographers emphasize, takes place without compromising one's standards and ideals. This adjustment creates, in a similar way to what we see in the Vita Antonii, new and equally worthy forms of religious life which may or may not be called rasceticr.

One early example would be Martin of Tours' career, which transforms a wandering monk and hermit eating roots and grass into the founder of a community of hermits and then into a bishop who finds a compromise between representing his office and retaining his former austerity and discipline. ${ }^{137}$ The Vita Martini poses the question of whether we should add the willingness to serve the Christian community, to relentlessly exorcize demons and to fight the errors of pagans to be considered part of an expanding rascetic r repertoire. ${ }^{138}$

The singing barbarian Hymnemodus, the first protagonist of the Vita Abbatum Acaunensium, like Antony and Martin, goes through an rascetic phaser, which he spends as a hermit in a cave. ${ }^{139}$ Later he is admitted to a proper monastic community, becomes their abbot and subsequently founds Saint-Maurice d'Agaune, the first royal monastery<, in which its monks, liturgical experts recruited from neighboring episcopal sees, were exempt from manual labor in order to dedicate themselves to incessant intercessory prayer. ${ }^{140}$ Does it make sense to understand submission to a liturgical regime and serving the world through ceaseless prayer as a form of rasceticism

The Vita of Romanus and Lupicinus, which was written roughly at the same time as the report on Hymnemodus' conversion and the foundation of Saint-Maurice d'Agaune, describes a similar process of transformation but develops a radically different monastic ideal. Romanus and Lupicinus start their religious career by emulating Antony, moving into the desert of the Jura mountains and fighting demons, ${ }^{141}$ but their saintliness attracted followers and turned them into leaders of a network of monastic foundations that succeeds in finding a balance between mild austerity and accessibility to everyone who wants to pursue a monastic life which is centered around labor for the community rather than incessant prayer. ${ }^{142}$

136 On the impact of the Vita Antonii on Western hagiography, see Bertrand, Die Evagriusübersetzung der Vita Antonii, 26-60.

137 Sulpicius Severus, Vita Martini, c. 6.5, ed. Fontaine, 266: on his life as a hermit; c. 10, ibid., 272-274: on retaining a monastic life after being elected bishop.

138 Sulpicius Severus, Dialogi I, c. 24-26, ed. Fontaine and Dupré, 198-210, esp. c. 24.3, ibid., 200, transl. Goodrich, Sulpicius Severus, 208 explicitly compares the achievements of the desert fathers with Martin's life in a "crowd and with various peoples, among disagreeing clerics, among savage bishops, pressured from every side by near-daily scandals."

139 Vita Abbatum Acaunensium, c. 1, ed. Krusch, 330.

140 Vita Abbatum Acaunensium, c. 3-7, ed. Krusch, 331-334. See Diem, Who is Allowed to Pray for the King?.

141 Vita Patrum Iurensium, c. 6-12, ed. Martine, 244-252: Romanus' and Lupicinus' life as hermits.

142 Vita Patrum Iurensium, c. 13-17, ed. Martine, 254-258; c. 22-24, ibid., 262-264: the foundation of the Jura monasteries. On the network of the Jura monasteries, see Fox, Swarm from the blessed hive. 
The author of the Vita patrum Iurensium exemplifies the tensions arising from such a transformation in a conflict between Romanus and a monk who wants to evict everyone who does not meet his high standards of discipline and austerity. Romanus prevails and convinces the monk that his ideas were induced by a demon. ${ }^{143}$ Are those monks who, often in search of healing and solace, joined the Jura monasteries in order to work in the fields and forests for the benefit of their community still to be considered rascetics ?

Caesarius of Arles's high standards caused him to be evicted from Lérins - at least that's what we can read between the lines of his Vita. ${ }^{144}$ Without compromising his ideals, he abandoned the strict life that got him into trouble with his fellow monks and almost ruined his health, in order to take on the duties of a bishop. He produced two monastic rules, neither of which showed an interest in bodily mortification. One of them imposes lifelong total enclosure and submission to a sancta regula; the other one places perseuerantia at the center of monastic existence and defines monastic life as a lifelong struggle against one's vices. ${ }^{145}$ We can ask the same question here: is it more productive to view virginity, total enclosure (paired with a life of assured comfort), and submitting to a sancta regula a part of a new repertoire of rasceticism

The Vita Benedicti, the second book of Gregory the Great's Dialogi, contains yet another variation on the theme. Benedict, like Antony, begins his life as a cave-hermit who refuses to break his fasting even at Easter. ${ }^{146}$ His eremitism is, again, a transitory state. As head of a monastic community he risks being killed by the monks who do not want to endure his strict regime. ${ }^{147}$ Only later in his life does he become the benevolent and mild abbot of Montecassino and the author of a Rule that is, in Gregory's words, a rule outstanding in judgment and clear in phrasing - possibly the Regula Benedicti as we know it. ${ }^{148}$

A last narrative of transformation to be discussed here (there are more, of course) is Jonas of Bobbio's Vita of the Irish peregrinus Columbanus, who came to the Continent about fifty years after Benedict's death. ${ }^{149}$ One of his foundations, Luxeuil, became the center of a monastic network and contributed just as much to shaping medieval monasticism as did the Regula Benedicti. ${ }^{150}$ As monachi peregrini, Columbanus and his followers performed what could be seen as a particularly strict form of rasceticism«: giving up one's home country. In an almost ironic transformation, Jonas turns Columbanus' successors Eusthasius and Waldebert into a new type of monachi peregrini: high-profiled negotiators who were constantly travelling back and forth between Luxeuil and its affiliations and the court in order to keep a network of Columbanian foundations intact. ${ }^{151}$ We could ask whether entering the snake pit of monastic politics and the - eventually failed - task of keeping a monastic network together, could be considered an rascetic achievement.

143 Vita patrum Iurensium, c. 27-34, ed. Martine, 268-278.

144 Vita Caesarii I, c. 6-7, ed. Morin et al., 154-158.

145 Caesarius, Regula ad uirgines, ed. de Vogüé and Courreau, 170-272; Caesarius, Regula ad monachos, ed. de Vogüé and Courreau, 204-226. See Diem, Das Monastische Experiment, 154-202.

146 Gregory the Great, Dialogi II, c. 1, ed. de Vogüé and Antin, 128-136.

147 Gregory the Great, Dialogi II, c. 3.1-4, ed. de Vogüé and Antin, 140-142.

148 Gregory the Great, Dialogi II, c. 36, ed. de Vogüé and Antin, 242.

149 Jonas of Bobbio, Vita Columbani, ed. Krusch, 1-294; transl. O’Hara and Wood, Jonas of Bobbio.

150 On the impact of Columbanian monasticism, see Diem, Pursuit of Salvation.

151 Diem, Monks, kings and the transformation of sanctity.

medieval worlds • No. 9 • 2019 • 112-138 
With Columbanian monasticism, the body as an object of religious practice returns to the Latin world, though it is not the body of the desert monk submitted to self-imposed mortificatio. When Columbanus talks about mortificatio in his Regula monachorum, it is the mortificatio of the will, not of the body. ${ }^{152}$ Yet the medicamenta paenitentiae (remedies of penance) that allegedly returned to the Continent with Columbanus' arrival are very physical remedies. ${ }^{153}$ There is no indication that Columbanus saw the body itself as inherently sinful or as the place of temptation, but he did make it an object of punishment and turned various practices that may be viewed as rascetic into practices of penance: flagellation, even for small transgressions; fasting; prayer and social exclusion. ${ }^{154}$ Can a practice remain rascetic if it is undergone or imposed as a punishment or retribution in order to attain forgiveness for a sin or transgression?

It would not be difficult to find other Latin hagiographic narratives that contain both elements: the transitional phase of radical rasceticism $<$ and the propagation of new practices that form a worthy alternative. ${ }^{155}$ There is, however, little of a general trend in these alternatives. The implicit critique of radical rasceticism distant country thus does not lead to one alternative model but - in a beautiful analogy to

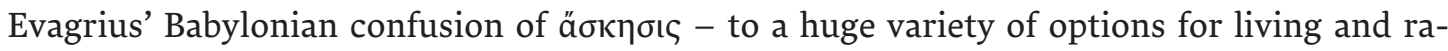
tionalizing religious life.

\section{Conclusion}

Neither my very narrow exploration of the meanings of ä $\sigma \kappa \eta \sigma \iota \varsigma$ in a handful of exemplary texts nor my exploration of transformations of religious practices that manifest themselves in Latin monastic rules and narratives can claim to be more than preliminary case studies. They show, however, that what we might call rasceticism practices ranging from extreme forms of harming and neglecting one's body to exercises of controlling one's impulses, or simply doing more good than is typical. These practices are tied to an equally broad range of motivations: the imitation of martyrdom, creating Christian alternatives to non-Christian forms of virtuous or disciplined life, gaining fame and the ability to perform miracles, expressing one's love of God, fighting a war as a soldier of Christ, battling demons, fighting vices, avoiding temptations, overcoming the effects of original sin, gaining control over one's body or thoughts, gaining discretio, restoring purity, gaining the power to perform intercession, doing penance in order to achieve forgiveness for one's sinful impulses or sinful deeds, or preempting future punishment. Some of these motivations, in turn, may require radically different theological frameworks.

152 Columbanus, Regula monachorum, c. 9, ed. Walker, 138-140.

153 Jonas, Vita Columbani I, c. 5, ed. Krusch, 161.

154 Columbanus, Regula coenobialis, ed. Walker, 142-168.

155 An important Carolingian example would be the Vita of the monastic reformer Benedict of Aniane, who first emulated desert rascetics`, then >fell in lover with the Regula Benedicti and founded Aniane, a community of poor and austerely living monks. Aniane later turned into a lavishly endowed royal monastery and Benedict became the leading monastic reformer who aimed at unifying Frankish monasticism under the Regula Benedicti. Benedict, thus, reinvented himself at least twice, of course without compromising his rascetic ideals. See Ardo, Vita Benedicti abbatis Anianensis, ed. Waitz, 198-220. See also Diem, Inventing the holy rule. 
Both the range of practices and the underlying motivations were, probably not much less than the grand theological questions, matters of dispute and disagreement, albeit often expressed more discreetly and under the disguise of harmony. ${ }^{156}$ Antony, Athanasius, Palladius, Theodoret, Evagrius of Antioch, Cassian, Benedict, Gregory the Great, Columbanus, and Jonas of Bobbio propagated, rationalized, and defended their respective range of rascetic practices and motivations against other existing models. They did it discretely but effectively, by creating their own idiom, by re-defining expressions, by placing a claim on the memoria of undisputed heroes of the past, by telling stories of transformation - to mention only a few discursive techniques.

Indiscriminately calling all the practices I listed rascetic and placing all the rationales and motivations under the umbrella of rasceticism fuscating small nuances and plain incompatibilities, ignoring historical developments, and making dissent and debates invisible. It makes things that are fundamentally different look dangerously similar, unless we use rasceticism $<$ as a hermeneutic `scratch post ‘ and read our sources consistently against the assumption that there is something like a universal concept behind this term.

The idea that there existed a unity and an overarching principle within the diversity of Christian rexercises` (to return to the classical meaning of the term ä $\sigma \kappa \eta \sigma \iota)$ ) is much older than the post-medieval creation of the word asceticus and the creation of an rascetical canon of texts from the sixteenth century onwards, or the postulation of an rascetic imperativer in the works of Foucault and Harpham. The oldest Latin collections of Vitae patrum that turned the divergent voices of rasceticism dex were produced in the Carolingian period. ${ }^{157}$ The textual construction of rasceticism $<$ may have started even earlier with Jerome's and Gennadius' bio-bibliography De uiris illustribus, which put a stamp of orthodoxy on a canon of rascetic « works. ${ }^{158}$ But it is also important to be aware that an early challenge of a shared notion of rasceticism pearing in the Pseudo-Gelasian Decretum Gelasianum de libris recipiendis et non recipiendis (probably written in the sixth century) that casts doubt on some of the works that we would consider foundational texts of Christian rasceticism<. ${ }^{159}$

Asking whether certain forms of religious life - obedience, humility, undergoing punishment, submission under a rule, assuming civic duties, sexual continence, submitting to a strict daily routine, etc. - could be considered as conforming to a universal rascetic principle, as I have done in the third part of this essay, causes the problem that each answer might alter a concept that is to be considered universal: To what extent does rasceticism $<$ have to

156 Brown, Body and Society.

157 Bertrand, Die Evagriusübersetzung, 89-154 and 445-504; Diem, Das monastische Experiment, 339-393; SchulzFlügel, Rufinus Historia Monachorum, 90-142.

158 Jerome and Gennadius, De viris inlustribus, ed. Bernoulli.

159 Decretum Gelasianum de libris recipiendis et non recipiendis, ed. von Dobschütz, 7-13. The text, which defines a canon of texts to be read in church, not only condemns some of the works of Origen, and Cyprian, the works of Tertullian, the Dialogi of Sulpicius Severus, the works of Cassian, Victorinus and Faustus, but also calls for caution in reading the acts of the martyrs and the works of Rufinus and does not even mention the Vita Martini or the Sayings of the Desert Fathers. 
involve the body? Is there a pure rasceticism ^ of the mind? Is rasceticism` necessarily a moral practice or can there be an ethically neutral rasceticism`? Is rasceticism untary, self-imposed practice, or is there an overlap between rasceticism and self-punishment? Is there rasceticism « without renunciation? It might be worthwhile to turn the assumption that there is a universal concept of rasceticism < into a hypothesis to be tested time and again on the sources we read. Regardless whether we come to a negative or affirmative answer, the testing itself will lead to a profusion of collateral insights that keep the excitement of studying the late antique and early medieval period alive. 


\section{References}

Abbreviations

CCSL = Corpus Christianorum Series Latina

MGH SRG = Monumenta Germaniae Historica, Scriptores Rerum Germanicarum un usum scholarum

MGH SRM = Monumenta Germaniae Historica, Scriptores Rerum Merovingicarum

MGH SS = Monumenta Germaniae Historica, Scriptores

PG = Patrologiae Cursus Completus, Series Graeca, ed. Jacques-Paul Migne (Paris, 18571866)

SC = Sources Chrétiennes

Antenhofer, Christina (ed.), Fetisch als heuristische Kategorie. Geschichte - Rezeption - Interpretation (Bielefeld, 2011).

Ardo, Vita Benedicti abbatis Anianensis et Indensis, ed. Georg Waitz, MGH SS 15 (Hannover, 1887) 198-220.

Ashbrook Harvey, Susan, Asceticism and Society in Crisis. John of Ephesus and The Lives of the Eastern Saints (Berkeley, 1990).

Athanasius of Alexandria, Vita Antonii (Greek text), ed. Gerhard J. M. Bartelink, SC 400 (Paris, 1994); trans. Tim Vivian and Apostolos N. Athanassakis, The Life of Antony: The Coptic Life and the Greek Life (Kalamazoo, 2003).

Bailey, Lisa Kaaren, »These Are Not Men«: Sex and drink in the sermons of Caesarius of Arles, Journal of Early Christian Studies 15 (2007) 23-43.

Beach, Alison and Isabelle Cochelin (eds.), The Cambridge History of Western Monasticism (Cambridge, forthcoming).

Bertrand, Pascal, Die Evagriusübersetzung der Vita Antonii. Rezeption - Überlieferung Edition. Unter besonderer Berücksichtigung der Vitas patrum-Tradition. Unpublished $\mathrm{PhD}$ thesis (Utrecht University, 2006).

Bhaldraithe, Eoin de, Obedience: The doctrine of the Irish monastic rules, Monastic Studies 14 (1983) 63-84.

Bloch, Ralph Howard, God's Plagiarist. Being an Account of the Fabulous Industry and Irregular Commerce of the Abbé Migne (Chicago, 1994).

Brakke, David, Athanasius and Asceticism (Baltimore, 2009).

Brakke, David, Athanasius and the Politics of Ascetism (Oxford, 1995).

Bremmer, Jan N., Athanasius' Life of Antony: Marginality, spatiality and mediality, in: Laura Feldt and Jan N. Bremmer (eds.), Marginality, Media, and Mutations of Religious Authority in the History of Christianity (Leuven, 2019) 23-45.

Brown, Peter, The Cult of the Saints. Its Rise and Function in Latin Christianity (Chicago, 1981).

Brown, Peter, The Body and Society. Men, Women and Sexual Renunciation in Early Christianity (New York, 1989).

Brown, Peter, The rise and the function of the holy man, The Journal of Roman Studies 61 (1971) 80-101.

Brown, Peter, Treasure in Heaven: The Holy Poor in Early Christianity (Charlottesville, 2016).

Butler, Cuthbert, The Lausiac History of Palladius (Cambridge, 1898). 
Campbell, Oman John, The Mystics, Ascetics, and Saints of India: A Study of Sadhuism, with an Account of the Yogis, Sanyasis, Bairagis, and other strange Hindu Sectarians (London, 1903). John Cassian, Collationes Patrum I-VII, ed. Eugène Pichery, Jean Cassien: Conférences, SC 42 (Paris, 1955).

Caesarius of Arles, Regula ad monachos, ed. Adalbert de Vogüé and Joël Courreau, SC 398 (Paris, 1994) 204-226.

Caesarius of Arles, Regula ad uirgines, ed. Adalbert de Vogüé and Joël Courreau, SC 345 (Paris, 1988) 170-272.

Clement of Alexandria, Paedagogus, ed. Henri-Irénée Marrou, Claude Modésert, Chantal Matray and Marguerite Harl, SC 70/108/158 (Paris 1960/1965/1970).

Columbanus, Regula monachorum, ed. G. S. M. Walker, Columbani Opera (Dublin, 1956) 124-142.

Columbanus, Regula coenobialis, ed. G. S. M. Walker, Columbani Opera (Dublin, 1956) 142168.

Corpus iuris civilis, ed. Paul Krüger, vol. 2: Codex Iustinianus (Berlin, 1954).

Decretum Gelasianum de libris recipiendis et non recipiendis, ed. Ernst von Dobschütz (Leipzig, 1912).

Dictionnaire d'ascétisme, ed. Jean Claude Gainet and J.-Clovis Poussin (Paris, 1865).

Dictionnaire de Spiritualité, ed. Marcel Villier et al. (Paris, 1932-1995).

Diderot, François, Encyclopédie, vol. 1 (Paris, 1751).

Diem, Albrecht, Antony, in: Paul van Geest and Bert Jan Lietaert Peerbolte (eds.), Brill Encyclopedia of Ancient Christianity (Leiden, forthcoming).

Diem, Albrecht, Das monastische Experiment: Die Rolle der Keuschheit bei der Entstehung des westlichen Klosterwesens (Münster, 2005).

Diem, Albrecht, Inventing the holy rule: Some observations on the history of monastic normative observance in the early medieval west, in: Hendrik Dey and Elizabeth Fentress (eds.), Western Monasticism ante litteram. The Spaces of Monastic Observance in Late Antiquity and the Early Middle Ages, Disciplina Monastica 8 (Turnhout, 2011) 53-84.

Diem, Albrecht, Monks, kings and the transformation of sanctity. Jonas of Bobbio and the end of the Holy Man, Speculum 82 (2007) 521-559.

Diem, Albrecht, The Pursuit of Salvation. Community, Space, and Discipline in Early Medieval Monasticism (forthcoming).

Diem, Albrecht, Who is allowed to pray for the king? Saint-Maurice d'Agaune and the creation of a Burgundian identity, in: Gerda Heydemann and Walter Pohl (eds.), Post-Roman Transitions. Christian and Barbarian Identities in the Early Medieval West (Turnhout, 2013) 47-88.

Diui Basilij Magni Archiepiscopi Caesariensis moralia; Ascetica magna; Ascetica parua, ed. Sébastien Gryphius (Lyon, 1540).

Encyclopedia Britannica, vol. 1 (first edition), (Edinburgh, 1776).

Mours des Chrétiens, ed. Claude Fleury (Paris, 1754).

Foucault, Michel, On the Government of the Living. Lectures at the College de France 19791980 (Basingstoke, 2016) 261-313.

Fox, Yaniv, A swarm from the blessed hive: The social networks of the Jura monasteries, Revue Bénénedictine 128 (2018) 252-280.

Freud, Anna, Das Ich und die Abwehrmechanismen (Vienna, 1936); English: The Ego and the Mechanisms of Defense, translated from German by Cecil Baines (London, 1942). 
Goehring, James L., Ascetics, Society and the Desert. Studies in Early Egyptian Monasticism (Harrisburg, Pa, 1999).

Goodrich, Richard J., Contextualizing Cassian. Aristocrats, Asceticism, and Reformation in Fifth-Century Gaul (Oxford, 2007).

Goodrich, Richard J., Sulpicius Severus. The Complete Works (New York, 2015).

Graiver, Inbar, Asceticism of the Mind. Forms of Attention and Self-Transformation in Late Antique Monasticism (Toronto, 2018).

Gregory of Nazianzus, Oratio 21, PG 35, col. 1082-1128.

Gregory of Tours, Decem Libri Historiarum, ed. Bruno Krusch and Wilhelm Levison, MGH SRM 1 (Hannover, 1951).

Gregory the Great, Dialogi II, ed. Adalbert de Vogüé and Paul Antin, SC 260 (Paris, 1979).

de Guibert, Joseph, Michel Olphe-Galliard and Marcel Viller, Ascèse/Aséticisme in: Dictionnaire de Spiritualité, vol. 1 (Paris, 1937) col. 936-1010.

Hardman, Oscar, The Ideals of Asceticism - An Essay in the Comparative Study of Religion (New York, 1924).

Harpham, Geoffrey, The Ascetic Imperative in Culture and Criticism (Chicago, 1987).

Hunt, Hannah, Clothed in the Body. Asceticism, the Body and the Spiritual in the Late Antique Era (Variorum Reprint), (Farnham UK, 2012).

Jerome and Gennadius, De viris inlustribus, ed. Carl Albrecht Bernoulli, Hieronymus und Gennandius, De viris inlustribus (Freiburg im Breisgau, 1895).

Jonas of Bobbio, Vita Columbani, ed. Bruno Krusch, MGH SRG 37 (Hannover, 1905) 1-294; transl. by Alexander O'Hara and Ian Wood, Jonas of Bobbio: Life of Columbanus, Life of John of Réomé, and Life of Vedast (Liverpool, 2017).

Knowles, David, Great Historical Enterprises (London, 1963).

Koch, Hugo, Quellen zur Geschichte der Askese und des Mönchtums in der alten Kirche (Tübingen, 1933).

Kohl, Karl-Heinz, Die Macht der Dinge. Geschichte und Theorie sakraler Objekte (Munich, 2003).

Krawiec, Rebekka, Asceticism, in: Susan Ashbrook Harvey and David G. Hunter (eds.), The Oxford Handbook of Early Christian Studies (Oxford, 2008) 764-785.

Leyser, Conrad, Authority and Asceticism from Augustine to Gregory the Great (Oxford, 2000). Markus, Robert Austin, The End of Ancient Christianity (Cambridge, 1990).

Miller, Patricia Cox and Dale B. Martin (eds.), The Cultural Turn in Late Ancient Studies: Gender, Asceticism, and Historiography (Durham, 2005).

Negrone, Giulio, De cura minimorum et praecipue de peccati venialis vitatione ... Tractatus asceticus (Milan, 1621).

Nietzsche, Friedrich, Zur Genealogie der Moral (Leipzig, 1887).

Palladius, Historia Lausiaca, ed. Edward Cuthbert Butler, The Lausiac History of Palladius (Cambridge, 1898-1904); Latin translation ed. Adelheid Wellhausen, Die lateinische Übersetzung der Historia Lausiaca des Palladius (Berlin, 2003); English translation by Robert T. Mayer, The Lausiac History of Palladius by Palladius, Bishop of Aspuna, Ancient Christian Writers 34 (Westminster, Md, 1965).

Pez, Bernard, Bibliotheca ascetica antiquo-nova, hoc est: collectio veterum quorundam et recentiorum opusculorum asceticorum, quae hucusque in variis mss, codicibus et bibliothecis delituerunt, vol. 1-12 (Regensburg, 1726-1740; reprint: Farnborough, 1969). 
Pietz, William, The problem of the fetish, I-IIIa, RES Journal of Anthropology and Aesthetics 9, I: (1985) 5-17; II: The origin of the fetish (1987) 23-45; IIIa: Bosman's Guinea and the enlightenment theory of fetishism (1988) 105-124.

Pinsent, John, Ascetic moods in Greek and Latin literature, in: Vincent L. Wimbush and Richard Valantasis (eds.), Asceticism (New York, 1995) 211-219.

Poussines, Pierre, Thesaurus asceticus (Paris, 1634).

Rapp, Claudia and Albrecht Diem, The monastic laboratory: Perspectives of research in late antique and early medieval monasticism, in: Alison Beach and Isabelle Cochelin (eds.), The Cambridge History of Western Monasticism (Cambridge, forthcoming).

Rapp, Claudia, Monastic jargon and citizenship language in Late Antiquity, Al-Masāq: Journal of the Medieval Mediterranean (forthcoming).

Regula Benedicti, ed. Adalbert de Vogüé and Jean Neufville, La Règle de Saint Benoit, SC 181-182 (Paris, 1972).

Rousseau, Philip, Ascetics, Authority, and the Church in the Age of Jerome and Cassian (Oxford, 1978; rev. ed. Notre Dame, IN, 2010).

Rousseau, Philip, Pachomius. The Making of a Community in Fourth-Century Egypt (Berkeley, 1985).

Rubenson, Samuel, Apologetics of asceticism: The life of Antony and its political context, in: Blake Leyerle and Robin D. Young (eds.), Ascetic Culture: Essays in Honor of Philip Rousseau (Chicago, 2013) 75-96.

Schulz-Flügel, Eva, Rufinus Historia Monachorum (Berlin, 1990).

Steiner, Franz Baerman, Taboo, Truth and Religion (New York, 1999).

Sulpicius Severus, Dialogi, ed. Jacques Fontaine and Nicole Dupré, Sulpice Sévère, Gallus. Dialogi de vita Martini dialogues sur les "vertus" de Saint Martin, SC 510 (Paris, 2006).

Sulpicius Severus, Vita Martini, ed. Jacques Fontaine, Sulpice Sévère, Vie de Saint Martin, SC 133, 1 (Paris, 1967) 247-317.

Theodoret of Cyrrhus, Historia religiosa, ed. Pierre Canivet and Alice Leroy-Molinghen, SC 234 (ch. I-XIV) and 257 (ch. XV-XXXI) (Paris, 1977/1979); English transl. by Richard Price, A History of the Monks of Syria (Kalamazoo, 2008).

Valantatsis, Richard, Constructions of power in asceticism, Journal of the American Academy of Religion 63 (1995) 775-821.

Veilleux, Amand, Pachomian Koinonia 1 (Kalamazoo, 1980).

Veyne, Paul, Did the Greeks believe in their myths? An essay on the constitutive imagination (Chicago, 1988).

Vita Abbatum Acaunensium, ed. Bruno Krusch, MGH SRM 7 (Hannover, 1920) 322-336.

Vitae Antonii Versiones latinae: Vita beati Antonii abbatis Euagrio interprete. Versio uetustissima, ed. Pascal H. E. Bertrand and Lois Gandt, CCSL 170 (Turnhout, 2018).

Vita Caesarii, ed. Germain Morin, Marie-José Delage and Marc Heijmans, Vie de Césaire d'Arles, SC 536 (Paris, 2010).

Vita Patrum Iurensium, ed. François Martine, Vie des Pères de Jura, SC 142 (Paris, 2004).

Wallnig, Thomas, Gasthaus der Gelehrsamkeit. Studien zu Herkunft und Bildungsweg von Bernhard Pez OSB vor 1709 (Vienna, 2007).

Wallnig, Thomas, Thomas Stockinger, Ines Peper and Patrick Fiska (eds.), Europäische Geschichtskulturen um 1700 zwischen Gelehrsamkeit, Politik und Konfession (Berlin, 2012). 
Weber, Max, Gesammelte Aufsätze zur Religionssoziologie, vol. 1: Die protestantische Ethik und der Geist des Kapitalismus (Tübingen, 1920); The Protestant ethic and the spirit of capitalism translated from German by Talcott Parsons (New York, 1930); L'Éthique protestante et l'esprit du capitalisme (Paris, 1964).

Wimbush, Vincent L. and Richard Valantasis (eds.), Asceticism (New York, 1995).

Wimbush, Vincent L. and Richard Valantasis, Introduction, in: Vincent L. Wimbush and Richard Valantasis (eds.), Asceticism (New York, 1995) XIX-XXXIII.

Zedler, Heinrich, Grosses vollständiges Universal-Lexicon aller Wissenschafften und Künste (Leipzig, 1731-1754). Accessed on 26 March 2019: www.zedler-lexikon.de

Zöckler, Otto, Kritische Geschichte der Askese. Ein Beitrag zur Geschichte christlicher Sitte und Cultur (Frankfurt am Main, 1863).

Zöckler, Otto, Askese und Mönchtum (Frankfurt am Main, 1897). 


\section{Greeks and »Greek« Writers in the Early Medieval Italian Papyri}

\section{Edward M. Schoolman*}

This article examines the instances when Greek script was used in the sixth- and seventh-century papyri documents originally preserved as part of the archive of the church of Ravenna. In interpreting these instances, we find both reflections of larger political events and smaller personal choices against the backdrop of continued migration from the Byzantine east to Italy following the conquest of the Ostrogothic kingdom by the armies of Justinian in the middle of the sixth century and the establishment of an exarchate dominated by military officials with various levels of clear "Greek" identity - political, hereditary, religious, and linguistic. Within this framework, participants in the creation of legal documents who were identified as grecus or wrote in Greek script did so for individual and micropolitical reasons that were distinct from conveying an ethnic identity, highlighting differences brought on by the situations in which they participated.

Keywords: Byzantine Italy, Naples, literacy, linguistic identity, ethnic identification, Italian papyri, migration and acculturation

Beginning in 536, the armies of the eastern Roman Empire undertook an invasion and reconquest of the Italian peninsula; by 540 the Ostrogothic kingdom had collapsed, leading to more than a decade of guerilla warfare against the surviving Gothic force. At the conclusion of these hostilities, new groups of easterners who we might identify as "Greeks" in origins and linguistic preference had settled in Italy, primarily in its administrative centers now under the control of the emperor in Constantinople. ${ }^{1}$ With the imposition of this new regime and the integration of soldiers and administrators to areas that possessed longstanding Greek-speaking communities, minorities, and religious institutions, the boundaries of "Greek" identity became harder to interpret, especially given the longstanding practice of using grecus as a pejorative epithet or as a veiled insult. ${ }^{2}$ Even more complex in this context were ideas related to the simultaneous applications of Romanness and Greek or Hellenic

* Correspondence details: Edward M.Schoolman, University of Nevada, Reno, 1664 N. Virginia St, Reno NV 895570308, USA, eschoolman@unr.edu.

1 On the origins of migrants in Italy during this period and various approaches to assessing or measuring the arrival of eastern populations, see Brown, Gentlemen and Officers, 65-69; Guillou, Régionalisme et indépendance, 78-80. In addition to people, physical objects also moved to Italy from the east before and after the Justinianic conquest, with a number identified in Russo, La presenza degli artefici greco-costantinopolitani. 
ethnicity, a subject that has been a recent topic of considerable review. ${ }^{3}$ Although the sixth and seventh centuries offer a number of opportunities to explore these aspects, this article focuses on the manifestations of Greekness when Greek script was used or the term grecus appeared in the process of creating legal documents, in this case those that were part of the archive of the church of Ravenna.

Despite difficulties in interpretation, there can be little doubt that a man who lived in Naples named Stephanus was a grecus, absent any pejorative sense. It was a term he used to identify himself in a donation he made to the church of Ravenna, preserved in its original seventh-century papyrus, and on which he himself wrote in Latin but using Greek script. The challenges in interpreting the term grecus are: first, what did it signify when Stephanus used it himself; and second, what did it mean to those around him. This article offers some preliminary answers to these two questions by re-evaluating the connections between language choice, graphicacy (taking script, and not the language it represents, as a graphical device), and identity in the context of early Byzantine Italy, but also more broadly addresses the contexts of those who wrote using the Greek language or Greek script in the legal documents of the period. The donation offered by Stephanus offers an entry point to examine not only aspects of his own identity in the wake of migration and political reorganization in Italy, but also the limited biographical materials of his contemporary Greek speakers and writer, and how the signalling of "Greekness " was employed through graphical choices, as well as movement through and migration to the environs of Naples in particular.

Stephanus's example survives as a papyrus document preserved in two fragments in the Vatican's collection of Latin papyri documents. ${ }^{4}$ Although incomplete, it includes a large portion of the latter half of the record of the donation to the church of Ravenna. This was executed on behalf of Stephanus, described also as vir illustris and magnificus, who offered property around the town of Gubbio at the very beginning of the seventh century. Like the other donations of this period, this papyrus was prepared by a tabellio (in this case named Theodosius), who was a public notarial official of the city of Rome, as part of the registration of legal documents into the municipal gesta. ${ }^{5}$ This particular copy was likely produced to be part of the records of the church of Ravenna, kept originally to support its claim over this property against the threat that others, especially presumptive heirs who would have been removed from inheritance in favor of the church, might later contest ownership.

3 The work of Anthony Kaldellis, Johannes Koder, and Yannis Stouraitis, has complicated our understanding of the self-identities of "Greeks" as with historical, linguistic, and literary contexts, but primarily from the perspective

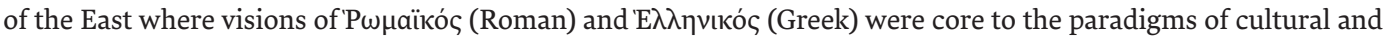
political identities. On account of the lack of self-reflective sources for the most part, these studies avoid the sixth and seventh centuries and the experiences of Byzantine Greek-speakers living in predominantly Latin-speaking areas as in central Italy under discussion here. Kaldellis, Hellenism in Byzantium; Stouraitis, Roman identity in Byzantium; Stouraitis, Byzantine Romanness; Koder, Griechische Identitäten im Mittelalter; Koder, Sprache als Identitätsmerkmal bei den Byzantinern. For notions of Hellenism of varying degrees in Naples in the following century, see Martin, Hellénisme politique.

4 P.Ital.18-19. Rome, Vatican, Biblioteca del Vaticano Pap. Lat. 16 (FrA) and 9 (FrB).

5 The gesta municipalia does not survive long after the creation of this document; however, references to the institution continue to be made through the end of the ninth century. On its operation in the sixth and seventh centuries and its afterlife, see Brown, On the Gesta municipalia; Everett, Lay documents and archives, 70-81. 
What is preserved includes the second half of the transcription of a donation declared orally by Stephanus and recorded by the notary Theodosius, then the written confirmation of the donor Stephanus (in Latin using Greek script), followed by the subscriptions of five witnesses all in their own hands and the closing of the text by the notary and his confirmation of the witnesses. No information survives from the first half of the document either about the actual gift, or when the document was created. The most recent editor of the papyri, JanOlof Tjäder, has dated this papyrus to the seventh century on paleographic grounds, and its content, form, and vocabulary tie it to the beginning of the period. ${ }^{6}$

To understand the application of grecus in the case of Stephanus, we must first examine the other aspects of his identity and their context, specifically his rank of magnificus, the witnesses he gathers to subscribe to his donation, his use of Greek script, and his mobility in Italy and citizenship in the city of Naples. To begin, although Tjäder's edition is more than satisfactory, it is worth looking in depth at this text, focusing on the best-preserved fragment beginning with the tabellio's closing of the proceedings, Stephanus's own subscription, and the first of the identical testaments of the witnesses (see table 1)

6 Tjäder, Die nichtliterarischen lateinischen Papyri Italiens, vol. I , 334-9. Commentary on this text also appears in ChLA 718 and in Crosara, P. Tjäder 18-19AB. 
Table 1: Donation of Stephanus (P. Ital 18-19.B1-34)

1 me haec omnia, quae praesens donationis textus elo[quit]ụr, inviolaviliter cons[erv]are atque adimplere, [cui] rei dolum malum abes[s]e afuturumque esse pro [mitto], eț hạnc donationis a me factae chartulam omni

$5 \quad$ [vi, dol]ọ malo, metu et circumscriptione cessante [T] heodosio v(iro) h(onesto), tabell(ioni) urb(is) Rom(ae), noto rogatarioque meo, [s]cribendam dictavi, cuique subter manu propria

[ag]novi, subscripsi, testibus a me rogịtis optuli subs[crib]endam. Allegandi etiam gestis, quibus vobis [pla]c[u]erit, et tempore, quo volueritis, non spectata [a]lia mea professione conced[o] ex [m] ore licentiam, d[e] [qua] re quibusque omnibus [stipulanti tibi, beatis][simo Domino me]o, et actori[bus s(upra)s(crip)tae s(an)c(t)ae eccl(esiae) Rav(ennatis)] [ego] Stephanus, magnif(icus) illustrius grecus donator, [in] verbis sollemnibus spopondi, et hanc donati[on]em

15 [vo]bis in praesenti contradedi. Act(um) Roma imperio, die anno et indict(ione) s(upra)s(crip)ta. + + +

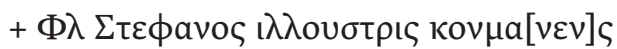

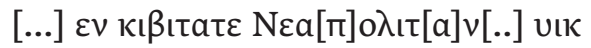

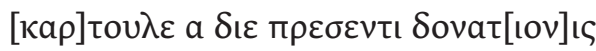

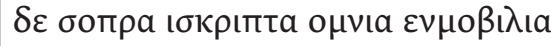

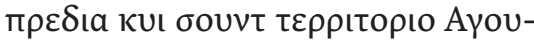

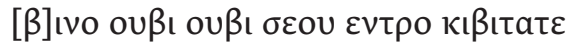

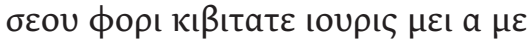

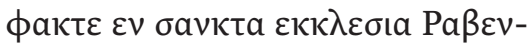

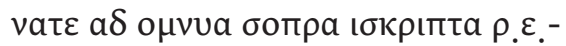

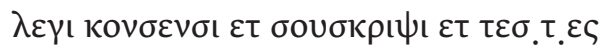

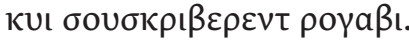
Ioannes, dom(esticus) num(eri) Dac(orum), huic chartule a die presenti donationis de s(upra)s(crip)ta

homnia inmobilia predia, que sunt territorio Agubio, seu intro cibitate seu [f]oris civitate, ubi ubi ei coppețit, facte ab Istefano magṇ[if(ico)] greco inll(ustro) in $\mathrm{s}(\mathrm{an}) \mathrm{c}(\mathrm{t}) \mathrm{a}$

30 eccç̣(esia) rabennate, sicut superius legitur, rogatus a s(upra)s(crip)to donatore, q(ui) $\mathrm{m}(\mathrm{e}) \mathrm{p}$ (raesente)

șụbṣç̣isit, ipso presente testis suscripsi, et hanc donationem in presenti [ac] toribus sce eclesị rabennatis traditam bidi. 


\begin{tabular}{|c|c|}
\hline 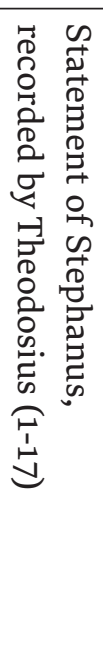 & $\begin{array}{l}\text {... to me all these thing, which being present I spoke aloud the text of the donation. } \\
\text { I promise to preserve and to execute it inviolably, to keep such a thing free of evil } \\
\text { treachery now and in the future. And with all authority, this charter of the pre- } \\
\text { pared donation, while free from evil treachery, fear, and fraud, was made by Theo- } \\
\text { dosius, the vir honestus, tabellio of the city of Rome, known and asked by me, writ- } \\
\text { ing down what I dictated. As these [proceedings] will be registered into the gesta, } \\
\text { those which might be acceptable to you and at whatever time you decide, without } \\
\text { regards to my other concerns, by declaration I grant as is the custom authority } \\
\text { over the very property and all the rest promised to you, my most reverend Lord, } \\
\text { and to the representatives of the above mentioned holy church of Ravenna, that I } \\
\text { Stephanus, magnificus illustrius grecus, the donor, promised in solemn words and } \\
\text { here I have given to you this donation. Executed in Rome, in the reign, day, year, } \\
\text { and indiction noted above. ++ + }\end{array}$ \\
\hline 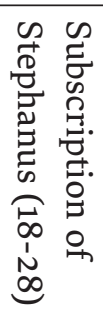 & $\begin{array}{l}\text { I, Fl(avius) Stephanus, illustris, resident in the city of Naples, present at this time in } \\
\text { which this charter of the gift [was made] over all the above mentioned real estate, } \\
\text { which is in the territory of Gubbio, whether in the city or outside of the city, made } \\
\text { by me within my right in favor of the holy church of Ravenna toward all of what is } \\
\text { mentioned above, I have thoroughly read it, I consented to its terms, and I signed, } \\
\text { and I have called for the witnesses to sign. }\end{array}$ \\
\hline 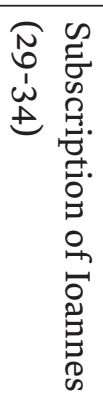 & $\begin{array}{l}\text { I, Ioannnes, domesticus (adjunct officer) of the Dacian platoon, present at this time, } \\
\text { in which this charter of the gift [was made] over all the above mentioned real es- } \\
\text { tate, which is in the territory of Gubbio, whether in the city or outside of the city, } \\
\text { wherever it happens to be, made by Stephanus magnficius grecus inllustrus in favor } \\
\text { of the holy church of Ravenna, just as it is read above, having been asked by the } \\
\text { abovementioned donor, who in my presence has undersigned, I myself signed as a } \\
\text { witness in his presence, and I saw that the donation was handed over in the pres- } \\
\text { ence of the representatives of the holy church of Ravenna. }\end{array}$ \\
\hline
\end{tabular}

The format and language of the text is consistent with other papyri donations, and in general with the other preserved texts from the corpus of Italian documentary sources. For example, Stephanus's statement points to the continuity of concerns about the subversion on account of malicious means or "evil treachery", dolus malus. This expression appears regularly in other texts, from one of the earliest papyri (P.Ital 12, from 491), which consists of donations and documents relating to gifts to the church of Ravenna read out from Ravenna's gesta municipalia (another example of which was done in 540, P.Ital 31), to receipts of land sales from 572 to 619 (P.Ital 35, 36, 38-41). 
The other feature worth noting concerns the practice of recitation in creating the document. Stephanus first completed the donation by having Theodosius "write down what I dictated ", scribendam dictavi. Like the example of keeping an exchange free of treachery, the language around the role of the notarial scribe is reflected in other texts, including both the accounts rerecording documents in the gesta (P.Ital 12 and 31). It is crucial here because it makes clear that even if Stephanus was being fed the proper formula, he clearly had the capacity to speak in Latin and did so, a point that becomes important when reviewing his own subscription.

While the format of this gift is broadly consistent with the other early medieval Italian papyri documents, it also preserved three distinct characteristics specific to the donor, Stephanus, where various aspects of his identity were mentioned or confirmed. The formal execution drawn up by the tabellio Theodosius recorded Stephanus as describing himself as magnificus illustris grecus, that is a Greek (grecus) of the highest aristocratic ranks (illustris) and the highest administrative honor (magnificus). This is the same language used by the witnesses, who included all three in their description of Stephanus. In his own subscription, Stephanus himself forgoes the magnificus and grecus, using the rank of illustris alone but including the fact that he was domiciled in Naples. We further learn from Stephanus's subscription that he included Flavius in his own address in abbreviated form, a common feature in the fourth and fifth centuries. In some circumstances, the abbreviation of $F l$. amounted to little more than a formal designation akin to "Sir" in English. While known in papyri from Egypt, there it was commonly applied in different contexts but also as a qualifier of a particular status. While the exact nature of Flavius in the case of Stephanus is certainly debatable, it likely reaffirmed his high political status. ${ }^{7}$

The use of magnificus is significant here, clearly positioning Stephanus among the most important bureaucrats and administrators in early seventh-century Byzantine Italy through the application of this honor. In the Italian papyri, magnificus only appears in three other instances all predating Stephanus; although from different contexts, its applications indicated individuals of the highest social strata. The first two instances were in a document drafted in 489 , in which a senior administrator Pierius, a comes domesticorum in the government of Odovacar (the title and position known from other sources), and a magister officiorum named Andromachus, were both described with the honor of magnificus. ${ }^{8}$ The charter was produced in Syracuse and confirmed Odovacar's gift of lands in Sicily and Dalmatia to Pierius the year before he would fall in the battle of Adda against the victorious forces of the Ostrogothic king Theoderic (P.Ital 10-11). ${ }^{9}$ After Italy rejoined the eastern Roman Empire, the title appeared once more in the papyri in a petition for guardianship in 557, made by the recent widow and illustris femina Gundihild who was seeking a legal representative in a case concerning the property that had come to her two children in Rieti. In the proceedings, the vir magnificus named Gundirit was listed as having taken an unnamed action against the deceased father (P.Ital 7)..$^{10}$ On onomastic grounds, the parties to this text were Goths or bore some Gothic identity, but still used the same ranks as their late Roman counterparts.

7 Cameron, Flavius: A nicety.

8 Andromachus 3 in PLRE II, 89 and Pierius 5 in PLRE II, 885-886.

9 Wolfram, History of the Goths, 282.

10 Gundirit in PLRE III, 564 and PIB II, 90; Amory, People and Identity, 382. On the case itself, see Everett, Lay documents and archives, 81; Tarozzi, La petitio faciendi tutoris specialis di Gundihild. 
In the 540s, Cassiodorus mentions a number of men styled as magnifici including praetorian prefects and patricians during the Ostrogothic administration of Italy, while the papal epistolary evidence from the second half of the sixth century introduces a number of individuals assigned the rank of magnificus in the letters of Popes Pelagius (556-561) and Gregory (590-604). Their occupations varied, but all were high-ranking administrators, and many were responsible for entire cities and regions: Aemilianus was a magister militum; Constantinus was presumably the governor of Apulia and Calabria; Leo (who later was styled as vir gloriosus), was the praetor Siciliae; Maurentius was a chartularius, traveling to Rome, but likely based in Sicily; and Severus was the scholasticus of the exarch. ${ }^{11}$ The list of magnifici is undoubtedly longer, although Pope Gregory also uses the term adjectively to describe personal qualities, so clarifying its application becomes complex. Ultimately, while no sources reported on how they might have used their ranks and titles in documents, it is with this cohort that we can place Stephanus.

The other identifying "rank « is that of illustris, or as it often appears, inlustris. Although it had been the highest of the senatorial ranks in the fourth century, by the end of the sixth century it had come to be used simply to demarcate elevated status within the imperial administration, and was especially common during the Gothic period. ${ }^{12}$ Because illustris could be employed by those in a wide range of services and positions, and because, unlike magnificus, it had inheritable elements, it appears with much greater frequency, including instances in seven of the Italian papyri. The application of it here simply reaffirms Stephanus's permanent elevated status, as it is what he uses to define himself rather than the earned rank of magnificus.

Beyond his titles, the men asked by Stephanus to witness the act of his donation provide a window in the networks to which he belonged, one in which friendship, occupational status, and hierarchical relationships all could play a role. ${ }^{13}$ Finding the right witnesses was both an exercise of network reaffirmation and a process in which geography and physical proximity were essential. The witnesses not only served as guarantors of the legitimacy of the donation, but they also had to meet for the declaration recorded by the tabellio, who confirmed their identities at the end of the donation with a short roster of witnesses known as a notitia testium, labeled in this early example as notitia testium id est: this is a record of the witnesses. ${ }^{14}$

Each witness followed the same formula as the first, Ioannes, in stating that he was present and that having been asked by Stephanus to attend, declared that: »I signed as a witness in his presence, and I saw that the donation was handed over in the presence of the representatives of the holy church of Ravenna."Because we have the closing of the donation we also know the location in which they likely met: in the outskirts of Rome at the "fourth district, " where the "office" of the tabellio Theodosius was located. ${ }^{15}$ Beyond their presence in

11 Aemilianus: PLRE III, 19 and Aemilianus 3 in PIB I,103; Constantinus 10 in PLRE III, 344 and Constantinus 12 in PIB I, 311-2; Leo 3 in PLRE III, 768 and Leo 14 in PIB II, 270; Maurentius 2 in PLRE III, 852-853 and Maurentius 2 in PIB II, 353; and Severus 4 in PLRE III, 1140.

12 Schoolman, Vir clarissimus and Roman titles, 6-7.

13 Schoolman, Local networks and witness subscriptions.

14 The notitia testium becomes a regular feature of Ravenna's later early medieval parchment and papyri, of which this example from Rome is a geographic and chronological outlier. Schoolman, Vir clarissimus and Roman titles, $15-24,33$.

15 P.Ital 18-19.B58-9, habens stationem in porticum de Subora, reg(ione) quarta. 
that place, each wrote his own subscription, a fact that did not limit the number of witnesses to those who could write but rather underscored the cultural and political groups to which they collectively belonged.

The papyrus contains the written testaments of five witnesses who subscribed to the production of the document:

Ioannes, domesticus numeri Dacorum

Vasacius, vir clarissimus

Chrisogonus, vir clarissimus and cancelarius

Marinus, vir honestus

Dominicis, vir clarissimus and optio numeri Sermisiani

Their identities, and their titles or the position for those that listed them, are reaffirmed in the notitia testium at the close of the record. From this list, two of Stephanus's witnesses were clearly soldiers, Ioannes and Dominicis. Although the order in which they subscribed may prove to offer some guide as to the hierarchy of the group, Ioannes, as a domesticus, stands out. ${ }^{16} \mathrm{He}$ is the only one without a title, even missing the low rank of honestus that commonly served as a sign of the legal ability to witness legal proceedings, but his rank as domesticus and the name of his unit, the numerus Dacorum, offer some insight. Domesticus was a lower grade officer in the seventh-century Byzantine Italian force, and because it could signify one of two different positions, here it likely indicated that Ioannes was the second-in-command of the numerus, a unit of 200 to 400 men typically led by a tribunus. ${ }^{17}$

The name of numerus Dacorum, the military unit to which Ioannes belonged, had a rich history long before the seventh century. Although it is likely that there were multiple iterations, the origins of the first unit called Dacorum date to the beginning of the second century, raised by Trajan or Hadrian in Dacia, and had been posted at locations across the Roman Empire. In 127, a diploma from Britain refers to Aelia Dacorum milliaria, and later inscriptions suggest that the unit was garrisoned at Hadrian's Wall in the third century. ${ }^{18}$ Greek inscriptions from Syria point to the existence of a $v \cup \mu \varepsilon$ po $\Delta a \kappa \tilde{\omega} v$ stationed in Syria in the fifth or sixth century, notably a tombstone of its commander, the tribunus Asterius, found in Apamea. ${ }^{19}$ Because Dacia was lost to the Byzantines by 580 , and the unit must have been raised before that point, it seems likely the numerus was later transferred to Italy, perhaps after its stay in Syria. By the beginning of the seventh century, it was just one of many units garrisoned there described as either numerus or bandus. ${ }^{20}$ 
The other witness who clearly belonged to the Byzantine military was Dominicis. Unlike Ioannes, he was styled with the rank of vir clarissimus, a title that once served to mark inheritable senatorial status but by the end of the sixth century had been applied to many members of the military and administrative service as well as to local urban elites. ${ }^{21}$ It was also the title that had the greatest continuity in the documents from Italy, and is found into the tenth century (although applied through very different criteria and only regularly in documents from Ravenna). Three other witnesses to Stephanus's donation were also clarissimi, Chrisogonus, Vasacius, and Marinus, and it is likely that they all had some official capacity, although only in the case of Chrisogonus was it expressly listed.

The connection between Dominicis and Ioannes was not just in their military service, but also in the origins of their units. Dominicis served as optio, or commander, of what had been a unit originally formed from foederati of foreign mercenaries and raised from northern Pannonia, specifically the area around Sirmium. ${ }^{22}$ Although the unit is not mentioned elsewhere, given the same fate as Dacia it must have existed earlier in the sixth century, and been established in Italy by the early seventh. The position of commander of this exact unit is mentioned a second time in the Italian papyri in the registration of a donation made in Rome contemporary to that of Stephanus. That donation described a gift of land to the "servants" of the Church of Sancta Maria ad Praesepe (now Santa Maria Maggiore) in Rome by a daughter of imperial secretary Megistus and listed the witnesses, including Georgius, optio numeri militum Sermisiani (P.Ital 17.31-2). ${ }^{23}$

The final witness who suggests the breadth of Stephanus's network was the cancelarius Chrisogonus. ${ }^{24}$ The role of cancelarius (or cancellarius) in the sixth century was relatively low status. In Cassiodorus's Variae, he includes a letter to a cancellarius Iohannes, in which he praised the man for advancing in ability beyond his position in the official hierarchy. ${ }^{25}$ By the seventh century, the position remained that of a functionary who served the administration, normally under a higher-ranking official, including examples where they served a praetor, iudex, and notarius, but was clearly a bureaucratic rather than military position.

What we can take away from this group of witnesses is that Stephanus chose men of lesser status and rank to legitimate his donation, men who had served the administration of Italy and could have been his past or current subordinates. The selection of two officers attached to units with origins on the eastern Latin frontier indicates that he had connections to those units, perhaps serving as magister militum overseeing both. More concretely, his selection of these officers along with the recipient of the donation, the church of Ravenna, also further binds him to the Byzantine administration. Despite the fact he was a grecus, he belonged within the same structures of authority as his Latin-speaking (or at least Latin-writing) witnesses.

Yet, he also belonged to another group, one that used Greek script either by choice or by necessity. This is apparent in how Stephanus wrote his own confirmation of the donation, which while in Latin, is transcribed in Greek script (table 2).

Schoolman, Vir clarissimus and Roman titles.

On the position of optio, which originally designated »quartermaster, « see Brown, Gentlemen and Officers, 59-60.

Ravegnani, Le unità dell'esercito bizantino, 201-202.

Chrysogonus 6 in PIB I, 296.

Cassiodorus Variae, XI.6.2. 
Table 2: Subscription of Stephanus (P.Ital 18-19, 18-28)

\begin{tabular}{|c|c|}
\hline Original text & Transliteration to Latin Script \\
\hline 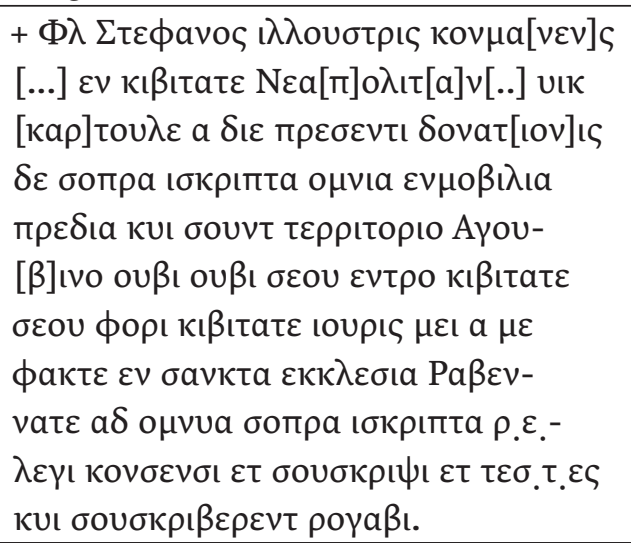 & $\begin{array}{l}\text { + Fl. Stefanos Illoustris conmanens } \\
\text { [...] in civitate Neapolitan[... uic } \\
\text { cartoule a die presenti donationis } \\
\text { de sopra iscripta omnia inmobilia } \\
\text { predia cui sount territorio Agou- } \\
\text { bino oubi oubi seou entro civitate } \\
\text { seou fori civitate iouris mei a me } \\
\text { facte en sancta ecclesia Raven- } \\
\text { nate ad omnia sopra iscripta re- } \\
\text { legi consensi et souscripsi et testes } \\
\text { cui souscriverent rogavi. }\end{array}$ \\
\hline
\end{tabular}

To form this kind of transliteration, it must have been the case that Stephanus was a fluent writer of Greek and had been trained as such, but likely did not have that capacity in Latin, or he acted as if he was essentially illiterate or unlettered in Latin script. Despite the relative flexibility of the form of the donation, Stephanus was being fed the proper Latin formula, and while he spoke and listened, he also transcribed the text.

Transcriptions like these are useful in illustrating the qualities of early medieval Latin and Romance vernacular, such as the continuity of dropping of the "n « in "iscripta" (for "inscripta «), a feature of modern Italian that dates back to the Oscan and Umbrian languages. ${ }^{26}$ Furthermore, the phonology does not seem to represent a version of grecicized Latin, but likely a longstanding local Latin dialect with these features.

In this case, the use of this script is emblematic of the acceptance and even preference of certain individuals to use Greek script in the production of legal documents: while the entire proceedings of many of these events took place in Latin, these byproducts suggest that Stephanus was able to signal a difference though his script, using graphical representations to confirm aspects of his status and identity. Stephanus was not alone in this regard. While the alternative phenomenon of writing Greek in Latin script had been long attested in the papyri from Egypt, it is primarily the documents from sixth and seventh century Italy that provide evidence for this particular type of graphical switching, writing Latin in Greek script, although there are a few notable earlier examples and the practice becomes common in southern Italy from the ninth century on.

26 The loss of the - $n$ - is also a feature of Oscan and Umbrian, Buck, Grammar of Oscan and Umbrian, 70-71. Illustrations of the conservative elements of various aspects of the phonology of this Latin as found in Greek transcriptions extends to other examples, such as $\beta$ for v noted at the beginning of the Common Era in Nishimura, Notes on Glide Treatment, 199-200. 
Perhaps the best studied of the early examples was written in Ravenna (but preserved in Egypt), a receipt for the sale of a slave of Asechines Flavianus to T. Memmius Montanus, who served in the Ravenna fleet. James Adams has carefully reviewed this document in its entirety, which features the Latin subscription of Asechines written in Greek script. ${ }^{27}$ Asechines was from Miletus, but his location in Italy and the fact that he seemed to have "awareness" of Latin morphology suggests that he had more than a simple familiarity with the language. In taking the whole of the errors and choices made, Adams concluded that although »the text is formulaic, Aeschines' own input can be detected, and this input provides evidence for the language use of a Greek with imperfect command of Latin as a second language. ${ }^{28}$

Because he both dictates the formula of the donation and then subscribes, the case of Stephanus suggests that his Latin was much more fluent than his Greek predecessor Asechines. Similarly, the possibility that Stephanus commanded units in the west also underscores a facility with Latin, but serving in the military was not the primary condition in which we find graphical switching. In fact, even though the total number of papyri from Italy is small, more than $10 \%$ have Latin written in Greek script, or a hybrid form of the two, and the case of Stephanus is the only one that indicates the practice extended to those in high-ranking administrative positions.

In 58 examples of non-literary papyri documents in the corpus, the use of Greek script for the subscriptions of witnesses appears in six instances excluding that of Stephanus, dating back to the first years after the Byzantine conquest of Italy (table 3).

Table 3: Witnesses using Greek Script in the Italian Papyri

\begin{tabular}{|c|c|c|}
\hline Text and type & Date & Witness \\
\hline $\begin{array}{l}\text { P.Ital } 30,92-97 \\
\text { Bill of sale }\end{array}$ & 539 & 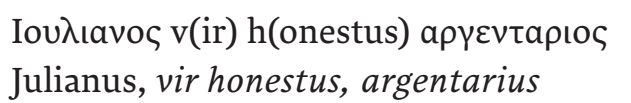 \\
\hline $\begin{array}{l}\text { P.Ital } 36,55-58 \\
\text { Bill of sale }\end{array}$ & $575-591$ & 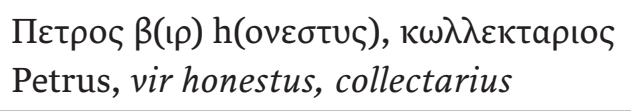 \\
\hline $\begin{array}{l}\text { P.Ital } 37,78-83 \\
\text { Bill of sale }\end{array}$ & 591 & 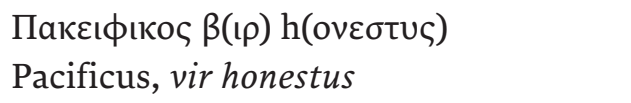 \\
\hline $\begin{array}{l}\text { P.Ital 16, 38-49 } \\
\text { Donation to the church of Ravenna }\end{array}$ & c. 600 & 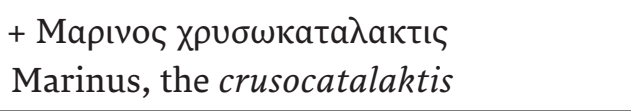 \\
\hline $\begin{array}{l}\text { P.Ital 20, } 83-90 \\
\text { Donation to the church of Ravenna }\end{array}$ & c. 600 & 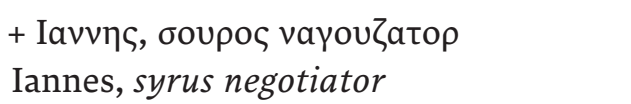 \\
\hline $\begin{array}{l}\text { P.Ital } 24,9-20 \\
\text { Donation to the church of Ravenna }\end{array}$ & $\begin{array}{l}\text { mid-70os } \\
\mathrm{AD}\end{array}$ & $\begin{array}{l}{[\ldots . . .] \mathrm{v}(\mathrm{ir}) \mathrm{h} \text { (onestus) }} \\
\text { a vir honestus [the remaining subscrip- } \\
\text { tion is in Greek script] }\end{array}$ \\
\hline
\end{tabular}

27 Adams, Bilingualism and the Latin Language, 53-63.

28 Adams, Bilingualism and the Latin Language, 61. 
These examples prove instructive as at least pointing to the groups engaged in this type of graphical code-switching, which only appears when witnesses or participants are required to subscribe to the closing of a legal agreement.

Out of the six other examples, four labeled themselves as viri honesti, in its abbreviated form, sometimes in Latin script, others in Greek or what appears to be a hybrid. According to Tom Brown, as a rank honestus was "predominantly ... applied to all well-to-do laymen who did not possess an official honor, including artisans, traders and notaries as well as landowners. The main characteristic of an honestus was his full judicial capacity ..." including the ability to act as a witness in court and subscribe to legal documents, which our writers exercised here. ${ }^{29}$ The title seems to have also been connected to Justinianic legislation, on the basis of the evidence from the documentary sources as well as those from legal statutes, the positions covered by honesti were similar to those who benefited from the exemption of civic duties named in Codex Iustinianus X.66.1, after an edict of Constantine from 337, and who included, among others, artisans such as sculptors, doctors, and even bankers (well represented in the examples above). ${ }^{30}$

Only four can be identified by their occupations. Three of these men were bankers or provided money-changing services of various types and one was a negotiator, an occupation which seemed to blend the divisions between trading, banking, and the wholesale distribution of goods. And in fact, Greek speakers or those with origins in the east as a whole were overrepresented in banking and finance, especially in Ravenna where our documentation is the strongest. ${ }^{31}$

The individual who held the occupation of argentarius and served as a witness in the sale of 539, and therefore was also the earliest of the witnesses to write in Greek, shared a name and title with one of the most well-known patrons of the mid-sixth century: the argentarius Julianus, who paid for the construction of San Vitale in Ravenna and Sant'Apollinare in Classe, among other churches according to the Liber pontificalis of Agnellus. Julianus operated in Ravenna in the first years after the fall of the Ostrogothic kingdom during the subsequent Gothic war and establishment of Byzantine rule, operating both as a banker and lender but likely also involved in commercial ventures as agentarii had long done. Although the title originally referred to silverwork, it had evolved to describe a position with a wide range of banking activities in the first and second centuries; yet it could be applied to a number of different situations and with a great degree of flexibility. ${ }^{32}$ In the case of Julianus, he may also have served in a government capacity, financing state enterprises through loans to taxpayers, or provided needed liquidity during the Gothic wars. ${ }^{33}$ Whatever the source of his income, his position allowed him to accumulate enormous wealth, to the point that he was

29 Brown, Gentlemen and Officers, 213-214.; see also Patlagean, Les armes et la cité à Rome, 48-52.

30 Schoolman, Vir clarissimus and Roman titles, 8-9.

31 Brown, Ebrei e orientali a Ravenna, 139-140.

32 Andreau, Banking and Business, 33-34. By the end of the sixth century, the title of argentarius would return to being applied to silversmiths who were not professionally lending money. Using Gregory Epistolae XI.16, Lopez, An Aristocracy of Money , 23, noted that: »Pope Gregory the Great was forced to intervene to save from bankruptcy the last argentarius doing business as a banker in Rome; the argentarii who are mentioned after that time seem to have been ordinary silversmiths." On the development of the terminology, see Roueché, Aurarii in the Auditoria.

33 Barnish, The Wealth of Iulianus Argentarius, esp. 34-36. Iulianus 7 in PLRE III, 730-1. 
able to contribute 26,000 solidi to the construction of San Vitale. ${ }^{34}$ That Julianus held Greek in a privileged position is visible in his patronage through the placement of a monogram of Iouגıavo in San Vitale, reaffirming his status as a member of the recently reinstalled elite from the East. ${ }^{35}$

Whether the Julianus argentarius who sponsored churches in Ravenna was one and the

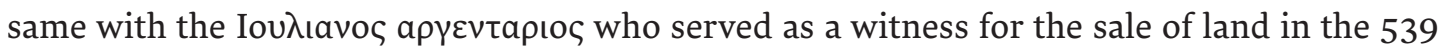
papyrus ( $t a b .3$, no. 1) is unclear. ${ }^{36}$ They had much in common, however, as both preferred to use Greek script if not Greek language, but the contexts where they were put to use differed. For the patron, supporting the churches of Ravenna was both a sign of his wealth and a manifestation of his civic euergitism, and his monogram (placed alongside that of the emperor Justinian) rightly signaled his status and allegiances.

For Iouגıavo the witness, something else was at play. The 20-iugera of land was being sold by a mother, Thulgilo, and her children, Dominca and Deutherius; Deutherius was, like many of the witnesses, a vir honestus. The buyer was Pelegrinus, who must have been of some means, as the agreed price of 110 gold solidi indicates wealth, and some of his wit-

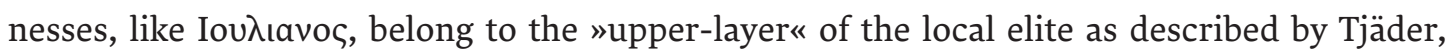
although others seem to have been lower-ranking officials. ${ }^{37}$ Furthermore, Thulgilo has a clearly Gothic name, and one of the witnesses, Latinus, may have subscribed to another document with a Gothic name, so the group in total represents the diversity of post-conquest Ravenna. It is in this milieu that Iouגıavos as a witness belongs, certifying the porous nature of local elites at that moment.

One further note of information about Iovilavo is that the notitia testium offers another distinguishing feature (which perhaps could have been used to differentiate him from the patron and argentarius Julianus), that he was the gener lohanni pimentari (P.Ital 30.109), the

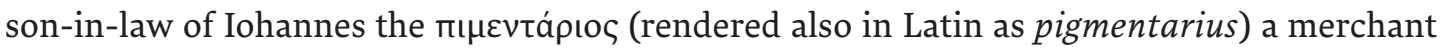
who traded in spices and unguents, or less likely also colors and paints, and who would have maintained strong links to the eastern Mediterranean through his professional contacts.

We have less information about the other witnesses, but they all likely operated within similar contexts. Petrus ( $t a b .3, n o .2$ ) was a collectarius, an occupation well-attested in the papyri of Italy that served to benefit a local administration by specific kinds of currency exchange. Tom Brown has identified this as "collecting in gold coins on behalf of the state from the public in return for copper. $\aleph^{38}$ Petrus appeared as a witness to the sale of half a fundus from the honestus Deusdedit to the clarissimus Hildigernus for 14 solidi; he was selected owing to his connection to the local government, or as the notary added, he was located ante custodia charceris, in front of the local jail (P.Ital 36.67). Marinus, who subscribed to a dona-

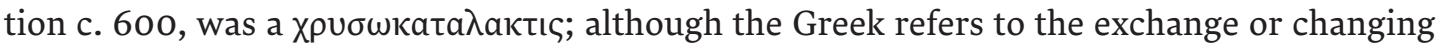

This amount was, however, a miniscule amount compared to the cost of Hagia Sophia in Constantinople, for example. Laiou and Morrisson, Byzantine Economy, 187-88.

35 Deichmann, Ravenna, vol. 2, 21-27.

36 The Iou $\lambda$ ıavos from this papyrus is mentioned under Iulianus 7 in PLRE III, 730-1. Likewise, they share an entry as Iulianus 12 in PIB II, 233.

37 Tjäder, Die nichtliterarischen lateinischen Papyri Italiens, vol. 2, 56, „Die Zeugen gehören zum Kreis der niedrigen öffentlichen Diener und der oberen Schicht der Bürgerschaft.«

38 Brown, Gentlemen and Officers, 77. 
of gold, it would be synonymous with argentarius in terms of the main activities, changing lower types of currency into more valuable ones or vice versa, an undertaking that was more of a banking role than the collectarius. ${ }^{39}$ What is clear is that Petrus was serving as a witness at least 40 years after the Byzantine occupation of Ravenna, and Marinus at least 65 years later, which indicates that administrators were either still being recruited from the East or, less likely, that those descended from the first generation maintained a preference for Greek even in terms of writing.

There are a number of reasons to support the first position, of the continued arrival of Greeks, as opposed to the second, that in communities with large numbers of Latin speakers, second-generation elites continued to learn the script as well as speak Greek. The first is a relatively common feature in all of the subscriptions, in which formulaic Latin abbreviations are rendered even in Greek characters. The example of the subscription of Marinus has another interesting feature, a case in which the Greek-writing subscriber seems to be following a written formula. In his subscription to P.Ital 16, in his first two lines he writes:

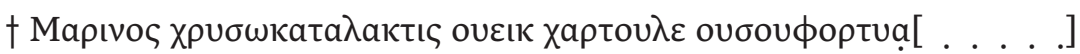

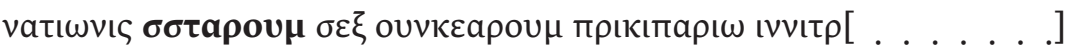

The form $\boldsymbol{\sigma \sigma \tau \alpha \rho o u \mu}$ is nothing other than a partial abbreviation of $\mathbf{s}$ (upra)s(crip)tarum, which is the form generated by the other witnesses..$^{40}$ In the example of Petrus's subscription, he first has trouble with rendering his own title in Greek and resorts to a hybrid abbreviation with a $\beta$ representing the "V« in vir and a Latin "h" for honestus (this is what Pacificus, or rather Паквıфıкос, another Greek-writer also did), as well as offering $\sigma \sigma$ for all forms of superscriptus where the Latin writers would often indicate the case endings. These instances demonstrate that most witnesses were working from a formula, and even if they had familiarity with Latin, there was sometimes difficulty in rendering the Latin in a consistent way.

Yet more persuasive is that one Greek-writing witness, the negotiator Ioannes, offered a glimpse of additional differentiation, as he also used the term syrus as a mark of his origins, either by birth or by heredity. Like Stephanus, this application of syrus in the Latin papyri is a hapax, only appearing in this instance, but when taken with the example of Stephanus's grecus supports the position that origins were included in the production of these agreements, perhaps as a way of differentiating two individuals or more likely to follow a self-declaration.

As with Stephanus, the names of these men give nothing away as to their political identity. They were simply common names, although some had derivations not in Greek or Christian

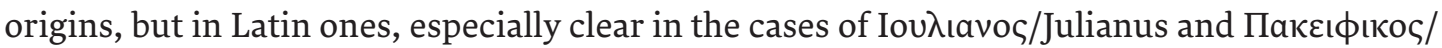
Pacificus. But unlike Stephanus, who belonged to a higher social and occupational category altogether, none of these men describe themselves, or are described, as grecus.

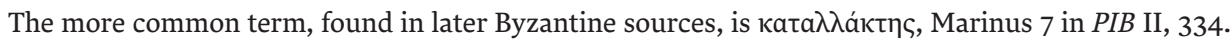

40 This was noted in the commentary of Tjäder and recognized as a feature in medieval charters in von Falkenhausen, Medieval Neapolitan document, 178. 
Instead of using grecus to describe the origins or heredity of individuals, the term appears more commonly to be a descriptor for the use of Greek script, which becomes clear in the case of a fragmentary papyrus register that collected the records of a number of openings and executions of wills. In one will (from between 552 and 575) a witness confirmed being present at the will's creation and that he recognized his signature "in Greek letters" (grecis litteris), and then further subscribes to its authenticity. ${ }^{41}$ The notary recorded the statement of Theodolus, a silk merchant (olosiricoprata), during the opening of the will of Georgius who shared the same occupation: »Theodolus, vir clarissimus, silk merchant said: I am present here willingly; I recognize on this document the seal of my ring, and the things I wrote above in Greek letters (grecis litteris), and I subscribe to this below." In that same collection of wills, at least two other individuals acknowledged their Greek letters, although the papyrus does not preserve anything further about their identities. ${ }^{42}$

In fact, in the early Italian papyri, the Latin adjective grecus is used almost exclusively to describe not only script, but also written language. The best evidence is preserved in a very early list of charters held by the treasurer of the praetorian prefect in Ravenna, created after 510. In this case, out of the 44 documents listed, four are described as being in Greek:

Line 5a: Another cautio of Macedonius in Greek made on the behalf of Peter for 1100 solidi.

Line 23a: A cautio in Greek of John, and John addressed to Peter for 1000 solidi in the consulship of Boethius the Younger, vir clarissimus ( = 510 AD).

Line 27a: A cautio made in Greek of Paul addressed to Peter for solidi numbering 100 and [....] in the consulship of Venantius ( = 507 AD).

Line 16b: Greek letter addressed to Peter. ${ }^{43}$

These listings, for a letter and three cautiones, a type of legal document guaranteeing future payment, all seem to be connected to a certain Peter, who may have had them entered together into the archive along with other documents related to his ventures, although given the limits of the text and its preservation, there can be no certainty.

All these examples demonstrate a certain kind of migration of Greek speakers to Italy, and one that pre-dated the conquest of Italy under Justinian, although significantly more conspicuous and better documented in the second half of the sixth century. What the donation of Stephanus suggests is that there would have been a great deal of individual mobility, at least within the territory under Byzantine control, although much of this is undocumented and likely undocumentable. The case of Stephanus, however, illustrates various links and paths that were likely well-travelled. Through his donation, we know that he owned land around Gubbio,

41 P.Ital 4-5.B8, Theodolus v(ir) c(larissimus) olosiricoprata d(ixit): pleriquae et ego interfui in hac voluntate, in qua agnosco anuli mei signaculum, superscribtionem meam grecis litteris, et infra subscribsi.

42 P.Ital 4-5.A1 and A5.

43 P.Ital 47-8.A5, cautio Macedon[i a]lia greca facta ad n(omen) Petri sol(idorum) mille cento. P.Ital 47-8.A23, cautio greca Iohannis et Iohannis ad n(omen) Petri sol(idorum) M Boethio Iun(iore) v(iro) c(larissimo) consul(e).

P.Ital 47-8.A27, c.[au]tio greca Pauli facta ad nom(en) Petri sol(idorum) n(umero) C[ . . . . ] Ṿeṇenati[o] c.[onsu]le. P.Ital 47-8. B16, ẹ[p]istula greca facta ad nomen Petri. 
which he either received for his service or purchased, and likely visited. Whatever his level of service, he would have had to travel to Ravenna where the exarchs were based, and perhaps his career there (and the fact that it had remained the administrative capital) made his donation also a reconfirmation of his membership to its community. The donation itself was given in Rome, in front of a Roman notary, and with witnesses who presumably were relatively local. Why Stephanus chose to make his gift in Rome rather than in Ravenna or in Naples is elusive, but the fact that he was in a third location further underscores his mobility.

What also sets Stephanus apart from the other Greek writers was that in his subscription to his donation he confirmed his home, that he was conmanens [...] in civitate Neapolitan[...], "residing in the city of the Neapolitans." Both archaeological studies and contemporary sources dating back to Justinian's conquest offer some details about the city when Stephanus was a resident. New geomorphological and paleo-ecological reconstructions offer a glimpse into the city's development, with the establishment of new farmland in silted harbors to the west and the subsequent development of harbors to the east and the rise in visibility of chestnuts on the landscape, all in the fifth century. ${ }^{44} \mathrm{~A}$ broad synthesis of the archaeological data supports the idea that commerce and manufacturing remained strong in the city during Late Antiquity, especially after the fifth-century decline of what had been Campagna's main port, Puteoli. ${ }^{45}$

Reference to Naples' continued trade in the first half of the sixth century, and with it connections to the east, appear as an anecdote in Procopius's Gothic Wars. On the eve of Belisarius's attack against the city on which he had set siege (on account of the fact that it had been favorable to Ostrogothic rule), the Neapolitans sent out a man named Stephanus, who debated with Belisarius about the fate of the city but ultimately returned to attempt reconciliation and convince the Neapolitans to accept Justinian's forces. In describing his exhortations to avoid battle through capitulation, Procopius offered this aside: "Stephanus reported the speech of Belisarius and expressed his own opinion that it was unwise to fight against the emperor. He was assisted in his efforts by Antiochus, a Syrian man who had long been resident in Naples for the purpose of carrying on a shipping business, who had a great reputation there for wisdom and justice. ${ }^{46}$ Although others would successfully argue against Stephanus and Antiochus, the fact that even during the Ostrogothic dominion of Italy, cities like Naples and Ravenna drew foreigners like Antiochus and Julianus and his father (described above), explains a crucial feature. These communities did not form with the arrival of Justinian's armies, but rather grew out of those predating the sixth century, and were originally composed of Greeks concerned with mercantile and banking interests that later incorporated soldiers and administrators working directly for the exarchate.

44 Russo Ermolli et al., Natural and cultural landscape of Naples, 408-409. On the importance of chestnuts in early medieval Italy, see Squatriti, Landscape and Change.

45 Arthur, Naples, from Roman Town to City-State; Arthur, Naples: A Case of Urban Survival.

46 Procopius, Gothic Wars V.8. Trans. after Dewing. 
During the Gothic wars, Naples fared poorly, suffering a year-long siege by Totila that ended with the city's capitulation and the raising of its walls. Procopius noted that Totila treated the citizens and the Byzantine garrison fairly, and by the end of the sixth century we can see that Naples had resumed its trade connections in the letters of Pope Gregory, but larger problems of cohesion remained. The Liber pontificalis described that in the early seventh century, during the papacy of Deusdedit (615-618), an independent commander appeared, John of Compsa (or Conza), who was later removed by the exarch Eleutherius. Finally, in 663, Naples welcomed the emperor Constans II as he travelled through Italy. This history, of Naples being pulled toward Byzantine rule, the papacy, and its own independence would continue until the middle of the eighth century. Its citizens reflect the influence of these various forces, and perhaps these are at play in the physical mobility of the magnificus Stephanus and his choice for the recipient of his donation.

Ultimately, grecus as applied to Stephanus must not only be understood as a personal quality, but also as a part of his larger identity. His titles of magnificus and illustris place him within the reestablished Byzantine military and administrative hierarchy in operation in Italy in the late sixth and early seventh centuries. The invocation of grecus as recorded by the notary and reiterated by the witnesses, clearly positions him as a member of a minority linguistically or ethnically - and along with his focus on the church of Ravenna as a member of an administration sent from afar. The use of Greek for his subscription, if a choice rather than out of necessity, connects to an observation made by Adams: "Some writers using Greek characters for the Latin Language did so not because they were unable to use Latin script, but because they chose to transliterate on a particular occasion. « ${ }^{47}$ Including the now unnamed witness to P.Ital 24, a donation of a garden in the city to the church of Ravenna made by Gaudiosus, vir reverentissimus and defensor sanctae ecclesiae Ravennatis, in the middle of the seventh century, Stephanus would be the last to use Greek in extant documents until the ninth and early tenth centuries, when Greek writers reappear in the case of the earliest surviving Neapolitan charters. ${ }^{48}$

Although he may have been a grecus, he was also a citizen of Naples, a magnificus, a donor to the church of Ravenna, and a man who could rely on military commanders to legitimate his gift. Yet among all these attributes, the self-reference as grecus was crucial, a micropolitical act that excluded Stephanus from the Latin speakers and writers and grouped him among an elite cohort of "Romans « not from Italy but from the east, sent by Constantinople to defend and govern Italy in the wake of the arrival of the Lombards.

47 Adams, Bilingualism and the Latin Language, 43.

48 Schoolman, Local networks and witness subscriptions, 39. On Greek subscriptions in the charters from Naples in the ninth and tenth century in general, Luzzati Laganà, Le firme greche, and von Falkenhausen, I documenti napoletani; for one of few surviving original charters, see von Falkenhausen, Medieval Neapolitan document. 


\section{Acknowledgements}

This article is part of a larger study on Greeks and the appearance of Greek identity in early Medieval Italy (500-1000), research for which was undertaken on the Wolfgang Fritz Volbach-Fellowship at the Leibniz-WissenschaftsCampus Project (RGZM, Mainz) in the Summer of 2017, as a visiting researcher in DiSSGeA (University of Padua) in the fall of 2017, and as a member of the DFG Center for Advanced Studies group on "Migration and Mobility in Late Antiquity and the Early Middle Ages« (Eberhard Karls Universität Tübingen) in the spring and summer of 2018. I would also like to acknowledge the financial support of the Office of the Provost and the Office of the Vice President for Research and Innovation at the University of Nevada, Reno. 


\section{References}

Adams, J. N., Bilingualism and the Latin Language (Cambridge, 2003).

Amory, Patrick, People and Identity in Ostrogothic Italy: 489-554 (Cambridge, 1997).

Andreau, Jean, Banking and Business in the Roman World, translated by Janet Lloyd (Cambridge, 1999).

Arthur, Paul, Naples, from Roman Town to City-State: An Archaeological Perspective (London, 2002).

Arthur, Paul, Naples: A Case of Urban Survival in the Early Middle Ages?, Mélanges de l'Ecole française de Rome, Moyen-Age 103 (1991) 759-784.

Barnish, S. J. B, The wealth of Iulianus Argentarius: Late antique banking and the mediterranean economy, Byzantion 55 (1985) 6-38.

Brown, Thomas S., Ebrei e orientali a Ravenna, in: Antonio Carile (ed.), Storia di Ravenna: II.1 Dall'età Bizanina all'èta Ottoniana: Territorio, economia e società (Ravenna, 1991) 135-154.

Brown, Thomas S., Gentlemen and Officers: Imperial Administration and Aristocratic Power in Byzantine Italy A.D. 554-80o (Rome, 1984).

Brown, Warren, On the Gesta municipalia and the public validation of documents in Frankish Europe, Speculum 87 (2012) 345-375.

Buck, Carl Darling, A Grammar of Oscan and Umbrian (2nd edition), (Boston, 1928).

Cameron, Alan, Flavius: A nicety of protocol, Latomus 47 (1988) 26-33.

Cassiodorus Variae = Magni Avrelii Cassiodri, Variarum libri XII, ed. Åke Jason Fridh, in: Magni Avrelii Cassiodri Senatoris, Opera, vol. 1, CCSL 96 (Turnhout, 1973).

ChLA $=$ Chartae Latinae antiquiores: facsimile edition of the Latin charters prior to the ninth century, ed. Albert Bruckner and Robert Marichal, vol 1-114 (Olten, 1954-2013).

Crosara, Fulvio, P. Tjäder 18-19AB e la Chiesa ravennate, in: Antonio Guarino and Luidi Labruna (eds.), Synteleia Vincenzo Arangio-Ruiz (Naples, 1964) 696-699.

Deichmann, Friedrich Wilhelm, Ravenna: Hauptstadt des spätantiken Abendlandes, 3 vols (Wiesbaden, 1958-1989).

Dubuisson, Michel, Graecus, Graeculus, Graecari: L'emploi péjoratif du nom des grecs en

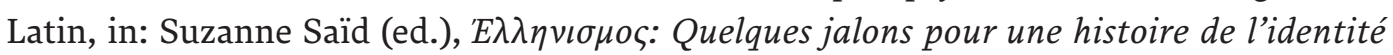
grecque (Leiden, 1991) 315-335.

Everett, Nicholas, Lay documents and archives in early Medieval Spain and Italy, c. 400-700, in: Warren Brown, Marios Costambeys, Matthew Innes and Adam Kosto (eds.), Documentary Culture and the Laity in the Early Middle Ages, (Cambridge, 2013) 63-94.

Gregory, Epistolae = Gregorius Magnus, Registrum epistularum, ed. Dag Norberg, CCSL 140104a (Turnhout, 1982).

Guillou, André, Régionalisme et indépendance dans l'Empire Byzantin au VIIe siècle (Rome, 1969).

Holder, Paul, Auxiliary units entitled Aelia, Zeitschrift für Papyrologie und Epigraphik 122 (1998) 253-262.

Kaldellis, Anthony, Hellenism in Byzantium: The Transformations of Greek Identity and the Reception of the Classical Tradition (Cambridge, 2008).

Koder, Johannes, Griechische Identitäten im Mittelalter - Aspekte einer Entwicklung, in

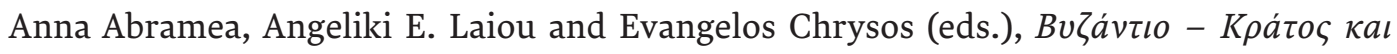

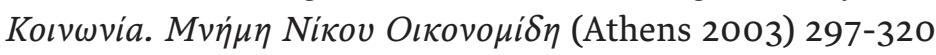


Koder, Johannes, Sprache als Identitätsmerkmal bei den Byzantinern: Auf -isti endende sprachenbezogene Adverbien in den griechischen Quellen, Anzeiger der philosophischhistorischen Klasse 147 (2012) 5-37.

Laiou, Angeliki E., and Cécile Morrisson, The Byzantine Economy (Cambridge, 2007).

Lopez, Robert Sabatino, An aristocracy of money in the early Middle Ages, Speculum (1953) $1-43$.

Luzzati Laganà, Francesca, Le firme greche nei documenti del Ducato di Napoli, Studi Medievali, ser. 3. 23.2 (1982) 729-752.

Martin, Jean-Marie, Hellénisme politique, hellénisme religieux et pseudo-hellénisme à Naples (VIIe-XIIe siècle), Nea Rhome 2 (2005) 59-78.

Nishimura, Kanehiro, Notes on glide treatment in Latin orthography and phonology: -icio, servus, aio, Historische Sprachforschung 124 (2011) 193-209.

Patlagean, Evelyne, Les armes et la cité à Rome du VIIe au IXe siècle et le monde européen des trois fonctions sociales, Mélanges de l'Ecole française de Rome. Moyen-Age, Temps modernes 86 (1974) 25-62.

P.Ital = Die nichtliterarischen lateinischen Papyri Italiens aus der Zeit 445-700, ed. Jan-Olof Tjäder, vol. 1-2 (Lund, 1955; 1982).

PIB = Prosopografia dell'Italia bizantina: 493-804 (v. 1: A-F, v. 2: G-O), ed. Salvatore Cosentino (Bologna, 1996; 2000).

Pollard, Nigel, Soldiers, Cities and Civilians in Roman Syria (Ann Arbor, 2000).

PLRE II = The Prosopography of the Later Roman Empire, part II: AD 395-527, ed. J. R. Martindale (Cambridge, 1980).

PLRE III = The Prosopography of the Later Roman Empire, part III: AD 527-641, ed. J. R. Martindale (Cambridge, 1992).

Procopius, Gothic Wars = Procopii Caesariensis opera omnia, vols. 1-2, ed. Gerhard Wirth (Leipzig: 1962-1963); trans. H. B. Dewing, Procopius, History of the Wars, Volume III: Books 5-6.15, Loeb Classical Library 107 (Cambridge, MA, 1916).

Ravegnani, Giorgio, Le unità dell'esercito bizantino nel VI secolo tra continuità e innovazione, in: Stefano Gasparri (ed.), Alto medioevo mediterraneo (Florence, 2005) 185-205.

Roueché, Charlotte, Aurarii in the Auditoria, Zeitschrift für Papyrologie und Epigraphik 105 (1995) 37-50.

Russo Ermolli, Elda, Paola Romano, Maria Rosaria Ruello, and Maria Rosaria Barone Lumaga, The natural and cultural landscape of Naples (southern Italy) during the Graeco-Roman and Late Antique periods, Journal of Archaeological Science 42 (2014) 399-411.

Russo, Eugenio, La presenza degli artefici greco-costantinopolitani a Roma nel VI secolo, Jahreshefte des Österreichischen Archäologischen Institutes in Wien 75 (2008) 243-298.

Schoolman, Edward M., Local networks and witness subscriptions in early Medieval Ravenna, Viator 44 (2013) 21-41.

Schoolman, Edward M., Vir clarissimus and Roman titles in the early Middle Ages: Survival and continuity in Ravenna and the Latin West, Medieval Prosopography 32 (2017) 1-39.

Squatriti, Paolo, Landscape and Change in Early Medieval Italy: Chestnuts, Economy, and Culture (Cambridge, 2013).

Stouraitis, Yannis, Roman identity in Byzantium: a critical approach, Byzantinische Zeitschrift 107 (2014) 175-220. 
Stouraitis, Ioannis, Byzantine Romanness: From geopolitical to ethnic conceptions, in: Walter Pohl, Clemens Gantner, Cinzia Grifoni and Marianne Pollheimer-Mohaupt (eds.), Transformations of Romanness in the Early Middle Ages: Regions and Identities (Berlin, 2018) 123-139.

Tarozzi, Simona, La petitio faciendi tutoris specialis di Gundihild in P.Ital. 1,7, in: Gisella Bassanelli Sommariva and Simona Tarozzi (eds.), Ravenna Capitale: Territorialità e personalità (Santarcangelo di Romagna, 2013) 107-26.

Tjäder, Jan-Olof, Die nichtliterarischen lateinischen Papyri Italiens aus der Zeit 445-70o, vol. I. (Lund, 1955).

Tjäder, Jan-Olof, Die nichtliterarischen lateinischen Papyri Italiens aus der Zeit 445-70o, vol. II. (Lund, 1982).

von Falkenhausen, Vera, A medieval Neapolitan document, The Princeton University Library Chronicle 30 (1968-1969) 171-182.

von Falkenhausen, Vera, I documenti napoletani come fonte per lo studio delle interferenze Greco-Latine (IX-XII secolo), in: Rosanna Sornicola and Paolo Greco (eds.), La lingua dei documenti notarili alto-medievali dell'Italia meridionale: bilancio degli studi e prospettive di ricerca (Cimitile, 2012) 107-126.

Wolfram, Herwig, History of the Goths (Berkeley, 1988). 


\title{
Resenting Byzantine Iconoclasm. Its Early Reception in Italy through an Inscription from Corteolona
}

\author{
Francesca Dell'Acqua and Clemens Gantner*
}

A source which can be dated to $c .730$ has never been discussed as evidence of an early reception of Byzantine iconoclasm in Italy. Now lost, this was an inscription put up to celebrate the foundation of a church in the newly established royal residence of the Lombard king Liutprand (712-744) in the countryside of Pavia along the river Olona, known as Corteolona. The inscription tells us that in the time in which >Caesar Leo fell into the pit of schism from the summit of righteousness persuaded by a miserable scholars, Liutprand dedicated a church to Saint Anastasius the Persian. Therefore, the inscription makes use of the perceived heterodoxy of the Byzantine ruler - his attitude towards sacred images - as a chronological and negative cultural reference. In the inscription, Liutprand is cast as a champion of the Catholic Church as opposed to the heterodox Leo III (717-741). This claim naturally had wider political implications: Liutprand wanted to be seen as the supreme ruler on the Italian peninsula. The inscription from Corteolona, with others from Pavia and its surroundings, was transcribed in the late eighth century and thus transmitted to posterity. Having often escaped the attention of those interested in the echoes of Byzantine iconoclasm outside Byzantium, its text is an important document since it suggests that in early eighth-century Lombard Italy, at least in some circles, it was believed that Emperor Leo III was acting against orthodoxy, and that this could potentially lead to a schism within the Catholic Church. In the same years, the early 730s, the papacy too reacted to rumours of heterodoxy in the east, specifically in Constantinople: both a letter by Pope Gregory III (731-741) and the Roman Liber Pontificalis attest to this.

Keywords: Byzantine iconoclasm, Liutprand (King of the Lombards), Corteolona, Saint Anastasius the Persian, Emperor Leo III, Paul the Deacon, Sylloge Laureshamensis, Lombard Italy, Papacy

* Correspondence details: Dr. Francesca Dell'Acqua, Dipartimento di Scienze del Patrimonio Culturale, Università degli Studi di Salerno, Via Giovanni Paolo II, 84084, Fisciano (Salerno), Italy, fdellacqua@unisa.it.

Dr. Clemens Gantner, Institut für Mittelalterforschung, Österreichische Akademie der Wissenschaften, Hollandstraße 11-13, 3. Stock, 1020 Wien, Österreich, clemens.gantner@oeaw.ac.at.

Though the contribution has truly been a collaborative effort, each author was responsible for particular sections: Francesca Dell'Acqua wrote the chapters on Saint'Anastasius the Persian and on the material appropriation of Rome in Italy, plus has generally been responsible for questions of material culture and inscriptions, as well as Liutprand's laws, whereas Clemens Gantner was responsible for the papal sources connected with the topic, political history between the Lombards, popes and Byzantium and the question of the alleged instigator of iconoclasm. The introduction, conclusion and the central chapter on the text of the Corteolona inscription and the Lorsch manuscript containing it can only be assigned to both. 


\section{Introduction}

This paper discusses a lost inscription originally set up in the church or in the monastery of Saint Anastasius the Persian annexed to Corteolona, a new residence the Lombard king Liutprand (712-744) established in the countryside of Pavia along the river Olona in the late 720s-early 730s. Known to scholars of Lombard Italy, the inscription has indeed been mentioned by researchers dealing either with the image of Liutprand as sovereign or with Lombard literacy. ${ }^{1}$ But despite offering an interesting and rare witness to an early reception of Byzantine iconoclasm (or controversy on sacred images) in Italy, it is absent even in thorough overviews of the subject. ${ }^{2}$ Here we intend to focus on what the inscription transmits about Byzantine iconoclasm and, at the same time, comment on its wider implications for the cultural and political history of the reign of Liutprand. The question of the transmission of the inscription, which is an intriguing issue, will also be addressed in this paper.

\section{The inscription - text and translation}

The following are the transcription and the translation of the first and the third inscriptions from Corteolona preserved in the Sylloge Laureshamensis (Rome, BAV, Pal. lat. 833), to which we shall return later. The first text reads:

Ecce domus domini perpulchro condita textu emicat et vario fulget distincta metallo.

Marmora cui pretiosa dedit museumque columnas

Roma caput fidei, illustrant quam lumina mundi.

Euge auctor sacri princeps Leutprando [sic!] laboris, te tua felicem camabunt acta per aevum qui proprie gentis cupiens orare triumphos his tituilis patriam signasti denique tot[a]m. ${ }^{3}$

Behold the house of the Lord, built with beautiful materials, it shines forth and glistens, decorated with various metals. Rome, the capital of the faith, has given it its precious marble, mosaics and columns - oh how these give light to the eyes of the world! Rejoice for Prince Liutprand, the author of this holy work! Your deeds will proclaim you fortunate throughout time, you, who, desiring to decorate the triumphs of your people, have stamped the whole country with these inscriptions. ${ }^{4}$

On the inscription, see Calderini, Il palazzo di Liutprando, 179-180; Badini, Concezione della regalità; Everett, Literacy, 248-250 (who does not discuss the figure of the mentioned emperor or the philosopher or which schism it was); Vircillo Franklin, Latin Dossier, 16-18; Lopez-Jantzen, Kings of all Italy?; Lauxtermann, Lombard epigram.

2 It has apparently escaped the attention of Noble, Images; and Brubaker and Haldon, Byzantium: A History, see ibid. 79-127.

3 BAV Pal. Lat. 833, fol. 48v. Emended in current editions.

4 Translation by Everett, Literacy, 248-250, adapted by the authors. 
The third inscription from Corteolona is the most relevant to the present study:

Quando Leo cecidit, misero Doctore suasus, scismatis in foveam recto de culmine Caesar, tunc ego regales statui his mihi condere thermas marmoribus pulchris Leutbrant Rex atque columnis.

Sed Romam properans postquam devotus ad ipsam perveni atque sacro capiti mea basia fixi Sancti Anastasii, servus tuus, ecce repente paterna de sede meo hanc in pectore, Christe, praeclaram fundare domum sub culmine monstras. Talibus unde meas tendens ad sidera palmas vocibus oro: 'Dei Fili, pro plebe fideli, Qui regis angelicos coetus, qui cuncta gubernas, Fac, precor, ut crescat mecum catholicus ordo, et templo concede isti ut Salomoni locutus. ${ }^{5}$

At the time Caesar Leo [the emperor] fell into the pit of schism from the summit of righteousness persuaded by a miserable scholar, I, King Liutprand decided to have baths built for myself, using these beautiful marble columns. But later I hastened, as a devoted man, to Rome herself - when I arrived there, as your [Christ's] servant, I kissed the holy head of Saint Anastasius. And see, all of a sudden, you, Christ, show me in my bosom from your heavenly seat that I am to donate this magnificent house [church] under the roof [of the palace]. Hence, elevating my hands towards the stars, I pray with these words: 'Oh son of God, for the faithful people, you, who leads the host of angels, you, who reigns over everything, I beg you, to make the Catholic community grow with me and support this temple, as was promised to Solomon< ${ }^{6}$

\section{The chronological context and the question of sacred images}

Those above are the two main inscriptions transmitted from Corteolona. ${ }^{7}$ They relate to many questions whose full analysis exceeds the scope of the present paper. We must focus on a selection of them, foremost among which is the reference to the Byzantine emperor seen as sschismatic . Let us first consider the chronological context of this unprecedented declaration.

The longer inscription under study ('Quando Leo cecidit`) claims that Liutprand had already established his residence at Corteolona by the time he went to Rome on a pilgrimage as a devout man. This spiritual experience evidently resolved him to abandon the idea of using Roman marble and columns to build baths and build instead a church. It should be stated clearly that there is no precise historical or archaeological data about the foundation of the residence of Corteolona nor of the church of Saint Anastasius the Persian. The area of the former Lombard court is under a working farm and has not been investigated by archaeologists. ${ }^{8}$ We are left with only the chronological hint to the establishment of the church of Saint Anastasius in the inscription that Liutprand commissioned after his visit to Rome.

5 Versus xii, In Ecclesia Beati Anastasi, ed. Dümmler, 106.

6 Translation by the authors, using Everett, Literacy.

7 There is a third inscription recorded, second in the manuscript. It is only two lines long and in hexameter, see BAV Pal. Lat. 833 , fol. $48 \mathrm{v}$.

8 See Calderini, Il palazzo di Liutprando. The authors were unable to consult Riccardi, Le vicende. 
The king arrived outside Rome twice during his tenure, on both occasions actually threatening the city and the pope. But he entered Rome only once, in 729. He was invited after prolonged negotiations, which led to a compromise between the Lombard kingdom, and its ally, the Byzantine exarch of Ravenna on the one side and the papacy, and its allies, the Lombard dukes of Spoleto and Benevento on the other side. Liutprand is said to have put down his coat at St Peter's confession as a devout gesture on this occasion..$^{9}$ Ottorino Bertolini linked the occasion of Liutprand's first visit in 729 to the establishment of the church at Corteolona. ${ }^{10}$ Carmela Vircillo Franklin instead favours a later date for the establishment of the church, connected to Liutprand's second visit to Rome in $739 .{ }^{11}$ We will see why the first date, c.729, is the most likely for the Roman pilgrimage mentioned and, at the same time, a terminus post quem for the dedication of the church and for the inscription. It is very likely that both happened between 729 and the early 730 s.

In order to understand what happened, we need to give a short introduction to the communication and conflict-triangle of the Lombards, the papacy, and the Byzantines in the early eighth century. The second half of the 720 s was a difficult time for Italy: Emperor Leo III, in reaction to continuous problems with the Umayyad caliphate in the east, raised taxes in the Italian provinces. With no significant military help coming from the east, these had been under pressure from the Lombard kingdom and the semi-independent duchies of Spoleto and Benevento for quite some time, and hence were disinclined to obey their eastern overlords. The result was what has rightfully been called a stax war between Rome and the Exarchate of Ravenna, which had been entrusted with executing the emperor's orders. Our best source on these events, the Roman Liber Pontificalis, that is the papacy's semi-official chronicle, gives a detailed account of these circumstances, although with an important alteration, as we shall see. ${ }^{12}$ At first, the Lombards helped defend Rome and Pope Gregory II (715-731) against the army of Ravenna. Note that at this point our source does not distinguish between the different Lombard powers. Soon thereafter, probably in 727, we are informed that the exarch had allied himself with Liutprand, king of the Lombards since 712. Both threatened Rome, but Liutprand soon broke off the military engagements and started to negotiate a peace agreement, the exact terms of which we do not know. Thomas Noble is probably spot on with his interpretation that Liutprand wanted to break the existing alliance between the southern Lombard duchies and the papacy, and the peace treaty seems to have resulted in just that. We do not know what the agreement with the exarch Eutychius which must have been reached during the same negotiations entailed, but we do know that in this case, too, a feeble accord was the outcome. ${ }^{13}$ Matters were, however, even more complicated. During the tax controversy, the countryside to the north of Rome, called Roman Tuscany at the time, had been in outright insurrection. The rebels supported an imperial pretender, called Tiberius Petasius.

10 Bertolini, Roma e i Longobardi, 38-42. This date is accepted by Badini, Concezione della regalità, 290-291, 299; Everett, Literacy, 248; Lopez-Jantzen, Kings of all Italy?, 85. See also: Berto, Liutprando, re dei Longobardi. Vircillo Franklin, Latin Dossier, 16, follows Giorgi, Il Regesto del monastero di S. Anastasio ad Aquas Salvias, 53. 
Maybe it was Pope Gregory II taking a firm stance against this usurpation that got him a deal with Byzantine representatives. The latter, at an earlier point in the conflict, had even plotted the assassination of the pope, as the Liber Pontificalis also informs us, so the relations must have been rather strained. ${ }^{14}$ Certainly Liutprand withdrawing the support of the largest army on the peninsula would have further induced the exarch to come to terms.

To this already complex narrative, the Liber Pontificalis added another major ingredient: it claimed that all the quarrels, which the text itself never styles as a war, resulted from the emperor wishing to impose a ban on images in the Italian province. An attempt to arrest and kill the pope is explained thusly: >A few days later the emperor's wickedness that made him persecute the pontiff became clear: to force his way on everyone living in Constantinople by both compulsion and persuasion to take down the images, wherever they were, of the Saviour, his holy mother and all the saints, and, what is painful to mention, to burn them in the middle of the city $<.{ }^{15}$

The entry for Gregory II was, with quite some certainty, started when the pope was still alive, but it was finished at the time of his successor Gregory III (731-741). Another, revised version of the Life of Gregory II was produced later, probably under Pope Zachary (741-752). Iconoclasm, or rather, more fitting to the worldview of the Liber Pontificalis, the image controversy, is present in both versions. Bede, active at the monastery of Jarrow in Northumbria used the older version of Gregory II's Life by the mid-730s at the very latest, as he died in 735, indicating that a first version of the Life was already circulating in the early 730 s. $^{16}$ Whether or not the attribution of spurring iconoclasm to Leo III was already part of this text-version cannot be proven, but it is very likely that some information tending in that direction was indeed part of it from an early date, and was certainly included when the earlier version of the Life was finished during the pontificate of Gregory III.

Liutprand visited Rome soon after he had concluded his negotiations with the papacy and restored to their property the castellum of Sutri, which he had seized in 728 , to Pope Gregory II. ${ }^{17}$ The sovereign wished to reconcile with the papacy, while he was keen to display his position as the supreme secular ruler of the peninsula. His attacks against the Byzantine Exarchate in 727 have been read in this light. ${ }^{18}$ We should pay attention to the fact that laws Liutprand promulgated in the late 720 s further manifest his intention to underline his status as supreme, orthodox, benign ruler of the whole Italian peninsula. ${ }^{19}$ Promulgating laws and displaying public inscriptions was a way of promoting the image of a ruler - undoubtedly, there remains a question of audience, since literacy was the prerogative of few, but laws were made for all. ${ }^{20}$

Gantner, Freunde Roms, 26-27, with n. 57: the terminus ante quem for this text is 735, but we do not know whether a full version reached Bede in northern England.

17 LP, Gregory II, c. 21, ed. Duchesne, vol. 1407.

18 Lopez-Jantzen, Kings of all Italy?, 85.

19 Badini, Concezione della regalità, 297, who bases his interpretation on Bertolini and Violante, Germani, 274; Everett, Literacy, 251; Lopez-Jantzen, Kings of all Italy?, 85. See also Pohl, Legal pluralism. At the conference >Liutprando re dei longobardi< (May 2018), Germana Gandino delivered a paper about Liutprand and his idea of sovereignty as projected by his laws which has not been published yet.

20 Everett, Literacy, is dedicated to this aspect in Lombard Italy before the conquest of Charlemagne. 
All the same, it is worth reporting a couple of excerpts where Liutprand speaks in the first person in a tone that seems echoed by the Corteolona inscription, despite the latter being more emphatic. This is what Liutprand says in the prologue to his laws of 727 :

We have taken care to add those provisions which we believed to be pleasing to God and to good men ... First of all, in defence of our Christian and Catholic law we make provision that no one may presume to wander from the faith of Christ, that we may have God as a defender and helper firmly and permanently in all things. ${ }^{21}$

And this is what he proclaims in 728 :

We have added to the ancient lawbook those laws which we regarded as beneficial to our soul and contributing to the salvation of our nation. We now in a like manner with divine aid in order that perjury may not occur nor quarrels arise among our faithful people [fideles], acting together with our judges and with the Lombard faithful people, add [these laws] on this first day of March in the sixteenth year of our reign, Christ protecting, in the eleventh indiction: we call upon God as our witness [that we do this] not for any vain glory or human praise but to please almighty God and remove our subjects from error. ${ }^{22}$

As said, the dating of the Corteolona inscription is closely related to the king's pilgrimage to the relic of Anastasius the Persian in Rome. A date for the pilgrimage - and for the inscription - in the late 730 s is not supported by the historical circumstances. While we have no clear indications about the developments of Byzantine iconoclasm in these years, ${ }^{23}$ the political scenario in Italy was changing. After 735 Liutprand did not issue laws and his voice is not heard as it was in the previous decade. Apparently in c.734, before or after the siege he laid to Ravenna, the king was afflicted by an illness that impaired him to the point that Lombard aristocrats delegated his power to his nephew Hildebrand. ${ }^{24}$ By 739 , however, Liutprand, evidently in better health, was campaigning against Rome and in the same year he joined forces with his nephew against the Byzantine Pentapolis. ${ }^{25}$ Therefore, Liutprand's second journey to Rome was no devout pilgrimage. He would only come to better terms with the pope in 742. In the meantime, the papacy had restored its good relations with the Byzantine Empire, because now the Lombard

21 Laws of Liutprand, ed. Pertz, 141: IIam enim vicibus illa in antico edicti corpore aucmentare previdemus, quae credimus deo et bonis hominibus placita esse .... Primum omnium statuere previdemus pro christianae et catholicae legis defensione, quatinus nullus a fide Christi oberrare presumat, sed firmiter in ea permanentis deum possemus habere defensorem atque propitium‘; English trans. Fischer Drew, Lombard Laws, 180.

22 Laws of Liutprand, ed. Pertz, 146-147: >Pluribus iam quidem vicibus in antiquo edicti corpore ea adiungere curavimus quae pro salute animae et gentis nostrae salvatione esse prospeximus; nunc itaque simili modo ea considerantes, quae secundum deum recta esse cognovimus, ut nec periura nec iurgia inter nostros emergantur fideles, una cum nostris iudicibus atque fidelibus langobardis, et modo presenti tempore die kalendarum martiarum anno Christo protegente regni nostri XVI, indictione XI, iterum adiungere, deum invocamus testem, non pro aliqua vana gloria aut laude humana querendum, sed dei omnipotenti placendo et nostros de errore tollendo subiectos<; English trans. Fischer Drew, Lombard Laws, 185-186.

23 Brubaker and Haldon, Byzantium: A History, 79-89.

24 Paul the Deacon, HL, vi, 55, ed. Waitz, 184.

25 At the conference 'Liutprando re dei longobardi< (May 2018), Claudio Azzara delivered a paper about Liutprand and his relationship with the popes which has not been published yet. 
king was the common enemy. ${ }^{26}$ Walter Pohl has pointed to the fact that all historiography we have on these events aims at construing an antagonism between the Lombards and the papacy, with the former clearly in the role of the aggressor. Not even Paul the Deacon, the author of the History of the Lombards, escapes this black and white scheme, because his main source for this period was the Liber Pontificalis. ${ }^{27}$ Unsurprisingly then, the preserved sources, be they of papal, Frankish or even Lombard origin, do not show Liutprand in a favourable light at this point, certainly not as the pious, benign, and orthodox ruler he was promoting himself as ten years earlier and as which he emerges from the longer Corteolona inscription.

We should remark that the inscription does not mention a specific theological controversy when noting that Emperor Leo had fallen into the pit of schism, with this implying that his actions could lead to a schism within the Catholic Church. ${ }^{28}$ But the only theological controversy which Leo III is associated with is that concerning sacred images. There is no proof that Leo issued an edict against sacred images in 726 or that he ordered the destruction of an image of Christ on the main door of his Constantinopolitan palace, as later historiography maintained. ${ }^{29}$ What the controversy about sacred images really was at first is not clear, and nor was it to its contemporaries. Its origins as well as its traits in the 720 s remain blurred despite an abundant scholarly production about it. As Leslie Brubaker and John Haldon have noted, 'while we will never know what exactly was known in Rome about what was happening in Constantinople, it seems clear that something to do with images, which was construed in some way as a threat, had attracted comment, in Rome at least.${ }^{30}$ The inscription tells us that this controversy, blurred as it seemed in the West, had nonetheless attracted comments at the Lombard court. The chosen expression sschism ‘ clearly signals that such a danger within the Catholic Church was truly feared as the consequence of Leo's unorthodox behaviour. In northern Italy, the events of the Three Chapter Controversy, which had put the episcopal sees there into opposition with nearly all centres of the empire, eventually also including Rome, were surely still in the back of everyone's mind. After all, communion in the Church had only been restored at the synod of Aquileia in $698 .{ }^{31} \mathrm{~A}$ split opinion and division within ecclesiastical ranks is also what the Constantinopolitan patriarch Germanos feared and expressed in a letter he wrote to a bishop between 720 and 730 , which is only known through the acts of the iconophile Council of Nicaea II (787)..$^{32}$ That contesting sacred images could lead to divisions in the Church is confirmed decades later by the sacra, or opening letter, addressed by emperors Irene and Constantine VI to the bishops convened at the Council of Nicaea II: it insists on the importance of ecclesiastical speace and concord.$^{33}$

26 Brubaker and Haldon, Byzantium: A History, 89, support the idea that the relations between the papacy and the empire had been tainted by fiscal and not doctrinal questions in the 720 s and early 730 s.

27 Pohl, Das Papsttum und die Langobarden.

28 Vircillo Franklin, Latin Dossier, 17, with no hesitation writes that the orthodoxy of Liutprand is contrasted 'with the heresy of the Byzantine ruler Leo (III Isauricus), the supporter of iconoclasm،.

29 For an appraisal of the evidence, see Brubaker and Haldon, Byzantium: A History, 119-135.

30 Brubaker and Haldon, Byzantium: A History, 86.

31 On the Three Chapter controversy see Sotinel, Dilemma des Westens.

32 Mansi, XIII, 105B-E; ACO II, 3.2, ed. Lamberz, 450-453; Brubaker and Haldon, Byzantium: A History, 94-98, and 101 on schism.

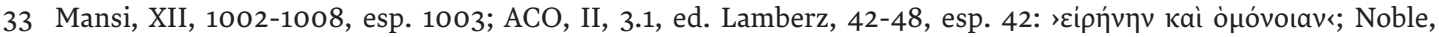
Images, 77-78. 
Who was the miserable scholar?

The longer inscription from Corteolona mentions a miserable scholar ('misero doctore ‘) who is to be blamed for having misguided Leo into the pit of schism. There is no hint as to whose was this learned but perverted mind, which had brought the emperor under the yoke of heresy. In the acts of Nicaea II, a priest recalls a story in which a Jewish soothsayer, named Tessarakontapechys or also Sarantapechys, the Caliph Yazid, and Leo feature simultaneously. The Jewish soothsayer (Hebraios) convinces the caliph to persecute Christians and also indirectly has an influence on Leo's actions against sacred images. Scholars maintain that this is the first secure reference to an alleged Islamic or Jewish influence on Leo's iconoclasm. ${ }^{34}$ Our inscription alludes to the influence of a bad advisor on the emperor already by $c .730$, without giving further information on that man's ethnic or religious background. It is possible that the Corteolona text is a very early witness to the legend of the bad advice in the making.

An alternative would be that the author of the inscription meant one of the several theologians who were involved in the development of a new doctrine of sacred images at that very time. These could have been collectively addressed with the smiserable doctor of the inscription. In the Latin of the eighth century, the term doctor was often used for theologians or religious scholars. For instance, Saint Augustine is frequently labelled as such. Therefore, we should ask who was meant by this expression. We know that Patriarch Germanos of Constantinople had been replaced by Anastasios, possibly his former pupil, in January 730. It is still impossible to say whether the inscription is actually referring to Anastasios, as next to nothing is known about the latter's theological position early in the conflict. Anastasios' defection to the iconophile usurper Artabastos between 741 and 744, accompanied by support for the iconodules at that time may indicate that he was neither a big ideologue nor the main instigator of a doctrine against images..$^{35}$ Other theologians are very prominent in later texts about iconoclasm, for example Bishop Constantine of Nakoleia. ${ }^{36}$ The problem here is that it is far from likely that these scholars could be implicated in having influenced the emperor directly, having no tangible connection to the court.

The connection between Emperor Leo and bad advisors was obviously made quite casually in later decades. This is proven by the synodical letter Pope Hadrian I sent shortly before the Second Council of Nicaea, included in the acts of the council. ${ }^{37}$ Considering our scarce information, we have to admit that we are unable to pinpoint who the smiserable scholar was. But this is not the point here either. There were indeed several candidates, who could

34 Mansi, XIII, 197B-20oB; ACO II, 3.2, ed. Lamberz, 590-595 (Actio V). See Speck, Ich bin's nicht, on the developments of this legend, that involved at one point also Leo III's son Constantine V; Brubaker and Haldon, Byzantium: A History, 116. Speck has argued, sometimes in a formulaic way, for a later date of documents related to Byzantine iconoclasm on the assumption that in the late eighth century iconophiles forged documents or interpolated them in order to exaggerate the iconoclasts « wrongs and essentially re-write the history of eighth-century Byzantium.

35 PmbZ, no. 285, Anastasios (Eirenaios), retrieved on 19 Feb. 2019: www.degruyter.com/view/PMBZ/PMBZ11367.

36 See Brubaker and Haldon, Byzantium: The Sources, 94-105 for these theologians. On Constantine see: PmbZ, no. 3779, Konstantinos, retrieved on 19 Feb. 2019: www.degruyter.com/view/PMBZ/PMBZ14929.

37 Mansi XII, 1060D-1061B; ACO II, 3.1, ed. Lamberz, 127: ^Sed ipse vester proauus per quorundam impiorum immissiones easdem deposuit sacras imagines, et ex hoc error magnus in ipsius Greciae partibus accrevit et ingens scandalum in universum evenit mundum. Hadrian's letter was included in an abridged version, excluding information unfavourable for the Byzantine Empire, see Lamberz, Falsata Graecorum more?. 
be implicated in this early stage of anti-image policy. It is very likely that one of these protagonists - or even a personal advisor to the emperor - was meant here. The most interesting feature of this part of the text is that the smiserable doctor/scholar clearly takes some of the blame away from Emperor Leo. In the eyes of a medieval onlooker, however, that would not have been enough: a good, God-loving emperor would also choose the right advisors, thereby preventing himself getting into this situation. In the inscription, Liutprand, who speaks to us in the first person, acknowledges that a ruler can indeed be misled by the experts he employs as advisors - only to emerge himself as a wise and orthodox ruler.

\section{The pious sovereign and the Persian martyr}

The Corteolona inscription casts Leo III as a schismatic, that is, as a heterodox ruler. As a matter of fact, for some years Leo III enjoyed the role of champion of the faith in having defended Constantinople from the Arab siege of 717 and having put an end to the monothelete revival of Philippikos Bardanes. His achievements as a practical and effective sovereign have been remarked by scholars reversing the bad image which iconophile sources of the late eighth century drew of him..$^{38}$ But although the role Leo had in the early stages of the iconoclastic controversy remains unclear, he must have at the very least tolerated the iconoclast argument and activities`, as noted by Brubaker and Haldon. ${ }^{39}$ Therefore, if we accept a date for the Corteolona inscription around 730, we have to conclude that Leo III must have gained a bad reputation in association with iconoclasm long before the late eighth century. We should also remark that the target of the Corteolona inscription is not Leo's active stance in favour of a potentially schismatic religious policy, but rather his lack of firmness against it (through the reference to a miserable scholar), and his negligence as sovereign and custodian of values, including religious orthodoxy.

We should now consider for which purpose the Corteolona inscriptions intended to exploit the (supposed) bad name of the Byzantine emperor. Liutprand and his advisors must have sensed that something 'wrong w was going on in the Eastern Church and that it could threaten the unity of Christendom as a whole. How they became aware of these unfolding and still quite obscure events relating to Leo's misconduct remains conjectural, although there were several persons or institutions in Italy that were apparently well informed, including the pope. It remains the case that they were quick to understand that these circumstances could turn into an opportunity. With Leo III in schism, Liutprand could rise to the role of the main protector of the Church headed by Rome, and potentially acquire the influence and prestige associated with the Byzantine emperor, the supreme ruler in the Christian world. ${ }^{40}$ In the Corteolona inscriptions, Liutprand clearly embraces this opportunity. In line with his predecessors who, after abandoning Arianism became integrated in the Catholic Church, ${ }^{41}$ and against the hetherodox Byzantine emperor Leo, Liutprand wishes to be seen

38 Brubaker and Haldon, Byzantium: A History, 69-155, evaluate a vast body of evidence.

39 Brubaker and Haldon, Byzantium: A History, 140.

40 See Gantner, Label Greeks.

41 After Aripert I (d. 661), Lombard kings abandoned Arianism. Paul the Deacon portrays them as pious rulers, see for example Perctarit (d. 688), HL, V, 33, ed. Dümmler, 155; Hallenbeck, Pavia and Rome, 15. See Cornford, Paul the Deacon, 52, on Paul the Deacon's 'willingness to incorporate himself into a Latin and Catholic identity<. 
as the true defender of the Catholic faith. He appears as a self-styled champion of orthodox faith: praying with his palms upward, he wholeheartedly invokes the help of the Son of God to make the Catholic faith grow with him. Rome is addressed as sthe capital of the faith', to which the sovereign had hastened in pilgrimage. Embracing Rome with its political and religious legacy had vast implications. The supremacy of Rome in the Christian oecumene had been recognised at the Sixth Ecumenical Council held in Constantinople in 680-681 and was ratified by the Byzantine emperor Constantine IV..$^{42}$ As Benjamin Cornford has epitomised, >The strength of the Roman-Christian discourse was such that the equation of this civilised ideal of Catholic Romanitas with the imperial idea of universality retained a clear potency in the eighth century ${ }^{4}{ }^{43}$

The final line of the longer inscription mentions King Solomon and his temple. Solomon and Emperor Justinian, who erected the Hagia Sophia in Constantinople, would be recalled by Paul the Deacon in verses praising the Duke of Benevento Arichis II, ${ }^{44}$ who had taken the reins of the Lombard people after Charlemagne's conquest of Langobardia Maior. Aldo Badini has remarked that in the case of Liutprand, Solomon offered an important role model not only because he built a temple to the Lord. Solomon represented the idea of a legitimate sovereign, of the kind Liutprand aimed at being recognised as since his power had been contested by some Lombards. ${ }^{45}$ Finally, Solomon represented the idea of a sovereign entitled to mediate between his subjects and God and therefore to control and coordinate the ecclesiastical organisation (1 Kings 2, 26-27).

We should now turn back to the question of Liutprand's establishment of a church dedicated to Anastasius the Persian. As mentioned, Liutprand visited the monastery of Saint Anastasius ad aquas salvias, not far from St. Paul outside the walls. ${ }^{46}$ This in all probability happened when he first went to Rome, in 729. The longer Corteolona inscription says that he paid his respect to the saint by kissing his head. Only a few years earlier, in 713, the head of Anastasius had performed a miracle in Rome which was recorded in Greek immediately afterwards, likely

42 Letter from the theologians convened at the council to Pope Agatho, in the Acts of the Sixth Ecumenical Council,

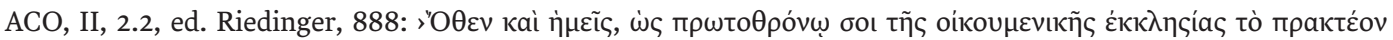

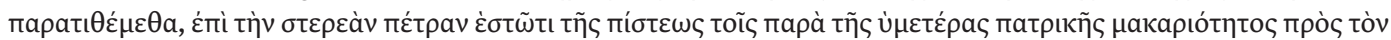

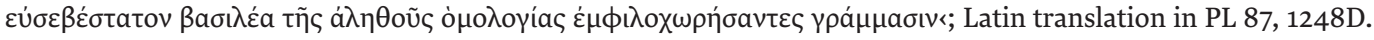

43 Cornford, Paul the Deacon, 60.

44 Paul the Deacon, Versus de Arichi duce, VII, 4-5, ed. Dümmler, MGH, PLAK 1, 45: `Regnator tibi summe decus trinominis ille / Hebreae gentis Solymis construxit asylumr. On Paul the Deacon's praise of Justinian as an ideal model for rulership, see HL, I, 25, ed. Dümmler, 62; Pohl, Creating cultural resources, 28. On Solomon, Justinian, and Arichis, see Everett, Literacy, 250; Falla Castelfranchi, Arechi II e Giustiniano, 83; Dell'Acqua, Arechi II, 80-81, 83-84. Paul the Deacon also extolled Arichis as ıcatholicus princeps‘, see Versus de Arichi duce, VI, 13, ed. Dümmler, 44.

45 Badini, Concezione della regalità, 292-296.

46 On Liutprand and the monastery of S. Anastasius ad aquas salvias, see Fentress et al., The Sixth-Century Settlement, 90-91. 
at the monastery of Saint Anastasius ad aquas salvias. The daughter of a Syrian bishop living in Rome had been delivered from an evil spirit thanks to the intervention of the precious relic, confirming the bishop, who had refused recourse to an amulet, in his orthopraxis. ${ }^{47}$ The agency of holy heads seems to be the focus of the miracle account, which underlines the fact that the monastery ad aquas salvias was the place where the apostle Paul was beheaded, and where the head of Anastasius was hosted. In its vicinity there was a chapel in memory of John the Baptist, who was beheaded, and where the miracle ultimately takes place. While we cannot advance the claim that accounts of miracles performed by the relics of Anastasius attracted the attention of Liutprand, it is a fact that in the early decades of the eighth century his relics, and his head in particular, were the object of popular devotion in Rome.

Once back in Langobardia after his visit to the monastery of Saint Anastasius ad aquas salvias, Liutprand decided to invest precious materials he had gathered for his baths in building a church in memory of the Persian martyr annexed to his new palatial complex. Building baths, which entailed using a specialised workforce and precious materials, had been a prerogative of the rich and powerful in Antiquity. In the early medieval period the public bath culture had declined, apparently more for economic reasons than as a result of Christian criticism, and had only survived, albeit strictly regulated, in Byzantine monastic establishments and in luxury private estates. ${ }^{48}$ Unusually for early medieval Italy, in the early eighth century a bishop of Pavia, probably of Greek origin, restored the local baths, as we know from his epitaph, which is transcribed in the Sylloge Laureshamensis. ${ }^{49}$ Badini suggested that, after having been to Rome to reconcile with the pope in 729, Liutprand abandoned the idea of building baths, and publicly declared it in his inscription, in order to demonstrate his intention of renouncing a typical symbol of secular power and instead embracing a symbol of pious patronage such as the erection of a church. ${ }^{50}$ Roman thermal baths were incorporated in the area of Arichis II's residence in Salerno and traces of a frigidarium and a balneum, dating later than the eighth century but within the eleventh century, have been uncovered. ${ }^{51}$

Let us consider the choice of Anastasius the Persian. Nothing in the Corteolona inscription explains the Lombard king's preference for this saint. For example, the fame of his relics in effecting miracles is not even hinted at. ${ }^{52}$ However, this was no fortuitous choice among the many saints venerated in Rome, which included those from the East who had been promoted by eastern communities between the seventh and the eighth centuries. ${ }^{53}$ First and

47 For the Greek text of this miracle (BHG 89), which bears a date corresponding to the year 713/4, see Flusin, Saint Anastase le Perse, vol. 1, 157-187, esp. 3, 168-169 and 6, 174-175 on the refusal of amulets. The account, like others, was then put into Latin, for which see Vircillo Franklin, Latin Dossier, 129-144. Smith, Cursing and Curing, 465469, comments on this miracle against the background of religious practices reflecting the varied ethnicity of Christians in eighth-century Rome.

48 The literature on baths, from Greek to post-Byzantine is vast; for an overview see Nielsen, Thermae et Balnea; for an update, see Fagan, Genesis; for the transition between the early and the middle Byzantine period, see Berger, Das Bad.

49 Epitaph of Bishop Damian of Pavia, ed. Strecker Rhytmi Langobardici, CXXXIV, 719-720; Everett, Literacy, 244245.

50 Badini, Concezione della regalità, 300 .

51 Peduto, Il gruzzolo, 34.

52 As noted by Vircillo Franklin, Latin Dossier, 18.

53 On eastern saints in Rome, see Sansterre, Les moines grecs, vol. 1, 146-156; for a recent appraisal of evidence and previous literature, see Maskarinec, City of Saints. 
foremost, Anastasius the Persian was a saint favoured by the Byzantine emperor Heraclius (610-641), who had defeated the Persians and brought back the True Cross to Jerusalem after they had taken it. The future Saint Anastasius was a soldier in the army of the Persian king Chosroes, who invaded Palestine in the early seventh century. After the fall of Jerusalem in 614, Anastasius developed an interest in the religion of the cross and later decided to be baptised and assumed a Christian name. He ardently embraced first the monastic life and then proselytism. Captured by Persians, he was beheaded in 628. Ten days later the victorious army of Heraclius arrived in the city of his martyrdom. Apparently, Anastasius soon became a symbol of a Christianity triumphant over paganism. ${ }^{54}$ By 630 his deeds were recounted in a text commissioned by Patriarch Modestus of Jerusalem. The return of his relics to Jerusalem from Persia by the late 631 was paralleled to Heraclius' restoration of the Cross which had been stolen by the Persians. ${ }^{55}$ Only a few years later, in the aftermath of the Arab invasion of Palestine of 638, the relics of Anastasius were taken by Palestinian monks to Rome..$^{56}$ There they found shelter at a monastery probably established by Cilician monks in the first half of the seventh century, which hence became one of the most important eastern monasteries of Rome with the name of Saint Anastasius ad aquas salvias. By the mid-seventh century it became the epicentre of the cult of Anastasius, since it hosted his relics and probably also the original hagiographical accounts on him. ${ }^{57}$ Not only was Anastasius associated with a rightful emperor Heraclius; according to Vircillo Franklin, the Persian martyr was associated very early with the defence of orthodoxy. ${ }^{58}$ She situates the early development of the cult of Anastasius in Rome within the monastic communities engaged against monotheletism, the doctrine of sone will of Christ, around the mid-seventh century, which could, in her eyes, rexplain the early link forged between the veneration of his relics and the defence of orthodoxy ${ }^{59}$ These eastern monks in fact supported Dyotheletism, the doctrine of Christ's human and divine swills', and labelled monotheletism as sheresy<, although it was a strand of Chalcedonian Christology ${ }^{60}$ Vircillo Franklin argues that the impression that the cult of Anastasius was associated with >orthodoxy - or, we should rather say, with its appropriation,- is reinforced when taking into account the acts of Nicaea II, where the Life of Anastasius is quoted in various instances, all related to iconophile practices. The first instance is to remark that Anastasius' conversion to Christianity when he was still a Persian soldier was inspired by stories of the martyrs (riotopías

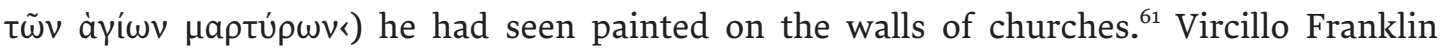

54 Vircillo Franklin, Latin Dossier, 3-4, with reference to Flusin, Saint Anastase le Perse, vol. 2, 329-352.

55 For a detailed and documented account of these facts, I refer to Vircillo Franklin, Latin Dossier, 5.

56 Vircillo Franklin, Latin Dossier, 11-12, notes that this remains conjectural. However, by 645 Anastasius was commemorated in Rome.

57 Vircillo Franklin, Latin Dossier, 8. The abundant Greek and Latin literature about Anastasius makes his cult perhaps the best documented among those of eastern saints in early medieval Rome.

58 Vircillo Franklin, Latin Dossier, 11 and 18 with reference to the Corteolona inscription.

59 Vircillo Franklin, Latin Dossier, 11.

60 See Jankowiak, Invention, 335, n. 1, for an updated bibliography on monotheletism. On the monothelete crisis and the Roman resistance, which culminated with the Lateran Synod of 649, see Price, Monotheletism, and Price et al., Acts, 14, 39-58; Booth, Crisis, 290-300.

61 Mansi, XIII, 21-22; ACO, II, 3.2, ed. Lamberz, 312-313; Vircillo Franklin, Latin Dossier, 7. 
specifically mentions Liutprand and it is therefore worth reporting what she writes: >Since Anastasius' status as a witness against iconoclasm is evident at Nicaea II, such a reputation may have already been established by the time of Liutprand's visit to Romer - a reputation which originated from the monastery's traditional alliance with the Church of Rome since the anti-monothelete resistance. ${ }^{62}$

\section{Appropriation of Rome?}

Liutprand's desire to forge for himself the image of a righteous and established ruler in the tradition of eminent predecessors can also be read in other features of the Corteolona texts. For example, in both main inscriptions there is an open reference to the appropriation of Roman-Christian remains (marbles, mosaics), ideally meant to be used in the material fabric of Liutprand's residence and certainly in his rhetoric of power. The appropriation and integration of spolia of former or other cultures is a vast subject which cannot even be summarised here. Importantly, it was a trait which characterised the rule of Constantine I, the first Roman emperor who accepted Christianity. He took possession of marbles carved for his predecessors or statues from pagan sanctuaries for monumental building projects which he carried out in Rome as well as in Constantinople, his new capital. ${ }^{63}$ Constantine set an example. Liutprand was ideally following in his steps, although on a much reduced scale, and this is what Charlemagne would also do.$^{64}$ In the first inscription, it is worth noting that the church at Corteolona, the shouse of the Lord<, is said to be made with sperpulchro ... textur, that is with a splendid fabric, made of marbles, mosaics, and columns provided by Rome, the scapital of the faith to the conclusion that, in Liutprand's eyes, since the fabric of the church was made of the fabric of Rome, it was permeated with its sanctity. The reference to splendid materials has both spiritual and material implications and is perfectly aligned with the late antique predilection for glittering materials and splendour which had become part of Christian aesthetics. ${ }^{65}$

A final element which deserves to be mentioned here, in that it has to do with the appropriation of traits of Roman imperial propaganda, is the reference in the first Corteolona inscription to the fact that Liutprand distributed inscriptions throughout the whole country. This passage conveys the idea that the Lombard king had embraced the practice of displaying script as a means of reminding people of his sovereignty. This practice had been embedded in the Roman imperial tradition of power since the age of Augustus, the first Roman emperor. ${ }^{66}$ While there is little left to witness the claim that Liutprand had commissioned many inscriptions, there is direct and indirect evidence of his sstrong involvement in epigraphic production<, certainly greater than any other Lombard king. ${ }^{67}$ This implies that Liutprand was aware that inscriptions were capable of transmitting messages and contributing to shaping his fame.

62 Vircillo Franklin, Latin Dossier, 18.

63 On the re-employment of ancient statues in Constantinople, see Bassett, Urban Image.

64 On the ideological re-employment of spolia, including a discussion of Charlemagne, see Brenk, Spolia; Kinney, Roman Architectural Spolia; Nelson, Charlemagne and Ravenna.

65 An evocative rhetoric of light is to be found in the inscriptions accompanying mosaics in Roman churches and it would be reprised by Carolingian poets. See Thunø, Decus suus splendet; idem, Inscription and divine presence; idem, Apse Mosaic; Dell'Acqua, Illuminando colorat. On the appropriation of Rome see Smith, Europe after Rome and Kramer and Gantner, Lateran Thinking.

66 Woolf, Monumental writing. Everett, Literacy, 253-254 on Liutprand.

67 Everett, Literacy, 250. 
The limited audience to which they were addressed was literate, and those who were learned could also read across the lines of the text and thus frame the sovereign's aspirations in a past in which Roman imperial power merged with Christian orthodoxy. That Liutprand did look back at the past for ideological reasons and with a learned approach is witnessed by the contents of one inscription that he, >devotus', commissioned in memory of the venerable Irish abbot Cumianus of Bobbio. ${ }^{68}$ The inscription, which runs in hexameters on the still extant tomb stone (Bobbio, Museo dell'Abbazia di San Colombano, Fig. 1), mentions sthe span of four Olympics` plus a year as a chronological reference to the twenty-one-year service of the abbot. Furthermore, the reference to the >dissolving limbs` of Cumianus has been retraced in Virgil (Aen. XII, 951), one of the most relevant poets of the Roman tradition. ${ }^{69}$ Although we cannot explore here how Liutprand's self-crafted image of a ruler had a bearing on later Lombard or Carolingian sovereigns, it is worth pointing out that after him the self-appointed Prince Arichis II in southern Langobardia also adopted elements of the Roman imperial culture and rhetoric in an effort to craft his own image as a legitimate and established ruler. ${ }^{70}$

\section{Other evidence of an early reception of the Image Controversy}

That there was a rising doctrinal problem with the Byzantine emperor - a problem with practical consequences for the Church - is witnessed not only by the Corteolona inscription, but by other testimonies, including the Liber Pontificalis, whose trustworthiness, however, has been questioned. The Liber Pontificalis is indeed a difficult source when it comes to the Image Controversy. As we have seen, this controversy was inserted into the Life of Pope Gregory II (d. 11 February 731). We have also seen that this must have happened at the time of his successor Gregory III (March 731-November 741). As mentioned earlier, the entry for Gregory II reached Bede in Northumbria in or before 735, since he managed to incorporate it into his Chronica maiora. ${ }^{11}$ We would suggest that the entry for Gregory II reached England in a form comparable to the older version of the Life that has come down to us. This cannot be proven since Bede did not include the latter parts of the text. Yet, the explanation that he had a partial, even older and therefore unfinished version of the Liber Pontificalis Life seems to be a far-fetched hypothesis. We can conclude that by the first half of the 730 s it was deemed acceptable in Rome to weave a theological controversy regarding images into a text that reflected the stax war the popes had had with the very same emperor in the previous decade. The adaptability of papal historical self-representation should not come as a surprise, because the tides of religious policy were shifting.

68 Epitaph of Abbot Cumianus, Rerum Italicarum Scriptores, ed. Muratori, vol. 3, 680; MGH, PLAK 4.2 ed. Strecker, 723: 'Hic sacra beati membra Cumiani solvuntur cuius caelum penetrans anima cum angelis gaudet. Iste fuit magnus dignitate genere forma hunc misit Scothia fines ad italicos senem locatur Ebovio domini constrictus amore ubi venerandi dogma Columbani servando vigilans ieiunans indefessus sidule orans olimpiadis quattuor uniusque circolo anni. Sic vixit feliciter ut felix modo credatur mitis prudens pius fratribus paceficus cunctis huic aetatis anni fuerunt novies deni. Lustrun quoque unum mensesque quattuor simul at pater egregie potens intercessor exsiste pro gloriosissimo Liutprando rege qui tuum praetioso lapide tymbum decoravit devotus sit ut manifestum almum ubi tegitur corpus depositus est hic dominus Cumianus Episcopus XIIII Kalendas Septembris‘; commented in Cassanelli, Materiali lapidei; Lomartire, L'iscrizione di Cumiano; see Calzona, Reimpiego e modelli, for an appraisal of earlier literature. See also Everett, Literacy, 251-253.

69 Cassanelli, Materiali lapidei, 513. In the English translation of Handley, Saxons, Britons and Scots, 749-750 the references to the Olympics and to Virgil have not been noted.

70 Dell'Acqua, Arechi II.

71 See Gantner, Freunde Roms 27, for details on the transmission. 


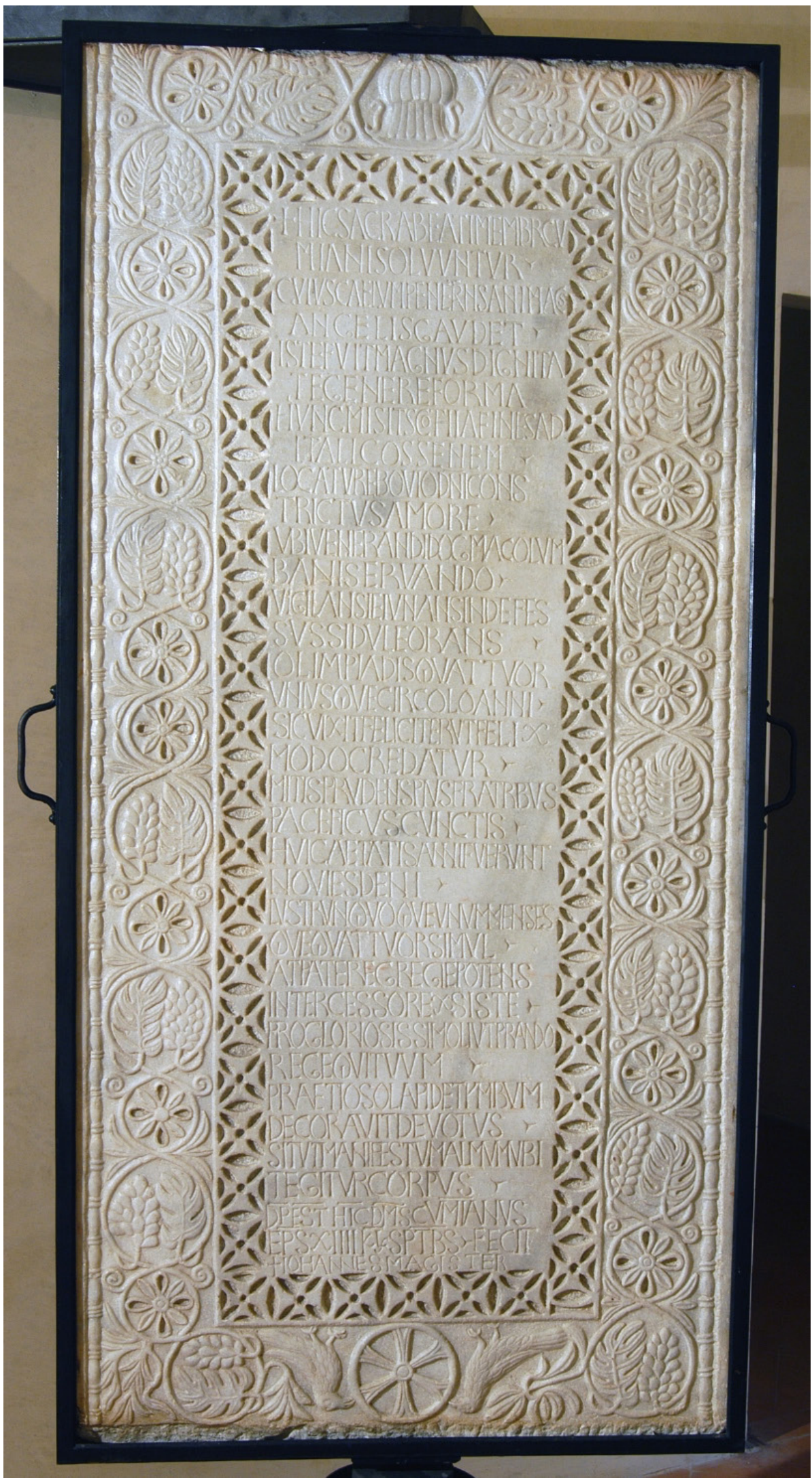

Fig. 1: Tombstone of Abbot Cumianus, c.736, marble, $180 \times 90 \mathrm{~cm}$, Bobbio (Piacenza), Museo dell'Abbazia di San Colombano 
The Life of Gregory III in the Liber Pontificalis informs us that in 731, shortly after his election as pope, he sent an embassy to Constantinople to address the question of sacred images. His envoys were carrying letters containing swritten warnings ( ‘commonitoria scripta`) against the removal and destruction of the sacred images of our Lord Jesus Christ, God's holy mother, the holy apostles and all the saints and confessors.$^{72}$ The same section of his Life claims that Gregory's predecessor (Gregory II) had already sent letters east concerning iconoclasm, clearly embracing the new papal narrative of the 720s, possibly elaborated within the same circles in the Lateran. The text also makes it clear that the diplomatic dispatch came to nothing, because one embassy lacked the courage to carry out their mission and the other was held up, detained and turned back towards Sicily instead. The next chapter in the same Life then reads:

So, spurred with a greater enthusiasm for the faith, the supreme and venerable pope [held] a sacerdotal synod in front of the most holy confessio of St Peter's most sacred body. With him in session were the archbishops Antoninus of Grado and John of Ravenna with other bishops of this Hesperian district, 93 in number and priests of this holy apostolic see; the deacons and all the clergy were in attendance, and the noble consuls and the rest of the Christian people assisted. The synod decreed that if anyone thenceforth, despising the faithful use of those who held the ancient custom of the apostolic church, should remove, destroy, profane and blaspheme against this veneration of the sacred images, viz. of our God and Lord Jesus Christ, of his mother the ever-virgin immaculate and glorious Mary, of the blessed apostles and of all the saints, let him be driven forth from the body and blood of our Lord Jesus Christ and from the unity and membership of the entire church. They also confirmed this by their signatures and sanctioned that it be attached to the other teachings of the previous approved orthodox pontiffs. ${ }^{73}$

Thus, in reaction to the first, luckless embassy, Gregory convened a synod in Rome, which is openly said to have threatened everyone holding riconoclast « views with excommunication. The problem is that we lack any secure dating for the Life of Gregory III. It is believed to have been written close to the events and finished during the tenure of Pope Zachary (741-752), yet manuscript evidence starts only in the late eighth century and we have no clear citations in other works far prior to that. ${ }^{74}$ The synod mentioned in the account was in all probability held starting on 1 November 731. Its acts are lost, however, with only the Liber Pontificalis as we have seen quite a partisan source - recounting the outcome.

We have, however, another source for the events of 731: the letter Gregory III sent to Patriarch Antoninus of Grado to convene him to the synod. Antoninus is then also mentioned as a participant of this synod in the Liber Pontificalis. The authenticity of this letter has been challenged, but on rather feeble grounds. ${ }^{75}$ The current version of the letter gives >Gregorius tertius as the author of the letter, which certainly is interpolated since the popes did not use ordinal numbers at this time. The letter itself, however, at least partly sounds authentic. ${ }^{76}$

LP, Gregory III, c. 2, trans. Davis, vol. 2, 19; ed. Duchesne, vol. 1, 415.

Gantner, Freunde Roms, 16-38. See also Davis, Lives of the Eighth-Century Popes, xvii-xx. See Speck, Kaiser Leon III, vol. 3, 586-87 and Conte, Regesto delle lettere dei papi, 200-201.

Regesta Pontificum Romanorum, vol. 2 (a. 604-844), ed. Jaffé, Könighaus, Schlauwitz, no. 3817 (olim JE 2232), 120, and ibid. nos. 3819 and 3820 (the latter indicating that the editors do not believe the account given in the LP, whereas they count the letter itself as authentic). 
The central accusation reads as follows: 'An unhappy impiety has arisen in the royal city [Constantinople], which - as we believe - you have noticed, and throughout many other provinces, so that, as we say lamenting and with a tearful voice, the holy images showing the likeness of our Lord himself and our saviour have all been scattered and [...] the churches of the same God [...] have been made into homes for men and for vile beasts.$^{77}$ The first part in particular is important here, because no one in Constantinople is clearly implicated yet. Later accounts always find Emperor Leo guilty - as we have seen for the Life of Gregory II, but there are other examples. We would argue that at least this part - where the pope speaks of an sinfelix impietas s that has arisen - is to be seen as genuine, while other parts of the text may have been altered to fit later perceptions. That this is the case is also backed up by the use of the expression rregia urbs ' which is typical of the time, whereas later forgeries tend to use the name Constantinople. ${ }^{78}$

Therefore, we can discern that at some point in 731 the pope was informed that the threat of a schism was again materialising in the East - a threat, which had dominated relations between Rome and Constantinople since the mid-seventh century. Gregory III was cautious enough not to blame anyone in particular for this development yet, at least not when writing to the patriarch of Grado. Instead, he chose a very vague expression, an sunhappy impiety, which is exactly what makes the text credible and authentic. The pope avoids including any personal charges against the emperor, while (possibly) giving a far more vivid and most likely exaggerated description of the general problems in the East. The Corteolona inscription, in contrast, clearly identifies the emperor as failing to rule in a religiously correct way.

Concerning images, Gregory III was quite outspoken, compared to the Liber Pontificalis and the Corteolona inscription. We can either count this latter part as spurious, or, more likely, as an attempt to plant the theme of resistance against the East into the heart of his addressee Antoninus. What the letter proves in any case is that there was some kind of hostility against images arising in Constantinople by 731 and that the western onlookers were swift to oppose it. ${ }^{79}$ The history of the relations teaches us that this was probably due to the papacy opposing teachings not previously negotiated.

77 Gregory III, Letter to Antoninus of Grado, ed. Gundlach: `Est enim infelix impietas apud regiam urbem, ut - credimus - notum habetis, et per diversas provincias, ita ut, quod lugentes dicimus et voce promimus lacrimosa, sanctorum imagines ad ipsius domini et redemptoris nostri instar omnes proiciantur, ecclesię delacerentur atque ipsius Dei ecclesiae, quod fatale malum est et intollerabile exitium, habitationes hominum, viliums utique efficiantur armentorum, ut iam in eis nulla debeat laus Deo cantari; unde cum profeta lamentabili voce dicendum est: Quis dabit capiti meo aquas aut oculis meis lacrimarum fontes, ut tantum defleamus exitum?

78 Gantner, Label Greeks, esp. 323. See discussion of interpolated letters of Gregory II in the same article.

79 See Brubaker and Haldon, Byzantium: A History, 119-120. 


\section{The afterlife of the Corteolona inscription}

It has been posited that the above-discussed Corteolona inscriptions were displayed in the monastery of Saint Anastasius annexed to Liutprand's residence, which also had a hospice for visitors. ${ }^{80}$ By the late eighth century, among the visitors or the permanent residents of Corteolona there must have been one who copied and thus transmitted these inscriptions and others from Pavia and its surroundings to posterity. They were then copied in a scriptorium in northeastern France. Between 821 and 835, the inscriptions were collated with others from Lombard Italy, Rome, and Ravenna at the monastery of Lorsch, forming the so-called Sylloge Laureshamensis (BAV, Pal. lat. 833, fols. 26r-82r). The Sylloge was either written at the monastery of Lorsch or transferred there promptly in the early ninth century. ${ }^{81}$ The collection seems to be a compilation of four separate collections, the first one possibly connected to a journey to Rome undertaken in 823 by Abbot Adalung of Lorsch (804-837). The texts from Lombard northern Italy, in the third section of the collection, likely stem from a different source, which was possibly produced at the end of the eighth century, judging from the latest inscriptions it includes, and was then copied into the Lorsch manuscript.

The varied nature of the inscriptions gathered suggests that they were transcribed to satisfy an antiquarian interest. However, we cannot entirely rule out the possibility that a political agenda dictated the collection of inscriptions related to the kingdom of Liutprand, which was already perceived in the late eighth century as the sgolden age of Lombard rule in Italy. At the same time, we cannot rule out scribal errors, since the inscriptions in the relevant section of the manuscript have come down to us in at least two steps. The Latin itself is not flawless. Since Carolingian epigraphy in the time of Charlemagne borrowed a lot from Lombard scholars summoned from Italy, we also cannot distinguish between a specific `Lombard or 'Carolingian s style.$^{82}$ The name form `Leutprand or >Leutbrant that is employed for the king himself in the two inscriptions from Corteolona, is, however, very clearly a Frankish rendering of the name. There is no sensible explanation other than that the copyist must have altered the name, which was probably used in an unfamiliar form, either in the Lombard language or in a Latinised hybrid that prompted the scorrection«. The most logical explanation would then be that the copyist of the extant manuscript transmitting the inscriptions (BAV, Pal. Lat. 833) or of the preceding collection from the late eight century was a Frank or at least must have lived in an area where Frankish versions of names were more common. It is clear, however, that the name form was deliberately chosen with a Frankish speaking audience in mind. We have shown in the previous section that this need not surprise us, as on Gregory III's letter the title of the pope was likewise adjusted by adding the ordinal number, making the letter meet the expectations of the audience it was copied for, in this case Italy during the

80 Everett, Literacy, 254.

81 The earliest testimony of the Sylloge is in the manuscript from Lorsch (BAV, Pal. lat. 833). The manuscript is easily accessible online: bibliotheca-laureshamensis-digital.de/bav/bav_pal_lat_833/0104 (retrieved 7 March 2019), second fascicle. The inscriptions from Pavia and surroundings form the third part of the Sylloge, and specifically those from Corteolona are to be found on fols. $48 \mathrm{v}-49 \mathrm{r}$, while the most relevant inscription for this article, the third copied, starts at the bottom of fol. 48v, after the second IITEM IBI rubric. On the manuscript, see Stevenson, Codices manuscripti, 292; Bischoff, Abtei Lorsch, 66 and 92, n. 47, 47a, 48, and idem, Lorsch, 114-115; for an appraisal and a critical overview on the Sylloge, see Vircillo Franklin, Epigraphic Syllogae, and more recently Hartmann, Karolingische Gelehrte.

82 See Hartmann, Karolingische Gelehrte, 259-263. 
Renaissance period. In sum, the name form `Leutprand/Leutbrant`, which cannot have been in the original inscription, proves that the text of the inscriptions was indeed altered, at least to render it more understandable for a Frankish audience, although we believe it highly unlikely that the content was significantly changed apart from the king's name. The metrics, for instance, were not tampered with and the grammar employed does not seem suspicious. ${ }^{83}$

There have been speculations as to who was responsible for collating the inscriptions. Dungal, a learned Irishman living in Pavia, has been proposed as a possible candidate. He is better known for having responded with a treatise to the iconoclastic Bishop Claudius of Turin in the 820s. ${ }^{84}$ But the date of Dungal's arrival in Pavia, in 825, makes it unlikely that he transcribed the inscriptions in the area of Pavia when considering, on the one hand, that the manuscript containing them arrived from northeast France to Lorsch between 821 and 835, as stated, and on the other, that the relevant part of the collection containing Corteolona was even older. ${ }^{85}$ In his stead, the name of another learned member of the Carolingian court has been put forward as a collector of ancient and Lombard antiquities: Angilbert of St Riquier, who resided in Pavia in $c .781 .{ }^{86}$ While the identity of the compiler of the part of the Sylloge including the inscriptions from Corteolona remains speculative and beyond the scope of this article, we can add a few comments on the reasons behind copying those texts from the Lombard country residence. A person connected with the Carolingians, if this was the case, would not have had any interest in praising Liutprand as a champion of faith. Instead, had the person been a Lombard, we can imagine they would have had a specific interest in extolling the memory of Liutprand as an orthodox ruler supportive of the popes, and thus probably amend the bad reputation he and his people acquired in papal and Frankish eyes and documents after they started threatening territories under papal control. ${ }^{87}$ It should be noted that the tone of the Corteolona inscriptions is echoed in the final book of the History of the Lombards, which Paul the Deacon wrote in the last decades of the eighth century ${ }^{88}$ Like the inscription set up in the Lombard royal residence, Paul portrays Liutprand as a spious king and contrasts him with the impious emperor Leo III. Probably relying on the Liber Pontificalis, as he does in other parts of the History of the Lombards, Paul blames the Byzantine sovereign for burning sacred images in Constantinople and for ordering the pope to dispose of sacred images if he wanted to retain imperial favour. Paul also reports that Leo obliged the citizens of Constantinople to take down images of the Saviour, his Mother, and all saints, which were burnt in the centre of the city, and those op-

83 For further thoughts on the nature of the inscriptions collected see Hartmann, Karolingische Gelehrte, 259-263.

84 Ferrari, In Papia. On the iconoclastic attitudes and exegetical work of Claudius of Turin, see Boulhol, Claude de Turin; Ballardini, Fare immagini. Against Claudius, in c.828 Dungal wrote the treatise Responsa contra Claudium, PL 105, 465-530, esp. 529; ed. and English trans. Zanna.

85 Vircillo Franklin, Epigraphic Syllogae, 985-986.

86 Vircillo Franklin, Epigraphic Syllogae, 986.

87 The popes labelled the Lombards as nefandissimi, that is most execrable. This would have a long-lasting effect on their image and even modern historiography; see Gasparri, Molteplici identità.

88 Goffart, Narrators, 340-341, for the debate on the date of the HL. 
posing this were either beheaded or mutilated. ${ }^{89}$ For his vision of the early period of the iconoclastic controversy, we can infer that, besides the Liber Pontificalis, Paul the Deacon was relying also on other sources, including the inscriptions from the royal residence of Corteolona, which were testimony to a more glorious period for the Lombards.

\section{Final remarks}

The inscriptions from Corteolona offer material for re-thinking a wide range of historical issues. We were only able to deal with some of them in this paper. For example, despite it being very important from a cultural-historical point of view, we had to leave aside the question of how the image of a pious Christian ruler, at the same time clad with symbols of Roman imperial power, that Liutprand construed for himself, eventually had an impact first on Arichis II and then on Charlemagne. We intended, in fact, to focus on the mention of Emperor Leo III in the longer inscription from Corteolona. But in the end, what has our investigation found out? First of all, we have come to the conclusion that the texts of the Corteolona inscriptions transmitted to us in the Sylloge Laureshamensis, a collection mainly following antiquarian interests, must be genuine. No one would have had an interest in interpolating a statement about the foundation of a church and a monastery of Saint Anastasius at Corteolona.

The dating of the inscription is admittedly less secure, with 729, the year Liutprand enters Rome, as a certain terminus post quem. There is no other documentary evidence about the establishment of the country residence of Liutprand, nor archaeological investigations about it. However, we have argued that a date between 730 and 734 for the inscription is by far the most convincing. In fact, the wording itself fits quite well in the then current political discourse. Liutprand wants to depict himself as more pious than Leo III, but he clearly avoids all too concrete allegations against the emperor.

The existence of the inscription indicates that it was already clear enough to well-informed onlookers in Italy that the emperor was indeed involved in the establishment of a new religious policy and that this new religious policy was deemed schismatic (possibly heretical) by several Italian churches (the Lombard, but also the Roman church). All the same, the inscription does not inform us what the schism was about, since it only conveys that Liutprand defined himself as true orthodox and Catholic in contrast to his eastern, higher ranking counterpart. By humiliating the great emperor, who had gained fame as a Christian hero against the Umayyad Empire, Liutprand exalted himself, and that certainly was the main goal of the first two lines of the poem. The author of the verse inscription, however, finds a way to shift part of the blame away from the emperor and put it instead on a nameless doctor.

The value of this specific inscription from Corteolona resides in the fact it conveys information that we do not have from any other contemporary source, mainly that the threat of a schism originating in Byzantium was perceived, resented, and condemned in Lombard territories at quite an early stage and that it was related to the emperor himself. That the rising image controversy is indeed implied in the text by the words about Leo's fall sinto the pit of schism < becomes clear from the Liber Pontificalis and from the letter from Gregory III to Antoninus of Grado, as well as, to a certain extent, from Greek sources from the core lands

89 Paul the Deacon, HL, VI, 49, ed. Dümmler, 181-182. 
of the empire in Asia minor. ${ }^{90}$ We have come to the conclusion that these different sources cannot all have been forged with a concerted effort aimed at pre-dating iconoclasm, as was postulated not too long ago. ${ }^{91}$ It now appears clear that several circles in Italy, namely in Rome and in northern Langobardia, reacted quite early to the controversy rising in the East, certainly by the early months of the year 731. In the same year, or shortly thereafter, scribes in the Lateran decided to alter the narrative of Gregory II's struggles against the emperor when presenting them in the Liber Pontificalis, making them, too, about images. In these years, independently from the pope, Liutprand decided to contrast the schismatic attitude of the emperor with the decision to establish a church and a monastery dedicated to an eastern saint associated with Byzantine imperial power in his new residential complex instead of luxurious baths.

As said previously, the inscription from Corteolona has, quite surprisingly, not been taken into account as a source for the emerging image controversy, nor for the early reactions against it in Italy. Albeit succinct, the inscription provides the missing piece to back up other sources and shows that the latter also represent a genuine and early reaction to Byzantine iconoclasm. With information having very different and unrelated origins, but dovetailing neatly all the same, we can see that the early 730 s were indeed the first hot phase of the image controversy in Italy.

90 See Brubaker and Haldon, Byzantium: The Sources, 69-155.

91 Speck, Kaiser Leon III. 


\section{Acknowledgements}

This research started during a Marie Skłodowska-Curie Fellowship ( $\mathrm{n}^{\circ}$ 657240, 'ICONOPHILIA') spent at the Centre for Byzantine, Ottoman and Modern Greek Studies, School of History and Cultures, College of Arts and Law, University of Birmingham.

It has been partly financed and facilitated by the participation of Francesca Dell'Acqua in the project `Mobility, Microstructures and Personal Agency in Byzantium` (2015 Wittgenstein-Prize of the Austrian National Research Foundation) directed by Prof. Dr. Claudia Rapp at the University of Vienna and the Austrian Academy of Sciences. The authors are grateful to Marc Lauxtermann, Oxford, for generously sharing his still unpublished paper dealing with the longer Corteolona inscription. Dell'Acqua wishes to thank the participants to the medieval seminar group of the Austrian Academy of Sciences, Vienna, with whom she first discussed the inscription from Corteolona in March 2018 and where the idea for this joint article came about. She also wishes to thank warmly Adriano Peroni, Saverio Lomartire, and Caterina Giostra for useful information on the site of Corteolona and the inscriptions from Pavia. Clemens Gantner wishes to thank Cinzia Grifoni, Christian Gastgeber, Bernhard Zeller, and Walter Pohl for fruitful discussions on the topics addressed here. 


\title{
References
}

\author{
Abbreviations \\ ACO = Acta Conciliorum Oecumenicorum \\ $\mathrm{BAV}=$ Biblioteca Apostolica Vaticana \\ BHG = Bibliotheca Hagiographica Graeca \\ $\mathrm{HL}=$ Historia Langobardorum \\ LP $=$ Liber Pontificalis \\ MGH EE = Monumenta Germaniae Historica, Epistolae \\ MGH, PLAK = Monumenta Germaniae Historica, Poetae Latini Aevi Karolini \\ MGH, SRL = Monumenta Germaniae Historica, Scriptores Rerum Langobardicarum et Ital- \\ icarum saec. VI-IX \\ PG = Patrologiae Cursus Completus, Series Graeca, ed. Jacques-Paul Migne (Paris, 1857- \\ 1866). \\ $\mathrm{PL}=$ Patrologiae Cursus Completus, Series Latina, ed. Jacques-Paul Migne (Paris, 1844-1890).
}

ACO II, 2.2 = Concilium Universale Constantinopolitanum Tertium, Concilii Actiones XIIXVIII, ed. Rudolf Riedinger, ACO, II, 2.2 (Berlin, 1992).

ACO II, 3.1 = Concilium Universale Nicaenum Secundum, Concilii actiones I-III, ed. Erich Lamberz, ACO, II, 3.1 (Berlin, 2008).

ACO II, 3.2 = Concilium Universale Nicaenum Secundum, Concilii Actiones IV-V, ed. Erich Lamberz, ACO, II, 3.2 (Berlin, 2012).

Badini, Aldo, La concezione della regalità in Liutprando e le iscrizioni della chiesa di S. Anastasio a Corteolona, in: Atti del VI Congresso internazionale di studi sull'Alto Medioevo. Milano, 21-25 ottobre 1978 (Spoleto, 1980) 283-302.

Ballardini, Antonella, Fare immagini tra Occidente e Oriente: Claudio di Torino, Pasquale I e leone V l'Armeno, in: Arturo Carlo Quintavalle (ed.), Medioevo mediterraneo: l'Occidente, Bisanzio e l'Islam, I convegni di Parma 7 (Milan, 2007) 194-214.

BAV, Pal. lat. 833 = Rome, Biblioteca Apostolica Vaticana, Palatinus Latinus 833. Retrieved 7 March 2019: bibliotheca-laureshamensis-digital.de/bav/bav_pal_lat_833/0104.

Bassett, Sarah, The Urban Image of Late Antique Constantinople (Cambridge, 2004).

Berger, Albrecht, Das Bad in der byzantinischen Zeit, Miscellanea Byzantina Monacensia 27 (Munich, 1982).

Berto, Luigi A., Liutprando, re dei Longobardi, in: Dizionario biografico degli Italiani 65 (2005). Retrieved 28 January 2019: www.treccani.it/enciclopedia/re-dei-longobardiliutprando_(Dizionario-Biografico).

Bertolini, Ottorino, Roma e i Longobardi (Rome, 1972).

Bertolini, Ottorino, and Cinzio Violante, Storia Universale 3.1. I Germani, migrazioni e regni nell'Occidente già romano, i Franchi (Milan, 1965).

Bischoff, Bernhard, Lorsch im Spiegel seiner Handschriften, Münchener Beiträge zur Mediävistik und Renaissance-Forschung 2 (Munich, 1974).

Bischoff, Bernhard, Die Abtei Lorsch im Spiegel ihrer Handschriften, Geschichtsblätter Kreis Bergstraße. Sonderband 10 (second expanded edition), (Lorsch 1989).

Booth, Philip, Crisis of Empire: Doctrine and Dissent at the End of Late Antiquity (Berkeley, London, 2014). 
Boulhol, Pascal, Claude de Turin: un évêque iconoclaste dans l'Occident Carolingien: Étude suivie de l'édition du Commentaire sur Josué, Collection des études augustiniennes, Série Moyen-âge et Temps Modernes 38 (Paris, 2002).

Brandes, Wolfram, Finanzverwaltung in Krisenzeiten: Untersuchungen zur byzantinischen Administration im 6.-9. Jahrhundert, Forschungen zur byzantinischen Rechtsgeschichte 25 (Frankfurt am Main, 2002).

Brenk, Beat, Spolia from Constantine to Charlemagne: Aesthetics versus ideology, Dumbarton Oaks Papers 41 (1987) 103-109.

Brubaker, Leslie, and Haldon, John F., Byzantium in the Iconoclast Era, c. 680-850: A History (Cambridge, 2011).

Brubaker, Leslie, and Haldon, John F., Byzantium in the Iconoclast Era (ca.680-850): The Sources, an Annotated Survey. Birmingham Byzantine and Ottoman Studies 7 (Aldershot, 2001).

Calderini, Caterina, Il palazzo di Liutprando a Corteolona, Contributi dell'Istituto di Archeologia 5 (1975) 174-208.

Calzona, Arturo, Reimpiego e modelli tra VIII e IX secolo al San Colombano di Bobbio, in: Arturo Carlo Quintavalle (ed.), Medioevo: $i$ modelli. Atti del convegno internazionale di studi, Parma 27 settembre-1 ottobre 1999, I convegni di Parma 2 (Milano, 2002) 291-308.

Cassanelli, Roberto, Materiali lapidei altomedievali decorati e iscritti nell'abbazia di San Colombano a Bobbio, in: Mirella Marini Calvani (ed.), Storia di Piacenza, vol. I: Dalle origini all'anno Mille (Piacenza, 1990) 503-533.

Conte, Pietro, Regesto delle lettere dei papi del secolo VIII (Milan, 1984).

Cornford, Benjamin, Paul the Deacon's understanding of identity, his attitude to barbarians, and his sstrategies of distinction in the Historia Romana, in: Richard Corradini, Rob Meens, Christina Pössel and Philip Shaw (eds.), Texts and Identities in the Early Middle Ages (Vienna, 2006) 47-60.

Dell'Acqua, Francesca, Arechi II: la promozione artistica come tratto reroicor?, in: Gabriella D'Henry and Chiara Lambert (eds.), Il popolo dei Longobardi meridionali (570-1076), Atti del convegno (Salerno, 2009) 75-92.

Dell'Acqua, Francesca, Illuminando colorat. La vetrata tra la tarda Antichità e l'alto Medioevo attraverso le fonti e l'archeologia, Studi e Ricerche di Archeologia e Storia dell'Arte 4 (Spoleto, 2003).

Dungal, Responsa contra Claudium. A Controversy on Holy Images, ed. and trans. Paolo Zanna (Florence, 2002); PL 105, 465-530.

Epitaph of Abbot Cumianus, ed. Muratori, Rerum Italicarum Scriptores, t. III, 680; ed. Dümmler, MGH, PLAK 4.2, ed. Karl Strecker (Berlin, 1923) 723.

Epitaph of Bishop Damian of Pavia, ed. Karl Strecker, Rhytmi Langobardici, CXXXIV, MGH, PLAK 4.2 (Berlin, 1923) 719-720.

Everett, Nicholas, Literacy in Lombard Italy, c. 568-774, Cambridge Studies in Medieval Life and Thought 53 (Cambridge, 2003).

Fagan, Garrett G., The Genesis of the Roman Public Bath: Recent Approaches and Future Directions, American Journal of Archaeology 105/3 (2001) 403-426.

Falla Castelfranchi, Marina, Arechi II e Giustiniano, in: Arturo Carlo Quintavalle (ed.), Medioevo. Immagini e ideologie. I convegni di Parma 5 (Milan, 2008) 83-89. 
Fentress, Elizabeth, Katherine Gruspier, and Vera von Falkenhausen, The Sixth-Century Settlement, in: Elizabeth Fentress, John Bodel, T. V. Buttrey, Stefano Camaiani, Fernanda Cavari, Laura Cerri, Enrico Cirelli, Sergio Fontana, Elisabetta Gliozzo, Katherine Gruspier, Elisa Gusberti, Michelle Hobart, Valentina Lolini, Francesca Lunghetti, Alex Moseley, Silvia Nerucci, Adam Rabinowitz, Alessia Rovelli, Rabun Taylor, C. J. Simpson and Vera von Falkenhausen (eds.), Cosa V: An Intermittent Town, Excavations 1991-1997 (Ann Arbor MI, 2003), 72-91.

Ferrari, Mirella, In Papia conveniant ad Dungalum, Italia Medievale e Umanistica 15 (1972) 1-52. Flusin, Bernard, Saint Anastase le Perse et l'histoire de la Palestine au début du VIIe siècle, 2 vols, Le monde byzantin (Paris, 1992).

Gantner, Clemens, The label "Greeks« in the papal diplomatic repertoire in the eighth century, in: Walter Pohl and Gerda Heydemann (eds.), Strategies of Identification: ethnicity and religion in early medieval Europe (Turnhout, 2013) 303-349.

Gantner, Clemens, Freunde Roms und Völker der Finsternis. Die päpstliche Konstruktion von Anderen im 8. und 9. Jahrhundert (Vienna 2014).

Gasparri, Stefano, Le molteplici identità etniche dei Longobardi in Italia. Linguaggi politici e pratiche sociali, Mitteilungen des Deutschen Archäologischen Instituts. Römische Abteilung 118 (2012) 493-504.

Giorgi, Ignazio, Il Regesto del monastero di S. Anastasio ad Aquas Salvias, Archivio della Società Romana di storia patria 1 (1877-1878) 49-77.

Goffart, Walter, The Narrators of Barbarian History (A.D. 550-80o): Jordanes, Gregory of Tours, Bede, and Paul the Deacon (Princeton NJ, 1988).

Gregory III, Letter to Antoninus of Grado, ed. Wilhelm Gundlach, MGH EE 3, Epistolae langobardicae collectae 13 (Berlin, 1892) 703.

Hallenbeck, Jan T., Pavia and Rome: The Lombard monarchy and the papacy in the eighth century, Transactions of the American Philosophical Society 72/4 (1982) 1-186.

Handley, Mark A., Saxons, Britons and Scots: pilgrims, travellers and exiles on the continent, in: Lesley Webster and Andrew Reynolds (eds.), Early Medieval Art and Archaeology in the Northern World. Studies in Honour of James Graham-Campbell (Leiden, 2013) 743-778.

Hartmann, Florian, Karolingische Gelehrte als Dichter und der Wissenstransfer am Beispiel der Epigraphik, in: Julia Becker, Tino Licht and Stefan Weinfurter (eds.), Karolingische Klöster. Wissenstransfer und kulturelle Innovation, Materiale Textkulturen 4 (Berlin, München, Boston, 2015) 255-274.

Jankowiak, Marek, The Invention of Dyotheletism, Studia Patristica 63 (2013) 335-342.

Kinney, Dale, Roman Architectural Spolia, Proceedings of the American Philosophical Society 145/2 (2001) 138-161.

Kramer, Rutger and Gantner, Clemens, Lateran thinking: Building an idea of Rome in the Carolingian Empire, Viator 47 (2016) 1-26.

Lamberz, Erich, "Falsata Graecorum more«? Die griechische Version der Briefe Papst Hadrians I. in den Akten des VII. Ökumenischen Konzils, in: Claudia Sode and Sarolta Takács (eds.), Novum Millennium. Studies on Byzantine History and Culture Dedicated to Paul Speck (Aldershot, 2001) 213-229.

Lauxtermann, Marc D., A Lombard epigram in Greek, in: Marc D. Lauxtermann and Ida Toth (eds.), Inscribing Texts in Byzantium: Continuities and Transformations (London, 2019).

Laws of Liutprand = Leges Langobardorum, ed. Georg Heinrich Pertz, MGH, Leges 4 (Hanover, 1868) 96-182; trans. Katherine Fischer Drew, The Lombard Laws, Sources of Medieval History (Philadelphia PA, 1973). 
Liber Pontificalis, ed. Louis Duchesne, Le Liber Pontificalis: Texte, introduction et commentaire, 3 vols [vol. 3: Additions et corrections de Mgr L. Duchesne, ed. Cyrille Vogel] Paris 1955-1957); vol. 1: trans. Raymond Davis, The Book of Pontiffs (Liber Pontificalis): The Ancient Biographies of the First Ninety Roman Bishops to AD 715, Translated Texts for Historians 6 (Liverpool, 2000); vol. 2: trans. Raymond Davis, The Lives of the EighthCentury Popes (Liber Pontificalis): The Ancient Biographies of Nine Popes from AD 715 to $A D$ 817, Translated Texts for Historians 13 (Liverpool, 1992); vol. 3: trans. Raymond Davis, The Lives of the Ninth-Century Popes (Liber Pontificalis): The Ancient Biographies of Ten Popes from AD 817 to AD 891, Translated Texts for Historians 20 (Liverpool, 1995). Lomartire, Saverio, L'iscrizione di Cumiano e l'epigrafia longobarda dell'età liutprandea, in: Flavio G. Nuvolone (ed.), La fondazione di Bobbio nello sviluppo delle comunicazioni tra Langobardia e Toscana nel Medioevo. Atti del Convegno Internazionale Bobbio, Auditorium di S. Chiara, 1-2 Ottobre 1999, Archivum Bobiense Studia III (Bobbio, 2000) 57-70.

Lopez-Jantzen, Nicole, Kings of all Italy? Overlooking political and cultural boundaries in Lombard Italy, Medieval Perspectives 29 (2014) 75-91.

Macrides, Ruth, and Magdalino, Paul, The Architecture of ekphrasis: Construction and Context of Paul the Silentiary's Poem on Hagia Sophia, Byzantine and Modern Greek Studies 12 (1988) 47-82.

Mansi, Giovanni Domenico (ed.), Sacrorum conciliorum nova, et amplissima collectio, 53 vols (Florence, 1692-1769).

Maskarinec, Maya, City of Saints. Rebuilding Rome in the Early Middle Ages, Middle Ages Series (Philadelphia PA, 2018).

Muratori, Ludovico Antonio, ed., Rerum Italicarum Scriptores, vol. 3 (Milan, 1723).

Nelson, Jinty, Charlemagne and Ravenna, in: Jinty Nelson and Judith Herrin (eds.), Ravenna: Its role in Earlier Medieval Change and Exchange (London, 2016) 239-252.

Nielsen, Inge, Thermae et Balnea: The Architecture and Cultural History of Roman Public Baths, 2 vols. (Aarhus, 1993).

Noble, Thomas F.X., Images, Iconoclasm, and the Carolingians, The Middle Ages Series (Philadelphia, 2009).

Noble, Thomas F.X., The Republic of St. Peter (Philadelphia, 1984).

Paul the Deacon, Historia Langobardorum, ed. Georg Waitz, MGH, SRL (Hanover, 1878) 12-187.

Paul the Deacon, Versus de Arichi duce, VI-VII, ed. Ernst Dümmler, MGH, PLAK 1 (Berlin, 1881) 44-45.

Peduto, Paolo, Il gruzzolo del S. Salvatore de fondaco a Salerno: follari, tari, denari del secolo XI, Rassegna storica salernitana 16.8 (1991) 33-71.

Pohl, Walter, Das Papsttum und die Langobarden, in: Matthias Becher and Jörg Jarnut (eds.), Der Dynastiewechsel von 751. Vorgeschichte, Legitimationsstrategien und Erinnerung (Münster 2004) 145-161.

Pohl, Walter, Creating cultural resources for Carolingian rule: Historians of the Christian Empire, in: Clemens Gantner, Rosamond McKitterick and Sven Meeder (eds.), The Resources of the Past in Early Medieval Europe (Cambridge, 2015) 15-33.

Pohl, Walter, Legal Pluralism in Lombard Italy, in: Helmut Reimitz (ed.), Legal Pluralism and Social Change in Late Antiquity and the Early Middle Ages: Essays in Honor of John Haldon (forthcoming).

Price, Richard, Monotheletism: A heresy or a form of words?, Studia Patristica 48 (2010) 221-232.

Price, Richard, Philip Booth, and Catherine Cubitt, The Acts of the Lateran Synod of 649, Translated Texts for Historians 61 (Liverpool, 2014). 
PmbZ = Ralph-Johannes Lilie, Claudia Ludwig and Beate Zielke, Prosopographie der mittelbyzantinischen Zeit (Berlin, 2013). PmbZ online accessed on 19 February 2019: www. degruyter.com/view/db/pmbz.

Regesta Pontificum Romanorum, vol. 2 (a. 604-844), ed. Philipp Jaffé, Waldemar Könighaus, Thorsten Schlauwitz (Göttingen 2017).

Riccardi, Alessandro, Le vicende, l'area e gli avanzi del regium palatium e della cappella e monastero di S. Anastasio (Milan, 1889).

Sansterre, Jean-Marie., Les moines grecs et orientaux à Rome aux époques byzantine et carolingienne (milieu du VIe s.-fin du IXe s.), 2 vols. (Brussels, 1983).

Smith, Julia M.H., Europe after Rome: A New Cultural History, 500-10oo (Oxford: Oxford University Press, 2005).

Smith, Julia M.H., Cursing and Curing, or the Practice of Christianity in Eighth-Century Rome, in: Ross Balzaretti, Julia Barrow and Patricia Skinner (eds.), Italy and Early Medieval Europe: Papers for Chris Wickham, The Past and Present Book Series (Oxford, 2018) 460-475.

Sotinel, Claire, Das Dilemma des Westens: Der Drei-Kapitel-Streit, in: Luce Pietri (ed.), Geschichte des Christentums, Altertum, vol. 3: Der lateinische Westen und der byzantinische Osten (Freiburg 2005) 462-490.

Speck, Paul, Ich bin's nicht, Kaiser Konstantin ist es gewesen. Die Legenden vom Einfluss des

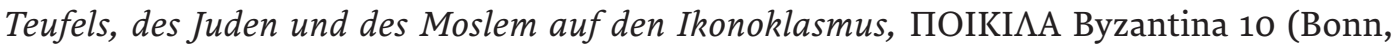
1990).

Speck, Paul, Kaiser Leon III., die Geschichtswerke des Nikephoros und des Theophanes und der Liber Pontificalis: Eine quellenkritische Untersuchung, Poikila Byzantina 20 (Bonn, 2003).

Stevenson, Henry M., Codices manuscripti Palatini graeci Bibliothecae Vaticanae, Bibliothecae Apostolicae Vaticanae codices manuscripti (Rome, 1886).

Thunø, Erik, Decus suus splendet ceu Phoebus in orbe. Zum Verhältnis von Text und Bild in der Apsis von Santa Maria in Domnica in Rom, in: Bernd Janowski and Nino Zchomelidse (eds.), Die Sichtbarkeit des Unsichtbaren, Arbeiten zur Geschichte und Wirkung der Bibel 3 (Tübingen, 2003) 147-164.

Thunø, Erik, Inscription and divine presence: Golden letters in the early medieval apse mosaic, Word \& Image 27/3 (2011) 279-291.

Thunø, Erik, The Apse Mosaic in Early Medieval Rome. Time, Network, and Repetition (New York, 2015).

Versus xii, In Ecclesia Beati Anastasi, MGH, PLAK 1, ed. Ernst Dümmler (Berlin, 1881) 106.

Vircillo Franklin, Carmela, The Epigraphic Syllogae of BAV, Palatinus Latinus 833, in: Jaqueline Hamesse (ed.), Roma, magistra mundi. Itineraria culturae medievalis. Mélanges offert au Père L.E. Boyle à l'occasion de son 75e anniversaire (Leuven, 1998) 975-990.

Vircillo Franklin, Carmela, The Latin Dossier of Anastasius the Persian. Hagiographic Translations and Transformations, Studies and Texts 147 (Toronto, 2004).

Woolf, Greg, Monumental writing and the expansion of Roman society in the early empire, The Journal of Roman Studies 86 (1996) 22-39.

\section{List of figures}

Figure 1: Tombstone of Abbot Cumianus, c.736, marble, 180 x $90 \mathrm{~cm}$, Bobbio (Piacenza), Museo dell'Abbazia di San Colombano @Ufficio per i Beni Culturali Ecclesiastici della Diocesi di Piacenza-Bobbio 


\title{
Mercantile and Religious Mobility between Byzantines, Latins and Muslims, 1200-1500: On the Theory and Practice of Social Networks
}

\author{
Johannes Preiser-Kapeller and Ekaterini Mitsiou*
}

This paper combines documentary evidence with concepts and tools of historical network science and social theory in order to explore phenomena of (especially) mercantile mobility and religious conversion in the late medieval Byzantine world. The intensification of commercial exchange and the multiplication of contact zones between ethnic and religious identities in the 13th to 15th centuries, both due to the growth of the activity of Italian merchant communities as well as due to the Mongol expansion across entire Asia, facilitated the change of places of residence and/or of religious confession for elite as well as non-elite members of these societies. With the help of network analytical and sociological concepts, potential underlying mechanisms such as the »social infrastructure « for these phenomena are described. In general, the last centuries of the relationship between Byzantium and the West saw the intensification of processes of individual and community-wide religious change, which equally shaped the following early modern period of Mediterranean history.

Keywords: Byzantine history, Mediterranean Studies, Religious studies, Network analysis, Social Theory, Late Medieval History, Religious conversions, Medieval trade, Church history

\section{Prologue: Byzantines, Latins and Muslims in Tanaïs, 1356-1360}

In the year $1356 \mathrm{AD}$, a document from the "Register of the Patriarchate of Constantinople" informs us that in the city of Tanaïs on the river Don (today Azov), which was under the sovereignty of the Muslim Khan of the Golden Horde, a Byzantine orthodox Christian »went over to the Persians " (here used as a synonym for Muslims) and »became a Muslim " (the verb used in the Greek text is "musulmanizo", to date a hapax legomenon). ${ }^{1}$ The menace for the souls of the Christians (psychikon kindynon) who had to live under Muslim (or Latin) rule

* Correspondence details: Johannes Preiser-Kapeller, Institute for Medieval Research/Division for Byzantine Research, Austrian Academy of Sciences, Hollandstraße 11-13/4, 1020 Vienna, Austria, email: Johannes.PreiserKapeller@oeaw.ac.at. Ekaterini Mitsiou, Arbeitsstelle Edition und Bearbeitung byzantinischer Rechtsquellen der Akademie der Wissenschaften zu Göttingen, Goethe-Universität, Historisches Seminar, Norbert-Wollheim-Platz 1, 60629 Frankfurt/Main, Germany, email: Mitsiou@em.uni-frankfurt.de.

1 See PRK III, no. 215, ll. 117-118; cf. also $L B G$ 5, 1049 (on the verb »musulmanizo«). 
and next to Muslim (or Latin) neighbours is a common topic in this most important collection of documents on the Late Byzantine Church. ${ }^{2}$ The worst fear of the patriarch and the Synod was, of course, the conversion of their spiritual children either "to the ungodliness of the Muslims" or the "heresy of the Latins «. ${ }^{3}$

Tanaiis at the mouth of the river Don was at the same time the most important trading post of the Venetians in the Northern Black Sea and a city of many religious and ethnic groups. Fortunately, the notarial records of Benedetto Bianco for the period September 1359-August 1360, preserved in the Archivio di Stato di Venezia and analysed by Sergei P. Karpov, ${ }^{4}$ allow us to reconstruct the religious and ethnic environment of this act of conversion in greater detail. ${ }^{5}$ Under the sovereignty of the Golden Horde, during this period Tanaïs attracted many merchants from Venice and its Italian hinterland as well as its colonies in the Adriatic and the Aegean Sea, but also many other Italians, even from Venice's main rival Genoa, as well as Catalans from the far west of the Mediterranean. In addition, we also find "Byzantine« or "Greek" traders from Constantinople and Trebizond in the city, other Orthodox Christians from Russia and Alania (in the north-western Caucasus), Armenians from diaspora communities in the Black Sea region as well as from Armenia proper, Jewish merchants and Muslim merchants, some of them subjects of the Golden Horde (»Tatars»), but also from Eastern Anatolia and Tabriz (Fig. 1). This mosaic becomes even more multifaceted if we look at the places of origin of the most important commodity traded in Tanaïs: slaves, especially young girls. Most of them originated from the immediate and wider hinterland of the city (Tatars, Circassians, Alans), but we also encounter Russian, Greek, Armenian and Jewish slaves as well as one Chinese girl in 1359/1360. ${ }^{6}$ At such a hub of encounters between Islam and Western as well as Eastern Christianity and Judaism, an act of religious conversion may not be a great surprise. $^{7}$

$2 \quad$ PRK I, no. 7 (July-Sept. 1315), 1. 5; Todt, Kaiser Johannes VI., 606; Vryonis, Byzantine Attitudes.

3 See also Preiser-Kapeller, Conversion, collaboration and confrontation.

4 Karpov, Tana; Karpov, Les Occidentaux.

5 Cf. also Epstein, Purity Lost, 118-130. For mercantile mobility in this period in general, see Mitsiou and PreiserKapeller, Moving hands, with further literature. For parallel examples from Mamluk Egypt in the same period see Christ, Trading Conflicts, and for Anatolia at large Preiser-Kapeller, Liquid Frontiers.

6 Karpov, Tana; Karpov, Les Occidentaux.

7 For the interplay between mercantile and religious mobility on the significance of social networks in the ancient western Indian Ocean cf. also Seland, Networks and social cohesion. 


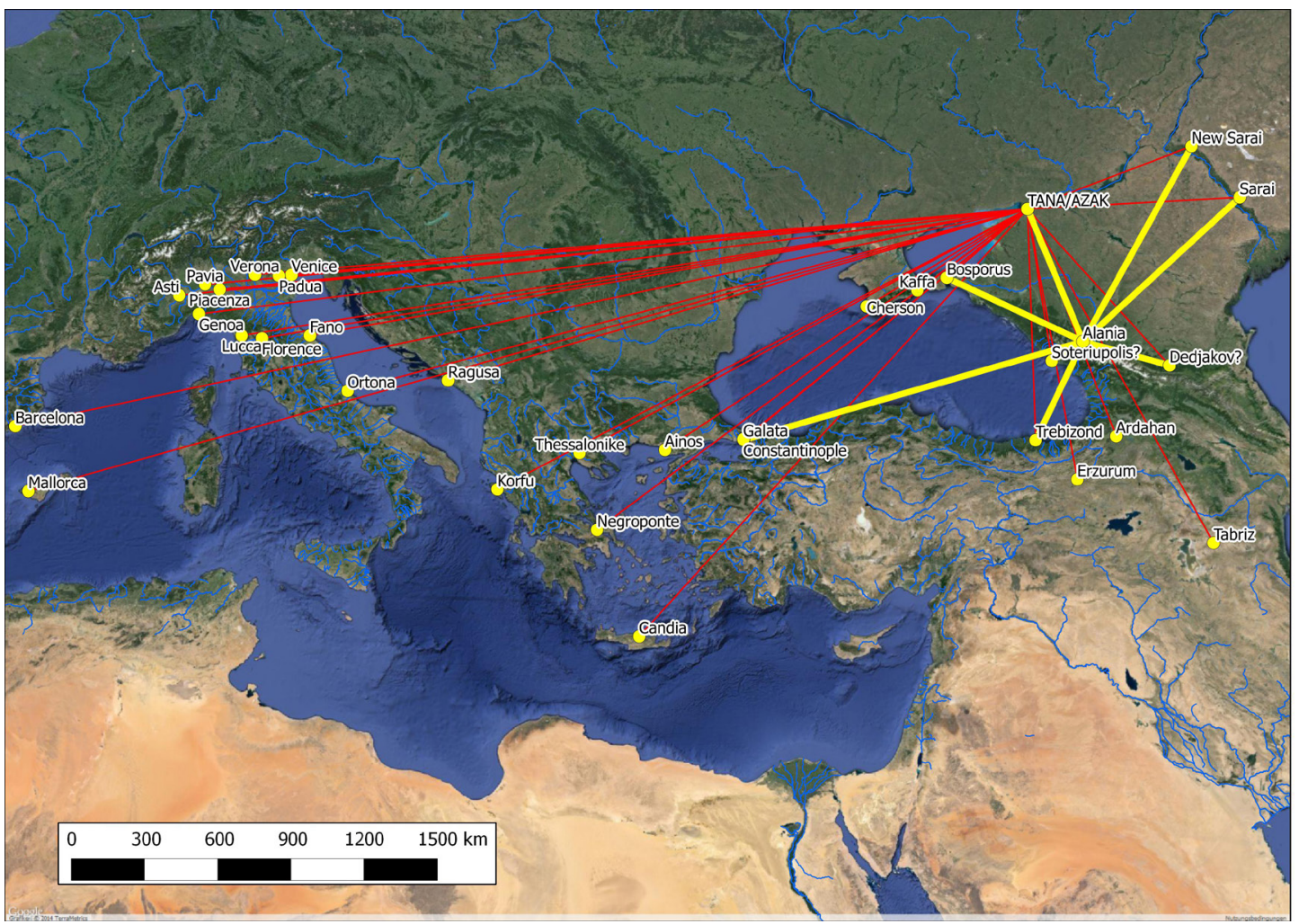

Fig. 1: The interconnections between Tanaïs and the Mediterranean world on the basis of the information on places of origin of merchants active in the city in 1359/1360 (red lines) and the range of connections and influence of the metropolitan Symeon of Alania in the 1350s and 1360 s on the basis of the information from the documents from the Register of the Patriarchate of Constantinople (yellow lines) (image: Preiser-Kapeller and Mitsiou, 2018)]

Yet, the Synod of bishops in Constantinople took notice of the specific conversion due to a peculiarity: the convert was the brother of the Byzantine Orthodox metropolitan Symeon of Alania in the northwestern Caucasus. ${ }^{8}$ The see of Alania, although at the periphery of the Byzantine ecclesiastical sphere, had since the 13th century been of increased importance for Byzantium's influence in the region. Alans lived not only in their homeland in the north-western Caucasus, but in many places within the realm of the Golden Horde in the Caucasus, in the Crimea and also in the capital of Saray on the River Volga, where they also served in the army of the Khan. Due to the "diffusion" of their flock, the metropolitans of Alania were active in many of these localities and served as intermediaries between Constantinople and the Khan. In addition, the metropolitans of Alania also traditionally had good relations with Trebizond, the capital of a Byzantine state in exile; it was from here that Symeon and his brother also originated (Fig. 1). ${ }^{9}$ This network the two of them also used for their purposes as they came into conflict with several orthodox priests (the protopapas Michael, the presbyteros Nikolaos and the presbyteros Theodoros) in the city of Tanaïs over property and ecclesiastical rights.

8 PRK III, no. 215, ll. 113-126; Kresten, Die Affäre des Metropoliten Symeon von Alania, 26-27.

9 Preiser-Kapeller, Der Episkopat im späten Byzanz, 16-21, Preiser-Kapeller, Zwischen Konstantinopel und Goldener Horde, and Preiser-Kapeller, The global Patriarch, with further literature. 
In order to counter an appeal by the three priests to the Synod in Constantinople, Symeon travelled to the Khan Jānībek (r. 1342-1357) of the Golden Horde and provided himself with a privilege charter (a jarlï; in the Greek text "dialeichion ${ }^{10}$ ), which allowed him (and his brother) to continue their occupation of the three priests' property. However, Symeon had to answer to the Synod in Constantinople and travelled to the Bosporus. In his absence, the three priests also made for the capital of the Golden Horde and were able to achieve a new decision in their own favour (the source indicates that bribery played an important role at the Khan's court in both cases). It was in this situation and especially in order to avoid the payment of compensation to the priests that Symeon's brother "went to the Persians" (which did not imply covering a long distance in Tanaïs) and "became a Muslim ", thereby outplaying his opponents. A priori, modern-day observers may be as astonished about the conversion of this man as was the Synod of Constantinople: he was the brother of a high-ranking orthodox hierarch, embedded in a network of secular and ecclesiastical Byzantine authorities in the region (Fig. 2/3). Yet, it was especially this network of Symeon of Alania, which criss-crossed political and religious borders, and which, in addition to the multi-religious and multi-ethnic environment of Tanaïs, also opened channels of interaction beyond their traditional religious community for his brother (Fig. 2/1). Before the Synod, Symeon, of course, officially condemned his brother's conversion; but further information suggests that Symeon, whom we get to know as a very smart politician on many occasions, ${ }^{11}$ continued cooperation with his brother, whose new status as a convert he may have accepted as a most welcome extension of the potential of his network.

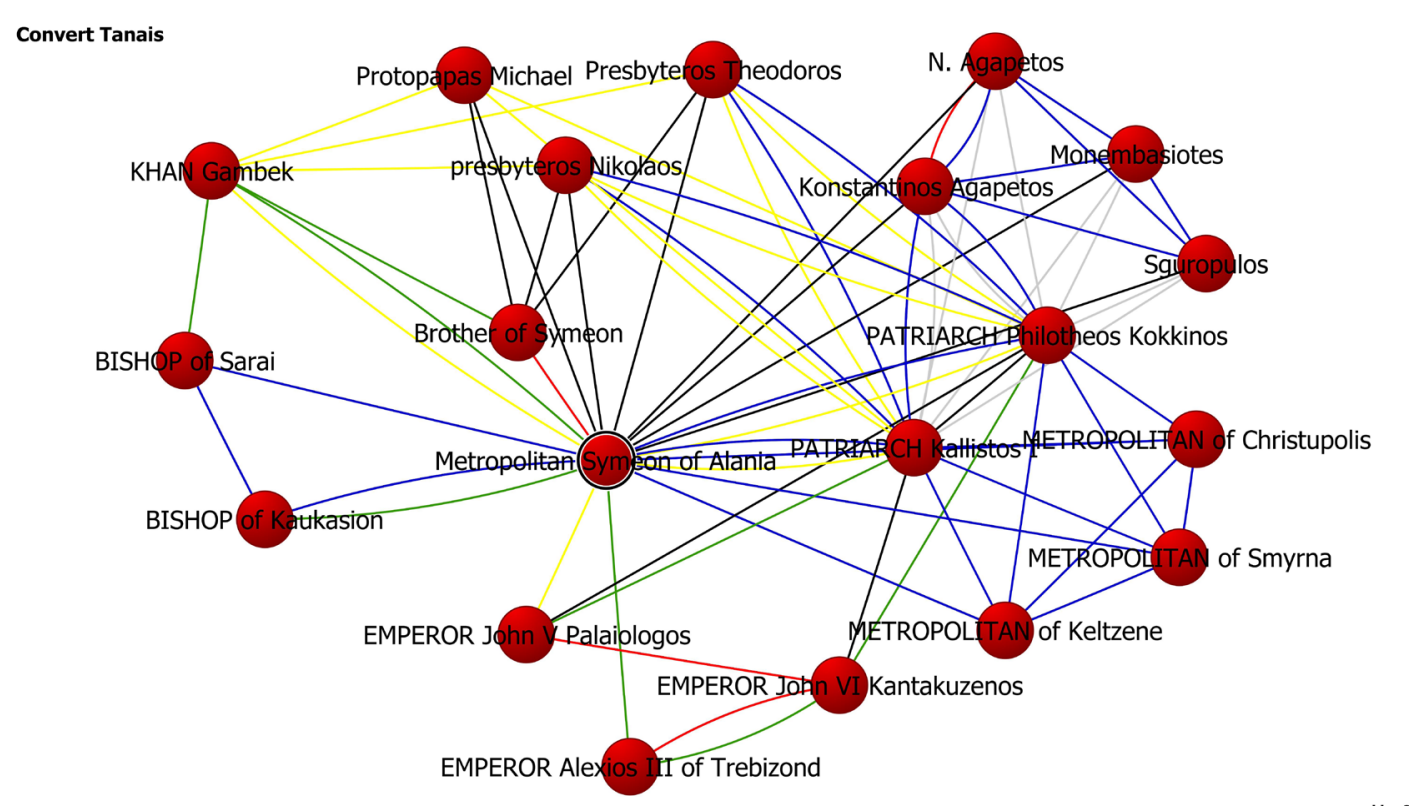

Fig. 2: The social network of Metropolitan Symeon of Alania and his brother between Byzantines and the Muslim Khan of the Golden Horde, with ties of kinship (red), support (green), appellation (yellow), conflict (black), subordination and professional association (blue) and of other qualities (grey) (image: Preiser-Kapeller and Mitsiou, 2018). 
Convert Tanais

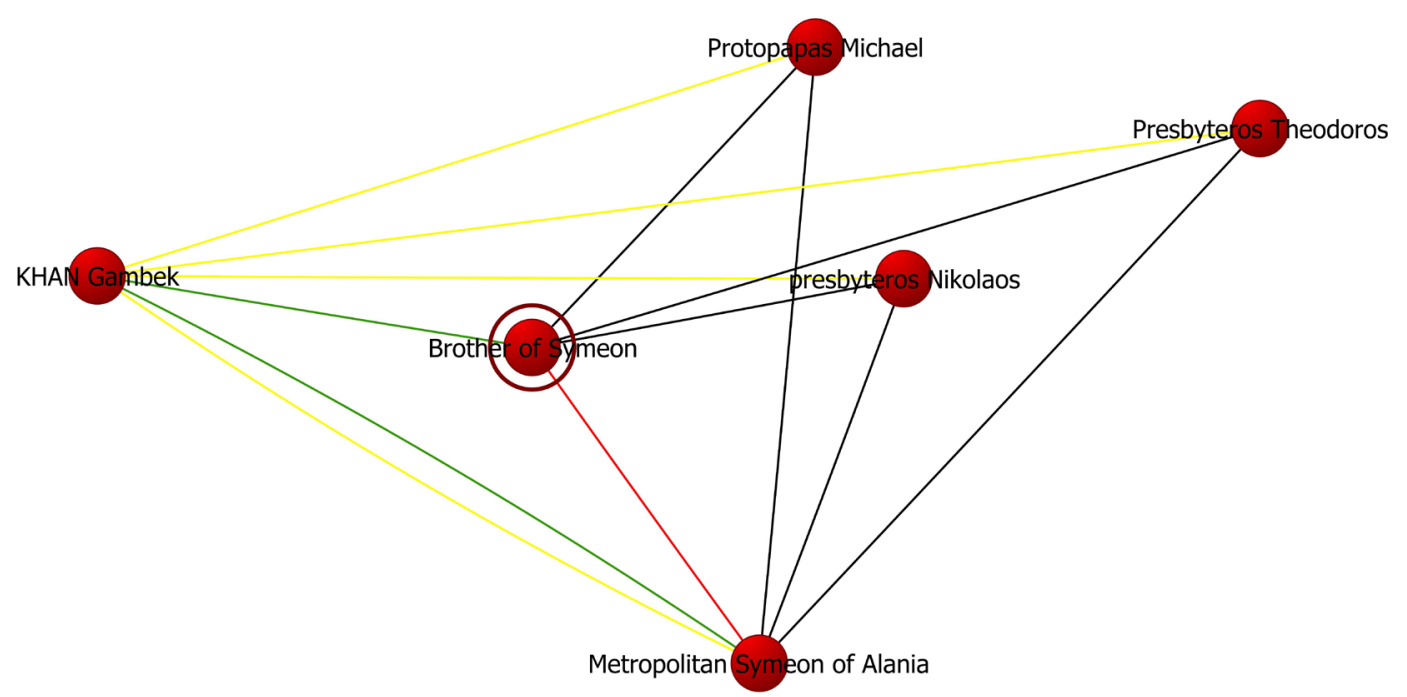

powered by ORA

Fig. 3: The immediate "Ego-network" of Symeon's brother (colours of ties as per Fig. 2) (image: Preiser-Kapeller and Mitsiou, 2018).

\section{Social networks and religious conversion}

The social environment of this late medieval act of conversion is relatively well documented, at least from a Byzantinist's point of view; the source evidence enables us to reconstruct the embedding of the convert in a personal (the social network centred around his brother) and local (the multi-religious environment of Tanaiis) web of relations and interactions (Fig. 1). Marc David Baer in his book »Honored by the Glory of Islam« (2008) stated:

"Most scholars writing about religious conversion today have moved away from the school of thought associated with the eminent William James, based on an uncritical reading of converts' narratives that emphasizes the (Protestant) individual's psychological experience of conversion. Historical sources, especially Ottoman material, seldom provide insight into the converted, so the psychological approach developed first by James is limited in its utility. Instead of such an interiorist approach, which focuses on an individual in isolation, scholars emphasize the social and historical context and aspects of conversion, arguing that conversion is motivated by social relationships and interpersonal bonds. Arguing against James, they maintain that conversion, which entails internal and external transformation, whether revivalist or transition to another tradition, does not occur in a vacuum, is not merely the result of an individual's studied reflection of his or her relation to the divine or the transformation of an individual living in solitude. Nor does conversion concern only an autonomous quest for spiritual meaning, the isolated interior path of selfrealization, or a moment in a single individual's private personal destiny. It is not only the life of the mind that matters, but also the life of the social being, for conversion is not only deeply private, but also deeply social. ${ }^{12}$ 
In her book »Contested Conversions to Islam: Narratives of Religious Change in the Early Modern Ottoman Empire« (2011), Tijana Krstić likewise wrote:

"Although the agents of syncretism and anti-syncretism were multiple and diverse, they all relied on social networks to incite religious change and create a feeling of an (interpretative) community. The importance of the household - common, noble, sultanic, or otherwise - was paramount in this process. This perspective contradicts historiography on conversion to Islam, which views the key agents of syncretism and conversion (the "state" and the dervishes) as external to the communities to which converts-to-be belonged. As the dialogue of narrative and archival sources presented here show, the importance of social networks in the study of conversion to Islam cannot be overstated. Even in the case of the janissaries, whose mode of recruitment inspires the view of the Ottoman state as an "external « agent of conversion, one could argue that the real religious change happened only within the sultan's household or in the context of homeschooling young recruits received when they were placed in different Anatolian Muslim families to learn Turkish and hard physical work as a part of their training. Other types of social relations, such as professional networks, also played an important role in the process of conversion to Islam. ${ }^{13}$

With these observations, Baer and Krstić support our approach of looking at the "social networks " of converts in detail. ${ }^{14}$ With "social network", Krstić uses a concept very popular in recent scholarship, but, as in many other cases, she does not take into account the conceptual and analytical framework established around this term in sociology as well as other new disciplines such as socio-physics. ${ }^{15}$ Recent studies work mainly within the framework of quantitative network analysis, which concentrates on the construction of quantifiable network models (with nodes and ties or links) on the basis of relational data and on the mathematical analysis of these models with regard to their general structure and the differences between nodes and groups or clusters of nodes. ${ }^{16}$ Yet, besides or in addition to quantitative analysis, the field of "relational sociology" has highlighted more "qualitative» aspects of social networks with regard to their relevance for the embedding and even construction of identities and relationships. ${ }^{17}$ In our studies of historical networks we have attempted to combine both approaches; ${ }^{18}$ we will do this also for the present study. Due to the character of source evidence, we will present a quantitative approach especially for the macro-perspective of religious conversion, while we will concentrate on the qualitative aspects for our view on the networks of individual converts.

13 Krstić, Contested Conversions, 72-73.

14 For an overview on earlier research, cf. Grivaud and Popovic, Les conversions à l'Islam.

15 Newman, Networks, and already Reinhard, Freunde und Kreaturen. Cf. also Preiser-Kapeller, Letters and network analysis, the new handbook of Düring et al., Handbuch Historische Netzwerkforschung, and for network theory and religious studies esp. Everton, Networks and Religion.

16 Prell, Social Network Analysis; Jullien, Netzwerkanalyse in der Mediävistik; Düring et al., Handbuch Historische Netzwerkforschung; Everton, Networks and Religion, 47-84.

17 Fuhse and Mützel, Relationale Soziologie; Mische, Relational sociology.

18 Mitsiou, Networks of Nicaea; Preiser-Kapeller, Luhmann in Byzantium; Preiser-Kapeller, Visualising Communities; Preiser-Kapeller, Maritime mobility; Preiser-Kapeller, Calculating the Middle Ages. 


\section{Religious conversion in the Middle Ages and models of "social contagion"}

A quantitative "macro-approach « to medieval conversion is not a new idea; already in 1979, Richard W. Bulliet tried to extract quantitative data on the growth of the Muslim community during the first centuries of Islam for Iran and Spain especially from biographical compilations on the genealogy of several hundred families. ${ }^{19}$ This data was used by the evolutionary biologist Peter Turchin to test his mathematical model for such a process of diffusion of new religious ideas within a community $;^{20}$ he plotted the proportions of Iranian and Spanish families converting to Islam during 25 years periods on a graph. Then he compared this plot with the trajectory of the rate of conversion calculated with his mathematical model, which followed this equation:

$$
C(t)=\frac{1}{1+\left[\frac{1-y}{y}\right] \exp [-r t]}
$$

where $C(t)$ is the proportion of converts at a specific time-step $(t), \gamma=C(0)$, the initial proportion of converts at time $t=0$, and $r$ is the relative rate of conversion. With his model, Turchin achieved what he claims to be an »excellent" fit (the curve of his model explains more than 99.5 \% of the variations in the data for the Iranian as well as the Spanish case). For the creation of his what he calls "autocatalytic model«, Turchin in turn relied on the observations of Rodney Stark, who attempted a similar quantitative analysis for the rise of Christianity from the time of Jesus Christ until the 4th century; Stark also stated: "The basis for successful conversionist movements is the growth through social networks, through a structure of direct and intimate interpersonal attachments. ${ }^{21}$ To model such diffusion processes on networks, Turchin and earlier researchers rely on models developed for the analysis of processes of contagion; therefore, one speaks of processes of »epidemic diffusion « or "social contagion «. ${ }^{22}$ This may suggest that processes of religious conversion follow some law of nature - once started they will not stop until an entire population is converted. Richard Bulliet also describes this process as a "chain reaction « and wrote: "This chain reaction leads to a brief period of very rapid growth, which I shall refer to as the "bandwagon « period. On the graph of conversion to Islam in Iran, the bandwagon period is represented by the steepest slope on the curve, between 791 and $864 . \aleph^{23}$ For the period and region we are especially interested in, Bulliet identified such a "bandwagon period" for the conversion to Islam in Anatolia in the early 13th century, but unfortunately without providing any quantitative or other evidence for this assumption. ${ }^{24}$

Considering the diffusion of religious ideas, however, many "unsuccessful« religious movements with regard to mass conversion suggest a contrary view. As recent research has demonstrated, the spread of a social contagion within a network very much depends on the position of nodes serving as "starting points" for such a process (are these nodes in the 
centre of a social network or at its periphery? Are they more or less well connected?) and on the predisposition of nodes towards such an innovation (also expressed in quantitative terms in the ratio of neighbouring nodes, who have already adopted the contagion, necessary for a specific node in order to adopt it itself). Overall, the general »topology« of a network (are most nodes equally well connected or do we observe a very unequal distribution of the number of connections between a mass of less well connected nodes and a small number of hubs?) very much influences the speed and success of such diffusion processes. ${ }^{25}$ If, for instance, a central hub within an unequally distributed network (in a medieval society, the ruler for instance) adopts a contagion, it actually can spread across the entire network in a short time (therefore, concentrating on rulers for spreading their message was not a bad idea for medieval missionaries, also from a network analytical point of view) ${ }^{26}$

\section{Dynamics of conversion}

Actually, conversion could also be a relatively rapid process from the point of view of contemporaries. Significant in this respect is a letter from Patriarch John XIV Kalekas to the clergy and laymen of the city of Nicaea in north-western Asia Minor, written in 1338/1339, a mere seven years after the capture of the city by the Ottomans. The Patriarch wrote: ${ }^{27}$

Now the attack of the Ismaelites has overwhelmed us, with the permission of God because of the quantity of (our) sins. They have captured many of us, (they have) enslaved and displaced them with violence, so that they (= the captured Christians) - alas! - select their wickedness and ungodliness. (... But) Those who choose the true faith in God and desist from the wickedness of the Muslims, in which they have fallen, (the church) will again attribute to the flock of Christians, heal and maintain them; they will not find an obstacle to the salvation of their souls because of their, as I said, earlier error.

A few years after the Ottoman occupation of Nicaea, the Patriarch was concerned about the number of conversions to Islam to such an extent that he was more or less prepared to promise exemption from punishment for those who were disposed to return to Christendom, although the canon law of course prescribed heavy penalization for apostasy. ${ }^{28}$ But the Patriarchate was also well aware that Islamic law imposed capital punishment on apostates, and thus John XIV Kalekas made even more concessions:

25 Newman, Networks, 627-675; Collar, Network Theory and Religious Innovation; Everton, Networks and Religion, 238-248. Most recently, the Generative Historiography of Religion Project (GEHIR) at the Masaryk University, Brno (PI: Prof. Aleš Chalupa), has experimented with various quantitative and computer-based models for religious diffusion and conversion for case studies of the ancient period, see gehir.phil.muni.cz

26 Cf. also Ormerod and Roach, The medieval inquisition; Collar, Network theory, 152, 155; Schor, Conversion by the numbers, 497.

27 PRK II, no. 116, ll. 17-30; cf. also Vryonis, The Decline of Medieval Hellenism, 341-343; Todt, Kaiser Johannes VI., 614-616.

28 Cf. Mitsiou and Preiser-Kapeller, Übertritte zur byzantinisch-orthodoxen Kirche, 234-239, with further literature. 
But all those, who from fear of punishment want to live for themselves and in secret, where they internalize and realize Christianity, will equally find (the) healing inasmuch as they make every effort to keep the commandments of God. ${ }^{29}$

This patriarchal statement equals an invitation to Crypto-Christianity and illustrates the flexibility of the Byzantine church hierarchy in their attempts to maintain Christian life in the face of what they considered a large scale conversion to Islam (»behaviors are more easily detectable than beliefs « $\left.^{30}\right)$. In this case, of course, conditions very much differed in comparison with a more or less deliberate crossing of borders like we observed in the case of the brother of Symeon of Alania; the social embedding of individuals already under the rule of potentates of a different faith constricted the free space for selection of religious alternatives. ${ }^{31}$ Especially within such frameworks of integration of a community into a polity dominated by a different faith, diffusion models such as those developed by Bulliet or Stark may prove their validity, although they always will explain only the possibly observable quantitative change in the ratio of converts on a macro-perspective. The actual structural and qualitative pre-conditions for conversion again only become visible with a more detailed inspection of their social embedding.

\section{The micro-perspective: the social embedding and networks of converts}

One problem for a »network-approach « to conversion is the character of most of the sources which have been preserved and interpreted; Krstić states, for instance, that the networkperspective "contradicts historiography on conversion to Islam, which views the key agents of syncretism and conversion (the "state" and the dervishes) as external to the communities to which converts-to-be belonged «. Nevertheless, »the importance of social networks in the study of conversion to Islam cannot be overstated . $^{32}$ Hagiographic texts, for instance, such as those used by Spyros Vryonis as the main source for his chapter on conversion in medieval Anatolia, connect acts of conversion to the deeds of holy men such as Ḥājì Baktāš Walì or Maulānā Ğalāl ad-Dīn ar-Rūmī. ${ }^{33}$ Yet, as Şevket Küçükhüseyin has highlighted, these texts may more reflect the self-perception of the followers of these saints, who understood the saint's personality as a primary mover for conversion. ${ }^{34}$ It may be difficult to reconstruct the actual social embedding, which could divert our perspective on conversion from single authoritative figures, ${ }^{35}$ of late medieval converts from these sources.

29 PRK II, no. 116, 1l. 34-38; cf. also Balivet, Byzantins et Ottomans, 231-254.

30 Cf. Stroope, Social networks and religion, 20.

31 Cf. Epstein, Purity Lost; for the situation in the territories under Muslim rule in Anatolia cf. also Korobeinikov, Orthodox communities I; Korobeinikov, Orthodox communities II; Preiser-Kapeller, Der Episkopat im späten Byzanz; Preiser-Kapeller, Conversion, collaboration and confrontation. For a relative frequency of "voluntary« conversions cf. the analysis of 297 cases of converts from territories within or near the Ottoman Empire in the late 16th/ early 17th century in Bennassar and Bennassar, Les Chrétiens d'Allah, 222-229: from these 297 converts, 174 were captives of war, 43 became Muslims through devşirme and 11 conversions were voluntary ones.

Cf. also Schor, Conversion by the numbers, 474-478; Czachesz, Women, charity and mobility, 131. 


\section{Motivations and backgrounds for conversion}

Contemporaneous documents referring to acts of conversion (as in the case mentioned above) or even written for this occasion may be more helpful in this regard. Within the above-mentioned Register of the Patriarchate of Constantinople, we find 29 confessions of faith of converts to the Orthodox Church for the period between 1360 and $1404 \cdot{ }^{36}$ Only one of the individuals converted from Islam, while all others were converts from the "Latin" Church. This may also indicate the actual frequency of such events, but most interestingly, this one convert from Islam had previously converted from Orthodoxy to Islam (see below). Even more pleasant for the Byzantine authorities would, of course, have been the conversion of a Muslim by birth to Christianity. In the year 1180, on the initiative of Emperor Manuel I Komnenos, the Byzantine church had modified the official formula for such conversions in order to make it more acceptable for Muslims. ${ }^{37}$

In the Register of the Patriarchate we encounter only one born Muslim who became Christian; but this man had been baptised a "Latin« (i.e. "Roman Catholic«) Christian and had received the name Antonius before he confessed his adherence to the dogmas of the church of Constantinople in February 1374. Based on the background to similar documents, the reason for this conversion may have been his intended marriage to an Orthodox woman. ${ }^{38}$ At the end of the document, Antonius declared:

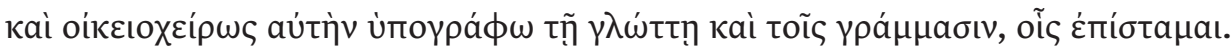

(»And by my own hand I sign this (confession) in the language and with the letters which I understand «). ${ }^{39}$

Actually, we possess Antonius' autograph signature in Arabic letters in the Persian language, which reads: "Andūn. The Muslim has passed away, I have believed with my heart in God «. ${ }^{40}$ Beneath the Persian signature, the scribe from the patriarchal chancellery wrote a rather imperfect translation:

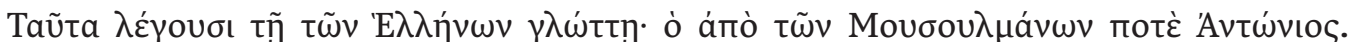
(»This means in Greek language: the former (convert) from the Muslims, Antonios«) ${ }^{41}$

36 Cf. Mitsiou and Preiser-Kapeller, Übertritte zur byzantinisch-orthodoxen Kirche. For a most recent analysis of these documents see Mitsiou, »I believe what the Great Church believes".

37 Montet, Un rituel d'abjuration, on the older formula; Darrouzès, Tomos inédit de 1180; Sahas, Ritual of conversion; Angold, Church and Society, 111-113; Hanson, Manuel I Comnenus; cf. also Beihammer, Orthodoxy and religious antagonism, for the wider background of Byzantine-Seljuk relations.

38 Todt, Kaiser Johannes VI., 243; Mitsiou and Preiser-Kapeller, Übertritte zur byzantinisch-orthodoxen Kirche, 255.

39 MM I, 550-551 (no. 293) = PRK IV, no. 374; Mitsiou and Preiser-Kapeller, Übertritte zur byzantinisch-orthodoxen Kirche, 255.

40 Vind. hist. graec. 47, fol. 284v; a picture in Mitsiou and Preiser-Kapeller, Übertritte zur byzantinisch-orthodoxen Kirche, 280, fig. 5. For the reading of the Persian signature cf. Shukurov, The Byzantine Turks, 373-374.

41 MM I, 550-551 (no. 293) = PRK IV, no. 374; Mitsiou and Preiser-Kapeller, Übertritte zur byzantinisch-orthodoxen Kirche, 255. 
The Muslim origin of Antonios was emphasized, although he had taken a detour to the Roman church before his conversion to the Church of Constantinople. The number of these spiritual victories was, however, small in comparison to the losses of bishoprics to the expanding Turkish and especially Ottoman power.

In addition, we possess the document with which Nikolaos Bulgaris, a former Orthodox Christian from Constantinople, declared his return to Christianity before Patriarch Antonios IV and the Synod in July 1391:

I, Nikolaos Bulgaris, declare and promise by my present letter in front of our most holy Lord, the ecumenical Patriarch, and the divine and holy Synod, that I will keep myself from now on in the Orthodox faith of the Christians, and that I reject and condemn the wickedness of the Muslims and all their rites, I assure that I also will bring here my children so that they live in Christianity. And everything I have done from resentment, with involvement of the evil demon, and (that) I went to the Turks and (that) I admired their wickedness, I now reject with God's grace and I promise to observe the Orthodox faith of the Christians. ${ }^{42}$

The circumstances of Bulgaris' emigration to Turkish territory (he "went to the Turks " as Symeon's brother "went over to the Persians") and conversion are presented in a vague way. Obviously, he took his children with him or they were born in the Turkish territory. His wife is not mentioned; she could have been dead already or maybe was a Muslim. Yet, as Nevra Necipoğlu has made plausible, the "timing « of his return to Constantinople and Christianity can be connected to recent political as well as ecclesiastical changes: »in September 1390 the revolt of John VII [son of Andronikos IV, who had, in turn, usurped the throne from his father John V between 1376 and 1379] in Constantinople had ended with the restoration of John V [as well as of Patriarch Antonios IV], and, following the latter's death in February 1391, Manuel II had ascended the throne. Conflicts soon picked up between Manuel II and John VII, but for a while it seemed as if the civil wars of the previous two decades were over and that internal peace was on the way to being re-established in Constantinople «. ${ }^{43}$ Thus, Bulgaris' "resentment «, emigration and conversion were probably caused by a conflict with the secular and/or ecclesiastical authorities in Constantinople. ${ }^{44}$ Illustrative in this respect is a statement made by a priest of the imperial clergy, Konstantinos Kabasilas, and recorded in the Register of the Patriarchate in 1383. After he had been sentenced to deposition by the Synod because of several offences, Kabasilas made a threat that he would defect "to the Franks or to the Turks" if the Synod's verdict was not reversed. Thus, "going over to the Turks" (which actually demanded only crossing the Bosporus or even just the walls of Constantinople in this period) obviously seemed a plausible option for someone who encountered difficulties in Byzantium. ${ }^{45}$

42 MM II, 155 (no. 425); Darrouzès, Reg. No 2891. The Greek text also in: Mitsiou and Preiser-Kapeller, Übertritte zur byzantinisch-orthodoxen Kirche, 271-272.

43 Necipoğlu, Byzantium, 147-148.

44 Mitsiou and Preiser-Kapeller, Übertritte zur byzantinisch-orthodoxen Kirche, 261-262.

45 MM II, 55 (no. 361/2, September 1383) = PRK V, no. 465; on Kabasilas cf. Kraus, Der Fall des Priesters Konstantinos Kabasilas, 248-263, and Kraus, Kleriker im späten Byzanz, 308-311. Cf. also Preiser-Kapeller, Liquid Frontiers. 
A parallel case from the Register of the Patriarchate illustrating a relatively flexible approach towards confessional borders is the one of George de Braze, a Genoese living in the commune of Galata/Pera in the north of the Golden Horn: in February 1402, his female slave had sought asylum in the Hagia Sophia because she had been abused by de Braze. In order to get his property returned, he had to promise before the Patriarch not to mistreat the woman again. In addition, we find the following sentence in his promise ${ }^{46}$ :

"But if I should do anything like that to her, then I should be fined by the Commune [of Galata] with a hundred nomismata [gold coins] and excommunicated by His Holiness [the Patriarch of Constantinople], if I am an Orthodox [at the time of the malefaction], but if not, then I should be excommunicated by the Pope."

The background to this clause seems evident, also in the context of other documents we possess. In this period of political and religious upheaval, Latin as well as Orthodox Christians in Constantinople, who were confronted with a threat of punishment, for instance, crossed confessional borders in order to elude the authorities of their original religious community; such a manoeuvre was to be parried in the case of de Braze. ${ }^{47}$ These findings can be connected to later periods of early modern Mediterranean history in the 16th and 17th century, for which "renegades« have become a prominent figure in recent research. Eric R. Dursteler for instance states for the period around 1600:

»A Mediterranean saying of the time suggests still another motivation: sout of spite [cf. the phrasing in Bulgaris' confession: "from resentment «], I will become a Turk.< Antonio Fabris summarizes well the varied motivations of conversion: ,We are dealing with artisans driven by a yearning for income, with Europeans, slaves of Muslims, desirous of a better life, with men greedy for adventure or in search of a power precluded them in the West. It is not surprising that periods of increased conversion usually coincided with crises in European society, economic depression, and religious and/or political persecution. $\aleph^{48}$

As motives for conversion Dursteler cites statements such as "to obtain the justice that he felt had been denied him by Christians «; he mentions the avoidance of juridical persecution or the paying of debts - very similar to our findings. He also states: "Although practical economic, social and political catalysts for conversion were common, it would be wrong to overlook the element of sincere belief and of a more transcendent religious conversion. (...) [But] while some people converted out of sincere religious conviction, this was probably not the predominant motivation «. ${ }^{49}$

46 Mitsiou and Preiser-Kapeller, Übertritte zur byzantinisch-orthodoxen Kirche, 245-246, edition of the text 274275.

47 Mitsiou and Preiser-Kapeller, Übertritte zur byzantinisch-orthodoxen Kirche, 245-246.

48 Dursteler, Venetians in Constantinople, 113.

49 Dursteler, Venetians in Constantinople, 114-117; cf. also Greene, A Shared World, 39-44, for the background to conversions on Crete before and after the Ottoman conquest in 1669, and 93-94 esp. for possible motivations of Christian women to convert to Islam. 
The counterpart to the motivation to avoid disadvantages within one's original community at 14th century Islamic-(Latin/Byzantine)Christian border zones in Anatolia, southeastern Europe and the Black Sea were opportunities offered by and within the religious community one was about to join. ${ }^{50}$ The successfully expanding "Ottoman project«, for instance, welcomed those, especially from the aristocratic elite, who joined the ranks of the Sultan, even as Christians, but even more so as Muslims. Heath Lowry and Karen Barkey have highlighted the relevance of this "network building " for the emergence of the Ottoman State in Bithynia and later for its expansion in south-Eastern Europe. ${ }^{51}$ Barkey reconstructed the "Ego-networks " of social ties of the first Ottoman rulers (Osman and Orhan) in 14th century Bithynia. She differentiated between Muslims, Christians and converts as well as ties of family or kinship, durable war friendships, religious ties, ties with members of akhi religious trade corporations, and also ties of allegiance which were established after a war against the respective individual. She thus demonstrated the contribution of »brokerage " between individuals from Muslim as well as Christian backgrounds for the rise of the first Ottoman rulers, stating: "We can understand the rise of Osman (1290-1324) and his son Orhan (1326-1359) as the leaders of an incipient state in terms of their initial construction of a hub-and-spoke network structure of which they became the centre, as well as the brokerage they initiated among otherwise separated groups and their effective multivocality maintained by the network structure they assembled through their actions "..$^{2}$

Yet even before this we can observe »the formation of a Christian Seljuk-Komnenian Elite" in 13th century Seljuk Anatolia, as Sara Nur Ylldız has done. ${ }^{53}$ She illuminates especially the fate of Manuel Komnenos Mavrozomes, a close relative of the Byzantine imperial house of the Komnenoi, and his descendants, who, despite their Christian faith, were important amirs at the Seljuk court of Konya until the end of the 13th century, as Ibn Bỉbi also informs us. While a daughter of Manuel Mavrozomes was married to Sultan Kaykhusraw I (1192-1196 and 1205-1211), his son married a daughter of the Sultan and became an wintimate confidant of Sultan 'Alā' al-Dīn Kayqubād (1220-1237)", the son of Kaykhusraw I ${ }^{54}$. This »ongoing pattern of Seljuk integration of Byzantine elites into their imperial households « $^{55}$ partly also provides the background to the most prominent act of conversion from Islam to the Church of Constantinople in the Late Byzantine Period, that of the Seljuk sultan Izzeddin Keykavus II of Kony ${ }^{56}$ and his family. They took refuge in Constantinople at the court of Emperor Michael VIII Palaiologos (who, in turn, had found refuge in Konya in the 1250 os before his accession to the throne, but without becoming a Muslim) after a defeat against the Mongols

50 Cf. also Schor, Conversion by the numbers, 489; Preiser-Kapeller, Liquid Frontiers.

51 Lowry, Early Ottoman State; Barkey, Empire of Difference.

52 Barkey, Empire of Difference, 28-66.

53 Ylldız, Manuel Komnenos Mavrozomes; cf. also Shukurov, Oriental margins.

54 Ylldız, Manuel Komnenos Mavrozomes; Shukurov, The Byzantine Turks, 105-120.

55 Ylldı, Manuel Komnenos Mavrozomes, 72-73.

56 PLP no. 328. 
in 1261 and received baptism from the hands of Metropolitan Makarios of Antiocheia (in Pisidia ${ }^{57}$ ). Equally, the mother of Izzeddin Keykavus II was a Byzantine Greek and the daughter of a priest; his descendants under the name of Sultanos were integrated in the Byzantine aristocracy and even became relatives of the imperial house of the Palaiologoi. ${ }^{58}$

\section{"Strong" and "weak ties" and "small worlds"}

As becomes evident from these examples, opportunities for the crossing of religious borders demanded pre-existing connections to and support within networks in the new religious community, through which expected benefits of conversion could be guaranteed or promised..$^{59}$ As studies of social networks from pre-modern times have demonstrated, differences between individuals from various social backgrounds not only existed with regard to the number, but also to the range and quality of relationships. ${ }^{60}$ These observations lead to two basic concepts of network theory: the one of "weak and strong ties « and the one of the »small world« character of social networks.

The first concept was developed by Mark S. Granovetter in his article »The Strength of Weak Ties $"{ }^{61}$ He defines the strength of a tie between two persons as the sum of the "amount of time, the emotional intensity, the intimacy and the reciprocal services that characterise the tie" (typical "strong ties « would be found within a family, for instance). Granovetter also hypothesized that within a group of persons to whom either A or B is connected with a social tie, "the stronger the tie between $\mathrm{A}$ and $\mathrm{B}$, the larger the proportion of individuals in the group to whom both of them will be tied, on average; since the stronger the tie between two people, the more time they will commit to this relationship. If $\mathrm{A}$ is connected to both $\mathrm{B}$ and $\mathrm{C}$ with strong ties, the chance is great that $B$ and $C$ will also meet and have a social tie of some strength at some point. ${ }^{62}$ Within network theory, this phenomenon is also called "triadic closure " (Fig. 4). ${ }^{63}$ "Weak ties «, by contrast, are characterized by less emotional intensity and intimacy and less frequency and duration of interaction (such as an acquaintance whom one

57 PLP no. 16271; Laurent, Reg. no. 1367.

58 Cahen, The Formation of Turkey, 124, 175, 186-187, 190-191; Melville, Anatolia under the Mongols, 59, 63, 68; Yaşar Ocak, Social, cultural and intellectual life, 405; Shukurov, Oriental margins, 182-186; Shukurov, The Byzantine Turks, 190-195. For the family of Sultanos cf. also PLP no. 26337-26341.

59 Cf. also Greene, $A$ Shared World, 42-43, for this phenomenon in 17th century Crete. On historical network analysis and religious dynamics cf. also the conference "Religiöse Differenz und soziale Netzwerke« of the Cluster of Excellence of the universities of Trier und Mainz »Gesellschaftliche Abhängigkeiten und soziale Netzwerke« (www.netzwerk-exzellenz.uni-trier.de/?site_id=111), which took place in June 2010 in Trier: hsozkult.geschichte. hu-berlin.de/tagungsberichte/id=3397. Some of these papers were published in: Bauerfeld and Clemens, Gesellschaftliche Umbrüche und religiöse Netzwerke.

60 Jullien, Netzwerkanalyse in der Mediävistik; Preiser-Kapeller, Luhmann in Byzantium; Preiser-Kapeller, Visualising Communities.

61 Granovetter, Strength of weak ties.

62 Cf. also Collar, Network theory, 151; Czachesz, Women, charity and mobility, 134-138 (from there the citations); Prell, Social Network Analysis, 76-77.

63 Prell, Social Network Analysis, 140-147. 
meets at professional conferences now and then). Such weak ties are relevant since they can serve as "bridges « between groups which are otherwise unconnected and as channels of information, for instance, which an individual would not have access to within the framework of "strong ties", as Granovetter has demonstrated in his study for people finding new jobs and as others have for the spread of innovation within professional communities. ${ }^{64}$

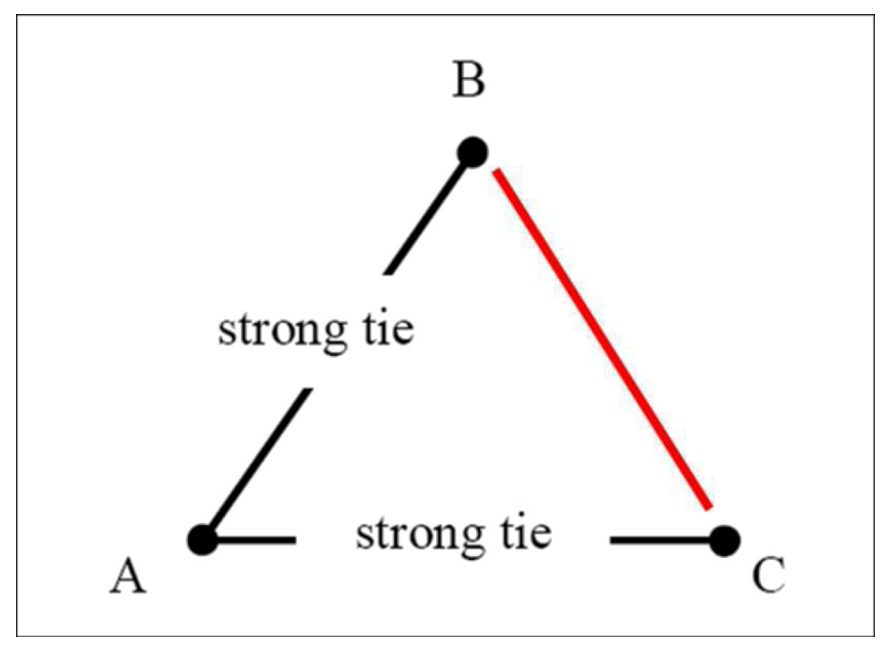

Fig. 4: The concept of the "closure" of triads of nodes within networks of "strong" ties (image: Preiser-Kapeller and Mitsiou, 2018).

Observations on the topology of social networks partly concur with Granovetter's concept: nodes are often found in close-knit clusters, in which all nodes are connected with each other (by "strong ties", following Granovetter). Yet, somehow, larger networks do not disintegrate into several smaller networks, but by contrast even maintain a relatively low average path length (the average number of links it takes to get from one node to another within the network). In order to explain this property, Duncan J. Watts and Stephen H. Strogatz created a "small world « model through a "rewiring" of links between nodes on a regular lattice from immediate neighbours to more distant nodes. This resulted in a decrease of clustering within the network (which thus became less "close-knit»), but also in a smaller average path distance between nodes. This model can also be connected with the concept of "scale-free networks« established by Réka Albert and Albert-László Barabási, in which links are not equally distributed among nodes, but most nodes possess a small number of links, while some hubs possess a high number (Fig. 5). These hubs can serve as short cuts within the network. ${ }^{65}$

64 Granovetter, Strength of weak ties; Czachesz, Women, charity and mobility, 134-138; Prell, Social Network Analysis, 76-77.

65 Watts, Small Worlds; Albert and Barabási, Statistical mechanics; Jackson, Social and Economic Networks, 56-65; Schor, Conversion by the numbers, 495-496: Czachesz, Women, charity and mobility, 138-141; Newman, Networks, 241-260. 
As was also confirmed in empirical analyses of larger social networks, some nodes possess more links and also more links to nodes other nodes are not connected with (which would more likely be "weak ties « after Granovetter); thereby, they can also serve as "social brokers" across "structural holes" between otherwise unconnected clusters and thereby gain "social capital ${ }^{66}$

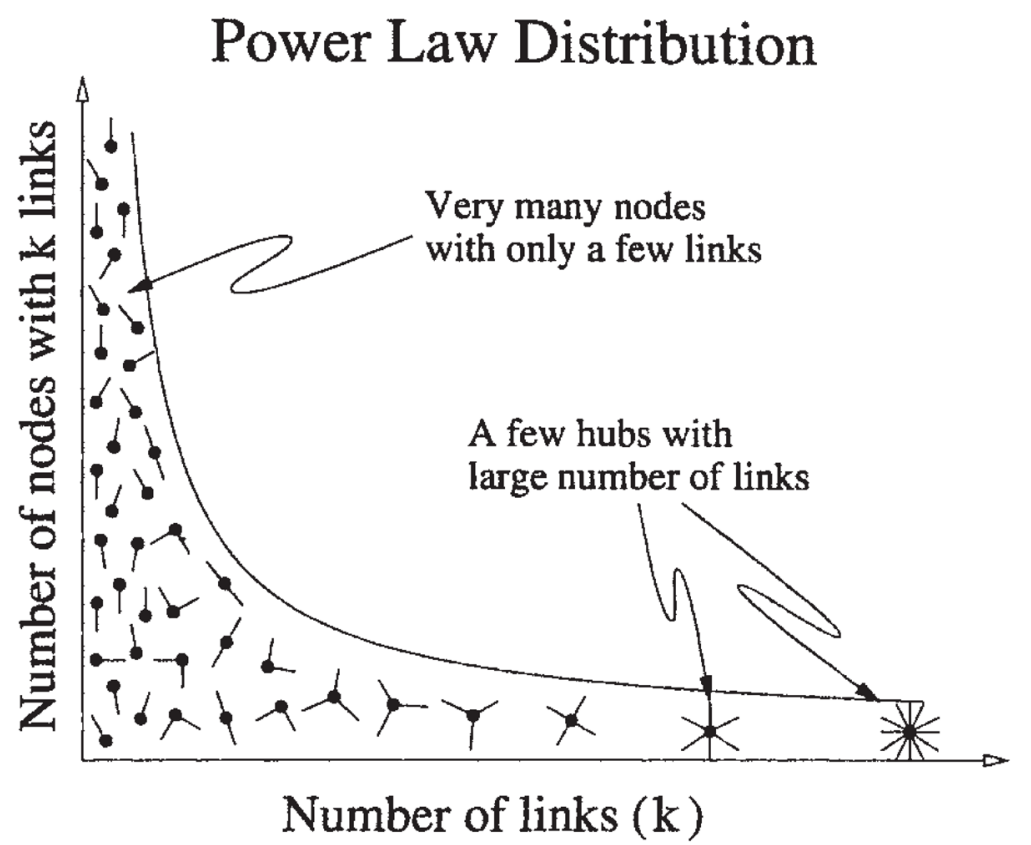

Fig. 5: The unequal distribution of links within "scale-free" networks (source: Preiser-Kapeller, Johannes, Thematic introduction, in: Johannes Preiser-Kapeller and Falko Daim [eds.], Harbours and Maritime Networks as Complex Adaptive Systems, Interdisziplinäre Forschungen zu den Häfen von der Römischen Kaiserzeit bis zum Mittelalter in Europa 2 [Mainz, 2015] 1-24, fig. 18) 


\section{Brokers, hubs, commerce and conversion across borders}

These models are, of course, ideal types, yet they help us to understand and conceptualize present and past social realities in a better way. ${ }^{67}$ In pre-modern societies, most individuals were still embedded in spatially limited networks of kinship and neighbourhood. At the same time, the emergence of close-knit clusters of nodes connected through "strong ties « is more probable among individuals sharing important markers of identity such as kinship, religious belief or common language (the phenomenon of "homophily «) ${ }^{68}$; in turn, communities tend to reproduce themselves in such networks of high density. ${ }^{69}$ Thus, we observe an interplay between structural (the density of social relations) and qualitative (the homogeneity of individuals) characteristics of social networks. ${ }^{70}$

Members of medieval religious elites and nobilities, in contrast, often established highly selective and supra-regional contacts for various political, familial or economic occasions (some of which, with regard to frequency or intimacy, could be considered as "weak«, but others also as "strong") with their peers, which also crossed borders within and beyond cultural-religious frontiers. ${ }^{71}$

But as the examples of Symeon's brother, Nikolaos Bulgaris or George de Braze have demonstrated, the increase in the number and "intensity « of pre-existing network ties especially of commerce, eased by geographical proximity, also opened up potential paths to border-crossing and conversion for other, non-aristocratic members of society ${ }^{72}$, especially if at the same time ties within the original community were "weakened« through conflicts with authorities, for instance. In commercial terms, the connection to individuals beyond the immediate "close-knit" community, also of other religious backgrounds, could be a priori advantageous; the possibility of attaining a position of brokerage was definitely a competitive edge, for an entire commercial community (such as for the Venetians between Egypt and Western Europe, for instance) as well as for individuals. ${ }^{73}$ Kate Fleet stated in her study of Genoese and Ottoman trade: "money largely formed the basis of the relationship between the Genoese and the Turks and this, rather than any religious scruple, dictated relations. ${ }^{74}$

67 Cf. also Schwara, Kaufleute, Seefahrer und Piraten, 27-29.

68 McPherson et al., Birds of a feather; Newman, Networks, 220-231; Prell, Social Network Analysis, 129-131.

69 For an empirical analysis of modern religious communities, cf. Stroope, Social networks and religion. For further application on religious communities, see Everton, Networks and Religion, 87-113.

70 Collar, Network theory, 151, 154; Fuhse, Ethnizität, Akkulturation und persönliche Netzwerke, 78-80; Schor, Conversion by the numbers, 494; Czachesz, Women, charity and mobility, 129; Stroope, Social networks and religion.

71 Cf. Luhmann, Interaktion in Oberschichten; Schor, Conversion by the numbers, 494; Preiser-Kapeller, Luhmann in Byzantium; Preiser-Kapeller, Visualising Communities.

72 Cf. also Schor, Conversion by the numbers, 484: »chemical reactions, like conversion, depend on the probability of interaction«.

73 Curtin, Cross-Cultural Trade; Czachesz, Women, charity and mobility, 136-137; Schwara, Kaufleute, Seefahrer und Piraten, 79-84. For a network analytical approach to this phenomenon, see also Apellániz, Venetian trading networks.

74 Fleet, European and Islamic Trade, 141. 
The case of Tanaïs indicates how hubs within the mercantile networks of the Late Medieval World system ${ }^{75}$ provided, even depended on, opportunities for the establishment of connections across borders. ${ }^{76}$

A further example also illustrates the same phenomenon for other places of interaction between merchants of Byzantine, Latin and Islamic backgrounds. For the middle of the 14th century, we possess, preserved in a manuscript of the Biblioteca Vaticana (Vat. gr. 1325, fols. 316-324), pages of an account book of an anonymous Byzantine merchant. The place where he did business is not mentioned explicitly, but Peter Schreiner as first editor of the text, located the Anonymous in the city of Herakleia Pontike on the Paphlagonian coast of the Black Sea (Fig. 6). ${ }^{77}$ While its hinterland had been occupied by Turkish groups since the 1260 , Herakleia remained an »island « under Byzantine control until July 1360, when the Ottomans conquered the city. In addition to Byzantines, since the second half of the 13th century, Genoese and Venetian merchants were active in Herakleia, where the later became the predominant Latin commercial power in the 14 th century. ${ }^{78}$ The city of Herakleia could thus serve as a plausible background to the mercantile network documented in the Vat. gr. 1325. David Jacoby, however, on the basis of a different reading of some of the geographical terms and product designations, proposed an identification of the place of activity of the Anonymous with Constantinople itself, which would make the text "highly relevant for the study of the long-distance supplies of the Empire's capital «. ${ }^{79}$ As the late David Jacoby personally communicated to the authors, his interpretation has since also been accepted by Peter Schreiner himself.

76 Cf. for instance also Bennassar and Bennassar, Les Chrétiens d'Allah, 195-209, for the places of origin of 172 French converts to Islam in the period 1560 and 1665, who came predominantly from coastal cities integrated into commercial webs with the Mediterranean.

77 Schreiner, Texte zur spätbyzantinischen Finanz- und Wirtschaftsgeschichte, 34-65.

78 Belke, Paphlagonien und Honōrias, 210-211; Preiser-Kapeller, Der Episkopat im späten Byzanz, 147-150.

79 Jacoby, Mediterranean food and wine, 127-148, esp. 145-147. 


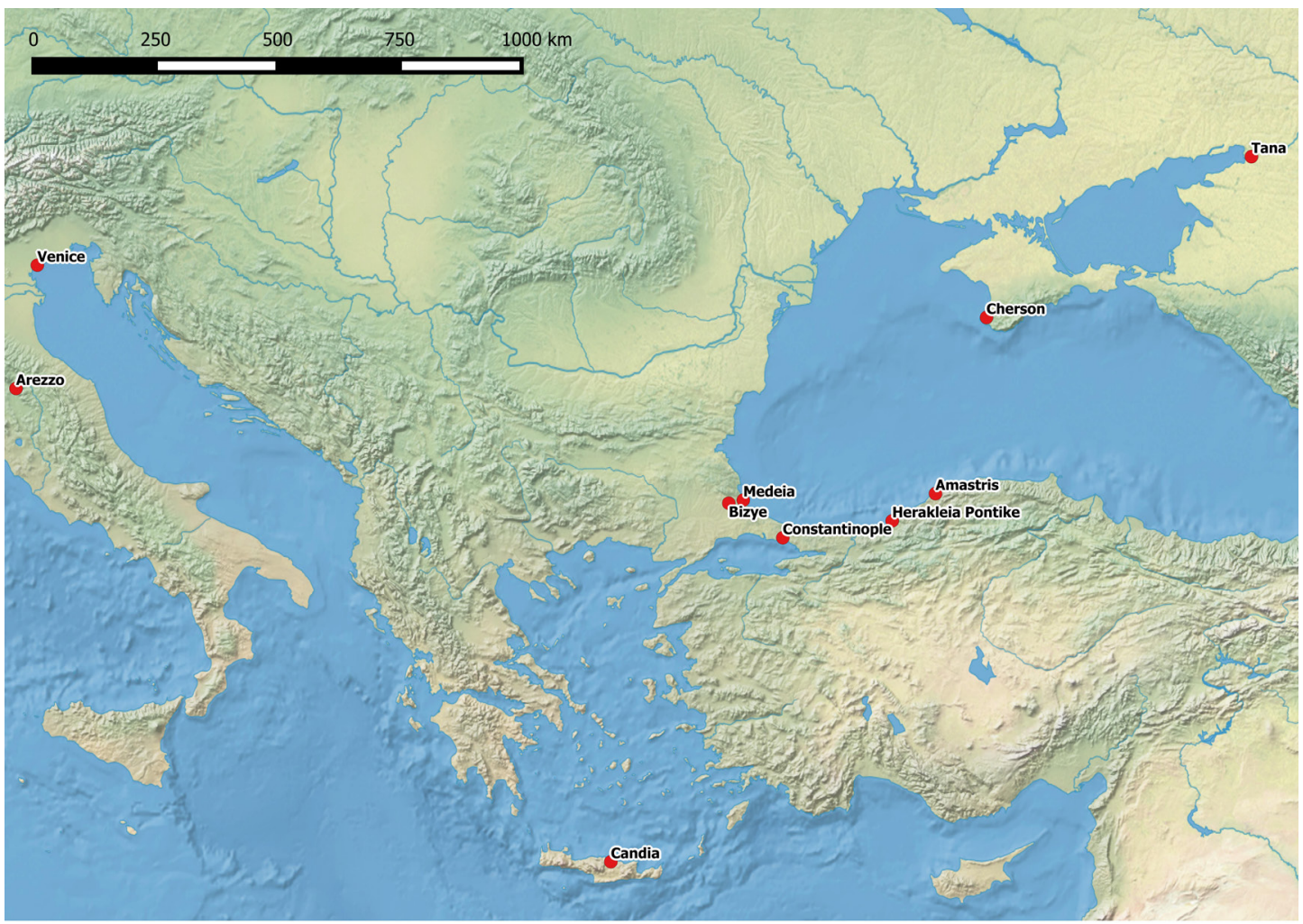

Fig. 6: Constantinople, Herakleia Pontike and several places mentioned in the anonymous account book in Vat. gr. 1325, fols. 316-324 (image: Preiser-Kapeller and Mitsiou, 2018).

The (thus most probably Constantinopolitan) account book is preserved for the period September-October of either 1357 or 1363. During this period, the Anonymous traded various commodities with 118 individuals; for some he also indicated their religious ("Musulmanos«) or ethnic background (»Turkos«), others we can identify on the basis of their names ("Mustaphas", "Machmutes«, but also "Boris" or "Phrantziskos«). In addition, the Anonymous referred to some of his trading partners with nicknames such as Kolokythokephalos (»Pumpkin-head») or Kleptomanoles (»thievish Manuel«), but none of these provides clear hints at ethnicity or religion. ${ }^{80}$ In total, we observe the Anonymous of $1357 / 1363$ in Constantinople embedded in a predominantly Byzantine or "Greek« commercial "small world«, in which some individuals of Latin, Muslim and other origin were integrated (Fig. 7). Some of these persons we encounter in a more important position as "brokers " (see above) in the network between the Anonymous and other merchants, such as Machmutes (PLP no. 94127) who established the connection with a certain Gabras (PLP no. 93291), or Turkos ("the Turk", $P L P$ no. 29185) who traded with the Anonymous as well as with Glykys (PLP no. 93354) and Adeniates (PLP no. 93028), who, in turn, were both part of larger companies of merchants.

80 Schreiner, Texte zur spätbyzantinischen Finanz- und Wirtschaftsgeschichte, 37-55. 
This commercial web illustrates network structures which could have provided footholds for a crossing of religious borders.

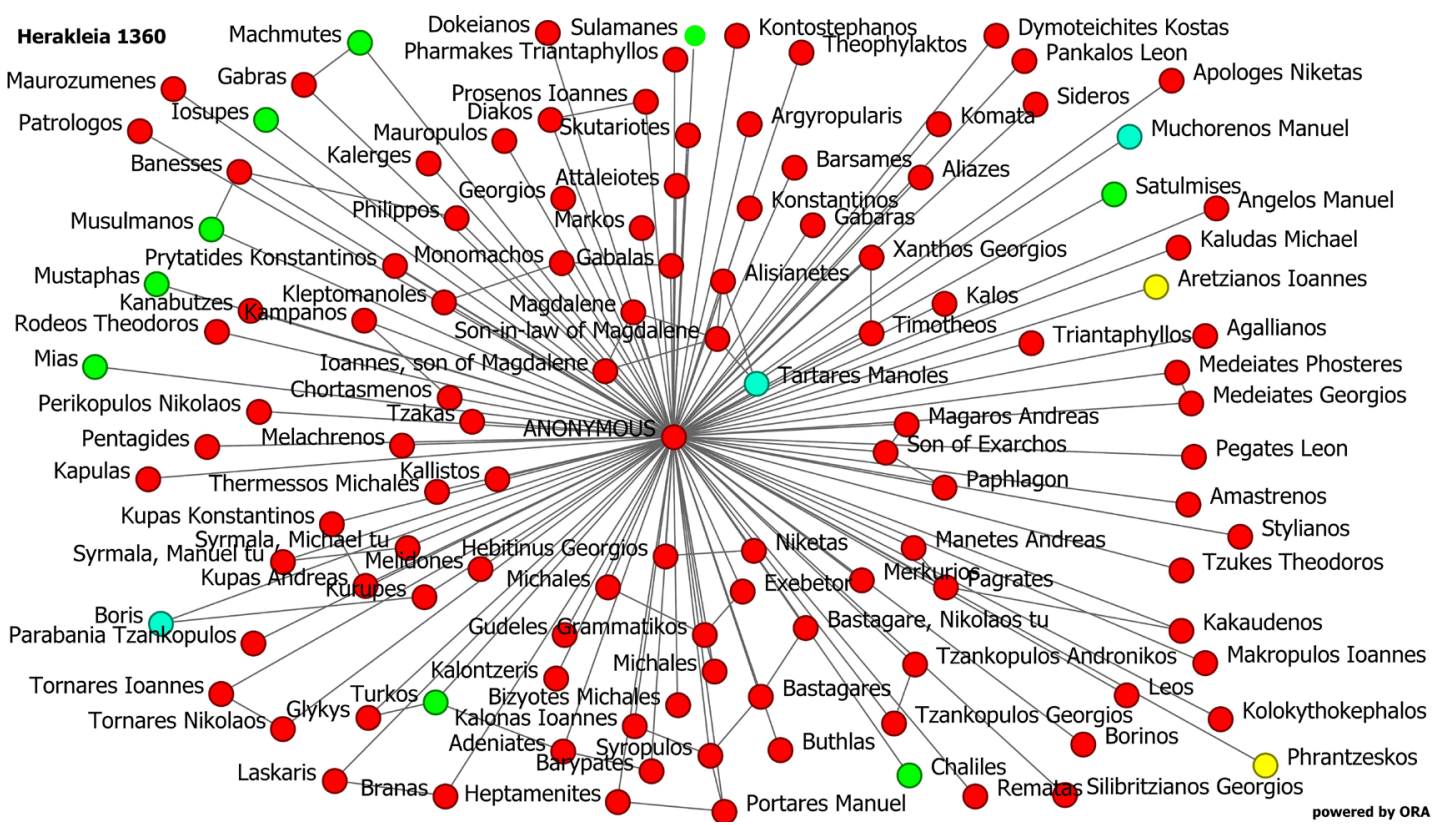

Fig. 7: The trading network (119 nodes) of the Anonymous in Vat. gr. 1325, fols. 316-324 in 1357/1363 (Byzantines: red; Latins: yellow; Muslims: green; Russians: blue); data from: Schreiner, Texte zur spätbyzantinischen Finanz- und Wirtschaftsgeschichte, 37-55) (image: PreiserKapeller and Mitsiou, 2018).

For the years 1436 to 1440 , we can reconstruct another trading network, this time of a Venetian merchant named Giacomo Badoer in Constantinople, again on the basis of his (much more extensive) account books (Fig. 8). Badoer's network included 74 Byzantines, among these many members of the Byzantine aristocracy up to the imperial family of the Palaiologoi, as well as a group of 12 »Turchi« (as he calls them), Ottoman merchants active in Constantinople and doing business with Byzantines as well as Italians. ${ }^{81}$ In addition, also several Greek inhabitants of towns already under Ottoman rule were active in trade with Constantinople, while merchants from Constantinople "made trips to important commercial centers of the Ottomans «. ${ }^{82}$ Nevra Necipoğlu states: "The picture that emerges is one of relatively busy trade, overland and by sea, between the Byzantine capital and Ottoman territories, both in the Balkans and in Asia Minor. Ottoman merchants, whether of Turkish, Greek, or other origin, were able to participate in this trade by going in person to Constantinople, while their Byzantine counterparts were admitted simultaneously into various Ottoman towns. $«^{83}$

81 Bertelè, Il libro dei conti di Giacomo Badoer; cf. also Mitsiou, Feinde, Freunde, Konkurrenten.

82 Necipoğlu, Byzantium, 205.

83 Necipoğlu, Byzantium, 205. 


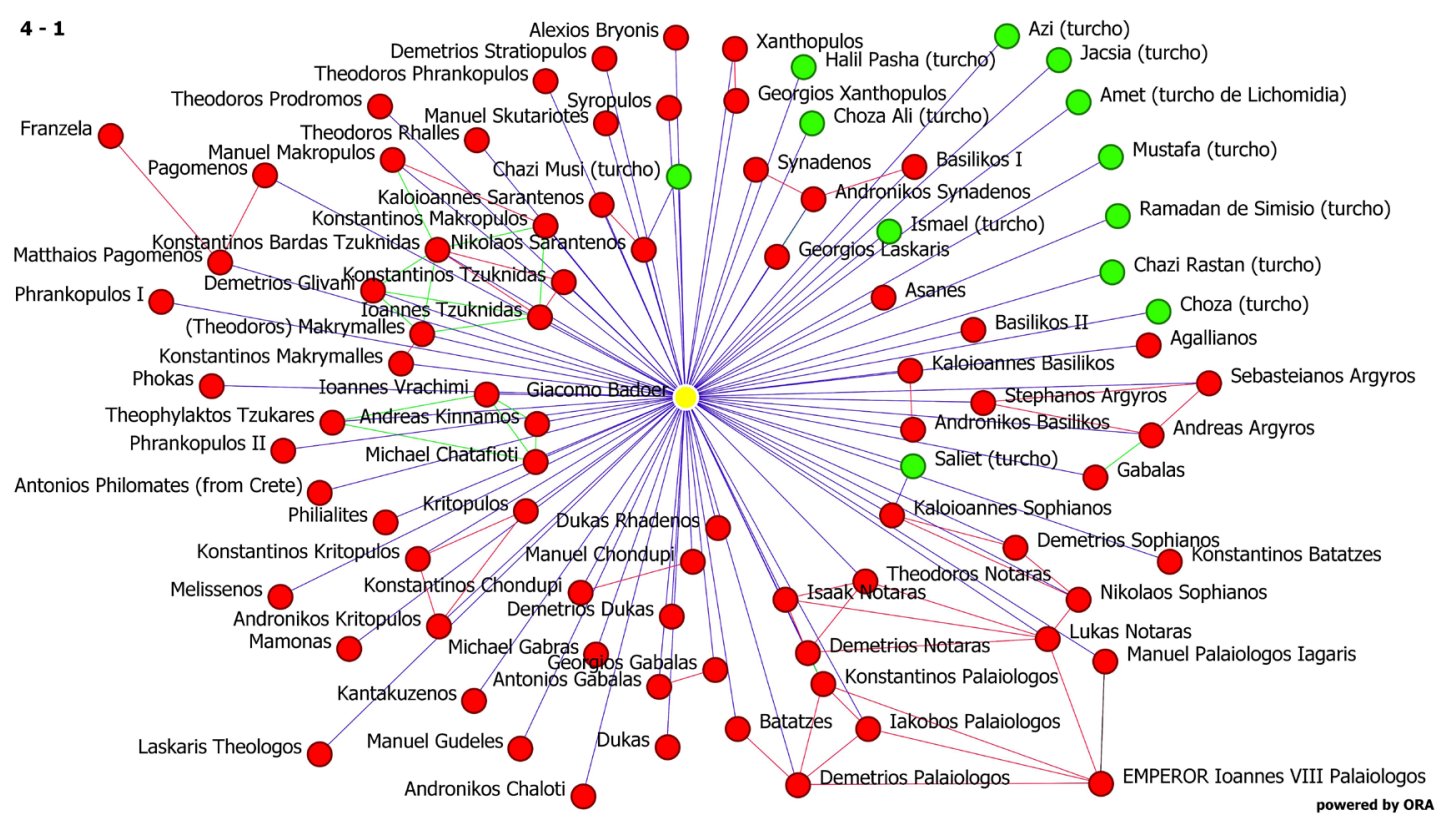

Fig. 8: The trading network (88 nodes) of the Venetian merchant Giacomo Badoer among Byzantines (red) and "Turchi" (green) in Constantinople, 1436-1440: blue = business, green = economic partnership, red $=$ kinship, black = other connections (data from: Bertelè, Il libro dei conti di Giacomo Badoer) (image: Preiser-Kapeller and Mitsiou, 2018).

Again, this interaction lead to the integration of Muslims in the commercial networks of Byzantines. The »turcho" Saliet we find, for instance, associated with the prominent family of Sophianos (PLP nr. 26406, 26412), who, in turn, was related to and a trading partner of the even more prominent Notaras-family ( $P L P$ nr. 20730 $)^{84}$, whose members occupied the highest positions at the imperial court (Fig. 9). The interconnections between this milieu of "aristocratic entrepreneurship", as Klaus-Peter Matschke has called it ${ }^{85}$ and commercial (as well as political) circles of the Venetians and Genoese as well as of the Ottoman state predated the conquest of 1453. After the fall of Constantinople, many of these "Greek entrepreneurs" were able to maintain these networks and profit from them within the new imperial framework. Some members of these families emigrated to the West and became citizens of Venice or Genoa as well as Catholics, some remained in Constantinople as Orthodox Christians, and some also converted to Islam, such as Andronikos-Mustafa Kantakuzenos, who served as a tax farmer in 1481; but familial and commercial ties across religious border were partly sustained. We encounter partnerships between such Orthodox entrepreneurs

84 On the Notaras see esp. Ganchou, Le rachat des Notaras.

85 Matschke, Some merchant families; Matschke and Tinnefeld, Die Gesellschaft im späten Byzanz, 158-220. 
and newly converted Muslims for the purpose of bidding for tax farming in the later 15th century, among these members of the former imperial clan of the Palaiologoi, from which some individuals, as converts, also held high positions at Mehmed's II court. ${ }^{86}$ Here, finally, the above-mentioned aristocratic network-building coincided with the potential of commercial ties as a basis for conversion.

4 - 1

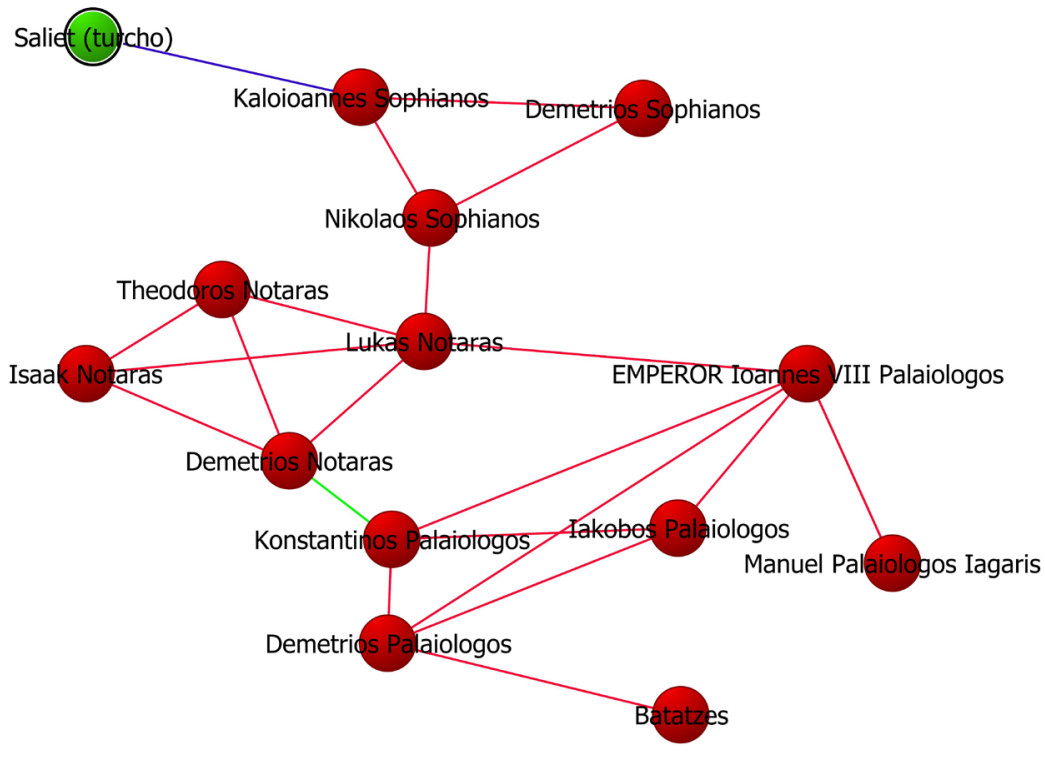

Fig. 9: The connection of the "turcho" Saliet with the families of Sophianos and Notaras within the trading network of Giacomo Badoer, 1436-1440; colours of ties as per Fig. 8 (image: PreiserKapeller and Mitsiou, 2018).

Equally, we again encounter phenomena similar to those observed for the early modern Mediterranean; Dursteler for instance states: "Not infrequently renegades maintained close economic ties with their families, and Scaraffia speaks of Euro-Barbaresque family businesses that saw members of the same family, in part renegades in part Christians, involved in the same business. ${ }^{87}$ Thus, conversion did not necessarily imply a total »disentanglement»

86 Matschke, Some merchant families; Matschke and Tinnefeld, Die Gesellschaft im späten Byzanz, 218-220; Necipoğlu, Byzantium, 227-230; Inalckk, Greeks, esp. 312-315.

87 Dursteler, Venetians in Constantinople, 114. 
of individuals from the close-knit web of "strong ties « within their original community, but could rather contribute to an "entanglement " of previously not or less (or "weakly«) connected networks across religious borders; in addition, the potential and benefits of a brokerage position established thereby become visible. ${ }^{88}$

\section{Conclusion}

As we tried to demonstrate: in many cases, the application of concepts and findings of network theory (even without the use of quantitative models, since the source evidence is too fragmentary) provides new frameworks for the description of religious conversion across and along Islamic-Christian borders.

Dursteler states: "If religion was one of the most important constituent parts of identity in the pre-modern world, then the presence of so many who traversed boundaries of belief suggests the malleability of even this aspect of identity. ${ }^{89}$ This "malleability" may become less surprising if one takes into consideration the interplay between social networks (the structure, frequency, density and intensity of connections and possibilities of interaction) and the reproduction, confirmation and modification of religious identities. As Anna Collar explained: "The ideology of a religion will always be part of the explanation of conversion. However, regardless of the persuasiveness of an ideology, or the transcendence of a vision, conversion does not happen in a social vacuum. ${ }^{90}$

The multiplication of border zones due to the political and especially also commercial dynamics within the late medieval Eastern Mediterranean provided ample opportunities for the establishment of "weak" and even "strong " ties between individuals, families and groups of different backgrounds. These individuals may have diverged with regard to significant "markers" of identity such as religious belief, but may also have shared important aspects of their "Lebenswelten" (their »lifeworlds«), as Şevket Küçükhüseyin employed this term for his analysis of texts from late medieval Anatolia. ${ }^{91}$ At the same time, the potential of »brokerage« across such borders (beyond or within a society) in particular increased the

88 Cf. also Greene, A Shared World, 106-108, for similar phenomena on 17th century Crete. Also the »return « of Nikolaos Bulgaris to Christianity (see above) indicates that he did not cut all ties to his former community in Constantinople. It would be worthwhile to analyse within this framework also similar phenomena for rural areas, and if and how the frequent (and peaceful) encounter between Byzantine farmers and Turcoman nomads, for instance, which we observe in the Maeander Valley in western Asia Minor across the Byzantine-Seljuk frontier in the 12th and 13th century contributed to an establishment of such connections even before the Turkish takeover in the region at the end of the 13 th/the beginning of the 14th century, cf. Thoneman, The Maeander Valley. But this is beyond the scope of the present study. This observation of "entanglement " is, as we have already seen, of course also true especially for the higher stratum of society: as Heath Lowry was able to show, individuals of Christian elite origin were almost predominant even in the highest ranks of Ottoman functionaries in the first decades after the fall of Constantinople 1453; many of these persons continued their contacts with their families, thus serving as »brokers « between the imperial centre and the old elites in the Balkan provinces, cf. Lowry, Early Ottoman State.

89 Dursteler, Venetians in Constantinople, 113.

90 Collar, Network theory, 157. Cf. also her monograph Collar, Religious Networks.

91 Küçükhüseyin, Selbst- und Fremdwahrnehmung, 11-31. On shared "Lebenswelten« with regard to food production and food consumption, see Trépanier, Foodways and Daily Life, esp. 105-120. Cf. also Preiser-Kapeller, Liquid Frontiers, on several aspects of contacts across the political and religious frontiers of late medieval Asia Minor. 
benefits of such connections, especially if they provided access to individuals and groups of power and prestige. ${ }^{92}$ The establishment of such interconnections does not necessarily imply a high degree of "strategic « network building; ${ }^{93}$ circumstances may simply have very much suggested or even necessitated cross-border relations or even the conversion of individuals within a family or community (see the cases of "Neo-Ottomans " through devşirme, who then maintained connections to their families of birth). ${ }^{94}$ In any case, social networks provided opportunities or constraints, which constituted the background to conversion and the crossing of borders.

For the future, the analysis and depiction of such entangled phenomena necessitate more intensive efforts to write an entangled history or an histoire croisée beyond geographical, religious and especially disciplinary borders, ${ }^{95}$ in which specialists from various disciplines combine their knowledge, sources, language skills and methods in order to "re-combine " the elements which constituted the background of such cross-border interactions. New journals such as Medieval Worlds may provide the ideal platform for such undertakings.

Acknowledgements: We would like to thank Prof. Birgitt Hoffmann and Dr. Şevket Küçükhüseyin, who hosted and organised the Workshop "Cross-cultural life-worlds in pre-modern Islamic societies: Actors, evidences and strategies" (22-24 June 2012) at the University of Bamberg for the opportunity to present an earlier version of this paper. The current version of this study was finished within the framework of the project »Moving Byzantium: Mobility, Microstructures and Personal Agency“ (PI: Prof. Claudia Rapp; http://rapp.univie.ac.at/) at the Institute for Medieval Research/Division for Byzantine Research of the Austrian Academy of Sciences.

92 Cf. also Prell, Social Network Analysis, 125.

93 For precautions in this regard cf. also Lemercier, Formale Methoden der Netzwerkanalyse, 22-23.

94 See also Popović, Kaiser, Zar und Sultan.

95 Werner and Zimmermann, De la comparaison à l'histoire croisée; Schwara, Kaufleute, Seefahrer und Piraten, 19-20; Hodder, Entangled, also on entanglements between humans and material objects. 


\section{References}

Abu-Lughod, Janet L., Before European Hegemony. The World System A.D. 1250-1350 (New York, 1989).

Albert, Réka and Albert-László Barabási, Statistical mechanics of complex networks, Reviews of Modern Physics 74 (2002) 48-97.

Angold, Michael, Church and Society in Byzantium under the Comneni, 1081-1261 (Cambridge, 1995). Apellániz, Francisco, Venetian trading networks in the medieval Mediterranean, Journal of Interdisciplinary History 44/2 (2013) 157-179.

Baer, Marc David, Honored by the Glory of Islam. Conversion and Conquest in Ottoman Europe (Oxford, 2008).

Balivet, Michel, Byzantins et Ottomans: relations, interaction, succession, Analecta Isisiana 35 (Istanbul, 1999).

Barkey, Karen, Empire of Difference. The Ottomans in Comparative Perspective (Cambridge, 2008).

Bauerfeld, Daniel and Lukas Clemens (eds.), Gesellschaftliche Umbrüche und religiöse Netzwerke. Analysen von der Antike bis zur Gegenwart (Bielefeld, 2014).

Beihammer, Alexander, Orthodoxy and religious antagonism in Byzantine perceptions of the Seljuk Turks (eleventh and twelfth centuries), Al-Masaq: Islam and the Medieval Mediterranean 23/1 (2011) 15-36.

Belke, Klaus, Paphlagonien und Honōrias, Tabula Imperii Byzantini 9 (Vienna, 1996).

Bennassar, Bartolomé and Bennassar, Lucile, Les Chrétiens d'Allah. L'histoire extraordinaire des renégats XVIe et XVIIe siècles (Paris, 2006).

Bertelè, Giovanni, Il libro dei conti di Giacomo Badoer (Constantinopoli 1436-1440). Complemento e indici (Padua, 2002).

Bulliet, Richard W., Conversion to Islam in the Medieval Period: an Essay in quantitative History (Cambridge, Mass., 1979).

Bulliet, Richard W., Islam. The View from the Edge (New York, 1994).

Burt, Ronald S., Brokerage and Closure: An Introduction to Social Capital (Oxford, 2005).

Cahen, Claude, The Formation of Turkey. The Seljukid Sultanate of Rüm: Eleventh to Fourteenth Century (Harlow, 2001).

Christ, Georg, Trading Conflicts: Venetian Merchants and Mamluk Officials in Late Medieval Alexandria, Medieval Mediterranean 93 (Leiden / Boston, 2012).

Collar, Anna, Network theory and religious innovation, Mediterranean Historical Review 22/1 (2007) 149-162.

Collar, Anna, Religious Networks in the Roman Empire. The Spread of New Ideas. (Cambridge, 2013).

Curtin, Philip D., Cross-Cultural Trade in World History (Cambridge, 1984).

Czachesz, István, Women, charity and mobility in early Christianity. Weak links and the historical transformation of religions, in: István Czachesz and Tamás Biró (eds.), Changing Minds: Religion and Cognition through the Ages (Leuven, 2010) 129-154.

Darrouzès, Jean, Tomos inédit de 1180 contre Mahomet, Revue des Études Byzantines 30 (1972) 187-197.

Darrouzès, Reg.: Darrouzès, Jean, Les regestes des actes du patriarcat de Constantinople. I/5: Les regestes de 1310 à 1376. I/6: Les regestes de 1377 à 1410. I/7: Les regestes de 1410 à 1453 (Paris, 1977-1991).

Düring, Marten, Ulrich Eumann, Martin Stark and Linda von Keyserlingk (eds.), Handbuch Historische Netzwerkforschung. Grundlagen und Anwendungen (Hamburg, 2016). 
Dursteler, Eric R., Venetians in Constantinople. Nation, Identity, and Coexistence in the Early Modern Mediterranean (Baltimore, 2006).

Epstein, Steven A., Purity Lost: Transgressing Boundaries in the Eastern Mediterranean, 100o1400 (Baltimore, 2007).

Everton, Sean F., Networks and Religion. Ties that bind, loose, build-up, and tear down (Cambridge, 2018).

Fleet, Kate, European and Islamic Trade in the Early Ottoman State. The Merchants of Genoa and Turkey (Cambridge, 1999).

Fuhse, Jan, Ethnizität, Akkulturation und persönliche Netzwerke von italienischen Migranten. (Opladen, 2008).

Fuhse, Jan, and Sophie Mützel (eds.), Relationale Soziologie. Zur kulturellen Wende der Netzwerkforschung (Wiesbaden, 2010).

Ganchou, Thierry, Le rachat des Notaras après la chute de Constantinople, ou les relations »étrangères« de l'élite byzantine au XVe siècle, in: Michel Balard and Alian Ducellier (eds.), Migrations et Diasporas Méditerranéennes (Xe-XVIe siècles). Colloque international, Conques 14-17 octobre 1999, Byzantina Sorbonensia 19 (Paris, 2002) 215-335.

Granovetter, Mark, The strength of weak ties, American Journal of Sociology 78 (1973) 1360-1380.

Greene, Molly, A Shared World. Christians and Muslims in the Early Modern Mediterranean (Princeton, New Jersey, 2000).

Grivaud, Gilles and Alexandre Popovic (eds.), Les conversions à l' Islam en Asie Mineure et dans les Balkans aux époques Seldjoukide et Ottomane. Bibliographie raisonée (180o-20oo) (Athens, 2011).

Hanson, Craig L., Manuel I Comnenus and the »God of Muhammad«: a study in Byzantine ecclesiastical politics, in: John Victor Tolan (ed.) Medieval Christian Perceptions of Islam: A Book of Essays (New York, 1996).

Hinterberger, Martin, Die Bezeichnung für eine mongolische Urkunde im Patriarchatsregis-

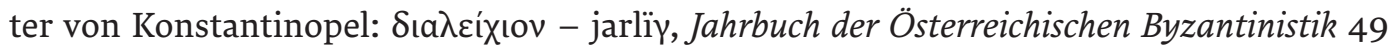
(199) $177-180$.

Hodder, Ian, Entangled. An Archaeology of the Relationships between Humans and Things (Maiden, 2012).

Inalclk, Halil, Greeks in the Ottoman economy and finances 1453-1500, in: John S. Langdon, Stephen W. Reinert, Jelisaveta Stanojevich Allen, Christos P. Ioannides (eds.), To Hellenikon. Studies in Honor of Speros Vryonis, Jr. 2 (New Rochelle, 1993) 307-319.

Jackson, Matthew O., Social and Economic Networks (Princeton, 2008).

Jacoby, David, Mediterranean and wine for Constantinople: the long-distance trade, eleventh to mid-fifteenth century, in: Ewald Kislinger, Johannes Koder and Andreas Külzer (eds.), Handelsgüter und Verkehrswege. Aspekte der Warenversorgung im östlichen Mittelmeerraum (4. bis 15. Jahrhundert). Akten des gleichnamigen internationalen Symposiums Wien, 19. bis 22. Oktober 2005 (Vienna, 2010) 127-148.

Jullien, Eva, Netzwerkanalyse in der Mediävistik. Probleme und Perspektiven im Umgang mit mittelalterlichen Quellen, Vierteljahrschrift für Sozial- und Wirtschaftsgeschichte 100/2 (2013) 135-153.

Karpov, Sergej P., Les Occidentaux dans les villes de la périphérie byzantine: la mer Noire "vénitienne" aux XIVe-XVe siècles, in: Michel Balard, Élisabeth Malamut and Jean-Michel Spieser (eds.), Byzance et le monde extérieur. Contacts, relations, échanges, Byzantina Sorbonensia 21 (Paris, 2005) 67-76. 
Karpov, Sergej P., Tana - Une grande zone réceptrice de l' émigration aus Moyen Age, in: Michel Balard and Alan Ducellier (eds.), Migrations et diasporas méditerranéennes (Xe-XVIe siècles) (Paris, 2002) 77-89.

Korobeinikov, Dimitri, Orthodox communities in Eastern Anatolia in the thirteenth and fourteenth centuries. Part 1: The two patriarchates: Constantinople and Antioch, Al-Masaq: Islam and the Medieval Mediterranean 15/2 (2003) 197-214.

Korobeinikov, Dimitri, Orthodox communities in Eastern Anatolia in the thirteenth to fourteenth centuries. Part 2: The time of troubles, Al-Masaq: Islam and the Medieval Mediterranean 17/1 (2005) 1-29.

Kraus, Christof, Der Fall des Priesters Konstantinos Kabasilas. Historische Bemerkungen zu einem Urkundenkomplex im Patriarchatsregister von Konstantinopel aus den Jahren 1383-1385, in: Wolfram Hörandner, Johannes Koder and Maria A. Stassinopoulou (eds.), Wiener Byzantinistik und Neogräzistik. Beiträge zum Symposion Vierzig Jahre Institut für Byzantinistik und Neogräzistik der Universität Wien im Gedenken an Herbert Hunger (Wien, 4.-7. Dezember 2002) (Vienna, 2004) 248-263.

Kraus, Christof, Kleriker im späten Byzanz. Anagnosten, Hypodiakone, Diakone und Priester 1261-1453, Mainzer Veröffentlichungen zur Byzantinistik 9 (Wiesbaden, 2007).

Kresten, Otto, Die Affäre des Metropoliten Symeon von Alania im Spiegel des Patriarchatsregisters von Konstantinopel, Anzeiger der philos.-histor. Klasse der Österreichischen Akademie der Wissenschaften 137 (2002) 5-40.

Krstić, Tijana, Contested Conversions to Islam: Narratives of Religious Change in the Early Modern Ottoman Empire (Stanford, 2011).

Küçükhüseyin, Şevket, Selbst- und Fremdwahrnehmung im Prozess kultureller Transformation. Anatolische Quellen über Muslime, Christen und Türken (13.-15. Jahrhundert), Veröffentlichungen zur Iranistik 63 (Vienna, 2011).

Laurent, Reg.: Laurent, Vitalien, Les regestes des actes du patriarcat de Constantinople I/4: Les regestes des 1208 à 1309 (Paris, 1971).

LBG: Lexikon zur Byzantinischen Gräzität, ed. Erich Trapp, in collaboration with Wolfram Hörandner, Johannes Diethart, Astrid Steiner-Weber, Sonja Schönauer and Maria Cassiotou-Panayotopoulos, Carolina Cupane, Andreas Rhoby and Elisabeth Schiffer (Vienna 1994-2017).

Lemercier, Claire, Formale Methoden der Netzwerkanalyse in den Geschichtswissenschaften: Warum und Wie?, in: Albert Müller and Wolfgang Neurath (eds.), Österreichische Zeitschrift für Geschichtswissenschaften 23/1: Historische Netzwerkanalysen (2012) 16-41.

Lowry, Heath W., The Nature of the Early Ottoman State (New York, 2003).

Luhmann, Niklas, Interaktion in Oberschichten: Zur Transformation ihrer Semantik im 17. und 18. Jahrhundert, in: Niklas Luhmann, Gesellschaftsstruktur und Semantik. Studien zur Wissenssoziologie der modernen Gesellschaft 1 (Frankfurt am Main, 1993) 72-161.

Matschke, Klaus-Peter, Some merchant families in Constantinople before, during and after the fall of the city 1453, Balkan Studies 38/2 (1997) 219-238.

Matschke, Klaus-Peter and Franz Tinnefeld, Die Gesellschaft im späten Byzanz. Gruppen, Strukturen und Lebensformen (Cologne, 2001).

McPherson, Miller, Lynn Smith-Lovin and James M.Cook, Birds of a feather: homophily in social networks, Annual Review of Sociology 27 (2001) 415-444.

Melville, Charles, Anatolia under the Mongols, in: Kate Fleet (ed.), The Cambridge History of Turkey, Vol. 1: Byzantium to Turkey, 1071-1453 (Cambridge, 2009) 51-100. 
MM I: Miklosich, Franz and Joseph Müller, Acta patriarchatus Constantinopolitani MCCCXVMCCCCII e codicibus manu scriptis Bibliothecae Palatinae Vindobonesis, Acta et diplomata graeca medii aevi sacra et profana I (Vienna, 1860; Reprint Aalen, 1968).

MM II: Miklosich, Franz and Joseph Müller, Acta patriarchatus Constantinopolitani MCCCXVMCCCCII e codicibus manu scriptis Bibliothecae Palatinae Vindobonesis, Acta et diplomata graeca medii aevi sacra et profana II (Vienna, 1862; Reprint Aalen, 1968).

Mische, Ann, Relational sociology, culture, and agency, in: John Scott and Peter J.Carrington (eds.), The Sage Handbook of Social Network Analysis (Los Angeles, 2011) 80-97.

Mitsiou, Ekaterini, Feinde, Freunde, Konkurrenten - Die Interaktion zwischen Byzantinern und »Lateinern« im Spätmittelalter, Historicum. Zeitschrift für Geschichte Sommer/Herbst 2011 (published 2012) 48-55.

Mitsiou, Ekaterini, "I believe what the Great Church believes «: Latin Christians and their confessions of faith in 14th century Byzantium, in: Falko Daim, Christian Gastgeber, Dominik Heher and Claudia Rapp (eds.), Menschen, Bilder, Sprache, Dinge. Wege der Kommunikation zwischen Byzanz und dem Westen (Mainz, 2018) 311-322.

Mitsiou, Ekaterini, Networks of Nicaea: 13th century socio-economic ties, structures and prosopography, in: Guillaume Saint-Guillan and Dionysios Stathakopoulos (eds.), Liquid and Multiple: Individuals and Identities in the Thirteenth-Century Aegean (London, 2012) 91-104.

Mitsiou, Ekaterini and Johannes Preiser-Kapeller, Moving hands: types and scales of labour mobility in the late medieval eastern Mediterranean (1200-1500 CE), in: Christian de Vito and Anne Gerritsen (eds.), Micro-Spatial Histories of Global Labour (London, 2017) 29-67.

Mitsiou, Ekaterini and Johannes Preiser-Kapeller, Übertritte zur byzantinisch-orthodoxen Kirche in den Urkunden des Patriarchatsregisters von Konstantinopel (mit 10 Tafeln), in: Christian Gastgeber and Otto Kresten (eds.), Sylloge Diplomatico-Palaeographica I (Vienna, 2010) 233-288.

Montet, Edouard, Un rituel d'abjuration des Musulmans dans l'église grecque, Revue de l'histoire des religions 53 (1906) 148-155.

Necipoğlu, Nevra, Byzantium between the Ottomans and the Latins. Politics and Society in the Late Empire (Cambridge, 2009).

Newman, Mark E. J., Networks. An Introduction (Oxford, 2010).

Ormerod, Pau and Andrew P. Roach, The medieval inquisition: scale-free networks and the suppression of heresy, Physica A 399 (2004) 645-652.

PLP: Prosopographisches Lexikon der Palaiologenzeit, ed. Erich Trapp et al., 12 Volumes and 2 Addenda (Vienna, 1976-1996), and the CD-ROM-Version (Vienna, 2001).

Popović, Mihailo, Kaiser, Zar und Sultan - Das Byzantinische Reich und die Integration Südosteuropas in das Osmanische Reich, Historicum. Zeitschrift für Geschichte Sommer/ Herbst 2011 (published 2012) 72-78.

Preiser-Kapeller, Johannes, Calculating the Middle Ages? The project "Complexities and Networks in the Medieval Mediterranean and the Near East «, Medieval Worlds 2: Empires in Decay (2015) 100-127.

Preiser-Kapeller, Johannes, Conversion, collaboration and confrontation: Islam in the Register of the Patriarchate of Constantinople (14th Century), International Review of Turkish Studies 1/4 (Winter 2011) 62-79.

Preiser-Kapeller, Johannes, Der Episkopat im späten Byzanz. Ein Verzeichnis der Metropoliten und Bischöfe des Patriarchats von Konstantinopel in der Zeit von 1204 bis 1453 (Saarbrücken, 2008). 
Preiser-Kapeller, Johannes, Letters and network analysis, in: Alexander Riehle (ed.), Companion to Byzantine Epistolography, Brill Companions to the Byzantine World (Leiden, 2019) forthcoming.

Preiser-Kapeller, Johannes, Liquid Frontiers. A relational analysis of maritime Asia Minor as religious contact zone in the 13th-15th century, in: Andrew Peacock, Sara Nur Ylddiz and Bruno de Nicola, (eds.), Islam and Christianity in Medieval Anatolia (Aldershot, 2015) 117-146.

Preiser-Kapeller, Johannes, Luhmann in Byzantium. A systems theory approach for historical network analysis. Working Paper for the International Conference »The Connected Past: people, networks and complexity in archaeology and history", Southampton, 24-25 March 2012 (online: oeaw.academia.edu/JohannesPreiserKapeller/Papers)

Preiser-Kapeller, Johannes, The global Patriarch. Aspects of Byzantine ecclesiastical activity and inactivity within the Mongol-Islamic World of the 13th-14th century, in: Christian Gastgeber, Ekaterini Mitsiou, Johannes Preiser-Kapeller and Vratislav Zervan (eds.), The Patriarchate of Constantinople in Context and Comparison. Proceedings of the International Conference Vienna, September 12th-15th 2012. In Memoriam Konstantinos Pitsakis (19442012) and Andreas Schminck (1947-2015) (Vienna, 2017) 351-360.

Preiser-Kapeller, Johannes, The maritime mobility of individuals and objects: networks and entanglements, in: Johannes Preiser-Kapeller and Falko Daim (eds.), Harbours and Maritime Networks as Complex Adaptive Systems, Interdisziplinäre Forschungen zu den Häfen von der Römischen Kaiserzeit bis zum Mittelalter in Europa 2 (Mainz, 2015) 119-140.

Preiser-Kapeller, Johannes, Visualising Communities. Möglichkeiten der Netzwerkanalyse und der relationalen Soziologie für die Erfassung und Analyse mittelalterlicher Gemeinschaften. Working Paper for a presentation for the SFB "Visions of Community«, 22 May 2012 (online: oeaw.academia.edu/JohannesPreiserKapeller/Papers).

Preiser-Kapeller, Johannes, Zwischen Konstantinopel und Goldener Horde: die byzantinischen Kirchenprovinzen der Alanen und Zichen im mongolischen Machtbereich im 13. und 14. Jahrhundert, in: Jürgen Tubach, Sophian Vashalomidze and Manfred Zimmer (eds.) Caucasus during the Mongol Period. Der Kaukasus in der Mongolenzeit (Halle-Wittenberg, 2012) 199-216.

Prell, Christina, Social Network Analysis. History, Theory and Method (Los Angeles, 2012).

PRK I: Das Register des Patriarchats von Konstantinopel. 1. Teil: Edition und Übersetzung der Urkunden aus den Jahren 1315-1331, Herbert Hunger, Otto Kresten et al. (eds.) Corpus Fontium Historiae Byzantinae XIX/1 (Vienna, 1981).

PRK II: Das Register des Patriarchats von Konstantinopel. 2. Teil: Edition und Übersetzung der Urkunden aus den Jahren 1337-1350, Herbert Hunger, Otto Kresten, Ewald Kislinger, Carolina Cupane, et al. (eds.), Corpus Fontium Historiae Byzantinae XIX/2 (Vienna, 1995).

PRK III: Das Register des Patriarchats von Konstantinopel. 3. Teil: Edition und Übersetzung der Urkunden aus den Jahren 1350-1363, Johannes Koder, Martin Hinterberger, Otto Kresten et al. (eds.), Corpus Fontium Historiae Byzantinae XIX/3 (Vienna, 2001).

PRK IV: Das Register des Patriarchats von Konstantinopel. 4. Teil: Edition und Übersetzung der Urkunden aus den Jahren 1364-1372, Otto Kresten and Christian Gastgeber (eds.), Corpus Fontium Historiae Byzantinae XIX/4 (Vienna, forthcoming).

PRK V: Das Register des Patriarchats von Konstantinopel. 5. Teil: Edition und Übersetzung der Urkunden aus den Jahren 1379-1390, Otto Kresten, Christian Gastgeber, Ekaterini Mitsiou and Johannes Preiser-Kapeller (eds.), Corpus Fontium Historiae Byzantinae XIX/5 (Vienna, forthcoming). 
Reinhard, Wolfgang, Freunde und Kreaturen. „Verflechtung" als Konzept zur Erforschung historischer Führungsgruppen. Römische Oligarchie um 1600 (Munich, 1979).

Sahas, Daniel J., Ritual of conversion from Islam to the Byzantine Church, Greek Orthodox Theological Review 36 (1991) 57-69.

Schor, Adam, Conversion by the numbers: benefits and pitfalls of quantitative modelling in the study of Early Christian growth, Journal of Religious History 33/4 (2009) 472-498.

Schreiner, Peter, Texte zur spätbyzantinischen Finanz- und Wirtschaftsgeschichte in Handschriften der Biblioteca Vaticana, Studi e Testi 344 (Città del Vaticano, 1991).

Schwara, Desanka, together with Luise Müller, Patrick Krebs, Ivo Haagand, Marcel Gosteli, Kaufleute, Seefahrer und Piraten im Mittelmeerraum der Neuzeit (Munich, 2011).

Seland, Eivind H., Networks and social cohesion in ancient Indian Ocean trade: geography, ethnicity, religion, Journal of Global History 8, Issue 03 (November 2013) 373-390.

Shukurov, Rustam, The oriental margins of the Byzantine world: a proposopographical perspective, in: Judith Herrin and Guillaume Saint-Guillain (eds.), Identities and Allegiances in the Eastern Mediterranean after 1204 (Farnham, 2011) 167-191.

Shukurov, Rustam, The Byzantine Turks, 1204-1461 (Leiden, 2016).

Stark, Rodney, The Rise of Christianity. A Sociologist reconsiders History (Princeton, 1996).

Stroope, Samuel, Social networks and religion: the role of congregational social embeddedness in religious belief and practice, Sociology of Religion 73/3 (2012) 273-298.

Thonemann, Peter, The Maeander Valley. A Historical Geography from Antiquity to Byzantium (Cambridge, 2011).

Todt, Klaus-Peter, Kaiser Johannes VI. Kantakuzenos und der Islam. Politische Realität und theologische Polemik im palaiologenzeitlichen Byzanz, Würzburger Forschungen zur Religionswissenschaft 16 (Altenberge, 1991).

Trépanier, Nicolas, Foodways and Daily Life in Medieval Anatolia. A new Social History (Austin, 2014).

Turchin, Peter, Historical Dynamics. Why States Rise and Fall (Princeton, 2003).

Vat. gr. 1325: Vatican, Bibliotheca Apostolica Vaticana, Cod. Vaticanus graecus 1325

Vind. hist. graec. 47: Vienna, Austrian National Library, Cod. Vindobonensis historicus graecus 47.

Vryonis, Speros, The Decline of Medieval Hellenism in Asia Minor and the Process of Islamization from the Eleventh through the Fifteenth Century (Berkeley, 1971).

Vryonis, Speros, Byzantine attitudes toward Islam during the late Middle Ages, ByzantinaMetabyzantina 2 (1981) 263-286.

Watts, Duncan J., Small Worlds. The Dynamics of Networks between Order and Randomness (Princeton, 1999).

Werner, Michael and Bénédicte Zimmermann, De la comparaison à l'histoire croisée (Le genre humain) (Paris, 2004).

Yaşar Ocak, Ahmet, Social, cultural and intellectual life, 1071-1453, in: Kate Fleet (ed.), The Cambridge History of Turkey, Vol. 1: Byzantium to Turkey, 1071-1453 (Cambridge, 2009) 353420.

Ylldız, Sara Nur, Manuel Komnenos Mavrozomes and his descendants at the Seljuk court: the formation of a Christian Seljuk-Komnenian elite, in: Stefan Leder (ed.), Crossroads between Latin Europe and the Near East: Corollaries of the Frankish Presence in the Eastern Mediterranean (12th-14th centuries), Istanbuler Texte und Studien 24 (Würzburg, 2011) 55-77. 


\section{List of figures}

Fig. 1: The interconnections between Tanaïs and the Mediterranean world on the basis of the information on places of origin of merchants active in the city in 1359/1360 (red lines) and the range of connections and influence of the Metropolitan Symeon of Alania in the 1350 s and 1360 s on the basis of the information from the documents from the Register of the Patriarchate of Constantinople (yellow lines) (image: Preiser-Kapeller and Mitsiou, 2018).

Fig. 2: The social network of Metropolitan Symeon of Alania and his brother between Byzantines and the Muslim Khan of the Golden Horde, with ties of kinship (red), support (green), appellation (yellow), conflict (black), subordination and professional association (blue) and of other qualities (grey) (image: Preiser-Kapeller and Mitsiou, 2018).

Fig. 3: The immediate "Ego-network" of Symeon's brother (colours of ties according to Fig. 2) (image: Preiser-Kapeller and Mitsiou, 2018).

Fig. 4: The concept of the "closure« of triads of nodes within networks of »strong " ties (image: Preiser-Kapeller and Mitsiou, 2018).

Fig. 5: The unequal distribution of links within »scale-free» networks (source: PreiserKapeller, Johannes, Thematic introduction, in: Johannes Preiser-Kapeller and Falko Daim [eds.], Harbours and Maritime Networks as Complex Adaptive Systems, Interdisziplinäre Forschungen zu den Häfen von der Römischen Kaiserzeit bis zum Mittelalter in Europa 2 [Mainz, 2015] 1-24, fig. 18)

Fig. 6: Constantinople, Herakleia Pontike and several places mentioned in the anonymous account book in Vat. gr. 1325, fols. 316-324 (image: Preiser-Kapeller and Mitsiou, 2018).

Fig. 7: The trading network (119 nodes) of the Anonymous in Vat. gr. 1325, fols. 316-324 in 1357/1363 (Byzantines: red; Latins: yellow; Muslims: green; Russians: blue); data from: Schreiner, Texte zur spätbyzantinischen Finanz- und Wirtschaftsgeschichte, 37-55) (image: Preiser-Kapeller and Mitsiou, 2018).

Fig. 8: The trading network (88 nodes) of the Venetian merchant Giacomo Badoer among Byzantines (red) and »Turchi « (green) in Constantinople, 1436-1440: blue = business, green $=$ economic partnership, red $=$ kinship, black = other connections (data from: Bertelè, Il libro dei conti di Giacomo Badoer) (image: Preiser-Kapeller and Mitsiou, 2018).

Fig. 9: The connection of the "turcho « Saliet with the families of Sophianos and Notaras within the trading network of Giacomo Badoer, 1436-1440; colours of ties according to fig. 8 (image: Preiser-Kapeller and Mitsiou, 2018). 


\title{
"A Universal Narrative of Humanity«. Travelling to the >Other from Constantinople: Priscus of Panion (5th c. CE) and William of Rubruk (13th c. CE) ${ }^{1}$
}

\author{
Pia Carolla*
}

Travelling to the >Other can be fascinating - and very dangerous, especially when the traveller moves to suncivilised` peoples like Huns and Mongols. The article shows unpredictable parallels between two travel accounts very far from each other in space and time: on the one hand Priscus of Panion, a learned Greek from the 5th century CE, who goes with the Byzantine ambassador to the king of the Huns, the terrible Attila; on the other hand William of Rubruk, a learned Franciscan from the 13th century CE, who writes in Latin a detailed report about his mission to the Mongol Empire. Both cross Constantinople, the city of cities, and both bear witness to the welcoming scivilisation s they found at their destination, beyond borders and boundaries. From a literary perspective, much to our surprise, Byzantium is the key to open the world of the >Otherness`.

Keywords: Priscus of Panion, William of Rubruk, Mongol Empire, Byzantine literature, King Louis IX of France, Attila, Sartaq, Byzantium East \& West, Constantinople, >Otherness،.

Sometimes stories travel to the end of the earth, sometimes storytellers do.

In order to explore the relevance of Byzantium for the East and the West, I try to compare two narrations very far from each other in space and time: on the one hand, the text about Attila and the Huns in the 5th century CE, taken from the History of Priscus of Panion; ${ }^{2}$ on the other hand, the Itinerarium written by William of Rubruk in the 13th century, after his

* Correspondence details: Pia Carolla, Dipartimento di Italianistica, Romanistica, Antichistica, Arti e Spettacolo (DIRAAS), University of Genoa, Italy. Postal address:Antichistica - via Balbi 4, 16126 Genova, Italy. Email address: pia.carolla@unige.it

1 I am sincerely grateful to Christian Gastgeber and Ingrid Hartl for inviting and welcoming my contribution. Many thanks are to be given to Chiara Zappalà, who pointed William's Itinerarium out to me during a nice stay in Stockholm. I also wish to thank those who have shared fruitful discussion: Sergio Basso, Lucia Castaldi, Paolo Chiesa, Omar Coloru, Matilde Cupiccia, Lia Raffaella Cresci, Roberto Gamberini, Silvia Ronchey, Nicolò Sassi, Denis Searby, Giusto Traina, Kurt Villads Jensen and the Centre for Medieval Studies at the University of Stockholm, which invited to my seminar about Priscus and William in 2019.

2 For Priscus' life see Hoffmann, Priscus of Panium, a summary to be carefully checked against the sources, e.g. with the help of Given, Introduction, ix-xii. See the primary sources in the bibliography below. The excerpts and fragments in my critical edition: Priscus, Excerpta, ed. Carolla; English translation with short commentary by Given, Fragmentary History of Priscus; an older edition with excellent Italian translation by Bornmann, Prisci Panitae Fragmenta. Very important for his historical analysis and a general survey of the 5th century Blockley, Fragmentary Classicising Historians, 222-376, which has Greek text, English translation, historiographical notes and bibliography. 
return from Mongolia. ${ }^{3}$ The first was composed in Greek and is the longest extract of a work which survives through indirect manuscript tradition only; the second was written in Latin and bears witness to the literary competence of a Franciscan friar who used to live in Palestine.

They are quite different from each other, as regards the authors, the texts and the genre: the one belongs to historiography, the second is an epistle; yet they share the impact with the >Other ${ }^{4}$ Furthermore both took their leave from Constantinople: the Byzantine ambassador Maximinos convinced Priscus to take part in the embassy to Attila and their route took thirteen days from Constantinople to Serdica (today Sofia, Bulgaria). William probably sailed first from Acre (today Akko) in Palestine; then he attests to having been in Constantinople and to having spoken publicly in S. Sophia on Palm Sunday, 13th April 1253; afterwards he reached the Black Sea on 7 th May $1253^{5}$. It was the age of the Latin Empire in Constantinople (1204-1261), a different situation from Priscus' age and, in some respects, quite the opposite. ${ }^{6}$

Priscus follows in the steps of Olympiodorus and Eunapius, who were the first Greek authors to describe the Huns; most of their histories are lost, no less than Priscus' work, so that we cannot fully compare the latter's text to his models. ${ }^{7}$

The main focus from hereon is on >Otherness: my research object is the perceptions of diversity - and, indeed, of the >contrary < - by the authors and their readers. ${ }^{8}$

This entails no claim for an exhaustive analysis: it is beyond the scope of the present article to discuss theories of the >Other from Lévinas to Derrida or Foucault, the Frankfurt School, Said, De Beauvoir, Gruen and others. ${ }^{9}$ Yet the purpose of my contribution is clear: I am looking for the links between the narrations about two different peoples from the steppe, both of whom had suddenly become (in)famous and powerful and were visited by ambassadors and swindlers.

I have chosen to start from the vivid perception of the opposite by two learned authors who visited in person and who appear so keen on watching ${ }^{10}$ the `Other as to disguise their literary imitation; or, rather, to push it into the background. One can wonder why these two have been picked out from among the many reports about the Huns or the Mongols; yet, as the comparative approach needs to start somewhere and to develop gradually, it is better to ask whether this investigation has paved the way for more: hopefully, others will expand it in the future.

3 A presentation by Auzépy, Guillaume de Rubrouck; see also Vermeulen, William van Rubroec, 103. The text in Paolo Chiesa's critical edition: William, Itinerarium (with Italian translation and commentary); English translation of an older text by Jackson and Morgan, Mission of Friar William (1990); older translation by Rockhill, Journey of William of Rubruck (1900).

4 About the relationship between Byzantium and the ethnic `Other see Howard-Johnston, Byzantium and its neighbours, 939-956: 944-945; Dzino and Parry (eds.), Byzantium, its Neighbours and its Cultures.

5 Priscus, Excerpta, 8, 5, ed. Carolla, 16; William, Itinerarium I 1, ed. Chiesa, 6-8; Chiesa, Commento, 392.

6 About the Ethnic identities in Late Antiquity and Early Medieval period see Pohl, Identità etniche e cristianesimi, 59-72. For the perceptions of Byzantine identity up to the 10th century see McCormick, Eternal Victory, esp. 388396 and the bibliographical additions in the Italian version: Id., Vittoria eterna, 492 n. 7. For the Byzantine identity during the Latin empire see Kaldellis, Hellenism in Byzantium, 345-360.

7 Eunapius of Sardis, fr. 41, ed. Blockley, 58; Olympiodorus of Thebes, fr. 19, ed. Blockley, 182.

8 On the subject see Mitsiou, Byzantines and the »others«, 65-74; Laiou, Byzantium and the Other, ch. VII. The many faces of medieval colonization, 13-30, esp. 13-17; Magdalino, Constantinople and the outside world, 149-162.

9 Gruen, Rethinking the Other in Antiquity.

10 Pittaluga, Sguardo dell'altro, 23-32. 
In the following some affinities between the two texts will be shown, even though it is highly unlikely that William read Priscus. Closeness is mainly related to similar circumstances or Realien, which in turn allow us to go further and to investigate a case-study of "a universal narrative of humanity «, ${ }^{11}$ as the theme of the present cluster suggests: not only a sample of the role played by Byzantium between the East and the West, but also a comparison between the age of Attila and that of the Latin Empire in Constantinople. Needless to say, a number of differences can be detected; yet here the focus is on the similarities.

\section{The Border ${ }^{12}$}

The impact of the >Other was impressive for both authors from the very beginning, when William was still in Crimea, because the Mongol Empire looked like a different world to him: "uisum fuit michi recte quod ingrederer quoddam aliud seculum «. ${ }^{13}$

Thereafter many other borders had to be crossed, as William and his companion Bartholomeus de Cremona ${ }^{14}$ traveled from one Mongol prince to the other: from the sulus of Čaghatai to Sartaq, from Batu to Möngke to Arigh Böke, then back to Möngke again during the return trip. The first stop was at the court of Čaghatai, where they were allowed to move on to Sartaq. William was bringing to the latter a message by King Louis IX of France: Sartaq was said to have converted to Christianity and William had been asked by his king to assess in person whether the news was true. ${ }^{15}$

Taking the first step from the ulus of Caghatai to Sartaq, William had the impression to enter hell: "uisum fuit michi quod unam portam inferni transissemus «. ${ }^{16}$ Soon after that, he came across a desolate camp where people who looked like lepers collected taxes on salt. ${ }^{17}$

Priscus expressed a perception of the >Other as strong as that expressed by William, with no explicit reference to a different world or hell, by depicting desolation and misery. His first step into Attila's land brought him to a relevant destination: it was no less than Naissus, ${ }^{18}$ Constantine I's place of birth. A small town with a great ancestor; yet when Priscus got there in $449 \mathrm{AD}$, he found it devoid of living people, while the bones of the war victims were scattered everywhere and the only survivors were some seriously ill people in the hostels of

11 Vindobona. Vienna International News, Lasting Rivals - Byzantium \& the West. See also Pittaluga, Sguardo dell'altro, 23-32, who compares the accounts by William of Rubruk, John of Plano Carpini and Odoricus from Portus Naonis (Pordenone).

12 For the very notion of sfrontier in Late Antiquity, far from anachronism, see Pohl, Conclusion, 247-260: 250-254.

13 William, Itinerarium I 14, ed. Chiesa, 18; trans. Rockhill, 52 "After having left Soldaia we came on the third day across the Tartars, and when I found myself among them it seemed to me of a truth that I had been transported into another century « [actually "into a different world « (my translation)]; the same is repeated at IX 1, ed. Chiesa, 48. For the different notions of seculum and aevum see Chiesa, Commento, 344. The first border of the land controlled by Mongols was in Crimea by then, according to William three days from the town of Sudak: see also ibid., 378. The very notion of "Mongol empire « is discussed: for an overview of the political situation framing William's mission see Pubblici, Antagonism and coexistence, esp. 25-27.

14 William, Itinerarium I 10, ed. Chiesa, 14; see also Chiesa, Commento, 340.

15 William, Itinerarium I 6-7, ed. Chiesa, 12. About Sartaq see Chiesa, Commento, 335.

16 William, Itinerarium XII 3, ed. Chiesa, 58.

17 William, Itinerarium XII 4, ed. Chiesa, 60.

18 Today Niš, Serbia. 
the church ${ }^{19}$. To represent that 'waste land,, so to speak, Priscus turned to Homer, mixing the literal imitation of Iliad 8 with an allusion to the Sirens' island in Odyssey $12 .{ }^{20}$ So he vividly depicted the "boundary between Scythian and Roman territories" as a border hostile to manhood. ${ }^{21}$

A first similarity is thus to be detected between the two accounts: entering the >Otherness means passing from a safe zone to uncertainty, where the border is a sort of ghost place, a no-man's-land.

\section{Wandering in the Steppe}

The path towards Attila's camp in Pannonia was tortuous and unpredictable, as is well documented by Priscus in his excerpt 8, 16: „We came into a thickly shaded area with many bends, twists and turnabouts. When day appeared, we believed we were journeying toward the west, but the rising sun appeared before us. Those inexperienced with the lay of the land cried out, believing that the sun was traveling backward and signifying more unexpected events. But thanks to the topographical irregularity that part of the road was looking east. « $^{22}$ Priscus was said to be a master in rhetoric: that is why we can label this passage an aprosdoketon, which was widely used in late antique literature and beyond. ${ }^{23} \mathrm{~A}$ modern reader appreciates the downplaying of the mostrum (i.e., the wonder) in the name of reason, although superstitious beliefs about the sun turning eastbound can be found up to our present; ${ }^{24}$ yet in the 5 th century it was probably perceived as just one of a million variations on the theme of the famous prolonged night of Odysseus and Penelope in Odyssey 23. Most of those variationes were scholastic products (Progymnasmata) and came easily to the mind of a master in rhetoric, without necessarily being an allusion any more. ${ }^{25}$ However, the fact that Priscus could immediately skip both any millenarianism and fear of "more unexpected events" means that he was not scared by entering the >Othernessı. Or at least he wanted to create that impression.

19 Priscus, Excerpta, 8, 13-14, ed. Carolla, 18; trans. Given, 49: "Arriving at Naissos, we found the city bereft of people because it had been overturned by the enemy, though there were some people in the sacred lodgings who were suffering from diseases. We camped a little bit upriver in a clearing, since the bank was everywhere covered with

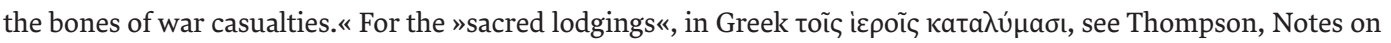
Priscus, 63: »the Christian hostels«.

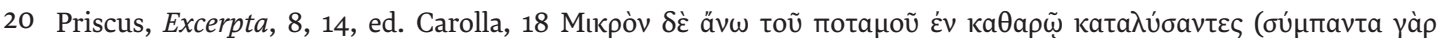

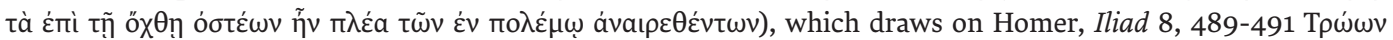

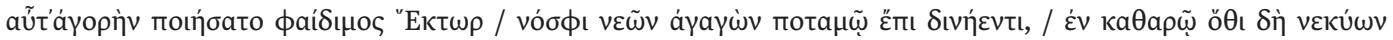

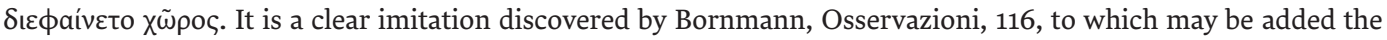
evocation of the bones around the Sirens in Circe's prophecy to Odysseus: Homer, Odyssey 12, 44-46 á $\lambda \lambda$ á $\tau \varepsilon$

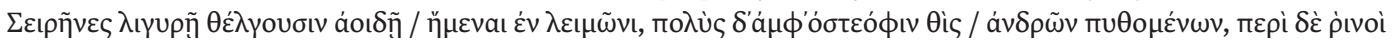

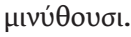

21 Attila had ordered that Naissus be the new marketplace in Illyria, instead of the older one on the Danube: Priscus, Excerpta, 7, 3, ed. Carolla, 13; trans. Given, 45. So the king of the Huns commanded the Byzantine Empire to withdraw »a five days' journey« (ibid.).

22 Priscus, Excerpta, 8, 16, trans. Given, 49; see the Greek text with apparatus fontium, ed. Carolla, 18-19.

23 For Suidas and Evagrius as testimonia to Priscus' ability in rhetorics see Testimonia de Prisco, in: Priscus, Excerpta, ed. Carolla, XLVIII.

24 The paradox e.g. in Manfredi, Faraone delle sabbie, 333.

25 About Progymnasmata see recently Berardi, Retorica degli esercizi preparatori, with bibliography. 
William had a quite similar experience, but with horses rather than with the sun: while wandering in the steppe they met no human being for days in a row and at the end they felt exhausted and lost; then, all of a sudden, two horses came towards them and they cried out in joy and relief. ${ }^{26}$ This time everybody was overwhelmed and there was neither downplaying nor overstating: William presents his own feeling as perfectly natural after the desolation of the steppe. Elsewhere he says that God chose the Mongol people as an instrument for His will, ${ }^{27}$ so he is familiar with Christian interpretation of history, but here he just sticks to the facts and gives us a round representation of a psychological phenomenon: the simple presence of animals as friends helped the men beyond expectation. One can infer that the author could recognise and express his feelings without exaggerating them.

\section{Nomadic Life}

Whenever in contact with the peoples they are visiting, nomadic life is the first feature for both Priscus and William.

Contrary to the collective image of the Huns, they had been settled in Pannonia for a long time when Priscus met them, yet Attila's camp was still traveling, in this way controlling land and tribes.$^{28}$ And everything could be discussed and settled on horseback, including food and drink receptions: for example, while still astride his horse, Attila received offerings from the wife of his collaborator Onegesios. ${ }^{29}$

The same can be noted about the Mongols according to William, who was impressed by the camp and wagons as well: "Nusquam habent manentem ciuitatem, sed futuram ignorant $"{ }^{30}$ Some pages can be fascinating for readers, especially when he reports having paced along some carts, to measure their width: »Ego enim mensuraui semel latitudinem inter

26 William, Itinerarium, XIII 14, ed. Chiesa, 68.

27 William, Itinerarium, XXI 4, ed. Chiesa, 104.

28 Huns were no more the wild barbarians described by Ammianus Marcellinus, Res gestae, XXXI 3-4 »In hominum autem figura licet insuavi ita visi sunt asperi, ut neque igni neque saporatis indigeant cibis sed radicibus herbarum agrestium et semicruda cuiusvis pecoris carne vescantur, quam inter femora sua equorumque terga subsertam fotu calefaciunt brevi. Aedificiis nullis umquam tecti sed haec velut ab usu communi discreta sepulcra declinant. Nec enim apud eos vel arundine fastigatum reperiri tugurium potest. Sed vagi montes peragrantes et silvas, pruinas famem sitimque perferre ab incunabulis adsuescunt. Peregre tecta nisi adigente maxima necessitate non subeunt: nec enim apud eos securos existimant esse sub tectis. "Yet Attila was still traveling with a tent, see e.g. Priscus, Excerpta, 8, 22, ed. Carolla, 20; §38, ibid., 23; §§41-48, ibid., 23-25; §83, ibid., 32; exc. 8.1, 1, ibid., 51; etc. Kelly, Neither conquest nor settlement, 195: "Certainly by the 420s, the Huns were firmly established on the Great Hungarian Plain in the heart of Europe, the only area of grassland west of the Black Sea capable of supporting horses on any scale and an ideal base for military operations on both sides of the Rhine and Danube."See also Maas, Reversals of fortune, 7-9 and 17-20; Thompson and Heather, Huns, esp. 41-62; Pohl, Migrations, ethnic groups, $247-263$.

29 Priscus, Excerpta, 8, 88, ed. Carolla, 32-33; trans. Given, 61 »As Attila approached Onegesios's compound (for the road to the palace ran through it), Onegesios's wife came out with a multitude of servants, some of whom were carrying food and others wine. This is a very great honor among Scythian women. She greeted him and begged him to partake of what she was kind-heartedly offering him. Showing favor to the wife of his adviser, he ate sitting on his horse as the barbarians accompanying him raised the platter up to him. It was made of silver."

30 William, Itinerarium, II 1, ed. Chiesa, 18; trans. Jackson and Morgan [e-book]: "Nowhere have they any >lasting city<; and of the sone to comer they have no knowledge«. See Chiesa, Commento, 344: the sentence is taken verbatim from Hebrews 13, 14 "non habemus hic manentem ciuitatem, sed futuram inquirimus «. About the purpose of riding together, see William, Itinerarium, XX 5, ed. Chiesa, 100; trans. Rockhill, 128: »I saw Baatu riding with all his horde; and all the heads of families were riding with him, but according to my estimate there were not over five hundred men.« 
uestigia rotarum unius bige $\mathrm{XX}$ pedum, et quando domus erat super bigam excedebat extra rotas in utroque latere $\mathrm{V}$ pedibus ad minus. Ego numeraui in una biga XXII boues trahentes unam domum, undecim in uno ordine secundum latitudinem bige, et alios XI ante illos; axis bige erat magnus ad modum arboris nauis, et unus homo stabat in hostio domus super bigam minans boues. $\aleph^{31}$

From a literary perspective, writing about the Mongol nomadic life could also be either a way to pay homage to John of Plano Carpini, the Franciscan friar who had visited the khan's court some years before William; ${ }^{32}$ or, even better, a way for William to distance himself from John.

\section{Ambassadors \& Conspiracies}

The work of John was the closest literary model for William, although some dislike can be perceived between the lines of the latter. ${ }^{33}$ William planned his Itinerarium with a structure similar to that of John, yet he insisted on the main difference, namely, that he was no ambassador whatsoever: he was only a preacher looking for conversions of both the powerful and the common Mongol people. ${ }^{34}$ Far from being a stereotype, William's claim could be dangerous: at the very beginning of his travels, the Byzantine traders in Crimea had advised him to accept being believed an ambassador, otherwise he could be rejected; ${ }^{35}$ soon after, he also learnt that Mongols used to execute people pretending to be ambassadors, ${ }^{36}$ probably charging them with being secret agents.

31 William, Itinerarium, II 2, ed. Chiesa, 18-20; trans. Jackson and Morgan [e-book]: "I myself once measured a breadth of twenty feet between the wheeltracks of a wagon, and when the dwelling was on the wagon it protruded beyond the wheels by at least five feet on either side. I have counted twenty-two oxen to one wagon, hauling along a dwelling, eleven in a row, corresponding to the width of the wagon, and another eleven in front of them. The wagon's axle was as large as a ship's mast, and one man stood at the entrance to the dwelling on top of the wagon, driving the oxen".

32 John of Plano Carpini was sent as a papal legate by Pope Innocent IV, Sinibaldo Fieschi, with a letter to the Mongol Great Khan at Qara-Qorum. His travel lasted from 1245 to 1247 and visited Güyük Khan, bringing back an official answer to the pope.

33 Paolo Chiesa, pers. comm., 16 March 2019.

34 Most of the Itinerarium is reworked by William on his notes taken during the journey, precisely like Priscus; once back in Palestine, William added a long general overview about the Mongols' habits and traditions, following a structure similar to John's: William, Itinerarium, II 1-VIII 5, ed. Chiesa, 18-46; John of Plano Carpini, Historia Mongalorum, 1, ed. Menestò, 229 »Volentes igitur facta scribere Tartarorum, ut lectores valeant facilius inuenire, hoc modo per capitula describemus. Primo dicemus de terra, secundo de hominibus, tertio de ritu, quarto de moribus, quinto de ipsorum imperio, sexto de bellis, septimo de terris quas eorum dominio subiugarunt, octavo quomodo bello occurratur eisdem (...)« For the persistent claim to be no ambassador see e.g., William, Itinerarium, I 6, ed. Chiesa, 12; XXXVI 13, ibid., 278-280. He was well aware of the difference between them on this point, see XIX 5, ed. Chiesa, 94 » fuerat enim ibi frater Iohannes de Policarpo [sic], sed ipse mutauerat habitum ne contempneretur, quia erat nuncius domini pape«. See also Chiesa, Introduzione, XXXV-XXXVI.

35 William, Itinerarium, I 6-7, ed. Chiesa, 12.

36 William, Itinerarium, VIII 2, ed. Chiesa, 44 "Item falsos nuncios, qui scilicet faciunt se nuncios et non sunt, interficiunt«; XIX 13, ibid., 170 »Tales trufatores currunt per mundum, quos Moal [i.e., Mongols] interficiunt, cum possunt eos deprehendere.« 
Priscus' journey to Attila became no less dangerous because there was, genuinely, an ongoing Byzantine conspiracy to kill Attila without the ambassador's knowledge. Priscus was no ambassador either: he went with Maximinus, who was in charge of the embassy and implored him to go together. ${ }^{37}$ The conspiracy was based on bribery of the Hun ambassador, named Edekon, who had come to Constantinople and then travelled back with Maximinus and Priscus. Edekon should have killed Attila, with the collaboration of other Hun noblemen. Eventually, Edekon informed Attila of the conspiracy instead, and the king decided to take advantage from the situation, sending back the Byzantine spy and letting him collect the gold intended to pay the killers, only to seize it all on his return and to ask for more as a ransom. This is why he spared Maximinus and Priscus' lives. The spy was their interpreter, Vigilas the Goth, who worked directly for the Byzantine magister officiorum Martialios and was allegedly engaged in the conspiracy by the powerful spatharius Chrysaphius. ${ }^{38}$

While in Qara-qorum, William was asked about everything he had to do there, because Möngke the Khan had had news of a conspiracy: no less than four hundreds "Hacsasini“ were said to have been diguised »in diuersis habitibus « to kill him ${ }^{39}$. That was why he ordered that every ambassador be questioned thoroughly.

It is no wonder: ambassadors and embassies were exposed to infiltrators, and interpreters were the most suitable profile for spies, such as in the case of Priscus.

\section{The Role of the Interpreter}

William had an interpreter travelling with him from the beginning, whose name was "Homo Dei«. William considered him really disappointing because the man could not translate properly what he mostly wanted, namely, his preaching Christianity to the Mongols. Some scholars have suggested that he was a native Arab from Palestine and that he was called 'Abd-Allāh. ${ }^{40}$. While this point is impossible to ascertain, the man's ineptitude in translating

37 No specific/official role of Priscus is mentioned; see Baldwin, Priskos; Given, Introduction, xii: »It is possible that Priscus held an official position on this and subsequent embassies, and that he was appointed to the missions because of some office he held in the Constantinopolitan bureaucracy. The language, though, suggests that Priscus did not receive an official appointment. It seems more likely that he followed Maximinos as an unofficial adviser and, given his training (see below), as an assistant in the skills of political and diplomatic rhetoric«. See also ibid., xli n. 1: »It used to be scholarly opinion that Priscus worked as a scriniarius, a minor bureaucrat in a financial or legal office. This belief turned on the identification of the ambassador Maximinos with a man of the same name who worked on the Theodosian Code as a magister scrinii. As this identification has been called into question, so too has Priscus lost his official employment. See, though, Treadgold [Early Byzantine Historians], 97, who revives the possibility«.

38 For Edekon see PLRE 2, 385-386. The conspiracy was planned by Chrysaphius, the eunuch spatharius of the emperor Theodosius II, who shared with his master his pure hatred of Priscus. See e.g. Priscus, Excerpta, 7, 5-4, ed. Carolla, 13-15; exc. 12, 1-4; exc. 12.1, 1; exc. 13, 1-4, ibid., 53-55, and elsewhere. On the powerful eunuch, see Chrysaphius qui et Ztummas, PLRE 3, 295-297.

39 William, Itinerarium, XXXII 2, ed. Chiesa, 232. For the »Hacsasini«, from the Arab »Hashāshīn (etymology of the Western word »assassin«), see Chiesa, Commento, 400.

40 William, Itinerarium, I 10, ed. Chiesa, 14. See Chiesa, Commento, 340-341. For the ineptitude, see XIII 6, ed. hiesa, 64 "Super omnia autem grauabat me quod quando uolebam eis dicere aliquod verbum edificationis, interpres meus dicebat: `Non faciatis me predicare, quia nescio talia uerba dicere!^ Et uerum dicebat. Ego enim percepi postea, quando incepi aliquantulum intelligere ideoma, quod quando dicebam unum, ipse totum aliud dicebat, secundum quod ei occurrebat.« 
concepts may be connected to a lack of familiarity with Christianity itself. Furthermore, to have one single interpreter is something that William regrets throughout. One might recall St. Francis, the founder of the Franciscans, who must have found very good interpreters for his preaching to Sultan al-Malik al-Kāmil at Damietta in $1219 .{ }^{41}$ The founder of the order was a model of preaching for William: after all, the latter belonged to the order of the Friars Minor and was sent on a very risky mission like many friars elsewhere. ${ }^{42}$

Priscus did not regret the interpreter's ability overtly, but pictured Attila's rage against him: it was the king of the Huns who yelled at Vigilas and attacked him with harsh words as soon as he entered the tent. ${ }^{43}$ The reader can $>$ decoder the situation, because he is well informed of the crucial role of the interpreter into the conspiracy; the persona auctoris, on the contrary, was completely in the dark at that moment.

Interpreters also suggested both to Priscus and to William that they should appease the >Other`, whatever he asked. The first issue was a strange request by the Hun leaders: a number of them came, riding on horseback, and surrounded the Byzantine entourage, who stood in the middle. The Hun $\lambda$ oүá $\delta \varepsilon \varsigma,{ }^{44}$ i.e., snoblemen«, staying on horseback, asked to be informed in advance of what Maximinus was going to say to Attila. The ambassador resisted the impossible demand and invoked the usual practice of diplomatic mission between Byzantium and the Huns from old times: no one but Attila was intended to know the emperor's letter and the oral message he had come to deliver. The Huns immediately left them and suddenly returned, listing every point of the Byzantine embassy. How could they know? Then Maximinus was ordered to tell them whether there was something else left to say; after his refusal to comply, he was obliged to go back to Constantinople straight away. At this point Vigilas the interpreter reproached him for his behaviour: a lie, in his opinion, would have been better than nothing. ${ }^{45}$ Again, the reader can read between the lines: Vigilas' suggestion came from greediness and could be fully explained by the ongoing conspiracy. In other words, Priscus' highlighting the episode was a literary way of 'ंӨoпой̈а or characterisation, ${ }^{46}$ and the message perceived by the reader was that the interpreter made the situation worse. In our modern perspective and terminology: the interpreter should have been a facilitator, whereas he enlarged the distance between the ambassador and the ১Other».

41 Ernoul, Chronicle, ed. Golubovich, 10-13 (datable between 1227 and 1229); see later (1263) Bonaventura, Legenda Maior, IX 7-8. For the Sultan see Gottschalk, »al-Kāmil«. The episode has been reconsidered by many scholars: see Ibrahim, Francis preaching to the sultan, (about the retelling of the meeting "in visual and textual sources between 1228 « and 1500, with bibliography).

42 About the literature of the new orders such as Franciscans and Dominicans see e.g. Chiesa, Introduzione, XLVI; see also Pittaluga, Sguardo dell'altro, 23-32.

43 Priscus, Excerpta, 8, 43-44, ed. Carolla, 24; trans. Given, 53-54 »He turned his attention straight to Bigilas, called him a shameless beast and asked why he wanted to come to him [...]. Growing angrier and reviling him all the more, Attila shouted that he would have crucified him and given him as food to the birds, if he did not think inflicting this penalty on his shamelessness and on the effrontery of his words would violate sacred diplomatic law." Note that Attila shows himself as caring a great deal about the dignity of ambassadors.

44 Priscus, Excerpta, 8, 23, ed. Carolla, 20 and elsewhere.

45 Priscus, Excerpta, 8, 23-30, ed. Carolla, 20-21; see also 35, ibid., 22.

46 It is explicitly added by Priscus himself, even though there is some verb missing here in the manuscripts: Priscus, Excerpta, 8, 31-32, ed. Carolla, 21; trans. Given, 51: "He said this, <believing> Edekon [i.e., the accomplice of the conspiracy] remained friendly toward him, so that, under the pretext of the embassy and of saying anything, true or false, he might find an excuse to discuss their intentions against Attila and how to convey the gold Edekon said he needed to pay the men appointed to perform the task. But Edekon had secretly betrayed him.« 
William underwent a similar treatment while arriving at the camp of Čaghatai: they were surrounded by men riding on horseback, ${ }^{47}$ who asked of them what the purpose of their mission was. William refused to tell anyone but Sartaq and proclaimed that it was none of their business, otherwise he would have gone back immediately. ${ }^{48}$ In this case William did not complain about the interpreter, which makes us think that Homo Dei was able to translate practicalities.

However, William complained when the interpreter was willing to donate everything they had at the court of Sartaq. It is easy for the reader to understand that the man was acting out of fear, anxious to be allowed to eat and to continue their journey; yet William depicts him as a coward and a bungler: »Timebam etiam de interprete, ne ipse aliquid aliter dixisset quam ego dixissem ei, quia ipse bene uoluisset quod de omnibus fecissemus exennium. « ${ }^{49}$

Elsewhere, William himself was willing to reveal in advance the contents of his mission. This was the case at Möngke's court, where he complied without hesitation before entering the khan's hearing. ${ }^{50}$ A contradictory behaviour was here felt obvious by both the author and the reader, once they had become familiar with the many difficulties of the mission to the >Other<.

\section{Dwellings \& Capitals}

Not only the interpreter was impressed, and not only by the Mongol power: their camps were impressive, as we have seen, as well as their capitals. When William entered the camp of Batu, he had a scary sensation of seeing a huge city, even though those were just Batu's dwellings: "Quando ergo uidi curiam Baatu expaui, quia uidebantur proprie domus eius quasi quedam magna ciuitas protensa in longum, et populus undique circumfusus usque ad tres uel quatuor leucas. « ${ }^{51}$

Priscus and his company often camped, during their travels, also before meeting the king and his entourage. ${ }^{2}$ As soon as they entered Attila's camp, he was impressed by the number of tents. Furthermore, he noted that location was used as a means of preserving a distinction: Attila's tent had to be higher than the others, both while traveling and when they stopped. ${ }^{53}$

William will also mention several times the strict hierarchical system as regards the location of tents or carriages. ${ }^{54}$

The same happens later, when they are at Sartaq's camp: see William, Itinerarium, XV 5, ed. Chiesa, 74.

48 William, Itinerarium, IX 1, ed. Chiesa, 48.

49 William, Itinerarium, XVI 3, ed. Chiesa, 78-80; trans. Jackson and Morgan, [e-book]: "I was also afraid that the interpreter had said something different from what I had told him, as he would have quite liked us to make a gift of everything«.

50 William, Itinerarium, XXVIII 2, ed. Chiesa, 144.

51 William, Itinerarium XIX 4, ed. Chiesa, 92; trans. Rockhill, 122: »When I saw the ordu of Baatu, I was astonished, for it seemed like a great city stretched out about his dwelling, with people scattered all about for three or four leagues."

52 Priscus, Excerpta, 8, 14, ed. Carolla, 18 at Naissus, because the town had been destroyed by the Huns (see above).

53 Priscus, Excerpta, 8, 22, ed. Carolla, 20; trans. Given, 50: »Around the ninth hour of the day we reached Attila's tents (and there were many tents there). We wanted to pitch ours on the crest of a hill, but the barbarians who met us prevented it, since Attila's tent was on lower ground«. See also 8, 41, ed. Carolla, 24; trans. Given, 53 »And so at last we came to Attila's tent, which was guarded by a barbarian multitude arrayed in a circle."

54 William, Itinerarium II 4, ed. Chiesa, 22; XIX 4, ibid., 92; XXIX 30-31, ibid., 184, et passim. 
Afterwards, when Priscus reached the unnamed scapitalı of Attila's kingdom, he saw separate houses for Attila and for Kreka, his most important wife. Whereas Attila had real houses, made of stone and wood, all the more precious because of the absence of both kinds of material in the steppe, Kreka, in fact, had some wooden houses and others made of something (»words") which was corrupted in the manuscript tradition. They were nothing else but yurts, as I have discovered during the emendatio of Priscus' text. ${ }^{55}$

Yurts are described with accuracy by William in his excursus about the habits and traditions of the Mongols. It is an ekphrasis - a learned technical description, intended for the addressee of the Itinerarium: the King Louis IX of France, who could fully appreciate it. ${ }^{56}$ "Domum in qua dormiunt fundant super rotam de uirgis cancellatis, cuius tingna sunt de uirgis et conueniunt in unam paruulam rotam superius, de qua ascendit collum sursum tamquam fumigatorium. Quam cooperiunt filtro albo, et frequentius imbuunt etiam filtrum calce uel terra alba et puluere ossium ut albius splendeat, et aliquando nigro; et filtrum illud circa collum superius decorant pulchra uarietate picture. Ante hostium similiter suspendunt filtrum opere polimitario uariatum: consuunt enim filtrum coloratum in aliud, faciendo uites et arbores, aues et bestias. Et faciunt tales domos ita magnas, quod habent aliquando triginta pedes in latitudine. ${ }^{57}$

55 Priscus, Excerpta, 8, 129, ed. Carolla, 39. See the critical apparatus, line 10: all the manuscripts have tà $\delta \dot{\varepsilon}$

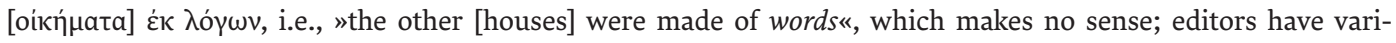
ously tried to correct it, until Bornmann, Prisci Panitae Fragmenta, 52 decided to put a crux desperationis here, i.e., showed that the passage is definitely corrupted. Thanks to the complete collation of all the manuscripts (including Cambridge, Trinity College, O.3.23 which was ignored by Carl de Boor in 1903) I was able to amend the

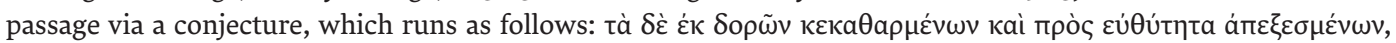

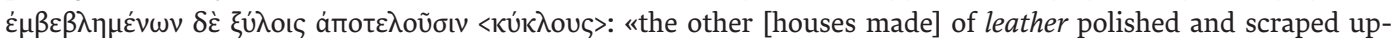
right, put into some wooden circular basis» (my translation). A different interpretation of the passage in trans. Given, 67 (text) and 90 n. 42 (commentary), who here follows Thompson, Camp of Attila, 113-114 and Priscus, Fragmenta 11.2, ed. Blockley, 274, as regards textual criticism.

56 The Itinerarium takes the form of an epistle, in order to be adequate for the rank of the king; see Chiesa, Introduzione, XLVI-XLVII.

57 William, Itinerarium II 2, ed. Chiesa, 18; trans. Jackson and Morgan [e-book]: »The dwelling in which they sleep is based on a hoop of interlaced branches, and its supports are made of branches, converging at the top around a smaller hoop, from which projects a neck like a chimney. They cover it with white felt: quite often they also smear the felt with chalk or white clay and ground bones to make it gleam whiter, or sometimes they blacken it. And they decorate the felt around the neck at the top with various fine designs. Similarly they hang up in front of the entrance felt patchwork in various patterns: they sew onto one piece others of different colours to make vines, trees, birds and animals. These dwellings are constructed of such a size as to be on occasions thirty feet across". See Chiesa, Commento, 345-346: Mongolian traditional houses are very similar to those from the 13th century. This passage, as well as the whole excursus about Mongolian uses \& traditions, was probably composed by William later than the rest (see above): Chiesa, Introduzione, XLIX-L. For literary parallels, see e.g. John of Plano Carpini, Historia Mongalorum, 2 (my italics) "Stationes rotundas habent in modum tentorii praeparatas, de virgis et baculis subtiliter factas. Supra vero in medio rotundam habent fenestram vnde lumen ingreditur, et vt possit fumus exire: quia semper in medio ignem faciunt. Parietes autem et tecta filtro sunt cooperta. Ostia etiam de filtro sunt facta. Quadam stationes sunt magna, quadam parua, secundum dignitatem et hominum paruitatem«. Note that William uses as much variatio as he can, comparing and contrasting John of Plano Carpini. 
What is relevant is the similar perspective, provided by Priscus and William: they stressed the circular base, the remarkable height of the circle and the huge size of some yurts. ${ }^{58}$ Most of all, they were really interested in the beautiful handicrafts which adorned the yurts, both inside and out. Priscus highlighted the fact that he found Attila's wife "lying on a soft mattress. The ground was covered with woollen felt pieces for walking on." Then he insisted: »female servants sat on the ground opposite her, dyeing some fine linens that were to be placed over the barbarians' clothing as adornment. ${ }^{59}$ The reader can feel the amazement of the author, who probably did not expect that much from his stay at Attila's.

As for William, we have seen his insistence on the coloured decoration on top of the yurts, as well as on the beautiful patchwork felt door. Furthermore, the patterns of "vines and trees, birds and beasts « spoke of a care for beauty by the Mongols, and the detail points to a positive view by the author as well. John of Plano Carpini had described the same things with a focus on technical details, rather than on those beautiful designs. ${ }^{60}$

\section{Beauty and ugliness}

Beauty surprised Priscus on several occasions during his stay at Attila's court. The same "capital" (with no name in his report) where he visited Kreka, the king's most important wife, was "a very large village, in which it was said Attila's compound was more conspicuous than everyone else's, fitted together with logs and well-polished boards and encircled with a wooden wall that contributed not to safety but to majesty « [my italics]. ${ }^{61}$ And the Getica of Jordanes, who drew on Priscus via Cassiodorus' Historia Gothorum, echoed: "A little ways on, we approached the village in which king Attila was tarrying, a village, I say, resembling a very populous city. We found there wooden walls made of shining planks, the interconnection of which mimicked something so solid that the planks' seam could hardly be seen even by someone looking for it. You could see dining rooms of great circumference and porticoes adorned with every beautification. The court's open space was embraced by so large a circuit that its very size displayed royal dignity. This was the dwelling of king Attila, who held the entire barbarian world. He preferred this abode to the cities he had captured. « ${ }^{62}$

58 See above, fn. 55: «the other [houses made] of leather polished and scraped upright, put into some wooden circular basis», and the following: Priscus, Excerpta, 8, 129, ed. Carolla, 39; trans. Given, 67 »The circles, starting from the ground, rose up to a height of good proportion«. About the size of the yurt see ibid., 131, ed. Carolla, 39; trans. Given "A number of male servants were gathered round her while female servants sat on the ground opposite her, dyeing some fine linens that were to be placed over the barbarians' clothing as adornment." The presence of a `crowd $\varsigma(\pi \lambda \tilde{\eta} \theta$ oc) of servants depicts a royal situation, with appropriate proportion between space and people. William insists on the circular basis (»super rotam de uirgis cancellatis») and the smaller swheek above it (»in unam paruulam rotam superius «); the size is given immediately afterwards: »tales domos ita magnas, quod habent aliquando triginta pedes in latitudine«.

59 Priscus, Excerpta, 8, 130-131, ed. Carolla, 39; trans. Given, 67.

60 See above, fn. 50. For William's positive view, see Pittaluga, Sguardo dell'altro, 23-32.

61 Priscus, Excerpta, 8, 83, ed. Carolla, 32: trans. Given, 59.

62 Jordanes, Getica, 178-179, ed. Giunta and Grillone, 104-105 = Priscus, Excerpta, 9, ed. Carolla, 52: "[...] ad vicum in quo rex Attila morabatur, accessimus, vicum, inquam, ad instar civitatis amplissimae, in quo lignea moenia ex tabulis nitentibus fabricata repperimus, quarum compago ita solidum mentiebatur, ut vix ab intento posset iunctura tabularum comprehendi. Videres triclinia ambitu prolixiore distenta porticusque in omni decore dispositas; area vero cortis ingenti ambitu cingebatur, ut amplitudo ipsa regiam aulam ostenderet. Hae sedes erant Attilae regis, barbariem totam tenentis, haec captis civitatibus habitacula praeponebat.« Trans. Given, 60. 
While Priscus is amazed by beautiful buildings, flatware, textiles, decorations and people, ${ }^{63}$ William is struck by the ugly pug-nosed women and their black makeup. ${ }^{64}$ Yet the Mongols display beautiful things and buildings as well, so he reports accurately every surprising detail, especially the great palace and its brick wall at Qara-Qorum, when William got there together with Möngke. "Ipse Mangu habet apud Caracarum magnam curiam iuxta muros uille, clausam muro latericio, sicut clauduntur prioratus monachorum apud nos. Ibi est unum magnum palatium in quo tenet potationem suam bis in anno [...]. Sunt ibi multe domus longe sicut grangie, in quibus reconduntur cibaria sua et thesauri sui. ${ }^{65}$ From a literary perspective, the palace is just preparation for an ekphrasis about a handicraft masterpiece, moreover a French one. Another Guilelmus, a French goldsmith who came from Paris and lived in Qara-Qorum at Möngke's service, had prepared his best work at the Mongol court precisely when William was there: a silver fountain in the form of a tree, spreading in four branches wine, beer, milk and sbalk. The description takes up several pages in the Itinerarium, and the artisan was a key person in William's journey. ${ }^{66}$

So both courts, the Hun and the Mongol ones, become places of beauty in the imagination of the readers.

\section{Freedom, Slavery and Polities}

No stone was to be found in the steppe to build houses, neither for the Huns in Pannonia ${ }^{67}$ nor for the Mongols in their vast empire: William reports tombs made of stones by the people of Comans, "although there was no stone«; they were the only building during his journey to Sartaq, like a spectral presence in a desert. ${ }^{68}$ Just like Priscus, he highlights the fact that building materials are worth a lot.

63 Priscus, Excerpta. 8, 88, ed. Carolla, 33; 161-162, ibid., 45 (flatware); 8, 87, ibid., 32; 154, ibid., 44 (textiles); see also above about Kreka's felt carpets; 8, 72, ibid., 29 (women); trans. Given, respectively, 61; 73; 61; 72; 57. About stone buildings, see below the following paragraph.

64 William, Itinerarium $\mathrm{X}$ 3, ed. Chiesa, 52.

65 William, Itinerarium XXX 1, ed. Chiesa, 210; trans. Rockhill, 207 »Mangu had at Caracarum a great palace, situated next to the city walls, enclosed within a high wall like those which enclose monks' priories among us. Here is a great palace, where he has his drinkings twice a year [...]. There are there many buildings as long as barns, in which are stored his provisions and his treasures."

66 William, Itinerarium XXX 1-4, ed. Chiesa, 210-214. For William's consideration about Guilelmus the goldsmith see esp. XXXVI 19, ibid., 284.

67 Priscus, Excerpta, 8, 85, ed. Carolla, 32; trans. Given, $60 »$ The barbarians of that region do not have a stone nor even a tree, but they use imported wood in this way."

68 William, Itinerarium, VIII 4, ed. Chiesa, 47: »alicubi lapideas domos, quamuis lapides non inueniantur ibi«; for the spectral landscape, see ibid. XII 5, ed. Chiesa, 60 »Et tendebamus recte in orientem (...) habentes mare ad meridiem et uastam solitudinem ad aquilonem, que durat per $\mathrm{xx}$ dietas alicubi in latitudine, in qua nulla silua, nullus mons, nullus lapis, herba optima.« See also Chiesa, Introduzione, XLIX. 
The author from Panion is especially interested in the story of the Illyrian architect, a prisoner of war who became a slave of Onegesios, sthe preeminent man among the Scythians after Attila". Onegesios requested of him that he build a bath »by conveying stones from Paionia « and the architect hoped to be rewarded with freedom, but he became the bath attendant for Onegesios and his fellowship instead. So "he unexpectedly fell into worse hardship than slavery among the Scythians. « ${ }^{69}$

Priscus recounts meeting another former prisoner of war, a Greek from Sirmium, who had had a brilliant recovery from slavery. The man greeted Priscus in Greek ("Xaĩp\&«), looked wealthy and felt satisfaction at his own life. It is the most renowned passage of Priscus' excerpts, where the vibrant dialogue between the two about the politeia of the Romans is reported. The Greek, naturalised by the Huns, had chosen to defend Attila's world because of his own better life, so he strongly criticised the Roman Empire for military ineptitude, official misconduct by the governors and bribery; Priscus, on the other hand, encountered problems in answering but insisted on the fact that good fortune among Huns was just by chance, while the Roman politeia was the best constitution ever. At the end, the man turned to tears and »he said that the laws were noble and the Roman constitution good, but the rulers, since they do not think like rulers of old, had corrupted it. « $^{70}$

The passage has been discussed and doubted. Was it mere criticism towards the emperor Theodosius II, rhetorically disguised as happens in Greek and Byzantine historiography? Did the dialogue really take place or was it invented by the author? ${ }^{71}$

The comparison with William's Itinerarium hints at the veracity of the meeting: even the Franciscan friar met a person from the Coman people who was delighted to greet him and his companion in Latin: "Saluete, domini! $\aleph^{72}$ Also the reaction was quite similar to Priscus: the Greek historian had "returned his greeting and asked who he was and from where he had come to the barbarian land and taken up the Scythian life." The other wondered at his wondering, so Priscus pointed out that "his speaking Greek was the cause" of his »inquisitiveness «. ${ }^{73}$ On his part, William was astonished by the Coman: »Ego mirans, ipso resalutato, quesiui quis eum docuerat illam salutationem." The Coman explained that he »in Hungaria fuit baptizatus a fratribus nostris qui docuerant eam « ${ }^{74}$ No news of a political talk here, of course: the focus is on the Franciscans - on the one hand, William and Bartholomeus; on

69 Priscus, Excerpta, 8, 84-86, ed. Carolla, 32; trans. Given, 60-61: [the compound of Onegesios] "was not equipped with towers like Attila's; rather there was a bath, not far from the enclosing wall, which Onegesios, as the preeminent man among the Scythians after Attila, built large by conveying stones from Paionia. The barbarians of that region do not have a stone nor even a tree, but they use imported wood in this way."

70 Priscus, Excerpta, 8, 94-114, ed. Carolla, 34-37; trans. Given, 62-65.

71 The episode is taken at face value by Greatrex, Government and mechanism, 37-38; Lenski, Captivity among barbarians, 230-246, esp. 240-241; see also Thompson, Notes on Priscus, 63-64; Thompson and Heather, Huns, 161-166; Priscus, Fragmenta, ed. Blockley, 385-386 n. 59.

72 William, Itinerarium XX 4, ed. Chiesa, 100; trans. Rockhill, 127: "One day a Coman joined us, who saluted us in Latin, saying: sSalvete domine! Much astonished, I returned his salutation, and asked him who had taught it him. He said that he had been baptized in Hungary by the brethren of our order, who had taught it to him«. See Chiesa, Introduzione, LIV.

73 Priscus, Excerpta, 8, 96-97, ed. Carolla, 34; trans. Given, 62.

74 William, Itinerarium XX 4, ed. Chiesa, 100; trans. Rockhill, 127: »Much astonished, I returned his salutation, and asked him who had taught it him. He said that he had been baptized in Hungary by the brethren of our order, who had taught it him.« 
the other, the anonymous friars in Hungary where the man was baptised. Yet we can read something relevant between the lines, because the Coman told William that Batu had asked him "multa about them and "ipse dixerat ei conditiones Ordinis nostri«. Immediately after that, William remembers having seen Batu riding with the heads of all the families: they were no more than "five hundred men «. This is relevant political information for Louis IX, who must be informed about the number of the Mongols. After all, the Epilogus of the Itinerarium ends up with military considerations about the French army and political suggestions to the pope. ${ }^{75}$

A comparison between the episodes shows that Priscus chose to highlight a contrast and William a consolation: the same Hun-Greek man was proud of his life at the beginning, but at the end of the dialogue he burst into tears of homesickness; William and Bartholomeus had been starving to death when they were visited first by some Hungarians who fed them, then by the Coman who had spoken well of them to Batu. From a literary perspective, this is a peaceful break before William's dramatic departure to Möngke. ${ }^{76}$

\section{Polygamy and Women's Power}

Villages were controlled by Hun kings through careful marriage politics, which left nothing to chance. For example, during Priscus' visit at Attila's camp the latter moved away to marry a young girl, Eskam's daughter, who was just one wife out of the many he had. Then the king left that village. ${ }^{77}$ A young newlywed, named Ildico, was the only witness of Attila's death in 453 and for this reason was also suspected of murder. ${ }^{78}$

During the absence of their husbands, Hun women had long been in charge of controlling the territory: Priscus himself met one of the widows of Bleda, the brother whom Attila had killed a few years earlier, and noticed that she was the boss of that village down to the slightest detail. ${ }^{79}$

75 William, Itinerarium, Epilogus 4-5, ed. Chiesa, 320; trans. Rockhill, 282: "It seems to me inexpedient to send another friar to the Tartars, as I went, or as the preaching friars go; but if the Lord Pope, who is the head of all Christians, wishes to send with proper state a bishop, and reply to the foolishness they have already written three times to the Franks [,,,] he would be able to tell them whatever he pleased, and also make them reply in writing. They listen to whatever an ambassador has to say, and always ask if he has more to say; but he must have a good interpreter - nay, several interpreters - abundant travelling fund, etc." See the conclusions below.

76 William, Itinerarium XX 6, ed. Chiesa, 100-101; trans. Rockhill, 128: «(...) there came a rich Moal to us, whose father was a chief of a thousand, which is a high rank among them, and he said: "I am to take you to Mangu chan. The journey is a four months one, and it is so cold on it that stones and trees are split by the cold. Think it over whether you can bear it.« I answered him : "I trust that, by the grace of God, we may be able to bear what other men can bear." Then he said : »If you cannot bear it, I shall abandon you on the road. «I replied : "That is not right; we are not going of ourselves, but are sent by your lord, so, being entrusted to your care, you should not abandon us." Then he said : "All will be well.«»

77 Priscus, Excerpta, 8, 63, ed. Carolla, 28; trans. Given, 56.

78 Priscus, Excerpta, 23, ed. Carolla, 62 (the fragment is transmitted by Jordanes, Getica); trans. Given, 112: »At the time of his death, as Priscus the historian reports, Attila married an exceedingly beautiful girl, Ildico by name, the last of his innumerable wives, as was the custom of that nation. (...) Late the following day, royal courtiers, suspecting something sorrowful, broke through the great doors and discovered Attila's unwounded corpse (...) and they found the girl crying under a cover, her face turned down." See also John Malalas, Chronicle, 14, 10, ed. Thurn, 279; trans. Jeffreys et al., 195: "This girl was suspected of having murdered him."

79 Priscus, Excerpta, 8, 66-73, ed. Carolla, 29-30 for the episode of the storm, the labyrinth and the powerful widow. About Bleda, probably killed in 445, see Theophanes, Chronography, AM 5942, ed. de Boor, 102; trans. Mango and Scott, 159: "Attila (...) after getting rid of his elder brother Bdellas, became sole ruler of the empire of the Scythians whom they call Huns.« 
William was also struck by the numerous and diverse wives of the Mongol khans, as well as by their ability to live together. For example, the most powerful wife of Möngke had been a Christian woman; when she died her daughter, also a Christian, inherited that power. Then Möngke married a young girl, which entered the number of his wives at a lower rank; yet, as she was rreplacing the Christian one, she used to live with the latter's daughter and got along very well with her. ${ }^{80}$

\section{The King's Power}

Attila's power, as Priscus puts it, was so overwhelming for both partes imperii that he received official honours and tributes, payed in gold only, and we are told that he sent ambassadors to Constantinople again and again, only because he wanted them to be covered in gold. ${ }^{81}$ One of these men was Edekon, who plotted the conspiracy with the Byzantine officials and then told everything to Attila.

William, for his part, describes repeatedly the immense land strictly controlled by the Mongols via tributes and slavery. ${ }^{82}$

\section{Food, Drinks \& Banquets}

Both Priscus and William found millet instead of wheat on their way. ${ }^{83}$ Priscus reported that Huns called their drinks >medos` and 'kamon ‘, ${ }^{84}$ whereas William records terms like >comos`, scaracomos` for horse milk and, occasionally, also sbal f for a drink made with honey and sterracinar for the beer of rice. ${ }^{85}$

A modern reader is astonished to learn that William could be satiated by drinks like broth or comos, ${ }^{86}$ a fact which cannot be fully explained even by the Franciscan dietary restrictions: he also thought it normal for the Mongols and complained whenever they were stingy in comos. ${ }^{87}$

The Byzantine ambassador and his entourage were invited to a banquet on three occasions, while at Attila's court: two were invitations by the king, the other by Kreka the queen. ${ }^{88}$

80 William, Itinerarium II 4, ed. Chiesa, 22; 8, ibid., 24; X 3, ibid., 52; XXIX 19, ibid., 174-176.

81 For this reason some scholars assume that Attila's power was actually fragile and that he needed to motivate his generals or rather to control their ambition. See e.g. Thompson and Heather, Huns, esp. 187-189.

82 Especially William, Itinerarium IV 5, ed. Chiesa, 32 (Baatu); XII 4, ibid., 60 (tax on salt); XXXVIII 6-7, ibid., 308310 (powerful Armenians stripped off by the Mongols) et passim.

83 Priscus, Excerpta, 8, 65, ed. Carolla 28; trans. Given, 57; William, Itinerarium XIII 12, ed. Chiesa, 68.

84 Priscus, Excerpta, 8, 65, ed. Carolla, 28; see also Gelzer, Médos bei Priskos.

85 William, Itinerarium III 1, ed. Chiesa, 28; IV 1, ibid., 30; IV 6, ibid., 32 for the "grut « (comos boiled until solidification). For the importance of comos in Mongol food see XII 2-3, ibid., 58; XVIII 2, ibid., 88; XXX 1, ibid., 210.

86 William, Itinerarium XXII 1, ed. Chiesa, 106-108.

87 William, Itinerarium XXXVII 23, ed. Chiesa, 302.

88 Priscus, Excerpta, 8, 151-173 (Attila); 178-179 (Kreka); 180-187 (Attila), ed. Carolla, 43-49; trans. Given, 72-78. 


\section{Prophecies}

During the first banquet, Priscus came to know Attila's predilection for his youngest son because of a prophecy which the king treasured: "I was amazed that he might be slighting his other children by paying attention to that son, but the barbarian sitting next to me, who understood Ausonian [i.e., Latin] and told me to repeat nothing of what he was going to tell me, said that prophets had predicted to Attila that his nation would fall but that it would rise again under this son ${ }^{89}{ }^{89}$ Elsewhere Priscus had reported Attila's trust in the "sword of Ares, an object holy and honored among royal Scythians because it was dedicated to the overseer of wars, which had disappeared long ago but was discovered with a bull's help. $^{90}$

However, the reverse was true, as Priscus did not fail to highlight: a passage of Jordanes taken from Priscus informed the readers that «a divinity stood above the Eastern emperor Marcian in his sleep. He had been suffering anxiety because of his fierce enemy. The dream showed him that the bow of Attila had been broken that very night, as if because the Huns relied so much upon that weapon. Priscus the historian says he received a true testimonial and so accepts this story. For Attila was considered so frightful to great empires that the gods revealed his death to rulers as a gift. «"1

It is easy to detect the literary pattern between the lines, however fragmentary: although proud of his fortune, Attila fell because the same god in which he had trusted turned his back and abandoned him. Moreover, even that pagan divinity payed homage to the Christian emperor Marcian (and not to the Western emperor, who in 453 was Valentinianus III). It was a story of hybris and punishment, perfect for demonstrating the Hun presumption and the excellence of Constantinople over Ravenna.

William wanted his king to be informed about a prophecy regarding the Mongols and appropriately put it at the end of his journey, recounting that he was told by an Armenian bishop in Nakičevan: "Alius propheta uocatur Acaton, qui in morte sua prophetauit de gente sagittaria uentura ab aquilone, dicens quod "Ipsi acquirent omnes terras orientis, et parcent regno orientis ut eis tradat regnum occidentis; sed fratres nostri (id est Franci uiri catholici) non credent eis. Et occupabunt terras ab aquilone usque in meridiem, et peruenient usque Constantinopolim et occupabunt portum Constantinopolitanum. Et unus ex eis, qui uocabitur uir sapiens, ingredietur ciuitatem, et uidens ecclesias et ritum Francorum faciet se baptizari, et dabit Francis consilium qualiter interficient dominum Tartarorum, et ibi confundentur. Hoc audientes qui erunt de medio terre (id est Ierusalem) insilient in Tartaros qui

89 Priscus, Excerpta, 8, 172-173, ed. Carolla, 47; trans. Given, 80.

90 Priscus, Excerpta, 8, 146, ed. Carolla, 42; trans. Given, 70. See also fr. 10 (from Jordanes), ed. Carolla, 53; trans. Given, 70-71.

91 Trans. Given, 112. Priscus, Excerpta, 23, ed. Carolla, 62. 
erunt in finibus eorum, et cum adiutorio nostre gentis (hoc est Hermenorum) persequentur eos, ita quod apud Taurinum in Perside ponet rex Francorum solium regale. Et tunc conuertentur omnes orientales et omnes increduli gentium ad fidem Christi, et erit tanta pax in mundo quod uiui dicent mortuis: /Ve uobis qui non uixistis usque ad tempora ista! « ${ }^{92}$

The prophecy was told by an Armenian monk who was also a bishop, and his entourage were twelve monks. Apparently, what William heard was the same as the Visio Norsei, ${ }^{93}$ with one crucial change: the "gens sagittaria" was there identified with the Mongols and not with the Seljukid Turks. ${ }^{94}$

Did William summarise and twist the oral text? An Armenian source might have done so, in order to persuade the French king, Louis IX, and have him attack the enemies of Armenia: not only the Mongols, but also the Muslims. This would make sense, especially because Armenians after the first Crusade re-interpreted the ancient prophecy identifying their help from Franks and no longer from the Byzantines. ${ }^{95}$ Furthermore, Pertusi suggests that Armenians re-adapted the prophecy from Late Antiquity throughout the Middle Ages until the fall of Constantinople; ${ }^{96}$ if the prophecy was readjusted to new situations every time, it is possible that a 5 th-century-old nucleus referred to Huns, a "gens sagittaria " who devastated the East "ab aquilone usque in meridiem «. We must remember that Attila came down to Constantinople in 447, when part of the walls collapsed because of an earthquake. ${ }^{97}$ And the enemy who came with hostile thoughts as an ambassador, only to convert to Christianity and suggest how to kill his own king, might even have links to the failed conspiracy plotted by the Byzantine court with Attila's envoy, Edekon. ${ }^{98}$ In that case, the latter could have been just

92 William, Itinerarium, XXXVIII 3, ed. Chiesa, 304; trans. Rockhill, 268-269: "The other prophet is called Acatron, who on his death-bed prophesied concerning the race of Archers to come from the north, saying that they would acquire possession of all the countries of the Orient, and that (God) would spare the Eastern kingdom so as to deliver unto them the kingdom of the West; but our brethren, like the Catholic Franks, would not believe in them, and they (i.e., the Archers) would occupy the earth from the north even unto the south, and would come to Constantinople, and would occupy the port of Constantinople; and one of them, who would be called a sage, would enter the city, and seeing the churches and the ceremonies of the Franks would be baptised, and he would tell the Franks how to kill the lord of the Tartars, and how to confound them. On learning this the Franks of the centre of the world, that is Jerusalem, would fall upon the Tartars in their borders, and with the help of our people, that is the Hermenians, would pursue them, so that the King of the Franks would place his royal throne in Tauris in Persia, and then all the Orientals and all the infidels would be converted to the faith of Christ, and there would be such peace on earth that the living would say to the dead: 'Woe is you, unfortunate ones, why lived ye not to these times?«.

93 About the Armenian Life of Nerses (LN), where the Visio is included, see the recent contributions: Pogossian, Armenians, Mongols and the end of times, 169-178 and 181-182 (esp. 169-170 n. 4; 182 n. 79); Pogossian, Last emperor or the last Armenian king?, 457-503. The Latin text of the Visio Norsei can be found in Pertusi, Visio Norsei, 130-135, who dates it to the first half of the 12th century; its relationship with the Armenian Life of St. Nerses (probably reworked slightly before the beginning of the 12th century, with some material older than the 5th century) is discussed ibid., 135-148 and with ps.-Epiphanius, Sermo de Antichristo, ibid., 148-149 (from the same period as the Visio Norsei). See also Pertusi, Conclusione, 151-155. That William is referring to the Visio Norsei is argued by most scholars, including Chiesa, Commento, 502-503.

94 Chiesa, Commento, 502; see also Scodellaro, Oracolo inedito, 26-27.

95 E.g., Matt'ēos Urhayec'i: see Pogossian, Last emperor or the last Armenian king?, 472-473.

96 Pertusi, Visio Norsei, 142-150; see also Scodellaro, Oracolo inedito, 26-27.

97 Thompson and Heather, Huns, 90-94.

98 About Edekon's role in plotting the conspiracy see Priscus, Excerpta, 7, 1-14, ed. Carolla, 13-15; trans. Given, 44-46. 
an inspiration for the production of a (now lost) idealised text in a myaphysite environment, favourable to the powerful eunuch Chrysaphius and his followers. It is only a hypothesis, of course; yet, if the prophecy had different "layers" throughout times, that could have been one of them.

\section{Which Constantinople?}

What is more interesting in the comparison between Priscus and William is that their journeys moved in completely divergent directions - Priscus towards Pannonia and beyond the Danube, William to Inner Asia and the Caspian Sea - but they brought vivid memories of the city of cities from their start. Most probably Priscus had previously lived in the capital, even though we do not know anything for sure. William, on the contrary, crossed Constantinople at the beginning of the journey and is said to have spoken publicly in St. Sophia on Palm Sunday. We may ask ourselves which image and aspect of Constantinople he brought to mind in the desolated land of the Mongols. His Constantinople was that of the Latin Empire, not the Byzantine one which would have prevailed a few years later; ${ }^{99}$ yet the polyphony of peoples and cultures was still there, especially in William's perception. ${ }^{100}$ This is why he remembered having read the prophecy in Constantinople specifically, thanks to some Armenians who had shown it to him there and he added: "sed non curaueram; sed quando locutus fui cum dicto episcopo, tunc memor magis curaui.$^{101}$ After all, the monk he lived with at Möngke's court was Armenian; ${ }^{102}$ a region where Armenians were living under the yoke of the Mongols inspired in him the sensation that Christians could overcome not only the Mongols, but also the Turks. ${ }^{103}$ Finally, whenever he claimed that Christian peasants could conquer the whole world, provided that they were willing to learn Mongol speed and to eat the same food, he is applying the Armenian prophecy to a real political context. ${ }^{104}$

We may infer that Armenians, expert in contact with every >Other«, were his facilitators in detecting the key to the >Otherness`. Or perhaps Armenian Otherness was the key to his (image of) Constantinople.

99 In 1261, after the Byzantine conquest of the City of cities, the emperor Michael VIII Palaiologos re-entered the Golden Gate as is attested by Georgios Acropolites I, ed. Heisenberg, 186-188.

100 For different perceptions of Constantinople through the centuries see Ronchey and Braccini, Romanzo di Costantinopoli; Braccini, Bisanzio prima di Bisanzio.

101 William, Itinerarium, XXXVIII 3, ed. Chiesa, 306; trans. Rockhill "I had read this prophecy in Constantinople, brought there by the Hermenians who live there, but had paid no particular attention to it; when I had had this conversation, however, with the bishop, it came back vividly to my memory".

102 Sergius the monk is a prominent character in William's narration, see e.g. ed. Chiesa, 149-151; 161-163; 171-175; 179 ; 185-195; 203-209; 225-231; 237-239; 283.

103 William, Itinerarium, XXXVIII 7, ed. Chiesa, 308-310.

104 See above nn. 92-95. 


\section{The Key to the >Otherness}

I offer here a reading of some relevant passages in both accounts: (a) Attila's messages to the emperors both in the East and in the West; ${ }^{105}$ (b) the long letter of Möngke to Louis IX. ${ }^{106}$ In my opinion, they summarise what the authors retained about >Otherness،.

The contents of the first and the last message by Attila look symmetrical: he asks that his requests be complied with, first regarding the restitution of $\phi u \gamma a ́ \delta \varepsilon \varsigma, ~ » d e s e r t e r s$ « who were, in fact, refugees, and afterwards about his asserted betrothal with Justa Grata Honoria Augusta, the sister of the emperor Valentinianus III. In both cases he threatens the Roman Empire that should his order not be satisfied, he will go to war; but the consequences in the two cases are the exact opposite of one another: while Theodosius II strives to obey Attila in 447, Marcian and Valentinianus dismiss his impossible demands in 450.

Most interesting is the third message, the one that Attila entrusts - orally, it seems - to the Byzantine ambassador Maximinus in 449. Here Theodosius II is openly challenged to show that he is an emperor and not a puppet: „Either, he [i.e., Attila] said, the audacious man would have paid the price, or the emperor's power was such that he did not even rule his own servants, against whom, if he would like, he was ready to provide an alliance. ${ }^{107}$ Here the >Other, however insolent, becomes what the author would have hoped to find in his emperor: bold, frank and able to make Theodosius accept his responsibilities. Praising Attila means belittling an emperor in name only.

The context of Khan Möngke's letter to Louis IX is different: the head of a vast empire speaks in the name of the one eternal god, on whom he relies for his earthly power. Furthermore, Möngke's words are interpreted through the wisdom of Psalms: he writes that his enemies "erunt habentes oculos non uidentes; et cum uoluerint aliquid tenere, erunt sine manibus; et cum uoluerint ambulare, erunt sine pedibus «. ${ }^{108}$ This is the way that William chooses to present the letter, no doubt because Psalm 114-115, 5-7 was what Möngke's words reminded him of.

Thus, the Khan's claim to be representative of the eternal god and his equation renemies = idolaters pave the way to William's recognition that the truth, in fact, is quite the opposite.

\section{The >Other, the Opposite}

So far we have detected many clues that reveal an identical perception, namely that travelling to the >Other entails an impact with the sopposites: what is contrary to their usual habits, traditions, ideas and practice becomes everyday life and experience for Priscus and William. Yet what both travellers retain is that their own side and situation should be the opposite of what it actually is. In other words, the perception of the >Otherness < becomes the perception of one's part to be sother than it should be: for instance, several times Priscus points out the

105 Priscus, Excerpta, 3, 1, ed. Carolla, 8 (Attila's letter to Theodosius II in 447); 8, 45-47, ibid., 25 (message for Theodosius II in 449); exc. 12.1, 1, ibid., 54 (official, oral answer to Theodosius in 449); exc. 15, ibid., 56 (envoys to Valentinianus III and Marcian in 450); trans. Given, 35, 54, 82 and 98.

106 William, Itinerarium, XXXVI 6-12, ed. Chiesa, 274-278; trans. Rockhill, 248-251.

107 Priscus, Excerpta, 12.1, 1, ed. Carolla, 54; trans. Given, 82.

108 Trans. Rockhill, 249: »they have eyes and see not; and when they shall want to hold anything they shall be without hands, and when they shall want to walk they shall be without feet«. 
failure of the emperor and his entourage, while William suggests learning from the Mongols their ability in speed and restraints with food, in order to conquer the whole world. ${ }^{109}$ Yet it is impossible to reduce their learning to a look-at-the-bright-side inspiration: indeed, Priscus' world appears turned upside down until the death of Theodosius II (450) and that of Attila (453); ${ }^{110}$ on the other hand, William feels acutely his own failure as a preacher among the Mongols. Here he takes one step further, as regards perception of the rotherness: he perceives himself to be sother (and probably the opposite) than his model. Saint Francis, the founder of his Order, was able to preach to the Sultan in Damietta and obtained permission for his brothers to visit the Holy Land. ${ }^{111}$ Perhaps this is why William, although a Franciscan friar, releases his work with the closing words about resources and money: »sed oporteret quod haberet bonum interpretem, immo plures interpretes, et copiosas impensas. «" ${ }^{112}$ Probably the opposite of what Francis of Assisi would have thought in the same situation.

Both Priscus and William bear witness to the last period of a political and cultural situation, to which they did not belong, yet to which they were linked: for Priscus it was the Roman Western Empire; for William, the Latin Empire in Constantinople. Both were periods of change and continuity which stimulated meditation on and self-awareness of imperial and Christian identities; in both cases the narrators struggled to resist the tides of change and pinpointed a tradition as a relief from the threat of the >Other the Eastern Roman Empire, the French Kingdom was suggested by William. No matter how mysteriously, both of them looked confident that their traditions would have survived the test as they had already done in the recent past - and they both contributed to a universal narrative of humanity, namely, that of Byzantium and the West.

\section{Biographical statement}

Pia Carolla is a tenure-track assistant professor in Byzantine Civilisation at the University of Genoa, Italy. She published a critical edition of Priscus of Panion in 2008 (Bibliotheca Teubneriana, W. de Gruyter); her research deals with Byzantine manuscripts, Medieval Greek textual traditions and their reception in the West up to the beginning of the 17th century.

109 William, Itinerarium, Epilogus 4, ed. Chiesa, 320; trans. Rockhill, 282 »I state it with confidence, that if your peasants - I speak not of the princes and noblemen - would but travel like the Tartar princes, and be content with like provisions, they would conquer the whole world".

110 See the recovery after the accession of the emperor Marcian to the throne: Priscus, Excerpta, 15, 1-2, ed. Carolla, 56; trans. Given, 98; and Marcian's dream about Attila's broken bow in the same night when the Hun king had died by haemorrhage: Priscus, Excerpta, 23, ed. Carolla, 62; trans. Given, 112.

111 For the different readings and interpretations of the sources, see Ibrahim, Francis preaching to the sultan.

112 William, Itinerarium, Epilogus 5, ed. Chiesa, 320; trans. Rockhill, 282 »but he [i.e., an ambassador to the Mongols] must have a good interpreter -nay, several interpreters - abundant travelling funds, etc. « See above, n. 75. 


\section{References}

Abbreviations

BBT = Golubovich, Girolamo, Biblioteca bio-bibliografica della Terra Santa e dell'Oriente francescano, serie I-III (Quaracchi, Firenze, 1906-1928).

$\mathrm{BT}=$ Bibliotheca Scriptorum Graecorum et Latinorum Teubneriana (Berlin).

CFHB = Corpus Fontium Historiae Byzantinae (Berolini - Novi Eboraci).

PLRE = Arnold Hugh Martin Jones, John Robert Martindale, John Morris, Edward Arthur Thompson, Alan D.E. Cameron and Philip Grierson (eds.), The Prosopography of the Late Roman Empire, 1-3 (Cambridge, 1971-1992, reprinted 2006).

Auzépy, Marie-France, Guillaume de Rubrouck chez les Mongols, in: Jacques Berlioz (éd.), Moines et religieux au Moyen Âge (Paris, 1994) 305-317.

Baldwin, Barry, Priskos, in: Alexander P.Kazhdan, Alice-Mary Talbot, Anthony Cutler, Timothy E. Gregory and Nancy P. Ševčenko (eds.), The Oxford Dictionary of Byzantium, 3 (New York, 1991) 1721.

Berardi, Francesco, La retorica degli esercizi preparatori: glossario ragionato dei Progymnásmata, Spudasmata 172 (Hildesheim, 2017).

Bonaventura, Legenda Maior $=$ Bonaventura de Bagnoregio, Legenda Major Sancti Francisci, in: Bonaventura de Bagnoregio, Opera omnia, 8 (Quaracchi, Firenze, 1898) 2-75. Accessed on 20 January 2019: www.documentacatholicaomnia.eu/o3d/1221-1274,_Bonaventura, Legenda_Major_Sancti_Francisci,_LT.pdf.

Bornmann, Fritz, Osservazioni sul testo dei frammenti di Prisco, Maia 26 (1974) 111-116.

Braccini, Tommaso, Bisanzio prima di Bisanzio. Miti e fondazioni della nuova Roma, Piccoli saggi 64 (Roma, 2019).

Chiesa, Paolo, Commento, in: William, Itinerarium, 323-515.

Chiesa, Paolo, Introduzione, in: William, Itinerarium, IX-LVI.

Chrysaphius, qui et Ztummas, PLRE 3, 295-297.

Dzino, Danijel and Ken Parry (eds.), Byzantium, its Neighbours and its Cultures, Byzantina Australiensia 20 (Brisbane, 2014).

Ernoul, Chronicle = Chronique d'Ernoul et de Bernard le Trésorier, in: Girolamo Golubovich (ed.), Biblioteca bio-bibliografica della Terra Santa e dell'Oriente francescano, serie I (Quaracchi, Firenze, 1906) 10-13; Italian translation: Francesco nei cronisti della quinta crociata. A) Cronaca di Ernoul, in: Caroli, Ernesto, Carlo Paolazzi, Felice Accrocca, Alfonso Marini et al. (eds.), Fonti Francescane. Nuova edizione (Padova, 2004).

Eunapius of Sardis, ed. Robert C. Blockley, The Fragmentary Classicising Historians of the Later Roman Empire. Eunapius, Olympiodorus, Priscus and Malchus, II. Text, Translation and Historiographical Notes, ARCA Classical and Medieval Texts, Papers and Monographs 10 (Liverpool, 1983) 1-127.

Gelzer, Heinrich, Médos bei Priskos, Byzantinische Zeitschrift, 24/2 (1923-1924) 313-314.

Georgios Acropolites = Georgii Acropolitae Opera, ed. August Heisenberg, BT (Leipzig, 1902).

Given, John, Introduction, in: John Given, The Fragmentary History of Priscus. Attila, The Huns and the Romans $A D$ 430-476, Christian Roman Empire Series 11 (Merchantville, NJ, 2014) xi-xliv. 
Gottschalk, Hans L., »al-Kāmil«, in: Peri J. Bearman, Thierry Bianquis, Clifford Edmund Bosworth, Emeri Johannes van Donzel, Wolfhart P. Heinrichs (eds.), Encyclopaedia of Islam, Second Edition (Leiden, 2012-). Accessed on 23 June 2019: dx.doi.org/10.1163/15733912_islam_COM_0432.

Greatrex, Geoffrey, Government and mechanism of control, East and West, in: Michael Maas (ed.), The Cambridge Companion to the Age of Attila, Cambridge Companions to the Ancient World (Cambridge, 2014) 26-43.

Gruen, Erich S., Rethinking the Other in Antiquity, Martin Classical Lectures (Princeton, 2011).

Howard-Johnston, James, Byzantium and its neighbours, in: Elizabeth Jeffreys, John Haldon and Robin Cormack (eds.), The Oxford Handbook of Byzantine Studies (Oxford, 2008) 939956.

Hoffmann, Lars Martin, Priscus of Panium, in: Graeme Dunphy and Cristian Bratu (eds.), Encyclopedia of the Medieval Chronicle (revised edition), (Leyden, 2016). Consulted online on 10 February 2019: dx.doi.org/10.1163/2213-2139_emc_SIM_02100.

Ibrahim, Mahmood, Francis preaching to the sultan: Art and literature in the hagiography of the saint, in: Cynthia Ho, Beth A. Mulvaney and John K. Downey (eds.), Finding Saint Francis in Literature and Art. The New Middle Ages (New York, 2009) 47-61.

John Malalas, Chronicle = Ioannis Malalae Chronographia, ed. Ioannes Thurn, CFHB Series Berolinensis 35 (Berlin, 2000); English translation: Elizabeth Jeffreys, Michael Jeffreys and Roger Scott, The Chronicle of John Malalas, Byzantina Australiensia 4 (Leiden, 1986, reprinted 2017).

John of Plano Carpini, Historia Mongalorum = Giovanni di Pian del Carpine, Storia dei Mongoli, ed. Paolo Daffinà, Claudio Leonardi, Maria Cristiana Lungarotti, Enrico Menestò and Luciano Petech (Spoleto, 1989, reprinted 2017).

Jordanes, Getica = Iordanis de origine actibusque Getarum, ed. Francesco Giunta and Antonino Grillone, Fonti per la storia d'Italia 117 (Roma, 1991).

Kaldellis, Anthony, Hellenism in Byzantium. The Transformation of Greek Identity and the Reception of the Classical Tradition, Greek Culture in the Roman World (Cambridge, 2007).

Kelly, Christopher, Neither conquest nor settlement: Attila's empire and its impact, in: Michael Maas (ed.), The Cambridge Companion to the Age of Attila, Cambridge Companions to the Ancient World (Cambridge, 2014) 193-208.

Laiou, Angeliki E., Byzantium and the Other. Relations and Exchanges, edited by Cécile Morrisson (Burlington, VT, 2012; reprinted London, 2018).

Lenski, Noel, Captivity among the barbarians and its impact on the fate of the Roman Empire, in: Michael Maas (ed.), The Cambridge Companion to the Age of Attila, Cambridge Companions to the Ancient World (Cambridge, 2014) 230-246.

Maas, Michael, Reversals of fortune: An overview of the age of Attila, in: Michael Maas (ed.), The Cambridge Companion to the Age of Attila, Cambridge Companions to the Ancient World (Cambridge, 2014) 3-25.

Magdalino, Paul, Constantinople and the outside world, in: Dion C. Smythe (ed.), Strangers to Themselves: The Byzantine Outsider, Papers from the Thirty-Second Spring Symposium of Byzantine Studies, University of Sussex, Brighton, March 1998. Publications of the Society for the Promotion of Byzantine Studies 8 (London, 2000; reprinted ebook 2016) 149-162.

Manfredi, Valerio Massimo, Il faraone delle sabbie (Milano, 1998, reprinted 2010). 
McCormick, Michael, Eternal Victory: Triumphal Rulership in Late Antiquity, Byzantium and the Early Medieval West (Cambridge, 19902); Id., Vittoria eterna. Sovranità trionfale nella tarda antichità, a Bisanzio e nell'Occidente altomedievale, Cultura e Storia (Milano, 1993).

Mitsiou, Ekaterini, The Byzantines and the "others«. Between transculturality and discrimination, in: Christian Gastgeber and Falko Daim (eds.), Byzantium as Bridge between West and East, Proceedings of the International Conference, Vienna, 3rd-5th May 2012, Veröffentlichungen zur Byzanzforschung 36 (Vienna, 2015) 65-74.

Morini, Enrico (ed.), Pertusi, Agostino, Fine di Bisanzio e fine del mondo. Significato e ruolo storico delle profezie sulla caduta di Costantinopoli in Oriente e in Occidente, Nuovi studi storici 3 (posthumous edition, Istituto storico italiano per il Medio evo), (Roma, 1988).

Olympiodorus of Thebes, ed. Robert C. Blockley, The Fragmentary Classicising Historians of the Later Roman Empire. Eunapius, Olympiodorus, Priscus and Malchus, II. Text, Translation and Historiographical Notes, ARCA Classical and Medieval Texts, Papers and Monographs 10 (Liverpool, 1983) 151-209.

Pertusi, Agostino, Conclusione (Seconda stesura provvisoria), in: Enrico Morini (ed.), Pertusi, Agostino, Fine di Bisanzio e fine del mondo. Significato e ruolo storico delle profezie sulla caduta di Costantinopoli in Oriente e in Occidente, edizione postuma, Istituto storico italiano per il Medio evo. Nuovi studi storici 3 (Roma, 1988) 151-155.

Pertusi, Agostino (ed.), La »Visio Norsei«, profezia di S. Nersete il Grande e il »Sermo de Antichristo« dello pseudo-Epifanio, in: Enrico Morini (ed.), Pertusi, Agostino, Fine di Bisanzio e fine del mondo. Significato e ruolo storico delle profezie sulla caduta di Costantinopoli in Oriente e in Occidente, edizione postuma, Istituto storico italiano per il Medio evo. Nuovi studi storici 3 (Roma, 1988) 128-150.

Pittaluga, Stefano, Lo sguardo dell'altro, Itineraria 10 (2011) 23-32.

Pohl, Walter, Migrations, ethnic groups, and state building, in: Michael Maas (ed.), The Cambridge Companion to the Age of Attila, Cambridge Companions to the Ancient World (Cambridge, 2014) 247-263.

Pohl, Walter, Identità etniche e cristianesimi, in: Luca Arcari (ed.), Identità etniche, identità collettive, identità religiose. Problemi aperti in prospettiva diacronica, special issue Reti Medievali Rivista 16.1, 2015, 59-72, DOI: dx.doi.org/10.6092/1593-2214/460.

Pohl, Walter, Conclusion: The transformation of frontiers, in: Walter Pohl, Ian Wood and Helmut Reimitz (eds.), The Transformation of Frontiers From Late Antiquity to the Carolingians, The Transformation of the Roman World (Leiden, 2001) 247-260.

Pogossian, Zaroui, Armenians, Mongols and the end of times: An overview of 13th century sources, in: Tubach, Jürgen, Sophia G. Vashalomidze and Manfred Zimmer (eds.), Caucasus during the Mongol Period - Der Kaukasus in der Mongolenzeit (Wiesbaden, 2012), 169-198.

Pogossian, Zaroui, The last emperor or the last Armenian king? Themes in Armenian texts from the Cilician period, in: Kevork B. Bardakijan and Sergio La Porta (eds.), The Armenian Apocalyptic Tradition. A Comparative Perspective. Essays Presented in Honor of Professor Robert W. Thomson on the Occasion of His Eightieth Birthday (Leiden, 2014) 457-503. 
Priscus, Excerpta = Priscus Panita, Excerpta et Fragmenta, ed. Pia Carolla, BT (Berlin, 2008); English translation: John Given, The Fragmentary History of Priscus. Attila, The Huns and the Romans AD 430-476, Christian Roman Empire Series 11 (Merchantville, NJ, 2014); Greek edition with different numeration of the fragments: Robert C. Blockley, The Fragmentary Classicising Historians of the Later Roman Empire. Eunapius, Olympiodorus, Priscus and Malchus, II. Text, Translation and Historiographical Notes, ARCA Classical and Medieval Texts, Papers and Monographs 10 (Liverpool, 1983) 222-376; Greek edition and Italian translation: Fritz Bornmann, Prisci Panitae Fragmenta (Firenze, 1979).

Pubblici, Lorenzo, Antagonism and coexistence. Local population and western merchants on Venetian Azov Sea in the 14th century, in: Claudia Pieralli, Claire Delaunay and Eugène Priadko (eds.), Russia, Oriente slavo e Occidente europeo. Fratture e integrazioni nella storia e nella civiltà letteraria, Biblioteca di Studi slavistici 36 (Firenze, 2017) 25-47.

Ronchey, Silvia and Tommaso Braccini, Il Romanzo di Costantinopoli. Guida letteraria alla Roma d'Oriente (Turin, 2010; reprinted 2016).

Scodellaro, Alberto, Un oracolo inedito sulla caduta di Costantinopoli, Tesi di Laurea in Scienze dell'Antichità, Università Ca' Foscari Venezia (Venezia, 2014). Accessed on 18 February 2019: hdl.handle.net/10579/4448.

Theophanes, Chronography = Theophanis Chronographia, ed. Carl de Boor, Bibliotheca Teubneriana (Lipsiae 1883); English translation: Cyril Mango and Roger Scott with the assistance of Geoffrey Greatrex, The Chronicle of Theophanes Confessor. Byzantine and Near Eastern History AD 284-813 (Oxford, 1997).

Thompson, Edward Arthur, The camp of Attila, Journal of Hellenic Studies 65 (1945) 112-115.

Thompson, Edward Arthur, Notes on Priscus Panites, The Classical Quarterly 41/1-2 (1947) 61-65.

Thompson, Edward Arthur and Peter Heather, The Huns, The Peoples of Europe (Oxford 1996, reprinted Malden, Ma, 2006).

Treadgold, Warren, The Early Byzantine Historians (Basingstoke, 2007).

Vermeulen, Jan, William van Rubroec in Mongolie, Leidschrift 12 (1997) 103-130.

Vindobona. Vienna International News, Lasting Rivals - Byzantium \& the West, 4 June 2018. Retrieved on 10 February 2019: www.vindobona.org/article/lasting-rivals-byzantiumand-the-west.

William, Itinerarium = William of Rubruk, Itinerarium, ed. Paolo Chiesa, Guglielmo di Rubruk. Viaggio in Mongolia (Itinerarium), Scrittori greci e latini (Milano, 2011); English translation: Peter Jackson and David Morgan, The Mission of Friar William of Rubruck. His Journey to the Court of the Great Khan Möngke 1253-1255, Hakluyt Society, second series, [e-book] (London, 2011; re-issued 2017). Retrieved on 10 February 2019: books.google.it/books?id=JAgkDwAAQBAJ\&printsec=frontcover\&hl=it\#v=onepage\&q\&f=false. Former English translation: William Woodville Rockhill, The Journey of William of Rubruck to the Eastern Parts of the World, 1253-55, Hakluyt Society (London, 1900; reprinted e-book 2017). 